\title{
Analityzmy \\ leksykalne i ich \\ syntetyczne \\ odpowiedniki \\ w prasie
}


造 
Katarzyna Burska

Analityzmy

leksykalne i ich

syntetyczne

odpowiedniki

w prasie 
Katarzyna Burska - Uniwersytet Łódzki, Wydział Filologiczny

Katedra Współczesnego Języka Polskiego, 90-236 Łódź, ul. Pomorska 171/173

\author{
RECENZENT \\ Iwona Loewe \\ REDAKTOR INICJUJĄCY \\ Urszula Dzieciątkowska \\ OPRACOWANIE REDAKCYJNE \\ Bogusława Kwiatkowska
}

SKŁAD I ŁAMANIE

Munda-Maciej Torz

PROJEKT OKŁADKI

Studio $7 A$

Zdjęcie wykorzystane na okładce: @ Depositphotos.com/66077941/ stock-photo-newspapers.html

(C) Copyright by Katarzyna Burska, Łódź 2016

(c) Copyright for this edition by Uniwersytet Łódzki, Łódź 2016

Wydane przez Wydawnictwo Uniwersytetu Łódzkiego

Wydanie I. W.07227.15.0.M

Ark. wyd. 20,0; ark. druk. 22,875

ISBN 978-83-8088-254-6

e-ISBN 978-83-8088-504-2

Wydawnictwo Uniwersytetu Łódzkiego

90-131 Łódź, ul. Lindleya 8

www.wydawnictwo.uni.lodz.pl

e-mail: ksiegarnia@uni.lodz.pl

tel. (42) 6655863 


\section{Spis treści}

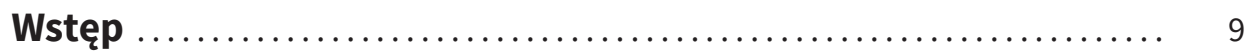

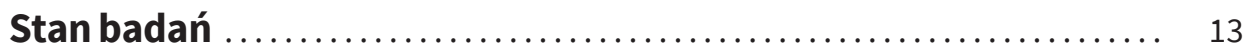

I. Struktura analityzmów leksykalnych w prasie ............. 39

1. Wyrazy pospolite .................................... 40

1.1. Analityzmy czasownikowe.......................... 40

1.1.1. Analityzmy pochodne strukturalnie................... 48

1.1.2. Analityzmy niepochodne strukturalnie................ 55

1.1.3. Frazeologizmy ................................ 64

1.2. Analityzmy rzeczownikowe $\ldots \ldots \ldots \ldots \ldots \ldots \ldots \ldots \ldots \ldots \ldots \ldots \ldots$

1.2.1. Analityzmy pochodne strukturalnie................... 78

1.2.2. Analityzmy niepochodne strukturalnie................ 89

1.2.3. Frazeologizmy ............................... 101

1.3. Analityzmy przymiotnikowe $\ldots \ldots \ldots \ldots \ldots \ldots \ldots \ldots \ldots \ldots \ldots \ldots \ldots$

1.3.1. Analityzmy pochodne strukturalnie.................. 104

1.3.2. Analityzmy niepochodne strukturalnie................ 105

1.3.3. Frazeologizmy ............................... 106

1.4. Analityzmy przystówkowe $\ldots \ldots \ldots \ldots \ldots \ldots \ldots \ldots \ldots \ldots \ldots \ldots \ldots \ldots \ldots$

1.4.1. Analityzmy pochodne strukturalnie.................. 107

1.4.2. Frazeologizmy ............................... 108 
1.5. Analityzmy i ekwiwalenty innych części mowy............ 111

1.5.1. Analityzmy zaimkowe. ..................... 111

1.5.2. Analityzmy liczebnikowe....................... 112

1.5.3. Analityzmy modulantowe ...................... 112

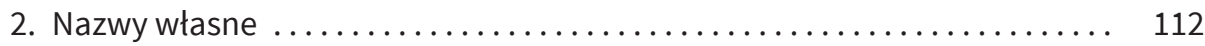

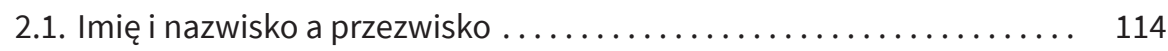

2.1.1. Przezwisko pochodzące od nazwiska ............... 116

2.1.2. Przezwisko pochodzące od imienia ................. 120

2.1.3. Przezwisko pochodzące od imienia i nazwiska ............ 121

2.1.4. Przezwiska niewykazujące morfologicznego pokrewieństwa zimieniem lub nazwiskiem .................... 122

2.2. Nazwa klubu a przydomek ......................... 123

2.2.1. Przydomki pochodzące od nazw klubów .............. 123

2.2.2. Przydomki niewykazujące morfologicznego pokrewieństwa z nazwą klubu.................................... 124

2.3. Przydomek jednoczłonowy, przydomek wieloczłonowy i peryfraza

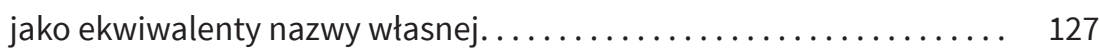

2.4. Nazwa własna wieloczłonowa a uniwerbizm ................ 128

2.5. Oficjalna nazwa własna jednoczłonowa a przydomek wielowyrazowy/

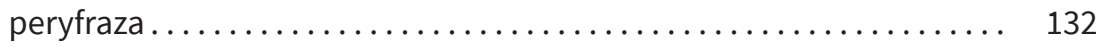

2.5.1. Nazwy geograficzne ........................ 132

2.5.2. Nazwy własne osobowe ...................... 140

2.5.3. Nazwy własne odnoszące się do różnych nieosobowych desyg-

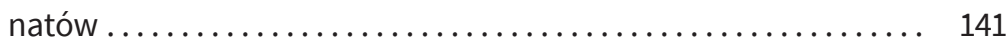

2.6. Skrótowiec nazwy własnej a nazwa wielowyrazowa. ............ 143

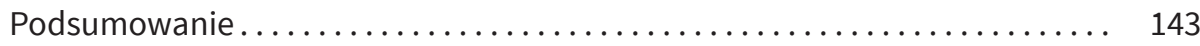

II. Semantyka ...................................... 147

1. Analityzmy leksykalne mające syntetyczne odpowiedniki równoważne

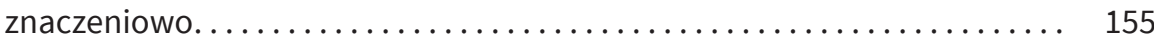

2. Analityzmy leksykalne mające syntetyczne odpowiedniki o znaczeniu

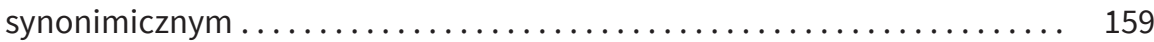

2.1. Prezentujące różne odcienie znaczeniowe ................. 159

2.2. Wyrażające odmienne nacechowanie stylistyczne ............ 182

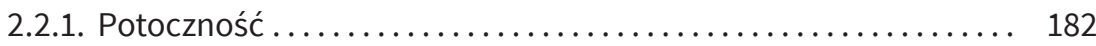

2.2.2. Oficjalność, urzędowość, podniosłość .............. 206 


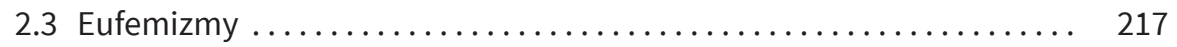

2.4. Metafora i metonimia jako główne sposoby tworzenia odpowiedników nazw własnych..................................... 239

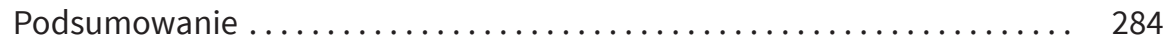

III. Pragmatyka ........................................ 289

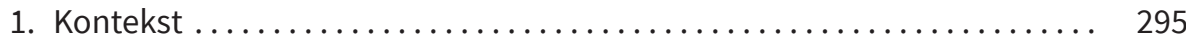

2. Wkaźniki metatekstowe.............................. 316

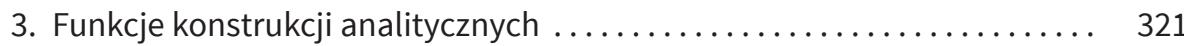

4. Analityzmy leksykalne a profil pisma i gatunek wypowiedzi ......... 330

Podsumowanie.................................... 333

Zakończenie ........................................... 337

Bibliografia............................................. 349

Analytical lexical constructions and their synthetic equivalents in the press. Summary ............................... 365 



\section{Wstęp}

Codziennie każdy z nas podejmuje decyzję, jakich środków językowych użyć, by przekazać informację, zaprezentować poglądy czy opisać uczucia. O ile przeciętni użytkownicy języka przeważnie koncentrują się jedynie na tym, by ich przekaz był zrozumiały dla odbiorcy, o tyle dziennikarze - dla których przecież słowo jest najważniejszym tworzywem wykorzystywanym w pracy - mają świadomość, że komunikat o podobnej wymowie można wyrazić na różne sposoby, niekoniecznie w najprostszej formie. Nie zawsze na pierwszym miejscu stawiają przystępność przekazu, czasem chcą zaprezentować swoje twórcze możliwości, sięgając po niekonwencjonalne rozwiązania, innym razem zależy im na niewyrażaniu wprost swoich opinii, a dzięki temu pozostawiają czytelnikowi swobodę interpretacyjną. Za każdym razem stają przed wyborem: napisać zwięźle i prosto czy może przekazać treści w sposób opisowy. Ów dylemat publikujących stał się inspiracją do powstania niniejszej pracy, gdyż dostrzeżono w tekstach prasowych dwa występujące obok siebie zjawiska: dbałość o ekonomię środków językowych i równocześnie skłonność do tworzenia struktur peryfrastycznych.

Celem rozprawy jest zatem przedstawienie pojawiających się w czasopismach analitycznych konstrukcji leksykalnych, które mają syntetyczne odpowiedniki. Analizie zostanie poddany materiał pochodzący z wybranych periodyków polskich o zróżnicowanej tematyce i przeznaczonych dla różnego kręgu odbiorców.

Analityzmy i odpowiadające im syntetyzmy leksykalne obecne we współczesnych tekstach prasowych nie doczekały się jak dotąd obszernego opracowania monograficznego zestawiającego oba zjawiska. Tym bardziej interesujące wydaje się podjęcie analizy zgromadzonego materiału z perspektywy strukturalnej, 
semantycznej oraz pragmatycznej. Dodatkową motywacją do podjęcia badań był fakt, że język nieustannie podlega ewolucji i to właśnie analiza materiału prasowego pozwoli dostrzec obowiązujące tendencje.

Praca ma przynieść odpowiedź na kilka pytań: z jakich elementów zbudowane są struktury złożone mające jednowyrazowe ekwiwalenty, jakie relacje znaczeniowe można zaobserwować między analityzmami a syntetyzmami, jakie czynniki pragmatyczne decydują o zgodnym z zamierzeniem dziennikarza odczytaniem połączeń wielowyrazowych, jakie funkcje pełnią analizowane jednostki leksykalne w najnowszej prasie.

Podjęta zostanie także próba odpowiedzi na pytanie, które formy syntetyzmów i analityzmów leksykalnych dominują w tekstach prasowych na początku drugiej dekady XXI w. Prowadzone będą rozważania nad tym, która tendencja - skrótowość opisu czy używanie struktur opisowych - ma obecnie szerszy zakres występowania i w jakich sytuacjach sięga się po przywoływane w pracy sformułowania. Wyniki badań zostaną skonfrontowane z wnioskami wypływającymi z opracowań poświęconych temu zagadnieniu.

Za podstawę badawczą posłużą przykłady wyekscerpowane $\mathrm{z}$ wybranych periodyków polskich z lat 2011-2012. Zgromadzonych zostało około trzech tysięcy jednostek, lecz ze względów praktycznych - by praca nadmiernie się nie rozrosła - wykorzystano tylko najbardziej charakterystyczne egzemplifikacje. Analizie poddano ponad 1300 przykładów, które zaprezentowano w zróżnicowanym otoczeniu leksykalnym, łącznie zatem zaprezentowano około dwóch tysięcy konkretnych zastosowań. Wszystkie przykłady zostały przywołane w oryginalnej postaci, z zachowaniem pojawiających się czasem usterek interpunkcyjnych, składniowych i ortograficznych.

Zamierzeniem było uzyskanie różnorodnego materiału, skierowanego do odbiorców zróżnicowanych pod względem płci, wieku, wykształcenia czy zainteresowań, dlatego za podstawę badawczą posłużyły cztery regularnie ukazujące się czasopisma: „Na Żywo”, „Piłka Nożna”, „Polityka” i „Victor Gimnazjalista”. Warto krótko scharakteryzować te periodyki.

„Na Żywo” to tygodnik ukazujący się od 15 listopada 2007 r. Zastąpił wydawany nakładem koncernu Axel Springer Polska w latach 1995-2006 dwutygodnik o tej samej nazwiel. Jak czytamy na stronie internetowej wydawnictwa

1 http://media.wp.pl/kat,1022939,title,Na-Zywo-na-rynku,wid,9391155,wiadomosc. html?ticaid=112f8d [dostęp: 15.02.2014]. 
Bauer, czasopismo „skierowane jest do aktywnych kobiet w wieku powyżej 30 lat, szukających informacji o gwiazdach i porad z różnych dziedzin życia"2 Pismo kreowane jest jako magazyn poradniczo-rozrywkowy. Dominują w nim teksty o charakterze informacyjnym (newsy, wzmianki, notatki) poświęcone życiu gwiazd, a także krótkie relacje z wydarzeń, bogato ilustrowane zdjęciami. Sporo artykułów przybiera - zgodnie z realizowaną linią redakcyjną - postać poradnikową. W każdym numerze są również komentarz, wywiad, porady prawne i lekarskie, horoskop, przepisy kulinarne, minirecenzje nowości kulturalnych filmów, książek i płyt.

„Piłka Nożna” to tygodnik dla miłośników futbolu. Ukazuje się od 1 czerwca 1956 r. W czasopiśmie tym pojawiają się przede wszystkim felietony, wywiady, relacje, zapowiedzi, sylwetki i reportaże. Dopełnieniem są krótkie gatunki informacyjne.

„Polityka” to tygodnik społeczno-politycznym obecny na polskim rynku prasowym od 1957 r. Jakgłoszą informacje na oficjalnej stronie internetowej odnoszące się do 2013 r.: „po raz ósmy z rzędu jest liderem sprzedaży w segmencie tygodników opinii”3. Na łamach „Polityki” publikowane są artykuły publicystyczne, felietony, komentarze, wywiady, sylwetki i reportaże. Nie brakuje także notatek, recenzji nowości technicznych, kinowych, teatralnych, książkowych i muzycznych.

„Victor Gimnazjalista” wydawany jest jako dwutygodnik edukacyjny adresowany do uczniów gimnazjum. Pierwszy numer ukazał się w 1998 r., czasopismo pojawiło się po reformie szkolnictwa w miejsce „Victora Ósmoklasisty”. W periodyku tym znajdziemy reportaże, opowiadania w odcinkach, recenzje produktów (np. kosmetyków, artykułów spożywczych, gier), psychotesty, zapowiedzi płyt, książek i filmów, listy psychologa, horoskopy, artykuły o charakterze poradnikowym i edukacyjnym (przybierające postać opisową lub analityczno-interpretacyjną).

Praca poprzedzona jest obszernym omówieniem stanu badań, a jej główna część składa się z trzech rozdziałów, w których treści teoretyczne łączą się z analizą zgromadzonych przykładów.

W rozdziale strukturalnym podzielono analityzmy ze względu na reprezentowane przez ich syntetyczne odpowiedniki części mowy: czasownik, rzeczownik, przymiotnik, przysłówek, zaimek, liczebnik, modulant. W każdej grupie osobno

\footnotetext{
2 http://www.wydawnictwo.bauer.pl/tytuly_rozw.html?id=65 [dostęp: 15.02.2014].

3 http://www.polityka.pl/opolityce/1571445,1,historia-polityki.read [dostęp: 15.02.2014].
} 
scharakteryzowano konstrukcje mające wspólne morfemy z ekwiwalentami, niemające wspólnych morfemów oraz związki frazeologiczne. Dokonano podziału na wyrazy pospolite i nazwy własne. W części poświęconej nomina propria zbadano przezwiska pochodzące od imienia, nazwiska, imienia i nazwiska oraz niewykazujące z nimi morfologicznego pokrewieństwa, przydomki pochodzące od nazw klubów i niespokrewnione z nimi morfologicznie, nazwy własne wieloczłonowe mające odpowiednik w postaci uniwerbizmu oraz nazwy własne jednoczłonowe mające odpowiednik peryfrastyczny, a także skrótowce, którym odpowiadają połączenia wielowyrazowe. W obrębie poszczególnych grup przykłady wymieniane są w kolejności alfabetycznej, wynotowano po jednym użyciu z każdego czasopisma - o ile jednostka taka została w nim zaobserwowana ${ }^{4}$. W przypadku gdy jedna forma syntetyczna miała kilka zróżnicowanych strukturalnie ekwiwalentów, umieszczono wszystkie możliwe egzemplifikacje.

W rozdziale semantycznym skoncentrowano się na relacjach znaczeniowych między analityzmem a odpowiadającym mu syntetyzmem. Wyróżniono konstrukcje równoważne znaczeniowo, a wśród struktur o znaczeniu synonimicznym wyzyskano takie, które prezentują różne odcienie znaczeniowe, wyrażają odmienne nacechowanie stylistyczne (potoczność, oficjalność, eufemizowanie). Scharakteryzowano także metaforę i metonimię jako główne sposoby tworzenia ekwiwalentów nazw własnych.

Część dotycząca pragmatyki poświęcona jest analizie kontekstu jako wartości wpływającej na odczytywanie struktur analitycznych i roli wskaźników metatekstowych w interpretacji struktur ekwiwalentnych. Omówione zostały także funkcje analityzmów leksykalnych w tekstach prasowych na początku drugiej dekady XXI w. Zbadano zależność między profilem pisma i gatunkiem wypowiedzi a używaniem omawianych konstrukcji.

4 W pracy zastosowano następujące oznaczenia czasopism: NŻ - „Na Żywo”, PN „Piłka Nożna, P - „Polityka”, VG - „Victor Gimnazjalista”. 


\section{Stan badań}

Sposób prezentacji omówionego niżej stanu badań opiera się na połączeniu porządku problemowego z chronologicznym. Uwzględnione zostały pozycje omawiające różne typy analityzmów i syntetyzmów, szerzej przedstawiono te, do których nawiązano w dalszych częściach niniejszej pracy.

Pierwszą powojenną monografią szczegółowo opisującą analityzmy leksykalne była wydana pod koniec lat 70. XX w. praca Janusza Anusiewicza pt. Konstrukcje analityczne we współczesnym języku polskim. Jak podkreślał autor we wstępie: „Głównym celem [...] jest przede wszystkim zebranie materiału pochodzącego z różnych odmian współczesnego języka polskiego, wydzielenie modelowych typów konstrukcji analitycznych, zbadanie ich związków referencjalnych oraz ustalenie zasięgu i frekwencji struktur opisowych w poszczególnych odmianach współczesnej polszczyzny"1. Językoznawca podzielił zgromadzony materiał według kryteriów formalnych, wyróżniając analityczne konstrukcje rzeczownikowe, czasownikowe, przymiotnikowe i przysłówkowe oraz przyimkowe. Podczas analizy skoncentrował się na zagadnieniach semantycznych, strukturalnych, stylistycznych i poprawnościowych. Na uwagę zasługuje zaproponowana przez J. Anusiewicza definicja: „konstrukcjami analitycznymi (opisowymi) nazywamy takie niewspółrzędne związki wyrazowe, które współistnieją obok znaczeniowo im ekwiwalentnych prostych (jednordzeniowych) wyrazów, przy czym morfem leksykalny wyrazu podrzędnego wchodzącego w skład danej konstrukcji jest

1 J. Anusiewicz, Konstrukcje analityczne we współczesnym języku polskim, Wrocław 1978, s. 22. 
tożsamy substancjalnie z morfemem leksykalnym wchodzącym w skład odpowiadającej jej formy prostej wyrazu"2 . Powtarzanie części ekwiwalentnego znaczeniowo wyrazu prostego jest charakterystyczne dla konstrukcji rzeczownikowych, czasownikowych, przymiotnikowych. Opisowe struktury przyimkowe, pojawiające się w miejsce syntetycznych, mogą - zdaniem autora monografii przejawiać się na kilka sposobów³ : przyimek przejmuje i pełni funkcję końcówki przypadka, stając się odrębnym znakiem dla oznaczania różnych relacji wyrażanych dotychczas tą końcówką, przyimek pierwotny zastępowany jest wyrażeniem przyimkowym lub jego znaczenie wzmocnione jest dodatkowym elementem leksykalnym, przyimek występuje wraz z rzeczownikiem odsłownym zamiast bezokolicznika bądź całe wyrażenie przyimkowe wzmacnia znaczenie następującego po sobie spójnika. J. Anusiewicz był świadomy, że w szerokim rozumieniu do konstrukcji analitycznych zaliczamy wszelkie określenia peryfrastyczne, celowo koncentruje się jednak tylko na takich połączeniach, w których widoczna jest substancjalna tożsamość. Badacz snuł także rozważania nad przyczynami szerzenia się konstrukcji analitycznych w polszczyźnie, biorąc pod uwagę czynniki wewnątrz- i pozajęzykowe, a także uwarunkowania wynikające z procesu komunikacji.

J. Anusiewicz podkreślał, że nie jest pierwszym językoznawcą, który zainteresował się tematyką analityzmów. Uczeni zwracali dotychczas uwagę na poszczególne typy konstrukcji opisowych, jego monografia jest zaś próbą kompleksowego ujęcia badanego zjawiska. Przedwojenną pracą, która miała duży wpływ na przemyślenia J. Anusiewicza, była publikacja Stanisława Szobera Na straży języka. Szkice z zakresu poprawności i kultury języka4. Wśród publikacji z II połowy XX w. na uwagę zasługują rozważania podjęte przez Agnieszkę Wierzbicką ${ }^{5}$, Marię Kniagininową ${ }^{6}$ oraz cykl Danuty Buttler Semantyka a składnia w związkach wyrazowych publikowany na łamach „Poradnika Językowego”.

2 Ibidem.

3 Ibidem, s. 23.

4 S. Szober, Na straży języka. Szkice z zakresu poprawności i kultury języka, Warszawa 1937.

5 A. Wierzbicka, Hipotaksa i konstrukcje nominalne w rozwoju polszczyzny, „Pamiętnik Literacki” 1962, s. 195-216.

6 M. Kniagininowa, Struktury opisowe - znamienna cecha stylu dziennikarskiego, „Język Polski” 1963, s. 148-157. 
Monograficzne ujęcie J. Anusiewicza poprzedziły artykuły, w których przedstawiał swoje uwagi na temat analityzmów w różnych odmianach polszczyzny. W pracy Konstrukcje analityczne w języku prasy ${ }^{7}$ skoncentrował się na analizie stylistycznej, funkcjach, celach i ocenie struktur opisowych w stylu publicystyczno-dziennikarskim. Współwystępują one w prasie z konstrukcjami syntetycznymi. Autor omówił konstrukcje analityczne rzeczownikowe (składające się z rzeczownika nadrzędnego o charakterze ogólnym i precyzującego rzeczownika podrzędnego), czasownikowe (w których skład wchodzą czasownik i rzeczownik odsłowny), przymiotnikowe (należą do nich rozwinięte przydawki), a także różne rodzaje analityzmów przyimkowych. Do przyczyn szerzenia się tej tendencji zaliczył zarówno dążenie do precyzji, jak i manierę używania utartych sformułowań analitycznych. Uważał za zasadne posługiwanie się konstrukcjami peryfrastycznymi w tekstach o funkcji komunikatywnej. Podkreślił, że formy te nadają artykułom charakter uroczysty.

Maria Kniagininowa, która badała teksty dziennikarskie z przełomu piątego i szóstego dziesięciolecia XX w., zauważyła, że piszący wykazują skłonność do używania struktur analitycznych zamiast syntetycznych, pojawiają się opisowe formy rzeczownikowe, czasownikowe, przymiotnikowe, a także wyrażenia przyimkowe z funkcją wzmacniającą spójnik, wyrażenia przyimkowe zamiast przyimków właściwych, określniki przyimkowe zamiast przypadkowych, wyrażenia przyimkowe z rzeczownikami odczasownikowymi zamiast bezokoliczników. Badaczka krytycznie oceniła użycie konstrukcji analitycznych, twierdząc: „Jeżeli się ma do wyboru dwie formy: analityczną i syntetyczną, wybiera się pierwszą, jeżeli zaś taka nie istnieje w języku, tworzy się sztuczną, stylistycznie niezręczną, bo

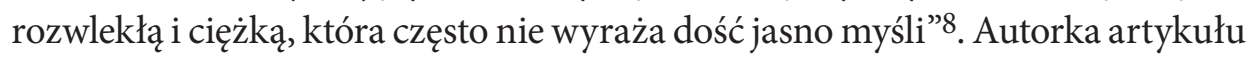
scharakteryzowała pokrótce wszystkie wymienione grupy analityzmów, ilustrując je przykładami z prasy. Była przeciwna tworzeniu struktur opisowych składających się z dwóch rzeczowników, z których jeden jest pojęciem zbyt ogólnym wymagającym uzupełnienia (np. atmosfera, fakt, klimat, problem, zagadnienie, zjawisko), czy czasownika i rzeczownika odsłownego (z podstawą w postaci dać, mieć, nastąpić, przeprowadzić, stworzyć, ulegać, wyrazić), a także pleonastycznych wyrażeń przyimkowych (pod warunkiem jeśli) oraz używaniu określników

7 J. Anusiewicz, Konstrukcje analityczne w języku prasy, „Wrocławski Rocznik Prasoznawczy" 1974, s. 61-86.

8 M. Kniagininowa, op. cit., s. 149. 
przyimkowych w miejsce przypadkowych. M. Kniagininowa zastanawiała się także nad przyczynami wzmożonej analityczności, dostrzegała wpływ języków obcych oraz względy stylizacyjne, doszła do wniosku, że używanie struktur opisowych wynika niekiedy z bierności i bezmyślności dziennikarza.

Na obecną w języku tendencję do zastępowania prostych form czasownika konstrukcjami opisowymi zwróciła uwagę Danuta Buttler w artykule Połączenia typu ulec zniszczeniu w języku polskim ${ }^{9}$, jako jej przyczynę wskazała dążenie do precyzji: „Ekspansywność połączeń dwuwyrazowych wynika z ich większej semantycznej wyrazistości"10. Zdarza się jednak, że formy syntetyczna i analityczna pełnią identyczne funkcje znaczeniowe (tak jest np. w przypadku czasowników fazowych z rzeczownikiem odsłownym). Lingwistka wymieniła zmiany strukturalne świadczące o formalizacji grup syntaktycznych oraz wskaźniki procesu gramatykalizacji struktury opisowej. Szczegółowemu oglądowi poddała konstrukcje z czasownikami dokonać, przeprowadzić, doznać i ulec z racji tego, że charakteryzują się konkretnym znaczeniem wyjściowym. Dostrzegła, że połączenia zarezerwowane wcześniej dla odmiany oficjalnej zaczynają pojawiać się w innych stylach, zaciera się też swoiste znaczenie wymienionych czasowników, pojawiają się w nowych, nienotowanych do tej pory kontekstach. Badaczka wskazała, że formy z rzeczownikiem odsłownym - w przeciwieństwie do podstawy werbalnej, która ma znaczenie ogólne - odznaczają się wyspecjalizowaniem semantycznym. Połączenia opisowe pozwalają nadać znaczenie receptywne w przypadku czasowników nieprzechodnich.

Problem jednego z typów konstrukcji analitycznych, tj. orzeczeń peryfrastycznych, zgłębił Andrzej Bogusławski pod koniec lat 70. XX w. ${ }^{11} \mathrm{~W}$ kręgu jego zainteresowań znalazły się wyrażenia czasownikowe z dopełnieniem w postaci rzeczownika abstrakcyjnego. Uczony zastanawiał się, które czasowniki pojawiają się najczęściej jako podstawa konstrukcji analitycznych, wymienił m.in.: prowadzić, przeprowadzać, dokonać, wykonać, dopuścić się, szczegółowo omówił każdą grupę, zaakcentował odcienie semantyczne i nacechowanie stylistyczne pojawiających się form, przywołał różne konteksty. A. Bogusławski podkreślił, że

9 D. Buttler, Połączenia typu ulec zniszczeniu w języku polskim, „Poradnik Językowy" 1968, z. 7, s. 349-359.

10 Ibidem, s. 350.

11 A. Bogusławski, Jednostki języka a produkty językowe. Problem tzw. orzeczeń peryfrastycznych, [w:] Z zagadnień słownictwa współczesnego języka polskiego, Wroclaw 1978, s. 17-30. 
konstrukcje nominalne „odznaczają się [...] swoistymi cechami semantycznymi, które nie pozwalają na ich dowolną wymianę z orzeczeniami prostymi”"12, w określonym kontekście mogą wprowadzać zasadnicze zmiany znaczeniowe.

Danuta Buttler ${ }^{13}$ pod koniec lat 80 . ubiegłego stulecia dokonała analizy leksykalnych czasowników posiłkowych występujących na przełomie XIX i XX w., które definiowała następująco: „Nazwa ta odnosi się więc do leksemów werbalnych, które występują w konstrukcjach peryfrastycznych odpowiadających treściowo jednowyrazowym określeniom czynności i stanów"14. Podkreślała nieregularność konstytuowania przez nie orzeczeń złożonych oraz zdolność do przekazywania tylko niektórych znaczeń uogólnionych. Jak zauważyła D. Buttler, niektóre analizowane jednostki wyrazowe wchodzą jednak w skład dużych serii konstrukcji peryfrastycznych (np. budzić + nazwa uczucia). „Ogólnie można byłoby powiedzieć, że leksykalne czasowniki posiłkowe konstytuują konstrukcje zajmujące pozycję pośrednią między złożonymi formami morfologicznymi, całkowicie potencjalnymi, tworzonymi od dowolnego czasownika a frazeologizmami - idiomami"15. Badaczka zwróciła uwagę na semantyczną precyzję konstrukcji peryfrastycznych. Porównując zestaw leksykalnych czasowników posiłkowych u schyłku XIX w. i sto lat później, doszła do wniosku, że ich skład jest bardzo podobny, zmieniły się jednak zakresy użycia i funkcje - te mające kiedyś nieograniczoną łączliwość występują z czasem w nielicznych kontekstach, niekiedy dochodzi do frazeologizacji. „Można też zaobserwować pewną ogólniejszą prawidłowość: równoległe osłabienie żywotności danego leksemu zarówno w użyciu posiłkowym, jak i w odcieniach szczegółowych, konkretnych"16.Zdarza się, że z biegiem lat funkcja posiłkowa czasownika ulega modyfikacji, typowym procesem jest zmiana odcienia znaczenia z biernego na czynny i odwrotnie. Częstym zjawiskiem jest ograniczenie liczby rzeczowników, z którymi czasownik posiłkowy może tworzyć orzeczenia peryfrastyczne - do głosu dochodzą człony konkurencyjne, które wchodzą na miejsce obecnego tam do tej pory czasownika

12 Ibidem, s. 29.

13 D. Buttler, Leksykalne czasowniki positkowe w konstrukcjach peryfrastycznych typu wywrzeć wpływ na przełomie XIX i XX wieku, [w:] Z problemów frazeologii polskiej i słowiańskiej, red. M. Basaj, D. Rytel, Wrocław-Warszawa-KrakówGdańsk-Łódź 1988, s. 71-82.

14 Ibidem, s. 71.

15 Ibidem, s. 72.

16 Ibidem, s. 76. 
posiłkowego. D. Buttler próbowała także znaleźć przyczyny ekspansywności danych form. Wymieniła wśród nich przede wszystkim wyrazistość słowotwórczą i zachodzącą pod wpływem tendencji do precyzji repartycję znaczeniową dubletów słowotwórczych. Podkreśliła, że w XX w. jest widoczna semantyczna specjalizacja środków.

Do badań prowadzonych przez J. Anusiewicza odwołał się Wacław Cockiewicz, porównując konstrukcje analityczne występujące w języku polskiej telewizji w latach 70. XX w. i u schyłku drugiego tysiąclecia ${ }^{17}$. Językoznawca postuluje przyjęcie tez swojego poprzednika w łagodnej formie i jako kryterium proponuje tożsamość znaczeniową. Struktury opisowe nie muszą zawierać więc - według autora - wspólnych morfemów z odpowiadającymi im syntetyzmami leksykalnymi. Sugeruje on, że „tak rozumiane konstrukcje można by również (dla odróżnienia) nazywać np. peryfrastycznymi"18. Uzupełniając zaproponowane w monograficznym ujęciu kryteria oceny normatywnej konstrukcji analitycznych, zwraca uwagę na czynniki negatywne warunkujące użycie analityzmu - funkcję retardacyjną i czynnik naśladowczy. W. Cockiewicz zestawia wyniki badań języka Telewizji Polskiej końca lat 70. pod przewodnictwem Zofii Kurzowej z zaobserwowanymi przez niego konstrukcjami pojawiającymi się w wiadomościach i programach publicystycznych i wysuwa zaskakujący dla niego wniosek, że w wypowiedziach dziennikarzy telewizyjnych analityzmy leksykalne występują sporadycznie lub prawie wcale. Obserwacja transmisji obrad Sejmu RP okazała się natomiast „prawdziwą kopalnią struktur opisowych”19.

Kontynuacją badań nad obecnymi w języku telewizji analityzmami zajęła się Iwona Loewe $\mathrm{e}^{20}$, skoncentrowała się na czasownikowych konstrukcjach analitycznych (zwanych przez badaczkę też czasownikowymi/werbalnymi/werbo-nominalnymi konstrukcjami analitycznymi, analityzmami, peryfrazami, kolokacjami), zdefiniowała je jako „kompozycję, która składa się z synsemantycznego bądź wtórnie synsemantycznego czasownika i rzeczownika abstrakcyjnego, który jest ekwiwalentem nominalnym werbalnego i pełnoznacznego odpowiednika tej

17 W. Cockiewicz, Konstrukcje analityczne w jezyku polskiej telewizji w latach siedemdziesiątych i dziś, [w:] Język w mediach masowych, red. J. Bralczyk, K. Mosiołek-Kłosińska, Warszawa 2000, s. 143-153.

18 Ibidem, s. 145.

19 Ibidem, s. 152.

20 I. Loewe, Konstrukcje analityczne w polskiej telewizji na progu drugiej dekady XXI wieku, „Stylistyka” 2010, s. 177-188. 
konstrukcji w leksykonie"21. Tym samym - podobnie jak W. Cockiewicz - odrzuciła warunek J. Anusiewicza o morfologicznym pokrewieństwie analityzmu i jego jednoleksemowego werbalnego w pełni semantycznego odpowiednika. I. Loewe dokonała analizy z uwzględnieniem podziału nadawców na instytucjonalnych i spoza instytucji, ale przez instytucję akceptowalnych. Zauważyła, że wciąż dominuje wtórnie synsemantyczny czasownik mieć, ale występuje w nowych - w porównaniu z badaniami W. Cockiewicza - połączeniach. Zwróciła także uwagę, iż dużą frekwencję w badanym korpusie mają kolokacje fazowe. Autorka dostrzegła tendencję zwyżkową występowania analityzmów w wypowiedzi telewizyjnej i podkreśliła nowe funkcje: demonstratywną, metajęzykową i stylizacyjną. Wysnuła także tezę - na podstawie znacznej przewagi w badanym materiale peryfraz nad uniwerbizmami - że „częstotliwość użycia analityzmów stoi w opozycji do opinii dość powszechnej o ekspansji potoczności w mediach jako cesze współcześnie dominującej”22.

Szczegółowe własności werbo-nominalnych konstrukcji analitycznych opisała I. Loewe w swojej książce zatytułowanej Konstrukcje analityczne w poezji Młodej Polski23. Zanalizowała „funkcje i możliwości stylistycznego wykorzystania peryfrastycznych jednostek w tekstach artystycznych”24. Zdaniem badaczki: „Predykat wyrażony analitycznie precyzyjniej oddaje treści, gdyż semantyka znaku jest rozłożona na dwa wzajemnie określające się elementy. Dysponuje zwielokrotnionym potencjałem ekspresywnym, oferuje bowiem możliwość rozbudowania zarówno elementu nominalnego, jak i werbalnego, stąd duża wariantywność struktur peryfrastycznych o różnym stopniu metaforyczności. O ile pełnoznaczny czasownik, będący w zdaniu orzeczeniem, w porządku składniowym tradycyjnie może być obudowany dopełnieniem i okolicznikiem, o tyle jednostka peryfrastyczna oprócz tych dwóch możliwości otwiera jeszcze miejsce na przydawkę"25. I. Loewe nadmieniła, iż istnieją problemy z terminologią - na określenie werbo-nominalnych jednostek analitycznych w funkcji predykatywnej używa się w polskich opracowaniach następujących terminów: multiwerbizmy, konstrukcje analityczne, struktury analityczne, analityzmy werbo-nominalne, analityczne czasowniki funkcjonalne,

\footnotetext{
21 Ibidem, s. 178.

22 Ibidem, s. 184.

23 I. Loewe, Konstrukcje analityczne w poezji Młodej Polski, Katowice 2000.

24 Ibidem, s. 7.

25 Ibidem, s. 10-11.
} 
orzeczenia peryfrastyczne w klasie zwrotów frazeologicznych, analityczne wykładniki predykatów, konstrukcje opisowe z czasownikiem funkcyjnym. Przyjęła ona następującą definicję: , analityzm werbo-nominalny jest jednostką planu wyrażania. Stanowi formalno-leksykalną realizację predykatu w postaci werbalizatora (którym jest synsemantyczny // operatorowy czasownik) oraz abstrakcyjnego rzeczownika. W porządku składniowym zdania analityzm werbo-nominalny pełni funkcję orzeczenia (orzeczenie tzw. peryfrastyczne, które wypełnia miejsce prymarnie przeznaczone dla jednoleksemowej finitywnej formy czasownika). Jego możliwym korelatem treściowym w systemie znaków werbalnych jest pełnoznaczny czasownik, semantycznie (i morfologicznie) tożsamy z elementem nominalnym"26. Badaczka poruszyła zagadnienie relacji między analityzmami a multiwerbizmami i frazeologizmami, odniosła się do kwestii predykacji peryfrastycznej jako zjawiska składniowego oraz typu leksyki analitycznej. Autorka zaznaczyła, że w obszarze jej badań znajdują się konstrukcje pokrewne semantycznie, niekoniecznie zaś morfologicznie, odrzuciła więc - podobnie jak W. Cockiewicz - substancjalną tożsamość postulowaną przez J. Anusiewicza. I. Loewe poddała oglądowi systemowe właściwości analityzmów werbo-nominalnych, zwróciła uwagę na relacje semantyczno-formalne wewnątrz pola peryfrastycznego (gniazda), naświetliła problem składni orzeczeń peryfrastycznych, zanalizowała ich możliwości tekstotwórcze, stawiając tezę, że „kollokacje ze względu na swoje właściwości formalnoskładniowe są niejednokrotnie manifestacją poetyckiej metaforyzacji pojęć, uszczegółowienia myśli, precyzowania detali kreowanej rzeczywistości"27. Rozważania teoretyczne uzupełnione są bogatym materiałem badawczym - I. Loewe szczegółowo prześledziła peryfrastykę werbo-nominalną w poezji Młodej Polski, którą podzieliła na trzy kręgi tematyczne: stany emocjonalne (uczucia), zjawiska naturalne (przyrodnicze) i doznania sensualne.

To, że konstrukcje analityczne nie są cechą charakterystyczną wyłącznie stylu publicystycznego czy urzędowego, ale pojawiają się także w tekstach artystycznych, I. Loewe starała się wykazać w artykule podejmującym temat analityzmów werbo-nominalnych w młodopolskim dekandentyzmie na podstawie pola stanów mentalnych ${ }^{28}$. Jak podkreślała badaczka, jej celem było znalezienie „konstrukcji

26 Ibidem, s. 13-14.

27 Ibidem, s. 37.

28 I. Loewe, Analityzmy werbo-nominalne a młodopolski dekadentyzm (na przykładzie pola stanów mentalnych), [w:] W kręgu języka polskiego. Śląsko-poznańskie kolokwia lingwistyczne, red. E. Jędrzejko, Katowice 2011, s. 131-150. 
werbo-nominalnych, których komponent rzeczownikowy ponosi ciężar znaczenia referencjalnego, a komponent czasownikowy wnosi do znaczenia analityzmu niebagatelne wartości, decydując o znaczeniu konotacyjnym i pragmatycznym"29. Autorka wskazała na relacje między analityzmami a poetyką Młodej Polski, szczegółowo omówiła peryfrazy odnoszące się do stanów mentalnych, przywołując liczne przykłady z młodopolskiej poezji.

Orzeczeniami peryfrastycznymi zainteresowała się również Grażyna Vetulani. W publikacji Kolokacje werbo-nominalne jako odrębne jednostki języka i ich zastosowanie ${ }^{30}$ podkreśliła, że są one „Związkami pośrednimi pomiędzy całkowicie potencjalnymi złożonymi formami morfologicznymi a konstrukcjami frazeologicznymi"31, pełnią w zdaniu funkcję orzeczenia i są wykładnikami jednego pojęcia. G. Vetulani wymieniła powody, dla których można traktować orzeczenia peryfrastyczne za specyficzne jednostki języka. Zastanawiała się, w jakich celach warto pozyskiwać kolokacje werbo-nominalne, wymieniła tu trzy główne grupy: badania leksykograficzne, dydaktyka języka polskiego i przekłady na język obcy. Poruszyła problem budowy hasła słownikowego odnoszącego się do omawianych jednostek, postulowała, by zestawienia takie były wprowadzane jako odrębne jednostki, przy czym ważne jest umieszczanie w słownikach informacji o zakresach łączliwości wyrazów. Zaznaczyła również, że w orzeczeniach peryfrastycznych często dochodzi do wymiany komponentu werbalnego, stąd zasadne byłoby odnotowywanie w opracowaniach leksykograficznych całych serii prezentujących różne odcienie znaczeniowe. „Zestawianie kolokacji werbo-nominalnych w rodziny może być bardzo cenne, gdyż w jasny sposób pokazuje bogactwo analitycznych form, wewnętrzne zróżnicowanie i wzajemne związki oraz cechy gramatyczne i pragmatyczno-stylistyczne"32. Badaczka zwróciła uwagę, że warto gromadzić materiał w postaci korpusów czy słowników elektronicznych, pokazała na wybranych przykładach, jak można pozyskiwać orzeczenia peryfrastyczne, wyszukując je za pomocą konkordancji.

Pierwszą pozycją próbującą w sposób leksykograficzny ująć kolokacje werbo-nominalne jest Słownik polskich zwrotów werbo-nominalnych. Zeszyt próbny pod

29 Ibidem, s. 133.

30 G. Vetulani, Kolokacje werbo-nominalne jako odrębne jednostki języka $i$ ich zastosowanie, [w:] W kręgu języka polskiego. Śląsko-poznańskie kolokwia lingwistyczne, red. E. Jędrzejko, Katowice 2011, s. 58-75.

31 Ibidem, s. 58.

32 Ibidem, s. 65. 
redakcją Ewy Jędrzejko ${ }^{33}$. Jest on rezultatem badań prowadzonych przez Ewę Jędrzejko, Iwonę Loewe i Piotra Żmigrodzkiego dotyczących „obecnych w systemie i tekstach współczesnej polszczyzny, częściowo lub całkowicie idiomatycznych konstrukcji o wartości pojedynczych znaków słownych"34. Autorzy, skupiając się na leksykograficznym ujęciu orzeczeń peryfrastycznych, podkreślają ich bogactwo, wewnętrzne zróżnicowanie i wzajemne związki, cechy gramatyczne i pragmatyczno-stylistyczne. „Omawiane konstrukcje tworzą we wszystkich językach rozległą sferę pogranicza między leksyką, frazeologią (idiomatyką) i składnią”35. Uczeni przywołują różne określenia nazywające badane jednostki, wymieniają ich cechy charakterystyczne (semantyczna wartość pełnoznacznego pojedynczego czasownika, wyrazista budowa - składnik werbalny i składnik imienny w formie rzeczownika abstrakcyjnego, zdolność pełnienia funkcji zdaniotwórczych, przysługiwanie gramatycznych kategorii werbalnych, możliwość tworzenia rodzin frazeologicznych). E. Jędrzejko wymienia kryteria, które muszą zostać spełnione, aby zaistniała synonimia funkcjonalna jednostki syntetycznej i analitycznej. Analizując specyfikę składniową jednostek peryfrastycznych, dochodzi do wniosku, że „leksyka analityczna wytwarza własny system walencji, odmienny - mimo podobieństw - w stosunku do «zwykłych» czasowników, które mogą je synonimizować"36. Podejmuje także próbę typologii czasowników analitycznych. Drugą część omawianej publikacji stanowi słownik struktur werbo-nominalnych zawierający 50 haseł - rzeczowników abstrakcyjnych nazywających zdarzenia wyrażane peryfrastycznie.

E. Jędrzejko ${ }^{37}$ zauważa, że trudno jest jednoznacznie wyróżniać, klasyfikować i opisywać leksykę analityczną, jednocześnie wskazuje na potrzebę wszechstronnego opisu, jako powody podając „znaczący (większy i bardziej zróżnicowany, niż się to powszechnie sądzi) udział tych jednostek w systemie i tekstach, a także skomplikowane mechanizmy ich tworzenia oraz swoiste cechy «perintegracji» semantycznej wewnątrz takich związków, właściwa im składnia i łączliwość «ze-

33 Słownik polskich zwrotów werbo-nominalnych. Zeszyt próbny, red. E. Jędrzejko, Warszawa 1998.

34 Ibidem, s. 7.

35 Ibidem, s. 8.

36 Ibidem, s. 36.

37 E. Jędrzejko, „Stary” problem - nowe (?) możliwości. Uwagi o analityczności w słowniku i wariancji mechanizmów znakotwórczych, [w:] Nowe czasy, nowe języki, nowe (i stare) problemy, red. E. Jędrzejko, Katowice 1998, s. 146-161. 
wnętrzna», zdolność generowania nowych wariantów o istotnej komunikatywnie wartości metaforycznej i ekspresywnej"38. Oparcie się na założeniach kognitywizmu pozwala wyjaśnić metaforyczność kolokacji werbo-nominalnych. Badaczka koncentruje się na czterech zasadniczych problemach: potrzebie uściślenia pojęcia analityczności, opisie procesu generującego orzeczenia peryfrastyczne i zakres wariancji, zbadaniu relacji między leksyką analityczną a jej odpowiednikami syntetycznymi ${ }^{39}$, własnościach formalnych konstrukcji analitycznych oraz regułach składniowych i wzorcach zdań minimalnych.

Istniejące zarówno w przeszłości, jak i w polszczyźnie współczesnej konstrukcje analityczne mające jednowyrazowe odpowiedniki czasownikowe znalazły się w kręgu rozważań w kolejnym artykule E. Jędrzejko ${ }^{40}$. Autorka zestawiła obecne peryfrazy z tymi odnotowanymi w słowniku Lindego. Dostrzegła zmiany kształtu i znaczenia, zachowanie znaczenia, ale ze zmianą składu leksykalnego, wymianę członu czasownikowego lub rzeczownikowego, szczątkowe tylko zachowanie konstrukcji długoseryjnych, desemantyzację członu werbalnego, leksykalizację całej konstrukcji peryfrastycznej. Trudności może sprawiać odczytanie właściwego znaczenia używanych w przeszłości kolokacji werbo-nominalnych, a co za tym idzie - ustalanie relacji synonimicznych. Nie wiadomo także, czy istniał paralelizm między analityzmem a odpowiadającym mu syntetyzmem i jaki był kierunek derywacji morfologicznej. Badaczka polemizuje ze stwierdzeniem, że „analityzmy werbo-nominalne są osobliwym zjawiskiem współczesnej polszczyzny oraz że źródłem tej tendencji analityzacji miałby być wpływ cywilizacji zachodu i języków obcych"41. Stawia tezę, że „wolno w nich [konstrukcjach analitycznych - przyp. KB] widzieć zjawisko systemowe i przykład wariantywności

38 Ibidem, s. 147.

39 Jako kryteria synonimii funkcjonalnej jednostki analitycznej i syntetycznej E. Jędrzejko wyróżnia: możliwość wzajemnej wymienialności w danym kontekście zdaniowym; możliwość pełnienia tej samej funkcji składniowej w planie formalnym; tożsamość hipotetycznej struktury wyjściowej w planie treści; tożsamość składników eksplikacyjnych członu imiennego, wspólnych także dla innych elementów danego pola leksykalno-pojęciowego. Zdaniem badaczki pełna synonimia między analitycznym czasownikiem a jego syntetycznym korelatem praktycznie nie istnieje.

40 E. Jędrzejko, Konstrukcje analityczne $w$ historii polszczyzny - zarys problematyki, [w:] Słowo i czas, red. S. Gajda, A. Pietryga, Opole 1998, s. 37-47.

41 Ibidem, s. 40. 
a także aktywności potencjału znakotwórczego polszczyzny w całej jej historii”42. Mechanizm powstawania tych jednostek pozostaje względnie stały, zmieniał się tylko inwentarz. Są one obecne w różnych językach, rzadko jednak znajdują się w centrum badań, zwłaszcza w aspekcie historycznym. Zainteresowanie strukturami analitycznymi wykazuje frazeologia, gdyż „większość z nich ma charakter dobrze utrwalonych w języku jednostek nieciągłych, których globalne znaczenie nie zawsze jest prostą sumą swoich składników, ma natomiast charakter metafor pojęciowych"43. E. Jędrzejko dwojako ujmuje mechanizm językowy generujący analityczne jednostki słownika werbalnego: „jako jednostopniowy proces bezpośredniej werbalizacji predykatu (= jednostki poziomu pojęciowego) za pomocą środków leksykalno-składniowych oraz jako proces dwustopniowy, który polega na wtórnej werbalizacji predykatu uprzednio znominalizowanego" 44 .

E. Jędrzejko poświęciła predykacji werbo-nominalnej także publikację pt. Problemy predykacji peryfrastycznej. Konstrukcje - znaki-pojęcia 45 , która była podsumowaniem wydanego cztery lata wcześniej Słownika polskich zwrotów werbo-nominalnych. Zeszytu próbnego. Omówiła badane zjawisko w ujęciu gramatyk generatywnych i niegeneratywnych, przedstawiła stan badań nad predykacją werbo-nominalną w językach słowiańskich, ujęła predykaty peryfrastyczne na tle frazeologii i w aspekcie stylistycznym. Opisała różne formy, funkcje i konceptualizacje analityzmów werbo-nominalnych, a także prześledziła ich losy w historii języka polskiego. Jak zaznaczyła we wstępie, stawiała „pytania o status i zasady kwalifikacji znaków predykacji analitycznej (peryfrastycznej), o stosunki semantyczne między AWN ${ }^{46}$ a syntetycznym czasownikiem, o relacje w obrębie różnych gniazd peryfrastycznych" 47 . Interesowały ją też stylistyczno-pragmatyczne właściwości tego rodzaju peryfrastyki oraz jej funkcje w różnych dyskursach, przede wszystkim artystycznym.

Szczegółowej analizie przez uczonych z Uniwersytetu Śląskiego poddane zostały kolokacje werbo-nominalne nazywające poszczególne uczucia (należące do

42 Ibidem.

43 Ibidem, s. 42.

44 Ibidem, s. 43.

45 E. Jędrzejko, Problemy predykacji peryfrastycznej. Konstrukcje - znaki - pojęcia, Katowice 2002.

46 Skrótowcem tym oznacza się w wielu opracowaniach analityzmy werbo-nominalne.

47 E. Jędrzejko, Problemy predykacji peryfrastycznej..., s. 14. 
grupy strachu czy opisujące pozytywne stany emocjonalne), a także łączące się z należącymi do tego samego pola znaczeniowego predykatami chęć, ochota, pragnienie, żądza. Agnieszka Karaś i Ewa Nowak ${ }^{48}$ zastanawiały się, z jakimi składnikami werbalnymi mogą łączyć się rzeczowniki abstrakcyjne o charakterze wolitywnym; celem autorek było „ustalenie, czy zachodzi związek między znaczeniem predykatów a repertuarem dopuszczonych przez nie werbalizatorów"49. Pierwsza $\mathrm{z}$ wymienionych badaczek w samodzielnym artykule obserwowała przebieg procesu konceptualizacji uczuć z grupy strachu (niepokój, obawa, lęk, strach, przestrach, przerażenie, trwoga, panika) w konstrukcjach analitycznych ${ }^{50}$, druga zaś zajęła się uczuciami pozytywnymi wyrażanymi za pomocą analityzmów werbo-nominalnych ${ }^{51}$. Przedstawiła klasyfikację omawianych jednostek ze względu na funkcję semantyczną, jaką pełnią w nich czasowniki. W części materiałowej przywołała bazowe formy analityzmów, omówiła konstrukcje: kauzatywne, zawierające informacje temporalne, określające sposób przeżywania uczucia, z parametrami akcesoryjnymi, modalne, przekształcenia semantyczno-formalne i antonimy. Ta sama uczona (publikująca już pod nazwiskiem Ewa Ulitzka) kontynuowała badania nad czasownikowo-rzeczownikowymi kolokacjami odwołującymi się do pozytywnych stanów emocjonalnych (radość, wesołość, uciecha, euforia, zadowolenie, szcześsie ${ }^{52}$, zastanawiając się m.in. nad tym, jakie dodatkowe treści modyfikujące znaczenie wnosi czasownik do peryfrazy. Doszła do konkluzji, że posługiwanie się konstrukcjami werbo-nominalnymi do opisania uczuć z kręgu radości „otwiera o wiele więcej możliwości ekspresji treści semantycznych, stylistycznych i metaforycznych niż nazywanie tych zdarzeń poprzez czasowniki syntetyczne"53. Przedstawiła ogólną charakterystykę opisywanych

48 A. Karaś, E. Nowak, Znaczenie predykatu a wybór werbalizatora $w$ konstrukcjach analitycznych (na przykładzie konstrukcji z predykatami chęć, ochota, pragnienie, żadza), „Poradnik Językowy” 1999, z. 1, s. 11-20.

49 Ibidem, s. 13.

50 A. Karaś, Językowa konceptualizacja uczuć z grupy strachu na podstawie konstrukcji werbo-nominalnych, „Poradnik Językowy” 2003, z. 4, s. 27-35.

51 E. A. Nowak, Opis semantyczny analitycznych konstrukcji werbo-nominalnych (na przykładzie AWN oznaczajacych wybrane uczucia pozytywne), „Polonica” 2000, t. XXI, Kraków, s. 25-49.

52 E. Ulitzka, Polskie werbo-nominalne konstrukcje analityczne oznaczajace pozytywne stany emocjonalne ( $z$ rzeczownikami radość, wesołość, uciecha, euforia, zadowolenie, szczęście), „Roczniki Humanistyczne” 2004, t. LII, z. 6, s. 113-148.

53 Ibidem, s. 124. 
predykatów, syntetyczne odpowiedniki peryfrastycznych konstrukcji czasownikowych, semantyczny opis analityzmów w ramach koncepcji parametrów semantycznych i formalnych, analizowała relacje między znaczeniem rzeczownika a doborem werbalizatora, opisała je także z kognitywnego punktu widzenia.

Piotr Żmigrodzki badał możliwości opisu analityzmów werbo-nominalnych w ramach modelu gramatyki transformacyjno-generatywnej ${ }^{54}$, zajął się również ich oddziaływaniem na inne składniki wypowiedzenia, rozpatrując dwa aspekty: stosunek formalnoskładniowych cech AWN do cech ich odpowiedników syntetycznych oraz do cech ich składników ${ }^{55}$. Szersze rozważania przyniosła publikacja książkowa tego autora zatytułowana Właściwości składniowe analitycznych konstrukcji werbo-nominalnych w języku polskim ${ }^{56}$. Analizując zagadnienia teoretyczno-metodologiczne, badacz przedstawił funkcjonowanie analityzmów czasownikowo-rzeczownikowych w różnych koncepcjach składniowych, ich obecność w słownikach oraz miejsce w modelu gramatyki. Zbadał także strukturę frazową omawianych jednostek, ich składnię zewnętrzną, a podczas analizy składu analityzmów werbo-nominalnych zwrócił uwagę na dystrybucje i funkcje werbalizatorów, podjął próbę usystematyzowanego opisu czasowników operatorowych.

Porównania polskich, serbsko-chorwackich i macedońskich złożonych konstrukcji predykatywnych z parafrazą przymiotnikową dokonała Jolanta Mindak 57 . Stworzyła ona uniwersalny semantyczny model klasyfikacji predykatów (ze względu na cechę, stan i zdarzenie) i reprezentujących je wyrażeń predykatywnych. Autorka zastanawiała się nad miejscem omawianych jednostek ${ }^{58} \mathrm{w}$ językowym systemie predykcyjnym. Analizie poddała ich budowę, łączliwość semantyczną, leksykalną i morfo-syntaktyczną komponentów wchodzących w skład tych konstrukcji, a także rolę, jaką odgrywają w procesie komunikacji językowej.

54 P. Żmigrodzki, Strukturyzacja analityzmów werbo-nominalnych w modelu gramatyki generatywnej, „Polonica” 1998, t. XIX, Kraków, s. 49-66.

55 P. Żmigrodzki, Oddziaływanie analitycznych konstrukcji werbo-nominalnych na inne składniki zdania, „Poradnik Językowy” 1998, z. 7, s. 1-16.

56 P. Żmigrodzki, Właściwości składniowe analitycznych konstrukcji werbo-nominalnych w języku polskim, Katowice 2000.

57 J. Mindak, Peryfrastyczne konstrukcje predykatywne z parafraza przymiotnikowa (na materiale polskim, serbsko-chorwackim i macedońskim), Wrocław-WarszawaKraków-Gdańsk-Łódź 1983.

58 Zwanych przez J. Mindak konstrukcjami typu $\mathrm{V}_{\mathrm{s}} \mathrm{N}$, gdzie $\mathrm{V}_{\mathrm{s}}$ to komponent werbalny, $\mathrm{N}$ to komponent nominalny. 
Rozważania na temat definicji konstrukcji z czasownikiem funkcyjnym występujących w języku rosyjskim prowadził Klaus Hartenstein ${ }^{59}$, opierając się na literaturze niemieckiej i radzieckiej. Próbował ustalić zakres tego pojęcia, bazując na kryteriach: syntaktycznym, semantycznym i frazeologicznym.

Językoznawcy zajmowali się także analityzmami występującymi w konkretnych odmianach stylistycznych polszczyzny, np. Agnieszka Sieradzka-Mruk60 obserwowała konstrukcje obecne w stylu liturgicznym (na podstawie przykładów z polskiego przekładu Mszału rzymskiego), zastanawiała się nad przyczynami ich występowania, funkcjami w tekście religijnym oraz konsekwencjami częstego użycia, z kolei I. Loewe ${ }^{61}$ omówiła strukturę, semantykę i funkcje analitycznych konstrukcji czasownikowych w poezji Kazimierza Przerwy-Tetmajera, traktując je jako jeden ze sposobów metaforyzowania. W centrum jej rozważań stała „stylistyczna konsekwencja wyboru formy peryfrastycznej zamiast syntetycznej"62.

Nie tylko konstrukcje czasownikowe były przedmiotem opisu językoznawców. D. Buttler w jednym z artykułów ${ }^{63}$ opublikowanych na łamach „Poradnika Językowego" w cyklu Semantyka a składnia w związkach wyrazowych w latach 60. ubiegłego wieku rozważała zagadnienia związane z ekspansją konstrukcji przyimkowych: szczegółowe przyczyny tego procesu, jego mechanizm i następstwa. Wśród semantycznych przyczyn wzrostu liczby owych analityzmów wymieniła analogię synonimiczną, rozluźnienie więzi słowotwórczo-znaczeniowych derywatów i ich podstaw oraz leksykalizację struktury wyrazów. Wszystkie one współdziałają z tendencją do usuwania wieloznaczności. Czynnikiem formalno-konstrukcyjnym jest dążenie do skrótu - część konstrukcji przyimkowych powstaje w wyniku elipsy; zdania złożone podrzędnie okolicznikowe zastępowane

59 K. Hartenstein, Konstrukcje z czasownikiem funkcyjnym (opisowe) we wspótczesnym języku rosyjskim - rozważania na temat definicji, [w:] Współczesna polszczyzna mówiona w odmianie opracowanej (oficjalnej), red. Z. Kurzowa, W. Śliwiński, Kraków 1994, s. 45-63.

60 A. Sieradzka-Mruk, Konstrukcje analityczne we wspótczesnym polskim stylu liturgicznym, „Język Polski” 2012, s. 194-203.

61 I. Loewe, Konstrukcje analityczne wśród metafor (struktura, semantyka, funkcja analityzmów w poezji K. Przerwy-Tetmajera), „Poradnik Językowy” 1996, z. 7, s. $42-52$.

62 Ibidem, s. 44.

63 D. Buttler, Semantyka a składnia w zwiazkach wyrazowych. V. Ekspansja konstrukcji analitycznych, „Poradnik Językowy” 1967, z. 1, s. 6-18. 
są przez wyrażenia złożone z przyimka i rzeczownika odsłownego. Przybliżając mechanizm ekspansji struktur analitycznych, badaczka zwróciła uwagę na zmiany w zakresie przypadków adwerbalnych (narzędnik, celownik), grup nominalnych (dopełniacz). Następstwami rozprzestrzeniania się są rozgraniczenie zakresu znaczeniowego dubletów konstrukcyjnych, przesunięcia zakresu użycia i funkcji szczególnie ekspansywnych przyimków.

D. Buttler, omawiając innowacje składniowe współczesnej polszczyzny ${ }^{64}$, przyjrzała się także ekspansji związków analitycznych. Zauważyła skłonność do zastępowania syntetycznych form przypadkowych połączeniami przyimka z odpowiednią formą fleksyjną rzeczownika. Podkreśliła, że analityzmy są wyrazem tendencji do precyzji. „Szerzenie się konstrukcji z przyimkami doprowadza do znacznego ograniczenia wielofunkcyjności, a zatem i nieprecyzyjności tradycyjnych przypadków syntetycznych" 65 , pojawiają się więc tam, gdzie syntetyzm jest zbyt ogólnikowy. Podkreśliła, iż tendencja do analityczności obejmuje także połączenia sfrazeologizowane, co świadczy o jej dużym zasięgu. Źródeł popularności tego zjawiska dopatrywała się również w dążności do skrótu. Omówiła typowe mechanizmy powstawania związków przyimkowych, zauważyła, że proces ten dotyczy zwłaszcza rzeczowników.

Stylistycznym i semantycznym opisem przymiotnikowych i przysłówkowych konstrukcji analitycznych w prasie zajęła się Ewa Pokorska-Szczodruch66. Doprecyzowała ona definicję J. Anusiewicza, stwierdzając, że pomiędzy analitycznym przymiotnikiem lub przysłówkiem a jego syntetycznym odpowiednikiem widoczne są często przesunięcia znaczeniowe, nie zawsze też formy opisowe mają jednowyrazowy ekwiwalent. Zauważyła, że „struktury należące do tego samego typu analityzmu zależnie od konkretnego użycia, otoczenia leksykalnego i kontekstu wnoszą często różne cechy stylistyczne"67, różniące się rodzajem oficjalności. Tworzenie konstrukcji analitycznych często prowadzi do procesu terminologizacji. Multiwerbizmy sprzyjają wartościowaniu, w przypadku form oficjalnych mają one zabarwienie pozytywne, potoczne zaś nacechowane są pejoratywnie.

64 D. Buttler, Innowacje składniowe współczesnej polszczyzny (Walencja wyrazów), Warszawa 1976.

65 Ibidem, s. 84.

66 E. Pokorska-Szczodruch, Przymiotnikowe i przysłówkowe konstrukcje analityczne w tekstach prasowych. Opis stylistyczny i semantyczny, „Poradnik Językowy” 2006, z. 10, s. 103-110.

67 Ibidem, s. 104. 
Rzadko występują analityzmy przysłówkowe i przymiotnikowe neutralne stylistycznie. Formy złożone „nie są w pełni ekwiwalentne treściowo ze swymi odpowiednikami” 68 , wzmacniają treść przymiotnika bądź przysłówka, czasem są niemal identyczne znaczeniowo, innym razem dodatkowy element wprowadza nowy składnik znaczeniowy. „Przymiotnikowe i przysłówkowe multiwerbizmy są wyraźnym przejawem tendencji do precyzji. Zdarza się, że wykluczają one dwuznaczność lub nawet wieloznaczność formy prostej"69.

Maria Lesz-Duk w artykule Przejście konstrukcji syntetycznych $w$ analityczne $e^{70}$ zainteresowała się przekształcaniem konstrukcji bezprzyimkowych (dopełnienia, okoliczniki, przydawki kazualne) w przyimkowe. Autorka pokazała na wybranych przykładach, w jakim stopniu i z jakich powodów dopełnienia dopełniaczowe, celownikowe, biernikowe i narzędnikowe uległy ekspansji struktur przyimkowych, wskazała też, w jakich sytuacjach wciąż są używane. Opisała ograniczenia lub nawet całkowity zanik użycia bezprzyimkowego okolicznika czasu, miejsca, sposobu, miary, przyczyny, celu, a także przydawki dopełniaczowej i celownikowej. Badaczka doszła do wniosku, że najczęściej przekształceniom w konstrukcje analityczne ulegają okoliczniki, rzadziej dopełnienia i przydawki. Najwcześniej zanikł bezprzyimkowy miejscownik. Przez struktury analityczne nie jest zastępowany mianownik, rzadko wypierany jest biernik, często natomiast dopełniacz. Proces ten nie przebiega harmonijnie, jest niezwykle powolny. Ekspansja struktur przyimkowych datowana jest na XVIII w.

Zagadnienie analityzmów przyimkowych omówiła też Monika Jabłońska, w centrum jej badań znalazły się „nieakceptowane przez normę wzorcową przyimkowe konstrukcje analityczne, będące wynikiem przeobrażeń walencji wyrazów"71. Autorka zastanawiała się, które syntetyzmy są najbardziej podatne na przekształcenia oraz co jest konsekwencją takich zmian. „Każda konstrukcja zawiera rzeczownik, czasownik, przymiotnik lub przysłówek w pozycji nadrzędnej oraz rzeczownik w pozycji podrzędnej. Oba człony połączone są

68 Ibidem, s. 107.

69 Ibidem, s, 108.

70 M. Lesz-Duk, Przejście konstrukcji syntetycznych $w$ analityczne, "Język Polski” 1985, z. 3, s. 157-171.

71 M. Jabłońska, Nowe przyimkowe konstrukcje analityczne w języku polskim, [w:] Ruch w języku - jezzyk w ruchu, red. K. Liszczyk-Kubina, M. Maciołek, Katowice 2012, s. 49. 
przyimkiem"72. Badaczka wykazała, że przeobrażeniom podlegają najczęściej konstrukcje zawierające rzeczownik w dopełniaczu, na kolejnych miejscach znalazły się konstrukcje biernikowe i miejscownikowe, tylko wyjątkowo przekształca się celownikowe i narzędnikowe - co można wiązać z rzadkim używaniem tych przypadków.

Konstrukcje analityczne doczekały się także ujęcia komparatywnego, porównania analityzmów polskich i słowackich podjęła się Halina Mieczkowska ${ }^{73}$. Oba języki uważane są za syntetyczne, co jednak nie przeszkadza w szerzeniu się złożonych jednostek leksykalnych w celu „zapewnienia wyższego stopnia precyzji wypowiedzi i efektywności komunikatu językowego ${ }^{74 " . ~ I s t o t n e ~ s a ̨ ~ t a k z ̇ e ~ w z g l e ̨ d y ~}$ stylistyczne. Struktury analityczne pojawiają się zarówno w odmianach specjalistycznych, jak i leksyce neutralnej. Do przyczyn pozajęzykowych można zaliczyć rozwój środków masowego przekazu i związane z tym pojawianie się słownictwa specjalistycznego z zakresu nowoczesnych technologii. Badaczka wymieniła wspólne dla obu języków kręgi tematyczne, w których udział słownictwa analitycznego jest znaczący, a także różnice pod względem występowania i budowy. H. Mieczkowska stawia „wstępną tezę o wyższym stopniu analityzmu w języku polskim"75. Wspomina o cykliczności zmian językowych: od analityzmu do syntetyzmu i od syntetyzmu do analityzmu. Sporą grupę analitycznych konstrukcji w obu omawianych językach stanowią hybrydy odwołujące się do zapożyczeń, zwłaszcza z języka angielskiego.

Autorem monografii poświęconej leksykalnym konstrukcjom syntetycznym jest Jan Miodek ${ }^{76}$. Mianem tym określił „takie nowe formacje słowotwórcze (utworzone za pomocą różnego rodzaju formantów), w których dochodzi do zastąpienia połączeń dwu- lub kilkuwyrazowych jednym określeniem"77. Są one rezultatem kondensacji formalnej i znaczeniowej mniej lub więcej rozbudowanych grup syntaktycznych. Uczony zwrócił uwagę na mniejszą precyzję syntetyzmów w porównaniu ze związkami wielowyrazowymi. Przedmiotem opisu uczynił „wszelkie odpowiedniki znaczeniowe nie wypartych z ogólnego języka

72 Ibidem, s. 50.

73 H. Mieczkowska, Analityzmy leksykalne w ujęciu słowacko-polskim, „Studia z Filologii Polskiej i Słowiańskiej” 2006, t. 41, Warszawa 2006, s. 177-190.

74 Ibidem, s. 179.

75 Ibidem, s. 184.

76 J. Miodek, Syntetyczne konstrukcje leksykalne w języku polskim, Wrocław 1976.

77 Ibidem, s. 6. 
konstrukcji opisowych, powstałe drogą derywacji"78, pominął zaś te konstrukcje syntetyczne, które zostały utworzone w wyniku elipsy. Jako najmniej skomplikowany przykład procesu o charakterze syntetycznym wymienił uniwerbizację. Jak podkreślał badacz, „głównym celem pracy jest wydzielenie modelowych typów połączeń wyrazowych, z których - w rezultacie procesu syntetyzującego - powstają jednowyrazowe określenia, uchwycenie mechanizmu powstawania nowych wyrazów polszczyzny"79. J. Miodek dokonał podziału zgromadzonego materiału ze względu na to, w jakiej odmianie języka występuje: potocznej, naukowej, artystycznej oraz prasie, radiu i telewizji. W każdej z nich wyróżnił konstrukcje rzeczownikowe nieosobowe i osobowe, przymiotnikowe i czasownikowe. Uwypuklił komunikatywne oraz estetyczno-emocjonalne funkcje realizowane przez analizowane komponenty.

Na proces uniwerbizacji jako przejaw tendencji do skrótu w słowotwórstwie zwróciły uwagę autorki Kultury języka polskiego ${ }^{80}$. Podkreśliły podwójną kondensację - formalną i semantyczną - form zuniwerbizowanych, zaznaczyły, że jednowyrazowe konstrukcje są synonimicznymi odpowiednikami wielowyrazowych połączeń, a ich „koegzystencja trwa na zasadzie rozdzielenia zakresów występowania obu typów struktur"81. Do trzech najbardziej produktywnych formantów tworzących uniwerbizmy zaliczyły -owiec, -ówka i -ak, ich występowanie przypisane jest do różnych odmian stylistycznych języka polskiego (-owiec ma wartość neutralną, -ówka pojawia się w nazwach o charakterze środowiskowym, -ak zaś używany jest w gwarze miejskiej i młodzieżowej).

Szczegółowej charakterystyki struktur zuniwerbizowanych dokonała D. Buttler w artykule Niektóre problemy opisu zjawisk uniwerbizacji ${ }^{2} 2$. Wskazała, że proces ten może odnosić się do rzeczowników, czasowników, przymiotników i przysłówków, najczęściej pojawia się w pierwszej grupie, najrzadziej zaś - w ostatniej. Definiując zjawisko, badaczka wskazała: „Uniwerbizacja - to przekształcenie nazw wielowyrazowych (najczęściej: dwuwyrazowych) w jednowyrazowe za pomocą różnorodnych zabiegów formalnych. Mogą one doprowadzać: 1) do

78 Ibidem, s. 8.

79 Ibidem, s. 9.

80 D. Buttler, H. Kurkowska, H. Satkiewicz, Kultura języka polskiego. Zagadnienia poprawności gramatycznej, Warszawa 1971.

81 Ibidem, s. 93.

82 D. Buttler, Niektóre problemy opisu zjawisk uniwerbizacji, „Slavistična revija” 1977, nr 25, s. 435-448. 
zespolenia dawniej samodzielnych członów nazwy złożonej w jeden leksem; 2) do redukcji składników nazwy wielowyrazowej aż do przybrania przez nią postaci jednego wyrazu"83. Wśród mechanizmów przekształcania nazw wielowyrazowych w pojedyncze leksemy wymieniła: derywację sufiksalną, elipsę, kompozycję, dezintegrację, skrót i adideację; wnikliwie je omówiła, ilustrując przykładami odwołującymi się do różnych kategorii. D. Buttler poruszyła także problem kryteriów pozwalających wyodrębniać uniwerbizmy z serii neologizmów innego rodzaju. Zastanawiała się także, w jaki sposób dokonywać analizy porównawczej zjawisk kondensacyjnych w kilku pokrewnych językach. Na płaszczyźnie środków formalnych może wystąpić identyczność struktur tworzonych tymi samymi formantami bądź odmienność struktur, przy jednoczesnym podobieństwie ogólnego mechanizmu ich powstawania w porównywanych językach ${ }^{84}$. Istotne jest również stwierdzenie, czy w przypadku identycznych form mamy do czynienia z niezależnym mechanizmem, kalką czy może przejęciem z tego samego źródła, a także określenie wartości stylowej i ekspresywnej uniwerbizmów. Warte konfrontacji byłyby mechanizmy uniwerbizacji wykorzystywane w badanych językach, a także umiejscowienie tego zjawiska na tle ogólnych tendencji onomazjologicznych.

Omawiając słownictwo polszczyzny powojennej85, D. Buttler wymieniła uniwerbizację jako najbardziej typowe zjawisko służące kondensacji treści. Podkreśliła powszechność form zuniwerbizowanych w rejestrze potocznym oraz ich ekonomię. Celom tym służy również wybieranie „struktur, które pod względem zawartości informacyjnej stanowią odpowiednik połączeń dwuwyrazowych, a nawet dłuższych opisów"86, np. przymiotniki z formantem -alny, pochodzące od nich rzeczowniki, zwłaszcza zaprzeczone, czasowniki z formantem -izować i pochodzące od nich rzeczowniki na -acja, rzeczowniki z formantem -ość czy tworzenie rzeczowników prefiksalnych. Wśród negatywnych skutków kondensacji wymieniła powstawanie wyrazów zbyt rozbudowanych, tworzenie nazw nieprecyzyjnych, dwuznacznych, ogólnikowych. By zapobiec wieloznaczności, wprowadzane są struktury analityczne, zjawisko multiwerbizacji szczególnie czę-

83 Ibidem, s. 437.

84 Ibidem, s. 444.

85 D. Buttler, Tendencje rozwojowe $w$ zasobie słownym powojennej polszczyzny, [w:] Współczesna polszczyzna. Wybór zagadnień, praca zbiorowa pod red. H. Kurkowskiej, Warszawa 1986, s. 187-219.

86 Ibidem, s. 216. 
sto obecne jest w kategorii czasowników. Badaczka zapowiadała dalsze współwystępowanie tendencji do ekonomii i analityczności.

D. Buttler w artykule Procesy multiwerbizacji we współczesnej polszczyźnie 87 przyglądała się pojęciom uniwerbizacji i multiwerbizacji, zwracając uwagę na relacje zachodzące pomiędzy wymienionymi procesami. Zauważyła: „Zasadnicza zbieżność między przebiegiem uniwerbizacji i multiwerbizacji polega na tym, że powstałe w ich wyniku nowe wyrazy zaczynają funkcjonować obocznie do tradycyjnych struktur nominatywnych" 88 oraz „stanowią one mechanizm nie tylko strukturalnej, ale i stylistycznej transpozycji nazw"89. Podkreśliła odmienność stylową i emocjonalną powstałych jednostek leksykalnych: w przypadku uniwerbizmów mamy do czynienia z przejściem z wyrazów neutralnych do odmian mówionych: potocznych, środowiskowych lub profesjonalnych, z kolei efektem multiwerbizacji jest słownictwo zaliczające się do stylów pisanych - zwłaszcza urzędowego i naukowego. Badaczka zaznaczyła różnice strukturalne, podkreślając skrótowość, ale i nieprecyzyjność, wieloznaczność, a nawet homonimiczność uniwerbizmów. D. Buttler postulowała założenie tożsamości znaczeniowej i leksykalnej morfemu głównego multiwerbizmu i morfemu głównego nazwy prostej. Starała się umieścić termin multiwerbizacja na tle pojawiającego się w polskich opracowaniach synonimicznego zjawiska leksykalna konstrukcja analityczna, tłumaczyła, w jaki sposób odróżnić multiwerbizmy od luźnych grup syntaktycznych i stałych związków frazeologicznych, zaliczając je do klasy pośredniej.

Halina Satkiewicz w opublikowanym w „Poradniku Językowym” szkicu Budżetówka, Krajówka, zbrojeniówk $a^{90}$ poddała analizie konstrukcje $\mathrm{z}$ formantem -(ów)ka, które są przeważnie rezultatem uniwerbizacji. Mechanizm powstawania takich wyrazów jest już zakorzeniony w polszczyźnie, posługiwanie się nimi wzbudza jednak wątpliwości poprawnościowe niektórych użytkowników z racji przynależności do polszczyzny potocznej. Formy te charakteryzują się ekonomicznością, co jednak przyczynia się do utraty „neutralności, która następuje

87 D. Buttler, Procesy multiwerbizacji we współczesnej polszczyźnie, „Poradnik Językowy" 1978, z. 2, s. 54-62.

88 Ibidem, s. 54.

89 Ibidem.

90 H. Satkiewicz, Budżetówka, Krajówka, zbrojeniówka, „Poradnik Językowy” 1993, z. 6, s. 371-374. 
w wyniku przeciwstawienia nowego derywatu, charakterystycznego dla swobodnych kontaktów językowych, jego odpowiednikowi oficjalnemu"91.

Zagadnieniu uniwerbizmów pojawiających się w prasie w drugiej połowie XX w. poświęcił swój artykuł Artur Rejter ${ }^{92}$. Obserwował on konstrukcje syntetyczne w dwóch okresach: 1972-1981 i 1993-2000, wybór tego typu leksyki motywował następująco: „Z jednej strony bowiem odzwierciedla tendencję do ekonomizacji środków językowych, z drugiej natomiast - daje świadectwo kreatywności języka oraz jego potencjału słowotwórczego"93. Zastanawiał się, których obszarów semantycznych dotyczy słownictwo zuniwerbizowane, który typ formalny jest najczęściej wykorzystywany, a także jakie czynniki kulturowe wpływają na zmiany w tym obszarze. Rozważania ilustrował przykładami uniwerbizmów pochodzących z omawianych etapów, przywołał jednostki odnoszące się do szeroko rozumianego życia społecznego (zarówno łatwe w deszyfracji, jak i wymagające kontekstu do prawidłowego odczytania), potoczne, specjalistyczne, środowiskowe, związane z określonym etapem rozwoju polszczyzny, okazjonalizmy. Popularność uniwerbizacji w polszczyźnie medialnej tłumaczył ekonomicznością i pojemnością semantyczną, za najpowszechniejszy typ formalny uznał sufiksację. Zwrócił uwagę na koegzystencję leksemów zuniwerbizowanych i ich analitycznych odpowiedników.

Ten sam badacz zainteresował się także procesami kondensacyjnymi w historii języka polskiego ${ }^{94}$. Analizując uniwerbizację jako proces historycznojęzykowy, skoncentrował się na zakresie zarówno pojęcia, jak i zjawiska, przyczynach i skutkach procesu, a także semantycznym i stylistycznym wymiarze uniwerbizmów. A. Rejter opowiedział się za procesualnym rozumieniem uniwerbizacji, „nie ograniczając zakresu uniwerbizmów do ekwiwalentów konstrukcji opisowych współwystępujących w języku w tym samym przekroju synchronicznym"95. Jak stwierdził: „uniwerbizm w perspektywie historycznojęzykowej zatem będzie często leksemem, który zastąpił strukturę analityczną występującą w polszczyźnie

\section{Ibidem, s. 372.}

92 A. Rejter, Uniwerbizmy w języku prasy drugiej połowy XX wieku. Próba analizy diachronicznej, [w:] Wokół słów i znaczeń, t. 4: Słowotwórstwo a media, red. E. Badyda, J. Maćkiewicz, E. Rogowska-Cybulska, Gdańsk 2011, s. 307-317.

93 Ibidem, s. 308.

94 A. Rejter, Uniwerbizacja jako proces historycznojęzykowy, [w:] Żywe problemy historii języka, red. M. Kuźnicki, M. Osiewicz, Poznań 2010, s. 75-85.

95 Ibidem, s. 78. 
wcześniej, chociaż nie wykluczamy uniwerbizmów pełniących rolę synchronicznych ekwiwalentów konstrukcji opisowych"96. Autor wzbogacił rozważania teoretyczne przykładami obrazującymi różne techniki kondensacyjne: derywację, kompozycję, elipsę i dezintegrację.

Próbę porównania procesów uniwerbizacyjnych na gruncie polskim i czeskim przeprowadziła Ewa Siatkowska ${ }^{97}$, skoncentrowała się na derywatach pochodzących od członu określającego w nazwach wielowyrazowych. Zaprezentowała materiał składający się z rzeczowników oznaczających konkretne przedmioty, wyróżniła dziesięć kręgów tematycznych ${ }^{98}$. Wyszczególniła również trzy główne działy: czeskiemu derywatowi odpowiada nazwa polska o innej strukturze (odpowiednik polski jest nazwą dwuwyrazową, kilkuwyrazową lub niespecjalną; odpowiednik polski jest nieprzekształconym członem określającym; odpowiednik polski jest wyrazem złożonym; odpowiednik polski jest wyrazem obcym), czeskiemu derywatowi odpowiada polski derywat (odpowiednik polski podkreśla tę samą cechę lub funkcję przedmiotu; odpowiednik polski podkreśla inną cechę lub funkcję przedmiotu), polskiemu derywatowi odpowiada nazwa czeska o innej strukturze (odpowiednik czeski jest nazwą dwuwyrazową, kilkuwyrazową lub niespecjalną; odpowiednik czeski jest nieprzekształconym członem określającym). Badaczka wykazała, że tendencja do tworzenia nazw syntetycznych jest silniejsza w języku czeskim. Zarówno w czeszczyźnie, jak i polszczyźnie syntetyzmy chętnie powstają na gruncie języka potocznego, odwołują się w znacznej mierze do elementów życia codziennego. Nie brak ich także w językach środowiskowych.

Ujęcie komparatywne zaproponowała też Elżbieta Szczepańska, która zastanawiała się nad różnicami między derywacją a uniwerbizacją na przykładzie języka polskiego i czeskiego ${ }^{99}$. Autorka do przyczyn procesów uniwerbizacyjnych

\section{Ibidem.}

97 E. Siatkowska, Syntetyczne i analityczne nazwy w języku polskim i czeskim, „Prace Filologiczne" 1964, t. 18, cz. 2, s. 219-237.

98 Podział obejmował m.in. nazwy: miejsc, osobowych wykonawców czynności, podkreślające cechy ludzi, narzędzi i podobnych przedmiotów, środków lokomocji, biletów itp., potraw i napojów, związane z odzieżą, związane ze szkołą i życiem społecznym, przyrodnicze, anatomiczne i fizjologiczne, osobowe wykonawców czynności.

99 E. Szczepańska, Derywacja a uniwerbizacja (na przykładzie sufiksu -ka w języku polskim i czeskim), „Rocznik Slawistyczny”, t. XLVIII, cz. 1, Wrocław 1992, s. 51-56. 
zaliczyła tendencję do usunięcia dysproporcji między kilkuczłonową nazwą a jednostkowym znaczeniem, dążność do kondensacji i ekonomii języka, ekspresywność wyrazów uniwerbizowanych ${ }^{100}$. Analizując różnice między derywacją a uniwerbizacją, doszła do wniosku, że w pierwszym przypadku powstają nowe jednostki zarówno pod względem formy, jak i znaczenia, w drugim zaś - zmienia się tylko forma, ponadto uniwerbizacja dotyczy nazw kilkuwyrazowych. E. Szczepańska przywołała przykłady form syntetycznych z sufiksem -ka, które należą do języka potocznego, publicystyki, a także gwar środowiskowych i zawodowych. Sufiks ten jest produktywny zarówno w polszczyźnie, jak i czeszczyźnie, przewagę liczebną mają uniwerbizmy w języku naszych sąsiadów.

Ta sama badaczka przyjrzała się również temu, jaką rolę w obu analizowanych językach w procesie uniwerbizacji odgrywa dezintegracja ${ }^{101}$, czyli redukcja i skracanie podstawy słowotwórczej. „Dezintegracja jako samodzielny proces dający wyrażenia uniwerbizowane występuje stosunkowo rzadko. Mowa tu o zjawisku, które daje uniwerbizmy będące efektem tylko i wyłącznie obcinania podstawy słowotwórczej o jakiś element niefleksyjny"102. E. Szczepańska dostrzegła, że część uniwerbizmów dezintegracyjnych jest zbieżna z istniejącymi już wyrazami, powstają zatem neosemantyzmy. Ten typ tworzenia leksemów to ważne źródło homonimii zarówno w języku polskim, jak i czeskim.

Zwieńczeniem badań polskiej lingwistki nad procesami kondensacyjnymi była monografia Uniwerbizacja w języku polskim i czeskim ${ }^{103}$. Autorka szczegółowo omówiła poglądy badaczy słowiańskich nt. uniwerbizacji, zastanawiała się nad miejscem tego zjawiska na tle innych zabiegów słowotwórczych. Jej celem było zbadanie funkcji wyrażeń uniwerbizowanych w różnych odmianach stylistycznych - ogólnej, potocznej, artystycznej, publicystycznej, naukowej, dokonała analizy jakościowej i ilościowej (szukając podobieństw i różnic w języku polskim i czeskim). E. Szczepańska szczegółowo omówiła rodzaje uniwerbizacji w czeszczyźnie i polszczyźnie (derywacja sufiksalna, dezintegracja, elipsa substantywizująca i deadiektywizująca, abrewiacja, kompozycja) w każdej odmianie, obrazując je licznymi przykładami. Dostrzegła, że procesy uniwerbizacyjne dominują

100 Ibidem, s. 51.

101 E. Szczepańska, O dezintegracji w procesie tworzenia uniwerbizmów (na przykładzie języka polskiego i czeskiego), „Poradnik Językowy” 1992, z. 2, s. 129-133.

102 Ibidem, s. 131.

103 E. Szczepańska, Uniwerbizacja w języku polskim i czeskim, Kraków 1994. 
w języku potocznym, za przyczyny podała skrótowość i ekspresywność. Najbardziej neutralnym sposobem tworzenia nowych nazw jest kompozycja, dlatego często pojawia się w odmianie naukowej. Charakter ekspresywny mają natomiast dezintegracja spełniająca zarazem wymogi adideacji, derywacja sufiksalna oraz substantywizacja uniwerbizująca. Autorka publikacji poruszyła problem wieloznaczności, która towarzyszy omawianemu zjawisku.

Warto przywołać także stanowisko Barbary Nykiel-Herbert na temat uniwerbizacji ${ }^{104}$. Jest ona zwolenniczką leksykalistycznego modelu morfologii, który zakłada, że „bazą do utworzenia nowego słowa może być jednostka leksykalna nie większa i nie mniejsza niż wyraz"105, przeciwnicy tej teorii powoływali się na procesy uniwerbizacyjne. Autorka wysunęła argumenty przeciwko regule uniwerbizacji zaproponowanej przez Romana Laskowskiego, twierdząc, że nie zawsze uniwerbizm ma taki sam rodzaj jak rzeczownik z podstawy (decydujący wpływ mają ograniczenia formalne przy wyborze formantu oraz czynniki semantyczne), ponadto - jak stwierdziła - „nie wszystkie zuniwerbizowane leksemy dają się wyprowadzić od prostych wyrażeń syntaktycznych typu rzeczownik przymiotnik (N - A)"106. Doszła do wniosku, że „zjawisko uniwerbizacji należy traktować nie jako proces sensu stricto słowotwórczy, w wyniku którego powstają nowe derywaty, ale raczej jako zastępowanie, już na płaszczyźnie języka (czyli w sferze «language performance») dwu- lub wielowyrazowych określeń pewnych istniejących w rzeczywistości pozajęzykowej desygnatów przez powstałe w niezależnie operującym procesie słowotwórczym jednowyrazowe formacje"107. B. Nykiel-Herbert stoi na stanowisku, że uniwerbizacja jest rodzajem synonimiczności, a o tym, którą formę wybierzemy (uniwerbizm czy jego wielowyrazowy synonim), decydują czynniki należące do sfery użycia języka.

Z powyższego przeglądu opracowań wynika, że językoznawcy najwięcej miejsca poświęcili analitycznym konstrukcjom czasownikowym, choć nie zabrakło także prac analizujących inne typy multiwerbizmów. W kręgu zainteresowania badaczy znalazły się przede wszystkim przyczyny ekspansji wielowyrazowych połączeń, funkcje pełnione przez analityzmy oraz ich syntetyczne odpowiedniki, prezentowano różnice semantyczne i stylistyczne. Nie zabrakło analizy obejmującej występowanie omawianych form w różnych odmianach polszczyzny:

104 B. Nykiel-Herbert, Jeszcze raz o uniwerbizacji, „Polonica” 1989, t. XIV, s. 193-201.

105 Ibidem, s. 193.

106 Ibidem, s. 196.

107 Ibidem, s. 200. 
urzędowej, artystycznej, naukowej, publicystyczno-dziennikarskiej (prasowej, radiowej i telewizyjnej), potocznej, religijnej. Podkreślano, że analityzmy werbo-nominalne usytuowane są na pograniczu leksyki, składni i frazeologii. Trochę miejsca poświęcono ujmowaniu peryfrastyki w opisie leksykograficznym, zaprezentowano też ujęcia komparatywne - zestawiano konstrukcje analityczne i syntetyczne obecne w polszczyźnie z tymi występującymi w kilku innych językach.

To, że wciąż warto badać struktury opisowe i ich jednoelementowe ekwiwalenty, podkreślała w 2010 r. I. Loewe, pisząc na łamach „Stylistyki”: „Z zaciekawieniem przyjdzie obserwować nie tylko w obszarze języka telewizji, jak funkcjonować będą kolokacje i jakie jeszcze role znajdziemy dla nich jako nadawcy"108. Sama zaś nazywała siebie kontynuatorką badań W. Cockiewicza. W niniejszej rozprawie znajdziemy liczne nawiązania do rozważań obydwojga uczonych, za podstawę przyjęto jednak jeszcze szersze spojrzenie na omawiane zjawisko, co pozwala lepiej przyjrzeć się obu opisywanym tendencjom. Jako analityzm leksykalny uznaje się co najmniej dwuwyrazowe określenie, które posiada jednowyrazowy odpowiednik tożsamy lub bliski znaczeniowo ${ }^{109}$. Do konstrukcji analitycznych zaliczane więc będą także związki frazeologiczne, analityzmy rzeczownikowe, przymiotnikowe, przysłówkowe, orzeczenia peryfrastyczne, a nawet nazwy własne, które da się zastąpić określeniem jednoelementowym - niezależnie od tego, czy zawierają one wspólne morfemy z odpowiadającymi im syntetyzmami leksykalnymi.

Nadmienić należy, że ze względów stylistycznych w opracowaniu używa się wymiennie pojęć: analityzm leksykalny, multiwerbizm, konstrukcja analitycznal peryfrastyczna, połaczenie wieloelementowe/wielowyrazowe, kolokacja werbo-nominalna (tylko w odniesieniu do analityzmów czasownikowych), formal struktura długa/rozbudowana/złożona, mając oczywiście świadomość niewielkich różnic między nimi, a zarazem nieostrych granic między ich definicjami. Problemy z terminologią zaznaczone zostały w powyższym przeglądzie literatury poświęconej omawianemu zagadnieniu.

Prześledźmy zatem najpierw strukturalne zróżnicowanie występujących w polskiej prasie konstrukcji analitycznych mających syntetyczne odpowiedniki.

108 I. Loewe, Konstrukcje analityczne w polskiej telewizji..., s. 186-187.

109 O różnicach semantycznych traktuje rozdział Semantyka, w którym podkreśla się, że równoznaczność form długich i krótkich jest zjawiskiem marginalnym, znacznie częściej dostrzegane są odmienne odcienie znaczeniowe. 


\section{Struktura analityzmów leksykalnych w prasie}

Ze względu na specyficzne właściwości leksemów należących do kategorii nazw własnych postanowiono wyodrębnić nomina propria ze zgromadzonego materiału egzemplifikacyjnego i przeanalizować je w osobnym podrozdziale. Za nadrzędne kryterium porządkujące wyrazy pospolite uznano - zgodnie z propozycją M. Kniagininowej - przynależność do części mowy. Badaczka wyróżniła: formy opisowe rzeczownikowe, formy opisowe czasownikowe, formy opisowe przymiotnikowe, wyrażenia przyimkowe z funkcją wzmacniającą spójnik, wyrażenia przyimkowe zamiast przyimków właściwych, określniki przyimkowe zamiast przypadkowych, wyrażenia przyimkowe z rzeczownikami odczasownikowymi zamiast bezokoliczników. W niniejszej pracy zgromadzono konstrukcje analityczne, których syntetyczne odpowiedniki są czasownikami, rzeczownikami, przymiotnikami, przysłówkami, zaimkami, liczebnikami i modulantami. Przyjęta w rozprawie szeroka definicja analityzmów pozwoliła na dokonanie w tych podgrupach podziału ze względu na pokrewieństwo morfologiczne między konstrukcjami analitycznymi a ich syntetycznymi odpowiednikami - wyróżniono takie, które mają wspólne morfemy, i takie, u których nie da się ich dostrzec. Oddzielnie potraktowano związki frazeologiczne. 


\section{Wyrazy pospolite}

\subsection{Analityzmy czasownikowe}

Na możliwość występowania form złożonych w miejsce pojedynczych czasowników zwrócił już uwagę w okresie międzywojennym Stanisław Szober1. Dostrzegł on dwa zjawiska: zamienianie osobowej formy czasownika konstrukcjami składającymi się z czasownika posiłkowego być oraz imiesłowów przymiotnikowych, np. sa przemawiajace $=$ przemawiaja, było pachnace $=$ pachniało, jest palacy $=$ pali, a także „upodobanie do zastępowania czasowników o wyrazistych i ściśle określonych treściach znaczeniowych czasownikami o rozległych zakresach i bardzo ogólnikowej i nikłej treści znaczeniowej, jak np. czasowniki dawać, mieć i być w połączeniu z jakimś rzeczownikiem"2. Dla zobrazowania tej drugiej tendencji wymienił choćby mieć możność = móc, być wielbicielem = wielbić, dawać rozkazy = rozkazywać. Językoznawca podkreślił, że przyczyną pojawiania się wyrażeń składających się z być i imiesłowu są różnice znaczeniowe w porównaniu z samym czasownikiem. Zaznaczył, że formy z imiesłowem pozwalają wyrazić właściwości ujmowane poza kategorią czasu.

Zastępowanie prostych czasowników wielowyrazowymi konstrukcjami wzbudziło szczególne zainteresowanie językoznawców w latach 60. XX w. M. Kniagininowa i D. Buttler zwróciły wówczas uwagę, że tendencja ta przybrała na sile, krytykowano posługiwanie się analityzmami, wskazując na ich sztuczność 3 i stylistyczną niezręczność: „Skłonność ta jest tak silna, że często pokonuje dobre nawyki uświęcone normą i staje się powodem niepoprawności wielu wypowiedzeń prasowych"4. Wśród opisowych form czasownikowych M. Kniagininowa wyróżniła zwroty frazeologiczne zadomowione w języku oraz struktury zbudowane według schematu czasownik + rzeczownik odsłowny.

1 S. Szober, Człowiek współczesny w zwierciadle języka, [w:] idem, Wybór pism, Warszawa 1959, s. 352.

2 Ibidem, s. 353.

3 M. Kniagininowa wprost stwierdziła, że tworzone są „różnego rodzaju wielosłowne dziwolągi - owoc pożałowania godnych poszukiwań stylistycznych, mających zaspokoić skłonność do analityzmu”, wyrażając tym samym swój negatywny stosunek do takich zabiegów językowych, por. M. Kniagininowa, Struktury opisowe..., s. 150.

4 M. Kniagininowa, op. cit., s. 149. 
D. Buttler w artykułach publikowanych na łamach „Języka Polskiego" analizowała poszczególne konstrukcje analityczne, szukając przyczyn ich ekspansji w chęci wyrażenia precyzji, „a konkretniej - w dążeniu do zasygnalizowania takich cech czynności, które się nie mieszczą w zakresie sformalizowanych kategorii czasów, trybów i aspektów, właściwych określonemu językowi” ${ }^{5}$. Doszła do wniosku, że pozwalają one wyrazić relacje temporalne, których z powodu ubóstwa czasów w polszczyźnie nie da się przedstawić za pomocą wykładników fleksyjnych. Pod względem formalnym do konstrukcji analitycznych zaliczyła formy mieć + bezokolicznik, mogą one odnosić się do sytuacji, które nastąpią w najbliższej przyszłości, lub sygnalizować czynność przeszłą nierzeczywistą, czyli taką, która była zamierzona, ale nie została zrealizowana ${ }^{6}$, „albo niezależną od woli podmiotu i w ostatniej chwili jak gdyby "powściągniętą»"7. Bywa, że są wykorzystywane do oznaczenia odcieni modalnych, których nie sposób wyrazić konwencjonalnymi formami trybów. Drugą grupę stanowią takie konstrukcje złożone, które występują w tych samych funkcjach obocznie z formami fleksyjnymi czasownika, zaliczymy do niej czasowniki fazowe z infinitiwem lub rzeczownikiem odsłownym. Pary takich synonimicznych określeń stanowią:przeczytać i skończyć czytać, zapiszczeć i zaczać piszczeć, nacierać i kontynuować natarcie ${ }^{8}$, będące kolejno wykładnikami terminatywności, inchoatywności i duratywności. Badaczka wymieniła także formy składające się z połączenia czasowników dokonać, przeprowadzić, ulec, doznać z rzeczownikami odsłownymi, dwie pierwsze konstrukcje odpowiadają formom strony czynnej z odcieniem terminatywnym lub duratywnym, dwie pozostałe pojawiają się zamiast strony biernej i występują w funkcji receptywnej.

D. Buttler, podsumowując badania innych uczonych, wymieniła następujące zmiany strukturalne, które wskazują na formalizację grup syntaktycznych ${ }^{9}$ :

a) częściowa stabilizacja składu leksykalnego konstrukcji, tj. niewymienność jej członu w formie osobowej na synonimy;

\footnotetext{
5 D. Buttler, Połączenia typu ulec zniszczeniu w języku polskim, „Poradnik Językowy” 1968, z. 7, s. 349.

6 Por. ibidem, s. 350.

7 Ibidem, s. 350-351.

8 Przykłady pochodzą z cytowanego wyżej artykułu D. Buttler.

9 Zmiany wymienione za D. Buttler.
} 
b) wzrost wewnętrznej spoistości struktury opisowej, niemożność interpolacji w jej obrębie dodatkowych członów syntaktycznych, np. przydawek, okoliczników;

c) utrwalenie się określonego szyku członów konstrukcji podlegającej morfologizacji;

d) nieregularność związków gramatycznych w obrębie konstrukcji.

Ta sama badaczka sprecyzowała także, co kryje się pod pojęciem leksykalny czasownik posiłkowy. Jak stwierdziła: „Nazwa ta odnosi się więc do leksemów werbalnych, które występują w konstrukcjach peryfrastycznych odpowiadających treściowo jednowyrazowym określeniom czynności i stanów, np. złożyć podpis $=$ podpisać, wywrzeć wpływ = wpłynaćc ${ }^{\prime \prime 10}$. Zw róciła uwagę na niewielki stopień gramatykalizacji tych leksemów, czyli nieregularne, wybiórcze konstytuowanie przez nie orzeczeń złożonych, a także niezupełne zatarcie ich szczegółowych cech semantycznych, co sprawia, że mogą przekazywać tylko niektóre znaczenia uogólnionel1. Podkreśliła, że leksykalne czasowniki posiłkowe mogą wchodzić w skład serii konstrukcji peryfrastycznych, przeważnie jednak ich łączliwość jest ograniczona. Zaznaczyła ich pośredniość między złożonymi formami morfologicznymi a frazeologizmami. Na możliwość tworzenia serii derywacyjnych, w których zmienia się komponent werbalny, rzeczownik pozostaje zaś ten sam, jako właściwość orzeczeń peryfrastycznych zwrócił uwagę Andrzej Maria Lewicki12. Ponadto zaznaczał otwartość zbioru składników, z których można budować takie orzeczenia, i jego niekategorialny charakter: „Nowe orzeczenia peryfrastyczne mogą powstawać na wzór istniejących, ale nie każdy wyraz należący do kategorii nazw czynności może być komponentem orzeczenia peryfrastycznego"13.

Istotny podział konstrukcji z bezokolicznikiem czasownikowym zaproponowała Renata Grzegorczykowa. Wyróżniła ona cztery typy ${ }^{14}$ :

10 D. Buttler, Leksykalne czasowniki posiłkowe w konstrukcjach peryfrastycznych typu „wywrzeć wpływ” na przełomie XIX i XX wieku, [w:] Z problemów frazeologii polskiej i słowiańskiej, t. 4, red. M. Basaj, D. Rytel, Wrocław 1988, s. 71.

11 Ibidem, s. 71-72.

12 A. M. Lewicki, Zwroty frazeologiczne, czyli predykaty w formie składników nieciagłych, „Studia Gramatyczne I” 1977, s. 141.

13 Ibidem.

14 Podział za: R. Grzegorczykowa, O konstrukcjach z bezokolicznikiem przyczasownikowym w języku polskim, „Biuletyn Polskiego Towarzystwa Językoznawczego” 1967, z. XXV, s. 123-132. 
a) konstrukcje z czasownikami fazowymi (zacząć, skończyć, przestać, jąć, kontynuować),

b) konstrukcje z czasownikami modalnymi,

c) konstrukcje z czasownikami typu kazać, zabraniać, pozwalać, które są wykładnikami kauzatywności,

d) konstrukcje o charakterze celowym, w których bezokolicznik jest okolicznikiem celu.

Uczona podkreśliła, że nie brakuje połączeń, w których nazwa czynności może występować zarówno w bezokoliczniku, jak i w formie rzeczownika odsłownego. Zauważyła: „Przewagę mają jednak konstrukcje z bezokolicznikiem chyba dlatego, że bezokolicznik ma szerszy zakres, formy rzeczownikowe nie tworzą się od wszystkich czasowników i często mają charakter sztuczny, a także oznaczają czynność bardziej oderwaną od podmiotu"15.

Omawiając peryfrastyczne konstrukcje predykatywne z parafrazą przymiotnikową ${ }^{16}$, Jolanta Mindak podkreśliła, że składają się one z komponentu werbalnego $\mathrm{V}_{\mathrm{s}} \mathrm{i}$ nominalnego $\mathrm{N}$. Komponentem werbalnym jest „czasownik synsemantyczny, tj. taki, który w ramach danej konstrukcji nie ma odrębnego, pełnego znaczenia leksykalnego"17 - zaliczyła tutaj leksemy czasownikowe predestynowane do roli kopuli lub takie, które w innym kontekście są pełnoznacznymi czasownikami, ale w konstrukcjach $\mathrm{V}_{\mathrm{s}} \mathrm{N}$ niosą treści ogólne „charakteryzujące dodatkowo właściwość wyrażaną komponentem nominalnym względnie odnoszące się do semantycznej wartości całej konstrukcji"18. Komponentem nominalnym N jest zwykle rzeczownik o charakterze nomen essendi. Skoncentrowała się także na łączliwości komponentów wchodzących w skład omawianych połączeń, przyjrzała się konstrukcjom o wspólnym komponencie werbalnym i różnych komponentach nominalnych oraz sytuacji odwrotnej - identycznym komponencie $\mathrm{N}$ i zmiennym $\mathrm{V}_{\mathrm{s}}$, badała zatem łączliwość czasowników i rzeczowników. Analizując grupę konstrukcji o wspólnym komponencie werbalnym, doszła do wniosku, że można wydzielić trzy podgrupy, w których dominować będzie: a) łączliwość semantyczna z możliwym

15 Ibidem, s. 128-129.

16 Jednostki te zwane są przez J. Mindak umownie konstrukcjami typu $\mathrm{V}_{\mathrm{s}} \mathrm{N}$.

17 J. Mindak, Peryfrastyczne konstrukcje predykatywne z parafraza przymiotnikowa (na materiale polskim, serbsko-chorwackim i macedońskim), Wrocław-WarszawaKraków-Gdańsk-Łódź 1985, s. 6.

18 Ibidem. 
udziałem kryteriów formalnych; b) łączliwość leksykalna i morfo-syntaktyczna z możliwym udziałem kryteriów semantycznych; c) wyłącznie łączliwość leksykalna. Po przeanalizowaniu połączeń, które mają identyczny rzeczownik, J. Mindak zauważyła, że możliwość przyłączania większej liczby czasowników warunkowana jest względami pozajęzykowymi: „Rzeczowniki denotujące cechy i stany, z którymi często spotykamy się w życiu codziennym (a więc, w konsekwencji, o których często mówimy), a szczególnie dotyczące sfery stanów emocjonalnych (charakteryzujących się dużą zmiennością, a także implikujących stosunek emocjonalny również nadawcy komunikatu językowego), tworzą zazwyczaj bogatsze zestawy niż inne, używane rzadziej i z mniejszym zaangażowaniem uczuciowym"19.

J. Anusiewicz w swojej monografii zaproponował, by przy podziale analityzmów pod względem kryteriów formalnych brać pod uwagę to, z jakich części mowy zbudowane są struktury opisowe oraz z jakimi częściami mowy są ekwiwalentne znaczeniowo. Do analitycznych konstrukcji czasownikowych zaliczył takie, „w których wyrazem nadrzędnym jest czasownik, a wyrazem podrzędnym przeważnie rzeczownik (najczęściej odsłowny), zaś całość wyrażenia jest tożsama znaczeniowo i substancjalnie z prostą formą czasownika"20. Językoznawca wymienił następujące typy czasownikowych struktur opisowych ${ }^{21}$ :

a) formy osobowe bądź nieosobowe czasownika (imiesłowy) + rzeczownik w przypadku zależnym, np. robię czyszczenie, dokonano podziału, dokonując klasyfikacji;

b) formy osobowe bądź nieosobowe czasownika + wyrażenie przyimkowe, np. jest w ruchu, będąc w podróży;

c) formy osobowe czasownika + bezokolicznik, np. mam zrobić.

Składniowo jest to orzeczenie słowne + dopełnienie lub orzeczenie złożone (imienne). Badacz zaznaczył, że do konstrukcji analitycznych należą także połączenie z bezokolicznikiem (np. ma nastąpić). Jak stwierdził: „Zwroty te są sprowadzalne znaczeniowo do prostych form czasownika. Istotą tego typu struktur jest rozłożenie między dwa wyrazy związku treści, którą równie dobrze mógłby przekazać nam czasownik prosty" 22 .

19 Ibidem, s. 83-84.

$20 \mathrm{~J}$. Anusiewicz, Konstrukcje analityczne we współczesnym języku polskim, Wrocław 1978, s. 28.

21 Podział za: ibidem, s. 100.

22 Ibidem, s. 71. 
J. Anusiewicz zauważył, że: „W analitycznych strukturach czasownikowych morfem leksykalny wyrazu podrzędnego jest identyczny z morfemem leksykalnym odpowiadających im jednowyrazowych czasowników, np. czynićstar-ania - star-ać się, dać rozkaz - rozkaz-ać, dokonać włam-ania-włam-ać się, dokonać zwrot-u-zwróc-ić, prowadzićsprzed-az-sprzed-awać itp. [...] W konstrukcjach tych nadrzędnikiem jest zawsze czasownik o znaczeniu bardzo ogólnym, sygnalizujący procesy ruchu, stawania się, dziania się czego lub ogólnie wyrażający jakąś czynność, natomiast podrzędnik jest zwykle właściwym nośnikiem znaczenia leksykalnego całego związku, a sama konstrukcja jest sprowadzalna do znaczenia i funkcji prostych form czasownika"23. Badacz podkreślił, że to nadrzędnik decyduje o właściwościach gramatycznych całego orzeczenia peryfrastycznego, wyraża stronę, czas, tryb, aspekt, liczbę i osobę.

$\mathrm{Na}$ dwuczłonowość analitycznych konstrukcji czasownikowych zwróciła też uwagę I. Loewe, która stwierdziła: „Schemat takiej konstrukcji stanowią: czasownik osobowy (verbum) oraz rzeczownik (nomen), który zawiera właściwą treść leksykalną związku, i to on jest semantycznie tożsamy z jednoleksemowym ekwiwalentem konstrukcji o postaci werbalnej"24.

Schemat formalny kolokacji werbo-nominalnych zaproponowała E. Jędrzej$\mathrm{ko}^{25}$ :

$$
\mathrm{L}_{\text {ANALIT }} \rightarrow\left[\operatorname{Verb}^{\text {SYNSEM }}+(\text { praep }) \bigcap \mathrm{N}_{\text {ABSTR }}{ }^{\text {PRED }}\right]_{\text {VERB }}
$$

gdzie:

$\mathrm{L}_{\text {ANALIT }}$ - symbol leksykalnej jednostki analitycznej o funkcji czasownika;

VerbSYNSEM - składnik verbalny o charakterze prymarnie lub wtórnie synsemantycznym, tzw. werbalizator // operator;

$\mathrm{N}_{\text {ABSTR }}$ PRED - składnik imienny w formie rzeczownika abstrakcyjnego, reprezentujący predykat - tzw. predykator (nośnik treści orzekanej; wchodzi w określony rodzaj formalnego związku rządu jako człon zależny od czasownika-werbalizatora, który wymaga czasem „pośrednictwa” przyimka (praep)).

23 Ibidem.

24 I. Loewe, Konstrukcje analityczne wśród metafor. Struktura, semantyka i funkcja analityzmów w poezji K. Przerwy-Tetmajera, „Poradnik Językowy” 1997, z. 7, s. 44.

25 Schemat za: Słownik polskich zwrotów werbo-nominalnych. Zeszyt próbny, red. E. Jędrzejko, Warszawa 1998, s. 18. 
Uwypuklona została zatem wyraźna dwuczłonowość werbalnej leksyki analitycznej. „Globalne znaczenie tych złożonych znaków słownych rozkłada się na dwa elementy: na synsemantyczny werbalizator (czasownik operatorowy // posiłkowy // funkcyjny) oraz semantycznie konstytutywny, choć formalnie podrzędny element imienny (tzw. predykator, reprezentowany przez rzeczownik abstrakcyjny)"26. Charakteryzując składnik werbalny, autorzy Słownika polskich zwrotów werbo-nominalnych zaznaczyli, że to właśnie on umożliwia pełnienie funkcji zdaniotwórczych, a także narzuca formę gramatyczną składnikowi imiennemu. Predykator z kolei „decyduje o leksykalno-pojęciowej wartości całej peryfrazy predykatywnej i o jej przynależności do określonego pola semantycznego (uczuć, działań, stanów itp.) - stanowiąc jego nadrzędny temat”27. Wpływa on także na łączliwość całej peryfrazy.

A. Karaś i E. Nowak skoncentrowały się na tym, z jakimi werbalizatorami mogą łączyć się konstrukcje analityczne z predykatami chęć, ochota, pragnienie, $\dot{z} a ̨ d z a$, i doszły do wniosku, że związek między oboma komponentami może być dwustronny, „oba człony konstrukcji mogą się wzajemnie motywować”28. Z ich analizy wyniknęło, że choć wszystkie rzeczowniki należą do tej samej klasy (mają charakter wolitywny), to jednak repertuar łączących się z nimi rzeczowników jest zróżnicowany, tylko trzy (czuć, ogarniać, budzić) wchodzą w związki z wszystkimi badanymi rzeczownikami.

Na przynależność konstrukcji analitycznych do sfery pogranicza wskazywali D. Buttler, I. Loewe, E. Jedrzęjko, G. Vetulani czy K. Hartenstein.

I. Loewe zaznaczyła, że w skład kolokacji werbo-nominalnej wchodzi synsemantyczny bądź wtórnie synsemantyczny czasownik i rzeczownik abstrakcyjny, „który jest ekwiwalentem nominalnym werbalnego i pełnoznacznego odpowiednika tej konstrukcji w leksykonie"29. Badaczka odrzuciła postulowany przez J. Anusiewicza wymóg morfologicznego pokrewieństwa analityzmu i jego jednoleksemowego odpowiednika. Zajęła się także relacjami między predykacją peryfrastyczną a związkami frazeologicznymi. Odwołała się do badań A. M. Le-

26 Ibidem, s. 23.

27 Ibidem, s. 24.

28 A. Karaś, E. Nowak, Znaczenie predykatu a wybór werbalizatora $w$ konstrukcjach analitycznych (na przykładzie konstrukcji z predykatami chęć, ochota, pragnienie, żądza), „Poradnik Językowy” 1999, z. 1, s. 13.

29 I. Loewe, Konstrukcje analityczne w polskiej telewizji na progu drugiej dekady XXI wieku, „Stylistyka” 2010, XIX, s. 178. 
wickiego. Językoznawca ten podkreślił, że zwroty analityczne są jednostkami pośrednimi między słowotwórstwem a frazeologią. Uwydatnił ich dwuczłonową strukturę: , jedną z części stanowi czasownik lub połączenie czasownika z innymi wyrazami, a drugą - nazwa jakiegoś stanu rzeczy, tzn. nazwa czynności, właściwości, relacji i innych abstrakcyjnych predykatów. Całość ma znaczenie globalne niesprowadzalne do znaczeń komponentów"30. Wspomniał o trudnościach w odróżnianiu orzeczeń peryfrastycznych od grup syntaktycznych. Dostrzegł, że szczególnie produktywnymi typami konstrukcji analitycznych są te tworzone za pomocą czasowników prowadzić i dokonać. Uczony stwierdził, że „każdy [...] model orzeczenia peryfrastycznego ma osobliwe ograniczenia leksykalne"31. Można tworzyć zbiory o wspólnym członie nominalnym, są one zbliżone do rodziny związków frazeologicznych.

Na pośredni charakter orzeczeń peryfrastycznych zwróciła uwagę G. Vetulani, sytuując je między całkowicie złożonymi formami morfologicznymi a konstrukcjami frazeologicznymi. Akcentowała, że są to połączenia składające się z czasownika i rzeczownika abstrakcyjnego i „powstają na zasadzie wzajemnej determinacji, co znaczy, że spełnione są w nich nie tylko wymogi formy (np. zgodność gramatyczna), lecz że zachodzi w nich semantyczna łączliwość wyrazów, determinowana przez systemy leksykalne języka (a nie kontekst sytuacyjny)"32. Jednocześnie uwypukliła, że kolokacje werbo-nominalne są wykładnikami jednego pojęcia. Jak zauważyła autorka, leksykalne czasowniki posiłkowe „chociaż są predykatywnie puste, przez fakt, że w języku polskim są silnie nacechowane, przyczyniają się do jakościowego wzbogacenia zwrotu analitycznego"33. Charakteryzując orzeczenia peryfrastyczne, badaczka wskazała, że mają one inną walencję niż ich syntetyczne odpowiedniki czasownikowe.

W rozdziale poświęconym strukturze przytoczono po jednym przykładzie danej konstrukcji analitycznej z każdego tygodnika (o ile została w nim odnotowana); więcej przykładów i w różnych kontekstach pojawi się w dalszych częściach

30 A. M. Lewicki, O możliwości zastosowania pojęcia formantu we frazeologii, [w:] idem, Studia z teorii frazeologii, Łask 2003, s. 245-246.

31 Ibidem, s. 247.

32 G. Vetulani, Kolokacje werbo-nominalne jako odrębne jednostki języka i ich zastosowanie, [w:] W kręgu języka polskiego. Śląsko-poznańskie kolokwia lingwistyczne, red. E. Jędrzejko, Katowice 2001, s. 58.

33 Ibidem, s. 60. 
pracy. Wtedy też zostaną podane zastosowania syntetycznych odpowiedników, tu jedynie się je wymienia, bez wskazywania na otoczenie leksykalne.

Niektóre przywołane w tej części analityzmy i ich syntetyczne odpowiedniki mogą budzić wątpliwości co do ich takiej samej lub podobnej wartości znaczeniowej, w rozdziale tym skoncentrowano się jednak na formie, a nie semantyce tych struktur, dlatego zaprezentowano możliwie najszersze spojrzenie na strukturę wielowyrazowych połączeń.

\subsubsection{Analityzmy pochodne strukturalnie}

Asystować: Reprezentant Polski legitymuje się czwartą w zespole najwyższą średnią not $(5,62)$; strzelił cztery gole i zaliczył trzy asysty, w każdym meczu należy do wyróżniających się postaci. (PN 48/2012, s. 35)

W 31 spotkaniach w Bundeslidze zdobył 13 bramek i zanotował 11 asyst. (PN 24/2012, s. 43)

Błądzić: Kiedy już niemal wszyscy zdążyliśmy się przyzwyczaić do opinii, że obserwujemy najgorszy sezon ekstraklasy w XXI wieku, piłkarze jakby na przekór postanowili udowodnić, iż jesteśmy w błędzie. (PN 48/2012, s. 2)

Fotografować: Razem z ukochaną Krysią będą przez tydzień szaleć na stoku w Szrenicy, robić zabawne fotki i delektować się pysznymi śląskimi przysmakami w ulubionych knajpkach Szklarskiej Poręby. (NŻ 2/2012, s. 34)

Jedni przychodzą wejść na Ściankę, drudzy - ustrzelić fotę, jeszcze inni - zjeść i zabrać gadżety. (P 24/2012, s. 107)

Głosować: Frekwencja wyborcza to odsetek osób uprawnionych do głosowania, które oddały swój głos w czasie wyborów bądź referendum. (VG 2/2011, s. 38)

Nie tylko dlatego, że związkowcy mogliby zostać zepchnięci do podziemia albo w następnych wyborach oddać głos na jakichś ultraradykałów. (P 24/2012, s. 18)

Kontrolować: Czy oszukujesz samego siebie, tłumacząc sobie, że wszystko masz pod kontrolą i że nic złego się nie dzieje? (VG 8/2011, s. 11)

Krytykować: Arbitra meczu w Bielsku-Białej krytyce poddał Ireneusz Jeleń. (PN 49/2012, s. 10)

Łudzić się: Ale teraz niech nikt nie ma złudzeń. (PN 51-52/2011, s. 89)

Bartek nie miał już złudzeń, zresztą skutecznie rozwiewał mu je Daniel, najbliższy kolega z klasy, którego rodzice już kilka lat temu się rozeszli. (VG 10/2011, s. 8)

Modlić się: Najlepiej uczynić to w rocznicę jego śmierci, bo tego dnia z całą pewnością pojawia się na ziemi, aby nieść pomoc tym, którzy wznoszą do niego modły. (P 24/2012, s. 100) 
Modyfikować: Propozycje tematów - wraz z rekomendacjami urzędników poczty trafiają do ministra administracji i cyfryzacji, który ostatecznie wybiera tematy do druku lub poddaje je modyfikacji. (P 50/2012, s. 101)

Myśleć: Czy nie to miał na myśli Dani Alves, mówiąc niedawno: - Pep Guardiola odszedł przez nas. (PN 48/2012, s. 27)

Obserwować: Nie muszę do nikogo chodzić w tej sprawie, właściciel klubu ma wypracowaną długoletnią strategię budowy zespołu, nieustannie prowadzone są obserwacje kandydatów do gry w Lechu. (PN 50/2012, s. 14)

Oddziaływać: Oznacza to, że projekt musi mieć oddziaływanie i przynosić korzyści zarówno dla Polski, jak i drugiego kraju, partnera projektu. (VG 20/2012, s. 65)

Odpierać: A wspólnotę tworzy przede wszystkim lud biało-czerwony, który dzięki swojemu instynktowi i przywiązaniu do tradycji i katolicyzmu daje odpór wszelkim kosmopolitom, „mało-Polakom”, liberałom, postępowcom. (P 24/2012, s. 22)

Odpowiedzieć: Niech każdy sam udzieli sobie odpowiedzi na to pytanie. (PN 44/2012, s. 3)

Nic się nie stanie, jeśli jutro dasz odpowiedź koleżance, a jak źle przeprowadzisz sprawę, to nic nie załatwisz. (VG 9/2011, s. 22)

Opiekować się: Inna metoda to harcerstwo - jako druhna czy druh będziesz mieć pod opieką dzieci, zobaczysz, jak to jest zajmować się młodszymi. (VG 12/2011, s. 7)

Pamiętać: Ma bardzo dobrych zawodników, ma w pamięci świeży sukces, którym było wywalczenie Pucharu Polski z Michałem Probierzem na ławce, ma wreszcie prezesa, który ligowym piłkarzem był i choć nie osiągnął spektakularnych sukcesów w futbolu, na pewno zna zapach szatni. (PN 10/2012, s. 2)

W pamięci utkwiły mi szczególnie słowa premiera Węgier Wiktora Orbana, który stwierdził, że władza może być dla sportu błogosławieństwem, ale również - przekleństwem. (PN 44/2012, s. 7)

Pomagać: Z czasem mocno umalowane panie w okienkach zaczęły reagować na chcących nieść pomoc i radę rodaków jak na obcych. (PN 24/2012, s. 26)

$\mathrm{Na}$ ich stronie internetowej niebieskalinia.pl znajdziesz informator placówek, które niosą pomoc ofiarom przemocy w twojej najbliższej okolicy. (VG 11/2011, s. 9) Najlepiej uczynić to w rocznicę jego śmierci, bo tego dnia z całą pewnością pojawia się na ziemi, aby nieść pomoc tym, którzy wznoszą do niego modły. (P 24/2012, s. 100)

Poprawić się: Syn aktora Maciej Stuhr zapewnił w wywiadzie, że stan zdrowia jego ojca uległ poprawie. (NŻ 13/2012, s. 3)

Porównać: Chyba nie ma sensu snuć porównań. (PN 49/2012, s. 9) 
Przeprosić: Bo błędnie uważamy, że pójść i powiedzieć „przepraszam” to okazać słabość. (VG 23/2012, s. 15)

Przeważać: Z upływem czasu Chorwaci, uzyskując przewagę liczebną, starali się jak najszybciej odbierać podopiecznym Trapa ochotę do gry, pozostawiając z tyłu trzech lub nawet tylko dwóch obrońców. (PN 24/2012, s. 23)

Pytać: Kiedy ktoś zadaje ci pytanie, czym się interesujesz i w jaki sposób lubisz spędzać wolny czas, w głowie pojawia się myśl: komputer. (VG 23/2012, s. 11)

Prawdą jest, że ostateczne wyjaśnienie zagadki okazało się boleśnie banalne i można zadać pytanie, dlaczego okablowanie eksperymentu nie zostało sprawdzone na samym początku. (P 24/2012, s. 81)

Radować: Takie mecze i takie wyniki dają kibicom mnóstwo radości. (PN 48/2012, s. 39)

Kibicom daje radość, a reszcie udrękę. (P 24/2012, s. 16)

Radzić: Z czasem mocno umalowane panie w okienkach zaczęły reagować na chcących nieść pomoc i radę rodaków jak na obcych. (PN 24/2012, s. 26)

Radzić (sobie): Gdyby w budżecie nie było potężnych dziur, tacy ludzie, bez żadnego doświadczenia w zarządzaniu i biznesie, pewnie daliby sobie jakoś radę. (PN 9/2012, s. 39)

Przychodzili ci, którym się nie powiodło, którzy potrzebowali wsparcia, i ci, którzy dawali sobie radę. (P 51-52/2012, s. 130)

Remontować: - Prowadziliśmy intensywne remonty i renowacje. (PN 24/2012, s. 27)

Rodzice postanowili zrobić remont w mieszkaniu. (VG 9/2011, s. 38)

Selekcjonować: 55-letni Nawałka jest w tej kwestii specjalistą, za długo siedzi też w futbolu, żeby liczyć na wieczne szczęście, dlatego dokonując selekcji, z natury unika piłkarzy lichej postury, w miarę możliwości pozbywając się z kadry zawodników podatnych na kontuzje. (PN 44/2012, s. 12)

Dziennikarzom nawet się nie śniło, że to na nich spadnie teraz ciężar ochrony najbardziej strzeżonych tajemnic państwowych i że to oni będą musieli dokonywać selekcji, co można ujawnić, a co jednak powinno zostać ukryte. (P 50/2012, s. 10) Skrzywdzić: Nie musisz mieć broni, aby zrobić komuś krzywdę. (VG 1/2011, s. 8) Spokornieć: Ale choć Patricka podkreśla, że z wiekiem nabrała pokory, wszyscy zauważyli, że sukces chyba leciutko uderzył jej do głowy... (NŻ 8/2012, s. 10)

Stracić: Ale jak dotąd więcej odnotowuje pan strat niż zysków? (PN 48/2012, s. 14) 
Strzelać: To fakt, ale z jednym, za to istotnym zastrzeżeniem - oprócz meczu z Włochami, w którym Kuba nie wykorzystał rzutu karnego, bardziej podając do Gianluigiego Buffona, niż oddając strzal. (PN 6/2012, s. 28)

Strzelić: Po raz pierwszy na listę strzelców w bieżącej edycji wpisał się 27-letni Fernando Llorente, ale po końcowym gwizdku Bielsa oświadczył, że mecz miał większe znaczenie dla wizerunku klubu niż w kwestii sportowej. (PN 49/2012, s. 3)

Lukaku został wypożyczony do West Bromwich i już strzela gole dla nowego klubu. (PN 36/2012, s. 23)

Świadczyć: Gdy rodzice Glorii Wrony udzielają świadectw ${ }^{34}$ o jej cudownym uzdrowieniu, publiczność jest proszona o oklaski dla tego dziecka. (P 50/2012, s. 26) Ale też swoją biedą daje świadectwo uczciwości, bo nie kradł i nie oszukiwał, jak ci wszyscy, którzy zawłaszczyli III RP. (P 24/2012, s. 22)

Sygnalizować: Gdyby tylko Guardiola dał sygnał ze swojego apartamentu w Nowym Jorku, gdzie odpoczywa i pobiera lekcje angielskiego, że jest gotów podjąć się pracy na Stamford Bridge, to wtedy Di Matteo musiałby czym prędzej sprzątać swoje biurko w ośrodku treningowym Chelsea w Cobham. (PN 48/2012, s. 23)

Daj jeszcze raz delikatny sygnał temu drugiemu, że jednak jesteś nim zainteresowana - to jedyne wyjście z tej sytuacji. (VG 9/2011, s. 20)

Jubilatka daje delikatne sygnały, jakie prezenty chciałaby dostać, ale nie wie, czy zostaną one właściwie odczytane. (NŻ 12/2012, s. 4)

Trafić: Jak wyliczono, ów snajper nie mógł trafić do siatki już od 344 minut. (PN 1/2012, s. 35)

Sześciokrotnie do siatki rywala trafiał trzy lata starszy od niego inny napastnik mistrzów Lucas Pratto. (PN 50/2012, s. 38)

Tonew podał do Patryka Wolskiego, który zdecydował się na rajd i kapitalnie trafił do bramki. (PN 41/2012, s. 40)

Marek Leśniak w latach 1988-96 zdobył na boiskach niemieckiej ekstraklasy 42 gole, a w reprezentacji w tym okresie dorobił się zaledwie pięciu trafień. (PN 49/2012, s. 37)

Trenować: Tak czy inaczej po prawie 40 latach, gdy zdążyli odcisnąć piętno na zespołach, które prowadzili z ławki trenerskiej w różnych krajach, obaj panowie wciąż nie mają o sobie najlepszego zdania. (PN 50/2011, s. 29)

Wątpić: Zatem etykieta została zachowana, nikt nie mógł mieć wątpliwości, że występuje reprezentacja kraju, nie zaś federacji. (PN 46/2011, s. 2)

34 Połączenie to wydaje się dziwaczne, błędne w tym kontekście. 
Wpływać: Wywierał większy wpływ na grę swoich zespołów niż Lewy i dlatego wyprzedził go w walce o miejsce w jedenastce miesiąca. (PN 49/2012, s. 32)

Co prawda w minionej kolejce Lewy zszedł z boiska bez trafienia, a jego zmiennik - Lucas Barrios - zdobył gola, ale to nie powinno mieć żadnego wpływu na kształt rankingu napastników Juergena Kloppa. (PN 6/2012, s. 13)

Dlatego jeśli chcemy mieć wpływ na to, kto nami rządzi i jakie podejmuje decyzje, musimy głosować. (VG 2/2011, s. 38)

Stopniowo dowiadujemy się też o przeszłości Rachel, o jej ciężkich relacjach z rodzicami oraz traumie z dzieciństwa, która wywiera na nią wpływ nawet w dorosłości. (VG 19/2012, s. 7)

Współczuć: Nie odczuwa współczucia, żalu za wyrządzoną komuś krzywdę, często kłamie i oszukuje, wobec nauczycieli bywa agresywny lub przeciwnie, nieprawdziwie ugrzeczniony. (VG 24/2012, s. 17)

Wybrać: Ich drużyna była naprawdę niezła, a on dawał z siebie wszystko, aby udowodnić, że trener dokonał właściwego wyboru, wybierając go do reprezentacji. (VG 1/2011, s. 9)

Wyrazić: W 16 minucie meczu fani wstali i głośnymi oklaskami dali wyraz, że nadal mają wielki szacunek do Di Matteo. (PN 48/2012, s. 23)

Wyzwać: Dopiero w Chorzowie dostało mu się w bardzo wymyślny sposób, od kibiców Ruchu - wyśpiewane przy wyniku 3:0 E viva Espana dowodzi, że polski fan może inteligentnie zakpić z rywala, nie zaś tylko obrzucić go wyzwiskami. (PN 9/2012, s. 11)

Zadebiutować: Polski pomocnik zaliczył już debiut w nowym klubie. (PN 33/2012, s. 16)

Zamierzać: Lecz mimo to miał zamiar pozostać w ich domu. (VG 22/2012, s. 23)

Zapomnieć: Każda wizyta Szymona w ich domu również będzie dla Wiki stresem trudno, żeby zupełnie wyrzuciła z pamięci scenę z parku. (VG 16/2012, s. 25)

Zdecydować: Władze podjęły decyzję o przerwaniu wystawiania spektaklu. (VG 9/2011, s. 63)

Prezydent Miguel Guillen nie potrafi podjąć decyzji o pozbyciu się któregoś z nich, uważa, że stanowią znakomity tandem. (PN 41/2012, s. 8)

Punkt przełomowy to była budowa wieży widokowej Kaszubskie Oko, chociaż kiedy wójt podejmował decyzję, niektórzy też pukali się w głowę. (P 24/2012, s. 117)

Złamać: Nigeryjczyk już w drugiej kolejce rozgrywek, w spotkaniu z Górnikiem Zabrze, doznał złamania ręki i przeszedł operację zespolenia przedramienia. (PN 36/2012, s. 38)

Zmienić: Bułgar Nikołaj Kostow, zastępca Pawła Kuczerwowa, dokonał pewnych zmian w składzie, taktyce, ale na efekty musieliśmy poczekać. (PN 48/2012, s. 20) 
Zranić się: Pielęgniarka lub lekarz, którzy doznali zranienia podczas dyżuru, nie mogą nawet liczyć na zastępstwo. (P 24/2012, s. 6)

Zrezygnować: Premier Mario Monti zdecydował, że natychmiast po przyjęciu przez parlament ważnej dla kraju ustawy stabilizacyjnej złoży rezygnację. (P 50/2012, s. 7)

Zwyciężyć: Sześć dni później w Bielsku-Białej w 48 minucie meczu z Podbeskidziem z kolei rzut karny zmarnował Paweł Wszołek, ale potem znowu udało się zdobyć bramkę i poloniści odnieśli zwycięstwo 1:0. (PN 48/2012, s. 16)

Zwycięsko z tego dwumeczu wyszli nasi południowi sąsiedzi, którzy odnotowali skromną wygraną i bezbramkowy remis. (PN 50/2012, s. 36)

Zyskać: Ale jak dotąd więcej odnotowuje pan strat niż zysków? (PN 48/2012, s. 14) Żyć: Zagorzałych fanów Elvisa to nie przekonuje - wielu z nich ciągle uważa, że Presley jest wśród żywych i mieszka sobie spokojnie gdzieś w Teksasie czy na Hawajach. (VG 2/2011, s. 10)

Jak wynika z powyższego zestawienia, dziennikarze chętnie sięgają po bezokolicznik mieć, który jest łączony z różnymi komponentami: mieć pod kontrola, mieć złudzenia, mieć na myśli, mieć oddziaływanie, mieć pod opieka, mieć w pamięci, mieć wątpliwości, mieć wplyw. Kolejną charakterystyczną podstawę orzeczeń peryfrastycznych stanowi dać występujące w połączeniach z rzeczownikami: odpór, odpowiedź, radość, radę, świadectwo, sygnał, wyraz. Czasownik doznać konotuje najczęściej rzeczowniki odczasownikowe.

Analiza materiału potwierdza zatem ustalenia J. Anusiewicza, A. Bogusławskiego i W. Cockiewicza, że do najczęściej pojawiających się podstaw konstrukcji analitycznych należą: dać, mieć, dokonać, prowadzić, udzielać35. Zestaw ten można rozbudować jeszcze chociażby o nieść, odnotować, poddać czy zaliczyć.

W zebranym rejestrze znalazły się także takie czasowniki, które badacze z Uniwersytetu Śląskiego pracujący nad zeszytem próbnym słownika analityzmów werbo-nominalnych zaliczyli do operatorowych. Są to: być, dać, dokonać, doznać, mieć, nabrać, poddać, podjać, prowadzić, robić, snuć, udzielić, ulec, uzyskać, zadać,

35 Por. J. Anusiewicz, Konstrukcje analityczne we współczesnym...; A. Bogusławski, Jednostki języka a produkty językowe. Problem tzw. orzeczeń peryfrastycznych, [w:] Z zagadnień słownictwa współczesnego języka polskiego, Wrocław 1978; W. Cockiewicz, Konstrukcje analityczne $w$ języku polskiej telewizji $w$ latach siedemdziesiatych i dziś, [w:] Język w mediach masowych, red. J. Bralczyk, K. Mosiołek-Kłosińska, Warszawa 2000. 
złożyć. Wyrazy hasłowe ${ }^{36}$, które pojawiły się zarówno w przytoczonym słowni$\mathrm{ku}$, jak i materiale zgromadzonym na potrzeby niniejszej pracy, to: pomoc, rada, współczucie, zwycięstwo.

Zdarza się, że do jednego rzeczownika dołącza się kilka komponentów czasownikowych, a mimo to syntetyczny odpowiednik jest taki sam, zmienia się zatem struktura konstrukcji wielowyrazowej, a znaczenie pozostaje zbliżone, np. asysta łączy się zarówno z zaliczyć, jak i zanotować, fotkęlfotę można zrobić, ale i ustrzelić, odpowiedzi się udziela albo daje, podobnie jest w przypadku świadectwa. Odnotowano też alternatywne konstrukcje: coś mamy w pamięci bądź coś nam w pamięci utkwiło, piłkarz natomiast może trafić do siatki lub do bramki. Syntetyczne watpić ma dwa wielowyrazowe odpowiedniki: mieć watpliwości oraz podać w wątpliwość. Jednakowy syntetyzm odpowiada też wielowyrazowym mieć wplyw i wywrzeć wplyw. Remont wchodzi w relacje z przeprowadzić i robić. Wszystkie wymienione połączenia, choć synonimiczne, mogą być nośnikiem innego zabarwienia semantycznego, o czym będzie szerzej w rozdziale następnym.

Z analizowanego materiału da się również wydzielić rzeczowniki, które mogą być dołączane do różnych czasowników, a każda taka konstrukcja odwołuje do innego syntetyzmu. Łączliwością taką odznaczają się pamięć (mieć w pamięci, utkwić w pamięci, wyrzucić z pamięci) i rada (nieść radę, dać (sobie) radę).

Okazuje się, że taki sam jednowyrazowy czasownik może odwoływać się do dwóch różnych nie tylko formalnie, ale i semantycznie orzeczeń peryfrastycznych. Dzieje się tak np. w przypadku strzelić, któremu mogą odpowiadać zarówno oddać strzał, jak i strzelić gola/wpisać się na listę strzelców. By dokonać właściwej interpretacji, niezbędne jest zapoznanie się z kontekstem.

Wartym uwagi zagadnieniem wydaje się też przeanalizowanie, jakie komponenty dołączane są do verbum. Najpopularniejszym rozwiązaniem jest zestawianie czasownika z rzeczownikiem w bierniku, np. oddać głos, robić fotkę, nieść pomoc, pojawiają się też dopełnienia wyrażone dopełniaczem (udzielić odpowiedzi, dokonać selekcji, nabrać pokory), celownikiem (poddać krytyce, poddać modyfikacji, ulec poprawie) czy - najrzadziej - narzędnikiem (obrzucić wyzwiskami). Nie brakuje połączeń składających się z bezokolicznika i wyrażenia przyimkowego (być w blędzie, mieć pod kontrola, podać w wątpliwość). Raz zaobserwowano zesta-

36 Tym mianem zespół kierowany przez E. Jędrzejko określa rzeczownik abstrakcyjny nazywający zdarzenie (czynności, procesy, stany, operacje) wyrażane peryfrastycznie. 
wienie czasownika z przysłówkiem (wyjść zwycięsko). Odnotowano dwie rozbudowane peryfrazy wpisać się na listę strzelców i prowadzić z ławki trenerskiej, dopiero w przydawkach ujawnia się pokrewieństwo morfologiczne z syntetyzmem. Komponentem nominalnym bywają rzeczowniki odczasownikowe, jak choćby oddziaływanie, złamanie, zranienie, nie jest to jednak powszechne zjawisko.

W zdecydowanej większości to składnik nieczasownikowy decyduje o znaczeniu całego orzeczenia peryfrastycznego, czasownik pełni jedynie funkcję pomocniczą. Wyjątkami są strzelić gola i trafić do bramki/trafić do siatki - to verbum jest równoznaczne z syntetycznym odpowiednikiem, odgrywa główną rolę w procesie semantyzacji, towarzyszące mu dopełnienia służą jedynie doprecyzowaniu analityzmu, pozwalają jednoznacznie dookreślić czynnośc 37 .

Godna rozważenia jest również liczba komponentów wchodzących w skład analitycznych konstrukcji czasownikowych mających wspólne morfemy z jednoelementowymi zastępnikami. Zdecydowanie najczęściej struktury takie zbudowane są z dwóch wyrazów, czasem odnajdziemy trzy składniki (przeważnie połączenie bezokolicznika z wyrażeniem przyimkowym, np. mieć w pamięci, mieć na myśli, utkwić w pamięci), do rzadkości należą połączenia składające się z czterech i więcej członów (prowadzić z ławki trenerskiej, wpisać się na listę strzelców). Nawet w strukturach złożonych widoczna więc jest tendencja do ekonomizacji środków językowych.

\subsubsection{Analityzmy niepochodne strukturalnie}

Awansować: Wywalczyć promocję możemy, najważniejsze jednak, by przygoda z ekstraklasą, gdy do niej trafimy, trwała dłużej niż sezon - mówi Dudek. (PN 6/2012, s. 45)

Bronić: I wydaje się, że w rundzie rewanżowej, przynajmniej na razie, to Szwed będzie stał między słupkami PSV. (PN 6/2012, s. 24)

W Copa del Rey grał Jose Manuel Pinto, Valdes pełnił straż w lidze. (PN 6/2012, s. 38)

Strzeże wrót Lechii Gdańsk i robi to nadspodziewanie dobrze. (PN 43/2011, s. 19)

Kierować: 64-letni Teixeira dzierży stery brazylijskiego futbolu od 1989 roku i w tym czasie miał oszukiwać fiskusa, brać łapówki, a także wprowadzać w błąd komisje kongresu, które prowadziły różne dochodzenia. (PN 9/2012, s. 39)

37 Można się zatem zastanawiać, czy w przykładach tych nie mamy do czynienia z kontekstową elipsą uzupełnienia predykatu, por. E. Szkudlarek, Kontekstowa elipsa akomodowanych jednostronnie uzupetnień predykatu, „Acta Universitatis Lodziensis. Folia Linguistica” 1999, 38, s. 89-96. 
Kłamać: Ok., wiedziałam, że nie mówię prawdy, że nie powinnam tego robić, ale Marta jest o wiele bardziej winna. (VG 16/2012, s. 17)

Kłócić się: Nie wchodź teraz w konflikt ze współpracownikami, bo w bezpośrednim starciu możesz tylko stracić. (NŻ 5/2012, s. 47)

Obrażać się: Próbowałam porozmawiać, ale oni nie widzą w tym problemu i uważają, że strzelam focha i że jestem kujon. (VG 12/2011, s. 34)

Odpocząć: Beata Kozidrak (52) była zmęczona, dlatego przed planowaną lada dzień premierą postanowiła zregenerować siły. (NŻ 12/2012, s. 4)

Płacić: Za poradę lekarską i część badań diagnostycznych nie ponosisz kosztów, za ewentualne leki trzeba będzie zapłacić. (VG 11/2011, s. 12)

Płakać: Ale to wszystko było takie... takie totalne i nagłe... nawet nie zauważył, kiedy z oczu pociekły mu łzy. (VG 1/2011, s. 23)

Kamili łzy popłynęły po policzkach. (VG 3/2011, s. 12)

Poronić: Luiza nie donosiła ciąży, z której tak bardzo się cieszyła. (NŻ 7/2012, s. 2)

Powołać: Większość wybrańców trenera Fornalika powołania słusznie traktuje jako przedświąteczny prezent, z którego warto skorzystać, by na dłużej zagościć w notesie selekcjonera. (PN 50/2012, s. 43)

Selekcjoner jest konsekwentny, wysyła zaproszenia do Tomka Kuszczaka, który doskonale zna Anglików, ale czy golkiper Brighton to obecnie najlepszy wybór? (PN 41/2012, s. 2)

Przegrać: I w tym sensie Wisła poniosła porażkę, skok na bank się nie powiódł. (PN 15/2012, s. 2)

Jesienią po każdym potknięciu liderującego Śląska Legia także obowiązkowo gubiła punkty. (PN 13/2012, s. 2)

Wiosną prowadzą już co prawda warszawianie, ale nadal nie zachwycają i tracą kolejne oczka, natomiast ekipa Oresta Lenczyka nie potrafi wykorzystywać spowolnienia najgroźniejszego rywala. (PN 13/2012, s. 2)

Choć Śląsk bił Legię przy Łazienkowskiej aż dwukrotnie, sam dostał baty od Rumunów. (PN 50/2011, s. 2)

Mimo że rozegrali dobre zawody, w mojej ocenie lepsze od gospodarzy, do domu wrócili bez punktów. (PN 44/2011, s. 2)

Ten zespół w ósmym meczu pod wodzą Del Neriego doznał siódmej porażki, co niemalże przesądza o rychłej dymisji szkoleniowca. (PN 50/2012, s. 31)

Należy jednak pamiętać, że zespół Szachtara u siebie nie lubi tracić punktów. (PN 49/2012, s. 2) 
Z kolei ta znalazła wreszcie ligowego pogromcę - oddała punkty Jagiellonii, dla której zwycięstwo przy Łazienkowskiej było jednak jedynym w analizowanym okresie. (PN 49/2012, s. 40)

Dziś łatwiej jest wygrać mecz, a wtedy prezentując zbyt ofensywną grę, łatwiej było otrzymać od rywali lekcję futbolu. (PN 48/2012, s. 15)

Rewelacyjne beniaminki - Eintracht i Fortuna w końcu poznały smak porażki. (PN 41/2012, s. 35)

W lidze są jednym z dwóch zespołów, które nie zaznały jeszcze goryczy porażki. (PN 41/2012, s. 28)

W Łowiczu podopieczni Grzegorza Wesołowskiego przegrali 2 razy, natomiast na wyjeździe jeszcze nie zaznali porażki. (PN 41/2012, s. 44)

Trzy kolejki przed końcem najbliżej ekstraklasy jest natomiast Piast Gliwice, ciekawe jednak, czy wzorem innych drużyn w jednej z dwóch najbliższych kolejek nie zechce stracić punktu. (PN 20/2012, s. 42)

Niestety, w życiu osobistym znów poniosła klęskę. (NŻ 12/2012, s. 44)

Przeklinać: Nie używaj wulgaryzmów, wyrazów z języka potocznego i takich, które nie pasują do tematu i formy wypracowania egzaminacyjnego. (VG 7/2011, s. 28)

Jak tam sobie chłopaki między sobą słowami na „k...” rzucają, to ich sprawa. (VG 7/2011, s. 17)

Chłopaka, który co drugie słowo wrzuca przecinek - żenada. (VG 3/2011, s. 22)

Przytyć: W zimę mniej się ruszam, więc jakoś tak na brzuchu i udach tłuszczu przybywa. (VG 9/2011, s. 27)

Działo się tak, bo było jej... zwyczajnie za dużo. (NŻ 13/2012, s. 5)

Niestety, po tym jak rzuciła palenie, sporo przybrała na wadze. (NŻ 13/2012, s. 5)

Jeśli przybyło Ci nieco ciała, to zadbaj już teraz o swoją sylwetkę, by zdążyć przed latem. (NŻ 9/2012, s. 47)

Reprezentować: Kiedy znudziło mu się życie w metropolii nad Bosforem, wrócił do Premier League, by bronić najpierw barw Boltonu, a ostatnio Chelsea. (PN 51-52/2011, s. 89)

Rozstać się: Wprawdzie 6 grudnia przyjechała do Olafa Lubaszenki jego ukochana Hanna Wawrowska, ale tylko po to, by mu oznajmić, że odtąd nie będą już parą. (NŻ2/2012, s. 9) Po 3 latach gorącego romansu i jeszcze bardziej ognistych kłótniach, para złożyła miłosną broń... (NŻ 3/2012, s. 17)

Schudnạć: Przestań myśleć, że wszystkie twoje kłopoty znikną i życie stanie się idealne, tylko dlatego, że będziesz ważyć kilka kilogramów mniej. (VG 17/2012, s. 36) 
Choć stracili niewiele kilogramów, to uczestnikom badań obniżyło się ciśnienie krwi i spowolnił rytm pracy serca, wzrosła wydolność, poprawił nastrój, a obwód pasa zmalał. (P 51-52/2012, s. 113)

Traci kilogramy (NŻ 10/2012, s. 4)

A jeśli już zrzucisz kilka kilo, dbaj o utrzymanie jędrnej skóry w tym miejscu. (NŻ 13/2012, s. 23)

Sporo kilogramów zrzucił ponownie Aleksander Kwaśniewski. (P 24/2012, s. 122)

Skorzystać: Ale to oni najbardziej na całym zamieszaniu skorzystali; jak to się ostatnio mówi: stali się największymi beneficjentami. (PN 11/2012, s. 18)

Trafić/strzelić: Wówczas to w ciągu 10 minut aż trzykrotnie posłał piłkę do bramki. (PN 50/2012, s. 2)

Isco zdobył dwie bramki w LM, tak jak starszy od niego o ponad dekadę były reprezentant Hiszpanii Joaquin, zaś po jednym golu strzelili: Urugwajczyk Seba oraz Argentyńczycy: Diego Buonanotte i Javier Saviola. (PN 50/2012, s. 34)

Gospodarze specjalnie się nie wysilali, tyle że piłkarze z Lizbony nie umieli skierować piłki do siatki i spotkanie zakończyło się rezultatem 0:0. (PN 50/2012, s. 35)

Po dośrodkowaniu z rzutu rożnego Filipa Starzyńskiego pilnujący Arkadiusza Piecha Rafał Grzyb skierował piłkę do własnej bramki. (PN 50/2012, s. 40)

Mariusz Magiera dośrodkował z rzutu rożnego, a stojący koło bliższego słupka Mateusz Zahara sprytnym strzałem głową umieścił futbolówkę w siatce. (PN 50/2012, s. 42)

Już w poprzednim sezonie dziewiętnastokrotnie pokonywał bramkarza rywali, w obecnym, mimo że do zakończenia zasadniczej części rozgrywek jeszcze dziewięć kolejek, znacznie poprawił to osiągnięcie. (PN 6/2012, s. 10)

Cieniem na jego dokonaniach kładzie się jedynie fakt, że nie potrafił ani razu umieścić piłki w bramce przeciwnika w europejskich pucharach. (PN 6/2012, s. 10)

Gdy szybko nie zdobywamy gola w meczu, wkrada się nerwowość. (PN 48/2012, s. 20)

Najpierw Szwed asystował przy dwóch trafieniach kolegów, a w końcówce sam dwukrotnie wpakował piłkę do siatki. (PN 48/2012, s. 35)

Wydawało się, że przyjęte przed meczem przez obu trenerów sposoby sforsowania defensywy rywali zawiodły, że Hiszpanie nie wjadą do bramki Włochów z piłką, a ci nie zaskoczą wysokich stoperów La Roja długimi, górnymi piłkami od napastników lub skrzydłowych, choć Pirlo zagrywał je niebywale dokładnie. (PN 24/2012, s. 31)

W znakomitej formie jest Ałan Dzagojew, który Czechom wbił dwa gole. (PN 24/2012, s. 16)

Wojciech Kędziora ze stoickim spokojem wpakował piłkę do bramki po zagraniu Mateusza Bodziocha. (PN 20/2012, s. 43) 
Mindaugas Kalonas z linii końcowej zagrał do wbiegającego Tomasza Strzelca, który wślizgiem wepchnąl piłkę do siatki. (PN 36/2012, s. 41)

Pan dotychczas nie błyszczał skutecznością we Flocie, a gdy już się odblokował, aż dwukrotnie posłał piłkę do siatki rywala. (PN 36/2012, s. 40)

Tomasz Kupisz w pucharowej konfrontacji z Lechią Gdańsk dwukrotnie posyłał piłkę do bramki rywala, ale zaliczył też bramkę samobójczą i o awansie do ćwierćfinałów zdecydowała seria rzutów karnych. (PN 41/2012, s. 22)

Gdyby nie feralne 11 minut w końcówce drugiej połowy, kiedy liderzy Premier League zaaplikowali podmęczonym gospodarzom trzy gole i można pokusić się o opinię, iż ów styl gry zdał egzamin. (PN 41/2012, s. 30)

Kibice osowiali i milczący, szaro, ziąb, a na koniec Łotysze wpakowali gola. (P 24/2012, s. 15)

Trenować: Jego następca, Amerykanin z krwi i kości, nigdy nie prowadził drużyny poza granicami Stanów Zjednoczonych. (PN 44/2011, s. 29)

Do 12 marca tego roku Ferguson, Wenger i Moyes zasiadali za sterami swoich zespołów w meczach ligowych 1954 razy. (PN 12/2012, s. 19)

Umrzeć/zginąć: Warto przypomnieć kilka innych zdarzeń stadionowych, w wyniku których ludzie tracili życie. (PN 6/2012, s. 5)

Oficjalnie podano, że śmierć poniosło 61 osób, ale nikt w to nie wierzył. (PN 6/2012, s. 5)

Do domu nie wróciło 96 kibiców, w tym wiele dzieci. (PN 6/2012, s. 6)

Nie ma już wśród żywych wojownika, sportowca o nieposkromionych ambicjach, Czarodzieja z narożnika, jak pisała o Nim prasa zagraniczna. (PN 11/2012, s. 4)

Teraz Czarodziej z narożnika będzie czarował już w innym, lepszym ze światów... (PN 11/2012, s. 5)

Za chwilę dosięgnie go śmiercionośna kula. (VG 10/2011, s. 57)

Anioł z New Jersey zamilkł na zawsze (NŻ 7/2012, s. 42)

Kiedy w końcu nadeszło to nieuniknione, to ona zamknęła mu powieki. (NŻ 7/2012, s. 14)

Dzieci megagwiazd, które zgasły przedwcześnie, nie chcą żyć w cieniu sławnych rodziców. (NŻ 8/2012, s. 17)

Kamera zaglądała w oczy roztańczonej Szaflarskiej, zatrzymywała się na Witoldzie Grucy, niegdyś wielkim tancerzu, na Irenie Kwiatkowskiej, która kilka miesięcy później będzie już daleko stąd, ale póki co głośno dowodzi, że diabła granego przez Nowickiego „wcale się nie przelękła, tylko strach zagrała”, na Stefanie Burczyku, który podpisze pakt z diabłem, byle ostatni raz zagrać przed widzami. (P 51-52/2012, s. 129) 
Z wyliczeń wynika, że gdyby rzeczywiście nie było różnic między dużymi, długo żyjącymi gatunkami i małymi, żyjącymi krótko, to każdy wieloryb lub słoń powinien dokonać żywota z powodu nowotworu, zanim osiągnąłby wiek reprodukcyjny. (P 50/2012, s. 81)

Trzy tygodnie później jej ukochany tata odszedł z tego świata. (NŻ 11/2012, s. 8)

Bo jego „pacjentami” są ludzie, którzy stracili życie w trudnych lub niewyjaśnionych okolicznościach. (VG 23/2012, s. 7)

W 2004 r. oddał życie kolejny kibic Wisły, 17-latek znany pod ksywką Fujin. (P 5/2011, s. 94)

Urodzić: Już od tygodni prasa spekulowała, kiedy Beyoncé (30) wyda na świat swoje pierwsze dziecko. (NŻ 2/2012, s. 7)

Urodzić się: Przed wyjazdową batalią ze Swansea City po raz ostatni na koncie Drozdów były cztery z rzędu wygrane, gdy większości graczy nie było jeszcze na świecie, a ich dzisiejszy opiekun zaczynał kopać piłkę w zespole juniorów szkockiego St Mirren. (PN 49/2012, s. 20)

W maju przyszła na świat moja druga córka, więc przykrych spraw zbyt długo nie rozpamiętywałem. (PN 36/2012, s. 13)

Dziecko Marianny ma przyjść na świat w kwietniu. (NŻ 4/2012, s. 5)

Usadowione wygodnie na kocach, chroniących od chłodu betonowej posadzki, dzielą się ryżem, karmią zatopione w ich ramionach niemowlęta i haftują beciki dla tych, które przyjdą wkrótce na świat. (P 24/2012, s. 57)

Tyle tygodni miała, kiedy opuściła łono. (P 50/2012, s. 27)

Współżyć: I dorosły, który uprawia seks z małoletnią, będzie karany. (VG 3/2011, s. 11) W ubiegłym roku sternik FIFA na wieść, iż rzeczony już Terry uprawiał seks z byłą partnerką kolegi klubowego Wayne’a Bridge’a oświadczył: - W krajach o kulturze łacińskiej takiego typu zachowania nie tylko nie potępia się, ale wręcz pochwala. (PN 47/2011, s. 27)

W listopadzie mieli pierwszy seks, zaraz potem Marysi jakby urósł brzuch. (P 24/2012, s. 37)

On ciągle nalega, żeby to zrobić. (VG 23/2012, s. 12)

Wybaczyć: Na ogół sami adwokaci radzą klientom, by obelgi i obrazy puścić płazem, a na sprawców spuścić zasłonę miłosierdzia. (P 38/2012, s. 97).

Wygrać: Pozostające wiosną bez wygranych - gdańska Lechia i Łódzki KS - w minionej kolejce wreszcie zainkasowały komplety punktów. (PN 14/2012, s. 47)

Oprócz przegranego meczu z Bułgarią nie potrafili także zdobyć punktów w spotkaniu z Izraelem, mimo prowadzenia u siebie 2:1, przegrali 3:2. (PN 13/2012, s. 20) 
Grający w dziewięciu gospodarze zdołali jednak utrzymać skromne prowadzenie i sięgnęli po ważne trzy punkty. (PN 11/2012, s. 28)

W tym momencie każdy mecz ma najwyższą stawkę i obojętnie, z kim zagramy, musimy zdobyć komplet punktów. (PN 36/2012, s. 9)

W piątek chorzowianie nieoczekiwanie wywieźli z Konwiktorskiej komplet punktów, tymczasem zespół Legii w sobotę po bezbarwnym występie uległ u siebie Lechowi Poznań. (PN 17/2012, s. 4)

Wcześniej, bo we wrześniu, dzięki bramce Roberto Soldado komplet punktów zgarnęła Valencia. (PN 17/2012, s. 17)

Najpierw więc zawodnicy Frederica Antonettiego w meczu kończącym poprzednią serię rozprawili się z Niceą, a w sobotę wywieźli komplet oczek z Brestu. (PN 17/2012, s. 29)

Możemy zgarnąć trzy punkty. (PN 33/2012, s. 15)

Nowicjusze zarówno na tym poziomie, jak i w tym fachu, czyli Corini oraz sardyński duet Pulga-Lopez zaliczyli w debiutach komplet punktów. (PN 41/2012, s. 25)

Zakochać się: Cała rodzina podśmiewała się z siedemnastoletniej Patrycji, która pierwszy raz w życiu została tak na poważnie „trafiona strzałą Amora”. (VG 16/2012, s. 24)

Zdradzić: Piotr twierdzi, że to Magda była niewierna. (NŻ 3/2012, s. 43)

Zejść: I po chwili Iniesta spudłował minimalnie, a po minucie Balotelli najpierw zabrał piłkę ostrzyżonemu specjalnie na turniej na krótko Sergio Ramosowi, a potem dał mu się ośmieszyć i powędrował do zajezdni decyzją trenera. (PN 24/2012, s. 31)

Sytuacja zmieniła się, gdy plac gry opuścił z powodu kontuzji Tomasz Bandrowski. (PN 41/2012, s. 22)

Zremisować: Myślałem, że w meczu Śląska Wrocław z Legią Warszawa drużyny podzielą się punktami. (PN 50/2012, s. 41)

Gospodarze prowadzili po 10 minutach 3:0, ale ostatecznie podzielili się z rywalem punktami. (PN 44/2012, s. 42)

Ktoś powie: z wielkiej chmury mały deszcz, bo ani Jaga specjalnie nie wzbogaciła się we Wrocławiu, ani tym bardziej Śląsk nie stracił szansy na mistrzostwo, gubiąc dwa punkty. (PN 48/2012, s. 2)

Mateusz Miłoszewski zastąpił Tomasza Reginisa i zdobył oczko w Łowiczu. (PN 36/2012, s. 43)

Tylko Motor zainkasował punkt, który pozwolił opuścić ostatnią lokatę w tabeli. (PN 41/2012, s. 45)

Zwolnić: Po czterech miesiącach i trzech punktach podziękowano mu za pracę. (PN 20/2012, s. 16) 
W złożonych konstrukcjach nieposiadających wspólnych morfemów z odpowiadającym im syntetyzmem o wiele częściej pojawiają się połączenia zbudowane $\mathrm{z}$ więcej niż dwóch komponentów. Odnotowano wiele form trójelementowych (tylko nieznacznie mniej od dwuleksemowych), nie brakuje i dłuższych, np. łzy popłynęły komuś po policzkach, zagościć w notesie selekcjonera, otrzymać od rywali lekcję futbolu, ważyć kilka kilogramów mniej, umieścić piłkę w bramce przeciwnika, kogoś nie ma już wśród żywych, zostać trafionym strzała Amora, podzielić się zrywalem punktami.

Zaobserwowano dużą kreatywność w tworzeniu wielowyrazowych konstrukcji, często zdarza się, że jednemu syntetyzmowi odpowiada kilka analityzmów o zróżnicowanej strukturze (np. bronić to stać między słupkami, strzec wrót i petnić straż; z oczu pociekły komuśłzy i łzy popłynęly komuś po policzkach to określenia informujące, że ktoś płacze; odpowiednikami przeklinać są $u \dot{z} y$ wać wulgaryzmów, wrzucać co drugie słowo przecinek, rzucać słowami na „k...”; komuś przybywa tłuszczu, kogoś jest za dużo, komuś przybyło ciała czy przybrać na wadze to ekwiwalenty czasownika przytyć; syntetyczne rozstać się może być wymiennie stosowane $\mathrm{z}$ nie być już para i złożyć miłosną broń; schudnać to stracić kilogramy, ważyć kilka kilogramów mniej, zrzucić kilka kilo/sporo kilogramów, a także komuś maleje obwód pasa; zamiast trenować można użyć prowadzić drużyne czy zasiadać za sterami; analityczne być na świecie, przyjść na świat i opuścić łono mają syntetyczny zamiennik w postaci urodzić się; współżyć jest synonimiczne z uprawiać seks, mieć seks i robić to; odpowiednikami zejść są powędrować do zajezdni i opuścić plac gry; zremisować ma pięć ekwiwalentów: podzielić się punktami, podzielić się punktami z rywalem, gubić dwa oczka, zdobyć oczko, zainkasować punkt), a czasem nawet kilkanaście - szczególną produktywnością odznaczają się zwroty odnoszące się do wygrać (zainkasować komplet punktów, zdobyć punkty, siegnąć po trzy punkty, zdobyć komplet punktów, wywieźć komplet punktów, zgarnać komplet punktów, wywieźć komplet oczek, zgarnać trzy punkty, zaliczyć komplet punktów), przegrać (gubić punkty, tracić oczka, dostać baty, ponieść porażkę, wrócić bez punktów, doznać porażki, oddać punkty, otrzymać od rywali lekcje futbolu, poznać smak porażki, zaznać goryczy porażki, zaznać porażki, stracić punkty, ponieść klęskę), trafić/strzelić (posłać piłkę do bramki, skierować piłkę do siatki, zdobyć bramkę, skierować piłkę do bramki, umieścić futbolówkę w siatce, pokonać bramkarza rywali, umieścić piłkę $w$ bramce przeciwnika, wpakować piłkę do siatki, wpakować piłkę do bramki, wjechać do bramki z piłką, wbić gola, wepchnąć piłkę do siatki, posłać piłkę do 
siatki rywala, posłać piłkę do bramki rywala, zaaplikować gola, wpakować gola) i umrzećlzginać (stracić życie, oddać życie, ponieść śmierć, nie wrócić do domu, kogoś nie ma już wśród żywych, czarować w innym, lepszym ze światów, kogoś dosięgła śmiercionośna kula, zamilknać na zawsze, nadeszło to nieuniknione, zgasnąć przedwcześnie, być daleko stąd, dokonać żywota, odejść z tego świata). Część z nich dosłownie opisuje zaistniałą czynność, inne mają natomiast charakter metaforyczny.

Przytoczone przykłady pokazują, że formy zmultiwerbizowane mogą różnić się między sobą nieznacznie (dochodzi zwykle do wymiany jednego określenia na synonimiczne, np. przynależne do innej odmiany stylistycznej lub socjolektalnej), zdarza się jednak, że powstają oryginalne złożone twory słowne, które są wynikiem niekonwencjonalnego opisu zdarzeń przez osoby publikujące w prasie. W przypadku konstrukcji niepokrewnych morfologicznie trudno jest mówić o charakterystycznych podstawach czasownikowych, każde orzeczenie peryfrastyczne jest bowiem wynikiem indywidualnych upodobań dziennikarzy, a wydaje się, że pomysłowość w wykorzystaniu tworzywa językowego jest niemalże nieograniczona.

Dwuelementowe orzeczenia peryfrastyczne składają się z czasownika i rzeczownika w dopełniaczu (np. bronić barw, doznać porażki, używać wulgaryzmów) lub bierniku (np. zregenerować sity, wywalczyć promocje, zaaplikować gola), zdarzają się też zestawienia czasownika z przymiotnikiem (np. być niewiernym). Konstrukcje trójelementowe rozbudowują rzeczownik o przydawkę (np. zaznać goryczy porażki, złożyć miłosna broń, zdobyć komplet punktów), bywa, że połączenie czasownika z rzeczownikiem poprzedza modulant nie (np. nie mówić prawdy, nie donosić ciąży, nie być już para). Niemałą grupę reprezentują połączenia bezokoliczników z wyrażeniami przyimkowymi (np. uciekać $z$ kraju, wejść w konflikt, powędrować do zajezdni). Wieloskładnikowe analityzmy czasownikowe są kombinacją bezokoliczników z rzeczownikami i wyrażeniami przyimkowymi (wydać na świat dziecko, dostać od rywali lekcję futbolu, posłać piłkę do bramki), rzeczownikami i liczebnikami (sięgnać po trzy punkty), rzeczownikami, liczebnikami i przysłówkami (ważyć kilka kilogramów mniej), rzeczownikami i modulantami (nie być już para), modulantami i wyrażeniami przyimkowymi (nie wrócić do domu), wyrażeniami przyimkowymi i zaimkami (odejść z tego świata), rzeczownikami i imiesłowami (zostać trafionym strzała Amora). 


\subsubsection{Frazeologizmy 38}

Bać się: Myślałem, że nie mam lęku wysokości, jednak pietra trochę miałem. (VG 12/2011, s. 38) - pot. mieć pietra 'odczuwać strach, bać się' (WSF, s. 357)

Cieszyć się: Trzeźwo patrzący zacierali jednak ręce. (PN 50/2012, s. 17) - zacierać ręce a) 'trzeć dłonią o dłoń z zimna albo na znak zadowolenia’; b) 'okazywać zadowolenie, radość; cieszyć się' (WSF, s. 662)

Producenci programu zacierają podobno ręce. (NŻ 10/2012, s. 3)

Denerwować: I je znalazł - z pożytkiem dla WBA, klubu niezaliczanego do potentatów, ale umiejącego pod batutą Szkota psuć krew tym, którzy opływają w luksusy. (PN 49/2012, s. 20) - psuć sobie, komuś krew, napsuć sobie, komuś krwi 'wprawiać, wprawić siebie, kogoś w zły humor, denerwować, zdenerwować się (kogoś) czymś, irytować się, zirytować się czymś' (WSF, s. 190)

Wśród nich m.in. Guerilla Girls (uwielbiająca wsadzać kij w mrowisko grupa amerykańskich artystek feministek od lat skrywających twarze pod maskami małp), Grupa Voina (Rosjanie, którzy zasłynęli malowidłem wielkiego penisa na zwodzonym moście w Petersburgu, vis-á-vis siedziby KGB) i Ai Wei Wei (chiński twórca, który od lat psuje krew rodzimym politykom). (P 24/2012, s. 87)

Chociaż nie będziesz jeszcze mieć narzędzi, znać technik postępowania, to jednak przekonasz się, czy w ogóle jesteś w stanie podołać podobnym zajęciom, czy nie masz uprzedzeń, czy nie przeraża cię upośledzenie drugiego człowieka, a trudne dzieci nie działają ci na nerwy tylko dlatego, że są, jakie są. (VG 12/2011, s. 7) - działać komuś na nerwy; grać, zagrać komuś na nerwach 'drażnić, denerwować, zdenerwować kogoś’ (WSF, s. 274)

Dokuczać: Mróz mocno dał się we znaki głównie samochodowym akumulatorom, ale znacznie utrudnił też przygotowania do rundy wiosennej piłkarzom, którzy otwarte boiska zamienić musieli na sportowe hale. (PN 6/2012, s. 47) - dawać się, dać się komuś we znaki 'być odczuwanym jako coś przykrego, uciążliwego, dokuczać komuś' (PSF, s. 115)

Dominować: Na ekipę, gdzie pierwsze skrzypce grali Miodrag Belodedici, Laszlo Boloni, Marius Lacatus, Victir Piturca i Gavril Balint, nie było mocnych w domu. (PN 6/2012, s. 39) - grać pierwsze skrzypce 'mieć głos decydujący, wpływać na kształt, charakter czegoś; dominować' (WSF, s. 484)

38 Wyjaśnienie związków frazeologicznych pochodzi z następujących słowników: WSF - Wielki słownik frazeologiczny PWN z przysłowiami, oprac. A. Kłosińska, E. Sobol, A. Stankiewicz, Warszawa 2009; PSF - K. Głowińska, Popularny słownik frazeologiczny, Warszawa 2000; SPPot - M. Czeszewski, Słownik polszczyzny potocznej, Warszawa 2008. 
Mimo tych przeciwności drużyna nadaje ton w rozgrywkach Ligue 1, a awans do pucharowej fazy Ligi Europy zapewniła sobie w imponującym stylu już po pierwszych czterech zwycięstwach. (PN 50/2012, s. 28) - nadawać ton czemuś 'wywierać wpływ na charakter lub wygląd czegoś; także: przewodzić, dominować gdzieś' (WSF, s. 561)

Takie spędzanie świąt może się wydawać sensowne tym osobom, które wiedzą, że przy wigilijnym stole górę wezmą emocje, uprzedzenia - i że to może je bardzo dużo kosztować. (P 51-52/2012, s. 22) - coś bierze nad kimś, nad czymś górę 'o poglądach, stanach psychicznych, uczuciach: dominować, kierować czyimś postępowaniem' (WSF, s. 126)

Dorównywać: Przez godzinę udawało im się dotrzymywać kroku gospodarzom. (PN 48/2012, s. 23) - dotrzymać komuś kroku a) 'iść z kimś z tą samą szybkością’ b) 'rozwijać się w tym samym tempie, dorównywać komuś w czymś' (WSF, s. 78)

Drwić, naśmiewać się: Gdy opiekun Ruchu Waldemar Fornalik opuszczał około godziny 22 klubową szatnię i dowiedział się, z kim jego zespółbędzie walczył o finał, uśmiechnął się pod nosem i powiedział, bardziej do siebie, niż towarzyszących mu osób: - Ktoś z nas wszystkich robi sobie jaja. (PN 44/2012, s. 19) - robić sobie z kogoś jaja 'ośmieszać kogoś, naśmiewać się, drwić sobie z kogoś’ (SPPot, s. 266)

Głodować: - Gdyby nie istniał, na Święta nie miałbym co do garnka włożyć. (P 5152/2012, s. 6) - nie mieć, nie ma co do garnka włożyć, do ust (w usta), pot. do gęby (w gębę), posp. do pyska włożyć 'nie mieć, nie ma nic do jedzenia, głodować' (WSF, s. 624)

Grymasić, kaprysić: Balotelli to napastnik, który miewa muchy w nosie, posadzenie go w takim momencie na ławce rezerwowych spowodowałoby, że zawodnik byłby kompletnie nieprzydatny do końca turnieju. (PN 24/2012, s. 22) - pot. ktoś ma muchy w nosie; mucha komuś usiadła na nos; mucha kogoś ugryzła, ukąsiła 'ktoś grymasi, kaprysi, złości sięi dąsa bez powodu' (WSF, s. 259)

Gwarantować, ręczyć: W cyrku wszystko jest możliwe, dlatego głowy nie dam, że podobnych tłumaczeń nie usłyszymy po odwołaniu zaplanowanego na 29 lutego międzypaństwowego meczu towarzyskiego Polska - Portugalia. (PN 7/2012, s. 47) - dać głowę 'zapewnić o czymś, być czegoś pewnym; gwarantować, ręczyć' (WSF, s. 60)

Kierować, rządzić: Dom i rodzinę trzymała w garści mama - kiedy żyła. (P 24/2012, s. 36) - mieć, trzymać kogoś, coś w garści 'uzależnić kogoś lub coś od siebie, kierować, rządzić kimś lub czymś' (WSF, s. 108)

Kłamać: Zresztą w meczach reprezentacji nie zawodziłem, to najlepszy dowód, że nie mijam się z prawdą. (PN 6/2012, s. 28) - euf. mijać się, rozmijać z prawdą 'mówić nieprawdę; kłamać' (WSF, s. 396)

Ale mężczyźni potrafią mijać się z prawdą też z innych powodów. (NŻ 8/2012, s. 37) 
Lekceważyć: Ale najgorsze jest to, że superprzystojny Jared ma w nosie umizgi Devon i wyraźnie chce umówić się z Lexi... (VG 15/2012, s. 34) - pot. mieć kogoś, coś w nosie, wulg. w dupie, euf. (głęboko) gdzieś, w dużym, głębokim poważaniu 'lekceważyć kogoś, coś, nie liczyć się z kimś, z czymś' (WSF, s. 242)

Mamić, zwodzić: Nie daj się wodzić za nos - wysłuchuj różnych stron i zajmij swoje stanowisko. (VG 3/2011, s. 38) - wodzić kogoś za nos 'mamić, zwodzić, oszukiwać kogoś, aby podporządkować go swej woli' (WSF, s. 626)

Czy prezes, czy trener także ma coś do powiedzenia, czy może jednak wszystkich za nos wodzą piłkarze? (PN 36/2012, s. 14-15)

Marnować, trwonić: Żeby czas nie przeciekł przez palce... zaplanuj ferie. (VG 3/2011, s. 6) - coś przecieka komuś przez palce 'ktoś coś marnuje, traci, trwoni, nie umie czegoś właściwie wykorzystać, należycie zużytkować' (WSF, s. 407)

Marzyć: Jovanović nie lubi bujać w obłokach. (PN 14/2012, s. 37) - bujać w obłokach 'być dalekim od realnego życia, także: być pogrążonym w marzeniach, marzyć' (WSF, s. 27)

Milczeć: Zawsze trzyma fason, ale gdy trzeba komuś przyłożyć, nie nabiera wody w usta i nie udaje Greka. (PN 1/2012, s. 47) - nabrać wody w usta 'przestać mówić, pisać na jakiś temat, zamilknąć; milczeć' (WSF, s. 266)

Narazić się: Z kolei The Special One musi pamiętać, że rosyjski oligarcha nie patyczkuje się, gdy ktoś nadepnie mu na odcisk. (PN 11/2012, s. 16) - nastąpić, nadepnąć komuś na odcisk 'narazić się komuś' (WSF, s. 303)

Obserwować: Włoski szkoleniowiec już na jesieni ubiegłego roku wspominał, że tego chłopaka ma na oku. (PN 6/2012, s. 33) - mieć kogoś, coś na oku a) 'obserwować kogoś, coś, być ostrożnym, czujnym w stosunku do kogoś’ b) 'strzec, pilnować kogoś, czegoś, czuwać nad kimś' (WSF, s. 315)

Musiałam mieć go na oku - zdradziła modelka. (NŻ 5/2012, s. 4)

Wszyscy oprócz gdańszczan, którzy raz spuścili Prezesa z oka i wystarczyło. (PN 11/2012, s. 36) - nie spuścić kogoś, czegoś z oczu (z oka) a) 'nieustannie na kogoś, na coś patrzeć, ani na chwilę nie przestać kogoś, czegoś obserwować; b) 'pilnować, strzec kogoś, czegoś' (WSF, s. 505)

Odbywać się, zdarzyć się, zachodzić: Ta druga sytuacja miała miejsce pięć metrów od pomocniczego asystenta pracującego za bramką. (PN 24/2012, s. 41) - mieć miejsce 'dziać się, odbywać się, zdarzać się, zachodzić' (WSF, s. 245)

Powinni wtedy głośno powiedzieć, że było im przykro i woleliby, żeby takie sytuacje nie miały miejsca. (VG 10/2011, s. 16) 
Oddziałać: Tak czy inaczej po prawie 40 latach, gdy zdążyli odcisnąć piętno na zespołach, które prowadzili z ławki trenerskiej w różnych krajach, obaj panowie wciąż nie mają o sobie najlepszego zdania. (PN 50/2011, s. 29) - odciskać, wycisnąć piętno 'oddziałać na coś, mieć istotny wpływ na coś' (WSF, s. 358)

Odpocząć: Mamy prawie miesiąc wolnego przed mistrzostwami i wszyscy potrzebujący złapać oddech będą mieli na to czas, a tym, którzy będą musieli ciężej popracować, też to się uda. (PN 17/2012, s. 3) - złapać, łapać, chwycić oddech 'odpocząć, odpoczywać' (WSF, s. 303)

Musiałam złapać oddech, więc pomyślałam, że wpadnę, to może coś ciekawego mi powiesz - mrugnęła. (VG 3/2011, s. 12)

\section{Lapie oddech w Hiszpanii (NŻ 12/2012, s. 4)}

Odpowiadać: Rosjanom to było na rękę, bo sami planowali ściągnąć rywali do środka boiska, by na bokach najlepsi w zespole Advocaata: Arszawin i Dzagojew mieli jak najwięcej miejsca, byli pilnowani bez podwajania. (PN 24/2012, s. 18) - coś jest komuś na rękę 'coś komuś odpowiada, jest dogodne dla kogoś' (WSF, s. 439)

Okazać się: No a na dodatek wyszło na jaw, że stadion nie jest przystosowany do rozgrywania meczów krajowych. (PN 6/2012, s. 2) - wyjść na jaw ‘stać się wiadomym, znanym, okazać się' (WSF, s. 149)

W roztańczonym tłumie wychodzą na jaw głęboko skrywane sekrety i zdrady. (VG 13/2011, s. 41)

Ostatnio wyszło jednak na jaw, że aktor zafascynowany jest animatorką kultury z Konina... (NŻ 3/2012, s. 8)

Kilka lat po śmierci Bettelheima wyszło na jaw, że i on w baśniach szukał przede wszystkim odreagowania własnych urazów. (P 51-52/2012, s. 79)

Oszczędzać: A przegrać cztery razy w siedmiu kolejkach (w tym z dwójką beniaminków), to niezależnie od tego, jak mocno pod Wawelem zaciska się pasa, dla klubu pokroju Wisły musi być obciachem. (PN 41/2012, s. 38) - zaciskać pasa 'ograniczać swoje wydatki; oszczędzać' (WSF, s. 342)

Oszukać: Tylko 19 lat i na koncie występy zarówno w Manchesterze United, jak i Juventusie, który podkradł (dla poprawy stosunków stanęło na milionie odstępnego) Anglikom Francuza mniej więcej tak, jak oni wcześniej wystrychnęli na dudka Le Havre. (PN 50/2012, s. 31) - pot. wystrychnąć kogoś na dudka 'oszukać kogoś, zrobić z kogoś głupca, ośmieszyć kogoś’ (WSF, s. 86)

Turysto, nie daj się nabić w butelkę. (NŻ 11/2012, s. 31) - pot. nabić kogoś w butelkę 'oszukać kogoś' (WSF, s. 266) 
Otoczenie konsumenta programami lojalnościowymi, które za pomocą punktów będą robiły wodę z mózgu, nigdy nie nastąpi. (P 24/2012, s. 105) - pot. robić, zrobić komuś wodę z mózgu świadomie wprowadzać, wprowadzić kogoś w błąd, oszukiwać, oszukać kogoś' (WSF, s. 625)

W światku narkotykowych baronów zasłużył na miano najbardziej pomysłowego: aby wyprowadzić w pole służby graniczne, ukrywał narkotyki nawet w konserwowych papryczkach chilli. (P 24/2012, s. 58-59) - wywieść, wyprowadzić kogoś w pole 'oszukać, zwieść kogoś' (WSF, s. 373)

Oświadczyć się: Jeszcze na początku grudnia Kaja chwaliła się swoim znajomym, że wreszcie Borys dojrzał do poważnych deklaracji i poprosił ją o rękę. (NŻ 1/2012, s. 6) - prosić kogoś o rękę ‘proponować kobiecie małżeństwo; oświadczać się’ (WSF, S. 400)

Pilnować: Ale trzeba trzymać rękę na pulsie. (VG 8/2011, s. 3) - trzymać rękę na pulsie (czegoś) 'orientować się doskonale w bieżącej sytuacji, śledzić przebieg czegoś, pilnować czegoś' (WSF, s. 570)

Płacić: Bez zastanowienia sięgają do portfeli, oczekują cudów, które mają robić ludzie tak naprawdę anonimowi. (PN 45/2011, s. 47) - sięgać do kieszeni, do portfela 'płacić za coś, dawać pieniądze na coś' (WSF, s. 474)

Pocieszyć: Kiedy jako 15-latek George Clooney (50) uległ porażeniu Bella, czyli paraliżowi mięśni twarzy, to ojciec Nick Clooney (78) podnosił go na duchu. (NŻ 10/2012, s. 14) - podnieść, pokrzepić, krzepić, podtrzymać w kimś ducha; podnieść, pokrzepić, krzepić, podtrzymać kogoś na duchu 'pocieszyć, pocieszać kogoś, wzmocnić, wzmacniać moralnie, dodać, dodawać otuchy, odwagi’ (WSF, s. 85)

Podupaść, pogorszyć się: A więc może jednak nie całe dziennikarstwo sportowe zeszło już na psy? (PN 44/2012, s. 10) - pot. zejść, schodzić na psy a) 'o stanie czegoś: pogorszyć się, pogarszać się, podupaść, podupadać’; b) 'o człowieku: wykoleić się, wykolejać się’ (WSF, s. 356)

Niewiele brakowało, a polskie prawodawstwo mogło zejść na psy. (P 50/2012, s. 98)

Pogawędzić: Po ubiegłorocznej Gali „Piłki Nożnej” uciąłem sobie pogawędkę z Maciejem Skorżą. (PN 50/2011, s. 16) - uciąć (sobie) pogawędkę, rozmowę, rozmówkę itp. 'porozmawiać z kimś niezbyt długo; pogawędzić' (WSF, s. 580)

Poskromić: Ano po to, żeby trochę utrzeć nosa Brytyjczykom. (PN 8/2012, s. 39) - pot. przytrzeć, utrzeć komuś nosa 'poskromić kogoś, dać komuś nauczkę, ukrócić czyjąś samowolę' (WSF, s. 291)

Korci Cię, żeby utrzeć nosa przełożonemu i pokazać mu, jak bardzo nieracjonalne są jego decyzje? (NŻ 13/2012, s. 47) 
Pomóc: Tym bardziej jeśli w sukurs przyjdzie jeszcze Białystok i zarządzany komisyjnie (już albo dopiero za chwilę, w każdym razie przez Jarosława Szostka) Olsztyn. (PN 3/2012, s. 1) - przychodzić, przyjść (iść, spieszyć) w sukurs 'pomagać komuś, wspierać kogoś w trudnej chwili' (PSF, s. 510)

W beznadziejnej sytuacji rękę do Ełksy wyciągnął biznesmen Andrzej Voigt, namówiony przez Mirosława Bulzackiego, jedną z największych legend klubu. (PN 7/2012, s. 2) - podać komuś, wyciągnąć do kogoś (pomocną, przyjazną) rękę, dłoń, bratnią dłoń a) 'okazać komuś życzliwość, chęć pomocy’; b) 'pomóc komus' (WSF, s. 441)

Wtedy rękę do Dołęgi wyciągnął biznesmen z Otwocka, Stefan Maciejewski, za młodu sztangista. (P 51-52/2012, s. 152)

Codziennie spotyka się z przemocą - fizyczną i psychiczną i zupełnie nikt nie wyciągnął do niej dłoni. (VG 5/2011, s. 20)

Odradzająca się Borussia to także zasługa Bayernu, którego władze po finansowym tąpnięciu, spowodowanym wejściem na giełdę, wyciągnęły pomocną dłoń i pożyczyły konkurentowi pieniądze. (PN 48/2012, s. 31)

Pomocną dłoń wyciągnęła do niej nauczycielka śpiewu i... była partnerka jej eksmęża Krystyna Prońko. (NŻ 11/2012, s. 14)

Nie spodziewaj się, że znajomi podadzą Ci pomocną dłoń - raczej to od Ciebie będą oni oczekiwać pomocy, a nawet gotowych recept na kłopoty. (NŻ 2/2012, s. 47)

Poprzeć: Bo na przykład Edgar Davids, który jest członkiem rady dyrektorów w tym klubie, stoi murem za Van Gaalem. (PN 50/2011, s. 29) - stanąć, stać murem za kimś, za czymś, przy kimś, przy czymś 'zdecydowanie, stanowczo kogoś, coś poprzeć, popierać, bronić' (WSF, s. 261)

Pozwolić: Kiedy ten stanowczo, mimo oferowanych mu bajecznych apanaży, odmówil, Abramowicz niechętnie dał zielone światło ${ }^{39}$ dla zatrudnienia na stałe Di Matteo. (PN 48/2012, s. 23)

Przeciwstawić się: Hiddink, tak jak obecnie Di Matteo, w półfinale Ligi Mistrzów musiał stawić czoło Barcelonie i tak samo awansował z The Blues do finału Pucharu Anglii. (PN 17/2012, s. 34) - stawić czoło (czoła) komuś, czemuś 'oprzeć się, przeciwstawić się komuś, czemuś, podjąć walkę z kimś, z czymś’ (WSF, s. 56)

39 Słowniki nie notują jeszcze zwrotu dać zielone światło, choć funkcjonuje wyrażenie zielone światło dla kogoś 'otwarcie przed kimś lub przed czymś możliwości rozwoju, przyznanie specjalnych przywilejów' (PSF, s. 759), 'specjalne przywileje, pierwszeństwo, udogodnienia dla kogoś albo do realizacji czegoś’ (WSF, s. 689), dlatego umieszczono ten analityzm czasownikowy w grupie związków frazeologicznych. 
Siła archetypowych potrzeb w nas jest tak silna, że stawiamy czoło. (P 51-52/2012, s. 22) Przejmować się: Jednak zdaniem Wengera jego chłopcy wzięli sobie do serca mocno krytyczne uwagi, zwłaszcza kibiców i efekty przeszły oczekiwania. (PN 6/2012, s. 42) - brać, wziąć (sobie) coś do serca 'przejmować się, przejąć się czymś, silnie odczuwać, odczuć coś' (WSF, s. 467)

Atmosfera w pracy zostanie zmęczona plotkami, ale nie bierz ich do serca, a na pewno nie myśl o tym po nocach. (NŻ 3/2012, s. 47)

Przeklinać: Mówił więcej niż inni, przeklinał na całego, każda okazja była dobra, żeby „rzucić mięsem”. (VG 14/2012, s. 22) - pot. rzucać mięsem, posp. mięchem, wulg. kurwami 'używać wulgarnych, obraźliwych słów; przeklinać' (WSF, s. 461)

Przekonać: Dziewczynom częściej wbija się do głowy, że mają być ciche i grzeczne, że nie wypada, aby zachowywały się głośno czy wulgarnie. (VG 14/2012, s. 22) - kłaść, wkładać, wbijać itp. coś komuś do głowy, w głowę, posp. do łba, w łeb 'starać się coś komuś przekazać, wytłumaczyć, przekonać go do czegoś' (WSF, s. 115-116)

Przemówić: Ale też Zbyszka można słuchać w nieskończoność, bo jeżeli zabiera już głos, to wie, co powiedzieć i w jakiej formie, żeby słowa odniosły pożądany skutek. (PN 1/2012, s. 47) - zabrać głos ‘zacząć mówić; przemówić, wypowiedzieć się’ (WSF, s. 112)

Ponieważ z każdym rokiem przybywało coraz to nowych teorii o „życiu po życiu” Presleya, głos zabrali lekarze, którzy z całą mocą oświadczyli, że autopsja naprawdę wykazała śmierć piosenkarza. (VG 2/2011, s. 10)

Najpierw wytknęła Dorocie brak klasy: „Ona jest wulgarna i często przegina”, teraz w tabloidzie znowu zabrała w jej sprawie głos. (NŻ 7/2012, s. 2)

Przerażać: Wspomnienia porażek z Lechią Gdańsk czy PGE GKS Bełchatów - w Warszawie i do zera - do dziś bardziej krewkim kibicom stołecznej drużyny ową krew w żyłach mrożą. (PN 50/2011, s. 16) - mrozić (zmrozić) krew w żyłach 'wywoływać strach, przerażać' (PSF, s. 312)

Przeszkodzić: Mecz z Irlandią miał zadecydować, która z dwóch reprezentacji - Irlandia czy Chorwacja - będzie mieć szanse na to, by pomieszać szyki faworytom. (PN 24/2012, s. 22) - pokrzyżować, pomieszać, mieszać, popsuć itp. komuś szyki 'przeszkodzić, przeszkadzać komuś w wykonaniu jakiegoś zamiaru’ (WSF, s. 536)

Przewodzić, przodować: Natomiast samo hrabstwo Merseyside, gdzie zameldowanych jest 1,4 miliona ludzi, wiedzie prym w tym północno-wschodnim rejonie Wyspy. (PN 15/2012, s. 37) wieść, wodzić prym, rej 'górować, celować w czymś, mieć przewagę w jakiejś dziedzinie; przodować, przewodzić' (WSF, s. 617)

Przewyższać: Przecież nawet pod względem organizacyjnym jest to firma, która bije wszystkie moje poprzednie kluby na głowę. (PN 11/2012, s. 23) - bić, pobić kogoś, coś na 
głowęa) 'znacznie przewyższać, przewyższyć kogoś, coś pod jakimś względem, górować nad kimś, nad czymś'; b) 'zwyciężać, pokonywać kogoś w rywalizacji, w walce, zadawać komuś druzgocącą klęskę' (WSF, s. 113)

Pod względem oczytania i sprawności językowej Korwin-Mikke bije na głowę większość współczesnych polityków. (P 50/2012, s. 19)

Ale jeździectwo pod tym względem bije inne dyscypliny na głowę (może jedynie żeglarstwo może z nim konkurować). (VG 14/2012, s. 39)

Przyglądać się: W pierwszej kolejności pod lupę wzięli zakup działki pod budowę nowej siedziby. (PN 50/2012, s. 2) - brać, wziąć kogoś, coś pod lupę ‘zaczynać się komuś lub czemuś uważnie przyglądać' (PSF, s. 28)

Rozgromić: Rywalem biało-czerwonych byli wtedy Holendrzy, ówcześni mistrzowie świata, którzy na Stadionie Śląskim, w obecności 85 tysięcy widzów zostali rozbici w pył. (PN 46/2011, s. 47) - rozbić kogoś na proch, w proch, w pył 'zupełnie kogoś pokonać, rozgromić kogoś' (PSF, s. 535)

Skompromitować się: Może się to zmienić, jeśli nasz Reprezentant Wybitny da plamę przy uzyskaniu licencji. (PN 3/2012, s. 13) - dać plamę 'skompromitować się' (WSF, s. 361)

A na dodatek jest na tyle niedowładne, że jego słabość próbują wykorzystać służby, niestety z policją i strażą na czele, aby tylko nie narobić się specjalnie przy Superpucharze i przy okazji nie dać gdzieś ciała. (PN 6/2012, s. 2) - dać ciała, dupy a) 'nie wykorzystać nadarzającej się okazji, zaprzepaścić jakąś szansę, nie spisać się, przegrać'; b) 'pozwalać się ośmieszyć, skompromitować się’ (SPPot, s. 67)

Spodobać się: Już dwa lata temu na początku roku w nowej klasie wpadł jej w oko. (VG 3/2011, s. 12) - ktoś w padł, coś wpadło komuś w oko 'ktoś spodobał się komuś, zwłaszcza osobie odmiennej płci, coś spodobało się komuś, zwróciło na siebie czyjąś uwagę' (WSF, s. 630)

Podobno Anna Czartoryska nie przypadła mamie Piotra do gustu... (NŻ 1/2012, s. 2) - przypaść komuś do gustu 'spodobać się komuś, zrobić na kimś pozytywne wrażenie' (WSF, s. 136)

Spokornieć: Przed nikim nie pękał i nawet krytykowany za błąd przez trenera, niby schylał głowę, niby przytakiwał, by już po chwili mruknąć niezrozumiałe słowo pod nosem i... dalej robić swoje. (PN 11/2012, s. 47) - giąć, zginać grzbiet, kark; schylać, pochylać głowę, kark przed kimś, przed czymś ‘ poddawać się czyjejś władzy, ulegać komuś, pokornieć' (WSF, s. 160)

Potem, kiedy rosły obciążenia, a także oczekiwania wobec jego osoby, rzeczywiście nieco spuścił z tonu, dały znać o sobie problemy z aklimatyzacją. (PN 50/2012, s. 13) 
- spuścić z tonu, spuścić uszy po sobie 'zmniejszyć swoje wymagania, spokornieć' (WSF, S. 506)

Konserwatysta - realista, który gromko sprzeciwił się Unii, ale potem, po cichu, spuścił z tonu. (P 50/2012, s. 16)

Sprawdzić się: Gdyby nie feralne 11 minut w końcówce drugiej połowy, kiedy liderzy Premier League zaaplikowali podmęczonym gospodarzom trzy gole i można pokusić się o opinię, iż ów styl gry zdał egzamin. (PN 41/2012, s. 30) - zdać egzamin 'sprawdzić się’ (WSF, s. 97)

Szczęścić, powodzić się: Warszawianie mieli też sporo szczęścia - puchar zdobyli po karnych, a w słynnym już meczu ze Spartakiem w Moskwie los tė̇ się do nich uśmiechnął. (PN 50/2011, s. 16) - szczęście, fortuna, los uśmiecha się do kogoś 'różne sprawy, wydarzenia układają się szczęśliwie dla kogoś, komuś się powodzi, szczęści’ (WSF, S. 595)

Ścigać: Na finiszu rozgrywek AS Roma mocno deptała po piętach późniejszemu mistrzowi Interowi. (PN 4/2012, s. 37) - deptać komuś po piętach; następować komuś na pięty 'chodzić za kimś ciągle, śledzić lub ścigać, nie dawać komuś spokoju’ (WSF, s. 358)

Tolerować: Dopóki nie plują, nie rzucają jedzeniem i nie wieszają się za okna, można przymknąć oko na chamskie odzywki i usiąść tuż obok kierowcy. (VG 18/2012, s. 16) - przymknąć, przymrużyć, zamknąć na coś oko (oczy) 'tolerować coś, udać, że się nie widzi czegoś negatywnego' (WSF, s. 318)

Dyrektor programowy TVN Edward Miszczak przymyka oczy na wybryki Magdy. (NŻ 1/2012, s. 11)

Ubolewać: Sięganie po wychowanków jest podstawową zasadą obowiązującą w futbolu, dlatego z politowaniem kiwam głową, gdy słyszę, że w danym zespole ekstraklasy nie ma miejsca dla młodzieżowców. (PN 44/2011, s. 47) - kiwać, pokiwać głową nad kimś, nad czymś 'litować się, ubolewać, zasmucić się nad kimś, nad czymś' (WSF, s. 115)

Uderzyć: Paweł zawsze był impulsywny, okazało się też, że zdenerwowany potrafi podnieść rękę na swoją dziewczynę. (VG 16/2012, s. 21) - podnieść rękę na kogoś a) 'zamierzyć się na kogoś lub uderzyć kogoś; b) ‘wystąpić przeciw komuś' (WSF, s. 368)

Ujawnić się: Obie reprezentacje prezentują zbliżony poziom, u nas i u Czechów coraz mocniej do głosu dochodzą młodsi piłkarze. (PN 6/2012, s. 15) - dojść do głosu 'ujawnić się' (WSF, s. 73)

Ulegać: Często pochylałam kark, nie potrafiłam stanąć w swojej obronie. (NŻ 2/2012, s. 42) - giąć, zginać grzbiet, kark; schylać, pochylać głowę, kark przed kimś, przed czymś 'poddawać się czyjejś władzy, ulegać komuś, pokornieć' (WSF, s. 160) 
Ułatwić: Podbeskidzie poszło mi na rękę. (PN 44/2012, s. 20) - iść, pójść komuś na rękę 'ułatwiać, ułatwić komuś coś, pomagać, pomóc komuś w czymś' (WSF, s. 440) Usamodzielnić się: Ku niezadowoleniu akcjonariuszy zarząd przeznaczył tylko 3,7 miliona na niedawną wypłatę dywidend, jednak Borussia coraz stabilniej finansowo stoi na nogach i przy polityce ekonomicznej wdrożonej na najbliższe lata widmo bankructwa wydaje się już nierealne. (PN 48/2012, s. 31) - stać, stanąć na mocnych, na własnych nogach; stać, stanąć o własnych siłach 'być samodzielnym, usamodzielnić się, być niezależnym, uniezależnić się, zwłaszcza pod względem materialnym’ (WSF, s. 507)

Uświadomić: Możliwość dysponowania takim budżetem otwiera ludziom oczy na potrzeby innych, nie tylko własnego podwórka, ulicy, dzielnicy. (P 24/2012, s. 30) - otworzyć komuś oczy (na coś) 'ukazać komuś prawdziwy stan rzeczy, pouczyć, uświadomić kogoś' (WSF, s. 331)

Uważać: Robert Lewandowski, który wygrał rywalizację z Barriosem, wykorzystując jego problemy ze zdrowiem, musi więc mieć się na baczności. (PN 6/2012, s. 41) - mieć się na baczności (przed kimś, przed czymś) 'być czujnym, ostrożnym w stosunku do kogoś, czegoś; uważać' (WSF, s. 9)

Wygadać się: Pytany o powody zwłoki, raz puścil farbę. (PN 20/2012, s. 34) - pot. puścić farbę 'zdradzić się z tym, co się ukrywało; wygadać się' (WSF, s. 101)

Wypytać: - Ja nic nie wiem, proszę mnie nie ciągnąć za język (śmiech). (PN 24/2012, s. 29) - pociągnąć, ciągnąć kogoś za język ‘wybadać, badać, wypytać kogoś, skłonić, skłaniać kogoś do wyjawienia czegoś' (WSF, s. 153)

Zaczerwienić się: „Spiec raka”, „stanąć w pąsach”, „strzelić buraka” to określenia, które pasują do ciebie jak ulał. (VG 17/2012, s. 31) - spiec raka, raczka 'zaczerwienić się, zwykle ze wstydu' (WSF, s. 497), stanąć w pąsach, w płomieniach, w ogniach; oblać się pąsem; pąsy biją na kogoś 'zarumienić się gwałtownie; ktoś się rumieni’ (WSF, s. 346), strzelić buraka 'zaczerwienić się, oblać się rumieńcem'40

Zakasować: Według zgodnych opinii fachowców przeciwnik z Ukrainy był do przejścia, ale w drugiej odsłonie meczu wybrańcy Saschy Lewandowskiego dwukrotnie dali się zapędzić w kozi róg i... przegrali. (PN 48/2012, s. 34) - zapędzić kogoś w kozi róg 'wykazać swoją zdecydowaną przewagę nad kimś, zakasować kogoś' (WSF, s. 453)

Zakochać się: Ale czy mogła przewidzieć, że mąż straci głowę dla menedżerki Joanny Gajewskiej? (NŻ 3/2012, s. 43) - stracić głowę dla kogoś 'ulec czyjemuś urokowi, zakochać się w kimś' (WSF, s. 516)

Kelner stracił dla niej głowę! (NŻ 9/2012, s. 9)

40 http://www.miejski.pl/slowo-Strzeli\%C4\%87+z+buraka [dostęp: 12.01.2014]. 
Zakpić: Justyna Kowalczyk po raz kolejny, tym razem w estońskiej Otepaeae, zagrała na nosie Norweżce Marit Bjoergen. (PN 4/2012, s. 47) - grać, zagrać (komuś) na nosie 'okazywać, okazać komuś lekceważenie, kpić, zakpić z kogoś' (WSF, s. 290)

Meksykańska policja twierdzi, że w lutym prawie go złapała, ale to Guzman gra jej na nosie. (P 24/2012, s. 58)

Zapamiętać: Ogłoś w domu, w które dni masz zamiar się uczyć i raz na zawsze wbij sobie do głowy, że robisz to dla siebie, a nie dla rodziców. (VG 3/2011, s. 7) - wbić coś sobie do głowy, w głowę, posp. do łba, włeb a) 'utrwalić sobie coś w pamięci, zapamiętać coś, nauczyć się czegoś; b) 'nabrać mocnego przekonania o czymś, uprzeć się przy czymś' (WSF, s. 602-603)

Zmniejszyć się: Do tego setki piłkarzy rocznie emigrowały gdzie popadnie, więc poziom sportowy nieuchronnie zleciał na łeb na szyję i kluby w pucharach zaczęły przegrywać z coraz słabszymi rywalami. (PN 5/2012, s. 11) - spaść, lecieć, polecieć na łeb, na szyję, z pieca na łeb a) 'gwałtownie zlecieć z czegoś, uderzając się boleśnie w różne części ciała'; b) 'o akcjach, cenach itp.: gwałtownie stracić na wartości, zmniejszyć się' (WSF, s. 224)

Zniesławić, oszkalować: To znaczy ten sam Lato, który został obrzucony błotem, bez towarzystwa Kręciny już byłby cacy? (PN 48/2011, s. 2) - obrzucić kogoś błotem 'powiedzieć o kimś wiele złych rzeczy; oszkalować, zniesławić kogoś’ (WSF, s. 301)

Jak zwykle przy okazji wielkich piłkarskich turniejów, staram się przyglądać i analizować pracę drużyny, na której najchętniej wiesza się psy. (PN 24/2012, s. 40) - pot. wieszać psy na kimś 'obmawiać, oczerniać, szkalować kogoś’ (WSF, s. 356)

Zamiast wieszać psy na Kuźniarze, lepiej wziąć przykład z kotów. (NŻ 9/2012, s. 18)

Bystry pasażer zadzwonił do gazety, która zmieszała z błotem selekcjonera. (PN 41/2012, s. 14) - pot. zmieszać, mieszać kogoś z błotem 'naubliżać, ubliżać komuś, zniesławić, zniesławiać, oczernić, oczerniać kogoś' (WSF, s. 19)

Zrezygnować: Każdy trener, który próbował go w jakiś sposób okiełznać, po jakimś czasie dawał za wygraną. (PN 48/2011, s. 29) - dać za wygraną 'zrezygnować z czegoś, pogodzić się z czymś, odstąpić od swoich zamiarów' (WSF, s. 61)

Tam zagrał ledwie sześć spotkań, by potem tułać się po niższych ligach i dać sobie spokój w powodu kolejnej kontuzji w roku 2007. (PN 47/2011, s. 11) - dać sobie spokój z kimś, z czymś 'przestać się kimś lub czymś przejmować, zrezygnować z kogoś, czegoś, zaniechać czegoś' (WSF, s. 500)

Czas zwijać żagle (PN 47/2011, s. 27) - zwinąć chorągiewkę, żagle 'wycofać się, zrezygnować z czegoś, zmienić decyzję, zdanie' (WSF, s. 707)

Nie składamy jednak broni. (PN 33/2012, s. 36) - złożyć broń 'zrezygnować z ubiegania się o coś' (WSF, s. 25) 
Człowiek zaczyna dostrzegać paradoksy - i nie macha ręką, tylko szuka wspólnego mianownika oraz jest w stanie go znaleźć. (P 51-52/2012, s. 24) - machnąć na kogoś, na coś ręką a) 'zrezygnować z kogoś, z czegoś, uznać coś za stracone’; b) 'zlekceważyć kogoś, coś, przestać zwracać na kogoś, na coś uwagę’ (WSF, s. 229)

Zwolnić: Gdy jednak AVB popadł w konflikt z innymi piłkarzami, do akcji wkroczył Roman Abramowicz i w marcu odesłał Portugalczyka na zieloną trawkę. (PN 41/2012, s. 31) - posłać, wysłać kogoś na zieloną trawkę, na grzybki 'zwolnić kogoś z pracy' (WSF, s. 689)

Mistrz świata z Brazylią miał nawet udany start, ale nie potrafił się dogadać z większością graczy w szatni i po siedmiu miesiącach pokazano mu drzwi ${ }^{41}$. (PN 11/2012, s. 17)

Żałować: Houlier sam powinien uderzyć się w piersi. (PN 13/2012, s. 20) - bić się, uderzać się, pot. walić się w piersi a) 'uderzać pięścią w pierś na znak potwierdzenia prawdziwości swoich słów’; b) 'uznawać swoją winę; kajać się, żałować' (WSF, s. 353)

Llorente zapewne pluje sobie w brodę, że nie zwolnił Pellegrino wcześniej i nie zatrudnił Rafy Beniteza, kiedy ten był jeszcze do wzięcia. (PN 49/2012, s. 34) - pot. pluć sobie w brodę 'wyrzucać sobie coś, żałować utraconej szansy, okazji’ (WSF, s. 362)

Co zrozumiałe, wszystkie związki frazeologiczne mające syntetyczny odpowiednik w postaci czasownika przyjmują formę zwrotów będących przeważnie połączeniem czasownika z rzeczownikiem bądź wyrażeniem przyimkowym, rozbudowanym czasem o przymiotniki, liczebniki czy zaimki.

Bywa, że jednemu syntetyzmowi odpowiada kilka trwałych połączeń wyrazowych, które składają się z różnych komponentów. Najwięcej ekwiwalentów odnotowano dla czasownika zrezygnować - dwa pośród nich są konstrukcjami opartymi na bezokoliczniku dać: dać za wygraną, dać sobie spokój, ponadto zaliczymy do tej grupy zwinać żagle, złożyć broń, machnąć ręką, niewiele mniej frazeologizmów odpowiada jednowyrazowemu oszukać: wystrychnąć na dudka, robić wodę z mózgu, wyprowadzić w pole, nabić w butelkę. Na składniku dać opierają się też oba równoważniki skompromitować: dać plamę i dać ciała. Identyczny komponent rzeczownikowy - błoto - został wykorzystany w zwrotach, których synonimem jest zniesławić: obrzucić kogoś błotem, zmieszać kogoś z błotem, zestaw

41 Słowniki wskazują na następujące znaczenia zwrotu pokazać, wskazać komuś drzwi: 'kazać komuś opuścić pomieszczenie, wyprosić kogoś' (PSF, s. 474), 'kazać komuś wyjść, wyprosić kogoś’ (WSF, s. 84), przywołany kontekst pozwala jednak twierdzić, że połączenie to zyskało w tekstach prasowych nowy odpowiednik, mianowicie zwolnić, wyrzucić kogoś z pracy. 
odnoszący się do tego syntetyzmu uzupełnia wieszać na kimś psy. Rzeczownik oko posłużył zaś do zbudowania połączeń, które mają ekwiwalent czasownikowy obserwować: mieć na oku i nie spuścić kogoś, czegośz oka. Jednoelementowe dominować może być wymiennie stosowane $\mathrm{z}$ analitycznymi formami grać pierwsze skrzypce, nadawać ton i cośbierze nad czymś górę. Denerwować to inaczej psuć krew i działać na nerwy, pomóc bywa zastępowane przez przyjść w sukurs czy wyciagnać do kogoś/podać komuś rękęl(pomocna) dłoń. Odpowiednikami spodobać się są wpaść w oko i przypaść do gustu, spokornieć natomiast - spuścić z tonu i pochylać głowe. Zaczerwienić doczekało się trzech zastępczych frazeologizmów: spiec raka, stanać w pasach i strzelić buraka. Zamiast żałować można użyć uderzyć się w piersi lub pluć sobie w brodę. Zwroty pokazać komuśdrzwi i odesłaćna zielona trawkę pojawiają się w miejsce zwolnić.

Przywołane związki frazeologiczne o zróżnicowanej budowie, mimo iż odwołują do takiego samego formalnie czasownika syntetycznego, mogą nadawać inne zabarwienie semantyczne, w związku z tym nie zawsze należy stosować je wymiennie. Warto też podkreślić, że zdarza się, iż odmienne strukturalnie analityzm i frazeologizm mają taki sam syntetyczny odpowiednik (np. kłamać, obserwować, odpoczać, pomagać, przeklinać, spokornieć) - i w tym przypadku funkcje pełnione przez omawiane konstrukcje czasownikowe mogą być wielorakie. O tym, w jakich kontekstach ujawniają się konkretne znaczenia, będą traktowały rozdziały poświęcone semantyce i pragmatyce wielowyrazowych konstrukcji.

\subsection{Analityzmy rzeczownikowe}

Analityczne konstrukcje rzeczownikowe nie doczekały się aż tylu opracowań co orzeczenia peryfrastyczne. Charakteryzując struktury opisowe, M. Kniagininowa przyjrzała się też rzeczownikowym. Jak zauważyła: „Należą tu grupy analityczne, składające się z dwóch rzeczowników, z których jeden, nadrzędny, oznacza pojęcie tak ogólne, że wymaga uzupełnienia, drugi, podrzędny, występujący w dopełniaczu, pojęcie to precyzuje" 42 . Badaczka określiła znaczeniowo niepełne rzeczowniki „natrętami językowymi”, które są właściwie zbędne. Jako przykłady podała: atmosfera, fakt, klimat, problem, zagadnienie, zjawisko.

42 M. Kniagininowa, op. cit., s. 149. 
Szczegółowej charakterystyki analityzmów rzeczownikowych dokonał w swojej monografii poświęconej różnym rodzajom form opisowych J. Anusiewicz. Wyróżnił następujące rodzaje ${ }^{43}$ : a) wyrażenia niewspółrzędne składające się z dwóch (lub więcej) rzeczowników, w których rzeczownik nadrzędny oznacza pojęcie bardzo ogólne, rzeczownik podrzędny w dopełniaczu (najczęściej odczasownikowy) jest zaś właściwym nośnikiem znaczenia leksykalnego, np. fakt powrotu, sprawa utworzenia; b) wyrażenia niewspółrzędne składające się z rzeczownika i przymiotnika (w tym samym przypadku, liczbie i rodzaju; pełni funkcję przydawki przymiotnikowej), w którym właściwym nośnikiem znaczenia leksykalnego jest sam przymiotnik - tożsamy semantycznie i słowotwórczo z ekwiwalentem rzeczownikowym całej konstrukcji, np. akcja żniwna - żniwa, masa ziemna - ziemia. Jak podkreślił uczony, podstawy konstrukcji rzeczownikowych „reprezentują klasy rzeczowników abstrakcyjnych, nieżywotnych, pospolitych, natomiast prawie nigdy w skład tych struktur nie wchodzą rzeczowniki osobowe, żywotne i własne"44. Nadrzędnik to przeważnie rzeczownik abstrakcyjny o treści ogólnej, który ma możliwość odmieniania się i oznacza zazwyczaj formę, gatunek, rodzaj, typ, klasę, zbiór. J. Anusiewicz do najbardziej charakterystycznych podstaw rzeczownikowych konstrukcji analitycznych zaliczył następujące wyrazy: sprawa, proces, fakt, problem, pojęcie, stan, zjawisko, akt, zagadnienie, szereg, sfera, akcja i kwestia. W grupie rzeczownikowo-przymiotnikowej najczęściej występowały zaś zakład, punkt, obiekt, akcja i urządzenie. Stwierdził: „Rzeczowniki te można w konstrukcji wypowiedzi pominąć prawie zawsze bez uszczerbku dla jej znaczenia i komunikatywności"45. Podkreślił, że zmianie uległa frekwencja łączliwości rzeczowników problem czy proces - wcześniej notowano jedynie ich występowanie z przymiotnikami, a w badanym przez niego materiale o wiele częściej zestawiane są z rzeczownikami. „Świadczyć to może o szerzeniu się w dość szybkim tempie tendencji do substancjalizacji opisu desygnatów przez zwarte połączenia nominalne" 46 .

Przyglądając się językowi prasy na początku lat 70. XX w., Maria Honowska zwróciła uwagę na wielowyrazowe struktury rzeczownikowe. Według badaczki:

43 Podział za: J. Anusiewicz, Konstrukcje analityczne we współczesnym..., s. 32-33.

44 Ibidem, s. 33.

45 J. Anusiewicz, Konstrukcje analityczne w języku prasy, „Wrocławski Rocznik Prasoznawczy" 1974, s. 68.

46 J. Anusiewicz, Konstrukcje analityczne we współczesnym..., s. 59. 
„Inne struktury analityczne znamienne dla stylu dziennikarskiego składają się $\mathrm{z}$ rzeczownika pustego w pierwszym członie, takiego jak fakt, problem, zagadnienie, klimat i znów z dopełniacza w członie drugim, właściwego nosiciela treści leksykalnej, typ: problem zaopatrzenia, fakt wznowienia"47.

$\mathrm{O}$ analityzmach rzeczownikowych wspomniał też W. Cockiewicz podczas omawiania wielowyrazowych konstrukcji w języku telewizji. Zdaniem lingwisty sprawa, proces, problem i zagadnienie to podstawy o największej produktywności ${ }^{48}$. Sporo połączeń budziło jego wątpliwości stylistyczne.

\subsubsection{Analityzmy pochodne strukturalnie}

Anglistyka: Na studiach na Uniwersytecie Łódzkim, na filologii angielskiej i filozofii, która też okazała się oazą ludzi nieprzypadkowych i bardzo głodnych wiedzy, organizowaliśmy wieczorami seminaria, dyskusje. (P 13/2012, s. 88)

Bojówka: Miał szczególny autorytet w grupie bojowej. (P 5/2011, s. 94)

Ale bandyckie tło zdarzenia nie wyklucza animozji między bojowymi oddziałami kibiców, często bowiem gangsterskie interesy łączą się z aktywnością stadionową. (P 5/2011, s. 94)

Bramka: A co do zdobyczy bramkowej - nie wystąpiłem we wszystkich meczach, na przeszkodzie stawał uraz oraz konieczność odpokutowania kary za czerwoną kartkę, którą dostałem w Grudziądzu. (PN 48/2012, s. 42)

Budowlanka: I dodawał, że mógł się akurat tego spodziewać - nadal mowa o trenerze Lenczyku - po człowieku, który jest po budowlanej zawodówce. (PN 44/2011, s. 2)

Czerwień: Mark Clattenburg najpierw pokazał dwie czerwone kartki Branislavowi Ivanoviciowi i Fernando Torresowi, a także uznał gola dla MU, gdy Javier Hernandez był na spalonym. (PN 44/2012, s. 29)

Defensywa: Jeśli wyczuje jakiś bałagan na korytarzach władzy, uderza z taką samą energią, jak robił to, gdy widział chaos w liniach defensywnych rywali. (PN 48/2011, s. 29)

Z kolei jego miejsce po prawej stronie bloku defensywnego zajmie w takiej sytuacji Rafinha. (PN 20/2012, s. 4-5)

Doping: Czy w przypadku policyjnej kontroli drogowej można, oprócz alkoholu we krwi, wykryć również inne środki dopingujące? (NŻ 9/2012, s. 31)

47 M. Honowska, Język prasy osobliwy twór socjalny, „Biuletyn Polskiego Towarzystwa Językoznawczego" 1972, z. XXX, s. 64.

48 W. Cockiewicz, op. cit., s. 50. 
Ekstraklasa: Latem odradzałem transfer Damianowi Szczęsnemu, który dostał ofertę z najwyższej klasy rozgrywkowej. (PN 50/2012, s. 44)

Energetyk: I żadna ilość kaw ani energetyzujących napoi nie pomoże - organizm i tak się upomni o to, co jest mu niezbędne. (VG 10/2011, s. 22)

Rynek napojów energetycznych w Polsce podobno wart jest miliardy złotych. (P 24/2012, s. 99)

Etosowiec: Druga grupa nazywana jest inteligencją etosową. (P 51-52/2012, s. 55)

Filmówka: Jest absolwentką praskiej szkoły filmowej FAMU. (NŻ 5/2012, s. 17)

$\mathrm{W}$ trakcie festiwalu zaprezentowane zostaną również dzieła najbardziej obiecujących studentów i absolwentów polskich szkół filmowych. (VG 16/2012, s. 5)

W przeciwieństwie do Francisa Forda Coppoli, Briana de Palmy, Martina Scorsese czy George’a Lucasa nie skończył żadnej szkoły filmowej. (P 24/2012, s. 93)

Fotografowanie: A zatem koniec pisania do szuflady i pstrykania fotek dla przyjemności. (VG 3/2011, s. 7)

Frazeologizm: I niestety, właśnie z powodu takiego nieprzemyślanego użycia związków frazeologicznych musieliśmy sporo prac odrzucić. (VG 22/2012, s. 36)

Głosowanie: Cztery lata temu, stojąc na mównicy jako gość honorowy, otwarcie nawoływał do oddawania głosów na Zbigniewa Bońka. (PN 44/2012, s. 7)

Główka: Centrę Marka Wasiluka na gola uderzeniem głową zamienił Przemysław Kaźmierczak. (PN 50/2011, s. 41)

Dośrodkowanie Zieńczuka na gola strzałem głową zamienił Paweł Abbott. (PN 47/2011, s. 40)

Human: Jaki z tego wniosek - autorzy testów doskonale wiedzą, że egzamin humanistyczny to połączenie języka polskiego, historii, WOS-u i sztuki. (VG 10/2011, s. 41)

Igrzyska/olimpiada: Najbardziej kusząca wydaje się propozycja występu na igrzyskach olimpijskich w Londynie w roli kapitana reprezentacji Wielkiej Brytanii. (PN 45/2011, s. 29) Trauma po tamtych wydarzeniach jest tak silna, że do dziś wielu Japończyków ostentacyjnie siedzi, kiedy na igrzyskach olimpijskich grany jest sławiący cesarza hymn narodowy. (P 50/2012, s. 57)

Internauta: $Z$ tego choćby powodu duże znaczenie ma tworzenie przez fundację bazy bezpłatnych i płatnych legalnych źródeł kultury, dzięki którym użytkownicy Internetu mają szansę uniknąć moralnego dyskomfortu czy nawet - jak grożą legislacyjni rygoryści - odpowiedzialności karnej. (P 50/2012, s. 97)

Karny: Nie potrafił sobie wytłumaczyć, dlaczego machnął chorągiewką i wymusił, zamiast oczywistego kornera, podyktowanie rzutu karnego przez arbitra Mike’a Jonesa. (PN 49/2011, s. 33) 
Komórka: Wtedy w Polsce panowała komuna, w telewizji można było oglądać maksymalnie dwa kanały, a ludzie nie wiedzieli, co to Internet, ba, nie wiedzieli nawet, co to telefony komórkowe. (PN 50/2012, s. 32)

Na egzamin można zabrać telefon komórkowy. (VG 7/2011, s. 3)

Izabela płakała, nerwowo ściskała w rękach telefon komórkowy... (NŻ 1/2012, s. 5)

Nie wystarczają im już zwykłe telefony komórkowe, coraz lepiej sprzedają się smartfony - tylko w 2012 r. polski rynek wchłonął 12 mln urządzeń tej klasy - smartfonem jest w tej chwili co trzeci używany w Polsce telefon komórkowy. (P 51-52/2012, s. 104)

Kredytowiec: Trzecią grupę nazwano burżuazją kredytową - to młode wilki kapitalizmu, nieźle zarabiające, ale obciążone sporym kredytem mieszkaniowym. (P 51-52/2012, s. 56) Kryminał: Kolejna edycja „Lata z kryminałem”, wspólnej serii POLITYKI i Wydawnictwa W.A.B., to dobra okazja, by sprawdzić, co nowego dzieje się w prozie kryminalnej. (P 24/2012, s. 95)

W ostatnich latach to właśnie powieść kryminalna - obok reportażu - jest jedną z najbujniej rozwijających się dziedzin prozy. (P 24/2012, s. 95)

Liniowy: - Docelowo, przy - powtórzę - 12 sędziach głównych, chciałbym dysponować 16 zawodowcami pracującymi na liniach. (PN 1/2012, s. 18)

Lotnisko: W niezbyt reprezentacyjnym, jak na tak znane miasto jak Liverpool, porcie lotniczym noszącym imię Johna Lennona czasami daje się słyszeć sączące się gdzieś z głośników w barze i sklepie muzycznym utwory słynnej czwórki - Beatlesów. (PN 44/2012, s. 11)

Będzie dużo zajęć praktycznych - w lotniczych zakładach remontowych, aeroklubach, biurach projektowych czy portach lotniczych. (VG 1/2011, s. 6)

Tak się złożyło, że jest to port lotniczy. (P 13/2012, s. 102)

Ławka: Piętnaście lat później Jovanić prowadził ten klub z lawki trenerskiej przeciwko Realowi Madryt. (PN 14/2012, s. 37)

Mecz oglądałem tuż zza lawki rezerwowych przyjezdnych, z sektora przeznaczonego dla ViP-ów, na który wejściówka kosztowała 80 złotych, co stanowi całkiem niemały wydatek. (PN 11/2012, s. 2)

Wszystkim naszym zawodnikom życzymy, aby na ławce rezerwowych siedzieli jak najrzadziej, a jeśli już, to tylko jako takie asy w rękawie. (VG 3/2011, s. 18)

Mikrofala: W sytuacji, gdy w ekspresowym tempie chcesz coś ugotować lub tylko podgrzać obiad, kuchenka mikrofalowa jest niezastąpiona. (NŻ 5/2012, s. 41)

Młodzieżówka: I nigdy nie pobierał żadnej części z owych 75 tysięcy, a jedynie gratyfikację należną trenerowi za prowadzenie jednej z reprezentacji młodzieżowych. (PN 49/2012, s. 12) 
Znając trenera Mroczkowskiego, zresztą byłego selekcjonera kadr młodzieżowych, świetnie orientuje się w temacie i jestem pewien, że Mariusz trafi do pierwszej jedenastki Widzewa w najbardziej odpowiednim dla niego momencie. (PN 48/2012, s. 2)

Czy jednak słusznie, skoro dla polskich szkoleniowców pracujących nie tylko z drużynami młodzieżowymi problem dostępu do dobrych boisk to chleb powszedni? (PN 50/2011, s. 43)

Narkobaron: W światku narkotykowych baronów zasłużył na miano najbardziej pomysłowego: aby wyprowadzić w pole służby graniczne, ukrywał narkotyki nawet $\mathrm{w}$ konserwowych papryczkach chilli. (P 24/2012, s. 58-59)

Nazwanie: Termin, o którym mówimy, oznacza natomiast zebranie wszystkich elementów pod jednym dachem, nadanie temu procesowi nazwy, usystematyzowanie go. (P 24/2012, s. 105)

Niemiecki: A pozostali zagraniczni zawodnicy starają się szybko uczyć języka niemieckiego. (PN 36/2012, s. 26)

Niepełnosprawny: W gabinecie Jacka Rostowskiego wisi pamiątkowa szabla, otrzymana za zasługi w budowaniu pozycji Polski w świecie, u prezesa GUS prof. Janusza Witkowskiego - dwa plakaty z branżowych kongresów statystyków, u Krystyny Szumilas (Ministerstwo Edukacji Narodowej) - rysunek z konkursu odkrywania młodych talentów, a u Władysława Kosiniaka-Kamysza - obrazy namalowane przez osoby niepełnosprawne. (P 51-52/2012, s. 139)

Nocny: Na dworzec jedzie nocnym autobusem. (P 13/2012, s. 102)

Ocenianie: Profesor Jan Chmura, specjalista z zakresu metodologii oraz fizjologii wysiłku fizycznego i teorii sportu, autor ponad 200 prac naukowych i popularnonaukowych w tej dziedzinie, w tym monografii „Szybkość w piłce nożnej”, nie podejmuje się jednak dokonania oceny formy fizycznej naszych piłkarzy. (PN 24/2012, s. 14)

Odrzutowiec: Jeśli marzysz o pilotowaniu ogromnych odrzutowców, wstąp do wojskowej „Szkoły Orląt” w Dęblinie - bo ćwiczyć na samolotach odrzutowych można jedynie w wojsku. (VG 1/2011, s. 6)

Ogólniak: Liceum ogólnokształcące, profil biologiczno-chemiczny - to idealny wybór, bo do biologii i chemii trzeba się szczególnie przyłożyć. (VG 9/2011, s. 41)

Okręgówka: O miejscowości zrobiło się głośniej właśnie dzięki trzecioligowemu klubowi piłkarskiemu, który jeszcze w sezonie 2007-08 występował w klasie okręgowej. (PN 47/2011, s. 20)

Parabank: Takie reguły obowiązują w branży pozabankowej, specjalizującej się w udzielaniu krótkoterminowych i stosunkowo niewielkich pożyczek. (P 50/2012, s. 48) 
Pozabankowy sektor finansowy, zwany na świecie shadow banking, czyli bankowością cienia, szybko rośnie. (P 50/2012, s. 49)

Piłka: Może więc wróćmy do rozmów o piłce nożnej, czekając, czy naprawdę w przyszłym roku skończy się Lato. (PN 48/2011, s. 11)

Podstawówka: Michał będzie grał w przedstawieniach w szkołach podstawowych, gdzie dzieci uczą się hiszpańskiego. (VG 4/2011, s. 9)

Mama gwiazdy, Krystyna Łaszewska, była higienistką w szkole podstawowej w Gdańsku, do której chodziła córka. (NŻ 5/2012, s. 19)

Działający tam prokomunistyczny Związek Patriotów Polskich organizował oddziały polskie przy szkołach podstawowych. (P 51-52/2012, s. 93)

Polski/polak: Najprawdopodobniej wasza aktualna pani, ta, z którą mieliście język polski od początku nauki w szkole, czyli od pierwszej klasy, została zatrudniona tylko na zastępstwo pani, która z jakiejś tam przyczyny była w tym czasie nieobecna. (VG 1/2011, s. 13)

Polonia osiągnie swe cele - także dotyczące nauczania języka polskiego w szkołach - gdy będzie silna i gotowa do współpracy z Niemcami, a zwłaszcza między sobą. (P 50/2012, s. 12)

Pomaganie: Ale taka jest prawda - jeżeli nie czujesz w sobie chęci niesienia pomocy, to nie myśl o tym zawodzie, bo... nie dasz rady. (VG 14/2012, s. 10)

Poprawka: Na początek życzę powodzenia na egzaminach poprawkowych. (VG 14/2012, s. 10)

Porównywanie: Bo to nie ja jestem od robienia takich porównań. (PN 41/2012, S. 5)

Potocyzm: Nadużywanie słów z języka potocznego w tekście, który miał być rozprawką (czy może raczej referatem) o charakterze socjologicznym. (VG 20/2012, s. 39)

Nie używaj wulgaryzmów, wyrazów z języka potocznego i takich, które nie pasują do tematu i formy wypracowania egzaminacyjnego. (VG 7/2011, s. 28)

Na zachowanie ludzi, ich stosunek do kultury należało spojrzeć z perspektywy badacza - obserwatora, a użycie słów potocznych zupełnie do tego nie pasuje. (VG 20/2012, s. 39)

Prawica: III RP jako nowa PRL jest wedle prawej strony czymś niemal oczywistym: oficjalna Polska to państwo opresyjne i antydemokratyczne. (P 50/2012, s. 12)

Prawko: Potem Marek zrobił prawo jazdy - szesnastoletni szoferak przyjeżdżał pod uczelnię Andrzeja powiedzieć cześć. (P 51-52/2012, s. 41)

Punkt: Każda zdobycz punktowa będzie sukcesem Korony, ale zagramy, jak zwykle, o pełną stawkę. (PN 33/2012, s. 19) 
Rożny/róg: Sędzia Robert Małek nie ustrzegł się rażących pomyłek, na pewno mniejszym błędem byłoby podyktowanie jedenastki dla zespołu Tomasza Kafarskiego (za faul Rafała Gikiewicza na Piotrze Wiśniewskim) niż niedostrzeżenie, iż po rzucie rożnym Marek Wasiluk niedopuszczalnie staranował bramkarza przyjezdnych, młodziutkiego Wojciecha Pawłowskiego. (PN 44/2011, s. 2)

Rzeczniczka: Rzeczniczka prasowa więzienia por. Iwona Kozak prowadzi Krystiana Balę z budynku, gdzie w pięcioosobowej celi odsiaduje karę. (P 24/2012, s. 32)

Samobój: Jak nie idzie, to na całego - autokar klubowy miał ponoć aż dwie stłuczki w drodze do Chorzowa, pierwszego gola zdobył samobójczym strzałem Hubert Wołąkiewicz. (PN 9/2012, s. 11)

Strzelił między innymi samobójczego gola w meczu swojego byłego zespołu z Lecce w maju ubiegłego roku. (PN 41/2012, s. 15)

Tomasz Kupisz w pucharowej konfrontacji z Lechią Gdańsk dwukrotnie posyłał piłkę do bramki rywala, ale zaliczył też bramkę samobójczą i o awansie do ćwierćfinałów zdecydowała seria rzutów karnych. (PN 41/2012, s. 22)

Schabowy: Szukasz sposobu na smaczne i soczyste kotlety schabowe? (NŻ 4/2012, s. 41)

Setka: - Niestety, zmarnowałem stuprocentową sytuację i nic tego nie zmieni - powiedział po meczu Buzi. (PN 36/2012, s. 38)

Siatkówka: Mam 14 lat i od 2 lat trenuję piłkę siatkową. (VG 18/2012, s. 14)

Skarbówka: Potem było kilka burzliwych rozwodów, głośne procesy o alimenty, problemy z urzędem skarbowym. (PN 48/2011, s. 29)

Na sprawdzenie Twojego rocznego zeznania PIT urząd skarbowy ma 5 lat. (NŻ 3/2012, s. 31)

Zwłaszcza że życie emeryta jest spokojniejsze, nie jest on nieustannie narażony na bankructwo, nieuczciwą konkurencję, prześladowania ze strony urzędów skarbowych. (P 24/2012, s. 110)

Soczewki/kontakty: Włoch ma już dość noszenia soczewek kontaktowych. (PN 36/2012, S. 11)

Spalony: W 58 minucie napastnik Miedzi Jakub Grzegorzewski posłał piłkę do bramki, uczynił to jednak będąc na pozycji spalonej. (PN 36/2012, s. 41)

Specsłużby: Także sensacyjne, bo dotyczące służb specjalnych, a właściwie jednej, która swoją widowiskowością nie zawodzi. (P 50/2012, s. 10)

Spożywczak: Jeśli jednak trening jest wyczerpujący, a w dodatku mocno się pocisz (bo lato), możesz zdecydować się na napój izotoniczny (są w każdym sklepie spożywczym, np. PowerRade). (VG 17/2012, s. 15) 
Strona: Na ich stronie internetowej niebieskalinia.pl znajdziesz informator placówek, które niosą pomoc ofiarom przemocy w twojej najbliższej okolicy. (VG 11/2011, s. 9)

Producenci gadżetów zarabiali krocie, obłowili się też twórcy apokaliptycznych filmów i stron internetowych. (P 51-52/2012, s. 16)

Syntetyk: Poza tym San Siro nie byłoby we Włoszech prekursorem w dziedzinie sztucznej murawy (a raczej syntetycznej najnowszej generacji). (PN 41/2012, s. 25)

Sztangista: Listopad to nie jest czas bicia rekordów, ludzie sztangi albo są wtedy na wakacjach, albo kładą się na stoły operacyjne reperować nadwyrężone zdrowie. (P 5152/2012, s. 151)

Wieprzowina: Turcy nie spożywają wieprzowiny, ponieważ mięso wieprzowe uważają za nieczyste. (VG 5/2011, s. 12)

Wolny: Gdyby tak jeszcze Niebiescy grali na nowym stadionie, zamiast pełnego dobrych wspomnień, ale przestarzałego obiektu przy Cichej, mielibyśmy idealną i darmową reklamę polskiej ekstraklasy w postaci gola z rzutu wolnego Marka Z. (PN 9/2012, s. 11)

Wojna: Dramatyczne losy Mazurów po zakończeniu działań wojennych. (P 51-52/2012, s. 114)

Zawodówka: Powinny mieć dostęp do szkół zawodowych (takich dla kobiet jeszcze nie było) i studiów wyższych. (VG 4/2011, s. 47)

Kandydaci do szkół średnich zawodowych muszą złożyć także zaświadczenie lekarskie o braku przeciwwskazań zdrowotnych do kształcenia w określonym zawodzie. (VG 9/2011, s. 3)

Złoto: Hymn i złoty krążek dla zwycięzcy, gratulacje i srebro lub brąz dla zdobywców drugiego i trzeciego miejsca. (VG 7/2011, s. 16)

Zmiana: Jeśli myślisz o dokonaniu radykalnych zmian w swoim życiu zawodowym, to jeszcze nie nadszedł na nie czas. (NŻ 11/2012, s. 47)

Znaczek: Nawet jeśli jego czas się kończy, w swoich ostatnich dniach znaczek pocztowy żyje pełnią życia - wywołując silne emocje. (P 50/2012, s. 100)

Zwycięstwo: Tym razem piłkarze Paris SG nie mieli żadnych kłopotów z odniesieniem zwycięstwa na Parc des Princes. (PN 50/2012, s. 29)

Źółtko: 29-letni Chorwat już w 17 minucie spotkania upomniany został żółtym kartonikiem, po przerwie kilkakrotnie był ostro atakowany przez rywali i gdy arbiter nie reagował, postanowił nauczyć go przepisów. (PN 33/2012, s. 36)

Życiówka: Satysfakcję z życiowego rekordu w podrzucie podkreślił, uderzając pięścią w klatkę piersiową, pozdrowił kibiców, po czym odebrał gratulacje od braci, Roberta i Daniela, również ciężarowców. (P 51-52/2012, s. 150) 
Najliczniejszą grupę a nalityzmów rzeczownikowych w badanym materiale stanowią połączenia rzeczowników z przymiotnikiem, np. żółty kartonik, szkoła filmowa, egzamin humanistyczny, ławka trenerska, urzą skarbowy, lub imiesłowem, np. środki dopingujące. Występują też połączenia rzeczownika (zwykle odczasownikowego) z rzeczownikiem w dopełniaczu (pstrykanie fotek, oddawanie głosów, nadanie nazwy, użytkownik Internetu, ławka rezerwowych, ludzie sztangi). Wśród rzeczowników odczasownikowych chętnie wykorzystywane jest dokonanie, które zestawia się choćby z ocena czy ze zmianą. Oba opisane schematy generatywne syntetyzujących procesów słowotwórczych połączenie rzeczownika z przymiotnikiem oraz rzeczownika z konstrukcją w dopełniaczu - zostały uznane przez J. Miodka za najczęściej wykorzystywane wśród formacji rzeczownikowych ${ }^{49}$. Odnotowano także nieliczne połączenia rzeczowników z wyrażeniami przyimkowymi: słowa z języka potocznego, wyrazy z języka potocznego - obu konstrukcjom odpowiada zresztą ten sam syntetyzm ${ }^{50}$.

Z wyjątkiem połączeń z wyrażeniami przyimkowymi wszystkie analityzmy rzeczownikowe mające wspólne morfemy z odpowiadającymi im syntetyzmami są konstrukcjami składającymi się z dwóch elementów.

Zdarza się, że jednej skondensowanej formie odpowiada kilka wielowyrazowych połączeń o różnej strukturze. Jednoelementowy kryminał ma swoje odpowiedniki zarówno w powieści kryminalnej, jak i prozie kryminalnej; syntetyzm ławka może odnosić się do ławki rezerwowych i ławki trenerskiej51; główka to określenie uderzenia głową i strzału głową, zamiennikami bojówki

49 Por. J. Miodek, Syntetyczne konstrukcje leksykalne w języku polskim, Wrocław 1976, s. 146, a także uwagi badacza podczas omawiania materiału przynależącego do różnych odmian stylistycznych polszczyzny.

50 Znaleziono także jedną analityczną konstrukcję rzeczownikową będącą zapożyczeniem z języka włoskiego: preparatore fisico: fizjolog: Nasz preparatore fisico będzie musiał zadawać piłkarzom pracę domową w postaci dodatkowych treningów i jeszcze monitorować jej odrabianie. (PN 49/2011, s. 2). Ze względu na jednostkowość sytuacji, kiedy to obecnym w polskiej prasie wieloelementowym konstrukcjom z języka obcego odpowiada jednowyrazowy polski ekwiwalent, jedynie zasygnalizowano zagadnienie, nie badano go szerzej.

51 Syntetyzm ławka odnosi się de facto do tego samego desygnatu, ławka trenerska i ławka rezerwowych to bowiem ten sam element rzeczywistości, występujący $\mathrm{w}$ analitycznej konstrukcji dopowiadający przymiotnik pozwala jedynie zaakcentować nawiązanie do trenera lub zawodnika rezerwowego. 
są grupa bojowa i oddziały bojowe; ekwiwalentami parabanku są branża pozabankowa specjalizująca się w udzielaniu krótkoterminowych i stosunkowo niewielkich pożyczek oraz pozabankowy sektor finansowany, struktury te kładą nacisk na różne aspekty działalności tej instytucji. Trzech równoważników doczekały się potocyzm (słowo potoczne, słowo z języka potocznego, wyraz z języka potocznego), samobój (strzał samobójczy, gol samobójczy, bramka samobójcza) i młodzieżówka (reprezentacja młodzieżowa, kadra młodzieżowa i dru̇̇yna młodzieżowa).

Charakterystyki wymagają też syntetyzmy będące ekwiwalentami wielowyrazowych konstrukcji rzeczownikowych. Pod względem formalnym w przeważającej mierze są to różne typy uniwerbizmów ${ }^{52}$. O tym, że proces ten jest charakterystyczny dla tych właśnie części mowy, przekonywała już D. Buttler, pisząc: „Największe bogactwo typów strukturalnych reprezentują uniwerbizmy rzeczownikowe"53. Spośród wszystkich sposobów kondensacji największą frekwencją w niniejszej pracy wykazuje się elipsa - najczęściej pomijany jest człon przymiotnikowy, czyli dochodzi do elipsy deadiektywizującej (rzeczniczka, igrzyska, znaczek), choć nie brakuje redukcji rzeczownika - elipsy substantywizującej (schabowy, karny, niemiecki). Popularna jest także dezintegracja, dla zobrazowania tego zjawiska można przywołać następujące przykłady: doping, samobój czy human. Egzemplifikacją derywacji sufiksalnej są natomiast filmówka, odrzutowiec i wieprzowina. O popularności form zuniwerbizowanych w tekstach prasowych może świadczyć fakt, że w zgromadzonym materiale odnotowano wiele syntetyzmów, które już na stałe wyparły swoje wielowyrazowe odpowiedniki, nie pojawiają się one bowiem w badanym materiale równolegle. Charakterystycznym formantem jest zwłaszcza -ówka54: Subsydia, obsługa długu i pensje w budżetówce zjadają trzy czwarte egipskiego budżetu. (P 50/2012, s. 54); Kolonia to specyficzne miejsce również pod względem medialnego rynku, na którym zajadle rywalizują ze sobą dwie agresywne bulwarówki. (PN 17/2012, s. 20); A kątem oka zauważasz, że nadjeżdżający kierowca zaczyna wyprzedzać ciężarówkę. (VG 13/2011, s. 19); Za-

52 Różne poglądy nt. uniwerbizacji zostały przedstawione w rozdziale Stan badań, s. 30-35.

53 D. Buttler, Niektóre problemy opisu zjawiska uniwerbizacji, „Slavistična revija” 1997, Lublana, s. 435.

54 Szczegółowo o tym sposobie tworzenia uniwerbizmów pisała H. Satkiewicz, $B u$ dżetówka, Krajówka, zbrojeniówka, „Poradnik Językowy” 1993, z. 6. 
nim powstała cyfrówka, którą dziś pstrykamy tysiące fotek, było urządzenie camera obscura, które w starożytności służyło do obserwacji astrologicznych. (VG 21/2012, s. 39); Oczywiście mieszczuchem nazywamy tu nie każdego mieszkańca miasta, ale mieszczucha mentalnego, dla którego życie bez prądu, sklepów całodobowych i kablówki nie ma sensu. (VG 12/2011, s. 41); Krótka miniówka. (VG 8/2011, s. 4); Cisza dotyczy nie tylko właścicieli motorówek. (VG 12/2011, s. 41); Gdyby rynek został zliberalizowany kilkanaście lat wcześniej, gdy każdy z nas wysyłał pocztówki z wakacji, dziesiątki kartek świątecznych czy imieninowych czy papierowe listy do rodziny za granicą, o klientów PP rozgorzałaby prawdziwa walka. (P 50/2012, s. 42); W brudnej puchówce nie pasuje zbytnio do towarzystwa, ale to właśnie numer 55 - między Billem Grossem, założycielem największego funduszu obligacji (54), a szefem pakistańskiego wywiadu ISI Ahmedem Szują Paszą (56). (P 24/2012, s. 58); To właśnie Ceauşescu za czasów swoich rządów nakazał wyburzyć znaczną część starówki oraz wiele obiektów sakralnych. (VG 8/2011, s. 23); Reformatorzy związani z Miedwiediewem są w odwrocie, nacierają zaś przedstawiciele resortów siłowych i ludzie związani ze zbrojeniówką, jak wicepremier odpowiedzialny za ten sektor Dmitrij Rogozin. (P 50/2012, s. 60). Drugim często wykorzystywaniem rozwiązaniem jest redukcja członu rzeczownikowego: Znajomość angielskiego jest dziś tak oczywista jak obsługa komputera. (VG 2/2011, s. 6); Poza tym mamy w klubie wystarczająco dużo graczy posługujących się także angielskim. (PN 36/2012, s. 26); Problem to miałem w Arisie, gdzie z niemieckiego byłem tłumaczony na grecki, dopiero z greckiego na hiszpański, a na koniec $z$ hiszpańskiego na francuski. (PN 11/2012, s. 23); Marta, najdłużej jak tylko się dało, jadła grzybową z łazankami, a łzy stały jej tuż pod powiekami. (VG 4/2011, s. 14); Michał będzie grał w przedstawieniach w szkołach podstawowych, gdzie dzieci uczą się hiszpańskiego. (VG 4/2011, s. 9); Zamiast schabowego czy mielonego daj dziecku mięso pieczone w folii lub gotowane na parze. (NŹ 4/2012, s. 32) Od razu po szkole prawie biegiem pognał do papierniczego, w którym oglądali misia o wielbłądzich stopach. (VG 1/2011, s. 12); Okazał się najsympatyczniejszym kumplem na świecie opowiadał o szczeniakach w domu babci, o tym, że nie cierpi pomidorowej, o maturze, która zbliża się wielkimi krokami. (VG 11/2011, s. 21). Z sytuacją odwrotną - tzn. występowaniem w prasie jedynie analityzmu z pary analityzm - syntetyzm (a formy skondensowanej wyłącznie np. w żywej mowie) - mamy do czynienia zdecydowanie rzadziej. 
Oprócz uniwerbizmów spotkać się można także ze złożeniami, jako przykład niech posłużą narkobaron i specsłużby. Donata Ochmann nazywa takie jednostki wyrazami złożonymi o podstawie zdezintegrowanej, co najmniej jeden z członów podstawy został bowiem uszczuplony fonetycznie ${ }^{55}$. Uczona podkreśliła współistnienie form analitycznych i syntetycznych: „Neutralność stylistyczna wielu analizowanych form ujawnia się $\mathrm{w}$ ich powszechnym występowaniu i funkcjonowaniu jako synonimów dłuższych określeń w tekstach (np. narkobaroni obok baronowie narkotykowi)" ${ }^{\prime 56}$.

Widać więc, że dochodzi do substantywizacji przymiotników, proces ten jak opisywał Stanisław Jodłowski - „polega na zmianie ich wartości leksykalnej, połączonej ze zmianą kategorii ontologicznej desygnatów, oraz na wynikającej stąd zmianie dyspozycji składniowej tych wyrazów"57. Choć podlegają urzeczownikowieniu, to zachowują swoje pierwotne cechy fleksyjne i słowotwórcze, zmieniają się natomiast kategoria znaczeniowa i łączliwość składniowa. Opisując mechanizm substantywizacji, badacz wymienił trzy etapy 58 : a) elipsa rzeczownika; b) leksykalizacja określającego go wyrazu przymiotnego (czyli nadanie nowego - rzeczownego - znaczenia, odbiegającego od podstawowej wartości tego wyrazu) i zmiana jego kategorii znaczeniowej na rzeczowną (zamiast cechy oznacza przedmiot); c) usamodzielnienie formantu przymiotnikowego jako wykładnika nazw rzeczownych (formanty takie mogą być używane do tworzenia nowych rzeczowników bez pierwotnej funkcji przymiotnej) ${ }^{59}$. W analizowanym materiale efektem procesu substantywizacji są chociażby niemiecki, karny, schabowy, spalony czy grzybowa.

55 D. Ochmann, Nowe wyrazy złożone o podstawie zdezintegrowanej w języku polskim, Kraków 2004. Autorka podkreśla seryjność takich złożeń, a do członów najczęściej występujących zalicza m.in. eko-, -fon, ero-, narko-, kato-, info-, euro-, cyber-, -mat, e-, top-.

56 Ibidem, s. 213.

57 S. Jodłowski, Substantywizacja przymiotników w języku polskim, Wrocław-Warszawa-Kraków 1964, s. 21.

58 Podział za: ibidem, s. 23.

59 S. Jodłowski opisuje dwa typy substantywizacji przymiotników: bezpośrednia (obejmuje wyrazy funkcjonujące pierwotnie jako rzeczywiste przymiotniki) i pośrednia (dotyczy wyrazów, które nigdy nie były przymiotnikami, powstały od razu jako rzeczowniki z formantem właściwym przymiotnikom). Szczegółowe informacje nt. omawianego procesu znajdują się w przytaczanej monografii S. Jodłowskiego. 


\subsubsection{Analityzmy niepochodne strukturalnie}

Angielski: Przy kaleczącym mowę Szekspira przybyszu z Italii szkoleniowiec wplatający do wypowiedzi gwarowe zwroty kogoś wychowanego we wschodnim Londynie (Cockney) działa na tubylców jak balsam. (PN 7/2012, s. 43)

Antykoncepcja: A najtrudniejszą do pokonania barierą w rozpowszechnianiu antykoncepcji jest nie tyle konserwatywne podłoże kulturowe i religijne, co brak rzetelnej wiedzy o zaletach i skutkach ubocznych medycznych procedur zapobiegania ciąży. (P 24/2012, s. 57) Arbiter/sędzia ${ }^{60}$ : Zwłaszcza w czasach zarazy, kiedy biegacze z gwizdkami mylą się (choć już pewnie nieumyślnie) na potęgę w każdej rozgrywanej kolejce. (PN 44/2011, s. 2) Dni między 14 a 17 października 2011 roku na długo pozostaną w pamięci kilku panów z gwizdkiem. (PN 50/2011, s. 18)

Asysta: Podobnie rzecz miała się z Kupiszem, autorem dziewięciu otwierających podań dla Jagiellonii. (PN 20/2012, s. 14)

Bank: Zachodnie instytucje finansowe wciąż pokazują, że kryzys niewiele je nauczył. (P 50/2012, s. 46)

Bicie: Ale niepokoi mnie, że mimo licznych kampanii społecznych i publicznej dyskusji przy okazji wprowadzania zakazu kar cielesnych dwa lata temu, akceptacja dla nich spada minimalnie. (P 50/2012, s. 34)

Boisko: Bo czym się różni chuligańskie zachowanie na trybunach od tego na placu gry, gdzie jeden z uczestników gry obraża drugiego ze względu na kolor skóry? (PN 47/2011, s. 27)

Bramkarz: Zresztą szkoleniowiec wicemistrzów Polski jest znany z tego, iż zdarza mu się żonglować obsadą pozycji między słupkami i obecność Gikiewicza można tłumaczyć taktyką szkoleniowca. (PN 11/2012, s. 38)

Oczywiście chodzi o komplet bramkarzy, zresztą w ogóle tę klasyfikację zdominowali specjaliści od łapania piłki. (PN 24/2012, s. 33)

Podczas gdy najlepsi polscy specjaliści od stania między słupkami zarabiają na życie w Anglii, Holandii i Włoszech, ich nieobecność wykorzystują wcale nie młodzi zdolni Polacy - choć i takich nie brakuje - ale górale zza południowej granicy, co musi dziwić o tyle, że jeszcze niedawno chwaliliśmy się tak zwaną krajową szkołą bramkarzy. (PN 20/2012, s. 12)

Cellulit: Z pomarańczową skórką zmagają się także nastolatki. (VG 17/2012, s. 30)

Chudnięcie: Pozbycie się nadwagi to nie problem - pomoże Ci sztab specjalistów. (NŻ 13/2012, s. 32)

60 Por. też sędzia na s. 95. 
Pod naszą szerokością geograficzną mocne postanowienie doprowadzenia wagi do normy to często słomiany zapał, co potwierdzają właściciele siłowni i klubów fitness. (P 51-52/2012, s. 113)

Z naukowego punktu widzenia efekty ćwiczeń są jednak znaczące, choć niewidoczne, nawet jeśli podstawowego celu, jakim jest utrata nadwagi, nie uda się szybko osiągnąć. (P 51-52/2012, s. 113)

Ciąża: Ale sądząc po jej rozanielonej minie na imprezie TVP, nie miałaby pewnie nic przeciwko rychłej wizycie bociana... (NŻ 9/2012, s. 5)

Dieta: Po przyjeździe do Niemiec musiałem zupełnie zmienić przyzwyczajenia żywieniowe, ale wyszło mi to wyłącznie na zdrowie. (PN 20/2012, s. 22)

Dyrygent/kapelmistrz: Z drugiej strony, co jest szczególnie ważne w czasach kryzysu, kierownicy orkiestry, czyli mówiąc $z$ angielska menedżerowie, a z niemiecka intendenci, bardzo zyskali na znaczeniu, bo to oni liczą pieniądze. (P 50/2012, s. 92)

Można być tylko zastępcą dyrektora do spraw artystycznych. (P 50/2012, s. 93)

Dziadek: Mężowie babć, czyli dziadkowie, są zmęczeni życiem, nie mają w sobie takich niespożytych sił jak one. (VG 1/2011, s. 27)

Ekstraklasa: Polski futbol jest od dawna niedoinwestowany, ale chyba jeszcze nigdy w obecnym stuleciu zespół z najwyższej ligi nie był tak bliski bankructwa. (PN 4/2012, s. 2)

Długo nie mógł przebić się do ekstraklasy, a jak już mu się udało, to akurat gnębiły go kontuzje i poważnie na najwyższym szczeblu nie zaistniał. (PN 49/2012, s. 8)

Eufemizm: Po trzecim z rzędu meczu bez zdobyczy bramkowej ciemne chmury zbierają się nad Jose Marią Bakero, prowadzącym ekipę poznańskiego Lecha, a debiut Pavla Hapala na ławce trenerskiej Zagłębia Lubin trzeba uznać za mało udany, używając słów z gatunku delikatnych. (PN 45/2011, s. 47)

Fiskus: Potem było kilka burzliwych rozwodów, głośne procesy o alimenty, problemy z urzędem skarbowym. (PN 48/2011, s. 29)

Na sprawdzenie Twojego rocznego zeznania PIT urząd skarbowy ma 5 lat. (NŻ 3/2012, s. 31)

Zwłaszcza że życie emeryta jest spokojniejsze, nie jest on nieustannie narażony na bankructwo, nieuczciwą konkurencję, prześladowania ze strony urzędów skarbowych. (P 24/2012, s. 110)

Fortuna: Bywała nim Fortuna, czyli boski kaprys. (P 51-52/2012, s. 26)

Futbol: Dla mnie bomba i mogę nawet przyklasnąć, biorąc pod uwagę, że dotychczas różnego rodzaju podszepty do rządowych decydentów wychodziły od ludzi niewiele mających wspólnego z piłką nożną, ale nawet ze sportem. (PN 1/2012, s. 47) 
Granat: Kolor elegancki, szykowny, tzw. nowa czerń. (NŻ 4/2012, s. 20)

Homoseksualiści: Oświadczenie prezydenta Obamy w wywiadzie dla telewizji ABC, że pary tej samej płci powinny móc się pobrać, przyjęły z radością. (P 20/2012, s. 52)

Internauta: Premier przestraszony spadkiem poparcia przez wiele godzin słuchał, co o tym wszystkim myślą ludzie sieci, i obiecał „sprawdzić każdą literkę w umowie”, aż wreszcie „podjął definitywną decyzję”, że Polska nie ratyfikuje ACTA. (P 51-52/2012, s. 12)

Jedenastka: Borussia zdołała wyrównać za sprawą rzutu karnego Błaszczykowskiego (faulowany był Lewandowski), ale wystarczyło kapitalne podanie Diego i celny strzał Dosta, żeby sensacja stała się faktem. (PN 50/2012, s. 27)

Karp: Przez lata karp był żelaznym punktem wigilijnej wieczerzy. (P 50/2012, s. 30)

Kawa: Lampka wina, mała czarna, aromatyczna herbata. (NŻ 8/2012, s. 22)

Kibic: Zamiast jeździć po ligowych stadionach, gdzie bracia po racy i tak zasłaniają dymem wszystko, co istotne na boisku, zaczął odwiedzać biura paszportowe i grzebać w metrykach chłopaków, co to mieli swojsko brzmiące nazwiska lub choćby imiona, a jeśli i tu pudło - ich prasłowiańskości dowodziła przynajmniej blond czupryna. (P 24/2012, s. 13)

- Chętnie was skontaktuję z ludźmi z bojówki Wisły, ale nie teraz - mówi inny krakowski bywalec stadionowy. (P 5/2011, s. 97)

Korner: Becks w pierwszym i drugim spotkaniu wykonał tak po mistrzowsku swoje firmowe dania, czyli rzuty wolne i rożne, że kolegom wypadało tylko przystawić głowę lub nogę. (PN 45/2011, s. 29)

Korupcja: Drugim podejrzanym o czerpanie korzyści majątkowych z racji zajmowanego stanowiska jest były zięć Havelange’a, prezydent konfederacji futbolu Brazylii Ricardo Teixeira. (PN 48/2011, s. 29)

Koszykówka: Oprócz takich gadżetów, mających coś wspólnego z dyscypliną legendarnego Michaela Jordana, w jego zbiorach odnaleźć można także bilety, programy i autografy żużlowe. (VG 12/2011, s. 59)

Kot: Czy Agata ulegnie namowom ukochanej jedynaczki i przygarnie pod dach miauczącego czworonoga? (NŻ 4/2012, s. 5)

Krew: Nawet Aleksander Wielki, który pewnie się sadowił w systemie religijnym, kiedy zobaczył własną krew, uznał, że to jednak nie jest niebiański płyn z żył bogów. (P 5152/2012, s. 82)

Kustosz: Oto trzy opowieści o niezwykłych strażnikach pamięci. (P 51-52/2012, s. 40)

Laptop: Dzięki przenośnym komputerom osobistym czy odtwarzaczom multimedialnym możesz czytać e-booki, słuchać audiobooków czy przeglądać strony w wybranym języku w autobusie, w poczekalni u dentysty czy gdziekolwiek zechcesz. (VG 21/2012, s. 15) 
Lew: W końcu lew to król zwierząt, a to do czegoś zobowiązuje (VG 13/2011, s. 46) Łapówka: Mariusz T. usłyszał dwa zarzuty przyjęcia korzyści majątkowych na łączną kwotę 5 tysięcy złotych. (PN 43/2011, s. 11)

Makijaż: I rzeczywiście, bez pełnych „barw wojennych” Edyta wygląda na zwyczajną dziewczynę z sąsiedztwa. (NŻ 10/2012, s. 17)

Mastektomia: Miała już też za sobą amputację piersi - nie jednej, obu! (P 5/2011, s. 56)

Matematyka: Już piąty rok z rzędu młodzi fani, w swych krótkich filmach video, pokażą, jaki potencjał drzemie w królowej nauk. (VG 17/2012, s. 5)

Menstruacja: Blanka napisała, że mogą się spotkać, ale raczej nie na basenie, bo z pewnych powodów nie może tam iść. (VG 17/2012, s. 25)

Ania zrozumiała, że „pewne powody” to kobiece sprawy, na które rady nie ma, basen musi poczekać. (VG 17/2012, s. 25)

Mundial: To dobra wiadomość dla tamtejszego ministra finansów, który potrzebuje więcej i więcej pieniędzy na mające się odbyć w 2014 roku finały mistrzostw świata. (PN 9/2012, s. 39)

Jeśli przygotowania do największej piłkarskiej imprezy na świecie wyprzedziłyby harmonogram albo chociaż się go trzymały, nominacja dwóch znakomitych piłkarzy nie wzbudziłaby kontrowersji. (PN 9/2012, s. 39)

Murarz: W wyjątkowe kwalifikacje mistrzów kielni nie należy jednak wierzyć. (P 24/2012, s. 66)

Nadwaga/otyłość: Jeśli czuje się kochana i akceptowana, nie walczy z puszystymi kształtami. (NŻ 12/2012, s. 10)

Namiestnictwo: Zaoferował Janowi Zamoyskiemu namiestnictwo, czyli wielką władzę nad krajem. (P 51-52/2012, s. 154)

Napastnik: I nie chodzi tylko o zawodników z pierwszej linii. (PN 11/2012, s. 14)

Netto: Kontrakt Lenczyka obowiązuje do czerwca 2013 roku i gwarantuje mu pobory wysokości 80 tysięcy złotych na rękę, zatem łatwo policzyć, że wrocławianie będą musieli wypłacić szkoleniowcowi 800 tysięcy. (PN 36/2012, s. 2-3)

Nieskuteczność: Mario Gomez przed przedostatnim meczem ligowym Bayernu z VfB Stuttgart naczytał się i nasłuchał sporo krytycznych uwag o swojej niemocy strzeleckiej. (PN 1/2012, s. 35)

Kibice za nim przepadają, w przeszłości wybaczali mu długie miesiące strzeleckiej abstynencji. (PN 11/2012, s. 33)

Ale indolencja strzelecka wcale nie była znakiem firmowym wyłącznie Holendra. (PN 20/2012, s. 19) 
Obcokrajowiec: Coraz częściej gwiazdami ligi zostają piłkarze z obcym paszportem, nasi reprezentanci stają się tłem - ludźmi od czarnej roboty, w czołowych klubach to nie oni kreują grę, nie oni zdobywają bramki, nie oni zdobywają doświadczenie w europejskich pucharach, które potem można by spożytkować w drużynie narodowej. (PN 11/2012, s. 15)

Lata minęły i w Milanie przestano sobie wyobrażać sukcesy bez wsparcia graczy z importu. (PN 48/2012, s. 12)

Obrażanie: Strzelenie focha to reakcja dziecinna, niedojrzała. (VG 8/2011, s. 21)

Opatrzność: Bywała nim Opatrzność, czyli boża troska. (P 51-52/2012, s. 26)

Orange $^{61}$ : Energizujące stroje w kolorze pomarańczy rozgrzeją Cię i ocieplą zimową aurę. (NŻ 7/2012, s. 24)

Ósemka: Zęby mądrości powodują często więcej szkód niż pożytku. (NŻ 3/2012, s. 34)

Parabank: Firmy pożyczkowe, zwane parabankami, kuszą ludzi, jak mogą. (P 50/2012, s. 48)

Peruka: Szał na sztuczne włosy osiągnął szczyt - także dosłownie - pół wieku później, w czasach Marii Antoniny, której nadworna stylistka Rosa Bertin, przez złośliwych nazywana ministrem urody, oraz fryzjer królowej Leonard tworzyli skomplikowane konstrukcje, wysokie na kilkadziesiąt centymetrów. (P 51-52/2012, s. 147)

Piersi: Młode, bez kompleksów, bezczelnie świadome swych poduszek rozkoszy, pokazują ich na stronach internetowych dziesiątkami - małe, duże, średnie. (P 7/2011, s. 87)

Pies: Dzięki swojemu czworonożnemu przyjacielowi poznasz wakacyjną miłość. (VG 13/2011, s. 46)

Pilot: Pilot - dowódca statku powietrznego - musi doskonale znać szczegóły budowy samolotu, a także nawigacji - oznacza to, że powinien mieć taką wiedzę jak wszyscy jego podwładni razem wzięci. (VG 1/2011, s. 4)

Pizza: Najlepszy symbol włoskiej kuchni, znany na całym świecie. (VG 6/2011, s. 14)

Polityk: Dzisiaj rezydenci Pałacu Burbońskiego zaczynają rozumieć, że popularny Ibra dysponuje porównywalną mocą przyciągania turystów jak o 475 lat starsza od niego, również ściągnięta do Paryża z północy Włoch, Mona Lisa. (PN 50/2012, s. 16)

Upiekł dwie pieczenie: dowiedział się, co jest ważne dla jego elektoratu i utrwalił wizerunek męża stanu wsłuchanego w głos internautów. (P 51-52/2012, s. 38)

61 Przymiotnikowym odpowiednikiem analityzmu $w$ kolorze pomarańczy jest pomarańczowy (por. s. 83), w materiale odnotowano też obcojęzyczny ekwiwalent rzeczownikowy orange. 
Pomoc: Bradley nie wie, jak będzie wyglądało w najbliższym meczu ustawienie drugiej linii. (PN 44/2011, s. 29)

Pomocnik: Wysokie miejsce zajęli także dwaj ludzie środka pola z rewelacyjnej Korony Kielce. (PN 20/2012, s. 15)

Powołanie, nominacja: Nieco na wyrost wydaje się zaproszenie do kadry Piecha, który ostatnią bramkę zdobył prawie dwa miesiące temu. (PN 50/2012, s. 42)

Potop: Podczas potopu, czyli wojny polsko-szwedzkiej, wojska Karola X Gustawa w 1656 r. oblegały Zamość. (P 51-52/2012, s. 154)

Premier: Władze za duże pieniądze zorganizowały także kilka kontrdyskusji, by zademonstrować jedność prezydenta z szefem rządu. (P 50/2012, s. 59)

Kim jest polski premier? Jest szefem państwowego aparatu. Jest szefem największej firmy w kraju. (P 51-52/2012, s. 29)

Prezydent: Czy może się zdarzyć, że główne trofeum w imprezie rozgrywanej pod patronatem prezydenta RP wręczy głowa państwa, a przed meczem puchar zaprezentuje na przykład nasza fenomenalna biegaczka Justyna Kowalczyk? (PN 20/2012, s. 2)

Jest wreszcie najwierniejszy z wiernych, czyli Jan Smoliński, który odpowiada za medialną aktywność głowy państwa. (P 24/2012, s. 26)

Przysłowie: Przysłowia, powiadają, są mądrością narodów, dlatego uciekam się do starych ludowych prawd po tym, jak fortuna przydzieliła biało-czerwonym do grupy Grecję, Rosję i Czechy. (PN 49/2011, s. 2)

Psycholog: Zresztą nie oszukujmy się - najlepszym psychologiem dla drużyny jestem ja, a specjalistę od przygotowania mentalnego sprowadzamy tak na wszelki wypadek. (PN 20/2012, s. 3)

Drugi warunek dokooptowania trenera mentalnego jest następujący - przed najbliższym spotkaniem potrzebę pracy z takim specjalistą musi zgłosić minimum dwóch kadrowiczów. (PN 6/2012, s. 22)

Remis: Podział punktów zasłużony, bo choć w ostatnim kwadransie Jaga, grając w osłabieniu, głównie się broniła, to wcześniej miała przewagę. (PN 50/2012, s. 40)

Reprezentacja: Dobrze, że przyjmując ofertę prowadzenia drużyny narodowej od federacji piłkarskiej Egiptu, nie omieszkał dodać, że bierze na swoje barki wielką odpowiedzialność. (PN 44/2011, s. 29)

Rewolucja, która doprowadziła do upadku dyktatury Hosniego Mubaraka, zbiegła się w czasie z katastrofalnymi wynikami teamu narodowego. (PN 44/2011, s. 29)

Selekcjoner ekipy narodowej musi być blisko ludzi. (PN 44/2011, s. 29)

Rok: Rok temu powiedział: Do zobaczenia za dwanaście miesięcy! (VG 25/2012, s. 3) 
Rower: Zwiedzanie na dwóch kółkach jest coraz bardziej popularne, także wśród młodzieży. (VG 12/2011, s. 42)

Rozmnażanie: Zdolność do wytwarzania osobników potomnych w sposób płciowy lub bezpłciowy zapewnia ciągłość istnienia gatunku. (VG 3/2011, s. 36)

Rozwód: Według naszych informacji, formalne zakończenie małżeństwa państwa Popków nastąpiło pod koniec sierpnia 2012 r. (NŻ 8/2012, s. 2)

Ryba: Ryby jako symbol chrześcijaństwa i produkt przyklasztorny wyłączone były Z wszelkich ograniczeń. (P 50/2012, s. 32)

Rząd: Zasiąść w Radzie Ministrów... nie jest tak łatwo (:) (VG 22/2012, s. 41)

Argumenty ministra, że konwencja to „dokument niechlujny”, który zniszczy tradycyjny model małżeństwa i „może upowszechniać homoseksualizm”, nie przekonała Rady Ministrów i Polska dołączy do 25 krajów, które będą respektować zapisy konwencji. (P 51-52/2012, s. 12)

Rzecznik: Szanuję zdanie szefa służb prasowych banku, tylko do końca nie godzę się ze stwierdzeniem, że właściciel BRE - niemiecki Commerzbank - nie lubi futbolu i nie reklamuje się na piłkarskich arenach. (PN 13/2012, s. 2)

Samolot: Pilot - dowódca statku powietrznego - musi doskonale znać szczegóły budowy samolotu, a także nawigacji - oznacza to, że powinien mieć taką wiedzę jak wszyscy jego podwładni razem wzięci. (VG 1/2011, s. 4)

Sandacz: Oprócz karpia ma jeszcze szczupaka, amura, okonia, karasia i króla ryb słodkowodnych - sandacza. (P 50/2012, s. 31)

Sąd: Fundamentalny problem polskiego wymiaru sprawiedliwości polega na tym, że polski sąd jest dzisiaj, niestety, w przytłaczającej większości sądem przepisu prawa, a nie sądem prawa. (P 50/2012, s. 25)

Selekcjoner: Ten ostatni ma prawie 34 lata i na mecz z Estonią nie był nominowany, ale dobra forma w meczach Legii, do której wrócił po siedmiu latach, nie uszła uwadze szefa kadry i po trzech latach wrócił także do reprezentacji. (PN 36/2012, s. 5)

Sẹdzia: Coraz wyraźniej - także w kontekście sprawy aresztowanej niedawno za długi matki dwójki dzieci - pojawia się dylemat, czy sędziowie są tylko bezrefleksyjnymi wykonawcami sztywnej litery prawa, czy prawdziwymi szafarzami sprawiedliwości? (P 50/2012, s. 24)

Sierociniec: Z domu dziecka w Konstancinie do salonów Nowego Jorku (NŻ 5/2012, s. 42-43)

Snajper: Oczywiście, Dudu Biton dobrze wywiązuje się z roli żądła drużyny, ale pozostali niespecjalnie mu pomagają. (PN 11/2012, s. 14) 
Po letnich przepychankach z Euzebiuszem Smolarkiem i Arturem Sobiechem właściciel Czarnych Koszul Józef Wojciechowski zainwestował w specjalistów od strzelania goli z zagranicy, dlatego w tym sezonie Polacy zdobyli tylko 2 bramki dla klubu, co daje 8,7 procent wszystkich goli. (PN 11/2012, s. 15)

Trio Maciej Jankowski, Arkadiusz Piech i Paweł Abbott w miarę regularnie zdobywa bramki i choć żaden z wymienionych piłkarzy na tytuł najskuteczniejszego zawodnika sezonu 2011-12 nie ma szans, to każdy z osobna pokazuje, że polski napastnik może być skuteczny. (PN 11/2012, s. 15)

Ta liczba świadczy dobitnie, że Podolski jest już dojrzałym łowcą goli. (PN 17/2012, s. 28)

Szczypiorniak/handball: Zdarza się oczywiście - na przykład w piłce ręcznej - że faworyt przegra niczym mistrz i wicemistrz w miniony weekend, ale tylko w futbolu możliwy jest scenariusz, w którym taka Barcelona ma dziesięć sytuacji, a traci wszystkie punkty po jednym, przypadkowym golu. (PN 11/2012, s. 11)

Szesnastka: Telewizyjne powtórki pokazały, iż stoper Czerwonych Diabłów Rio Ferdinand prawidłowo wybił piłkę spod nóg szarżującego w polu karnym Hatema Ben Arfy. (PN 49/2011, s. 33)

Tartinki: Na takie okazje wymyślono tartinki, czyli małe, acz bardzo wymyślne i smakowite kanapeczki. (P 51-52/2012, s. 154)

Uczestnik: Wszyscy biorący udział w plebiscycie otrzymają nagrodę gwarantowaną miesięczny dostęp do Polityki Cyfrowej, którą można odbierać na wszystkich nośnikach elektronicznych. (P 51-52/2012, s. 119)

Wejściówka: Stało się to możliwe, gdyż wciąż popyt na karty wstępu na Old Trafford znacznie przewyższa podaż. (PN 33/2012, s. 17)

Woda: Świadomość, że życiodajny płyn pokrywa 71\% powierzchni globu, powoduje, iż traktujemy go jako dobro nieograniczone i ogólnodostępne. (VG 6/2011, s. 3)

Oznacza to, że sięgając po małą Cisowiankę, możemy być pewni, że całość zysku z jej sprzedaży zostanie przekazana na ten konkretny cel - budowę ujęć wodnych w jednym z najuboższych w „niebieskie złoto” regionów świata. (VG 6/2011, s. 5)

Tycie: Tymczasem odczuwają one głód, często potworny, ale w obawie przed przyrostem masy ciała odmawiają przyjmowania jedzenia. (VG 21/2012, s. 16)

Wojna: Trudności pojawiają się dopiero wówczas, kiedy chodzi o przeszłe czyny zbrojne służące zdobyczom terytorialnym, podbijaniu czy kolonizowaniu innych ludów. (P 24/2012, s. 21)

Współczesna wrażliwość etyczna, i rodząca się (w bólach co prawda) europejska wspólnotowość skłaniają do niepodkreślania samych militarnych wyczynów, niestawiania 
na piedestale podbojów, nieczynienia z nich głównych elementów narodowej dumy. (P 24/2012, s. 21)

Wolontariat: I dlatego zadania w naszym konkursie będą związane właśnie z wolontariatem - ideą bezinteresownego niesienia dobra i pomocy. (VG 4/2011, s. 4)

Wolność: Obaj pozowali na nieprzejednanych szeryfów i zbawicieli, tymczasem L. został skazany prawomocnym wyrokiem za korupcję, zaś T. musiał w minionym tygodniu wpłacić gigantyczną kaucję, żeby nadal przebywać na świeżym powietrzu. (PN 48/2011, s. 2) Wulgaryzm/przekleństwo: Z wyroku sądu, który uniewinnił pana za używanie nieprzyzwoitych słów w miejscu publicznym, chyba jest pan zadowolony? (PN 20/2012, s. 45)

- Magda przeklina, by przypodobać się Edwardowi Miszczakowi, bo szef stacji lubi soczyste słowa - zdradza nam znajomy słynnej kucharki. (NŻ 1/2012, s. 11)

Wówczas była już pewna, że soczyste słownictwo popłaca, więc dlatego tak szaleje. (NŻ 1/2012, s. 11)

Dziennikarz Marcin Meller (43) jest znany ze swej słabości do nieparlamentarnych słówek. (NŻ 1/2012, s. 11)

Nie będziecie przez to lepsi, a jeśli śmieciarska gadanina was dowartościowuje, to tylko pogratulować. (VG 3/2011, s. 22)

Zabijanie: Widać przez niego szaleńca, który po objęciu władzy ogłosił się Bogiem i dał sobie prawo do odbierania życia. (PN 6/2012, s. 11)

Złotówka/złoty: Kurs polskiej waluty przestał być dla jego interesów aż tak istotny. (P 51-52/2012, s. 60)

Znaczek: Pierwszy papierek potwierdzający dokonanie opłaty za przesyłkę, wydany w 1840 r. w Wielkiej Brytanii, zadrukowano podobizną królowej Wiktorii. (P 50/2012, s. 100)

Zwierzę: Medycyna braci mniejszych (P 51-52/2012, s. 108)

Zwycięstwo $^{62}$ : Dlatego tak bardzo zależało nam na trzech punktach. (PN 50/2012, s. 41)

Tomasz Hajto nauczył Jagiellonię wygrywać w meczach wyjazdowych, ale drużyna ma problemy ze zdobywaniem kompletów punktów u siebie. (PN 49/2012, s. 15)

Spodziewał się pan wywiezienia kompletu punktów z bardzo trudnego terenu? (PN 36/2012, s. 42)

Żużel: Tutaj jednak nie możemy się dziwić, bowiem Daniel pochodzi spod Częstochowy, zagłębia polskiego czarnego sportu. (VG 12/2011, s. 59)

62 Por. rozważania na temat analityzmów czasownikowych zwyciężać i wygrać. 
Pod względem formalnym analityzmy rzeczownikowe niemające wspólnych morfemów z odpowiadającym im syntetyzmem są przede wszystkim połączeniami rzeczowników z rzeczownikiem w dopełniaczu (plac gry, szafarz sprawiedliwości, mistrz kielni), podstawą są czasem rzeczowniki odczasownikowe, np. strzelanie focha, odbieranie życia, odniesienie zwycięstwa ${ }^{63}$, nieraz drugim elementem jest nazwa własna (mowa Szekspira, rezydent Pałacu Burbońskiego, dyscyplina legendarnego Michaela Jordana - tutaj rozbudowana jeszcze o przymiotnik). Liczną grupę stanowią konstrukcje składające się z rzeczowników i przymiotników, np. kara cielesna, przyzwyczajenia żywieniowe, barwy wojenne, lub rzeczowników i imiesłowów, np. otwierajace podanie, miauczacy czworonóg, nie brak też zestawiania rzeczowników z liczebnikami: druga linia, dwanaście miesięcy, dwa kółka. Wyróżnić można także struktury zbudowane z rzeczowników i wyrażeń przyimkowych: gracz z importu, pozycja między słupkami, zaproszenie do kadry. Licznie reprezentowane są połączenia kilku rzeczowników: wywiezienie kompletu punktów, przyrost masy ciała, czasem dodatkowo uzupełnione przez przydawkę przymiotną: medyczne procedury zapobiegania ciąży, wykonawca sztywnej litery prawa, idea bezinteresownego niesienia dobra i pomocy, nierzadko pojawia się kombinacja rzeczowników i przymiotników z wyrażeniami przyimkowymi: specjalista od stania między słupkami, niebiański płyn z żył bogów, największa impreza piłkarska na świecie.

Z powyższego zestawienia wynika, że konstrukcje dwuelementowe, choć występują licznie, to jednak nie mają tak dużej przewagi nad pozostałymi jak w poprzedniej grupie. Wiele jest zestawień obejmujących trzy (król ryb słodkowodnych, formalne zakończenie małżeństwa, dowódca statku powietrznego), cztery (doprowadzenie wagi do normy, żelazny punkt wigilijnej wieczerzy, słowo z gatunku delikatnych), a nawet pięć członów (szef największej firmy w kraju, specjalista od stania między słupkami, zastępca dyrektora do spraw artystycznych). Wielowyrazowe określenia przybierają czasem kształt definicji64: najlepszy symbol włoskiej kuchni, znany na całym świecie, papierek potwierdzajacy dokonanie opłaty za przesyłke, małe, acz bardzo wymyślne i smakowite kanapeczki.

Na uwagę zasługują także struktury opisowe, które przyjmują postać zdań: istota, która nie wie, czy nici jej istnienia nagle nie przetnie sarkoma płuc, ostatni

63 Por. identyczne połączenia z podstawą czasownikową, np. odnieść zwycięstwo, strzelać focha, s. 53, 56.

64 Sformułowania takie mogą też budzić skojarzenia z hasłami krzyżówek. 
towar w całej Unii, który trafia do klienta w formie żywej, rozrabiaki, przez których nawet kluby piłkarskie maja kłopoty i których nikt nie chce widzieć na trybunach, ludzie, w których ręce została złożona największa władza, gość, który ma prowadzić grę i być reżyserem. Oto przykłady ich zastosowania:

Człowiek: Uważano, że istota, która nie wie, czy nici jej istnienia nagle nie przetnie sarkoma płuc - jak szyderczo wyłożył sprawę Wolland - nie może kierować nawet własnym życiem, nie mówiąc o życiu całych społeczeństw. (P 51-52/2012, s. 26)

Karp: Karp jest ostatnim towarem w całej Unii, który trafia do klienta w formie żywej. (P 50/2012, s. 32)

Kibol: Są kibice i... są kibole, czyli rozrabiaki, przez których nawet kluby piłkarskie mają kłopoty i których nikt nie chce widzieć na trybunach. (VG 1/2011, s. 18)

Playmaker: Nie jesteśmy bowiem uzależnieni od formy gościa, który ma prowadzić grę i być reżyserem. (PN 11/2012, s. 12)

Polityk: W roli reżyserów wydarzeń obsadziliśmy więc polityków. Ludzi, w których ręce została złożona największa władza. (P 51-52/2012, s. 27)

Ich pozycja jest odmienna od pozostałych analityzmów, występują one okazjonalnie i - być może ze względu na swoją długość - nie są notowane przez słowniki. Ponieważ pojawiają się nie tylko sporadycznie, to warto podkreślić skłonność współczesnych dziennikarzy do coraz częstszego tworzenia takich form - brak powtarzalności świadczy jednak o tym, że konstruowane są tylko na potrzeby pojedynczego tekstu. Mimo swojej objętości wpisują się jednak w pojęcie definicji - syntetyzm jest tu członem definiowanym, analityzm zaś - członem definiującym.

Jak i w poprzednio omawianych podgrupach, tak i w tej mamy do czynienia z sytuacją, kiedy jednej skondensowanej formie odpowiada kilka multiwerbizmów o różnej budowie. Dyrygent jest używany wymiennie z kierownikiem orkiestry oraz zastępca dyrektora do spraw artystycznych. Dwóch rozbudowanych określeń doczekał się wyraz menstruacja, są to: kobiece sprawy oraz pewne powody. Syntetyczny leksem sędzia zyskał odpowiedniki w postaci wykonawcy sztywnej litery prawa i szafarza sprawiedliwości. Woda określana jest mianem życiodajnego płynu i niebieskiego złota. Alternatywnymi określeniami psychologa są specjalista od przygotowania mentalnego i trener mentalny. Czyn zbrojny i militarny wyczyn pojawiają się w miejsce wojny. Dziennikarze nazywają mundial mistrzostwami świata i największą impreza piłkarska na świecie, obcokrajowiec to w nomenklaturze sportowej piłkarz z obcym paszportem i gracz z importu, 
nieskuteczność nazywana jest zaś niemoca strzelecka, strzelecka abstynencja i strzelecką indolencja, wszystkie te sformułowania opierają się na przymiotniku strzelecki. Trzy odpowiedniki przynależą do bramkarza: pozycja między słupkami, specjalista od łapania piłki, specjalista od stania między słupkami, czterech określeń doczekał się także zawodnik występujący na innej pozycji - mianowicie snajper: $\dot{z} a$ dło drużyny, specjalista od strzelania goli, najskuteczniejszy zawodnik, łowca goli. Odpowiedniki reprezentacji bazują na konstrukcjach z przymiotnikiem narodowy: drużyna narodowa, team narodowy, ekipa narodowa. Kibice zostali określeni przez piszących braćmi po racy oraz bywalcami stadionowymi. Ekstraklasa zwana bywa najwyższa liga lub najwyższym szczeblem - człon przymiotnikowy pozostaje zatem niezmienny, pojawiają się za to synonimiczne określenia rzeczownikowe ${ }^{65}$. Zwycięstwo można określić na trzy sposoby: trzy punkty, zdobycie kompletu punktów, wywiezienie kompletu punktów, każde z tych połączeń uwypukla inny odcień semantyczny opisywanego zdarzenia. Ekwiwalenty arbitra/sędziego opierają się na wyrażeniu przyimkowym $z$ gwizdkiem/z gwizdkami, do którego dołączono różne komponenty rzeczownikowe: biegacze i panowie.

Jak widać, wiele struktur odnosi się do słownictwa sportowego. Odnotowano również trzy ekwiwalenty chudnięcia: pozbycie się nadwagi, doprowadzenie wagi do normy i utrata nadwagi. Zamiast leksemu polityk w prasie pojawiają się analityczne połączenia rezydenci Pałacu Burbońskiego czy mężowie stanu66, premier z kolei zwany jest szefem rządu, szefem państwowego aparatu i szefem największej firmy w kraju - rzeczownikowy komponent szef uzupełniany jest różnymi przydawkami. Najwięcej - bo aż pięć - odpowiedników zanotował leksem wulgaryzm: nieprzyzwoite słowa, soczyste słowa, soczyste słownictwo, nieparlamentarne słówka, śmieciarska gadanina. Podkreślenia wymaga fakt, że istnieją syntetyzmy, które mają odpowiedniki zarówno zawierające wspólne z nimi morfemy, jak i niespokrewnione morfologicznie, zaliczają się do nich rzecznik, znaczek czy internauta. Czasem spotykamy się też z sytuacją, kiedy ta sama wielowyrazowa konstrukcja ma różnie zbudowane skondensowane ekwiwalenty (np. rzut rożny to róg i korner, piłka nożna - piłka i futbol, urząd skarbowy-fiskus i skarbówka).

65 O tym, w jaki sposób zmiana rzeczownika wpływa na znaczenie całej konstrukcji, będzie mowa w rozdziale Semantyka.

66 A także rozbudowane: ludzie, w których ręce została złożona największa władza, por. s. 99. 


\subsubsection{Frazeologizmy}

Cukier/sól 67: Uwaga na białą śmierć! (VG 20/2012, s. 19) - biała śmierć a) 'narkotyki, zwłaszcza kokaina'; b) 'cukier, zwłaszcza wtedy, gdy używany jest w zbyt dużych, szkodzących zdrowiu ilościach’; c) 'śniegi i lody grożące życiu, będące przyczyną śmierci' (WSF, s. 542)

Dom/mieszkanie: Wielkie trzęsienie ziemi w San Francisco, w katastrofie zginęło około 1000 osób, a 250 tys. straciło dach nad głową. (VG 6/2011, s. 46) - dach nad głową 'dom, mieszkanie' (WSF, s. 60)

Drobnostka: Tyle że wspomniane spodziewane ruchy transferowe to małe piwo w porównaniu z akcją: zatrzymajmy Milę we Wrocławiu. (PN 49/2012, s. 5-6) - pot. małe piwo 'coś łatwego, prostego do załatwienia; drobnostka' (WSF, s. 360)

Film: Atlas chmur jest ucztą nie tylko dla wielbicieli zapierających dech w piersiach opowieści przygodowych, ale także spostrzegawczych miłośników X Muzy. (VG 24/2012, s. 28) - dziesiąta muza 'film, twórczość filmowa' (WSF, s. 261)

Impas: Na ligowym finiszu Mourinho, nie chcąc brnąć w ślepą uliczkę, postanowił na prawej obronie obsadzić Raula Albiola (8), który dawał najmniejsze ryzyko popełniania prostych pomyłek. (PN 20/2012, s. 7) - ślepa uliczka, ślepy zaułek, ślepy tor 'o trudnej sytuacji, sytuacji bez wyjścia; impas' (WSF, s. 540)

Kobieta: Krzysztof Rutkowski zawsze miał powodzenie u płci pięknej. (NŻ 12/2012, s. 19) - płeć piękna, słaba płeć, przestarz. płeć nadobna 'kobiety' (WSF, s. 364)

Marzenie/fantazjowanie: A może wolisz poukładane życie, bez bujania w obłokach? (VG 3/2011, s. 15) - bujać w obłokach 'być dalekim od realnego życia, także: być pogrążonym w marzeniach, marzyć' (WSF, s. 27)

Mężczyzna: W 2004 roku zasugerował, iż kobiety grające w piłkę powinny nosić bardziej obcisłe spodenki, aby wzbudzić większe zainteresowanie brzydkiej płci tym, co się dzieje na boisku. (PN 47/2011, s. 27) - żart. płeć brzydka; brzydka (brzydsza) połowa ludzkości, rodzaju ludzkiego 'o mężczyznach' (WSF, s. 26)

Narciarstwo: Alpy Sabaudzkie cieszą się wśród amatorów białego szaleństwa szczególnymi względami. (NŻ 8/2012, s. 24) - białe szaleństwo o sportach zimowych, zwłaszcza o narciarstwie' (WSF, s. 527)

67 Słowniki nie notują znaczenia sól w odniesieniu do związku frazeologicznego biała śmierć, jednak po zapoznaniu się z artykułem można jednoznacznie stwierdzić, że dziennikarze posłużyli się tym połączeniem zarówno dla określenia soli, jak i cukru. 
Oszczędzanie: Po drugie zaś, miał nadzieję, że wraz z zakończeniem budowy nowego stadionu zmieni się sytuacja w klubie, przestanie obowiązywać zasada zaciskania pasa i w końcu będzie mógł dłużej popracować z tą samą ekipą i powieść ją do sukcesów. (PN 50/2012, s. 22) - zaciskać pasa 'ograniczać swoje wydatki; oszczędzać' (WSF, s. 342)

Trudno będzie jednak przed świętami przekonać Polaków do zaciskania pasa. (P 50/2012, s. 49)

Pierwszeństwo: W kategorii wolej wciąż palmę pierwszeństwa dzierży ten Van Bastena z finałowego meczu Euro 1998 Holandia - Rosja. (PN 48/2012, s. 2) - palma pierwszeństwa, zwycięstwa itd. 'pierwsze miejsce, pierwszeństwo' (WSF, s. 336)

Przeklinanie: Gdyby sądy miały karać wszystkich za rzucanie mięsem, to po każdej kolejce ligowej mandaty płaciłoby wielu trenerów, a także piłkarzy. (PN 20/2012, s. 45) pot. rzucać mięsem, posp. mięchem, wulg. kurwami 'używać wulgarnych, obraźliwych słów; przeklinać' (WSF, s. 461)

Samochód: - Mam manię czterech kółek, to chyba kryzys wieku średniego - śmieje się Hugh. (NŻ 9/2012, s. 12) - pot. cztery kółka ‘samochód, zwłaszcza osobowy' (WSF, s. 185)

Spojrzenie/zerknięcie: Wystarczy rzut oka na klasyfikację najskuteczniejszych zawodników polskiej ligi w tym sezonie, aby zrozumieć, że już wkrótce polski futbol będzie cierpiał na deficyt graczy, którzy potrafią zdobywać bramki. (PN 11/2012, s. 14) - (jeden, pierwszy) rzut oka ‘spojrzenie, zwłaszcza pobieżne, powierzchowne; zerknięcie' (WSF, s. 314)

Spokój/opanowanie: - W starciu z Werderem Brema byłem bliski szczęścia, jednak w najważniejszym momencie, przy uderzeniu piłki, zabrakło precyzji, może raczej zimnej krwi - mówi Jakub Świerczok. (PN 6/2012, s. 8) - zimna krew ‘przytomność umysłu, spokój, opanowanie' (WSF, s. 190)

Talent/zdolności: Jak już chłopak, który miał iskierkę od Boga, dostał się do ligi - dzięki agentom, trenerowi czy zwykłemu przypadkowi - to co widział? (PN 47/2011, s. 11) - iskra boża 'talent, zdolności' (WSF, s. 144)

Wściekłość/pasja: Z dzisiejszej perspektywy widać, że nie był to taki zły czas, jak się wówczas wydawało, chociaż kolejne ekscesy katolickich fundamentalistów czy „inwigilowanej prawicy”, wyrosłej na rządzie Jana Olszewskiego, mogły doprowadzać przeciwników do białej gorączki. (P 51-52/2012, s. 35) - biała gorączka 'wściekłość, pasja' (WSF, s. 124)

Złość/wściekłość: Tego, który w pojedynkę doprowadzał do szewskiej pasji ośmieszonych i wymanewrowanych rywali. (PN 11/2012, s. 4) - pot. szewska pasja 'gwałtowny gniew, złość, wściekłość’ (WSF, s. 343) 
Znawca: Jeśli poświęcisz chwilę na ich przestudiowanie lub lepiej - trafisz na kogoś znającego się na rzeczy, kto ci je wyjaśni - okazuje się, że pozornie nudne przestoje, narady i dyskusje wewnątrz zespołu przerywane krótkimi akcjami mogą być bardziej pasjonujące niż niejeden mecz piłki kopanej. (PN 44/2011, s. 11) - znać się na rzeczy a) 'być znawcą czegoś, mieć dużo wiadomości z jakiejś dziedziny’; b) pot. 'umieć się odpowiednio zachować wobec kogoś' (WSF, s. 699)

W zdecydowanej większości związki frazeologiczne mające syntetyczny odpowiednik w postaci rzeczownika są pod względem formalnym klasyfikowane jako wyrażenia. Zdarza się jednak, iż wykorzystuje się pierwotne zwroty, jednak w celu dopasowania do otoczenia składniowego posłużono się rzeczownikiem derywowanym od czasownika, np. rzucanie mięsem, zaciskanie pasa, bujanie w obłokach. Nie zanotowano przypadków, by jednemu syntetycznemu określeniu odpowiadało kilka stałych połączeń wyrazowych. Zbliżone odpowiedniki mają biała goraczka i szewska pasja.

\subsection{Analityzmy przymiotnikowe 68}

Literatura podejmująca problem analitycznych konstrukcji przymiotnikowych jest dość uboga. Jako pierwsza wspomniała o nich cytowana już kilkakrotnie w niniejszej pracy M. Kniagininowa, poświęciła im zaledwie jedno zdanie: „Należą tu nierozdzielne skupienia przydawkowe, tym charakterystyczne, że dla wszystkich istnieją synonimiczne formy proste"69. Wśród przykładów podała takie, które opierały się na podstawach: w kolorze, natury, pochodzenia, w sposób. Najobszerniej scharakteryzował analityzmy przymiotnikowe J. Anusiewicz. Początkowo podkreślał, że są to grupy rozwiniętych przydawek ${ }^{70}$, z czasem zaproponował definicję: „konstrukcjami analitycznymi przymiotnikowymi i przysłówkowymi nazywamy nierozdzielne skupienia wyrazowe, pełniące w zdaniu najczęściej role przydawek lub okoliczników, które istnieją obok ich synonimicznych form prostych, czyli przymiotników i przysłówków"71. Przywołał on też

\footnotetext{
68 W grupie tej znalazły się również imiesłowy przymiotnikowe, które funkcjonalnie są przymiotnikami.

69 M. Kniagininowa, op. cit., s. 152.

70 J. Anusiewicz, Konstrukcje analityczne w języku..., s. 72.

71 J. Anusiewicz, Konstrukcje analityczne we współczesnym..., s. 103.
} 
najbardziej reprezentatywne schematy tworzenia takich form ${ }^{72}: 1$ ) wyrażenie przyimkowe + przymiotnik $=$ przymiotnik, np. problem o charakterze specjal nym - problem specjalny; 2) rzeczownik w dopełniaczu + przymiotnik (rzadziej imiesłów przymiotnikowy) = przymiotnik, np. łacina typu kościelnego = łacina kościelna; 3) wyrażenie przyimkowe + rzeczownik = przymiotnik, np. usługi $w$ zakresie grawerstwa - usługi grawerskie; 4) przysłówek + przymiotnik = przymiotnik, np. zalecenia czysto praktyczne - zalecenia praktyczne; 5) wyrażenie przyimkowe zastępujące przymiotnik, np. marynarka ze skóry - marynarka skórzana. Wśród najczęściej powtarzających się podstaw znalazły się zdaniem uczonego wyrażenia przyimkowe o charakterze oraz rzeczowniki typ, natura, charakter, pochodzenie. Opisowym konstrukcjom przymiotnikowym i przysłówkowym poświęciła artykuł w „Poradniku Językowym” E. Pokorska-Szczodruch, jednak skupiła się ona przede wszystkim na cechach stylistycznych i semantycznych, a zagadnienia te będą szczegółowo omawiane w kolejnych częściach rozprawy. Badaczka opierała się na założeniach J. Anusiewicza, jednocześnie podkreślając istnienie przesunięć znaczeniowych oraz fakt, że nie zawsze analityzmy współistnieją z formami syntetycznymi: „Nierzadkie są takie związki złożone, których z przyczyn formalnych nie można zastąpić niezłożonymi [...] na przeszkodzie stoi zazwyczaj brak odpowiednich przymiotników lub przysłówków w języku polskim, a więc brak formalnej ekwiwalencji"73.

\subsubsection{Analityzmy pochodne strukturalnie}

Marketingowy: Decyzje o zrezygnowaniu z emblematu, na którym widnieje godło narodowe, z powodów czysto marketingowych, i to w meczu rozgrywanym w dniu Święta Niepodległości, można porównać do samobójczej bramki albo kiepskiego dowcipu, których, jak na ironię, byliśmy świadkami nie tylko na wrocławskim obiekcie. (PN 46/2011, s. 33)

Pomarańczowy: Energizujące stroje w kolorze pomarańczy rozgrzeją Cię i ocieplą zimową aurę. (NŻ 7/2012, s. 24)

Socjologiczny: Nadużywanie słów z języka potocznego w tekście, który miał być rozprawką (czy może raczej referatem) o charakterze socjologicznym. (VG 20/2012, s. 39)

72 Podział za: ibidem.

73 E. Pokorska-Szczodruch, Przymiotnikowe i przysłówkowe konstrukcje analityczne w tekstach prasowych: opis stylistyczny i semantyczny, „Poradnik Językowy” 2006, z. 10, s. 103. 
Żółto-niebieski: Szwedzi wstępnie wybrali Hotel Nadmorski w Gdyni, a ćwiczyć mieli na obiekcie Arki Gdynia, którego krzesełka są w kolorach... żółto-niebieskich. (PN 6/2012, s. 25)

Żywy: Karp jest ostatnim towarem w całej Unii, który trafia do klienta w formie żywej. (P 50/2012, s. 32)

Analityczne konstrukcje przymiotnikowe mające wspólne morfemy z odpowiadającymi im syntetycznymi przymiotnikami budowane są według schematu wyrażenie przyimkowe + przymiotnik (o charakterze socjologicznym, $w$ formie $\dot{z} y w e j, w$ kolorach żółto-niebieskich). Odnotowano także połączenia wyrażenia przyimkowego z rzeczownikiem $\mathrm{w}$ dopełniaczu ( $w$ kolorze pomarańczy) oraz przysłówka z przymiotnikiem (czysto marketingowy). Oprócz ostatniej wymienionej formy peryfrastycznej wszystkie zgromadzone przykłady zbudowane są $\mathrm{z}$ trzech elementów.

\subsubsection{Analityzmy niepochodne strukturalnie}

Najstarszy: Z kolei najbardziej zaawansowani wiekiem piłkarze znaleźli się w drużynie Irlandii. (PN 24/2012, s. 33)

Nieżonaty: Przystojny, błyskotliwy, zamożny, ale wciąż bez obrączki na palcu. (NZ̈ 5/2012, s. 5)

Otyły: Ale jej mama też do szczupłych nie należała, starsza siostra również była słusznej budowy. (VG 8/2011, s. 10)

Pijany: Nowe przepisy przewidują też kary dla osób, które wchodzą na stok pod wpływem alkoholu lub narkotyków. (NŻ 3/2012, s. 31)

W profesjonalnym futbolu nie ma miejsca na pracę pod wpływem, i zostało to Patrikowi przypomniane. (PN 50/2012, s. 4)

Śmierdzący: O wiele sympatyczniej pakować się po feriach do czystego niż „dziwnie pachnącego" plecaka. (VG 3/2011, s. 7)

W grupie analityzmów niespokrewnionych morfologicznie z ekwiwalentami przymiotnikowymi wyróżnić można składające się z wyrażenia przyimkowego i rzeczownika w dopełniaczu (pod wpływem alkoholu - zredukowane w innym wynotowanym przykładzie do samego wyrażenia przyimkowego), dwóch wyrażeń przyimkowych (bez obraczki na palcu), przymiotnika i rzeczownika (stuszna budowa), przysłówka i imiesłowu (dziwnie pachnacy), przysłówka, przymiotnika, rzeczownika w narzędniku (najbardziej zaawansowany wiekiem). Pod względem 
liczebności członów opisowe konstrukcje przymiotnikowe reprezentują połączenia dwu- (dziwnie pachnacy, pod wplywem, słusznej budowy), trzy- (najbardziej zaawansowany wiekiem, pod wplywem alkoholu) i czteroelementowe (bez obraczki na palcu).

\subsubsection{Frazeologizmy}

Elokwentny: Nie mogę więc pojąć, dlaczego tak mocny nie tylko w gębie człowiek, i naprawdę tęgi fachman, nie umie/nie chce przyznać: - Mili państwo, wraz z zespołem spieprzyłem święto. (PN 44/2011, s. 2) - ktoś (jest) mocny, obrotny w języku, pot. w gębie, posp. w pysku 'o kimś elokwentnym, umiejącym przekonać do swoich racji' (WSF, s. 109)

Nieznany: Pozbawiony wielkich nakładów finansowych trener zaufał legijnej młodzieży i piłkarzom bez wielkich nazwisk, a ci odwzajemniają się ambitną walką na boisku i odnoszą zaskakujące zwycięstwa. (PN 50/2011, s. 47) - wielkie nazwisko 'o kimś znanym, sławnym' (WSF, s. 615)

Prawdziwy, autentyczny: Jego następca, Amerykanin z krwi i kości, nigdy nie prowadził drużyny poza granicami Stanów Zjednoczonych. (PN 44/2011, s. 29) - ktoś z krwi i kości 'o kimś, kto ma wszystkie cechy charakterystyczne dla ludzi danego rodzaju; prawdziwy, autentyczny’ (WSF, s. 190)

A wystarczy być sobą, być dziewczyną z krwi i kości. (VG 4/2011, s. 20)

Jest człowiekiem z krwi i kości, zmagającym się ze zwyczajnymi problemami, z którymi radzi sobie (raz lepiej, raz gorzej) dzięki zachowywaniu dystansu wobec siebie i świata. (P 24/2012, s. 86)

Przeciętny: Jego fryzury też nie były pierwsze lepsze. (PN 45/2011, s. 29) - pierwszy lepszy 'jakikolwiek, którykolwiek; także: przeciętny, byle jaki' (PSF, s. 450)

Radosny, zadowolony: Bo ona wiesz, cała w skowronkach, jakby się autentycznie cieszyła i że ma nadzieję, że pokażę, na co mnie stać, bo uważa mnie za dobrego ucznia. (VG 21/2012, s. 29) - ktoś (jest) cały w skowronkach 'ktoś jest bardzo zadowolony, radosny' (WSF, s. 479)

Sprytny, przebiegły: Nie mam bladego pojęcia, kto w Cracovii odpowiada za transfery, wiem za to, że albo jest największym ciemniakiem w branży, albo cwaniakiem kutym na cztery nogi. (PN 12/2012, s. 2) - ktoś kuty na cztery nogi 'o kimś bardzo sprytnym, przebiegłym, umiejącym zadbać o swoje interesy' (WSF, s. 200)

Zmyślony: I zazwyczaj okazuje się, że to totalna bzdura, jakieś podejrzenia wyssane z palca. (VG 8/2011, s. 27) - wyssać coś z palca 'zmyślić, wymyślić coś' (WSF, s. 336)

- To są sprawy wyssane z palca. (NŻ 13/2012, s. 9) 
Związki frazeologiczne, których odpowiedniki należą do klasy przymiotników, są pod względem formalnym przede wszystkim wyrażeniami, np. mocny w gębie, z krwi i kości, pierwszy lepszy. Odnotowano także zwrot wyssać cośz palca, który uległ przekształceniu w imiesłów przymiotnikowy bierny wyssane.

\subsection{Analityzmy przysłówkowe}

Typowe modele syntaktyczne wykorzystywane do tworzenia analitycznych konstrukcji przysłówkowych to według J. Anusiewicza ${ }^{74} 1$ ) wyrażenie przyimkowe + przymiotnik (rzadziej imiesłów przymiotnikowy) = przysłówek, np. w sposób dialektyczny - dialektycznie, w ostatnim okresie - ostatnio; 2) wyrażenie przyimkowe zastępujące przysłówek, np. powinien być zawiadomiony na piśmie - pisemnie. Językoznawca podkreślił, że najliczniej reprezentowana jest podstawa w postaci wyrażenia przyimkowego $w$ sposób. Wymienił też: pod względem, w stopniu i $w$ tempie. Jak zauważył, „podstawami analityzmów przysłówkowych są wyłącznie wyrażenia przyimkowe"75. Na uwagę zasługuje jeszcze jedno stwierdzenie: „przy sprowadzaniu formy analitycznej do prostej zawarty w wyrażeniu opisowym przymiotnik przechodzi w odpowiadający mu przysłówek, np. w ostatnim okresie-ostatnio"76.

\subsubsection{Analityzmy pochodne strukturalnie}

Naturalnie: W sposób naturalny kojarzy nam się z mistrzostwami w piłce nożnej, ale takie miano noszą przecież wszystkie turnieje o mistrzostwo Europy rozgrywane w tym roku. (PN 4/2012, s. 11)

Płciowo: Zdolność do wytwarzania osobników potomnych w sposób płciowy lub bezpłciowy zapewnia ciągłość istnienia gatunku. (VG 3/2011, s. 36)

W materiale pochodzącym z polskich periodyków odnaleziono jedynie analityczne konstrukcje przysłówkowe, których podstawą było wyrażenie przyimkowe $w$ sposób. Dołączono do niego przymiotniki naturalny oraz płciowy. Obie wymienione konstrukcje peryfrastyczne zbudowane są z trzech elementów.

\footnotetext{
74 Podział za: J. Anusiewicz, Konstrukcje analityczne we współczesnym..., s. 104.

75 Ibidem, s. 114.

76 Ibidem, s. 117.
} 


\subsubsection{Frazeologizmy}

Bezustannie: Nagrania rozmów Zdzisława Kręciny z jednym z byłych sponsorów PZPN oraz Grzegorza Laty z tajemniczym działaczem dowodzą, że w piłkarskiej centrali nie myślą dzień i noc nad tym, jak poprawić jakość polskiej piłki. (PN 48/2011, s. 11) - dzień i noc; dniem i nocą; dniami i nocami 'jednym ciągiem, bez przerw, bezustannie’ (WSF, s. 93)

Blisko: David wprawdzie w tym kiepskim filmie o młodej Hindusce ogarniętej pasją futbolu nie zagrał, ale w końcu nadal mieszka w Los Angeles o rzut beretem od Hollywood. (PN 45/2011, s. 29) - rzut beretem 'niedaleko, bardzo blisko, opodal' (SPPot, s. 273)

Całkowicie: Obrzydzili mi tego faceta do imentu. (VG 3/2011, s. 12) - pot. do imentu 'zupełnie, całkowicie' (WSF, s. 142)

Trzeba być naprawdę do szpiku kości Europejczykiem lub Amerykaninem z XXI w., żeby myśleć w ten sposób. (P 50/2012, s. 75) - do (szpiku) kości 'do głębi, na wskroś, całkowicie, bardzo' (WSF, s. 183)

Jednocześnie: Skąd tak brawurowy intelektualnie pomysł, by za jednym zamachem ująć historię ludzkości od Aleksandra Wielkiego po komunistyczną dynastię despotów koreańskich? (P 51-52/2012, s. 80) - za jednym zamachem 'przy okazji załatwiania jakiejś innej sprawy, jednocześnie z czymś’ (WSF, s. 150)

Koniecznie: Tylko że o ile Tomka można zrozumieć, iż powodowany niepokornym i niecierpliwym charakterem, a także przyzwyczajony do medialnego świecznika brnął za wszelką cenę i na skróty do posady, którą sprawuje, o tyle dla Kuleszy trudno znaleźć usprawiedliwienie. (PN 10/2012, s. 2) - za wszelką cenę; za jaką bądź cenę; bez względu na cenę 'bez względu na poniesiony koszt, wysiłek; koniecznie; bezwarunkowo' (WSF, s. 33)

Lekkomyślnie: Spora rzesza ludzi odwiedza nawet trzy razy w tygodniu kolektury, z nieustającą nadzieją, że w najbliższym losowaniu wytypuje sześć prawidłowych cyfr, inkasując z tej okazji minimum dwa miliony, ale opodatkowane, a tymczasem dzięki mediom wszyscy grający dowiedzieli się, że są w Polsce ludzie, którzy lekką ręką pozbywają się miliona złotych, byleby jednocześnie pozbyć się niechcianego pracownika, w tym przypadku szkoleniowca zespołu ekstraklasy. (PN 15/2012, s. 37) - mieć lekką rękę, robić coś lekką ręką a) 'robić coś łatwo, bez wysiłku’; b) 'robić coś lekkomyślnie, bez zastanowienia' (WSF, s. 210)

Momentalnie: Wartość sportowa spadła, a wkrótce Antoni Ptak (kto go dziś jeszcze pamięta?) zapomniał o miłości do ŁKS i lotem błyskawicy go opuścił, po czym siał zniszczenie w innych miejscach, ze szczególnym uwzględnieniem Szczecina. (PN 45/2011, s. 9) - lotem błyskawicy, strzały, ptaka itp. 'bardzo szybko, momentalnie' (WSF, s. 216) 
Nago: Zapytany, czy przedstawia go w stroju Adama, Rafał Maserak odparł tajemniczo: - No cóż, na obrazie jest cała moja sylwetka... (NŻ 7/2012, s. 9) - żart. w stroju Adama, w stroju adamowym 'nago' (WSF, s. 518)

Natychmiast: Doceniliśmy skuteczność pomocników, którzy gole zdobywają wprost na zawołanie. (PN 50/2011, s. 2) - na (każde) zawołanie 'w każdej chwili, natychmiast' (WSF, s. 678)

O wspomnianej sprawie z miejsca zrobiło się głośno, tym bardziej że Akademia Piłkarska świadcząca wcześniej PZPN usługi transportowe, pod której szyldem działał słynny od czasu ujawnienia taśm prawdy Grzegorz Kulikowski, była zarejestrowana na nazwisko Władysława Żmudy. (PN 49/2012, s. 12) - z miejsca 'od razu, natychmiast' (WSF, s. 246)

Nieregularnie: Inna sprawa, że marcowa - grająca w kratkę - Legia jest znacznie mniej łakomym kąskiem niż w swym lutowym rozpędzeniu. (PN 13/2012, s. 2) - chodzić, uczęszczać itp. gdzieś, pracować w kratkę 'chodzić, uczęszczać itp. gdzieś, pracować nieregularnie, z przerwami' (WSF, s. 187)

Omal: Peszko przebył natomiast niebywałą drogę z niebytu na szczyt (oczywiście z zachowaniem odpowiednich proporcji), bo dwa tygodnie po usunięciu z kadry o mały włos nie stał się bohaterem kolońskich kibiców. (PN 17/2012, s. 20) - o włos, o mały włos, figiel 'mało brakowało, omal' (WSF, s. 623)

Osobiście: Co więcej, podejrzewali to już na pewno wcześniej, teraz tylko przeżyli to na własnej skórze. (PN 48/2012, s. 36) - poznać coś, doświadczyć czegoś, przekonać się o czymś na własnej skórze 'poznać coś, doświadczyć czegoś osobiście, bezpośrednio’ (WSF, s. 480)

Ostatecznie: Koniec końców gospodarkę może również wspomóc polityka płynnego kursu walutowego, która doprowadzi w końcu do ustabilizowania się złotego na atrakcyjnym dla eksporterów poziomie. (P 50/2012, s. 45) - koniec końców 'ostatecznie, wreszcie' (WSF, s. 177)

Pobłażliwie: Powrót Mordercy o twarzy dziecka na początku 2011 roku do klubu, z którego wyruszył na podbój europejskiej piłki, traktowano w Norwegii z przymrużeniem oka. (PN 48/2012, s. 36) - z przymrużeniem oka 'pobłażliwie, wyrozumiale, niezbyt poważnie, lekko' (WSF, s. 423)

Rzadko: Maggio w zasadzie cały czas był prawym obrońcą, wypuszczał się do przodu od wielkiego dzwonu (co było uzasadnione tym, że po jego stronie szalał Iniesta), podczas gdy Giaccherini znacznie odważniej atakował swoją, lewą flanką; Pirlo do niego adresował wiele przerzutów. (PN 24/2012, s. 22) - od (wielkiego) święta; od wielkiego dzwonu a) 'rzadko, tylko przy szczególnej okazji, w szczególnych przypadkach; czasem dosłownie: z okazji święta’; b) 'występujący, używany w rzadkich przypadkach, na nadzwyczajne okazje; świąteczny' (WSF, s. 551) 
Samodzielnie: Za niemal nieprawdopodobne prokuratorzy uznali, że bezpośredni podwładny Conte, którym był asystent Stellini działał na własną rękę, za plecami lubiącego dyktatorskie rządy szefa. (PN 33/2012, s. 27) - na własną rękę 'samodzielnie, na własną odpowiedzialność' (WSF, s. 441)

Heller jak każdy uczony ostatecznie pracuje na własną rękę. (P 51-52/2012, s. 94)

Skwapliwie: Trzy lata później z pocałowaniem w rękę ${ }^{77}$ przyjął ofertę Portugalczyków opiewającą na 3,5 miliona. (PN 6/2012, s. 35) - pot. z pocałowaniem ręki 'bardzo chętnie, skwapliwie, z zadowoleniem' (WSF, s. 365)

Spokojnie: W pierwszym rozegranym w bieżącym roku meczu ligowym zespół łódzkiego Widzewa bez szemrania oddał punkty przyjezdnym z Bielska-Białej. (PN 9/2012, s. 47) - bez szemrania 'bez protestu, bez narzekań, spokojnie, cierpliwie' (WSF, s. 529)

Wykorzystał to z zimną krwią Wayne Rooney, który raz jeszcze potwierdził, że potrafi się zmobilizować w meczach o wielką stawkę i prestiż. (PN 50/2012, s. 25) - z zimną krwią ‘spokojnie, bez emocji, z wyrachowaniem' (WSF, s. 191)

Wszystkie ewolucje muszą być wykonane z zimną krwią. (VG 13/2011, s. 6)

Stopniowo: Baczko pokazał krok po kroku, jak ona była robiona. (P 51-52/2012, s. 82) krok za krokiem, krok po kroku 'bardzo wolno, pomału, stopniowo' (WSF, s. 192)

Szczerze: Tak z ręką na sercu - stać Koronę na występ w europejskich pucharach? (PN 17/2012, s. 7) - z ręką na sercu 'szczerze, otwarcie' (WSF, s. 471)

Szybko: Takich piłkarzy nie da się zastąpić tak z dnia na dzień. (PN 48/2012, s. 33) z dnia na dzień a) 'stopniowo'; b) 'nagle, szybko' (WSF, s. 94)

Wprost, szczerze: Oczywiście nie marzyłem, żeby zostać trenerskim strażakiem stwierdził bez ogródek Kramer. (PN 50/2012, s. 27) - mówić, powiedzieć itp. bez ogródek 'mówić, powiedzieć itp. coś wprost, szczerze' (WSF, s. 312)

Wszędzie: Po losowaniu grup Euro 2012 Polska - jak długa i szeroka - podzieliła się na dwa stronnictwa. (PN 49/2011, s. 2) - jak długi i szeroki 'wszędzie, od krańca do krańca, na całym obszarze' (WSF, s. 68)

Widać je zresztą na ulicach Barcelony na każdym kroku. (PN 41/2012, s. 26) - na każdym kroku 'ciągle, zawsze, wszędzie' (WSF, s. 193)

Wyraźnie: To wyszło jak na dłoni. (PN 49/2012, s. 5) - (jasno) jak na dłoni 'wyraźnie, w sposób widoczny, oczywisty' (WSF, s. 68)

77 Kanoniczna postać wykorzystanego w tym przykładzie związku frazeologicznego uległa zniekształceniu, mogło to wynikać z niewiedzy dziennikarza lub być celowym zabiegiem. 
Na ostatnim Konkursie im. Fitelberga było to widoczne jak na dłoni, choć dotyczyło jedynie młodych kapelmistrzów, stających przed orkiestrą Filharmonii Śląskiej pierwszy raz w życiu i na kilkadziesiąt minut. (P 50/2012, s. 93)

W wierszu Znicz będziemy mieli Friedricha jak na dłoni. (VG 7/2011, s. 20)

Zgodnie: Wszystko zweryfikuje plac, ale też wszyscy - jak jeden mąż - musimy bardzo pragnąć sukcesu. (PN 44/2012, s. 20) - jak jeden mąż a) 'wszyscy naraz, w tym samym momencie, jednocześnie'; b) 'wszyscy razem, zgodnie, solidarnie' (WSF, s. 236)

Związki frazeologiczne, które da się zastąpić przysłówkiem, stanowią dość liczną grupę. Reprezentują one w większości klasę wyrażeń (na własną rękę, koniec końców, o mały włos), nie brakuje też połączeń, które w formie kanonicznej są zwrotami, ale w przywoływanych fragmentach zostały uszczuplone o bezokolicznik (powiedzieć cośbez ogródek, robić coś lekką ręką, poznać coś na własnej skórze).

Bywa,że jednemu syntetycznemu określeniu przysłówkowemu odpowiada kilka frazeologizmów o różnej budowie - z taką sytuacją mamy do czynienia w przypadku na zawołanie i z miejsca, którym odpowiada natychmiast, do imentu i do szpiku kości zastępowanymi przez całkowicie, a także na każdym kroku i jak długi i szeroki, których ekwiwalentem jest wszędzie. Spokojnie z kolei może pojawiać się w miejsce wyrażeń z zimną krwią i bez szemrania. Przywołane związki - choć posiadają taki sam odpowiednik - są używane w różnym otoczeniu składniowym i nie mogą być stosowane wymiennie, ponieważ różnią się zabarwieniem semantycznym ${ }^{78}$.

\subsection{Analityzmy i ekwiwalenty innych części mowy}

\subsubsection{Analityzmy zaimkowe}

W zgromadzonym materiale można także wyodrębnić nieliczne przykłady związków frazeologicznych, które odpowiadają zaimkom, liczebnikom i modulantom. Konstrukcje takie nie były do tej pory przedmiotem opisu, być może dlatego, że definicja analityzmów nie pozwalała dotąd na tak szerokie ich ujęcie.

Lakikolwiek: Jego fryzury też nie były pierwsze lepsze. (PN 45/2011, s. 29) - pierwszy lepszy ‘jakikolwiek, którykolwiek; także: przeciętny, byle jaki’ (PSF, s. 450)

Frazeologizm pierwszy lepszy jest pod względem strukturalnym wyrażeniem.

78 O czym szerzej w rozdziale Semantyka. 


\subsubsection{Analityzmy liczebnikowe}

Troszeczkę: Niestety jest ich jak na lekarstwo i łączą jedynie stadion z lotniskiem oraz lotnisko z centrum. (PN 24/2012, s. 27) - (jak) na lekarstwo 'bardzo mało, troszeczkę' (WSF, s. 210)

Budowa odpowiadającego liczebnikowi związku frazeologicznego jak na lekarstwo wskazuje na przynależność do kategorii wyrażeń.

\subsubsection{Analityzmy modulantowe}

Oczywiście: Realne zagrożenie degradacją do 2. Bundesligi, bardzo mizerna postawa piłkarzy i przechodzenie obok meczów, tragikomiczne wręcz wyczyny całego bloku defensywnego (FC Koeln swoimi 67 straconymi golami bije pozostałych ligowców na głowę) - to rzecz jasna tylko aspekty sportowe, najbardziej widoczne i najzajadlej krytykowane. (PN 17/2012, s. 20) - rzecz jasna, prosta, wiadoma 'oczywiście, naturalnie' (WSF, s. 460)

Pod względem strukturalnym trwałe połączenie wyrazowe rzecz jasna zaliczane jest do wyrażeń.

\section{Nazwy własne}

Nazwa własna jest definiowana przez Encyklopedię językoznawstwa ogólnego jako „takie wyrażenie, które może być użyte w zdaniu tylko do wskazania jakiegoś indywidualnego przedmiotu, do wyróżnienia go spośród innych przedmiotów. Termin «przedmiot» jest tu rozumiany szeroko i obejmuje zarówno przedmioty fizyczne, jak i osoby. [...] Imię własne przyporządkowane jest danemu przedmiotowi indywidualnemu nie na podstawie właściwych mu cech, ale niezależnie od nich, na mocy arbitralnej konwencji"79. Zdaniem badaczy nomina propria charakteryzują się nieskończenie bogatą treścią i wąskim zakresem oraz tym, że nazywają, a nie znaczą ${ }^{80}$. Zofia Kaleta pisze: „Nazwy własne nie zawierają zatem tre-

79 Encyklopedia językoznawstwa ogólnego, red. K. Polański, Wrocław-WarszawaKraków 1993, s. 217.

80 A. Zaręba, Osobowe nazwy własne i ich miejsce w systemie językowym, „Poradnik Językowy” 1979, z. 1, s. 2. Na tę cechę jako odróżniającą nomina propria i nomina appelativa zwrócił też uwagę M. Karaś w artykule Nazwy własne i ich klasyfikacje (nazwy osobowe), „Biuletyn Polskiego Towarzystwa Językoznawczego” 1972, 
ści językowej, czyli znaczenia leksykalnego (słownikowego), dla którego podstawą są cechy charakterystyczne wspólne dla danej grupy obiektów. Ich rola w języku ogranicza się do wskazywania (oznaczania, wyznaczania) bez przekazywania treści znaczeniowej" 81 . Warto przywołać więc pojęcie referencji (inaczej denotacji), czyli bezpośredniego związku między obiektem indywidualnym a nazwą własną, który „zachodzi przy użyciu nazwy własnej w odniesieniu do konkretnego, niepowtarzalnego obiektu"82. Pod względem formalnym nazwy własne są różnorodne, na pojedynczy desygnat może bowiem wskazywać nazwa zbudowana z jednego, dwóch, trzech, a nawet większej liczby wyrazów.

Celem niniejszej pracy nie jest szczegółowa charakterystyka poszczególnych typów nazw własnych, dlatego też przy omawianiu analitycznych form mających syntetyczne odpowiedniki dokonano podziału tylko na najważniejsze grupy, nie koncentrowano się na szczegółowej klasyfikacji. Wprowadzono jedynie rozróżnienie na nazwy własne osobowe i nieosobowe, nie przybliżając wyczerpujących podziałów. Zgromadzony materiał pozwala na wyróżnienie dwóch możliwości - zarówno analityzm, jak i jego ekwiwalent należą do kategorii nomina propria lub syntetycznej nazwie własnej odpowiada rozbudowana konstrukcja składająca się z wyrazów pospolitych. Do pierwszej grupy zaliczymy następujące przypadki:

- ekwiwalentem imienia i nazwiska/nazwy klubu jest przezwisko/przydomek,

- przydomek wieloczłonowy może być używany wymiennie z przydomkiem jednoczłonowym,

- jednoczłonowej nazwie geograficznej odpowiada złożona forma peryfrastyczna utrwalona w świadomości odbiorców jako nierozerwalne połączenie wyrazowe,

- wieloczłonowa nazwa własna zastępowana jest nazwą własną o strukturze zuniwerbizowanej.

W drugiej grupie umieścić można:

- nomina propria jednoczłonowe i ich peryfrastyczne odpowiedniki o doraźnym charakterze,

s. 103-150. Jerzy Kuryłowicz twierdzi natomiast, że nazwy własne mają znaczenie, posiadają zakres (ekstensję) i treść. Por. Z. Kaleta, Teoria nazw własnych, [w:] Polskie nazwy własne. Encyklopedia, red. E. Rzetelska-Feleszko, Warszawa-Kraków 1998, s. 21.

81 Z. Kaleta, op. cit., s. 18.

82 Ibidem. 
- stosowanie dla określenia tej samej nazwy uniwerbizmu oraz wielowyrazowych połączeń zbudowanych z wyrazów pospolitych,

- posługiwanie się skrótowcami nazw własnych i multiwerbizmami, które nie są rozwinięciem tychże skrótowców.

\subsection{Imię i nazwisko a przezwisko}

Dużą grupę stanowią imiona i nazwiska, którym odpowiadają syntetyczne konstrukcje w postaci przezwisk - mogą one wykazywać morfologiczne pokrewieństwo $\mathrm{z}$ imieniem lub nazwiskiem albo - rzadziej - i imieniem, i nazwiskiem ${ }^{83}$. Często zdarza się, że nie posiadają wspólnych morfemów, a ich motywacja wiąże się z rzeczywistością pozajęzykową.

Czesław Kosyl, charakteryzując nazwy osobowe, zauważył, że przydomek różni się od przezwiska „brakiem aktualnej motywacji (przezwisko na ogół ją zachowuje), odniesieniem do wszystkich członków jednej rodziny (przezwisko zwykle odnosi się do jednej osoby) oraz możliwością dziedziczenia zwyczajowego, jednakże bez sankcji prawnych, jakie związane są z nazwiskiem"84. Wśród głównych cech przezwiska wymienia się nieoficjalność, fakultatywność, wtórność, ekspresywność, nacechowanie emocjonalne, pełnienie funkcji adresatywnej i identyfikacyjnej. W przeciwieństwie do nazwisk przezwiska „nie są [...] dziedziczone i mają inną denotację (przezwisko jest w zasadzie indywidualne, nazwisko obejmuje wszystkich członków rodziny)"85. Badacz podkreśla, że istnieje możliwość odtworzenia okoliczności, które przyczyniły się do powstania przezwiska. O tej klasie antroponimów wypowiedziała się również Ewa Rzetelska-Feleszko: „są tą kategorią nazw własnych, która powstaje w sposób spontaniczny, rejestruje więc najbardziej żywe i aktualne tendencje w języku"86, zdaniem uczonej nomina propria są składnikiem budującym tożsamość grupy, podkreślają poczucie

83 Przedstawione tu rozważania dotyczące struktury oraz motywacji semantycznej alternatywnych określeń piłkarzy (por. s. 270-272 i 274-284) zostały opublikowane w artykule K. Burska, Właściwości strukturalne i semantyczne antroponimów i ich odpowiedników w prasie sportowej, „Język. Komunikacja. Informacja” 2016, t. 11, red. A. Godzich, M. Lewandowski, I. Koutny, P. Nowak, J. Taborek.

$84 \mathrm{Cz}$. Kosyl, Nazwy osobowe, [w:] Encyklopedia kultury polskiej XX wieku, t. 2: Współczesny język polski, red. J. Bartmiński, Wrocław 1993, s. 423.

85 Ibidem, s. 435.

86 E. Rzetelska-Feleszko, W świecie nazw własnych, Warszawa-Kraków 2006, s. 79. 
jedności i spoistości, a zarazem wyrażają odrębność wobec innych ${ }^{87}$. Aleksandra Cieślikowa zaznacza, że „różnica między przezwiskami a przydomkami polega przede wszystkim na czasie ich powstania. Przezwiska istniały, odkąd człowiek zaczął obserwować bliźniego i te obserwacje zawierać w nazwie"88. Początki przydomków - jak sama nazwa wskazuje - związane są z powstawaniem nazw wspólnot rodowych, rodzin i domów. Badaczka podkreśla, że nie ma ścisłego rozgraniczenia między przydomkiem a przezwiskiem i nawet w pracach onomastycznych zdarza się wymienne stosowanie tych pojęć. Akcentuje występowanie przydomków jedynie w gwarach, pojawiają się one „w środowiskach wiejskich ze względów tradycyjno-zwyczajowych" 89 . Są one traktowane jak nieoficjalne nazwiska: „Przyczyną ich funkcjonowania jest protest rządzącej się własnymi prawami, tradycją nazewniczą wspólnoty przeciw narzuconemu z zewnątrz obce$\mathrm{mu}$, oficjalnemu sposobowi nazywania"90. Przydomki różnią się od nazwisk tym, że nie mają jednak charakteru oficjalnego i nie są obligatoryjne.

Jak czytamy w encyklopedii Słowiańska onomastyka: „Przezwiska są tworzone w mikrowspólnotach i na ogół w nich pozostają. Współcześnie łączy je nieoficjalność i brak narzuconej przez przepisy pewnej stabilności, a zatem nieobowiązkowe użycie, w przeciwieństwie do imion i nazwisk" 91 . Zwraca się uwagę na różnice między przezwiskami gwarowymi a tymi występującymi w socjolektach. Fakt, iż przezwiska powstają na podstawie wyrazów pospolitych, powoduje, że wyposażone są one w semantykę. ,Tworzywem przezwisk jest przede wszystkim leksyka konkretna: rzeczowniki (nazwy zwierząt, roślin, przedmiotów), przymiotniki, zdarzają się też ukonkretnione derywaty od abstraktów. Udział metafor i metonimii w powstawaniu przezwisk powoduje równokształtność wielu przezwisk z motywującymi je apelatywami"92.

Przydomki wyodrębniły się później niż przezwiska, mają charakter raczej rodzinny niż indywidualny, obecnie występują przede wszystkim

87 Opozycja swój - obcy szczególnie widoczna jest wśród kibiców sportowych, o jej wpływie na posługiwanie się przezwiskami sportowców i przydomkami klubów będzie mowa w kolejnych częściach niniejszej pracy.

88 A. Cieślikowa, Przezwiska zbiorowe i przydomki, [w:] Polskie nazwy własne..., s. 178.

89 Ibidem, s. 180.

90 Ibidem.

91 Słowiańska onomastyka. Encyklopedia, t. 1, red. E. Rzetelska-Feleszko, A. Cieślikowa, przy współudziale J. Dumy, Warszawa-Kraków 2002, s. 476.

92 Ibidem, s. 477. 
w środowiskach wiejskich ze względów tradycyjno-zwyczajowych ${ }^{93}$. A. Cieślikowa pisze: „Pseudonim najczęściej wybiera lub tworzy sam podmiot nazwania, a jeśli inni, to ci, z którym łączy go wspólna idea - w imię której przyjmuje on nadaną nazwę"94. Do czynników wpływających na posługiwanie się pseudonimami zalicza się powody osobiste, ideowe, zwyczaj lub modę, przyczyny wymuszone sytuacją - przyczyny polityczne i społeczne (pseudonimy konspiracyjne, wojskowe, partyjne, niektóre literackie, np. w czasie zaborów i okupacji). „Celem przybrania pseudonimu jest ukrycie się pod inną nazwą niż znane ogółowi imię i nazwisko"95. Podkreśla się, że w komunikacji grupowej pseudonimy pełnią funkcje adresatywne i identyfikacyjne. Zwraca się uwagę na to, że „używają [ich - przyp. KB] zazwyczaj ludzie pod jakimś względem nieprzeciętni i dzięki swym czynom lub dziełom zostają utrwaleni w pamięci części narodu często nie pod pierwotnym nazwiskiem, ale pod przybranym pseudonimem"96.

W niniejszej pracy terminy przezwisko, pseudonim i przydomek będą traktowane wymiennie przede wszystkim z tego względu, że większość z nich odnosi się do sportowców, a w języku sportu w powszechnym użyciu - wbrew temu, co czytamy w opracowaniach językoznawczych - jest sformułowanie boiskowy pseudonim/przydomek. Pojęcie przydomek będzie dodatkowo wykorzystywane w odniesieniu do alternatywnych nazw klubów sportowych.

\subsubsection{Przezwisko pochodzące od nazwiska}

Ajwen: Przypomina mi Ajwena (Andrzeja Iwana - przyp. red.), gdy zaczynał grać w piłkę. (PN 48/2012, s. 19)

Balu/Bomber-Balu: Początek był jednak wspaniały, bo w 16 sekundzie gry prowadzenie dla gospodarzy zdobył Henryk Bałuszyński. (PN 11/2012, s. 47)

Trafiłem na Henia Bałuszyńskiego, Tomka Wałdocha. (PN 44/2012, s. 15)

Becks: Agencje doniosły, że David Beckham miał udział w dwóch golach, które dały ekipie LA Galaxy awans do finału MLS w Konfederacji Zachodniej. (PN 45/2011, s. 29)

Błaszczu: A obok niego koledzy z Borussii Dortmund - Jakub Błaszczykowski i Łukasz Piszczek. (PN 51-52/2012, s. 3)

Boguś: Pierwsze wyjazdowe zwycięstwo w tym sezonie Wisła Kraków zawdzięcza Rafałowi Boguskiemu. (PN 44/2012, s. 39)

93 Ibidem, s. 477-478.

94 A. Cieślikowa, Pseudonimy, [w:] Polskie nazwy własne..., s. 135.

95 Słowiańska onomastyka..., s. 478.

96 A. Cieślikowa, Pseudonimy, s. 140. 
Buzi: Goście uparcie atakowali bramkę Macieja Mielcarza, ale kulała skuteczność, zwłaszcza jedynego w ich zespole napastnika - Pawła Buzały. (PN 36/2012, s. 38)

Fergie: Pytacie, czy jestem w Lechii kimś w rodzaju sir Aleksa Fergusona w Manchesterze? (PN 48/2012, s. 19)

Franek: Najpierw Dawid Plizga do Tomasza Frankowskiego, a ten do Euzebiusza Smolarka, który wykorzystał sam na sam z Michalem Peskoviciem. (PN 50/2012, s. 40)

Dziekan: Mecz obserwował uważnie Dariusz Dziekanowski. (PN 33/2012, s. 2)

Gazza: Przez wiele sezonów Speed spotykał się na boiskach ligi angielskiej ze starszym od niego o dwa lata reprezentantem Anglii Paulem Gascoigne’em, o którego kłopotach psychicznych wiadomo od dawna. (PN 1/2012, s. 21)

Giki: Skoro tak, to dlaczego wystąpił pan przeciw Łukaszowi Gikiewiczowi, który całą tę aferę z Mrazem w roli głównej ujawnił pracodawcom? (PN 50/2012, s. 4)

Ibra/Ibracadabra: Tuż po ściągnięciu do francuskiej stolicy za arabskie petrodolary Zlatana Ibrahimovicia przedstawiciele rządu i ówczesny kandydat na prezydenta Francji François Hollande łapali się przed kamerami za głowy i zapowiadali wprowadzenie 75-procentowego podatku dla najbogatszych. (PN 50/2012, s. 16)

Jankes: Cieszyć musi przede wszystkim fakt, że do siatki trafiają napastnicy - trzy gole strzelił Arkadiusz Piech, po dwa Maciej Jankowski i Paweł Abbott. (PN 6/2012, s. 18)

Janosik: Za stołem pojawia się główny bohater dnia, selekcjoner biało-czerwonych, Paweł Janas. (PN 20/2012, s. 47)

Lelonek: Arbitra meczu w Bielsku-Białej krytyce poddał Ireneusz Jeleń. (PN 49/2012, s. 10)

Lodła: Niewątpliwie Tomaszowi Jodłowcowi bardzo pomógł fakt, że wraz z nim na środku obrony Stanisław Lewy zaczął ustawiać Marcina Kowalczyka. (PN 50/2012, s. 41)

Jusko: Drugim z polskich napastników pod względem goli strzelonych w 1. Bundeslidze jest Andrzej Juskowiak, który od 1996 do 2003 roku w barwach Borussii Moenchengladbach, VfL Wolfsburg i Energie Cottbus zdobył 56 bramek. (PN 49/2012, s. 36)

Kaka: Marcin Kaczmarek po pierwszej części sezonu także był na piątym miejscu, ale wśród lewych obrońców. (PN 20/2012, s. 15)

Kałuża: Kiedy w październiku 2004 roku Paweł Janas ogłasza kadrę na eliminacyjne mecze z Austrią i Walią, zapada konsternacja. Radosław Kałużny? (PN 41/2012, s. 14)

Kazimiera: Piechniczek ma pretensje do bramkarza Jacka Kazimierskiego. (PN 6/2012, s. 47)

Kosa: Bohaterem meczu natomiast został Jakub Kosecki - zdobywca dwóch bramek i autor asysty przy trafieniu Danijela Ljuboi. (PN 49/2012, s. 39) 
Lewy: Juventus złożył ponoć Borussii oficjalną propozycję transferu Roberta Lewandowskiego, zakładającą przelew z Turynu do Dortmundu 25 milionów euro. (PN 49/2012, s. 10)

Listek: W tym tygodniu ma zostać utworzony w PZPN departament zagraniczny, na którego czele ma stanąć Michał Listkiewicz. (PN 49/2012, s. 13)

Liza: Ulubiony numer Bixente Lizarazu. (PN 6/2012, s. 37)

Mały: Na liście nie ma żadnego z wiślaków, a jeszcze pół roku temu byli dwaj- Patryk Małecki i Ivica Iliev. (PN 20/2012, s. 14)

Zbigniew Małkowski, bramkarz Korony Kielce, wziął udział w treningu piłkarzy ręcznych Vive Targi Kielce. (PN 44/2012, s. 10)

Mandaryna: - Ja miałam implanty tak dawno, że już nawet o nich zapomniałam - powiedziała nam Marta Wiśniewska, czyli Mandaryna97 (33). (NŻ 1/2012, s. 13)

Mou: A jak poczuł się pan, słysząc, jak Jose Mourinho mówi, że Piszczek zbyt szybko zdecydował się na przedłużenie kontraktu z Borussią, bo tym samym zamknął sobie drogę do Realu Madryt. (PN 49/2012, s. 18)

Muraś: Przemek Czerwiński na ten moment więcej umie niż na przykład Rafał Murawski w tym samym punkcie kariery. (PN 48/2012, s. 19)

Niedźwiedź: Teraz podejrzewam, że to samotność wybrała mnie, a ja z czasem ją polubiłem - wyznaje Marek Niedźwiedzki (57) w autobiografii „Nie wierzę w życie pozaradiowe”. (NŻ 7/2012, s. 44)

Ox: Ano dlatego, że menedżer Arsene Wenger wpuścił nielubianego Andrieja Arszawina, a wycofał Aleksa Oxlade-Chamberlaina. (PN 6/2012, s. 33)

Peszkin: Ich uwadze nie umyka żadna przewina będących na świeczniku zawodników, o czym boleśnie przekonał się Sławomir Peszko. (PN 17/2012, s. 20)

Poldi: Informacja podana przez dziennik „Bild” o przejściu Lukasa Podolskiego do Arsenalu Londyn zelektryzowała niemieckich kibiców, a już w szczególności fanów FC Koeln. (PN 11/2012, s. 28)

Rado: Jedyna konkretna oferta napłynęła latem dla Miro Radovicia. (PN 48/2012, s. 7)

Reksio: W Poznaniu nie ukrywano, że usilnie szukają środkowego napastnika, ale angaż 40-letniego Piotra Reissa, z którym rozstano się przed trzema laty, jest trudny do wytłumaczenia. (PN 36/2012, s. 10-11)

Rutek: Trwał tylko dlatego, że miał poparcie właściciela klubu Jacka Rutkowskiego. (PN 9/2012, s. 2)

97 Muzyczny pseudonim Marty Wiśniewskiej nawiązuje do jej panieńskiego nazwiska Mandrykiewicz. 
Ryba: - Jakoś mi się specjalnie nie podobała - mówił Andrzej Rybiński (62). (NŻ 12/2012, s. 46)

Sagan: Ani z klubu, ani do klubu, jeśli oczywiście do zdrowia wróci Marek Saganowski. (PN 48/2012, s. 7)

Schweinie: Gdyby nie ta sama, charakterystyczna twarz, Bastian Schweinsteiger sprzed pięciu lat nie miałby jako piłkarz nic wspólnego z obecnym, nikt pamiętający go z początków kariery by nie poznał, że to ten sam zawodnik. (PN 50/2012, s. 20)

Stoki: Trenerzy stawiają na młodzież w różnych konfiguracjach, ale na pewno nie można teraz upraszczać, mówiąc, że Piotrek Stokowiec, nie mając wyboru, postawił na młodych. (PN 48/2012, s. 15)

Ślusarz: Linetty trenuje więc tyle, ile powinien, czyli... nieco więcej niż na przykład Murawski, Bartek Ślusarski czy Piotr Reiss, choć oczywiście z inną intensywnością, naturalnie mniejszą. (PN 50/2012, s. 14)

Po porażce Lecha $\mathrm{z}$ Legią najmocniej oberwało się Bartoszowi Ślusarskiemu. (PN 48/2012, s. 12)

Świr: Niestety, tylko do momentu, gdy ogłoszono, że trenerem menedżerem został Piotr Świerczewski. (PN 7/2012, s. 2)

Taraś: Znamienne są słowa Ryszarda Tarasiewicza byłego trenera Śląska, który twierdzi, że drużyna w tym składzie i w tej lidze wciąż ma potencjał na mistrzostwo, pod warunkiem jednak, że będzie zdrów i będzie grał Diaz. (PN 49/2012, s. 38)

Vuko: Mózgiem drużyny jest Aco Vuković, za to sercem - Maciej Korzym. (PN 11/2012, s. 8)

Tomek: Jan Tomaszewski, człowiek, który w 1973 roku zatrzymał na Wembley Anglię, tak wspomina Smolarka. (PN 11/2012, s. 5)

Trap: W Poznaniu kibice uniknęli greckiej tragedii, bo obaj trenerzy Giovanni Trapatoni i Slaven Bilić zdecydowali się na ustawienie taktyczne z dwoma napastnikami. (PN 24/2012, s. 23)

Zieniu: Marek Zieńczuk - rocznik '78, niedawno skończył 33 lata, a formę osiągnął jak za najlepszych, wroniecko-krakowskich czasów. (PN 47/2011, s. 39)

Wykazujące morfologiczne pokrewieństwo z nazwiskiem przydomki piłkarzy, trenerów, piosenkarzy i dziennikarzy - bo tylko tych obszarów tematycznych dotyczą omawiane przykłady, przy czym zdecydowana większość odnosi się do problematyki sportowej - odznaczają się ekonomiczną formą. Wyjątkiem są antroponimy Ibracadabra (funkcjonujący zresztą równolegle z Ibra), Janosik, 
Jelonek, Peszkin i Reksio, które pod względem formalnym są nieznacznie dłuższe od odpowiadających im nazwisk ${ }^{98}$ (Ibrahimović, Janas, Jeleń, Peszko, Reiss).

Wśród mechanizmów tworzenia nazw jednoelementowych w tej grupie na plan pierwszy wysuwa się ucięcie, np. Giki, Jusko, Ox, Rado, Vuko, nierzadko towarzyszy mu zmiana paradygmatu fleksyjnego, np. Błaszczu - Jakub Błaszczykowski, Buzi - Paweł Buzała, Muraś - Rafał Murawski, czasem w śródgłosie dochodzi do alternacji w podstawie słowotwórczej: Balu - Henryk Bałuszyński. Bywa, że zmiana taka powoduje, iż nowo utworzone przezwisko upodabnia się formalnie do już istniejących wyrazów pospolitych (rzeczowników: Jodła, $\mathrm{Ka}$ łuża, Kosa, Listek, Niedźwiedź, Stoki, przymiotników: Mały, Lewy) czy imion (Kazimiera, Liza99, spieszczone Boguś, Franek, Tomek). Jedna forma syntetyczna - Mandaryna - reprezentuje klasę augmentativum. Antroponimy Listek, Boguś, Franek powstały w wyniku ucięcia i dodania sufiksów (-uś, -ek). Do uciętej formy mogą zostać także dodane głoski, rozwiązanie to widoczne jest w syntetyzmach Becks, Fergie, Zieniu, Gazza czy Jankes ${ }^{100}$. Możliwe jest także powtórzenie sylaby nagłosowej, jako przykład niech posłuży Kaka. Opisywane sposoby tworzenia skondensowanych strukturalnie przydomków są charakterystyczne zarówno dla zestawień składających się z polskich, jak i obcych imion i nazwisk.

Wart uwagi jest fakt, że przydomek Mały odnosi się do dwóch różnych konstrukcji analitycznych - tym mianem określono zarówno Patryka Małeckiego, jak i Zbigniewa Małkowskiego, ten sam syntetyzm ma zatem dwa ekwiwalenty.

\subsubsection{Przezwisko pochodzące od imienia}

Bobo: Dopiero kiedy wróciło stare, to znaczy po 20 latach przerwy skończyła się odyseja - jak sam barwnie mówi - trenera Bogusława Kaczmarka po kraju, zespół z Wybrzeża zaczął grać efektownie, a przy tym skutecznie. (PN 48/2012, s. 18)

Ebi: - To ona przekłada się na wyniki meczów wyjazdowych - stwierdził w telewizyjnym wywiadzie Euzebiusz Smolarek, a potwierdzeniem jego słów mógł być przebieg meczu wyjazdowego ze Śląskiem. (PN 49/2012, s. 16)

98 Jeśli weźmiemy pod uwagę całą konstrukcję analityczną (czyli imię i nazwisko), to oczywiście wymienione syntetyzmy i tak będą od niej krótsze.

99 Oba przywołane imiona (Kazimiera, Liza) odnoszą się powszechnie do kobiet, ale jako przydomki są tu używane dla określenia mężczyzn, trzeba zatem podkreślić zmianę rodzaju gramatycznego.

100 Przydomki Becks, Fergie czy Gazza funkcjonują w takiej samej postaci w przestrzeni międzynarodowej, zostały przeniesione do polszczyzny z języka angielskiego. 
Franz: Jeśli zresztą tego nie zrobi, Franciszek Smuda będzie musiał zrobić użytek ze swego niemieckiego paszportu i ewakuować się za Nysę i Odrę, gdyż nad Wisłą nie będzie miał czego szukać. (PN 49/2011, s. 2)

Ludo: Tydzień temu, oceniając ligowy debiut w drużynie Girondins Bordeaux, Ludovic Obraniak szczerze wyznał w rozmowie z przedstawicielami klubowej witryny Żyrondystów: - Nasz występ z Evian był przeciętny. (PN 6/2012, s. 3)

Ossie: Nosił ją na mundialu w 1982 roku pomocnik Osvaldo Ardiles. (PN 6/2012, s. 36)

Prezes: Po centrze Magiery piłkę do bramki skierował głową Prejuce Nakoulma. (PN 11/2012, s. 37)

Podobnie jak i w poprzednio omawianej grupie, tak i w zbiorze przezwisk mających wspólne morfemy z imionami chętnie wykorzystywanym zabiegiem jest ucięcie wraz ze zmianą paradygmatu fleksyjnego ( Ludo), połączone często z wymianą głoski na podobnie brzmiącą (Franz) lub dodaniem głosek (Ossie). Czasem zachowana jest tylko nagłosowa sylaba, do której dołączone są inne cząstki, by osiągnąć efekt skojarzenia oraz tożsamości strukturalnej ze znanymi wyrazami pospolitymi: Bobo, Prezes. Jeden przydomek (Ebi) przybrał formę hipocoristicum, inny (Franz) ma postać imienia obcego.

\subsubsection{Przezwisko pochodzące od imienia i nazwiska}

Zibi: Może nieco bardziej, ale niewiele, frapująca jest deklaracja Zbigniewa Bońka, który zapowiedział w miniony czwartek, że nie zamierza w ogóle ubiegać się o fotel prezesa związku. (PN 14/2012, s. 2)

Wszystkie znaki na niebie i ziemi wskazują, że po dłuższej przerwie Zbyszek Boniek powróci do polskiego futbolowego piekiełka. (PN 1/2012, s. 47)

Zizou: Juve A.D.2012 odstaje poziomem i pięknem gry jeszcze także od tego, gdy na krajowych i europejskich boiskach w ekipie Zebr występowali Michel Platini, Zinedine Zidane, Zbigniew Boniek czy Roberto Baggio. (PN 20/2012, s. 35)

Zgromadzono jedynie dwa przykłady, w których pseudonim nawiązywał swoją strukturą zarówno do imienia, jak i nazwiska. Przydomki Zibi101 i Zizou przypominają budową współczesne skrótowce, które rzadko odwołują się do

101 Można również założyć, że pseudonim Zibi pochodzi tylko od imienia Zbigniew, nie wykazuje pokrewieństwa $\mathrm{z}$ nazwiskiem. 
tradycyjnego podziału na głoskowce, sylabowce, literowce i skrótowce mieszane. Jak zauważa Grażyna Sawicka: „Wśród mieszanych struktur panują nieregularne, zawierające elementy nazwiska i/lub imienia powstałe w drodze mutylacji, a także mieszania - sylab z głoskami czy literami, głosek z elementami uciętymi, pełnych imion lub nazwisk z cząstkami tychże, powstałymi w wyniku różnych zabiegów dezintegrujących strukturę, itp." $102 \mathrm{~W}$ obu analizowanych przypadkach mamy do czynienia z połączeniem znajdujących się w nagłosie liter lub sylab z elementami nieznajdującymi odzwierciedlenia w dalszej części analitycznej nazwy (Zizou) lub pojawiającymi się w podstawie (Zibi).

\subsubsection{Przezwiska niewykazujące morfologicznego pokrewieństwa z imieniem lub nazwiskiem}

Doktor: Podobnie jak Stefan Majewski - na wiceprezesa do spraw szkoleniowych. (PN 49/2012, s. 13)

Generał: Rinus Michels doprowadził Ajax Amsterdam do pierwszego triumfu w Pucharze Mistrzów, a reprezentację Holandii do pierwszego wicemistrzostwa świata i tytułu mistrza Europy. (PN 17/2012, s. 27)

Gianni: Tomasz Hajto nauczył Jagiellonię wygrywać w meczach wyjazdowych, ale drużyna ma problemy ze zdobywaniem kompletów punktów u siebie. (PN 49/2012, s. 15)

Grubcio: Chojniczanka była dużo skuteczniejsza i... miała w swoich szeregach Rafała Misztala. (PN 44/2012, s. 44)

Faraon: Stephan El Shaarawy po 11 kolejkach przewodzi klasyfikacji strzelców. (PN 45/2012, s. 28)

Księgowy: Być może Abramowicz postanowił dać Hiszpanowi ostatnią szansę i i zatrudnił na miejsce Di Matteo do końca sezonu Rafę Beniteza. (PN 48/2012, s. 23)

Nestor: Mowa oczywiście o Oreście Lenczyku, który jako trener wprowadził Śląsk Wrocław w zupełnie nową erę, na na wskroś nowoczesny obiekt. (PN 44/2011, s. 2)

Łowca: Podobnego zdania jest Tomasz Frankowski, ikona zespołu znad Białej Rzeki. (PN 49/2012, s. 14)

Nędza: Djibril Cisse kiedyś rywalizował o miejsce w wyjściowym składzie Auxerre z naszym Piotrem Włodarczykiem. (PN 6/2012, s. 30)

Sfinks: Vicente del Bosque 27 maja ogłosi skład kadry i trudno sobie wyobrazić, by włączył do niej swego podstawowego środkowego obrońcę. (PN 20/2012, s. 27)

102 G. Sawicka, Struktura współczesnych skrótowców, „Acta Universitatis Lodziensis. Folia Linguistica” 1998, z. 37, s. 156. 
Tato: Kiedy w październiku 2004 roku Paweł Janas ogłasza kadrę na eliminacyjne mecze z Austrią i Walią, zapada konsternacja. Radosław Kałużny? (PN 41/2012, s. 14)

Wódz: W pobliskim przysiółku Tajenko ludzie mówią o Darku Karpie niewiele. (P 5152/2012, s. 164)

Wtorek: Na pierwszym zgrupowaniu w Kamieniu koło Rybnika Andrzeja Niedzielana jeszcze nie było. (PN 6/2012, s. 18)

Wszystkie przydomki, które nie mają wspólnych morfemów z odpowiadającymi im imionami i nazwiskami, należą do kategorii rzeczowników. Zdecydowana większość jest tożsama strukturalnie z wyrazami pospolitymi (np. Generał, Nestor, Nędza czy Wtorek), tylko dwa przykłady mają taką samą budowę jak nazwy własne: Gianni odwołuje do imienia obcego pochodzenia, Sfinks zaś - do postaci z mitologii greckiej. Pseudonim Grubcio jako jedyny nie ma notowanego przez słowniki pierwowzoru.

\subsection{Nazwa klubu a przydomek}

\subsubsection{Przydomki pochodzące od nazw klubów}

Barca: Mecz z Deportivo La Coruna piłkarze i kibice FC Barcelona wspominać będą bardzo długo. (PN 43/2012, s. 34)

Jaga: W poprzednim tygodniu Gieksa straciła jeszcze Filipa Modelskiego, który przeszedł do Jagiellonii Białystok. (PN 24/2012, s. 44)

Luve: Jeżeli w Doniecku mający 10 punktów gospodarze wygrają z legitymującym się tylko jednym punktem mniej Juventusem Turyn, zaś mająca siedem punktów przewagi Chelsea w Londynie pokona Nordsjaelland, to dalej przejdą The Blues, którzy ostatnio przeżywają kryzys i na razie niewiele dało zatrudnienie w roli menedżera Rafy Beniteza. (PN 49/2012, s. 2)

Miedzianki: Miedź Legnica, po nierównej grze w rundzie jesiennej, na wiosnę wespół z GKS Tychy powoli odjeżdża grupie pościgowej. (PN 17/2012, s. 44)

Piastunki: W Piaście Gliwice nie zamierzają wymyślać prochu. (PN 33/2012, s. 14)

Żyrondyści: To oczywiście nie jest przypadkowy szkoleniowiec, bo doprowadził Girondins Bordeaux do mistrzostwa Francji 1999 (głównym rywalem Żyrondystów była wówczas - co ciekawe - Marsylia), ale ostatnio nie wiodło mu się zbyt dobrze. (PN 39/2012, s. 31) 
Wśród alternatywnych nazw klubów o wspólnych morfemach z oficjalnymi nazwami wyróżnić można takie, które albo powstały na drodze ucięcia wraz ze zmianą paradygmatu (Barca, Juve, Jaga), albo sufiksacji (formanty-ank(i), -unk(i), -yśc(i): Miedzianki, Piastunki, Żyrondyści). Te drugie są pod względem formalnym dłuższe niż nazwy, od których pochodzą. W przykładzie Żyrondyści można odnaleźć wspólne morfemy z Girondins Bordeaux w śródgłosie, dodatkowo nagłos uległ spolszczeniu. Podkreślić należy, że przydomki Piastunki i Miedzianki mają formy liczby mnogiej, a ich oficjalne odpowiedniki reprezentują liczbę pojedynczą, dochodzi więc do zmiany paradygmatu fleksyjnego. Syntetyzmy te wymagają zatem innych form składniowych niż pierwowzory.

\subsubsection{Przydomki niewykazujące morfologicznego pokrewieństwa z nazwą klubu}

Aptekarze: Przed nami piąta, przedostatnia kolejka fazy grupowej LE, ale dla sympatyków Interu Mediolan, Rubinu Kazań, Olympique Lyon, Bayeru Leverkusen i Metalista Charków prawdziwe pucharowe emocje rozpoczną się dopiero w przyszłorocznych meczach 1/16 finału. (PN 47/2012, s. 33)

Colchoneros: Warto przypomnieć, że rewelacją pierwszej edycji LE w sezonie 2009-10 był londyński Fulham, który w finale uległ Atletico Madryt. (PN 46/2012, s. 34)

Drozdy: Wszystko, czego dotykał w tym sezonie Steve Clarke, opiekun West Bromwich Albion, przemieniało się w złoto. (PN 49/2012, s. 20)

Fiołki: Do ubiegłotygodniowego meczu fazy grupowej z Anderlechtem Bruksela zespół prowadzony przez Chilijczyka Manuela Pellegriniego przystępował z piątej pozycji La Liga. (PN 50/2012, s. 34)

Górale: W środę kibice Cracovii oczekiwać będą na wielki cud, jakim niewątpliwie będzie ewentualna wygrana Pasów nad Podbeskidziem Bielsko-Biała. (PN 14/2012, s. 47)

Aktualny lider Scottish Premier League Celtic Glasgow pokonał na trudnym terenie Inverness CT 2:0. (PN 6/2012, s. 42)

Górnicy: Przekonują o tym choćby wyniki Szachtara Donieck, dla którego wszystkie gole w ostatnim meczu z Nordsjaelland strzelili właśnie zawodnicy pochodzący z Kraju Kawy. (PN 48/2012, s. 32)

Jaskółki: Czwartą Resovię dzieli jedynie pięć punktów od trzynastej Unii Tarnów. (PN 44/2012, s. 45)

Kanonierzy: To był fenomenalny mecz Arsenalu Londyn $\mathrm{z}$ fenomenalnym Robinem van Persiem w ataku. (PN 6/2012, s. 42) 
Koenigsblauen: Jednym z najdroższych, sprowadzonym przed dwoma laty, jest Atsudo Uchida, za którego Schalke 04 Gelsenkirchen zapłaciło 1,3 miliona euro, generalnie jednak większość z nich z Japonii przyjeżdżała za niezbyt wielkie pieniądze. (PN 43/2012, s. 26)

Koguty: W Tottenhamie Hotspur numer ten przynależny jest Garethowi Bale'owi, jednemu z najbardziej ofensywnie ustawionych graczy Kogutów. (PN 6/2012, s. 36) 24-letni Anglik jest wychowankiem Tottenhamu Londyn, gdzie jednak dosyć szybko zrezygnowano z jego osoby, gdyż uznano, że słabo rokuje na przyszłość. (PN 6/2012, s. 40)

Kolejorz/Kolejorze: Co prawda w ostatni piątek podopieczni Radosława Mroczkowskiego po raz pierwszy w tym sezonie ligowym zeszli z boiska pokonani, ale ich wpadki nie potrafili wykorzystać ani Legia Warszawa, ani Lech Poznań. (PN 40/2012, s. 40)

Koniczynki: Wszystko przez Józefa Wandzika, którego dublerem był długo w Panathinaikosie Ateny i dlatego od 1990 do 1997 roku rozegrał zaledwie 15 meczów w greckiej ekstraklasie. (PN 11/2012, s. 27)

Kozły: Informacja podana przez dziennik „Bild” o przejściu Lukasa Podolskiego do Arsenalu Londyn zelektryzowała niemieckich kibiców, a już w szczególności fanów FC Koeln. (PN 11/2012, s. 28)

Królewscy: Od trzech lat nieustannie ucieka rywalom z całego świata, w tym zaciekle ścigającemu Realowi Madryt. (PN 7/2012, s. 13)

Lwy: Bo Benfica, która w Lidze Mistrzów zmierzy się z Zenitem Sankt Petersburg, podpisała umowę z byłym graczem Sportingu Lizbona Yannickiem Djalo. (PN 6/2012, s. 31)

Nafciarze: Za plecami niepołomiczan czai się spadkowicz z I ligi Wisła Płock. (PN 48/2012, s. 45)

Niebiescy: Tyle co nic, biorąc pod uwagę, że to Ruch Chorzów dysponuje prawdopodobnie najsilniejszą linią ataku w ekstraklasie. (PN 6/2012, s. 18)

Orly: El Comendante, jak nazywają 31-letniego Argentyńczyka koledzy, spróbuje teraz pomóc FC Porto odzyskać stracony dystans punktowy do lidera ekstraklasy Benfiki Lizbona. (PN 6/2012, s. 31)

Papużki: Dopiero po 13 serii spotkań poleciała w Hiszpanii pierwsza trenerska głowa: z Espanyolu Barcelona zwolniono Mauricio Pochettino. (PN 50/2012, s. 22)

Portowcy: Liderująca Pogoń Szczecin podejmie u siebie Piasta Gliwice. (PN 11/2012, s. 40) 
Scyzoryki: Gdyby ułożyć tabelę, okazałoby się, że przewodzi w niej Korona Kielce, która w dodatku jako jedyny zespół w tym czasie odniosła komplet zwycięstw, za rywala mając między innymi Wisłę w Krakowie. (PN 11/2012, s. 6)

Smoki: Po majowym zwycięstwie nad Bayernem Monachium w finale Pucharu Mistrzów piłkarzy FC Porto zna i szanuje już cały świat. (PN 50/2012, s. 10)

Święci: W sobotę były bramkarz reprezentacji Polski podpisał kontrakt z beniaminkiem Premier League Southampton FC. (PN 39/2012, s. 25)

Wyspiarze: Po rundzie jesiennej na miejscach premiowanych awansem są jednak drużyny, które nigdy nie grały w ekstraklasie - Flota Świnoujście i Termalica Bruk-Bet Nieciecza. (PN 49/2012, s. 44)

Zebry/Zeberki: W listopadzie i grudniu na meczach z udziałem Pawłowskiego pojawiali się skauci m.in. Udinese Calcio, którzy wcześniej z Młodej Ekstraklasy Zagłębia Lubin wyłowili także Piotra Zielińskiego. (PN 6/2012, s. 16)

Żubry: Tym razem zabrakło jej czasu, determinacji, a trochę też i szczęścia, żeby wygrać z Jagiellonią Białystok. (PN 46/2012, s. 39)

Źrebaki: Z niedocenianą Borussią Moenchengladbach zajął czwarte miejsce w Bundeslidze, wystąpił na Euro 2012, a następnie za 17,1 miliona euro przeszedł do Borussii Dortmund. (PN 39/2012, s. 32)

Bardzo liczna grupa przydomków niemających wspólnych morfemów z pierwotną nazwą drużyny piłkarskiej przyjmuje formy liczby mnogiej, np. Drozdy, Kanonierzy, Nafciarze, Scyzoryki, Żubry, zmieniony zostaje zatem paradygmat fleksyjny. Wyjątkiem jest Kolejorz, który - podobnie jak nazwa urzędowa zespołu z Poznania - przybiera liczbę pojedynczą, a nawet ten sam rodzaj. Raz spostrzeżono formę Kolejorze, która bywa jednak używana bardzo rzadko zarówno w przekazach pisanych, jak i ustnych. Podkreślenia wymaga fakt, że w przydomku tym uwidacznia się cecha dialektu wielkopolskiego, jaką jest podwyższenie artykulacji - głoska a ulega ścieśnieniu do $o^{103}$. Wszystkie zgromadzone w tej kategorii alternatywne określenia są rzeczownikami (np. Aptekarze, Smoki, Wyspiarze), czasem pierwotnie były to przymiotniki, które uległy procesowi substantywizacji (Królewscy, Niebiescy, Święci). Kilka syntetyzmów to zdrobnienia, np. Zeberki, Papużki, Koniczynki. Alternatywna nazwa Górale ma dwa analityczne odpowiedniki: polski Podbeskidzie Bielsko-Biała i szkocki Inverness CT. Przydomki w języku

103 Tworzenie przydomków w oparciu o cechy dialektalne służy podkreśleniu identyfikacji klubu $\mathrm{z}$ regionem. 
polskim są tworzone i dla określenia klubów z naszego kraju, i z zagranicy. Odnotowano też funkcjonujące w prasie obce przydomki, które zostały przyswojone do polszczyzny (Colchoneros, Koenigsblauen).

\subsection{Przydomek jednocztonowy, przydomek wieloczłonowy i peryfraza jako ekwiwalenty nazwy własnej}

Barca: FC Barcelona to nie tylko Duma Katalonii, to duma sportowego świata. (PN 7/2012, s. 13)

Ełksa: Tragiczna sytuacja w zespole ŁKS spowodowała, że od kilku dni jesteśmy świadkami ogólnospołecznej zrzutki pieniężnej na rzecz wsparcia ekstraklasowego klubu z siedzibą w centralnej części Polski. (PN 5/2012, s. 47)

Nawet jednak oni mówili głośno od momentu powrotu zespołu z alei Unii do ekstraklasy, że harcerze władający klubem nie mają pojęcia, jak radzić sobie z wyzwaniami w piłkarskim biznesie. (PN 4/2012, s. 2)

Przecież już w listopadzie minionego roku jeden z potencjalnych, ale niedoszłych, inwestorów alarmował, że w sportowej spółce z alei Unii brakuje co najmniej czterech milionów złotych na dokończenie rozgrywek, a po zaległe należności zgłaszają się wierzyciele. (PN 4/2012, s. 2)

Skoro Wieszczycki i Kłos, a więc ludzie, w których żyłach płynie ełkaesiacka krew, powiedzieli: pas, $w$ trakcie rundy, na dodatek przed meczem z Bełchatowem, który może zadecydować o pozostaniu w ekstraklasie lub degradacji, to oznacza, że finanse i wydolność organizacyjna klubu z alei Unii są w dramatycznym stanie. (PN 47/2011, s. 2)

Nie ma obaw, że ktoś wspomni Rycerzy Wiosny. (PN 3/2012, s. 13)

Juve: Kibicom Starej Damy zachodzącym w głowę, jak można było na kogoś takiego wyrzucić 9 milionów euro, przypominamy, że nieco wcześniej za Felipe Melo klub z Turynu zapłacił 25 milionów. (PN 17/2012, s. 31)

Kolejorz: Zaś miejsce na podium mógłby uratować tylko cud, który jednak przy kiepskim przygotowaniu Dumy Wielkopolski do rozgrywek nie ma prawa się zdarzyć. (PN 9/2012, s. 2)

W języku sportu uwidacznia się też tendencja do funkcjonowania równolegle kilku przydomków tego samego klubu - jeden to określenie syntetyczne, drugi natomiast zaliczyć można do konstrukcji analitycznych - a także posługiwania się peryfrazami (niekoniecznie nazwami własnymi) obok jednowyrazowych przydomków. Pierwszą regułę obrazują pary: Barca - Duma Katalonii, Juve - Stara 
Dama, Kolejorz-Duma Wielkopolski, Ełksa - Rycerze Wiosny. Podkreślić trzeba, że dwukrotnie bazą dwuwyrazowych połączeń jest leksem duma. Połączenia te składają się z rzeczownika w mianowniku i rzeczownika w dopełniaczu lub przymiotnika i rzeczownika.

Inne rozwiązanie prezentują peryfrazy odnoszące się do Ełksy: ekstraklasowy klub z siedzibą w centralnej części Polski ${ }^{104}$, zespół z alei Unii, sportowa spółka $z$ alei Unii, klub $z$ alei Unii. Trzy z czterech wymienionych analityzmów opierały się na lokatywnym wyrażeniu przyimkowym $z$ alei Unii, dwa poprzedzone były rzeczownikami (zespół, klub), raz wystąpił przymiotnik z rzeczownikiem (sportowa spółka). W skład rozbudowanego określenia ekstraklasowy klub z siedziba w centralnej części Polski wchodziła kombinacja przymiotników, rzeczowników i przyimków.

\subsection{Nazwa własna wieloczłonowa a uniwerbizm}

Atlantyk: Dodatkowo do Portugalii należy szereg wysp położonych na Oceanie Atlantyckim, w tym Archipelag Azorski i Madera. (VG 1/2011, s. 16)

Mały raj na Oceanie Atlantyckim odkryli w XVI wieku portugalscy żeglarze. (NŻ 7/2012, s. 24)

Bałtyk: W każdej chwili pływa tam około 2 tys. statków, czyli tyle samo, co na całym Morzu Bałtyckim. (P 50/2012, s. 8)

Eskaemka: Z lotniska nowiutką eskaemką (Stołeczna Kolej Miejska) Kowalski w 25 min przyjechał do stacji Śródmieście - parę kroków od strefy kibica. (P 24/2012, s. 15)

Euro: Teraz mam okazję występować na większych i bardziej nowoczesnych stadionach, choć z tych, na których rozgrywane były spotkania mistrzostw Europy, zaliczyłem tylko obiekt w Poznaniu. (PN 48/2012, s. 10)

Odchodząc z posady, Capello zostawia Anglię bez opiekuna, a za cztery miesiące rozpoczyna się czempionat Europy w Polsce i na Ukrainie. (PN 7/2012, s. 43)

Platforma: Platforma Obywatelska nie świętowała dziesiątej rocznicy powstania. (P 5/2011, s. 98)

Popielec: To czas niezliczonej ilości balów, parad, absolutnie szalonych zabaw, a kończą się one po 7 dniach, w Środę Popielcową. (VG 7/2011, s. 15)

104 Peryfraza ta jest mało precyzyjna, nie wskazuje jednoznacznie na konkretny klub, do jej deszyfracji niezbędne jest zaznajomienie się z kontekstem. 
Narodowy: To był udany tydzień, który niewątpliwie zapisze się w annałach polskiego futbolu, biorąc pod uwagę, że wywalczyliśmy bezbramkowy remis z Portugalią i że na Stadionie Narodowym wreszcie zadebiutowali piłkarze. (PN 10/2012, s. 47)

Męską wersją seansu pamięci był z kolei grany w tym czasie w Teatrze Narodowym „Żar” według powieści Sandora Maiara, ze sporem o kobietę, pojęciem lojalności i zdrady w centrum. (P 51-52/2012, s. 129)

Słonie: Drużyna Wybrzeża Kości Słoniowej wygrała wszystkie dotychczasowe mecze w tym turnieju i nie straciła jeszcze gola. (PN 6/2012, s. 4)

Stany: Pamiętajmy, że tacy piłkarze jak Stephen Schroeck, który reprezentuje Filipiny, czy Daniel Williams i Fabian Johnson, którzy grają dla Stanów Zjednoczonych, dorastali w Niemczech. (PN 36/2012, s. 26)

Unia: Spodziewamy się gospodarczego spowolnienia, większego bezrobocia, stagnacji zarobków, obcinania różnych wydatków w oczekiwaniu na nowe pieniądze z Unii Europejskiej, która też zapowiada cięcia budżetowe, dokonywane na kolejnych męczących szczytach zmęczonych przywódców. (P 51-52/2012, s. 8)

Wielkanoc: Teraz Ala debatuje z mamą czy wracać za ocean, czy jednak zostać w Krakowie i urządzić prawdziwie rodzinne święta wielkanocne. (NŻ 13/2012, s. 5)

Wyspy: Po Wyspach Brytyjskich znalazło się niestety kolejne miejsce, gdzie nasza chęć pracy i determinacja napotykają opór. (PN 10/2012, s. 9)

Po 1945 r. nie zdarzyło się nikomu (przynajmniej mnie znanemu) napisać historię Polski od Piasta po Wałęsę, Wysp Brytyjskich od A do Z plus monografię powstania warszawskiego, wojny polsko-bolszewickiej i jednego z największych miast polskich o nader burzliwej i skomplikowanej przeszłości. (P 51-52/2012, s. 159)

Zachód: Selekcjoner Waldemar Fornalik interesuje się nie tylko Europą Zachodnią. (PN 36/2012, s. 8)

Kolejną dużą grupę stanowią te nomina propria, których syntetyczny odpowiednik jest pod względem formalnym uniwerbizmem. W zestawieniu tym znalazły się m.in. nazwy geograficzne (oceany, morza, kraje), a także nazwy partii politycznych, świąt, budowli czy obiektów. Skondensowane struktury reprezentują różne typy form zuniwerbizowanych. Licznie obserwowane są elipsy deadiektywizujące (Stany, Wyspy), pomijany bywa także człon rzeczownikowy (Narodowy) ${ }^{105}$. Jako przykłady derywacji paradygmatycznej z udziałem

105 Formy te można zaliczyć do derywacji paradygmatycznej. Pojęcie to i jej zakres szczegółowo scharakteryzowała Krystyna Waszakowa w publikacji Słowotwórstwo 
dezintegracji wymienić można Wielkanoc, Słonie, Zachód, Atlantyk, Bałtyk czy Popielec. Nazwa eskaemka jest derywatem od skrótowca SKM. Syntetyzm Narodowy posłużył do określenia dwóch różnych nazw własnych - Stadion Narodowy i Teatr Narodowy - do trafnego odszyfrowania pierwowzoru konieczna jest znajomość kontekstu. Euro natomiast ma dwa analityczne ekwiwalenty - mistrzostwa Europy i czempionat Europy.

Wszystkie zgromadzone w tym zestawieniu konstrukcje syntetyczne są rzeczownikami, czasami powstałymi w wyniku substantywizacji przymiotników (Narodowy). Trzykrotnie reprezentują formy liczby mnogiej - Słonie, Stany i Wy$s p y$ - jednak tylko w dwóch przykładach zarówno konstrukcja analityczna, jak i jej odpowiednik wykazywały zgodność w tej kategorii. Wybrzeże Kości Słoniowej i Stonie nie są tożsame pod względem liczby.

Warto zwrócić uwagę na jeszcze jeden sposób współwystępowania konstrukcji syntetycznych z analitycznymi - przechodzenie dwuwyrazowej nazwy w uniwerbizm i jednocześnie tworzenie rozbudowanego określenia peryfrastycznego. W wyekscerpowanym z polskich czasopism materiale z taką sytuacją spotykamy się w odniesieniu do Stadionu Narodowego oraz mistrzostw Europy.

Euro: Ze względu na finałowy turniej mistrzostw Europy, którego uroczyste rozpoczęcie nastąpi 8 czerwca w Warszawie, zaczynamy z niepokojem odliczać dni dzielące nas od najważniejszego sportowego wydarzenia dekady, a może i ćwierćwiecza. (PN 13/2012, s. 47)

Narodowy: Nowy wspaniały obiekt piłkarski jednocześnie podniósłby rangę wyjątkowo mało prestiżowego i traktowanego w Polsce po macoszemu turnieju tysiąca drużyn. (PN 13/2012, s. 47)

Dziś już wiemy, że nie tylko Superpuchar, ale również Puchar Polski otrzymał zakaz wstępu na imponujący i monumentalny obiekt usytuowany po drugiej stronie Wisły, ale jednak na wprost Pałacu Kultury i Nauki. (PN 13/2012, s. 47)

Kiedy bowiem - jeśli nie podczas meczu podwyższonego ryzyka - najlepiej jest sprawdzić wszystkie procedury, zabezpieczenia i ogólne funkcjonowanie najdroższego - a zatem pewnie (choć wcale nie na pewno) także najnowocześniejszego i najbardziej funkcjonalnego - obiektu piłkarskiego w Polsce? (PN 6/2012, s. 2)

współczesnego języka polskiego. Rzeczowniki z formantami paradygmatycznymi, wyd. 2 popr., Warszawa 1996. 
Ktoś powie: pomieszanie z poplątaniem, i zapewne będzie miał rację, bo w kwestii reprezentacyjnego obiektu wybudowanego w stolicy nie wiadomo, czy lepiej się śmiać, czy raczej płakać. (PN 6/2012, s. 47)

Cóż, jeśli wszystko nadal wokół Narodowego będzie się tak ślimaczyć jak dotychczas, to na pełne i bezwarunkowe oddanie do użytku sztandarowego stadionu w kraju poczekamy do mistrzostw Europy. (PN 6/2012, s. 2)

Nigdy nie przepadałem za cyrkowymi występami, ale sytuacja z naszym reprezentacyjnym obiektem, czyli Stadionem Narodowym, przypomina kiepski spektakl pod namiotem albo rozsuwanym dachem, jak kto woli. (PN 7/2012, s. 47)

Główna polska arena finałów Euro 2012 została oddana do użytku. (PN 5/2012, s. 2)

Chciał wynająć nasz reprezentacyjny stadion na kilka godzin, dla potrzeb kilkudziesięciu osób. (PN 12/2012, s. 11)

Zdążyliśmy, choć organizowanie uroczystości oddania do użytku Stadionu Narodowego było zabawne - o samym fakcie poinformowano ledwie dzień wcześniej, a na naszym sztandarowym obiekcie nie ma jeszcze... boiska. (PN 51-52/2011, s. 9)

Wymienione nazwy funkcjonują powszechnie w skróconej postaci (Narodowy, Euro), ale przynależne im są także liczne rozbudowane formy. Narodowy doczekał się następujących ekwiwalentów: główna polska arena finałów Euro 2012, sztandarowy stadion $w$ kraju, nasz reprezentacyjny obiekt, nasz reprezentacyjny stadion, nasz sztandarowy obiekt, nowy wspaniały obiekt piłkarski, najdroższy obiekt piłkarski w Polsce ${ }^{106}$, reprezentacyjny obiekt wybudowany w stolicy, imponujacy i monumentalny obiekt usytuowany po drugiej stronie Wisły, ale jednak na wprost Pałacu Kultury i Nauki. Widoczna jest powtarzalność schematów, do których dołączane są synonimiczne określenia, np. nasz sztandarowy, nasz reprezentacyjny, reprezentacyjny obiekt. Odpowiednikiem Euro jest z kolei sformułowanie najważniejsze sportowe wydarzenie dekady, a może i ćwierćwiecza. Przywołane połączenia wskazują na skłonność do tworzenia peryfraz okazjonalnych, mocno osadzonych w kontekście, część z nich (np. odwołujące do nowości czy ceny) dość szybko może się zdezaktualizować i prawdopodobnie zostanie wyparta przez

106 Pełna wersja tej peryfrazy to najdroższy - a zatem pewnie (choć wcale nie na pewno) także najnowocześniejszy i najbardziej funkcjonalny - obiekt piłkarski w Polsce, główna myśl jest zatem przedzielona wtrąceniem, które wyraża wątpliwości autora artykułu. Szczegółowo przyjrzano się znaczeniu wymienionych analityzmów w rozdziale Semantyka. 
kolejne struktury, oparte na nowych skojarzeniach. Być może jednak niektóre wynotowane przykłady zagoszczą na stałe w powszechnym użyciu.

Liczba członów zaprezentowanych konstrukcji analitycznych jest zróżnicowana, najliczniej reprezentowane są połączenia trzy- (nasz reprezentacyjny obiekt) i czteroskładnikowe (nowy wspaniały obiekt piłkarski), nie brakuje też struktur zbudowanych z pięciu (reprezentacyjny obiekt wybudowany w stolicy) i sześciu (główna polska arena finatów Euro 2012) elementów. Warto odnotować też wieloczłonowe określenia imponujący i monumentalny obiekt usytuowany po drugiej stronie Wisły, ale jednak na wprost Pałacu Kultury i Nauki oraz najważniejsze sportowe wydarzenie dekady, a może ićwierćwiecza, które mimo rozbudowanej struktury da się z łatwością wyodrębnić z tekstu zasadniczego.

Pod względem formalnym wymienione multiwerbizmy składają się z rzeczowników i towarzyszących im przydawek przymiotnych (nowy wspaniały obiekt piłkarski, nasz sztandarowy obiekt), przymiotnych i przyimkowych (sztandarowy stadion w kraju), przymiotnych i rzeczownych (główna polska arena finałów Euro 2012), a także połączeń przymiotników, rzeczowników, imiesłowów i wyrażeń przyimkowych (reprezentacyjny obiekt wybudowany w stolicy).

\subsection{Oficjalna nazwa własna jednoczłonowa a przydomek wielowyrazowy/peryfraza}

\subsubsection{Nazwy geograficzne}

Afryka: Według pracującego od połowy roku w krajowej federacji Igesunda w najbliższym czasie jego zespół mecze towarzyskie powinien rozgrywać na Czarnym Lądzie, bo przecież na początku przyszłego roku właśnie w RPA odbędzie się Puchar Narodów Afryki. (PN 41/2012, s. 12)

Rozgrywany w cyklu dwuletnim turniej ma status mistrzostwa Czarnego Kontynentu. (PN 46/2011, s. 33)

Anglia: A mimo to na Anglię, kolebkę futbolu, zagłosowało 2 z 22 członków komitetu wykonawczego FIFA (powinno głosować 24 członków, ale dwóch wykluczono ze względu na ciążące na nich zarzuty korupcyjne). (P 13/2012, s. 15)

Białystok: W stolicy Podlasia dobiegł końca konflikt ultrasów z organizatorami masowych imprez sportowych, za jakie zgodnie z ustawą uznawane są mecze piłkarskiej ekstraklasy. (PN 49/2012, s. 14) 
Brazylia: Przekonują o tym choćby wyniki Szachtara Donieck, dla którego wszystkie gole w ostatnim meczu z Nordsjaelland strzelili właśnie zawodnicy pochodzący z Kraju Kawy. (PN 48/2012, s. 32)

Bukareszt: Kiedyś był piękny, określany nawet mianem „małego Paryża”. (VG 8/2011, s. 23)

Chicago: Teraz, w prezencie na szóste urodziny (obchodzą 16 czerwca), podarowali sobie wyjazd do mekki improwizacji - Chicago. (P 24/2012, s. 98)

Chiny: W Chinach natomiast to potwierdzenie prymatu partii komunistycznej, która może wbijać Chińczyków w dumę i udowadniać, że pod jej kierownictwem Państwo Środka skazane jest na zmierzanie ku wielkości (Yang Liwei proponuje nawet, by podczas lotu taikonauci zawiązali pierwszą pozaziemską komórkę partii). (P 51-52/2012, s. 65)

Nauka mandaryńskiego (to język urzędowy Chin, w całym Państwie Środka jest ponad 50 różnych jego odmian) to nie tylko alfabet i artykulacja. (VG 2/2011, s. 7)

Jednak to nie koniec informacji z Państwa Środka. (PN 51-52/2011, s. 89)

Cypr: Podczas pierwszego podejścia w fazie grupowej, przedstawicielom Wyspy Afrodyty z Marcinem Żewłakowem i Kamilem Kosowskim w składzie nie udało się odnieść żadnego zwycięstwa. (PN 11/2012, s. 34)

Częstochowa: Tutaj jednak nie możemy się dziwić, bowiem Daniel pochodzi spod Częstochowy, zagłębia polskiego czarnego sportu. (VG 12/2011, s. 59)

Miasto polskie położone na siedmiu wzgórzach, zwane czasem „małym Rzymem”. (VG 12/2011, s. 63)

Dubrownik: Dubrownik - perła Adriatyku (VG 12/2011, s. 20)

Europa: Gdy poprzednio dwukrotnie byli drugim zespołem świata, na mistrzostwach Starego Kontynentu jednak zawodzili. (PN 11/2012, s. 24)

Nobel, kasa, bezrobocie: za zasługi w jednoczeniu Starego Kontynentu uhonorowano Unię Pokojową Nagrodą Nobla. (P 51-52/2012, s. 17)

Finlandia: Ale w stolicy Kraju Tysiąca Jezior, prawie nikt nie robił z tego narodowej tragedii. (PN 33/2012, s. 30)

Francja: Ale Francuzi są podzieleni - w ojczyźnie wolności seksualnej rośnie front obrony tradycyjnej rodziny. (P 51-52/2012, s. 67)

Jeden z nich dotyczy piłkarzy i trenera w kraju nad Sekwaną. (PN 13/2012, s. 20)

Gdańsk: Wszystkim zaparło dech, gdy dziewczęta w bursztynowych kostiumach efektowną choreografią otworzyły finały ME w mieście Neptuna. (PN 24/2012, s. 31)

Grecja: To w ogóle dziwny kraj - niby kolebka naszej europejskiej cywilizacji, a gdyby nie ogrom ruin, które spotyka się tu co krok - nikt by się tego nie domyślił. (VG 9/2011, s. 24) 
Holandia: - Skład reprezentacji Holandii przez prawie dwa lata, czyli od czasu mistrzostw świata, prawie się nie zmienia - mówi Janusz Kowalik, były reprezentant Polski mieszkający w Kraju Tulipanów. (PN 11/2012, s. 24)

Hollywood: W Fabryce Snów po raz 84. wręczono najbardziej pożądane złote statuetki na świecie. (NŻ 9/2012, s. 7)

Irlandia: Irlandia - zielona wyspa z celtycką tradycją (VG 10/2011, s. 18)

Indonezja: Obecnie Konspol buduje ogromną wytwórnię wędlin w Indonezji, największym kraju muzułmańskim. (P 51-52/2012, s. 60)

Jamajka: Kraj Bonda, Marleya i Bolta (P 51-52/2012, s. 73)

Sprinterzy byli w kraju witani morzem zielono-żółto-czarnych flag, a Jamajkę - nie pierwszy raz - nazywano światową fabryką sprinterów. (P 51-52/2012, s. 75)

Jeszcze Kolumb twierdził, że to najpiękniejsza wyspa Karaibów. (P 51-52/2012, s. 75)

Japonia: Anna Kieda odsłania uroki (ale i mankamenty) życia w Kraju Kwitnącej Wiśni. (VG 17/2012, s. 35)

Meksykański Monterrey miał więcej czasu od Chelsea na aklimatyzację w Kraju Wschodzącego Słońca, bo już w ostatnią niedzielę w meczu ćwierćfinałowym najlepszy zespół klubowy strefy CONCACAF spotkał się z południowokoreańskim Ulsan Hyundai i wygrał 3:1. (PN 50/2012, s. 37)

Katowice: Od trzech lat tereny nieczynnej Kopalni Węgla Kamiennego Katowice położone w samym centrum Katowic, stolicy Górnego Śląska, są prawdziwą Mekką dla wszystkich miłośników nowych brzmień elektronicznych. (VG 16/2012, s. 4)

Kluż-Napoka: Jeśli chodzi o stolicę Siedmiogrodu, znacznie lepiej wiedzie się szczególnie w XXI wieku zespołowi CFR. (PN 49/2012, s. 11)

Kraków: Ponieważ miasto pod Wawelem nie jest areną Euro 2012, liczba fanów, którym zechce się zboczyć z trasy, aby zobaczyć być może reprezentantów robiących zakupy w Galerii Krakowskiej albo pijących kawę na przykład w Sukiennicach, będzie więcej niż skromna. (PN 46/2011, s. 38)

U stóp Wawelu narodziło się plemię wojowniczych partyzantów miejskich, rodzaj krakowskich guerillas. (P 5/2011, s. 96)

Bo nie dość, że włoski szkoleniowiec, który uchodzi za konesera dzieł sztuki, zdecydował się na stolicę Małopolski, to jeszcze spodobał mu się hotel położony o rzut kamieniem od Rynku Głównego. (PN 46/2011, s. 38)

Przecież w mieście Kraka są dwa nowoczesne obiekty Wisły i Cracovii, gdzie warunki do prowadzenia treningów są o niebo lepsze niż na Suchych Stawach. (PN 46/2011, s. 38) 
WAGs, jak zwie się te panie, zapewne są już po wstępnych rozmowach z jakąś agencją turystyczną, która zorganizuje im przyjemny pobyt w grodzie Kraka. (PN 46/2011, s. 38)

Księżyc: Także w 2014 r. na Księżycu ma się stawić indyjsko-rosyjski lądownik bezzałogowy, poprzednio indyjska sonda była na Srebrnym Globie w 2008 r. i jako pierwsza w historii odnalazła tam ślady wody. (P 51-52/2012, s. 63-64)

Liverpool: Liverpool, czyli miasto Beatlesów, jest położony na zachodnim wybrzeżu północnej Anglii, około 340 km od Londynu, na północnym brzegu estuarium rzeki Mersey. (PN 15/2012, s. 37)

Łomnice: Łomnice - imprezowa stolica słowackich Tatr - nocą rozbrzmiewa klubowymi rytmami. (NŻ 2/2012, s. 24)

Łódź: Wychowankowie - MichałŁabędzki, Marek Saganowski, Rafał Kujawa czy Artur Gieraga - mogą chodzić po mieście włókniarzy z podniesionymi głowami. (PN 20/2012, s. 18)

Społeczeństwo zawsze mieliśmy ofiarne, ale łódzkie szwaczki nie należą do bogatej kasty, co prężniejsze zakłady pracy w polskim Manchesterze też już dawno odwróciły się plecami do piłkarzy. (PN 5/2012, s. 47)

Jeśli potwierdzi się podpisanie kontraktu przez byłego już ełkaesiaka Marcina Kaczmarka z Widzewem, to przez chwilę przy Piotrkowskiej i wokół zrobi się o tym głośno. (PN 3/2012, s. 13)

Manchester: Po remisie Manchesteru United u siebie z Evertonem i wygranej Manchesteru City z Wolverhampton hitowo zapowiada się konfrontacja zespołów z miasta włókniarzy w poniedziałek 30 kwietnia. (PN 17/2012, s. 34)

Mars: Hindusi przechwalają się nawet, że jako pierwsi z Azji zameldują się na marsjańskiej orbicie. (P 51-52/2012, s. 63)

Start ich sondy zaplanowano na listopad 2013 r., więc w okolice Czerwonej Planety powinna dotrzeć w połowie 2014 r. (P 51-52/2012, s. 63)

Meksyk: Wydawało się, że mecz zakończy się wynikiem 2:0 dla piłkarzy z kraju Azteków, ale w czasie doliczonym przez sędziego honorowego gola dla Brazylii strzelił Hulk. (PN 33/2012, s. 38)

Monachium: Jednak przeważającym czynnikiem była chyba trudna adaptacja w specyficznym otoczeniu klubu ze stolicy Bawarii. (PN 17/2012, s. 28)

Niemcy: Niemcy - kraj autostrad i porządku... (VG 7/2011, s. 14)

A wam z czym kojarzy się nasz zachodni sąsiad? (VG 7/2011, s. 14) 
Jeśli zresztą tego nie zrobi, Franciszek Smuda będzie musiał zrobić użytek ze swego niemieckiego paszportu i ewakuować się za Nysę i Odrę, gdyż nad Wisłą nie będzie miał czego szukać. (PN 49/2011, s. 2)

Jeszcze kilkadziesiąt godzin przed pierwszym meczem reprezentacji Niemiec na Euro za naszą zachodnią granicą panował spory niepokój. (PN 24/2012, s. 29)

Palestyna: Aktorka (38) zabrała narzeczonego Roberta w podróż przedślubną do Ziemi Świętej. (NŻ 13/2012, s. 4)

Mało komu trzeba opisywać urodę tych okolic Ziemi Świętej, do której dziś masowo pielgrzymują i Polacy. (P 51-52/2012, s. 20)

Polska: Polska zza żelaznej kurtyny, ojczyzna Wajdy, Kantora, potem Wałęsy i Solidarności - to był temat. (P 51-52/2012, s. 159)

Ba, że w ogóle ktoś między Bugiem i Odrą wykaże się tak szaloną inicjatywą. (PN 5152/2011, s. 2)

O to samo chciałbym zapytać odpowiedzialnych za arbitrów i asystentów w pięknym kraju nad Wisłą. (PN 49/2011, s. 33)

Jeśli Jürgen Klopp nam pokazał, co może osiągnąć z polskimi piłkarzami utalentowany trener z kraju o wyżej rozwiniętej kulturze futbolowej, to Franz Smuda dowiódł, jak można błyskawicznie zwinąć im skrzydła i sformatować na jedenastkę po polsku rozmemłaną, co to wciela w życie najsłynniejsze bon moty legendarnych trenerów z kraju nad Wisłą (w tym przypadku sławetne „Wygraliśmy jedną połowę” Wojciecha Łazarka). (P 24/2012, s. 14)

Paryż: David B., jako jeden z ekspertów od wody kolońskiej po goleniu, czułby się jak ryba w wodzie w stolicy mody i perfum. (PN 45/2011, s. 29)

Portugalia: Portugalia - kraj odkrywców, kibiców i fado (VG 1/2011, s. 16)

Rumunia: Rumunia - ojczyzna wampira i niedźwiedzi... (VG 8/2011, s. 22)

Rzym: Włochy - rodzina, pizza i Wieczne Miasto (VG 6/2011, s. 2)

Dzięki tej wygranej piłkarze z Wiecznego Miasta awansowali na piątą pozycję w tabeli. (PN 41/2012, s. 28)

Stambuł: Kiedy znudziło mu się życie w metropolii nad Bosforem, wrócił do Premier League, by bronić najpierw barw Boltonu, a ostatnio Chelsea. (PN 51-52/2011, s. 89)

Szwecja: Nie znamy wyniku pierwszego meczu Ukraińców na Euro 2012 (w poniedziałek współgospodarze zagrali na Stadionie Olimpijskim w Kijowie ze Szwecją), ale jeśli Błochinowi udało się ograć zespół Trzech Koron, dobitnie potwierdził wszystkie przedturniejowe zapowiedzi. (PN 24/2012, s. 24)

Ukraina: Wkrótce Puchar Henri Delaunaya trafi do innych miast nad Wisłą, a potem zostanie przeniesiony do kraju współorganizatora Euro 2012. (PN 17/2012, s. 21) 
Węgry: Węgry - kraj, który ma ostry smak papryki... (VG 2/2011, s. 2)

Wiedeń: Chciał pooddychać alpejskim powietrzem, poczuć atmosferę światowej stolicy walca, a przy okazji rzucić pańskim okiem na nieruchomość, którą ma w Austrii od czasu występów w tamtejszej Bundeslidze. (PN 50/2012, s. 4)

Wisła: Kto wie, może osiemdziesiąt lat po tak zwanym Cudzie nad Wisłą, ponownie na obiekcie położonym nad królową polskich rzek zdarzy się cud - piłkarski. (PN 24/2012, s. 47)

Wrocław: Trudno w to uwierzyć, ale w największym muzeum stolicy Dolnego Śląska nie można było obejrzeć europejskiej sztuki od ponad 20 lat. (P 50/2012, s. 83)

Zefat: Tradycja tych przedziwnych pielgrzymek ma swoje początki w XVI stuleciu, gdy miasteczko Zefat przekształciło się w światowe centrum żydowskiego mistycyzmu, czyli Kabały, a mędrcy owego okresu znajdowali wieczny odpoczynek w galilejskiej ziemi, w pobliżu ich uczonych w Piśmie Świętym poprzedników. (P 24/2012, s. 100)

Żyrardów: Jest ich coraz więcej, bo mieszkania w Skierniewicach są tańsze niż w Żyrardowie, nazywanym już od dawna sypialnią stolicy. (P 13/2012, s. 102)

W zgromadzonym materiale bardzo liczną grupę stanowią peryfrazy zastępujące oficjalne jednoczłonowe nazwy geograficzne - dotyczy to miast, krajów i kontynentów, a nawet planet. Wyróżnić można kilka charakterystycznych podstaw: komponent stolica (stolica Podlasia, stolica Siedmiogrodu, stolica Małopolski, imprezowa stolica słowackich Tatr, stolica mody i perfum, światowa stolica walca) i miasto (miasto Neptuna, miasto Beatlesów, miasto włókniarzy, Wieczne Miasto, miasto pod Wawelem) w odniesieniu do miast; ojczyzna (ojczyzna wolności seksualnej, ojczyzna wampira i niedźwiedzi), kraj (Kraj Kawy, Kraj Tysiąca Jezior, kraj nad Sekwaną, Kraj Tulipanów, Kraj Kwitnacej Wiśni, Kraj Wschodzącego Słońca, kraj autostrad i porządku, kraj odkrywców, kibiców i fado, kraj współorganizatora Euro 2012, kraj, który ma ostry smak papryki) i kolebka (kolebka futbolu, kolebka naszej europejskiej cywilizacji) - w odniesieniu do państw. Charakterystyczne jest to, że w celu opisania nazw własnych niejednokrotnie wykorzystuje się inne nomina propria, np. stolica Bawarii, kraj Azteków, kraj nad Wisłą, ojczyzna Wajdy, Kantora, potem Wałęsy i Solidarności. Wydaje się, że ostatni przywołany przykład mógłby też funkcjonować w postaci czterech odrębnych wyrażeń omownych: ojczyzna Wajdy, ojczyzna Kantora, ojczyzna Wałęsy, ojczyzna Solidarności. Zatem oprócz nawiązań funkcjonujących już od dawna pojawiły się także nowsze określenia, odwołujące do wydarzeń politycznych i kulturalnych. 
Liczba komponentów wchodzących w skład konstrukcji analitycznych waha się od dwóch (najliczniej reprezentowana grupa, np. Czarny Ląd, Stary Kontynent, maly Paryż), przez trzy (kraj nad Sekwana, najpiękniejsza wyspa Karaibów, światowa fabryka sprinterów), cztery (zagłębie polskiego czarnego sportu, światowe centrum żydowskiego mistycyzmu, ojczyzna wampira i niedźwiedzi), pięć (zielona wyspa z celtycką tradycją, kraj odkrywców, kibiców i fado) do siedmiu (ojczyzna Wajdy, Kantora, potem Wałęsy i Solidarności). Odnotowano też rozbudowane połączenie, które przyjmuje postać zdania: kraj, który ma ostry smak papryki.

Niektóre wielowyrazowe określenia, np. odnoszące się do Nyonu: Decyzje dotyczace sprzedaży praw do transmisji zawodów, wyboru sponsorów międzynarodowych i narodowych, a także licencjobiorców chcących wykorzystywaćprawa do symboliki mistrzostw zapadaja w Nyon, małej szwajcarskiej miejscowości nieopodal Genewy, gdzie centralę ma UEFA. (P 13/2012, s. 13), pojawiają się jednostkowo, są mocno osadzone w kontekście, trudno określić, czy przyjmą się w języku na stałe.

Pod względem formalnym badane analityzmy składają się z rzeczowników w mianowniku i rzeczowników w dopełniaczu w funkcji przydawki (perła Adriatyku, mekka improwizacji, Wyspa Afrodyty), rzeczowników uzupełnionych o przydawki przymiotne (polski Manchester, mały Paryż, największy kraj muzułmański), przyimkowe (kraj nad Sekwana, kraj nad Wisła, metropolia nad Bosforem), przydawkowych określeń w postaci różnych części mowy, np. rzeczowników i przymiotników (kraj wolności seksualnej, najpiękniejsza wyspa Karaibów, imprezowa stolica słowackich Tatr), zaimka i przymiotnika (kolebka naszej europejskiej cywilizacji, nasz zachodni sasiad), rzeczownika i imiesłowu (Kraj Kwitnącej Wiśni, Kraj Wschodzącego Słońca), rzeczownika i liczebnika (Kraj Tysiaca Jezior).

Konstrukcja peryfrastyczna miasto włókniarzy odnosiła się do dwóch różnych jednowyrazowych nazw własnych (Łódź, Manchester), jednak zdecydowanie częściej zdarza się, że to ten sam syntetyzm ma kilka odpowiedników o zróżnicowanej strukturze. Pięć odpowiedników ma Kraków - z czego dwa zawierają wspólne morfemy z oficjalną nazwą (gród Kraka, miasto Kraka), kolejne trzy nie wykazują pokrewieństwa morfologicznego, są to stolica Małopolski i - wykorzystujące odwołanie do nazwy własnej - miasto pod Wawelem oraz u stóp Wawelu. Po trzy określenia o odmiennej budowie przylgnęły do Jamajki (kraj Bonda, Marleya i Bolta, światowa fabryka sprinterów, najpiękniejsza wyspa Karaibów), Łodzi (miasto włókniarzy, polski Manchester, przy Piotrkowskiej i wokót), Niemiec (nasz zachodni sąsiad, za Nysą i Odrą, za naszą zachodnią granica) 
i Polski (ojczyzna Wajdy, Kantora, potem Wałęsy i Solidarności, między Bugiem a Odrą, kraj nad Wisła - raz odnotowane z wartościującą przydawką piękny). Oba alternatywne określenia Afryki - Czarny Ląd i Czarny Kontynent - opierają się na komponencie przymiotnikowym czarny. Częstochowa bywa nazywana małym Rzymem, a także zagłębiem polskiego czarnego sportu. Francję określa się jako ojczyznę wolności seksualnej oraz kraj nad Sekwaną. Peryfrazy odnoszące się do Japonii - Kraj Wschodzącego Słońca i Kraj Kwitnącej Wiśni - mają w podstawie element rzeczownikowy kraj. Mars określany jest opisowo marsjańska orbita (widoczna jest substancjalna tożsamość między tymi dwoma określeniami) oraz Srebrnym Globem (syntetyzm i odpowiadający mu analityzm nie mają wspólnych morfemów).

Odnotowano też przykłady wyrażeń omownych, które odwołują co prawda do nazw geograficznych (Anglia, Czarnogóra, Ghana, Nigeria), jednak odnoszą się raczej do przydomków reprezentacji tych krajów, a nie kraju rozumianego jako region charakteryzujący się swoistymi cechami geograficzno-historycznymi. Ze względu na podobny schemat tworzenia tych nazw można umieścić je w tej grupie:

Anglia: Polak potrafi, a rywal również przeżywa ostatnio spore problemy, bo prezentująca najwyższy poziom i jakże lukratywna Premiership nie przekłada się na sukcesy drużyny narodowej spod znaku trzech lwów. (PN 41/2012, s. 47)

Czarnogóra: W eliminacjach mistrzostw świata, które w 2012 roku odbyły się w RPA, Waleczne Sokoły spisały się słabo, zajęły dopiero piąte miejsce w grupie za Włochami, Irlandią, Bułgarią i Cyprem, a wyprzedziły tylko Gruzję, z którą odniosły jedyne zwycięstwo. (PN 36/2012, s. 6)

Ghana: W zespole Czarnych Gwiazd grał wtedy Abedi Ayew Pele, a na PNA 2012 rodzinne tradycje kontynuują jego synowie: Jordan Ayew i Andre Ayew, który wykorzystał koszmarny błąd tunezyjskiego bramkarza i strzelił gola dającego Ghanie zwycięstwo 2:1. (PN 6/2012, s. 6)

Nigeria: Fankluby reprezentacji Super Orłów ${ }^{107}$ rozsiane są w wielu krajach. (PN 46/2011, s. 33)

107 Zgodnie z polskimi zasadami ortograficznymi wyrazy z przedrostkiem supernależy pisać łącznie i wówczas byłby to syntetyzm leksykalny, przydomek ten funkcjonuje jednak jako nazwa składająca się z dwóch elementów i dlatego może być zaliczony do konstrukcji analitycznych. 
Wśród zgromadzonych przykładów wyodrębniono też jeden przypadek, kiedy to nazwie własnej dwuczłonowej odpowiada jednoelementowe określenie mamy więc do czynienia z odwrotnym zjawiskiem niż to w opisywanej wyżej grupie. Dzieje się tak w parze Wielka Brytania - Wyspa: Poddawani sa przy tym presji, której w Wielkiej Brytanii nie doświadcza minister pomniejszego resortu. (PN 49/2011, s. 33)

\subsubsection{Nazwy wtasne osobowe}

Adriano: Nikt nie zawraca sobie nim głowy, mimo że Inter bije rywala aż 4:0 po bramce Figo i aż trzech Adriano. Balangowicza z Rio. (PN 48/2012, s. 12)

Diego: Brazylijski marszałek jego [trenera Lorenza-Guenthera Koestnera - przyp. KB] wojska nadal grał bardzo dobrze. (PN 49/2012, s. 23)

Eusebio: Częściej od Czarnej Perły z Mozambiku na telebimach pojawiał się inny Portugalczyk, trener Realu Madryt Jose Mourinho, który oglądał mecz w towarzystwie synka. (PN 24/2012, s. 10)

Grek: Obrona przybyszów z Hellady ze wspaniałym Traianosem Dellasem oraz bezbłędnym bramkarzem Antoniosem Nikopolidisem na czele grała doskonale. (PN 11/2012, s. 27)

Madonna: Łzy królowej popu (NŻ 5/2012, s. 12)

Maryja: Marek Jurek, Michał Kamiński i Tomasz Wołek postanowili w dowód wsparcia i uznania wręczyć mu ryngraf z Matką Boską jako wyraz solidarności w imieniu polskiej prawicy. (P 51-52/2012, s. 34)

Pele: Taką koszulkę przygotował sobie Król Futbolu, Pele, na mecz, w którym zdobył pamiętną, tysięczną, bramkę w karierze. (PN 6/2012, s. 37)

Żyd: A skoro tak uważa Grant, czyli Żyd, a więc człowiek nacji słynącej z biznesowej żyłki, to musi być w tym duża porcja prawdy. (PN 51-52/2011, s. 89)

Wielowyrazowe odpowiedniki mają nie tylko nazwy geograficzne, ale także antroponimy. Jako że w pracy zajęto się jedynie peryfrazami zastępującymi jeden wyraz, to w materiale znalazły się tylko odniesienia do osób, które na co dzień posługują się wyłącznie syntetycznym pseudonimem czy przypisane im jest jedynie imię. Pominięto liczne wyrażenia omowne wprowadzane w miejsce imienia i nazwiska. Najliczniejszą grupę w tym zestawieniu reprezentują złożone określenia zastępujące przydomki piłkarzy: Adriano bywa używany wymiennie ze sformułowaniem balangowicz z Rio, Diego nazywany jest brazylijskim marszałkiem wojska, Eusebio - Czarna Perła z Mozambiku, peryfrastyczne miano 
Pelego zaś to Król Futbolu. Na komponencie królowa opiera się analityczne określenie Madonny - królowa popu. Kilkuwyrazowymi połączeniami posłużono się także w odniesieniu do narodowości - analityczne przybysz z Hellady pojawiło się w miejsce Greka, nacja slynąca z biznesowej żytki to z kolei odpowiednik Żyda. Zastępnikiem Maryi - oprócz przywołanego połączenia Matka Boska - może być także wypowiedzenie złożone ciężarna dziewica, która stanęła samotnie naprzeciwświata, wczasach, gdy kamienowano za przedmalżeński seks: W historii tej ciężarnej dziewicy, która stanęła samotnie naprzeciw świata, w czasach, gdy kamienowano za przedmałżeński seks? (P 51-52/2012, s. 24). Ponieważ sformułowanie takie ma charakter doraźny, mało prawdopodobne, by zostało zastosowane ponownie, a tym bardziej weszło do powszechnego użycia.

Ze względu na strukturę można wyróżnić połączenia zbudowane z rzeczownika w mianowniku i rzeczownika w dopełniaczu (królowa popu, Król Futbolu), rzeczownika i wyrażenia przyimkowego (przybysz z Hellady, balangowicz z Rio), przymiotnika i rzeczownika (Matka Boska), przymiotnika, rzeczownika i zaimka (brazylijski marszałek jego wojska), rzeczownika, przymiotnika i wyrażenia przyimkowego (Czarna Perła z Mozambiku), rzeczownika, imiesłowu, przymiotnika i wyrażenia przyimkowego (nacja stynąca $z$ biznesowej żyłki). Liczba komponentów w tej grupie waha się od dwóch do pięciu.

\subsubsection{Nazwy własne odnoszące się do różnych nieosobowych desygnatów}

Biblia: Młody Jezus rozmawiał z rabinami, znawcami Pisma Świętego. (P 51-52/2012, s. 21)

Chevrolet: Z początkiem sezonu 2014-15 na koszulkach zawodników najpopularniejszego klubu piłkarskiego na świecie pojawi się logo amerykańskiego giganta samochodowego. (PN 33/2012, s. 17)

Facebook: Politycy lubią pokazywać się na największym portalu społecznościowym. (P 51-52/2012, s. 38)

Ferrari: Obsługa ocenia, czy to potencjalny klient, czy może zwykły miłośnik motoryzacji, który chce tylko z bliska zobaczyć, jak wygląda 1,2 mln zł na kołach. (P 51-52/2012, s. 54)

Auta sprzedają się jak świeże bułeczki, tegoroczna pula została wyczerpana już w lutym, a polski dealer firmy z Maranello dostał z centrali nagrodę za sprzedaż samochodów z najbogatszym wyposażeniem. (P 51-52/2012, s. 54)

Koran: Świętą księgę islamu czeka wkrótce to, co spotkało Biblię pod koniec XIX w., czyli zderzenie z rozumem. (P 51-52/2012, s. 70) 
Oskary: W Fabryce Snów po raz 84. wręczono najbardziej pożądane złote statuetki na świecie. (NŻ 9/2012, s. 7)

Rolls-Royce: Autami z silver lady na masce cieszy się już kilkudziesięciu Polaków. (P 51-52/2012, s. 55)

Słynna ikona brytyjskiej motoryzacji - Rolls-Royce - została uratowana przed bankructwem przez koncern BMW, a Bentleya ocalił Volkswagen. (P 51-52/2012, s. 56)

Wembley: W ostatnią niedzielę w świątyni futbolu, za jaką uchodzi Wembley, królowała meksykańska fala. (PN 33/2012, s. 38)

Alternatywnych sformułowań używa się również dla określenia chrematonimów, wśród nich znaczącą grupę stanowią peryfrazy odnoszące się do marek samochodów. Firmom Rolls-Royce oraz Ferrari odpowiadają po dwa analityczne związki o zróżnicowanej strukturze: odpowiednio auto $z$ «silver lady» na masce i ikona brytyjskiej motoryzacji oraz 1,2 mln zł na kołach ${ }^{108}$ i firma z Maranello. Pozostałe nazwy zgromadzone w tej grupie mają po jednym odpowiedniku. Podstawą obu analityzmów odnoszących się do atrybutów religijnych jest przymiotnik święty - Biblia nazywana jest Pismem Świętym, do Koranu zaś przylgnęło miano święta księga islamu.

W skład konstrukcji analitycznych zgromadzonych w tym zestawieniu wchodzą połączenia rzeczowników z przydawką przymiotną (Pismo Święte, amerykański gigant samochodowy, największy portal społecznościowy), przydawką rzeczowną wyrażoną rzeczownikiem w dopełniaczu (świątynia futbolu), oboma wymienionymi rodzajami przydawek (ikona brytyjskiej motoryzacji), przydawką przyimkową (firma z Maranello). Nie zabrakło także połączeń różnych części mowy (rzeczowniki, liczebniki, przysłówki, przymiotniki, imiesłowy) z wyrażeniami przyimkowymi, np. 1,2 mln zł na kołach, najbardziej pożadane złote statuetki na świecie, auto $z$ «silver lady» na masce.

Pod względem liczebności komponentów grupa ta jest zróżnicowana, pojawiają się bowiem konstrukcje liczące od dwóch do sześciu elementów, żadna z nich nie jest dominująca.

\subsection{Skrótowiec nazwy własnej a nazwa wielowyrazowa}

108 Określenie to jest mało precyzyjne, może odnosić się do wielu desygnatów, by trafnie je odczytać, trzeba zapoznać się z artykułem. 
UEFA: Na początku ubiegłego tygodnia do położonej nad Jeziorem Genewskim w Nyonie siedziby władz europejskiego futbolu zaproszono przedstawicieli mediów, którym przedstawiono międ zy innymi dość znamienne dane. (PN 5/2012, s. 33)

FIFA: Ze światowej federacji wyszedł do AFA faks przypominający, że statut FIFA zabrania mieszania sportu i polityki. (PN 8/2012, s. 39)

Z najnowszego audytu obejmującego rok finansowy 2009-10 wynika, iż 665 klubów, w których sprawozdania księgowe ma wgląd centrala futbolu, dorobiło się strat sięgających 1,6 miliarda euro. (PN 5/2012, s. 33)

Wśród skrótowców nazw własnych odnaleziono dwa, które bywają używane naprzemiennie nie tyle z pełnymi nazwami, ile z określeniami peryfrastycznymi. Przyczyną nieużywania rozwiniętych nazw może być fakt, że są to skrótowce nazw obcojęzycznych, stąd pełne nazwy nie są tak rozpowszechnione w polszczyźnie. W ich miejsce pojawiają się wielowyrazowe władze europejskiego futbolu w odniesieniu do UEFA oraz światowa federacja i centrala futbolu w miejsce FIFA.

Przywołane analityzmy są kombinacją przymiotnika z rzeczownikiem (światowa federacja), rzeczownika w mianowniku z rzeczownikiem w dopełniaczu (centrala futbolu), uzupełnionego raz o przymiotnik (władze europejskiego futbolu). Składają się zatem z dwóch lub trzech komponentów.

\section{Podsumowanie}

Zaprezentowana w tym rozdziale analiza strukturalna analitycznych konstrukcji leksykalnych mających syntetyczne odpowiedniki dowodzi, że grupa ta jest wewnętrznie zróżnicowana. Kryterium nadrzędnym było przeciwstawienie wyrazów pospolitych nazwom własnym. Na kolejny plan wysuwa się podział multiwerbizmów na takie, które zawierają wspólne morfemy z odpowiadającymi im formami prostymi, oraz te, które nie wykazują morfologicznego pokrewieństwa. Wśród wyrazów pospolitych spokrewnionych z ekwiwalentami najliczniej reprezentowane są analityczne rzeczowniki, dużą grupę stanowią też czasowniki, zdecydowanie rzadziej występują przymiotniki i przysłówki - odnotowano zaledwie po kilka przykładów. Na szczególną uwagę zasługują związki frazeologiczne, których jednowyrazowe odpowiedniki reprezentują bogaty repertuar części mowy (czasowniki, rzeczowniki, przymiotniki, przysłówki, a nawet zaimki, liczebniki i modulanty - poświadczone w jednostkowych tekstach). Pod względem formalnym zgromadzone frazeologizmy zaliczane są do wyrażeń i zwrotów, te 
drugie nierzadko podlegają nominalizacji (np. bujanie w obłokach, zaciskanie pasa, rzucanie mięsem) lub adiektywizacji (np. znający się na rzeczy, wyssane $z$ palca). W zbiorze nazw własnych wspólne morfemy widoczne są zwłaszcza w grupie przezwisk zastępujących imiona i nazwiska oraz przydomków klubów, znacznie rzadziej substancjalna tożsamość obecna jest w nazwach geograficznych i ich peryfrastycznych ekwiwalentach. Zabieg formalny, który uwidacznia obecność wspólnych cząstek, to uniwerbizacja - wykorzystywana przez dziennikarzy do tworzenia różnorodnych syntetyzmów, przede wszystkim za pomocą elipsy deadiektywizującej lub substantywizującej, choć pojawiają się też - i to wcale nierzadko - przykłady zastosowania derywacji sufiksalnej i dezintegracji.

Wyraźnie zaznacza się tendencja do substantywizacji przymiotników, procesowi temu podlegają wyrazy należące do obu głównych grup, np. apelatywy wolny, polski, schabowy oraz takie nomina propria, jak chociażby: Niebiescy, Królewscy czy Lewy.

Charakteryzując użycie poszczególnych części mowy w strukturach analitycznych, trzeba podkreślić, że bardzo chętnie wykorzystywane są połączenia rzeczowników w mianowniku z rzeczownikami w dopełniaczu, rzeczowników z przymiotnikami (w przypadku analityzmów rzeczownikowych), czasowników z rzeczownikiem w bierniku i dopełniaczu, a także wyrażeniem przyimkowym (w przypadku analityzmów czasownikowych), wyrażeń przyimkowych z przymiotnikami (w przypadku analityzmów przymiotnikowych i przysłówkowych). Charakterystycznymi podstawami leksykalnych struktur czasownikowych są m.in. dać, doznać, mieć, odnotować, poddać, prowadzić, udzielać i zaliczyć, wśród wielowyrazowych połączeń rzeczownikowych dużą frekwencję wykazuje rzeczownik odczasownikowy dokonanie, do którego przyłączane są rzeczowniki $\mathrm{w}$ dopełniaczu.

Liczba członów wchodzących w skład multiwerbizmów jest zróżnicowana, wydaje się jednak, że przeważają połączenia zbudowane z dwóch i trzech składników. Nie brakuje także pięcio-, sześcio- czy nawet siedmioelementowych połączeń. Zaznaczyć należy, iż kilkanaście konstrukcji analitycznych złożonych było z wielu komponentów (często przyjmowało nawet formę wypowiedzenia), co uzmysławia, że nawet w dobie ekonomizacji języka wieloczłonowe struktury są obecne w artykułach prasowych - służyć mają być może precyzyjnemu przekazaniu treści albo - wręcz przeciwnie - zakamuflowaniu intencji autora. Rozważania nad stylistycznymi aspektami tych połączeń zostaną szczegółowo przedstawione w kolejnych częściach niniejszej rozprawy. 
Warto podkreślić, że nierzadko spotykamy się z możliwością, kiedy jednemu syntetyzmowi odpowiada kilka analityzmów o zróżnicowanej budowie (mogą one mieć z nim wspólne morfemy, nie posiadać wspólnych cząstek lub przynależeć do związków frazeologicznych). Wśród czasowników da się wyróżnić nawet takie, które mają kilkanaście ekwiwalentów, np. wygrać, przegrać, umrzeć. Pamiętać należy, że bardzo rzadko zachodzi między pojedynczym leksemem a jego rozbudowanym zastępnikiem całkowita zgodność znaczeniowa, zwykle każda z tych konstrukcji ma na celu podkreślenie konkretnych odcieni semantycznych.

Czasem dochodzi do sytuacji odwrotnej - ta sama konstrukcja peryfrastyczna może być wyrażona ekonomicznymi odpowiednikami o odmiennej strukturze. Bywa też tak, że ten sam pod względem formy syntetyzm odnosi się do zupełnie odmiennych desygnatów, sytuacja taka została odnotowana zwłaszcza w grupie nazw własnych, jako egzemplifikacje mogą posłużyć Narodowy, Mały czy Górale. 



\section{Semantyka}

Semantyka definiowana jest jako dziedzina językoznawstwa zajmująca się znaczeniem wyrazu, badaniem zależności między znaczeniem a formą wyrazu oraz wartością podstawową wyrazu a jego aktualnym znaczeniem w wypowiedzeniu1. Stanisław Kania i Jan Tokarski, opisując główne językoznawcze koncepcje znaczenia, zwrócili uwagę na trzy teorie: asocjacjonistyczną, określającą znaczenie jako sposób użycia wyrazu oraz relatywistyczną. Według pierwszej z nich znaczenie to związek skojarzeniowy między stroną brzmieniową wyrazu a odpowiadającym mu obrazem przedmiotu (zjawiska)². Druga koncepcja głosi, że „znaczenie wyrazu jest nam wtedy znane, gdy wiemy, jaki kiedy tego wyrazu używać, jak się nim posługiwać, tzn. w jakich okolicznościach jego użycie jest poprawne, a w jakich niepoprawne"3. Relacja wyrazu do przedmiotu (do rzeczywistości), relacja wyrazu do pojęcia i relacja wyrazu do systemu leksykalnego to - zgodnie z teorią relatywistyczną - czynniki, które pozwalają określić znaczenie ${ }^{4}$. Władysław Miodunka twierdzi, że semantyka strukturalna „obejmuje swym zasięgiem nie tylko analizę składnikową znaczenia wyrazów tworzących pole językowe, lecz także opis relacji znaczeniowych między wyrazami"5. Podstawowe zadanie polega na

1 S. Kania, J. Tokarski, Zarys leksykologii i leksykografii polskiej, Warszawa 1984, s. 155.

2 Ibidem, s. 156.

3 Ibidem.

4 Ibidem, s. 157.

5 W. Miodunka, Podstawy leksykologii i leksykografii, Warszawa 1989, s. 134. 
wydzielaniu semów ${ }^{6}$, czyli najmniejszych składników znaczenia 7 . Semy powinny być ułożone hierarchicznie: „od semów ogólnych do coraz bardziej szczegółowych, pozwalających różnicować znaczenia poszczególnych wyrazów"8. Włodzimierz Zwiegincew postuluje, że znaczenie leksykalne wyrazu kształtowane jest przez trzy czynniki: łączliwość wyrazu z określoną klasą przedmiotów, związek wyrazu z określonym pojęciem, funkcję językową, czyli „moment, który rodzą i determinują wewnętrzne stosunki między jednostkami leksykalnymi jako częściami konkretnego (leksykalnego) systemu"9. Zmiany wartości wyrazu mogą więc dotyczyć treści, zakresu i funkcji ${ }^{10}$.

Niezbędne dla prowadzenia dalszych rozważań na temat różnic znaczeniowych między pojawiającymi się we współczesnej polskiej prasie analityzmami leksykalnymi a ich syntetycznymi odpowiednikami jest wyjaśnienie terminu synonimia. Przez pojęcie to rozumie się „wyrażanie tej samej treści za pomocą dwu lub więcej różnych form językowych"l1, badacze wyróżniają synonimię pełną (zwaną inaczej absolutną, całkowitą) oraz synonimię częściową. Jak czytamy w Encyklopedii językoznawstwa ogólnego: „Pierwsza zakłada nieograniczoną wymienność odnośnych wyrażeń we wszystkich kontekstach i całkowitą ich identyczność znaczeniową. [...] Synonimia częściowa polega na wymienności wyrażeń tylko w niektórych kontekstach, [...] nie zakłada także całkowitej identyczności znaczeniowej”'12. Językoznawcy podkreślają, że synonimia całkowita jest zjawiskiem, które w obrębie słownictwa praktycznie obecnie nie występuje.

6 Sem to najmniejsza jednostka w planie treści. W tym samym znaczeniu używa się także terminów „cecha semantyczna” i „składnik semantyczny”. Semy nie mają swoich odpowiedników w planie wyrażania. Definicja za: Encyklopedia językoznawstwa ogólnego, red. K. Polański, Wrocław-Warszawa-Kraków 1993, s. 478.

7 W. Miodunka podkreśla: „semami powinny być w miarę możliwości wyrazy nie należące do analizowanego języka. Jeśli jednak są to wyrazy występujące w słowniku tego języka, ich użycie w roli semów powinno być jednoznacznie określone, tzn. wolne od wieloznaczności typowej dla języka potocznego", W. Miodunka, op. cit., s. 131 .

8 W. Miodunka, op. cit., s. 132.

9 W. Zwiegincew, Semazjologia, Warszawa 1962, s. 203.

10 Por. B. Kudra, Kreatywność leksykalna $w$ dyskursie polskiej prasy lat osiemdziesiatych i dziewięćdziesiątych, Łódź 2001, s. 145; K. Michalewski, Kreowanie wartości wyrazów, [w:] Współczesna leksyka, red. K. Michalewski, cz. 2, Łódź 1998, s. 3-8.

11 Encyklopedia językoznawstwa..., s. 533.

12 Ibidem, s. 534. 
Stanisław Skorupka dokonał rozróżnienia na synonimy bliższe i dalsze. Do pierwszych zaliczył „wyrazy, których treści znaczeniowe i zakresy użyć pokrywają się ze sobą w znacznej mierze”13, synonimy dalsze natomiast to „wyrazy, których treści znaczeniowe i zakresy użyć pokrywają się tylko częściowo”14. D. Buttler, H. Kurkowska i H. Satkiewicz zauważyły, że synonimy łączą się w szeregi zorganizowane wokół jednego wyrazu, zwanego dominantą. W przeciwieństwie do pozostałych członów ciągu jest on nienacechowany emocjonalnie i stylistycznie ${ }^{15}$. Zdaniem badaczek synonimy mogą różnić się ubocznymi cechami znaczeniowymi, przynależnością do odmian współczesnej polszczyzny lub jej warstw stylowych oraz dystrybucją, czyli zdolnością do występowania w określonych kontekstach. W. Miodunka uważa, że o synonimii można mówić wtedy, gdy „między dwoma zdaniami zachodzi implikatura dwustronna, czyli zdania zawierające dane wyrazy są ekwiwalentne [...]. Dodatkowym argumentem za uznaniem wyrazów za synonimy jest fakt, że ich znaczenie daje się opisać za pomocą tych samych semów"16.

Jako przykłady wyrazów równoznacznych autorzy Zarysu leksykologii i leksykografii polskiej podają wyrazy obcego pochodzenia i ich spolszczenia, zaznaczając jednocześnie, że często taka równoznaczność okazuje się pozorna. We wstępach do współczesnych słowników synonimów redaktorzy niejednokrotnie podkreślają, że choć zakresy znaczeniowe wyrazów jednoznacznych często na siebie zachodzą (czyli wyrazy odsyłają do tego samego desygnatu), to niejednokrotnie różnią się one wartością stylistyczną ${ }^{17}$, np. niektóre są traktowane jako przestarzałe, inne używane są tylko w konkretnych odmianach stylowych (przynależą do stylu potocznego, urzędowego, naukowego, artystycznego) lub środowiskowych (słownictwo regionalne czy socjolektalne), można też dostrzec różnice w nacechowaniu emocjonalnym. Zwraca się też powszechnie uwagę na ograniczenia wymienności

13 S. Skorupka, Z zagadnień leksykografii. Synonimika, „Poradnik Językowy” 1953, z. 4 , s. 24 .

14 Ibidem.

15 D. Buttler, H. Kurkowska, H. Satkiewicz, Kultura języka polskiego. Zagadnienia poprawności gramatycznej, Warszawa 1971, s. 89.

16 W. Miodunka, op. cit., s. 126.

17 Por. Słownik wyrazów bliskoznacznych, red. D. Ludwiczak, A. Piskadłowa, E. Tarka-Huczek, Warszawa 1998; Słownik synonimów, red. A. Dąbrówka, E. Geller, R. Turczyn, Warszawa 1995; hasło synonim w Encyklopedii językoznawstwa...; S. Skorupka, op. cit., s. 15. 
wyrazów bliskoznacznych: „wspólne znaczenie ogólne dwóch lub kilku synonimów nie przesądza jeszcze o możliwości ich zamiennych użyć"18.

Z odpowiedniością znaczenia wiąże się też zagadnienie polisemii, czyli posiadania kilku znaczeń powiązanych ze sobą. „Za wyrazy polisemiczne uważa się takie, które da się sprowadzić do wspólnego źródła, natomiast za homonimy takie, które mają różne pochodzenie etymologiczne"19.

Warto zdefiniować także pojęcie ekwiwalencji. W słownikach języka polskiego możemy przeczytać, że ekwiwalent to 'rzecz równa innej wartością; odpowiednik, równoważnik'20. W pracach poświęconych przekładowi termin ten bywa stosowany wymiennie z adekwatnością, równowartością znaczeniową, równorzędnością oraz równoznacznością ${ }^{21}$. Wśród właściwości ekwiwalencji wymienia się koreferencyjność i względność. Jak twierdzi Dariusz Bralewski, „identyczność ekwiwalentów ze względu na cechę, która stanowi podstawę ekwiwalencji, stwarza możliwość ich wzajemnej zamienności”22. Czesław Lachur podkreśla, że „ten sam wycinek rzeczywistości może być oznaczony wyrazami należącymi do różnych części mowy"23. Twierdzenie to znalazło wielokrotnie potwierdzenie w niniejszej pracy, bardzo często do opisu określonego elementu otaczającego świata używa się bowiem struktur reprezentujących różne kategorie gramatyczne.

Badający relacje między synonimią a ekwiwalencją zaznaczają: „O ile ich wspólną właściwością jest tożsamość odniesienia przedmiotowego, o tyle na synonimy nakłada się dodatkowo warunek identyczności sensu"24. Werner Koller wyróżnił następujące rodzaje ekwiwalencji przekładowej25:

- denotacji - zawarcie tej samej informacji co w oryginale, odsyłanie do tej samej rzeczywistości pozajęzykowej,

18 D. Buttler, H. Kurkowska, H. Satkiewicz, op. cit., s. 103.

19 Encyklopedia językoznawstwa..., s. 408.

20 Mały słownik języka polskiego, red. E. Sobol, Warszawa 2000, s. 183.

21 Por. D. Bralewski, Od przekładu do słownika. Korpus równoległy w redakcji słowników tłumaczeniowych, Łask 2012, s. 201.

22 Ibidem, s. 205. Jako przykład przywołano różne tłumaczenia powieści Maupassanta, w których odpowiednikiem francuskiego zwrotu raz był czasownik ujrzeć, a w kolejnej wersji wyrażenie złożone czyjś wzrok padł na.

23 Cz. Lachur, Zarys językoznawstwa ogólnego, Opole 2004, s. 171.

24 D. Bralewski, op. cit., s. 219.

25 A. Pisarska, T. Tomaszkiewicz, Współczesne tendencje przekładoznawcze. Podręcznik dla studentów neofilologii, Poznań 1998, s. 184. 
- konotacji - jednakowość na poziomie stylu (ten sam rejestr języka, socjolekt, charakterystyka żargonowa),

- normy tekstowej - odpowiedniość norm redakcyjnych (rodzaj tekstu: literacki, naukowy, techniczny, epistolarny itd.),

- pragmatyczna - uwzględnienie możliwości percepcyjnych odbiorców oryginału i przekładu,

- formalno-estetyczna - podobieństwo oryginału i przekładu pod względem efektów estetycznych.

Jako że zaprezentowana typologia dotyczy przekładu, to oczywiście nie wszystko, co zostało przedstawione, będzie istotne dla prowadzonych badań, odrzucić trzeba ekwiwalencję normy tekstowej oraz formalno-estetyczną. Wydaje się, że pozostałe typy mogą znaleźć zastosowanie nie tylko w relacjach między odmiennymi językami, ale także na płaszczyźnie tego samego języka - posługiwanie się konstrukcjami analitycznymi i syntetycznymi można też bowiem potraktować jako rodzaj swoistego przekładu tych samych treści za pośrednictwem wielowyrazowych połączeń i pojedynczych leksemów. Zdaniem D. Bralewskiego ekwiwalencja opiera się na całkowitej i wzajemnej wymienności określonych formuł w tych samych kontekstach komunikacyjnych ${ }^{26}$.

W celu nazwania określonych wycinków rzeczywistości wykorzystuje się czasem relację podobieństwa między dwoma elementami i tworzy określenia metaforyczne. Ryszard Tokarski twierdzi: „dzięki dwutematowej budowie, gdy o właściwościach jednego przedmiotu czy zjawiska orzeka się za pośrednictwem przedmiotu bądź zjawiska innego, metafora poetycka ujawnia często nowe, niejednokrotnie bardzo subiektywne wyobrażenia o istocie metaforyzowanego elementu, nowe aspekty istnienia czegos'"27. Uczony wskazuje na zróżnicowanie funkcjonalne metafor poetyckich i słownikowych: „ta pierwsza jakiś przedmiot czy zjawisko opisuje - często w sposób nowatorski, odkrywczy, metafora słownikowa natomiast ten przedmiot czy zjawisko nazywa"28, w pierwszym przypadku dominuje funkcja predykatywna, a w drugim - identyfikująca.

Mechanizmy substytucyjne leżą u podstaw metonimii, jej istota opiera się na „bardzo regularnych szeregach czasowej lub przestrzennej przyległości, styczno-

26 D. Bralewski, op. cit., s. 226.

27 R. Tokarski, Słownictwo jako interpretacja świata, [w:] Encyklopedia kultury polskiej XX wieku, t. 2: Współczesny język polski, red. J. Bartmiński, Wrocław 1993, s. 347. 28 Ibidem, s. 348. 
ści przedmiotów, zjawisk itp."29 Wśród wielu rodzajów metonimii do najczęściej spotykanych zaliczyć można metonimie ${ }^{30}$ : przyczyny (przyczyna zamiast skutku), skutku (skutek zamiast przyczyny), autora (autor zamiast dzieła), przedmiotu ogarniającego (przedmiot zamiast zawartości, miejsce zamiast przedmiotu lokalizowanego), znaku (znak zamiast rzeczy oznaczanej), narzędzia (narzędzie zamiast wytworu lub osoby), ubioru (elementy stroju zamiast osoby), materiału (materiał zamiast wytworu).

Jako rodzaj metonimii traktuje się synekdochę, która polega na „zastąpieniu wyrażenia o znaczeniu ogólnym, a zwłaszcza wyrażenia oznaczającego całość przez wyrażające część i odwrotnie"31. Oprócz dwóch wymienionych rodzajów wyróżnia się też m.in. synekdochy32: liczby (liczba pojedyncza zamiast liczby mnogiej i liczba określona zamiast nieokreślonej), gatunku (gatunek zamiast rodzaju), rodzaju (rodzaj zamiast gatunku), abstrakcji (abstrakt zamiast konkretu).

Posługiwanie się metaforami, metonimiami i synekdochami jest ściśle powiązane z procesem neosemantyzacji, czyli nadawaniem nowego znaczenia istniejącym już wyrazom. Neologizmy semantyczne pozwalają zaspokoić potrzeby nominacyjne, a wykorzystanie słowa utrwalonego w świadomości odbiorców do nazywania elementów rzeczywistości pozajęzykowej sprzyja ponadto rozwijaniu kreatywności leksykalnej.

Każdy użytkownik języka, który chce - czy to w formie ustnej, czy pisemnej - zakomunikować innym określone treści, musi podjąć decyzję, jakich środków językowych użyć, by wyrazić swoje myśli. Wybór nie jest prosty, ponieważ - jak piszą autorki Kultury języka polskiego - „Słownictwo każdego języka obejmuje wielką liczbę środków równoważnych znaczeniowo, zdolnych przekazać tę samą podstawową informację, choć w odmiennej za każdym razem formie"33. Nadawcy mogą przyświecać różnorodne cele. Zdarza się, że za prymarną wartość uznaje precyzyjność i zrozumiałość wypowiedzi, wówczas dobiera takie jednostki, które w sposób jednoznaczny będą nazywały opisywane zjawisko i staną się czytelne dla przeciętnego odbiorcy. Jeśli chce zaakcentować nacechowanie stylistyczne, to odrzuci neutralne wyrazy i posłuży się takimi, które

29 Ibidem, s. 350.

30 Podział za: Encyklopedia językoznawstwa..., s. 331.

31 Ibidem, s. 532.

32 Podział za: ibidem, s. 532-533.

33 D. Buttler, H. Kurkowska, H. Satkiewicz, op. cit., s. 44. 
są immanentnie związane z wybraną odmianą stylu. Wykorzystanie połączeń leksykalnych przynależnych do socjolektów czy profesjolektów umożliwia stworzenie poczucia identyfikacji z określoną grupą społeczną. Gdy mówiący lub piszący nie prezentuje obojętnej postawy wobec zaistniałej sytuacji i chce wyrazić swoje odczucia, sięga po leksykę o zabarwieniu emocjonalnym. Czasem nadawcy zależy na wydobyciu określonego odcienia znaczeniowego i spośród szeregu synonimów decyduje się na ten, który uwypukla wybraną cechę przedmiotu. Możliwa jest też sytuacja, że wypowiadający się z góry zakłada, iż jego przekaz ma zawierać informację zakamuflowaną, w tym celu posługuje się konstrukcjami niewyrażającymi wprost jego stanowiska czy poglądów. Bywa i tak, że nadawca chce wywołać określoną reakcję odbiorcy, dlatego buduje swoją wypowiedź z wykorzystaniem środków o charakterze perswazyjnym czy manipulacyjnym. Nierzadko zależy mu na rozbawieniu adresata, zbudowaniu bliskich relacji, dominantą tekstów o funkcji ludycznej staje się słownictwo familiarne, humorystyczne czy żartobliwe. Czasami autor wypowiedzi chce zaprezentować swoje nieprzeciętne umiejętności językowe, dlatego używa wyszukanych środków, które mają za zadanie udowodnić jego oryginalność, a co za tym idzie - wzbudzić zainteresowanie otoczenia.

D. Buttler, H. Kurkowska i H. Satkiewicz zwracają uwagę, że podczas doboru jednostek leksykalnych użytkownik języka dokonuje wyboru m.in. między nazwą jednowyrazową a wielowyrazową, nazwą skrótową a rozbudowaną (np. peryfrastyczną), nazwą jed noznaczną a polisemantyczną, słownictwem neutralnym a nacechowanym, nazwą ustabilizowaną a neologizmem ${ }^{34}$. Decyzja, którą podejmie, ma wpływ nie tylko na jego postrzeganie, lecz także komunikatywność treści: „użycie środków tradycyjnych może stwarzać wrażenie pewnej szablonowości wypowiedzi, nadmiar inwencji nazewniczej, operowanie indywidualnymi metaforami przeradza się czasem w manieryzm stylu; pewnych neosemantyzmów odbiorca po prostu może nie zrozumieć"35.

J. Miodek twierdzi: „Liczba równorzędnych form, które możemy zamiennie wykorzystywać w poszczególnych wypowiedziach, jest przecież miarą naszego stylistycznego bogactwa"36. Wydaje się, że autorzy artykułów, które są publikowane na łamach współczesnych polskich periodyków, nie pozostali obojętni

\footnotetext{
34 Ibidem, s. 56.

35 Ibidem, s. 57.

36 Słowo wstępne do Słownika synonimów, s. VII.
} 
wobec słów polskiego językoznawcy, o czym może świadczyć liczba zgromadzonych na potrzeby niniejszej rozprawy konstrukcji analitycznych mających syntetyczne odpowiedniki. Pominąć należy ocenę normatywną przy toczonych tutaj przykładów, gdyż od samego początku nie stawiano sobie za cel analizy multiwerbizmów pod kątem poprawności.

Podstawową funkcją języka jest nazywanie przedmiotów, stanów, zjawisk, sytuacji, obserwuje się to już od momentu narodzin każdego człowieka, rozwój mowy u dzieci polega bowiem na przyswajaniu słów i ich znaczenia. Dziennikarze - a więc osoby z założenia świadomie posługujące się słowem i wykorzystujące możliwości tkwiące w zasobach leksykalnych polszczyzny czy innego języka - stają przed zadaniem, jak wyrazić swoje myśli, by nazwać to, co chcą przekazać. Takie samo lub zbliżone znaczenie może zostać niejednokrotnie przedstawione za pomocą formy długiej i krótkiej.

W rozdziale tym główny nacisk zostanie położony na zróżnicowanie semantyczne analityzmów i ich jednoelementowych ekwiwalentów w polskich czasopismach o różnorodnej tematyce. Podjęta zostanie próba odpowiedzi na pytanie, dlaczego dziennikarz, mając do wyboru kilka równorzędnych konstrukcji, posługuje się konkretną formą. Czy publikującym zależy na tym, by ich przekaz został właściwie odczytany już po pobieżnym zapoznaniu się z tekstem? Czy może wręcz przeciwnie - posługując się oryginalnymi złożonymi połączeniami, oczekują oni od czytelnika, by podjął wyzwanie i w procesie interpretacji próbował odszyfrować ukryte sensy? Chcą go rozbawić czy zmusić do refleksji, chcą się z nim zaprzyjaźnić czy zachować dystans?

Analiza materiału pozwoliła na wyróżnienie dwóch głównych grup: konstrukcji równoznacznych (czyli rzeczywistych ekwiwalentów) oraz synonimicznych, w której zaprezentowane zostaną różne odcienie znaczeniowe między formami analitycznymi a syntetycznymi. W tej drugiej grupie w celu dokładnego zbadania charakterystycznych połączeń wyrazowych i odpowiadających im pojedynczych leksemów dokonano podziału pod względem następujących kategorii:

- potoczność,

- oficjalność, urzędowość,

- eufemizowanie.

Zaprezentowana typologia nie jest z pewnością wyczerpująca. Nie wszystkie analizowane w części strukturalnej przykłady zostały wykorzystane w rozdziale poświęconym semantyce; by praca nadmiernie się nie rozrosła, przedstawiono tylko najbardziej reprezentatywne egzemplifikacje. Granica między przywoła- 
nymi kategoriami jest płynna, czasem jedna analizowana jednostka może realizować jednocześnie różne zadania, zaklasyfikowano ją do tej funkcji, która wysuwała się na plan pierwszy, mając jednak świadomość, że inny użytkownik języka mógłby dokonać odmiennego wyboru.

\section{Analityzmy leksykalne mające syntetyczne odpowiedniki równoważne znaczeniowo}

Rzadko zdarza się, o czym była już mowa, by funkcjonujące równolegle w systemie leksykalnym jednostki były równoważne znaczeniowo. Uczeni podkreślają nawet, że istnienie rzeczywistych ekwiwalentów semantycznych jest wręcz niemożliwe ${ }^{37}$. Przychylając się do zdania badaczy oraz mając świadomość sporadyczności omawianego zjawiska, postanowiono zaliczyć do tej grupy takie pary, których nadrzędną funkcją jest informacyjność. Zarówno połączenie wielowyrazowe, jak i jego odpowiednik mogą zatem wystąpić w każdym tekście, bez względu na poruszaną problematykę, profil pisma, gatunek dziennikarski, są neutralne stylistycznie, nie mają nacechowania emocjonalnego. $Z$ całą stanowczością można stwierdzić, że z sytuacją taką nie spotkamy się w klasie nazw własnych, ponieważ odpowiadające oficjalnym nazwom przezwiska, przydomki i wszelkie określenia peryfrastyczne mają wartość ekspresywną. Odrzucić należy również wszystkie związki frazeologiczne, gdyż już sama definicja wskazuje, że jest to „konstrukcja językowa, której znaczenia nie da się wyprowadzić ze znaczeń i reguł łączenia składających się na nią wyrazów"38, frazeologizm ma zatem zwykle przenośny charakter, może pojawiać się tylko w określonych kontekstach. Jego syntetyczny odpowiednik nigdy nie będzie w stanie wyrazić identycznych treści, zawsze jedna z zastosowanych opcji będzie bardziej pojemna semantycznie - najczęściej to stałe połączenie wyrazowe eksponuje konkretne cechy przedmiotu, zjawiska lub czynności, którą nazywa, podczas gdy odpowiadający mu pojedynczy wyraz ma znaczenie bardziej ogólne.

W której zatem grupie szukać rzeczywistych ekwiwalentów? Wydaje się, że nieliczne przykłady równoznacznych form można odnaleźć wśród analitycznych konstrukcji przymiotnikowych i przysłówkowych oraz odpowiadających im przymiotników i przysłówków. J. Anusiewicz podkreślał, że przymiotnik „znaczeniowo jest

37 Por. rozważania na s. $148-149$.

38 Encyklopedia językoznawstwa..., s. 215. 
raczej bardzo konkretny i ograniczony w tym sensie, że stosując go w formie prostej, nie sposób wyrazić wielu skomplikowanych i subtelnych odcieni znaczeniowych, cech przejściowych czy też nie w pełni przysługujących danemu desygnatowi. Możliwość taka istnieje wtedy, gdy przydawkę właściwościową, charakteryzującą (lub też inną) uzupełni się dodatkowym elementem (rzeczownikiem bądź wyrażeniem przyimkowym). Zyskuje się wtedy szansę na zasygnalizowanie dodatkowych, czasami ważnych odcieni znaczeniowych, a przez to większą precyzję i wyrazistość”39. Zbliżone spostrzeżenia wysnuł także w odniesieniu do przysłówków: „Nie można bowiem wyrazić, stosując prostą formę przysłówka, wielu różnych odcieni znaczeniowych. Stąd też tworzymy często formy wyrazowe opisowe, bliskoznaczne w stosunku do nieopisowych, ale precyzyjniejsze i dokładniejsze"40. Podobnie o analitycznych konstrukcjach przymiotnikowych i przysłówkowych wypowiadała się E. Pokorska-Szczodruch, stwierdzając, że występuje w nich „dodatkowy element leksykalny, który powoduje, że nie są one w pełni ekwiwalentne treściowo ze swymi odpowiednikami. Nowy element przyczynia się najczęściej do intensyfikacji treści przymiotnika lub przysłówka, podkreśla jego znaczenie"41.

Nie sposób nie zgodzić się z przywołanymi wyżej tezami, wydaje się jednak, iż czasem różnice znaczeniowe czy stylistyczne są tak niewielkiee ${ }^{42}$, że nie będzie błędem uznanie poniższych przykładów za ekwiwalenty na płaszczyźnie semantycznej: [zdolność do wytwarzania osobników potomnych] w sposób płciowy i płciowo, [kojarzyć się] w sposób naturalny i naturalnie, [stroje] w kolorze pomarańczy i pomarańczowe, [krzesełka] w kolorach żólto-niebieskich i żótto-niebieskie, [karp] $w$ formie $\dot{z} y w e j \mathrm{i} \dot{z} y w y$. Wyrażenia przyimkowe stanowiące podstawę wymienionych konstrukcji, czyli w sposób, $w$ kolorze/w kolorach i $w$ formie, nie przyczyniają się do wyraźnie odczuwalnych zmian semantycznych, odznaczają się brakiem nacechowania, co najwyżej mogą - właśnie poprzez wielowyrazową strukturę kierować wzrok adresata na ten fragment tekstu w większym stopniu, niż czyni to ich syntetyczny równoważnik.

39 J. Anusiewicz, Konstrukcje analityczne we współczesnym języku polskim, Wrocław 1978, s. 116.

40 Ibidem, s. 116-117.

41 E. Pokorska-Szczodruch, Przymiotnikowe i przysłówkowe konstrukcje analityczne w tekstach prasowych: opis stylistyczny i semantyczny, „Poradnik Językowy” 2006, z. 10, s. 107.

42 J. Anusiewicz nazywa je wręcz subtelnymi - por. J. Anusiewicz, Konstrukcje analityczne we współczesnym..., s. 123. 
Wnikliwa obserwacja materiału pozwoliła na odnotowanie - nielicznych co prawda - jednoznacznych form także wśród rzeczowników. W przypadku mistrzostw świata i mundialu mamy do czynienia z rzeczywistą ekwiwalencją znaczeniową, zarówno dwuelementowe połączenie, jak i pojedynczy wyraz mogą być stosowane wymiennie we wszystkich kontekstach, nie różnią się stopniem oficjalności, nie są nacechowane aksjologicznie, wykazują podobną łączliwość ${ }^{33}$.

Wprawdzie szkolili i przygotowywali ich do gry w wielkim futbolu inni, ale w decydującym momencie młodzi piłkarze nie zawiedli i w perspektywie mistrzostw świata stanowią promyk nadziei, że w polskim futbolu nadal pojawią się diamenty. (PN 50/2011, s. 47)

Przez wiele lat reprezentacja Polski nie potrafiła nawet zakwalifikować się do turnieju finałowego mistrzostw Europy, ale niepowodzenia odbijaliśmy sobie na turniejach mistrzostw świata, bo jeżeli nawet nie zdobywaliśmy na mundialach medalu, to zajmowaliśmy miejsca tuż za najlepszymi. (PN 49/2011, s. 47)

O takim samym znaczeniu można mówić też wówczas, gdy analityzm przyjmuje kształt nieskomplikowanej definicji, dzięki której wyjaśnione jest syntetyczne pojęcie. Właściwość taka uwidacznia się w parach: rok i dwanaście miesięcy, złoty i polska waluta ${ }^{44}$, uczestnik i bioracy udział.

Rok temu powiedział: Do zobaczenia za dwanaście miesięcy! (VG 25/2012, s. 3)

Kurs polskiej waluty przestał być dla jego interesów aż tak istotny. (P 51-52/2012, s. 60) Koniec końców gospodarkę może również wspomóc polityka płynnego kursu walutowego, która doprowadzi w końcu do ustabilizowania się złotego na atrakcyjnym dla eksporterów poziomie. (P 50/2012, s. 45)

Wszyscy biorący udział w plebiscycie otrzymają nagrodę gwarantowaną - miesięczny dostęp do Polityki Cyfrowej, którą można odbierać na wszystkich nośnikach elektronicznych. (P 51-52/2012, s. 119)

43 W oficjalnych nazwach imprez sportowych używa się jedynie połączenia mistrzostwa świata, np. XX Mistrzostwa Świata w Piłce Nożnej w Brazylii, skład nazw własnych stanowi jednak nierozerwalną całość, dlatego nie może się tu wymiennie pojawić wyraz mundial.

44 Przymiotnik złoty uległ procesowi substantywizacji; tylko w użyciu rzeczownikowym będzie tożsamy z analityczną konstrukcją polska waluta. Właściwa interpretacja syntetyzmu wymaga zapoznania się z całym zdaniem, w którym został użyty. 
Zadaniem uczestników będzie stworzenie krótkiego filmu, w którym zaprezentują, co w matematyce pociąga ich najbardziej. (VG 17/2012, s. 5)

Tożsamość semantyczna dostrzegalna jest też w grupie czasowników. Podstawą kolokacji werbo-nominalnych, która sprzyja akcentowaniu równoznaczności, jest mieć. Jako egzemplifikacja mogą posłużyć zestawienia: mieć złudzenia i łudzić się, mieć oddziaływanie i oddziaływać, mieć pod opieką i opiekować się, mieć w pamięci i pamiętać, mieć wątpliwości i wątpić, mieć zamiar i zamierzać. W przytoczonych poniżej wypowiedzeniach mogłyby pojawić się syntetyzmy, a semantyczny wymiar zdań nie zmieniłby się.

Ale teraz niech nikt nie ma złudzeń. (PN 51-52/2011, s. 89)

Bartek nie miał już złudzeń, zresztą skutecznie rozwiewał mu je Daniel, najbliższy kolega z klasy, którego rodzice już kilka lat temu się rozeszli. (VG 10/2011, s. 8)

Oznacza to, że projekt musi mieć oddziaływanie i przynosić korzyści zarówno dla Polski, jak i drugiego kraju, partnera projektu. (VG 20/2012, s. 65)

Zatem etykieta została zachowana, nikt nie mógł mieć wątpliwości, że występuje reprezentacja kraju, nie zaś federacji. (PN 46/2011, s. 2)

Fakt, nie graliśmy może najukładniej, ale tylko kwestią czasu było, że ten mecz zacznie nam się układać, nie mam wątpliwości. (PN 17/2012, s. 7)

Lecz mimo to miał zamiar pozostać w ich domu. (VG 22/2012, s. 23)

Wyjątek stanowią opiekować się i mieć pod opieką, ponieważ wymagają dopełnienia w innym przypadku: opiekować się kim? czym? - czyli w narzędniku, mieć pod opieką kogo? co? - czyli w bierniku.

Inna metoda to harcerstwo - jako druhna czy druh będziesz mieć pod opieką dzieci, zobaczysz, jak to jest zajmować się młodszymi. (VG 12/2011, s. 7)

Wydaje się, że ten sam walor znaczeniowy prezentuje ponadto spokornieć i nabrać pokory. Ani analityzm leksykalny, ani syntetyczny odpowiednik nie wartościują stanów, które wyrażają:

Ale choć Patricka podkreśla, że z wiekiem nabrała pokory, wszyscy zauważyli, że sukces chyba leciutko uderzył jej do głowy... (NŻ 8/2012, s. 10) 


\section{Analityzmy leksykalne mające syntetyczne odpowiedniki o znaczeniu synonimicznym}

\subsection{Prezentujące różne odcienie znaczeniowe}

Jak już wspomniano, równoważność znaczeniowa jest zjawiskiem niezwykle rzadkim, jednostki synonimiczne różnią się często zabarwieniem semantycznym, choć różnice te mogą być bardzo subtelne. Na wybranych przykładach podjęta zostanie próba zaprezentowania, jakie relacje znaczeniowe zachodzą między analityzmami a ich prostymi odpowiednikami.

Różnice semantyczne najlepiej zobrazować na strukturach mających odpowiedniki w postaci syntetycznego czasownika, któremu mogą odpowiadać zróżnicowane konstrukcje - powszechnie używane połączenia czasowników z innymi częściami mowy, mające rozmaite nacechowanie stylistyczne; nienotowane wcześniej oryginalne zestawienia wyrazów silnie osadzone w kontekście, czasem o charakterze metaforycznym; czy wreszcie związki frazeologiczne.

Bezokolicznik pomagać może przyjąć analityczną postać nieść pomoc, która podkreśla podniosłość działań. Ekwiwalentami frazeologicznymi są wyciagnąć do kogoś rękę, wyciąnąć do kogoś (pomocna) dłoń, podać pomocną dłoń i przyjść $w$ sukurs, czasowniki wchodzące w skład tych stałych połączeń wyrazowych uwypuklają, że ktoś zdobył się na jakiś wysiłek, wysuwają na plan pierwszy szlachetne intencje osób niosących wsparcie. Komponent przymiotnikowy pomocny jednoznacznie doprecyzowuje, o jaką czynność chodzi, podpowiada, by nie traktować dosłownie połączeń wyciagnąć rękę i podać dłoń. Za pomocą frazeologizmu przyjść w sukurs podkreślone zostaje raczej wsparcie kogoś w trudnej chwili niż konkretna materialna pomoc. Warto w tym miejscu przywołać pojęcie profilowania. Po raz pierwszy terminu tego użył Ronald Langacker. R. Grzegorczykowa tłumaczy je następująco: „ujmowanie pola postrzeżeniowego lub pojęciowego (wiedzy o pewnym wycinku rzeczywistości), tzw. bazy, z określonego punktu widzenia przez wyróżnienie (podświetlenie) pewnych elementów jako ważnych (desygnowanie), a usuwanie innych w cień, na dalszy plan, do tła"45. Podkreśla się subiektywny charakter tej operacji. Jerzy Bartmiński i Stanisława Niebrzegowska

45 R. Grzegorczykowa, Profilowanie a inne pojecia opisujące hierarchiczna strukture znaczenia, [w:] Profilowanie w języku i w tekście, red. J. Bartmiński, R. Tokarski, Lublin 1998, s. 11. 
z kolei - którym bliższe jest znaczenie tego pojęcia pojawiające się w pracach Anny Wierzbickiej - twierdzą, że „profilowanie jest subiektywną (tj. mającą swój podmiot) operacją językowo-pojęciową, polegającą na swoistym kształtowaniu obrazu przedmiotu poprzez ujęcie go w określonych aspektach (podkategoriach, fasetach), takich jak np. pochodzenie, cechy, wygląd, funkcje, zdarzenia, przeżycia, itp., w ramach pewnego typu wiedzy i zgodnie z wymogami określonego punktu widzenia”46. Jak wyjaśnia R. Grzegorczykowa, „profilowanie Langackerowskie [...] operuje na polu doświadczeniowym, prowadząc dopiero do skonstruowania pojęcia i nazwy. Profilowanie w ujęciu Bartmińskiego [...] operuje na już wyróżnionych (utworzonych) pojęciach, ukazując różne aspekty nazwanego przedmiotu (zjawiska), co w konsekwencji może prowadzić do powstawania nowych znaczeń lub wariantów znaczeniowych nazwy" 47 .

Nie we wszystkich przytoczonych kontekstach analityzmy mające ekwiwalent w postaci pomagać mogłyby funkcjonować wymiennie:

Z czasem mocno umalowane panie w okienkach zaczęły reagować na chcących nieść pomoc i radę rodaków jak na obcych. (PN 24/2012, s. 26)

Lekarz musi chcieć pomagać. (VG 14/2012, s. 10)

Ale tacy muszą być - bez sentymentów, fachowo i z pełną odpowiedzialnością nieść pomoc. (VG $15 / 2012$, s. 9)

Najlepiej uczynić to w rocznicę jego śmierci, bo tego dnia z całą pewnością pojawia się na ziemi, aby nieść pomoc tym, którzy wznoszą do niego modły. (P 24/2012, s. 100) Tym bardziej jeśli w sukurs przyjdzie jeszcze Białystok i zarządzany komisyjnie (już albo dopiero za chwilę, w każdym razie przez Jarosława Szostka) Olsztyn. (PN 3/2012, s. 1)

Wtedy rękę do Dołęgi wyciągnął biznesmen z Otwocka, Stefan Maciejewski, za młodu sztangista. (P 51-52/2012, s. 152)

Codziennie spotyka się z przemocą - fizyczną i psychiczną i zupełnie nikt nie wyciągnąl do niej dłoni. (VG 5/2011, s. 20)

Odradzająca się Borussia to także zasługa Bayernu, którego władze po finansowym tąpnięciu, spowodowanym wejściem na giełdę, wyciągnęły pomocną dłoń i pożyczyły konkurentowi pieniądze. (PN 48/2012, s. 31)

46 J. Bartmiński, S. Niebrzegowska, Profile a podmiotowa interpretacja świata, [w:] Profilowanie w jezyku..., s. 212.

47 R. Grzegorczykowa, Profilowanie a inne pojęcia..., s. 12. 
Jeśli chodzi o mnie, nie miałem innych propozycji, a działacze Kolejarza wyciągnęli do mnie rękę, za co jestem im wdzięczny. (PN 48/2012, s. 42)

Pomocną dłoń wyciągnęła do niej nauczycielka śpiewu i... była partnerka jej eksmęża Krystyna Prońko. (NŻ 11/2012, s. 14)

Nie spodziewaj się, że znajomi podadzą Ci pomocną dłoń - raczej to od Ciebie będą oni oczekiwać pomocy, a nawet gotowych recept na kłopoty. (NŻ 2/2012, s. 47)

Analityczna konstrukcja czasownikowa może obrazować intensywność podejmowanej czynności. Różnice te można zaobserwować między wpływać a wywierać wpływ i mieć wpływ. W grupie tej najsilniejsze oddziaływanie wyrażone jest za pomocą konstrukcji z czasownikiem wywierać, mniejszą moc ma sam syntetyzm, nie do końca precyzyjne jest zaś połączenie mieć wpływ, ponieważ nie wiadomo, czy opisuje jedynie sam fakt posiadania możliwości nacisku na kogoś lub coś, czy może rzeczywiste podejmowane w tym celu kroki.

I w ten sposób wpływać na jego działania. (PN 44/2012, s. 9)

Gruntowna i wszechstronna wiedza teoretyczna i praktyczna umożliwia architektowi krajobrazu stworzenie właściwych dla konkretnych roślin warunków siedliskowych, co wpływa na ich wzrost, rozwój i walory dekoracyjne. (VG 10/2011, s. 7)

Wywierał większy wpływ na grę swoich zespołów niż Lewy i dlatego wyprzedził go w walce o miejsce w jedenastce miesiąca. (PN 49/2012, s. 32)

- Bez kilku małych nieporozumień, które nie miały wpływu na wynik i przebieg meczu, wszystko było w porządku. (PN 24/2012, s. 29)

W przeszłości kilku aktywnych polityków związanych z piłką nożną było w strukturach PZPN i mieli jakiś wpływ na szefa związku. (PN 41/2012, s. 18)

Jednym z ważniejszych zjawisk, które miało duży wpływ na zmiany światopoglądowe w Europie był gwałtowny skok demograficzny. (VG 6/2011, s. 45)

Stopniowo dowiadujemy się też o przeszłości Rachel, o jej ciężkich relacjach z rodzicami oraz traumie z dzieciństwa, która wywiera na nią wpływ nawet w dorosłości. (VG 19/2012, s. 7)

Dziennikarze publikujący w polskich periodykach wypracowali liczne zastępniki pojawiające się zamiast czasownika umrzeć. Śmierć jest tematem podlegającym tabuizacji, dlatego wiele z nich ma charakter eufemistyczny, np. być daleko stąd, nie wrócić do domu, zgasnąć przedwcześnie, odejść z tego świata, zamilknąć 
na zawsze czy nadeszło to nieuniknione ${ }^{48}$. Wydaje się, że część z nich może przekazywać wręcz przeciwstawne treści, np. czarować w innym lepszym ze światów sugeruje, że śmierć to nie koniec, ale początek, człowiek nie znika, lecz rozpoczyna kolejny etap, peryfraza ta jest więc niejako zaprzeczeniem umrzeć. Tracić życie i ponieść śmierć nadają podniosły wymiar temu, co się dokonało. Badająca zastępcze określenia śmierci Anna Engelking twierdzi: „Nacechowanie takie uwzniośla desygnat, powoduje, że staje się on bezpieczniejszy dla mówiącego o nim. Wyrażenia podniosłe często są dość ogólnikowe, mają szeroki zakres, co sprawia, że namacalność znaczenia podstawowego osłabia się i zaciera. [...] Próbują one jedynie łagodzić «kontekst», osłabić jego grozę, a przez to uwznioślić fakt, na który generalnie wyraża się zgodę"49. Ponadto przywołane orzeczenia peryfrastyczne wydobywają dodatkowe składniki semantyczne - informują, że przyczyną śmierci nie były czynniki naturalne, ale nastąpiła ona w wyniku nieoczekiwanych, tragicznych w skutkach zdarzeń, ich bliskoznacznym jednoleksemowym ekwiwalentem jest więc zginąć. Podobną wymowę ma oddać życie, które akcentuje, że ktoś umarł w imię wyższych wartości, poświęcił istnienie ludzkie w jakimś celu - i najczęściej zrobił to świadomie.

Po operacji wrócił na boisko, a gdyby grał bez niej - w każdej chwili mógłby umrzeć. (PN 33/2012, s. 37)

Samotność starego człowieka jest jeszcze większa, jeżeli jego najbliższy partner umiera i babcia lub dziadek pozostają sami. (VG 3/2011, s. 29)

Był 1 lipca 2005 r., trzy miesiące wcześniej umarł Jan Paweł. (P 50/2012, s. 27)

Wielkie trzęsienie ziemi w San Francisco, w katastrofie zginęło około 1000 osób, a 250 tys. straciło dach nad głową. (VG 6/2011, s. 46)

Zginęło 25 osób, a 517 poważnie ucierpiało. (PN 6/2012, s. 5)

W wyniku pomeczowych zamieszek życie straciło 318 osób, ponad 500 zostało rannych. (PN 6/2012, s. 5)

Bo jego „pacjentami” są ludzie, którzy stracili życie w trudnych lub niewyjaśnionych okolicznościach. (VG 23/2012, s. 7)

48 Szczegółowa charakterystyka zastępczych określeń łagodzących związanych $\mathrm{z}$ umieraniem została przedstawiona $\mathrm{w}$ podrozdziale niniejszej pracy poświęconym eufemizmom. Por. s. 232-235.

49 A. Engelking, Istota i ewolucja eufemizmów (na przykładzie zastępczych określeń śmierci), „Przegląd Humanistyczny” 1984, nr 4, s. 127. 
Ogromny tumult sprawił, że śmierć poniosły 43 osoby, a dwa razy tyle zostało rannych. (PN 6/2012, s. 6)

Nie ma już wśród żywych wojownika, sportowca o nieposkromionych ambicjach, Czarodzieja z narożnika, jak pisała o Nim prasa zagraniczna. (PN 11/2012, s. 4)

Z wyliczeń wynika, że gdyby rzeczywiście nie było różnic między dużymi, długo żyjącymi gatunkami i małymi, żyjącymi krótko, to każdy wieloryb lub słoń powinien dokonać $\dot{z}$ y wota ${ }^{50}$ z powodu nowotworu, zanim osiągnąłby wiek reprodukcyjny. (P 50/2012, s. 81)

W 2004 r. oddał życie kolejny kibic Wisły, 17-latek znany pod ksywką Fujin. (P 5/2011, s. 94)

Kilka związków frazeologicznych zbudowanych z różnych elementów może mieć ten sam jednowyrazowy odpowiednik, każdy z nich wydobywa jednak inne aspekty działania, które nazywa. Barbara Rejakowa zajmująca się wartościami pojedynczych wyrazów i związków frazeologicznych w przekładzie twierdzi, że „nie każdy użyty w tłumaczeniu odpowiednik jednowyrazowy w stosunku do frazeologicznego bywa wykładnikiem tej samej wartości semantycznej"51. Te same własności ujawniają się nie tylko w tekstach tłumaczonych, ale także podczas analizy relacji, jakie zachodzą między frazeologizmem a odpowiadającym mu pojedynczym leksemem w tym samym języku. Związki frazeologiczne pozwalają pomnożyć zasób synonimicznych środków leksykalnych i zapełnić luki na płaszczyźnie semantycznej, której nie są w stanie w całości pokryć samodzielne

50 Zastosowanie peryfrazy dokonać żywota w tym wypowiedzeniu wiąże się również $\mathrm{z}$ tym, że artykuł podejmuje temat zwierząt, a leksem umrzeć w znaczeniu 'kończyć życie’ odnosi się zazwyczaj do ludzi.

51 B. Rejakowa, Pojedynczy wyraz jako forma przekładu związku frazeologicznego (wartości referencyjne i stylistyczne), „Annales UMCS. Sectio F” 1988, s. 346. Przyglądając się relacjom semantycznym dostrzeganym w przekładach zwrotu frazeologicznego przez czasownik, badaczka zaproponowała następującą typologię (s. 348-349): frazeologizmowi języka oryginału odpowiada czasownik języka oryginału mający taką samą wartość semantyczną; między znaczeniem czasownika a znaczeniem związku frazeologicznego nie ma pełnej odpowiedniości; czasownik jest swoistą interpretacją znaczeniową, wynikającą z powtórzenia (przetłumaczenia) jedynie komponentu czasownikowego wchodzącego w skład stałego połączenia wyrazowego; znaczenie czasownika w przekładzie odbiega od znaczenia związku frazeologicznego (należącego zwykle do substandardowej sfery słownictwa). 
wyrazy ${ }^{52}$. Graćpierwsze skrzypce, nadawać ton czemuś, coś bierze nad czymś górę to związki o wspólnym znaczeniu dominować, lecz - jak pokazują konteksty nie zawsze mogą być stosowane wymiennie. Równoznaczne treści przekazują dwa pierwsze, podkreślając czyjś wpływ na kształt, charakter czy wygląd czegoś. Brać górę odnosi się z kolei do sfery psychicznej człowieka, dzięki temu stałemu połączeniu wyrazowemu można zobrazować dominację uczuć nad racjonalnym postrzeganiem otaczającego nas świata.

Oczywiście chodzi o komplet bramkarzy, zresztą w ogóle tę klasyfikację zdominowali specjaliści od łapania piłki. (PN 24/2012, s. 33)

Na ekipę, gdzie pierwsze skrzypce grali Miodrag Belodedici, Laszlo Boloni, Marius Lacatus, Victir Piturca i Gavril Balint, nie było mocnych w domu. (PN 6/2012, s. 39)

Zespoły kieleckiej Korony i chorzowskiego Ruchu, które wiosną nadawały ton rozgrywkom, obecnie zgodnie ciągną się w ogonie krajowej elity i doszło do tego, że wielką radość sprawiłoby zdobycie punktu nawet wtedy, gdy gra toczy się przed własną publicznością. (PN 36/2012, s. 47)

Takie spędzanie świąt może się wydawać sensowne tym osobom, które wiedzą, że przy wigilijnym stole górę wezmą emocje, uprzedzenia - i że to może je bardzo dużo kosztować. (P 51-52/2012, s. 22)

Frazeologiczne zróżnicowanie połączeń dających się sprowadzić do znaczenia zrezygnować jest jeszcze bogatsze. Ekwiwalent taki przynależy do dać za wygrana, dać sobie spokój, zwijać żagle, złożyć broń i machnać ręką, każdy z tych zakorzenionych w świadomości odbiorców związków odwołuje się do innych odcieni znaczeniowych nadrzędnego czasownika. Dać za wygrana informuje, że ktoś się z czymś pogodził, zaniechał wykonania czegoś, podobny sens można odczytać ze zwrotu złożyć broń. Dać sobie spokój sugeruje ponadto, że przestaliśmy się kimś lub czymś interesować. Machnąć ręką ma nieco inne przesłanie - podpowiada, że uznaliśmy coś za stracone. Zwinąć żagle natomiast ma dodatkowo znaczenie wycofania się, porzucenia czegoś. Zrezygnować może także przybrać złożoną formę złożyć rezygnację, która jest bardziej oficjalna od pojedynczego leksemu.

52 A. M. Lewicki, A. Pajdzińska, Frazeologia, [w:] Współczesny język polski, red. J. Bartmiński, Lublin 2001, s. 327. 
Zamiast wobec twardych dowodów zgromadzonych przez komisję dyscyplinarną posypać głowę popiołem stoper Chelsea najpierw na znak protestu zrezygnowal z gry w reprezentacji, a potem w jego imieniu na Tweeterze głos zabrał właśnie Cole. (PN 41/2012, s. 31)

TVP utarło jej nosa i z niej zrezygnowało. (NŻ 7/2012, s. 6)

Wbrew początkowym objawom, że po mastektomii będzie musiała zrezygnować z seksu, nic takiego się nie stało. (P 5/2011, s. 56)

Premier Mario Monti zdecydował, że natychmiast po przyjęciu przez parlament ważnej dla kraju ustawy stabilizacyjnej złoży rezygnację. (P 50/2012, s. 7)

Każdy trener, który próbował go w jakiś sposób okiełznać, po jakimś czasie dawał za wygraną. (PN 48/2011, s. 29)

Tam zagrał ledwie sześć spotkań, by potem tułać się po niższych ligach i dać sobie spokój w powodu kolejnej kontuzji w roku 2007. (PN 47/2011, s. 11)

Czas zwijać żagle. (PN 47/2011, s. 27)

Także oba zespoły z Ukrainy, która jest rywalem naszej reprezentacji w eliminacjach World Cup 2014, nie składają broni w walce o awans. (PN 41/2012, s. 34)

Człowiek zaczyna dostrzegać paradoksy - i nie macha ręką, tylko szuka wspólnego mianownika oraz jest w stanie go znaleźć. (P 51-52/2012, s. 24)

Zdarza się, że rozbieżności pomiędzy analityzmem a syntetyzmem są znaczne. W parze zapomnieć i wyrzucić z pamięci widoczne jest zróżnicowanie pod względem świadomości działań. Użycie pojedynczego czasownika sugeruje, że czynność ma charakter samoistny, ktoś o czymś nie pamięta nie dlatego, że nie chce czy miał taki zamiar, ale dokonało się to bez jego zaplanowanego udziału. Odmienne treści przedstawia konstrukcja peryfrastyczna - oznajmia bowiem, że nasze postępowanie jest zamierzone i celowe.

Każda wizyta Szymona w ich domu również będzie dla Wiki stresem - trudno, żeby zupełnie wyrzuciła z pamięci scenę z parku. (VG 16/2012, s. 25)

Wartość sportowa spadła, a wkrótce Antoni Ptak (kto go dziś jeszcze pamięta?) zapomniał o miłości do ŁKS i lotem błyskawicy go opuścił, po czym siał zniszczenie w innych miejscach, ze szczególnym uwzględnieniem Szczecina. (PN 45/2011, s. 9)

Podobnie jest w przypadku skrzywdzić i zrobić komuś krzywdę. Skrzywdzić wskazuje na niewielkie rozmiary szkody, wywołuje skojarzenia z płaszczyzną moralną, niewłaściwym potraktowaniem kogoś, wielowyrazowe połączenie 
czasownikowe informuje zaś o konkretnym, przeważnie fizycznym lub materialnym, uszkodzeniu, które zostało dokonane bezprawnie i niezasłużenie.

Nie musisz mieć broni, aby zrobić komuś krzywdę. (VG 1/2011, s. 8)

Wiele określeń jest tematycznie związanych ze sportem. Czynność zdobycia gola - jako jedna z najistotniejszych podczas meczu piłkarskiego - może być określana na kilka sposobów. Najprostsze syntetyczne czasowniki to strzelić i trafić, są one dość pojemne semantycznie, mogą odnosić się też do innych działań (np. strzelić odwołuje do co najmniej dwóch analitycznych konstrukcji czasownikowych: oddać strzał i strzelić gola), dlatego często bywają rozszerzone o dopełnienie, które narzuca właściwą interpretację: strzelić gola, trafić do bramki, trafić do siatki, a także zdobyć bramkę, zdobyć gola czy wyraźnie nacechowane potocznością wbić gola ${ }^{53}$, wpakować gola, zaaplikować gola czy dorobić się gola. Dochodzi czasem do zaburzenia łączliwości wyrazów, aplikować bowiem to 'stosować coś, dawać coś', 'naszywać, nakładać na coś wzór zdobniczy', 'odbywać aplikację’ 54 , dorabiać się tłumaczy się natomiast jako 'osiągać, zdobywać coś, zwykle dobra materialne, pieniądze', pot. 'doczekać się konsekwencji swego niewłaściwego zachowania; doigrać się 55 , żadne z wymienionych znaczeń nie są notowane tradycyjnie w połączeniach ze słowem gol.

Cesc strzelił dwa gole i zakończył w ten sposób ośmiomiesięczną passę bez zdobyczy bramkowej - poprzednio strzelił 8 lutego w pucharowym meczu z Valencią. (PN 50/2012, s. 21)

Z Krywbasem trafiliśmy już na początku spotkania i skończyło się naszą wygraną 6:0. (PN 48/2012, s. 20)

Kiedy gospodarze strzelą gola albo mają rzut wolny, z głośników rozlega się szczekanie psa, rasy Xoloitzcuintles, oczywiście. (PN 50/2012, s. 39)

Jak wyliczono, ów snajper nie mógł trafić do siatki już od 344 minut. (PN 1/2012, s. 35)

53 Funkcjonuje sfrazeologizowane połączenie wbić piłkę (do bramki, do kosza itp.) 'trafić piłką do celu', w analizowanym przykładzie prawdopodobnie doszło do kontaminacji sformułowań wbić piłkę i strzelić gola.

54 Nowy słownik poprawnej polszczyzny, red. A. Markowski, Warszawa 2002, s. 24.

55 Ibidem, s. 162. 
Po rzucie rożnym Reusa i niefortunnym zgraniu piłki przez Mario Mandżukicia do bramki monachijczyków trafił Goetze. (PN 49/2012, s. 35)

W znakomitej formie jest Ałan Dzagojew, który Czechom wbił dwa gole. (PN 24/2012, s. 16)

Gdy szybko nie zdobywamy gola w meczu, wkrada się nerwowość. (PN 48/2012, s. 20)

Kaczmarek oddał mu futbolówkę, a Stępiński ośmieszył w szesnastce Piotra Malarczyka i pewnym uderzeniem zdobył bramkę. (PN 49/2012, s. 40)

Gdyby nie feralne 11 minut w końcówce drugiej połowy, kiedy liderzy Premier League zaaplikowali podmęczonym gospodarzom trzy gole i można pokusić się o opinię, iż ów styl gry zdał egzamin. (PN 41/2012, s. 30)

Marek Leśniak w latach 1988-96 zdobył na boiskach niemieckiej ekstraklasy 42 gole, a w reprezentacji w tym okresie dorobił się zaledwie pięciu trafień. (PN 49/2012, s. 37)

Kibice osowiali i milczący, szaro, ziąb, a na koniec Łotysze wpakowali gola. (P 24/2012, s. 15)

Lider przegrał pierwszy raz na wyjeździe i pierwszy raz w tym sezonie nie zdobył bramki, bo zaszwankowała najmocniejsza broń, czyli trio Ljuboja - Kosecki - Radović. (PN 50/2012, s. 40)

Zdobycie bramki może się nieznacznie różnić, np. siłą czy sposobem strzału. By dokładnie opisać, co zawodnicy wykonali z piłką, sięga się po wyrażające różne odcienie semantyczne czasowniki, używa się także synonimicznie wyrazów bramka i siatka, czasem podkreśla się za pomocą rzeczowników rywal czy przeciwnik, że nieodłącznym elementem sportu jest współzawodnictwo: posłać piłkę do bramki, skierować piłkę do siatki, umieścić futbolówkę w siatce, umieścić piłkę w bramce przeciwnika, wpakować piłkę do siatki, wpakować piłkę do bramki, wepchnać piłkę do siatki, posłać piłkę do siatki rywala, posłać piłkę do bramki rywala.

Wojciech Kędziora ze stoickim spokojem wpakował piłkę do bramki po zagraniu Mateusza Bodziocha. (PN 20/2012, s. 43)

W 58 minucie napastnik Miedzi Jakub Grzegorzewski posłał piłkę do bramki, uczynił to jednak będąc na pozycji spalonej. (PN 36/2012, s. 41)

Mindaugas Kalonas z linii końcowej zagrał do wbiegającego Tomasza Strzelca, który wślizgiem wepchnął piłkę do siatki. (PN 36/2012, s. 41) 
Pan dotychczas nie błyszczał skutecznością we Flocie, a gdy już się odblokował, aż dwukrotnie posłał piłkę do siatki rywala. (PN 36/2012, s. 40)

Tomasz Kupisz w pucharowej konfrontacji z Lechią Gdańsk dwukrotnie posyłał piłkę do bramki rywala, ale zaliczył też bramkę samobójczą i o awansie do ćwierćfinałów zdecydowała seria rzutów karnych. (PN 41/2012, s. 22)

Po dośrodkowaniu z rzutu rożnego Filipa Starzyńskiego pilnujący Arkadiusza Piecha Rafał Grzyb skierował piłkę do własnej bramki. (PN 50/2012, s. 40)

Mariusz Magiera dośrodkował z rzutu rożnego, a stojący koło bliższego słupka Mateusz Zahara sprytnym strzałem głową umieścił futbolówkę w siatce. (PN 50/2012, s. 42)

Cieniem na jego dokonaniach kładzie się jedynie fakt, że nie potrafił ani razu umieścić piłki w bramce przeciwnika w europejskich pucharach. (PN 6/2012, s. 10) Magiera tym razem $z$ akcji bardzo precyzyjnie zagrał w pole karne, gdzie największym refleksem wykazał się Wojciech Łuczak i uderzeniem nogą skierował piłkę do siatki tuż przy słupku bramki bezradnego Michała Buchalika. (PN 50/2012, s. 42)

Najpierw Szwed asystował przy dwóch trafieniach kolegów, a w końcówce sam dwukrotnie wpakował piłkę do siatki. (PN 48/2012, s. 35)

W celu zwrócenia uwagi na wykonawcę czynności używa się analitycznych konstrukcji: wpisać się na listę strzelców, pokonać bramkarza rywali, trafić do siatki rywala. Nie ma w nich wyrazów piłka i futbolówka, cały przekaz skoncentrowany jest na strzelcu.

W składzie Żubrów pojawił się i wpisał na listę strzelców Adam Dźwigała, syn Dariusza, bo zmiana pokoleń jest nieuchronna. (PN 33/2012, s. 45)

Sześciokrotnie do siatki rywala trafiał trzy lata starszy od niego inny napastnik mistrzów Lucas Pratto. (PN 50/2012, s. 38)

Już w poprzednim sezonie dziewiętnastokrotnie pokonywał bramkarza rywali, w obecnym, mimo że do zakończenia zasadniczej części rozgrywek jeszcze dziewięć kolejek, znacznie poprawił to osiągnięcie. (PN 6/2012, s. 10)

Warto przyjrzeć się też metaforycznemu określeniu wjechać do bramki zpiłką, które nawiązuje do stylu gry polegającego na wymienianiu nieskończenie wielu podań i strzelaniu do bramki z jak najbliższej odległości ${ }^{56}$.

56 Por. K. Burska, Analityczne konstrukcje czasownikowe w polskich tygodnikach, [w:] Słowo we współczesnych dyskursach, red. B. Kudra, K. Jachimowska, E. Szkudlarek-Śmiechowicz, Łódź 2014, s. 75. 
Wydawało się, że przyjęte przed meczem przez obu trenerów sposoby sforsowania defensywy rywali zawiodły, że Hiszpanie nie wjadą do bramki Włochów z piłką, a ci nie zaskoczą wysokich stoperów La Roja długimi, górnymi piłkami od napastników lub skrzydłowych, choć Pirlo zagrywał je niebywale dokładnie. (PN 24/2012, s. 31)

Dziennikarze sportowi wypracowali także szereg sposobów, by przekazać informację o końcowym rezultacie spotkania. Powiadomienie o wygranej może być wyrażone syntetycznymi czasownikami bliskoznacznymi wygrać lub zwyciężyć, mają one neutralny charakter.

Pod jego wodzą zespół wygrał w Pampelunie pierwszy mecz wyjazdowy w tym sezonie ligowym. (PN 50/2012, s. 23)

Piłkarze mogą wygrać, zremisować oraz, co najbardziej prawdopodobne, przegraćEuro będzie trwało. (P 24/2012, s. 16)

Czyli tym razem wyciągnęli lekcję z ostatniego meczu poprzedniego sezonu, gdy przegrywali już z londyńskim klubem 0:2, by po dramatycznej końcówce zwyciężyć i wydrzeć mistrzostwo Anglii Manchesterowi United. (PN 36/2012, s. 23)

Wiadomość o pokonaniu przeciwnika może też przybrać formę orzeczeń peryfrastycznych, które nie są obojętne stylistycznie, czasem służą uwypukleniu jakichś treści. Odnieść zwycięstwo, wyjść zwycięsko czy zejść z boiska $w$ roli zwycięzców to połączenia o podniosłym nacechowaniu, poprzez gloryfikowanie wygranej nadają wypowiedzi patetyczności.

Zwycięsko z tego dwumeczu wyszli nasi południowi sąsiedzi, którzy odnotowali skromną wygraną i bezbramkowy remis. (PN 50/2012, s. 36)

Gdyby ułożyć tabelę, okazałoby się, że przewodzi w niej Korona Kielce, która w dodatku jako jedyny zespół w tym czasie odniosła komplet zwycięstw, za rywala mając między innymi Wisłę w Krakowie. (PN 11/2012, s. 6)

Dotąd 17 razy reprezentacja Polski grała z Anglią, a tylko raz nasi piłkarze schodzili z boiska w roli zwycięzców. (PN 41/2012, s. 5)

Pierwsze zwycięstwo odniósł wreszcie mistrz kraju, a do triumfu w Sochaux poprowadził Montpellier Remy Caballa. (PN 36/2012, s. 30)

Potocznością odznaczają się z kolei sformułowania zainkasować komplet punktów, zgarnąć komplet punktów, zgarnąć trzy punkty czy zaliczyć komplet 
punktów. O ich przynależności do niższej warstwy stylistycznej decyduje użycie bezokoliczników nienadających się do wykorzystywania w formalnej komunikacji. Większym stopniem oficjalności charakteryzują się analityzmy czasownikowe sięnąć po trzy punkty, zdobyć komplet punktów, wywieźć komplet punktów, wywieźć komplet oczek. Przywołane w tej grupie konstrukcje podkreślają, jaką zdobycz osiągnęła drużyna dzięki wywalczeniu zwycięstwa. Ważna jest zatem nie tyle sama wygrana, ile jej następstwo. Dodatkowo posłużenie się komponentem czasownikowym wywieźć podpowiada odbiorcy, że mecz został rozegrany na boisku przeciwnika. Struktury składające się z czasownika oraz liczebnikowo-rzeczownikowego zestawienia trzy punkty są charakterystyczne tylko dla określonych profesjolektów, nie w każdej dyscyplinie sportowej za zwycięstwo przyznawane są bowiem trzy punkty, a co za tym idzie - przekaz taki może być zrozumiały tylko dla wyznaczonej grupy docelowej.

Pozostające wiosną bez wygranych - gdańska Lechia i Łódzki KS - w minionej kolejce wreszcie zainkasowały komplety punktów. (PN 14/2012, s. 47)

Grający w dziewięciu gospodarze zdołali jednak utrzymać skromne prowadzenie i sięgnęli po ważne trzy punkty. (PN 11/2012, s. 28)

W tym momencie każdy mecz ma najwyższą stawkę i obojętnie, z kim zagramy, musimy zdobyć komplet punktów. (PN 36/2012, s. 9)

W piątek chorzowianie nieoczekiwanie wywieźli z Konwiktorskiej komplet punktów, tymczasem zespół Legii w sobotę po bezbarwnym występie uległ u siebie Lechowi Poznań. (PN 17/2012, s. 4)

Wcześniej, bo we wrześniu, dzięki bramce Roberto Soldado komplet punktów zgarnęła Valencia. (PN 17/2012, s. 17)

Najpierw więc zawodnicy Frederica Antonettiego w meczu kończącym poprzednią serię rozprawili się z Niceą, a w sobotę wywieźli komplet oczek z Brestu. (PN 17/2012, s. 29)

Możemy zgarnąć trzy punkty. (PN 33/2012, s. 15)

Nowicjusze zarówno na tym poziomie, jak i w tym fachu, czyli Corini oraz sardyński duet Pulga-Lopez zaliczyli w debiutach komplet punktów. (PN 41/2012, s. 25) Oprócz przegranego meczu z Bułgarią nie potrafili także zdobyć punktów w spotkaniu z Izraelem, mimo prowadzenia u siebie 2:1, przegrali 3:2. (PN 13/2012, s. 20)

Niepowodzenie w zmaganiach sportowych też bywa określane za pomocą form długich i krótkich. Najczęściej używane, a zarazem najbardziej neutralne 
syntetyczne określenie to przegrać57. Jego patetyczne odpowiedniki to ponieść porażkę lub - rzadziej - doznać porażki czy poznać smak porażki i zaznać goryczy porażki, które mają charakter przenośny.

Mówiąc o tym, że zespół może przegrywać, chyba się nie spodziewał, że trener Kramer od razu skorzysta z pozwolenia i gładko polegnie w Hamburgu. (PN 50/2012, s. 27) Piłkarze mogą wygrać, zremisować oraz, co najbardziej prawdopodobne, przegrać - Euro będzie trwało. (P 24/2012, s. 16)

Owszem, ponoszą też porażki, bolesne, jak choćby z PSV Eindhoven, ale chcę wierzyć, że będą solidną lekcją pokory dla trenera i piłkarzy z Łazienkowskiej. (PN 50/2011, s. 47)

W lidze są jednym $z$ dwóch zespołów, które nie zaznały jeszcze goryczy porażki. (PN 41/2012, s. 28)

W Łowiczu podopieczni Grzegorza Wesołowskiego przegrali 2 razy, natomiast na wyjeździe jeszcze nie zaznali porażki. (PN 41/2012, s. 44)

Rewelacyjne beniaminki - Eintracht i Fortuna w końcu poznały smak porażki. (PN 41/2012, s. 35)

Od dziesięciu lat reprezentacja Polski, po zakwalifikowaniu się do finałów mistrzostw świata (2002 i 2006 rok) lub mistrzostw Europy (2008), już w pierwszym meczu turniejowym doznawała porażki. (PN 24/2012, s. 14)

W celu oznajmienia niekorzystnego wyniku można posłużyć się komponentem punkt lub jego rzadziej wykorzystywanym synonimem oczko. Gubić punkty, tracić punkty, tracić oczka ma za zadanie złagodzić złe informacje, funkcję eufemistyczną pełni także połączenie z modulantem nie sprostać. Wrócić do domu bez punktów - oprócz delikatniejszej wymowy niż syntetyczne przegrać - informuje dodatkowo, że do przegranej doszło na stadionie drużyny przeciwnej.

Szansa jest całkiem realna, tylko nie wolno zapominać, że grupa jest bardzo wyrównana i pewnie wszyscy będą gubić punkty. (PN 49/2012, s. 19)

Wiosną prowadzą już co prawda warszawianie, ale nadal nie zachwycają i tracą kolejne oczka, natomiast ekipa Oresta Lenczyka nie potrafi wykorzystywać spowolnienia najgroźniejszego rywala. (PN 13/2012, s. 2)

57 Czasem pojawia się bardziej sugestywne polec, które sugeruje, że przegraną trzeba traktować w kategoriach klęski: Frankfurtczycy polegli 0:2 w Moenchengladbach, ale i tak utrzymali pozycję wicelidera. (PN 41/2012, s. 35). 
Mimo że rozegrali dobre zawody, w mojej ocenie lepsze od gospodarzy, do domu wrócili bez punktów. (PN 44/2011, s. 2)

Trzy kolejki przed końcem najbliżej ekstraklasy jest natomiast Piast Gliwice, ciekawe jednak, czy wzorem innych drużyn w jednej z dwóch najbliższych kolejek nie zechce stracić punktu. (PN 20/2012, s. 42)

Tym razem piłkarze Andrzeja Konwińskiego nie sprostali na własnym terenie niezbyt silnemu przecież Turowi Turek i z jednym punktem na koncie okupują ostatnie miejsce w tabeli. (PN 36/2012, s. 42)

Oparte na składniku punkt sformułowanie oddać punkty eufemizmem już nie jest, co więcej, może sugerować czytelnikom, że drużyna poddała się bez walki.

Z kolei ta znalazła wreszcie ligowego pogromcę - oddała punkty Jagiellonii, dla której zwycięstwo przy Łazienkowskiej było jednak jedynym w analizowanym okresie. (PN 49/2012, s. 40)

By uwypuklić poniesioną stratę, stosuje się potoczne dostać baty lub należące do rejestru wysokiego ponieść klęskę. Pierwsza konstrukcja wskazuje, że porażka była wysoka i bolesna, druga - choć nie odnosi się do tematyki sportowej - też uwypukla wielkość niepowodzenia. Oba sformułowania wyolbrzymiają negatywne informacje.

Choć Śląsk bił Legię przy Łazienkowskiej aż dwukrotnie, sam dostał baty od Rumunów. (PN 50/2011, s. 2)

Niestety, w życiu osobistym znów poniosła klęskę. (NŻ 12/2012, s. 44)

Warto przywołać jeszcze jedno metaforyczne, a jednocześnie eufemistyczne połączenie - przegrać jest definiowane jako otrzymać od rywali lekcje futbolu. „Odwołuje się ono do przestrzeni szkolnej i relacji uczeń - nauczyciel, wywyższa przeciwników, nie przekazuje jednak zaś żadnej negatywnej informacji na temat postawy przegranej drużyny" 58 .

Dziś łatwiej jest wygrać mecz, a wtedy prezentując zbyt ofensywną grę, łatwiej było otrzymać od rywali lekcję futbolu. (PN 48/2012, s. 15)

58 K. Burska, Analityczne konstrukcje czasownikowe..., s. 77. 
Ciekawie przedstawiają się wielowyrazowe odpowiedniki bezokolicznika zremisować, gdyż każdy z nich ma inny wymiar semantyczny. Podzielić się punkta$m i$, występujące czasem $\mathrm{z}$ dopowiedzeniem $\mathrm{z}$ rywalem, informuje, że w wyniku konfrontacji każda drużyna osiągnęła tyle samo. Gubić dwa punkty wskazuje, iż rezultat remisowy nie satysfakcjonuje piłkarzy, jest traktowany raczej jako przegrana niż zadowalające osiągnięcie. Przeciwne znaczenie niosą kolokacje zdobyć oczko i odznaczająca się potocznością zainkasować punkt, podkreślają bowiem, że wywalczenie remisu to sukces.

Piłkarze mogą wygrać, zremisować oraz, co najbardziej prawdopodobne, przegrać Euro będzie trwało. (P 24/2012, s. 16)

Źrebaki bezbramkowo zremisowały w Wolfsburgu, a Bawarczyków stać było wyłącznie na remis 1:1 w Hamburgu. (PN 6/2012, s. 43)

Myślałem, że w meczu Śląska Wrocław z Legią Warszawa drużyny podzielą się punktami. (PN 50/2012, s. 41)

Gospodarze prowadzili po 10 minutach 3:0, ale ostatecznie podzielili się z rywalem punktami. (PN 44/2012, s. 42)

Ktoś powie: $\mathrm{z}$ wielkiej chmury mały deszcz, bo ani Jaga specjalnie nie wzbogaciła się we Wrocławiu, ani tym bardziej Śląsk nie stracił szansy na mistrzostwo, gubiąc dwa punkty. (PN 48/2012, s. 2)

Mateusz Miłoszewski zastąpił Tomasza Reginisa i zdobył oczko w Łowiczu. (PN 36/2012, s. 43)

Tylko Motor zainkasował punkt, który pozwolił opuścić ostatnią lokatę w tabeli. (PN 41/2012, s. 45)

Z wykorzystaniem analitycznych konstrukcji czasownikowych opisywane są także czynności związane z poszczególnymi formacjami na boisku. „Bronić bywa stosowane wymiennie ze stać między słupkami - akcentującym miejsce przebywania bramkarza - oraz petnić straż - przypisującym golkiperowi odpowiedzialną funkcję i jednocześnie patetycznie podkreślającym jego rangę"59. Podobną rolę odgrywa peryfrastyczne sformułowanie strzec wrót, które przedstawia obrazowo bramkarza jako tego, który - niczym mitologiczne postacie - dba, by coś niepowołanego (czyli w tym przypadku piłka) nie przedostało się na nadzorowany przez niego obszar.

59 Ibidem. 
W zespole Kogutów broni bowiem wiekowy Amerykanin Brad Friedel, a sir Alex Ferguson nie jest zadowolony ani z postawy Davida de Gei, ani Andersa Lindegaarda. (PN 6/2012, s. 29)

W Copa del Rey grał Jose Manuel Pinto, Valdes pełnił straż w lidze. (PN 6/2012, s. 38) Wydawało się, że przy obsadzie reprezentacyjnej bramki mogą być jedynie kłopoty bogactwa, tymczasem po kontuzji Wojtka Szczęsnego i obniżce notowań w PSV Przemka Tytonia naprawdę nie sposób nie martwić się o to, kto stanie między słupkami 16 października. (PN 41/2012, s. 2)

Strzeże wrót Lechii Gdańsk i robi to nadspodziewanie dobrze. (PN 43/2011, s. 19)

Nie tylko czynność wykonywana przez gracza przedstawiana jest peryfrastycznie. Analogicznych określeń doczekał się też zawodnik występujący na tej pozycji, syntetyzmy bramkarz czy mający angielskie proweniencje jego synonim golkiper nie są jedynymi sposobami deskrypcji. Opisowe konstrukcje pozycja między stupkami i specjalista od stania między słupkami uwypuklają, która część boiska przypisana jest bramkarzowi, połączenie specjalista od łapania piłki informuje zaś, co należy do obowiązków piłkarza. Posłużenie się komponentem specjalista nie jest obojętne aksjologicznie, koncentruje uwagę odbiorcy na ponadprzeciętnych umiejętnościach zawodnika. Zgodnie z przytaczanym już terminem profilowanie pewne elementy zostają uwypuklone, inne zaś odsuwane są na dalszy plan.

To ewidentnie był sezon Słowaków, jeśli chodzi o bramkarzy w T-Mobile Ekstraklasie. (PN 20/2012, s. 12)

Golkiper Bogdanki Sergiusz Prusak odbił główkę Szymona Kaźmierowskiego, ale przy dobitce Michała Świderskiego był bezradny. (PN 36/2012, s. 41)

Zresztą szkoleniowiec wicemistrzów Polski jest znany z tego, iż zdarza mu się żonglować obsadą pozycji między słupkami i obecność Gikiewicza można tłumaczyć taktyką szkoleniowca. (PN 11/2012, s. 38)

Oczywiście chodzi o komplet bramkarzy, zresztą w ogóle tę klasyfikację zdominowali specjaliści od łapania piłki. (PN 24/2012, s. 33)

Podczas gdy najlepsi polscy specjaliści od stania między słupkami zarabiają na życie w Anglii, Holandii i Włoszech, ich nieobecność wykorzystują wcale nie młodzi zdolni Polacy - choć i takich nie brakuje - ale górale zza południowej granicy, co musi dziwić o tyle, że jeszcze niedawno chwaliliśmy się tak zwaną krajową szkołą bramkarzy. (PN 20/2012, s. 12 
Inne zadania przypisane są strzelcowi, zwanemu też snajperem, oba wyrazy uwydatniają nawiązanie do powszechnej w sporcie terminologii wojskowej60. Peryfrazy specjalista od strzelania goli i łowca goli jednoznacznie podpowiadają, że do obowiązków tego zawodnika należy strzelanie bramek i wywiązuje się z nich bez zarzutu. O ich częstym zdobywaniu świadczy analityczna konstrukcja najskuteczniejszy zawodnik. Metafora żąło drużyny sugeruje, że działania gracza sprawiają przykrość przeciwnikom, są powodem ich cierpienia.

W każdym innym kraju niż Niemcy taki wynik oznaczałby, że mamy do czynienia z pierwszorzędnym snajperem. (PN 17/2012, s. 28)

W jego drugiej ojczyźnie słychać komentarze, iż brakuje mu cech rasowego strzelca, który sprawdza się w najbardziej wymagającym otoczeniu. (PN 17/2012, s. 28)

Oczywiście, Dudu Biton dobrze wywiązuje się z roli żądła drużyny, ale pozostali niespecjalnie mu pomagają. (PN 11/2012, s. 14)

Po letnich przepychankach z Euzebiuszem Smolarkiem i Arturem Sobiechem właściciel Czarnych Koszul Józef Wojciechowski zainwestował w specjalistów od strzelania goli z zagranicy, dlatego $\mathrm{w}$ tym sezonie Polacy zdobyli tylko 2 bramki dla klubu, co daje 8,7 procent wszystkich goli. (PN 11/2012, s. 15)

Trio Maciej Jankowski, Arkadiusz Piech i Paweł Abbott w miarę regularnie zdobywa bramki i choć żaden z wymienionych piłkarzy na tytuł najskuteczniejszego zawodnika sezonu 2011-12 nie ma szans, to każdy z osobna pokazuje, że polski napastnik może być skuteczny. (PN 11/2012, s. 15)

Ta liczba świadczy dobitnie, że Podolski jest już dojrzałym łowcą goli. (PN 17/2012, s. 28)

Zróżnicowanie konstrukcji rzeczownikowych można zobrazować też na przykładach podejmujących inną problematykę niż sportowa. Sędzia, analityzm odznaczający się neutralnością, bywa zastępowany opisowymi konstrukcjami, dzięki którym ujawnia się specjalizacja znaczenia, są to: wykonawca sztywnej litery prawa czy szafarz sprawiedliwości, „pierwsze zaznacza znikomą możliwość wpływania subiektywnej opinii sądzących na wyroki, drugie zaś ma nadać wzniosłości. Siłę wyrazu analitycznych konstrukcji wzmacniają

60 Por. J. Ożdżyński, Polskie wspótczesne słownictwo sportowe, Wrocław-WarszawaKraków 1970, s. 134. 
poprzedzające je przydawki bezrefleksyjny i prawdziwy, które mają wyraźne zabarwienie aksjologiczne"61.

Coraz wyraźniej - także w kontekście sprawy aresztowanej niedawno za długi matki dwójki dzieci - pojawia się dylemat, czy sędziowie są tylko bezrefleksyjnymi wykonawcami sztywnej litery prawa, czy prawdziwymi szafarzami sprawiedliwości? (P 50/2012, s. 24)

Co zrobić, by sędziowie przestali być automatami zaprogramowanymi na rozstrzyganie spraw według jednego standardu? (P 50/2012, s. 24)

Słyszę od razu głosy sprzeciwu sędziów, że byłby to pierwszy krok do dowolności. (P 50/2012, s. 25)

Innym zawodem, który doczekał się peryfrastycznych odpowiedników, jest psycholog. Peryfraza trener mentalny uwypukla, że do jego głównych zadań należy wyćwiczenie właściwego sposobu myślenia. Biegłość w dziedzinie zagłębiania się w ludzki umysł podkreślona została za pomocą konstrukcji analitycznej specjalista od przygotowania mentalnego.

Co ze specjalistą od przygotowania mentalnego? (PN 6/2012, s. 22)

Drugi warunek dokooptowania trenera mentalnego jest następujący - przed najbliższym spotkaniem potrzebę pracy z takim specjalistą musi zgłosić minimum dwóch kadrowiczów. (PN 6/2012, s. 22)

Rzeczywiście nie chce pan psychologa w sztabie? (PN 6/2012, s. 22)

Zdarza się, że dziennikarze - aby zastąpić nazwę podstawową - wykorzystują nawiązanie do powszechnie znanych postaci. Zabieg taki ma właściwości wartościujące, zwracając uwagę na konkretną osobę, odwołuje czytelnika do rzeczywistości pozajęzykowej, a to pozwala wydobyć oczekiwane przez autora znaczenie konstrukcji analitycznej, nierzadko oryginalnej, wcześniej nienotowanej. Jako egzemplifikacja powyższego zjawiska niech posłużą ekwiwalenty

61 K. Burska, Peryfraza a jej jednowyrazowy odpowiednik (na materiale polskich tygodników), [w:] Idee, wartości, słowa w życiu publicznym, red. G. Majkowski, J. Makowska, L. Kuras, Łódź 2014, s. 245. 
leksemów angielski i koszykówka, w których wykorzystano nazwiska pisarza i koszykarza ${ }^{62}$.

- Nie jest łatwo utrzymać nerwy na wodzy na mojej pozycji - mówi w niemal perfekcyjnej mowie Szekspira. (PN 44/2012, s. 29)

Poza tym mamy w klubie wystarczająco dużo graczy posługujących się także angielskim. (PN 36/2012, s. 26)

Oprócz takich gadżetów, mających coś wspólnego z dyscypliną legendarnego Michaela Jordana, w jego zbiorach odnaleźć można także bilety, programy i autografy żużlowe. (VG 12/2011, s. 59)

Kiedy po raz pierwszy idziesz na zajęcia aerobiku albo na trening siatkówki czy koszykówki, wrzucasz do torby zwykłą koszulkę i spodenki. (VG 12/2011, s. 24)

Z podobnym rozwiązaniem - czyli odwołaniem do nazw własnych - spotykamy się w przypadku omówienia odnoszącego się do francuskich polityków. Zostali oni nazwani rezydentami Pałacu Burbońskiego, wykorzystano więc nazwę siedziby parlamentarzystów z Francji. Odnotowano też jeszcze dwa inne równoważniki leksemu polityk: peryfraza ludzie, w których ręce została złożona największa władza „podkreśla, że z jednej strony są oni wybrańcami mogącymi decydować o losach innych, ale z drugiej stawia się im wysokie wymagania"63, z kolei sfrazeologizowane połączenie mą̇̇ stanu przypisuje rządzącym duże znaczenie i nieprzeciętną umiejętność sprawowania rządów.

W roli reżyserów wydarzeń obsadziliśmy więc polityków. Ludzi, w których ręce została złożona największa władza. (P 51-52/2012, s. 27)

Dzisiaj rezydenci Pałacu Burbońskiego zaczynają rozumieć, że popularny Ibra dysponuje porównywalną mocą przyciągania turystów jak o 475 lat starsza od niego, również ściągnięta do Paryża z północy Włoch, Mona Lisa. (PN 50/2012, s. 16) Upiekł dwie pieczenie: dowiedział się, co jest ważne, dla jego elektoratu i utrwalił wizerunek męża stanu wsłuchanego w głos internautów. (P 51-52/2012, s. 38)

62 Wielowyrazowe konstrukcje zbudowane z elementów będących nazwami własnymi są często spotykane jako odpowiedniki innych pojedynczych nazw własnych. Kilka reprezentatywnych przykładów zostanie omówionych w kolejnym podrozdziale.

63 K. Burska, Peryfraza a jej jednowyrazowy..., s. 244. 
W przeszłości kilku aktywnych polityków związanych z piłką nożną było w strukturach PZPN i mieli jakiś wpływ na szefa związku. (PN 41/2012, s. 18)

Pod względem oczytania i sprawności językowej Korwin-Mikke bije na głowę większość współczesnych polityków. (P 50/2012, s. 19)

Z odwołaniem do innego desygnatu spotykamy się w przypadku analitycznego odpowiednika granatu. Kolor ten został opisowo nazwany nowa czernia, co ma na celu wzbudzenie skojarzeń związanych właśnie z tą barwą. Przymiotnik nowa wartościuje pozytywnie odcień granatowy, dodatkowo może sugerować, że popularność koloru czarnego spadła, a jego miejsce zajęło coś do tej pory niespotykanego, co jednak ma zbliżone do czerni właściwości.

Kolor elegancki, szykowny, tzw. nowa czerń. (NŻ 4/2012, s. 20)

Żółty ociepla granat, wnosząc do całej stylizacji powiew świeżości. (NŻ 4/2012, s. 21)

Analogiczny mechanizm został wykorzystany przy budowaniu peryfrazy niebieskie złoto zastępującej leksem woda, odwołano się do innego elementu rzeczywistości pozajęzykowej - posłużenie się nazwą kruszcu sprawia, że odbiorca przypisuje wodzie wszystkie znaczenia kojarzące się ze złotem, dochodzi do przeniesienia właściwości przypisywanych metalowi szlachetnemu na będącą przedmiotem opisu ciecz. Drugie omówienie - życiodajny płyn - nie tylko wskazuje na postać, w jakiej występuje woda, lecz także - dzięki zastosowaniu przekazującej jednoznaczne treści semantyczne przydawki - uwypukla, że jest to niezbędny składnik funkcjonowania organizmów żywych.

Świadomość, że życiodajny płyn pokrywa 71\% powierzchni globu, powoduje, iż traktujemy go jako dobro nieograniczone i ogólnodostępne. (VG 6/2011, s. 3)

Brak dostępu do wody może dotknąć każdego mieszkańca Ziemi. (VG 6/2011, s. 3) Oznacza to, że sięgając po małą Cisowiankę, możemy być pewni, że całość zysku z jej sprzedaży zostanie przekazana na ten konkretny cel - budowę ujęć wodnych w jednym z najuboższych w „niebieskie złoto” regionów świata. (VG 6/2011, s. 5)

Warto jeszcze powrócić do stałych połączeń wyrazowych, które da się zastąpić pojedynczym leksemem. B. Rejakowa podkreśla, że „związek frazeologiczny ujawnia swoją specyfikę na tle jednostki leksykalnej lub swobodnego połączenia wyrazowego w ten sposób, że jest od niej (niego) «bogatszy» o takie wartości, jak: 
sugestywność, wyrazistość, ładunek ekspresyjny, dokładność, obrazowość itd."64 Wcześniej omówione zostały frazeologizmy, którym odpowiada czasownik, teraz przyjrzyjmy się złożonym ekwiwalentom innych części mowy. Zamiennikami wściekłości mogą być biała goraczka oraz szewska pasja. Oba wyrażenia przekazują informację o stanie zdenerwowania, jednak różnicują jego natężenie, są bardziej wyraziste niż syntetyzm - biała goraczka akcentuje siłę złości, sugeruje, że graniczy ona niemal z pasją, szewska pasja uwypukla zaś gwałtowność reakcji.

Z dzisiejszej perspektywy widać, że nie był to taki zły czas, jak się wówczas wydawało, chociaż kolejne ekscesy katolickich fundamentalistów czy ,inwigilowanej prawicy”, wyrosłej na rządzie Jana Olszewskiego, mogły doprowadzać przeciwników do białej gorączki. (P 51-52/2012, s. 35)

Tego, który w pojedynkę doprowadzał do szewskiej pasji ośmieszonych i wymanewrowanych rywali. (PN 11/2012, s. 4)

Zróżnicowanie semantyczne wśród konstrukcji odpowiadających przysłówkom jest również godne rozpatrzenia. Całkowicie może być zastąpione frazeologizmami do imentu i do szpiku kości. Pierwszy - tłumaczony również z wykorzystaniem wyrażenia przyimkowego do cna - ma wyraźne nacechowanie potoczne, nie nadaje się do wykorzystania w każdym rodzaju tekstu, wydaje się, że jest notowany dość rzadko w tekstach prasowych, a w związku z tym może być mało zrozumiały. Drugi natomiast niesie dodatkowe znaczenie do głębi, na wskroś, co uwydatnia rozległość cech czy kompletność czynności opisywanych za jego pośrednictwem.

Obrzydzili mi tego faceta do imentu. (VG 3/2011, s. 12)

Trzeba być naprawdę do szpiku kości Europejczykiem lub Amerykaninem z XXI w., żeby myśleć w ten sposób. (P 50/2012, s. 75)

W celu podkreślenia opanowanego podejścia do tego, co się dzieje, można użyć syntetycznego spokojnie, a także wyrażeń bez szemrania i z zimną krwią. Składający się z dwóch komponentów związek unaocznia, że działania zostały podjęte bez jakiegokolwiek sprzeciwu czy narzekania, trzyelementowe połączenie

64 B. Rejakowa, Pojedynczy wyraz..., s. 344-345. 
przedstawia, że spokój, który towarzyszył postępowaniu, wiąże się z beznamiętnym, wyrachowanym, pozbawionym emocji podejściem.

W pierwszym rozegranym w bieżącym roku meczu ligowym zespół łódzkiego Widzewa bez szemrania oddał punkty przyjezdnym z Bielska-Białej. (PN 9/2012, s. 47) Wszystkie ewolucje muszą być wykonane z zimną krwią. (VG 13/2011, s. 6) Strzeleckie okazje wykorzystuje z zimną krwią. (PN 51-52/2011, s. 89)

Szybkość wykonywania czynności bywa wyrażana przysłówkiem natychmiast oraz analitycznymi konstrukcjami na zawołanie i z miejsca. Pierwsza podpowiada, że coś może zostać wykonane w każdej chwili, druga z kolei sugeruje, że przystąpiono do działania od razu.

Doceniliśmy skuteczność pomocników, którzy gole zdobywają wprost na zawołanie. (PN 50/2011, s. 2)

O wspomnianej sprawie $\mathbf{z}$ miejsca zrobiło się głośno, tym bardziej że Akademia Piłkarska świadcząca wcześniej PZPN usługi transportowe, pod której szyldem działał słynny od czasu ujawnienia taśm prawdy Grzegorz Kulikowski, była zarejestrowana na nazwisko Władysława Żmudy. (PN 49/2012, s. 12)

Do przestrzeni odnoszą się następujące sformułowania o synonimicznym znaczeniu: wszędzie, jak długi i szeroki oraz na każdym kroku. Wyrażenie jak dtugi i szeroki podkreśla, że coś obejmuje zasięgiem cały obszar, którego dotyczy, jego równoważnikiem może być połączenie od krańca do krańca. Frazeologizm na każdym kroku oprócz odniesień do powierzchni może także dotyczyć ciągłości działań, wydobywa więc dodatkowe aspekty znaczeniowe.

Po losowaniu grup Euro 2012 Polska - jak długa i szeroka - podzieliła się na dwa stronnictwa. (PN 49/2011, s. 2)

Widać je zresztą na ulicach Barcelony na każdym kroku. (PN 41/2012, s. 26)

Opisane w tej części synonimiczne zestawienia złożone z syntetyzmu i wielowyrazowych konstrukcji - często zróżnicowanych formalnie - pokazują, że odrębności semantyczne w takich grupach są bardzo rozpięte: od subtelnych, trudno dostrzegalnych dla przeciętnego czytelnika rozbieżności, przez wydobycie nowych sensów, niewyrażalnych za pomocą pojedynczego wyrazu, aż do ta- 
kich zbiorów, w których można zaobserwować treści kontrastowe. Co podkreślali już niejednokrotnie badacze języka, połączenia wyrazowe odznaczają się większą precyzją niż ich jednoelementowe odpowiedniki. Wspominali o tym w swoich pracach m.in. J. Anusiewicz, D. Buttler, E. Pokorska-Szczodruch, H. Mieczkowska czy J. Miodek ${ }^{65}$.

Dużą grupę stanowią frazeologizmy, które - mimo identycznego ekwiwalentu syntetycznego - nie mogą być stosowane wymiennie we wszystkich kontekstach. Każdy z nich wyzyskuje inny odcień znaczeniowy, spośród wielu możliwych interpretacji pozwala skoncentrować uwagę odbiorcy na jednym, konkretnym elemencie. Jak twierdzą Andrzej Maria Lewicki i Anna Pajdzińska: „Nawet związki będące synonimami wyrazów lub innych frazeologizmów nie są elementami zbędnymi, ekwiwalencja semantyczna nie oznacza bowiem, że między jednostkami leksykalnymi nie istnieją żadne różnice"66. Zróżnicowaniu semantycznemu często towarzyszy inne zabarwienie stylistyczne. „Związek frazeologiczny w porównaniu z wyrazem, należącym do neutralnego zasobu słownictwa, ma swoistą nadbudowę w postaci nacechowania stylistycznego, trudną często do precyzyjnego określenia. Nie w każdej jednak parze synonimicznej, składającej się ze związku frazeologicznego i pojedynczego wyrazu, frazeologizm ma większy ładunek ekspresyjny"67. Nie sposób nie wspomnieć także o wartościowaniu, które często ujawnia się w konstrukcjach opisowych.

65 Por. J. Anusiewicz, Konstrukcje analityczne w języku polskim, Wrocław 1978; idem, Konstrukcje analityczne we współczesnym...; D. Buttler, Połaczenia typu ulec zniszczeniu w języku polskim, „Poradnik Językowy” 1968, z. 7; eadem, Leksykalne czasowniki posilkowe w konstrukcjach peryfrastycznych typu „wywrzeć wpływ” na przełomie XIX i XX wieku, [w:] Z problemów frazeologii polskiej i słowiańskiej, t. 4, red. M. Basaj, D. Rytel, Wrocław 1988; eadem, Tendencje rozwojowe współczesnej polszczyzny, [w:] Współczesna polszczyzna. Wybór zagadnień, praca zbiorowa pod red. H. Kurkowskiej, Warszawa 1986; eadem, Procesy multiwerbizacji we wspótczesnej polszczyźnie, „Poradnik Językowy” 1978; I. Loewe, Konstrukcje analityczne w poezji Młodej Polski, Katowice 2000; eadem, Konstrukcje analityczne w polskiej telewizji na progu drugiej dekady XXI wieku, „Stylistyka” 2010, XIX; E. Pokorska-Szczodruch, op. cit.; H. Mieczkowska, Analityzmy leksykalne w ujęciu słowacko-polskim, „Studia z Filologii Polskiej i Słowiańskiej” 2006, t. 41, Warszawa; J. Miodek, Syntetyczne konstrukcje leksykalne w języku polskim, Wrocław 1976.

66 A. M. Lewicki, A. Pajdzińska, op. cit., s. 327.

67 B. Rejakowa, op. cit., s. 350-351. 
Beata Burska-Ratajczyk zaznacza, że „połączenia wyrazowe stwarzają więcej możliwości ekspresji semantycznych i stylistycznych niż pojedyncze leksemy"68. Wydaje się, że dotyczy to nie tylko związków frazeologicznych, ale wszystkich analityzmów. Wartość semantyczna często sprowadza się bowiem do specjalizacji znaczenia, którą najłatwiej wyrazić właśnie rozbudowaną formą. Struktury złożone pozwalają także zniwelować wieloznaczności, które może powodować posługiwanie się syntetyzmem.

\subsection{Wyrażające odmienne nacechowanie stylistyczne}

\subsubsection{Potoczność}

Kategorii potoczności zostały poświęcone w ostatnich dziesięcioleciach liczne opracowania językoznawcze ${ }^{69}$. Podkreśla się, że ,język potoczny jest powszechnym środkiem informacji, językiem dnia powszedniego; pojawia się on w nieoficjalnym typie kontaktu, funkcjonuje w opozycji do uznanych wzorców i norm języka literackiego"70. Jerzy Bartmiński zaznacza, że potoczność to pierwszy przyswajany przez człowieka wariant, „którego uczymy się w rodzinnym domu jako dzieci i który potem długo jeszcze wystarcza nam do posługiwania się w codziennych sytuacjach życiowych"71. Andrzej Markowski uwypukla występowanie tej odmiany zwłaszcza w kontaktach nieoficjalnych (czyli prywatnych, a nawet intymnych) pomiędzy osobami pozostającymi w bliskich relacjach między sobą, używa się jej, by „wyrazić swój familiarny stosunek do uczestników rozmowy, podtrzymać jej swobodny nastrój albo by zaprezentować swoje skłonności ga-

68 B. Burska-Ratajczyk, Wartościowanie komunikacji językowej (na materiale frazeologii gwar mazowieckich), [w:] Język, społeczeństwo, wartości, red. E. Laskowska, I. Benenowska, M. Jaracz, Bydgoszcz 2008, s. 81.

69 Por. m.in. Język a kultura, t. 5: Potoczność w języku i kulturze, red. J. Anusiewicz, S. Nieckula, Wrocław 1992; A. Markowski, Polszczyzna końca XX wieku, Warszawa 1992; K. Ożóg, Polszczyzna przełomu XX i XXI wieku. Wybrane zagadnienia, wyd. 3, Rzeszów 2007; J. Warchala, Dialog potoczny a tekst, Katowice 1991; idem, Kategoria potoczności w języku, Katowice 2003; Język w mediach masowych, red. J. Bralczyk, K. Mosiołek-Kłosińska, Warszawa 2000; M. Kita, Ekspansja potoczności, „Prace Językoznawcze”, t. 19: Studia polonistyczne, red. A. Kowalska, A. Wilkoń, Katowice 1991, s. 83-90.

70 A. Dąbrowska, Eufemizmy mowy potocznej, [w:] Język a kultura, t. 5: Potoczność w języku i kulturze, red. J. Anusiewicz, S. Nieckula, Wrocław 1992, s. 119.

71 J. Bartmiński, Styl potoczny, [w:] Encyklopedia kultury polskiej XX wieku, t. 2: Współczesny język polski, red. J. Bartmiński, Wrocław 1993, s. 113. 
wędziarskie, popisać się umiejętnością barwnego, żywego opowiadania, wykazać poczucie humoru czy wreszcie umiejętność bawienia się językiem"72. Choć prymarnie styl potoczny występuje w przekazie ustnym, to akcentuje się też jego pojawianie w zróżnicowanych gatunkowo wypowiedziach pisemnych.

Słownictwo wykorzystywane w tym rejestrze języka koncentruje się wokół człowieka: „Do potocznego inwentarza należą, z jednej strony, wyrazy najczęściej używane, powszechne w najróżniejszych tekstach języka [...], z drugiej zaś - wyrazy odnoszące się do elementarnych dziedzin zainteresowań przeciętnego człowieka i powiązane ze sobą wewnętrzną więzią semantyczną, wyrazy, bez których nie możemy się obyć w określonych sytuacjach życiowych oraz przy definiowaniu innych wyrazów"73. Zwraca się uwagę na zróżnicowanie stylu potocznego, można dokonać podziału na rejestry neutralny i emocjonalny, swobodny i staranny. Potoczność stawiana jest w opozycji do poetyckości, naukowości i oficjalności ${ }^{74}$. Badacze wskazują na ekspresywne nacechowanie wyrazów potocznych, na plan pierwszy wysuwa się ujemne wartościowanie.

Kazimierz Ożóg zwraca uwagę na ekspansję stylu potocznego od lat 90. XX w., stwierdzając: „Mamy tu do czynienia ze swoistym awansem tej odmiany, jej nobilitacją i dowartościowaniem”75. Obserwuje przenikanie elementów stylu potocznego do innych odmian stylowych polszczyzny: „Panuje nawet charakterystyczna moda na potoczność w tekstach reklamowych, w artykułach prasowych, w audycjach radiowych, telewizyjnych, oficjalnych wypowiedziach polityków, wreszcie w literaturze pięknej, która - jak nigdy dotąd - wykorzystuje ten styl (obok odmian środowiskowych) do celów artystycznych"76. O przewartościowaniu statusu języka potocznego wspomina A. Rejter, wskazując, że zyskuje on coraz większą aprobatę i jest obecny niemal we wszystkich sytuacjach werbalnego obcowania ludzi ze sobą ${ }^{77}$. Widoczne jest więc zacieranie przywołanych wcześniej opozycji, okazuje się bowiem, że potoczność przedostaje się tam, gdzie wcześniej nie było dla niej miejsca. Do głównych typów tekstów,

72 A. Markowski, op. cit., s. 26.

73 J. Bartmiński, op. cit., s. 119.

74 Por. ibidem, s. 128-131.

75 K. Ożóg, op. cit., s. 54.

76 Ibidem, s. 55.

77 A. Rejter, Uniwerbizmy w języku prasy drugiej połowy XX wieku. Próba analizy diachronicznej, [w:] Wokół słów i znaczeń, t. 4: Słowotwórstwo a media, red. I. Badyda, J. Maćkiewicz, E. Rogowska-Cybulska, Gdańsk 2011, s. 307. 
w których się ona pojawia, K. Ożóg zalicza: teksty reklamowe; publiczne wypowiedzi polityków, dziennikarzy, ludzi kultury, naukowców; homilie; różne artykuły prasowe, zwłaszcza ich tytuły.

Halina Kurkowska i Stanisław Skorupka podkreślają, że w stylu potocznym wszechobecna jest dążność do skrótu, która przejawia się na różnych płaszczyznach. „W zakresie słownictwa i słowotwórstwa [można jej upatrywać - przyp. KB] w faworyzowaniu tych typów struktur wyrazowych, tych wyrazów i zwrotów, które pozwalają na szybsze choć mniej dokładne formułowanie myśli"78. Podstawową metodą wzbogacania leksyki potocznej jest słowotwórstwo. Na uniwerbizację jako charakterystyczny dla polszczyzny potocznej sposób powstawania wyrazów kładą akcent m.in. D. Buttler, A. Markowski, J. Miodek, H. Satkiewicz, T. Orłoś czy E. Szczepańska79. Uwypukla się, że z pary dwuwyrazowe połączenie - uniwerbizm to określenie peryfrastyczne ma charakter oficjalny. Podkreśla się, że to w tekstach mówionych (a jak już wspomniano - jest to pierwotna forma występowania odmiany potocznej) istnieje silniejsza potrzeba ekonomii środków językowych, uniwerbizacja sprawia, że nazwa traci swój neutralny charakter („nacechowanie potoczne danego wyrazu jest odczuwane tym silniej, im silniejsze jest odczucie oficjalności sfery działania, do której się on odnosi"80), uniwerbizmy przynależą do stylu niższego (zalicza się tu - oprócz języka potocznego - także żargon i odmiany środowiskowe i profesjonalne). D. Buttler wprost zaznacza: „Powszechność struktur uniwerbizowanych stanowi uderzającą cechę współczesnej polszczyzny potocznej odróżniającą ją od języka pisanego"81, H. Sat-

78 H. Kurkowska, S. Skorupka, Stylistyka polska. Zarys, Warszawa 1966, s. 239.

79 Por. D. Buttler, Tendencje rozwojowe współczesnej polszczyzny, [w:] Współczesna polszczyzna. Wybór zagadnień, praca zbiorowa pod red. H. Kurkowskiej, Warszawa 1986, s. 187-219; eadem, Procesy multiwerbizacji we współczesnej polszczyźnie, „Poradnik Językowy” 1978, s. 54-62; A. Markowski, op. cit.; J. Miodek, Syntetyczne konstrukcje...; T. Orłoś, Nowsze uniwerbizmy w czeskim języku potocznym, [w:] W kręgu języka. Materiały konferencji „Słowotwórstwo - słownictwo - polszczyzna kresowa” poświęconej pamięci Profesor Zofii Kurzowej Kraków 16-17 maja 2008, red. M. Skarżyński, M. Szpiczakowska, Kraków 2009, s. 301-307; H. Satkiewicz, Budżetówka, Krajówka, zbrojeniówka, „Poradnik Językowy” 1993, z. 6; E. Siatkowska, Syntetyczne i analityczne nazwy w języku czeskim i polskim, „Prace Filologiczne” 1964, t. 18, cz. 2; E. Szczepańska, Uniwerbizacja w języku w języku czeskim i polskim, Kraków 1994.

80 H. Satkiewicz, Budżetówka..., s. 372.

81 D. Buttler, Tendencje rozwojowe..., s. 215. 
kiewicz dodaje, że używanie w tekstach prasowych uniwerbizmów z formantem -(ów)ka traktowane jest przez niektórych użytkowników języka polskiego „jako zgrzyt stylistyczny, ponieważ na tle słownictwa o charakterze oficjalnym wyodrębniają się ze szczególną ostrością jako składniki innej odmiany języka"82.

ChoćJ. Miodek i E. Szczepańska nie odmawiają uniwerbizacji przynależności do stylu potocznego, to ich stanowisko w tej kwestii jest trochę odmienne od przedstawionego powyżej. W swoich monografiach dotyczących syntetyzmów leksykalnych wykazują bowiem, że zjawisko to obecne jest także w innych odmianach stylistycznych - ogólnej, naukowej, artystycznej, publicystyczno-dziennikarskiej - można je zatem potraktować jako proces ogólnojęzykowy. Oboje odnotowują jednak najwięcej zastosowań takich konstrukcji w języku potocznym i tutaj dopatrują się źródła kondensacji. E. Szczepańska wymienia dwie przyczyny takiego stanu: „Jedną z nich jest dążenie do oszczędności i ekonomii wypowiedzi, a więc do jej skrócenia - drugą zaś jest nadanie wypowiedzi charakteru emocjonalnego, ekspresywnego"83.

Przyglądający się konstrukcjom zuniwerbizowanym w języku XX-wiecznej prasy A. Rejter konstatuje: „Zwraca ponadto uwagę rozmaitość stylistyczna badanego słownictwa, uniwerbizmy występujące w prasie pochodzą bowiem z różnych odmian językowych (potocznej, oficjalnej, specjalnej, środowiskowej), wiele pośród nich okazjonalizmów"84.

Biorąc pod uwagę wszystkie zaprezentowane powyżej opinie nt. przynależności uniwerbizacji do potoczności, postanowiono zaliczyć takie formy do tej właśnie grupy. W pracy zajęto się tylko parami analityzm - syntetyzm (a nie samodzielnie występującymi uniwerbizmami), które pojawiają się równolegle w tekstach prasowych, co może sugerować, że użycie jednej z nich podyktowane jest konkretnymi względami, np. chęcią podkreślenia przynależności do niższego stylu czy wyrażenia ekspresywności. Obecność wielu zuniwerbizowanych form w najnowszym Słowniku polszczyzny potocznej pod red. Macieja Czeszewskiego może świadczyć o tym, że mimo upływu lat wciąż traktowane są jako nieodpowiednie w komunikacji oficjalnej. I odwrotnie - podkreślić też należy, że wiele przywołanych odpowiedników nazw długich na tyle zakorzeniło się w powszechnym użyciu, że ich odmienność stylistyczna jest niemal niedostrzegalna.

82 H. Satkiewicz, Budżetówka..., s. 371.

83 E. Szczepańska, Uniwerbizacja w języku..., s. 72.

84 A. Rejter, Uniwerbizmy w języku prasy..., s. 315-316. 
Najczęściej spotykanym sposobem jest derywacja sufiksalna. Dla zobrazowania warto posłużyć się przykładami, które pozwolą przyjrzeć się funkcjonowaniu konstrukcji analitycznych i ich ekwiwalentów w zróżnicowanych kontekstach.

a) derywaty z sufiksem -(ów)ka:

Jego bojówka kilka tygodni wcześniej poraniła nożem fana Cracovii, ten potem szukał zemsty. (P 5/2011, s. 94)

Wojnę toczą dorośli liderzy bojówek klubowych, ale ofiarami padają głównie małolaty. (P 5/2011, s. 95)

Miał szczególny autorytet w grupie bojowej. (P 5/2011, s. 94)

Ale bandyckie tło zdarzenia nie wyklucza animozji między bojowymi oddziałami kibiców, często bowiem gangsterskie interesy łączą się z aktywnością stadionową. (P 5/2011, s. 94)

Byłby dumny, gdyby wiedział, że po kilku latach, jego córka zdała najlepiej egzamin do praskiej filmówki. (NŻ 5/2012, s. 16)

Zachwiało nim nieszczęście, które zdarzyło się, gdy miała 22 lata i studiowała w łódzkiej filmówce. (NŻ 9/2012, s. 10)

Jest absolwentką praskiej szkoły filmowej FAMU. (NŻ 5/2012, s. 17)

$\mathrm{W}$ trakcie festiwalu zaprezentowane zostaną również dzieła najbardziej obiecujących studentów i absolwentów polskich szkól filmowych. (VG 16/2012, s. 5)

W przeciwieństwie do Francisa Forda Coppoli, Briana de Palmy, Martina Scorsese czy George’a Lucasa nie skończył żadnej szkoły filmowej. (P 24/2012, s. 93)

Gra przecież w mistrzowskim zespole jednej z najsilniejszych lig świata, a całkiem niedawno zakończył dopiero wiek młodzieżowca - ocenia trener naszej młodzieżówki i ekspert w dziedzinie Bundesligi, Stefan Majewski. (PN 6/2012, s. 13)

I nigdy nie pobierał żadnej części z owych 75 tysięcy, a jedynie gratyfikację należną trenerowi za prowadzenie jednej z reprezentacji młodzieżowych. (PN 49/2012, s. 12) Znając trenera Mroczkowskiego, zresztą byłego selekcjonera kadr młodzieżowych, świetnie orientuje się w temacie i jestem pewien, że Mariusz trafi do pierwszej jedenastki Widzewa w najbardziej odpowiednim dla niego momencie. (PN 48/2012, s. 2) Czy jednak słusznie, skoro dla polskich szkoleniowców pracujących nie tylko z drużynami młodzieżowymi problem dostępu do dobrych boisk to chleb powszedni? (PN 50/2011, s. 43)

Jeszcze wiosną grał w okręgówce, w barwach Drzewiarza Jasienica. (PN 41/2012, s. 37) O miejscowości zrobiło się głośniej właśnie dzięki trzecioligowemu klubowi piłkarskiemu, który jeszcze w sezonie 2007-08 występował w klasie okręgowej. (PN 47/2011, s. 20) 
I tylko najwięksi geniusze potrafią przeskoczyć bezboleśnie z podstawówki od razu do szkoły wyższej z pominięciem gimnazjum i liceum. (PN 10/2012, s. 2)

Pomoc w nauce słabszym uczniom ze swojej szkoły albo sąsiedniej podstawówki. (VG 3/2011, s. 3)

Trenowałem przez całą podstawówkę - opowiada Marcin. (NŻ 4/2012, s. 14)

Michał będzie grał w przedstawieniach w szkołach podstawowych, gdzie dzieci uczą się hiszpańskiego. (VG 4/2011, s. 9)

Mama gwiazdy, Krystyna Łaszewska, była higienistką w szkole podstawowej w Gdańsku, do której chodziła córka. (NŻ 5/2012, s. 19)

Działający tam prokomunistyczny Związek Patriotów Polskich organizował oddziały polskie przy szkołach podstawowych. (P 51-52/2012, s. 93)

Prosty przykład: dlaczego na realizacje różnych projektów siatkówka dostała od państwa 30 milionów złotych, natomiast piłka nożna tylko 3 miliony? (PN 41/2012, s. 19) Kiedy po raz pierwszy idziesz na zajęcia aerobiku albo na trening siatkówki czy koszykówki, wrzucasz do torby zwykłą koszulkę i spodenki. (VG 12/2011, s. 24)

Mam 14 lat i od 2 lat trenuję piłkę siatkową. (VG 18/2012, s. 14)

Pięć lat na kontrolę skarbówki. (NŻ 3/2012, s. 31)

Informacje, że w całej Polsce ponad milion złotych rocznie zarabia 11,5 tys. osób, z tego aż 830 mieszka w Nowym Sączu, wyciekły ze skarbówki. (P 51-52/2012, s. 58) Potem było kilka burzliwych rozwodów, głośne procesy o alimenty, problemy z urzędem skarbowym. (PN 48/2011, s. 29)

Na sprawdzenie Twojego rocznego zeznania PIT urząd skarbowy ma 5 lat. (NŻ 3/2012, s. 31)

Zwłaszcza że życie emeryta jest spokojniejsze, nie jest on nieustannie narażony na bankructwo, nieuczciwą konkurencję, prześladowania ze strony urzędów skarbowych. (P 24/2012, s. 110)

W Hamburgu chłop sobie jeszcze postrzela, a w Poznaniu Ślusarz już siedem zapakował i idzie na życiówkę. (PN 50/2012, s. 11)

Satysfakcję z życiowego rekordu w podrzucie podkreślił, uderzając pięścią w klatkę piersiową, pozdrowił kibiców, po czym odebrał gratulacje od braci, Roberta i Daniela, również ciężarowców. (P 51-52/2012, s. 150)

Golkiper Bogdanki Sergiusz Prusak odbił główkę Szymona Kaźmierowskiego, ale przy dobitce Michała Świderskiego był bezradny. (PN 36/2012, s. 41)

Centrę Marka Wasiluka na gola uderzeniem głową zamienił Przemysław Kaźmierczak. (PN 50/2011, s. 41) 
Dośrodkowanie Zieńczuka na gola strzałem głową zamienił Paweł Abbott. (PN 47/2011, s. 40)

Planowałem pojechać popracować do Holandii na całe wakacje, a nawet dłużej, ale wychowawca wyznaczył mi poprawki pod koniec sierpnia. (VG 14/2012, s. 15)

Na początek życzę powodzenia na egzaminach poprawkowych. (VG 14/2012, s. 10)

A wcześniej setkę, w której wielu powinien uderzać lewą, a nie prawą nogą. (PN 41/2012, s. 7)

- Niestety, zmarnowałem stuprocentową sytuację i nic tego nie zmieni - powiedział po meczu Buzi. (PN 36/2012, s. 38)

b) derywaty z sufiksem -ak

W gimnazjum i ogólniaku chodziłam na kursy. (VG 4/2011, s. 9)

Liceum ogólnokształcące, profil biologiczno-chemiczny - to idealny wybór, bo do biologii i chemii trzeba się szczególnie przyłożyć. (VG 9/2011, s. 41)

Spożywczak był jedynym sklepem, do którego lubiła chodzić. (VG 8/2011, s. 11)

Jeśli jednak trening jest wyczerpujący, a w dodatku mocno się pocisz (bo lato), możesz zdecydować się na napój izotoniczny (są w każdym sklepie spożywczym, np. PowerRade). (VG 17/2012, s. 15)

c) derywaty z sufiksem -ina

Turcy nie spożywają wieprzowiny, ponieważ mięso wieprzowe uważają za nieczyste. (VG 5/2011, s. 12)

Nierzadko spotykamy się też z dezintegracją towarzyszącą derywacji paradygmatycznej. Jako przykłady niech posłużą:

Za kierownicą na dopingu (NŻ 9/2012, s. 31)

Czy w przypadku policyjnej kontroli drogowej można, oprócz alkoholu we krwi, wykryć również inne środki dopingujące? (NŻ 9/2012, s. 31)

Jak to było na humanie... (VG 10/2011, s. 40)

Jaki z tego wniosek - autorzy testów doskonale wiedzą, że egzamin humanistyczny to połączenie języka polskiego, historii, WOS-u i sztuki. (VG 10/2011, s. 41) 
Czasy, kiedy kryminały uważano za „literaturę wagonową”, niezbyt wyrafinowaną rozrywkę czytelniczą, którą nie należy się zbytnio przed nikim chwalić, na szczęście odeszły już w niepamięć. (P 24/2012, s. 95)

Kolejna edycja „Lata z kryminałem”, wspólnej serii POLITYKI i Wydawnictwa W.A.B., to dobra okazja, by sprawdzić, co nowego dzieje się w prozie kryminalnej. (P 24/2012, s. 95)

W ostatnich latach to właśnie powieść kryminalna - obok reportażu - jest jedną z najbujniej rozwijających się dziedzin prozy. (P 24/2012, s. 95)

Nowe mikrofale Samsung uwodzą funkcjonalnością i ładnym wzornictwem, mają ceramiczne wnętrze, które nie absorbuje zapachów ani smaków. (NŻ 5/2012, s. 41) W sytuacji, gdy w ekspresowym tempie chcesz coś ugotować lub tylko podgrzać obiad, kuchenka mikrofalowa jest niezastąpiona. (NŻ 5/2012, s. 41)

Zamiast utrzymać ją w tej okolicy, czyli osłaniać lub ewentualnie spróbować wywalczyć róg lub aut, wstrzelił futbolówkę w pole karne. (PN 13/2012, s. 20)

Sędzia Robert Małek nie ustrzegł się rażących pomyłek, na pewno mniejszym błędem byłoby podyktowanie jedenastki dla zespołu Tomasza Kafarskiego (za faul Rafała Gikiewicza na Piotrze Wiśniewskim) niż niedostrzeżenie, iż po rzucie rożnym Marek Wasiluk niedopuszczalnie staranował bramkarza przyjezdnych, młodziutkiego Wojciecha Pawłowskiego. (PN 44/2011, s. 2)

Blisko samobója, ale ostatecznie mamy tylko rzut rożny. (PN 24/2012, s. 7)

Jak nie idzie, to na całego - autokar klubowy miał ponoć aż dwie stłuczki w drodze do Chorzowa, pierwszego gola zdobył samobójczym strzałem Hubert Wołąkiewicz. (PN 9/2012, s. 11)

Strzelił między innymi samobójczego gola w meczu swojego byłego zespołu z Lecce w maju ubiegłego roku. (PN 41/2012, s. 15)

Tomasz Kupisz w pucharowej konfrontacji z Lechią Gdańsk dwukrotnie posyłał piłkę do bramki rywala, ale zaliczył też bramkę samobójczą i o awansie do ćwierćfinałów zdecydowała seria rzutów karnych. (PN 41/2012, s. 22)

Trzy lata później za sprawą Gallipoli grano na syntetyku w Serie B. (PN 41/2012, s. 25)

Poza tym San Siro nie byłoby we Włoszech prekursorem w dziedzinie sztucznej murawy (a raczej syntetycznej najnowszej generacji). (PN 41/2012, s. 25)

Popularność zyskała także elipsa - zarówno deadiektywizująca, jak i substantywizująca, np.: 
I to na tyle mocno, że Maciej Skorża - a więc trener z nazwiskiem, pozycją i realnymi sukcesami w piłce seniorskiej - aż przebiera nogami, żeby zostać selekcjonerem reprezentacji olimpijskiej, która powalczy o udział w igrzyskach w Rio de Janeiro. (PN 14/2012, s. 2)

Po klęsce na igrzyskach w Londynie wrócił do kieratu, bo brak olimpijskiego medalu w jego kolekcji wymyka się logice. (P 51-52/2012, s. 150)

Ale ten scenariusz był pisany z myślą o igrzyskach olimpijskich w Londynie. (P 5152/2012, s. 150)

Najbardziej kusząca wydaje się propozycja występu na igrzyskach olimpijskich w Londynie w roli kapitana reprezentacji Wielkiej Brytanii. (PN 45/2011, s. 29)

Teodorczyk był świeżo po zgrupowaniu pierwszej reprezentacji Polski, gdzie pewnie jedenastki też ćwiczył, więc może stąd chęć pokazania, że potrafi lepiej strzelać karne niż koledzy. (PN 48/2012, s. 16)

Mając przeciwnika na kolanach, o jednego gola i jednego gracza więcej, mając też po swojej stronie sędziego (nie uznał Grekom prawidłowo zdobytej bramki i nie podyktował karnego za rękę Perquisa) - Polacy postanowili obrazić Pana Boga i dowieść, że nawet najszczęśliwszy zbieg okoliczności nic tu nie da. (P 24/2012, s. 14)

Nie potrafił sobie wytłumaczyć, dlaczego machnął chorągiewką i wymusił, zamiast oczywistego kornera, podyktowanie rzutu karnego przez arbitra Mike'a Jonesa. (PN 49/2011, s. 33)

Ginola, który wszedł do gry z lawki, dostał piłkę przy chorągiewce końcowej nieopodal pola karnego Bułgarów. (PN 13/2012, s. 20)

Rezerwowi czekają na ławce. (VG 3/2011, s. 18)

Ma bardzo dobrych zawodników, ma w pamięci świeży sukces, którym było wywalczenie Pucharu Polski z Michałem Probierzem na ławce, ma wreszcie prezesa, który ligowym piłkarzem był i choć nie osiągnął spektakularnych sukcesów w futbolu, na pewno zna zapach szatni. (PN 10/2012, s. 2)

Z wyjątkiem mistrzów w kreowaniu własnego wizerunku, a takich pojawia się na trenerskich ławkach coraz więcej. (PN 12/2012, s. 47)

W kolejnym meczu, wygranym z Luksemburgiem, Pawłowski nie zagrał, odpoczywał na ławce rezerwowych. (PN 47/2011, s. 47)

Wszystkim naszym zawodnikom życzymy, aby na ławce rezerwowych siedzieli jak najrzadziej, a jeśli już, to tylko jako takie asy w rękawie. (VG 3/2011, s. 18)

Problem to miałem w Arisie, gdzie z niemieckiego byłem tłumaczony na grecki, dopiero z greckiego na hiszpański, a na koniec z hiszpańskiego na francuski. (PN 11/2012, s. 23) 
A pozostali zagraniczni zawodnicy starają się szybko uczyć języka niemieckiego. (PN 36/2012, s. 26)

Dzięki temu ona nie musi jeździć nocnymi i mają chwilę dla siebie. (P 13/2012, s. 103) Na dworzec jedzie nocnym autobusem. (P 13/2012, s. 102)

Rzeczniczka wychodząc, pyta, czy zamknąć drzwi. (P 24/2012, s. 32)

Rzeczniczka prasowa więzienia por. Iwona Kozak prowadzi Krystiana Balę z budynku, gdzie w pięcioosobowej celi odsiaduje karę. (P 24/2012, s. 32)

Zamiast schabowego czy mielonego daj dziecku mięso pieczone w folii lub gotowane na parze. (NŻ 4/2012, s. 32)

I faktycznie, jak jeden Hiszpan spróbował schabowego, to potem wszyscy zamówili. (P 24/2012, s. 121)

Szukasz sposobu na smaczne i soczyste kotlety schabowe? (NŻ 4/2012, s. 41)

Mark Clattenburg najpierw pokazał dwie czerwone kartki Branislavowi Ivanoviciowi i Fernando Torresowi, a także uznał gola dla MU, gdy Javier Hernandez był na spalonym. (PN 44/2012, s. 29)

W 58 minucie napastnik Miedzi Jakub Grzegorzewski posłał piłkę do bramki, uczynił to jednak będąc na pozycji spalonej. (PN 36/2012, s. 41)

Internet - surfowanie po stronach, uczestniczenie w portalach społecznościowych, komentowanie różnych artykułów lub czytanie komentarzy innych. (VG 8/2011, s. 11)

Na ich stronie internetowej niebieskalinia.pl znajdziesz informator placówek, które niosą pomoc ofiarom przemocy w twojej najbliższej okolicy. (VG 11/2011, s. 9)

Producenci gadżetów zarabiali krocie, obłowili się też twórcy apokaliptycznych filmów i stron internetowych. (P 51-52/2012, s. 16)

W przypadku uderzeń z wolnych, bez pracy i setek powtórzeń sukcesu się nie osiągnie, bo smykałki do tego, jak ma Leszek Pisz, nie mam. (PN 11/2012, s. 13)

Piękny gol z rzutu wolnego wbity podczas wyjazdowego meczu w Bełchatowie sprawił, że o pomocniku Pogoni Szczecin zrobiło się ostatnio głośno. (PN 48/2012, s. 10) Całkiem współczesny znaczek jest jednak bytem, który ciągle się zmienia, żyje, potrafi poruszać. (P 50/2012, s. 100)

Nawet jeśli jego czas się kończy, w swoich ostatnich dniach znaczek pocztowy żyje pełnią życia - wywołując silne emocje. (P 50/2012, s. 100)

Wśród derywacji sufiksalnej najwięcej form zuniwerbizowanych odnotowano z formantem -(ów)ka, który już na stałe zadomowił się w polszczyźnie. Dwie dekady temu H. Satkiewicz pisała o wyrazach z tym elementem słowotwórczym 
tak: „przynależność omawianych formacji do stylu potocznego jest uznawana powszechnie, zwłaszcza gdy w grę wchodzą wyrazy nowe, które z obiegu środowiskowego przedostają się do ogólnego, co następuje głównie za pośrednictwem prasy"85. O tym, że - mimo dużej częstotliwości występowania - wciąż są tak postrzegane, świadczyć może ich obecność w słownikach polszczyzny potocznej.

A. Markowski zauważa: „Niewielki ładunek emocjonalny zawierają już dziś liczne nazwy z przyrostkiem - ak, wywodzące się z warszawskiej gwary miejskiej, które następnie upowszechniły się w całej polszczyźnie potocznej"86. O ile spostrzeżenie to jest trafne w odniesieniu do wyrazów z klasy nazw osobowych (cwaniak) czy nazw zwierząt (kurczak, prosiak), o tyle wydaje się, że inne syntetyzmy z tym formantem wciąż nie zyskują powszechnej aprobaty i ich używanie w odmianie oficjalnej jest pretensjonalne. Spożywczak czy polak są bardziej nacechowane nawet od eliptycznych spożywczy i polski.

Wynikiem procesu uniwerbizacji są niejednokrotnie wyrazy już funkcjonujące w języku, mamy więc do czynienia z neosemantyzacją, np. główka, setka, komórka, doping, ławka, róg, strona. Z jednej strony pokazuje to, jak duże możliwości tkwią w języku i pozwala odnaleźć nowe zastosowanie znanych leksemów, z drugiej jednak - właśnie poprzez wykorzystanie utrwalonego już w świadomości odbiorców wyrazu - wymaga od czytelnika uważnego zapoznania się z tekstem, by wydobyć nowe znaczenie.

W przypadku wykorzystywania derywatów, które mogą być mało czytelne dla odbiorcy, bo używane są tylko w określonym środowisku albo cechuje je wieloznaczność, zauważalna jest skłonność do posługiwania się w jednym artykule najpierw precyzyjniejszą formą rozbudowaną, a dopiero w kolejnych akapitach syntetyzmem, którego znaczenie nie powinno budzić dzięki temu żadnych wątpliwości.

Niektóre przywołane uniwerbizmy - mimo takiej samej formy - mogą odnosić się do zróżnicowanych semantycznie desygnatów. J. Miodek, charakteryzując dublety znaczeniowe, pisał: „Z istoty konstrukcji syntetycznych wynika ich potencjalna wieloznaczność. Teoretycznie każda z nich może być użyta jako jednowyrazowa nazwa wielu elementów rzeczywistości pozatekstowej"87. Dzieje się tak np. w przypadku młodzieżówki - choć wszystkie analityczne odpowied-

85 H. Satkiewicz, Budżetówka..., s. 373.

86 A. Markowski, op. cit., s. 35

87 J. Miodek, Syntetyczne konstrukcje leksykalne..., s. 38. 
niki odnoszą się do terminologii sportowej, to jednak drużyna młodzieżowa nie zawsze będzie tożsama z reprezentacją i kadra młodzieżową, ponieważ nie każdy jej członek będzie równocześnie reprezentantem kraju w tej grupie wiekowej. Powstała w wyniku redukcji członu przymiotnikowego ławka - chociaż odnosi się cały czas do tego samego fragmentu rzeczywistości - raz będzie wskazywać na związek z trenerem (gdy wywodzić się będzie od analityzmu ławka trenerska), innym razem - z zawodnikiem rezerwowym (od ławki rezerwowych).

Posługiwanie się elipsą wymaga od odbiorcy większego zaangażowania podczas lektury, ponieważ usunięcie jednego członu - przede wszystkim przymiotnikowego - powoduje, że powstałe uniwerbizmy są często tożsame $\mathrm{z}$ istniejącymi już wyrazami. Pomijanie fragmentów nazw własnych, charakterystyczne dla języka dnia powszedniego, gdy liczą się szybkość przekazywanych treści i ekonomia, razi w oficjalnych tekstach prasowych, ponieważ może świadczyć o lekceważącym stosunku dziennikarza wobec tego, co jest przedmiotem opisu. Dodatkowo ten sam wyraz może być stosowany dla nazwania zróżnicowanych obiektów, dlatego czytający musi zagłębić się w kontekst, by właściwie odczytać skróconą nazwę.

Jak Madzia z mężem, ale razem pod różują tylko rano, potem ona wraca z całą grupą o 15.19 z Centralnego, a on dopiero o 18. (P 13/2012, s. 105)

Ryszard Kalisz powiedział wręcz, że Platforma w tej sprawie abdykowała, a prokuratorzy muszą nauczyć się mówić. (P 51-52/2012, s. 13)

Platforma Obywatelska nie świętowała dziesiątej rocznicy powstania. (P 5/2011, s. 98)

Wszystko o budowie, lokalizacji i przeznaczeniu Narodowego wiadomo było dokładnie już prawie pięć lat temu, kiedy Michel Platini odczytał werdykt UEFA w sprawie wyboru organizatora Euro 2012. (PN 6/2012, s. 2)

Organizatorzy muszą też zapewnić gościom wydzielony parking, a na obecną chwilę nikt z zarządzających Stadionem Narodowym czy Stadionem Miejskim we Wrocławiu nie zawraca tym sobie głowy. (PN 13/2012, s. 47)

W ciasnym foyer Narodowego zasiadali Zbigniew Zapasiewicz i Ignacy Gogolewski, świece donosiła Danuta Szaflarska. (P 51-52/2012, s. 129)

Męską wersją seansu pamięci był z kolei grany w tym czasie w Teatrze Narodowym „Żar” według powieści Sandora Maiara, ze sporem o kobietę, pojęciem lojalności i zdrady w centrum. (P 51-52/2012, s. 129) 
Pewnie także znają Państwo osoby, które często zachowują się, jakby nie znały używanego w Stanach zwrotu: oszczędzaj powietrze. (PN 17/2012, s. 11)

W dodatku Jędrek zaczął studia w Stanach. (NŻ 9/2012, s. 43)

Dominacja piłkarek ze Stanów Zjednoczonych na olimpiadach została potwierdzona. (PN 33/2012, s. 38)

Wejście do Unii otworzyło mu Europę. (P 51-52/2012, s. 60)

Unia Europejska to odbiorca 80 proc. naszego eksportu. (P 50/2012, s. 45)

W pierwszej scenie aktorzy Współczesnego schodzą się na próbę. (P 24/2012, s. 84)

Tyle że po meczu media z Wysp informowały, że już w zimowym okienku transferowym United po raz kolejny złoży Borussii ofertę, tym razem przewyższającą 20 milionów euro. (PN 41/2012, s. 5)

Bo wiesz, na Wyspach jest trochę inny poziom. (VG 5/2011, s. 21)

Wprawdzie na Wyspach program odszedł w niebyt z powodu skandalu, a nie z winy słabych wyników, to jednak próby przywrócenia koncepcji, podjęte przez samą Turner, nie wypaliły. (P 50/2012, s. 105)

To było akurat pierwsze lato po wejściu Polski do Unii Europejskiej, ruszyła na Wyspy fala zarobkowej emigracji. (P 51-52/2012, s. 152)

Natomiast doświadczony Daniel Cousin wrócił do ojczyzny po latach gry nie tylko we Francji, ale i na Wyspach Brytyjskich. (PN 6/2012, s. 5)

Po 1945 r. nie zdarzyło się nikomu (przynajmniej mnie znanemu) napisać historię Polski od Piasta po Wałęsę, Wysp Brytyjskich od A do Z plus monografię powstania warszawskiego, wojny polsko-bolszewickiej i jednego z największych miast polskich o nader burzliwej i skomplikowanej przeszłości. (P 51-52/2012, s. 159)

Wartość potoczną ma użycie derywatu eskaemka na określenie Stołecznej Kolei Miejskiej. Mimo swej krótkiej formy jednoznacznie definiuje on desygnat, jest łatwy do rozszyfrowania.

Z lotniska nowiutką eskaemką (Stołeczna Kolej Miejska) Kowalski w 25 min przyjechał do stacji Śródmieście - parę kroków od strefy kibica. (P 24/2012, s. 15)

Wydaje się, że nomina propria powstałe w wyniku derywacji paradygmatycznej i dezintegracji są bardziej czytelne i jednoznaczne w odbiorze, choć przekształcenie oficjalnej nazwy powoduje, że nie we wszystkich sytuacjach właściwe jest posługiwanie się nimi. 
Szczególną atrakcją zachodniego wybrzeża jest zbudowany ze skał wulkanicznych potężny klif Los Gigantem, wznoszący się nad Atlantykiem na wysokość $800 \mathrm{~m}$ (największe wrażenie robi, gdy oglądasz go od strony oceanu). (NŻ 4/2012, s. 24)

Dodatkowo do Portugalii należy szereg wysp położonych na Oceanie Atlantyckim, w tym Archipelag Azorski i Madera. (VG 1/2011, s. 16)

Mały raj na Oceanie Atlantyckim odkryli w XVI wieku portugalscy żeglarze. (NŻ 7/2012, s. 24)

Na Bałtyku najgorszym możliwym scenariuszem byłoby zderzenie się tankowca przewożącego ropę naftową z promem pasażerskim. (P 50/2012, s. 8)

Od lat jeździmy całą paczką nad Bałtyk, do Chałup. (NŻ 8/2012, s. 43)

W każdej chwili pływa tam około 2 tys. statków, czyli tyle samo, co na całym Morzu Bałtyckim. (P 50/2012, s. 8)

$\mathrm{Na}$ Zachodzie nieprawidłowo rosnące ósemki usuwa się jeszcze przed 18. rokiem życia. (NŻ 3/2012, s. 34)

Czy Polak może zrobić karierę na Zachodzie mówiąc po polsku? (P 50/2012, s. 114) Selekcjoner Waldemar Fornalik interesuje się nie tylko Europą Zachodnią. (PN 36/2012, s. 8)

Kiedy okazało się, że obaj nie mogą zagrać w meczu kwalifikacji Euro 2012 z Walią, opaskę kapitana odzyskał Terry. (PN 2/2012, s. 27)

W czerwcu w finałach mistrzostw Europy zaakcentują swój udział wybrańcy Franciszka Smudy i wierzymy, że będziemy ich wspierać dłużej niż w trzech meczach fazy grupowej. (PN 2/2012, s.47)

Czasem zdarza się, że tworzone są triady na określenie jednego desygnatu, wówczas łatwo jest dokonać stopniowalności nacechowania każdego z trzech wymienionych elementów. Na uwagę zasługuje fakt, że syntetyzm komórka - odnotowany (podobnie jak jego rozbudowana wersja) we wszystkich analizowanych periodykach - raz przyjął postać augmentatywną komóra, którą posłużono się w czasopiśmie młodzieżowym. Zgrubienie zostało prawdopodobnie wprowadzone w celach stylizacyjnych, by jeszcze bardziej podkreślić potoczny, slangowy charakter wypowiedzi.

Zafascynowani niemieccy fani nagrywali niecodzienną marszrutę telefonami komórkowymi, co chwilę powtarzając: - Tak wygląda ukraińskie Euro. (PN 24/2012, s. 26)

Na egzamin można zabrać telefon komórkowy. (VG 7/2011, s. 3) 
Śledczy ustalili, że parę dni po zaginięciu mężczyzny w 2000 r. jego telefon komórkowy trafił na aukcję internetową. (P 24/2012, s. 32)

Izabela płakała, nerwowo ściskała w rękach telefon komórkowy... (NŻ 1/2012, s. 5)

Dla mnie najgorszą rzeczą jest brak komórki. (PN 33/2012, s. 31)

Czy model komórki ma dla Ciebie znaczenie? (VG 7/2011, s. 13)

- Chyba zupełnie nie rozumie, co się do niego pisze i czego się od niego wymaga ocenia Kamil, który w zeszłym roku, zamiast nowej komórki, pod choinką znalazł pudełko kredek i książki dla dzieci. (P 51-52/2012, s. 6)

Wyciągam komórę, chcę zadzwonić do Marcina, zagadać, przy okazji o Wizgonowej powiedzieć. (VG 21/2012, s. 29)

Trzy sposoby określenia naszego języka narodowego jako przedmiotu nauczanego w szkole pod względem stopnia oficjalności prezentowałyby się w następującej kolejności: język polski, powstały w wyniku elipsy substantywizującej polski oraz będący efektem derywacji sufiksalnej polak.

Polonia osiągnie swe cele - także dotyczące nauczania języka polskiego w szkołach - gdy będzie silna i gotowa do współpracy z Niemcami, a zwłaszcza między sobą. (P 50/2012, s. 12)

Najprawdopodobniej wasza aktualna pani, ta, z którą mieliście język polski od początku nauki w szkole, czyli od pierwszej klasy, została zatrudniona tylko na zastępstwo pani, która z jakiejś tam przyczyny była w tym czasie nieobecna. (VG 1/2011, s. 13)

A ona - pięć języków obcych, olimpiady z polskiego wygrywane na poziomie wojewódzkim, technikum ukończone z wyróżnieniem. (P 24/2012, s. 36)

Dowiedzieliśmy się niedawno, że nasza pani od polskiego po feriach już nie będzie nas uczyć. (VG 1/2011, s. 13)

Mam nadzieję, że nie piszesz tego wypracowania na polaka. (VG 3/2011, s. 12)

Dwóch analitycznych określeń i jednego syntetycznego użyto do nazwania typu szkoły ponadgimnazjalnej, jako neutralne potraktować można szkoła zawodowa, charakter oficjalny uwidacznia się w trzyelementowym połączeniu szkoła średnia zawodowa, potoczność dominuje zaś w derywowanej od konstrukcji analitycznych zawodówce. 
Kandydaci do szkół średnich zawodowych muszą złożyć także zaświadczenie lekarskie o braku przeciwwskazań zdrowotnych do kształcenia w określonym zawodzie. (VG 9/2011, s. 3)

Powinny mieć dostęp do szkół zawodowych (takich dla kobiet jeszcze nie było) i studiów wyższych. (VG 4/2011, s. 47)

I dodawał, że mógł się akurat tego spodziewać - nadal mowa o trenerze Lenczyku po człowieku, który jest po budowlanej zawodówce. (PN 44/2011, s. 2)

Potoczność może przejawiać się nie tylko dzięki wykorzystaniu konkretnych zabiegów słowotwórczych, lecz także używaniu słownictwa, które wykazuje stylistyczną odmienność od ogólnej odmiany języka, nie we wszystkich sytuacjach mogłoby być zatem używane wymiennie z oficjalnymi odpowiednikami. Kwalifikatorem 'potoczny' opatrzony jest w słownikach języka polskiego chociażby wyraz fiskus ${ }^{88}$ na określenie urzędu skarbowego, strzelić focha (występujące na przemian z obrazić się) to sformułowanie, które można odnaleźć w internetowym słowniku slangu ${ }^{89}$, o częstym używaniu tego zwrotu w środowisku młodzieżowym wspomina też J. Miodek ${ }^{90}$.

64-letni Teixeira dzierży stery brazylijskiego futbolu od 1989 roku i w tym czasie miał oszukiwać fiskusa, brać łapówki, a także wprowadzać w błąd komisje kongresu, które prowadziły różne dochodzenia. (PN 9/2012, s. 39)

Wiśniowski nie boi się tak jak starsi koledzy, że fiskus zniszczy mu firmę. (P 5152/2012, s. 60)

Potem było kilka burzliwych rozwodów, głośne procesy o alimenty, problemy z urzędem skarbowym. (PN 48/2011, s. 29)

Na sprawdzenie Twojego rocznego zeznania PIT urząd skarbowy ma 5 lat. (NŻ 3/2012, s. 31)

88 Por. Mały słownik języka polskiego, s. 205.

89 Por. http://www.slangu.pl/definicja,68,Strzeli\%C4\%87+focha [dostęp: 12.04.2014].

90 http://www.gazetawroclawska.pl/artykul/704127,jan-miodek-strzelac-focha,id,t. html?cookie=1 [dostęp: 12.04.2014], znamienne są zwłaszcza słowa: „Wracając zaś do zwrotu strzelać focha, powiedzmy na koniec, że jego pojawienie się w poważnym artykule popularnego czasopisma świadczy nie tylko o niezwykłej wyrazistości gwar młodzieżowych, ale i o ich stylistycznej atrakcyjności i wyjątkowej ekspansywności”. 
Zwłaszcza że życie emeryta jest spokojniejsze, nie jest on nieustannie narażony na bankructwo, nieuczciwą konkurencję, prześladowania ze strony urzędów skarbowych. (P 24/2012, s. 110)

Strzelenie focha to reakcja dziecinna, niedojrzała. (VG 8/2011, s. 21)

Próbowałam porozmawiać, ale oni nie widzą w tym problemu i uważają, że strzelam focha i że jestem kujon. (VG 12/2011, s. 34)

Kto się obraża? (VG 8/2011, s. 21)

Czy to jest jednak obrażanie? (VG 8/2011, s. 21)

Potoczności nie można odmówić także wszystkim odnalezionym w tygodnikach i dwutygodniku ekwiwalentom fotografowania, tj. robić fotki, pstrykać fotki i ustrzelić fotę. Oba użyte w wymienionych połączeniach ekwiwalenty fotografii są uznawane za kolokwialne, większe nacechowanie ma augmentatywne fota, również czasowniki pstrykać i ustrzelić nie są stylistycznie obojętne. Dodatkowo ustrzelić fotę przedstawia trochę inną wartość semantyczną, uwydatnia, że czynność miała charakter jednorazowy.

Fotografuj, rysuj, rób tabelki i zestawienia - im praca bardziej plastyczna, tym lepiej będzie się ją oceniać. (VG 9/2011, s. 55)

Razem z ukochaną Krysią będą przez tydzień szaleć na stoku w Szrenicy, robić zabawne fotki i delektować się pysznymi śląskimi przysmakami w ulubionych knajpkach Szklarskiej Poręby. (NŻ 2/2012, s. 34)

Jedni przychodzą wejść na Ściankę, drudzy - ustrzelić fotę, jeszcze inni - zjeść i zabrać gadżety. (P 24/2012, s. 107)

A zatem koniec pisania do szuflady i pstrykania fotek dla przyjemności. (VG 3/2011, s. 7)

Warto przyjrzeć się peryfrazom z komponentem szef, które zastępują oficjalne nazwy stanowisk. Premier jest opisowo nazywany szefem rządu, szefem państwowego aparatu czy szefem największej firmy w kraju, selekcjoner zyskał zaś miano szefa kadry. Mimo iż leksem ten uwypukla piastowaną funkcję, to jednak - ze względu na swoją potoczność - posługiwanie się taką formą może być traktowane jako nadmierne spoufalanie się, ma ona w związku z tym zabarwienie lekko pejoratywne. Jako neutralna mogłaby być potraktowana tylko wówczas, gdy wypowiadającego łączyłyby familiarne więzi z osobą, o której pisze, a w tekstach prasowych istnieje bardzo małe prawdopodobieństwo takiej sytuacji. Ciekawie 
prezentuje się też zestawienie szef służb prasowych, dochodzi do wymieszania stylów - służby prasowe brzmią bowiem podniośle, a szef, jak już wspomniano, ma w sobie pierwiastek powszedniości. Posłużmy się konkretnymi zastosowaniami opisanych konstrukcji i ich odpowiedników:

Premier przestraszony spadkiem poparcia przez wiele godzin słuchał, co o tym wszystkim myślą ludzie sieci, i obiecał „sprawdzić każdą literkę w umowie”, aż wreszcie „podjął definitywną decyzję", że Polska nie ratyfikuje ACTA. (P 51-52/2012, s. 12)

Władze za duże pieniądze zorganizowały także kilka kontrdyskusji, by zademonstrować jedność prezydenta z szefem rządu. (P 50/2012, s. 59)

Kim jest polski premier? Jest szefem państwowego aparatu. Jest szefem największej firmy w kraju. (P 51-52/2012, s. 29)

Dość szybko zareagował rzecznik tej instytucji, Piotr Rutkowski, który pośpieszył z dementi. (PN 13/2012, s. 2)

Szanuję zdanie szefa służb prasowych banku, tylko do końca nie godzę się ze stwierdzeniem, że właściciel BRE - niemiecki Commerzbank - nie lubi futbolu i nie reklamuje się na piłkarskich arenach. (PN 13/2012, s. 2)

Selekcjoner Waldemar Fornalik interesuje się nie tylko Europą Zachodnią (PN 36/2012, s. 8)

Ten ostatni ma prawie 34 lata i na mecz z Estonią nie był nominowany, ale dobra forma w meczach Legii, do której wrócił po siedmiu latach, nie uszła uwadze szefa kadry i po trzech latach wrócił także do reprezentacji. (PN 36/2012, s. 5)

Szczególnie często obserwowana jest analityczna konstrukcja dać (sobie) radę, która występuje równolegle z poradzić (sobie), obie formy są używane chętnie w artykułach o różnorodnej tematyce. Wydaje się, że to peryfrastyczny czasownik ma bardziej potoczny charakter niż jego prosty ekwiwalent.

Poza wszystkim jednak - już raz nie dał rady w pracy z ŁKS, po letnich przygotowaniach wytrwał na posadzie zaledwie jedną kolejkę. (PN 7/2012, s. 2)

Z dobrej strony w kilku ostatnich meczach pokazał się Rymaniak, doświadczony Broź powinien dać sobie radę w reprezentacyjnej próbie. (PN 50/2012, s. 42)

Osobiście jestem zachwycony postawą Alexisa, który imponuje dojrzałością i w formacji obronnej potrafi zagrać na każdej pozycji, ale poradziłby sobie również w środku pola - dodaje Dźwigała. (PN 49/2012, s. 14-15) 
Jak radzisz sobie ze szkolnymi obowiązkami - jesteś systematyczny czy wręcz przeciwnie? (VG 12/2011, s. 17)

Chęć udowodnienia samemu sobie, że jestem okej, dam radę, wszystko będzie grało. (P 51-52/2012, s. 22)

Przychodzili ci, którym się nie powiodło, którzy potrzebowali wsparcia, i ci, którzy dawali sobie radę. (P 51-52/2012, s. 130)

Zbyt duże oczekiwania wiążą się jednak nierozerwalnie z wielką presją, z którą nie wszyscy potrafią sobie poradzić. (PN 47/2011, s. 47)

Podstawami kolokacji werbo-nominalnych charakterystycznymi dla stylu potocznego są bezokoliczniki zaliczyć i zanotować. Oba spotkać można w połączeniu z rzeczownikiem asysta, z zaliczyć występuje też debiut.

Polski pomocnik zaliczył już debiut w nowym klubie. (PN 33/2012, s. 16)

Polski bramkarz Bartosz Białkowski zadebiutował w barwach angielskiego Notts County FC. (PN 33/2012, s. 16)

Użycie liczebnika z dwuwyrazową konstrukcją zastępującą asystować pozwala ściślej wyrazić dane statystyczne; wypowiedzenie tych samych treści z użyciem syntetycznego sformułowania wymagałoby dodatkowego elementu w postaci razy (np. asystował dwa razy) lub przy (np. asystował przy pięciu bramkach). Najlepiej zobrazują to przykłady:

Zaliczył bowiem asystę i gola miesiąca, cztery razy trafił na Wembley. (PN 49/2012, s. 32)

Piłkarz urodzony w Gliwicach praktycznie w pojedynkę ciągnie grę Koeln - oprócz goli zanotował także pięć asyst. (PN 11/2012, s. 28)

Reprezentant Polski legitymuje się czwartą w zespole najwyższą średnią not $(5,62)$; strzelił cztery gole i zaliczył trzy asysty, w każdym meczu należy do wyróżniających się postaci. (PN 48/2012, s. 35)

Najpierw Szwed asystował przy dwóch trafieniach kolegów, a w końcówce sam dwukrotnie wpakował piłkę do siatki. (PN 48/2012, s. 35)

W tym sezonie zagrał już w 34 meczach, zdobył osiem bramek i przy sześciu asystował. (PN 6/2012, s. 41) 
Bezokolicznik dać bywa łączony z takimi rzeczownikami, jak np. wyraz, sygnat, odpowiedź czy radość. Wyrazić, zasygnalizować, odpowiedzieći1 czy uradować niosą to samo znaczenie, struktury z dać częściej spotykane są w codziennej mowie.

Poderwałem się natychmiast z ławki, a Franciszek Smuda dał sygnał, bym wchodził. (PN 24/2012, s. 12)

Daj jeszcze raz delikatny sygnał temu drugiemu, że jednak jesteś nim zainteresowana - to jedyne wyjście z tej sytuacji. (VG 9/2011, s. 20)

Jubilatka daje delikatne sygnały, jakie prezenty chciałaby dostać, ale nie wie, czy zostaną one właściwie odczytane. (NŻ 12/2012, s. 4)

Niech każdy sam udzieli sobie odpowiedzi na to pytanie. (PN 44/2012, s. 3)

Nic się nie stanie, jeśli jutro dasz odpowiedź koleżance, a jak źle przeprowadzisz sprawę, to nic nie załatwisz. (VG 9/2011, s. 22)

Na część tych pytań dziewczyna nie musi odpowiadać przy mamie, można jeszcze raz porozmawiać $\mathrm{z}$ lekarzem po wyjściu mamy z gabinetu na czas badania. (VG 12/2011, s. 57)

W 16 minucie meczu fani wstali i głośnymi oklaskami dali wyraz, że nadal mają wielki szacunek do Di Matteo. (PN 48/2012, s. 23)

Takie mecze i takie wyniki dają kibicom mnóstwo radości. (PN 48/2012, s. 39)

Kibicom daje radość, a reszcie udrękę. (P 24/2012, s. 16)

Omawiając charakterystyczne cechy polszczyzny potocznej, badacze zwracają także uwagę na rozbudowaną frazeologię, która często ma charakter obrazowy, oraz tendencję do tworzenia znaczeń metaforycznych. Andrzej Markowski podkreśla plastyczność oraz emocjonalność i żartobliwość stałych połączeń wyrazowych typowych dla powszedniego porozumiewania się: „Frazeologiczne związki potoczne ujmują przekazywane treści obrazowo i konkretnie, a przez to plastycznie. Dlatego najczęściej występują zamiast bezbarwnych wyrazów standardowych, wyrażając te same, co one treści, wzbogacone jednakże o nacechowanie emocjonalne, żartobliwe itp." $92 \mathrm{Na}$ odzwierciedlanie w idiomach codziennej

91 Odpowiedzieć może mieć jeszcze inny wielowyrazowy odpowiednik - udzielić odpowiedzi - który w przeciwieństwie do dać odpowiedź ma podniosłe nacechowanie.

92 A. Markowski, op. cit., s. 38. 
rzeczywistości otaczającej człowieka wskazują autorki Kultury języka polskiego: „Potoczną frazeologię cechuje konkretność, skłonność do przedstawiania pojęć i czynności oderwanych w sposób obrazowy, oparty na naturalnych czynnościach człowieka lub jego otoczenia"93. Potwierdzenie tego faktu można odnaleźć chociażby w związkach frazeologicznych, w których skład wchodzą nazwy części ciała. Często wykorzystywany jest komponent nos, np. miewać muchy w nosie, mieć w nosie, utrzeć nosa, zagrać na nosie, odnotowano także frazeologizmy z rzeczownikiem broda. Mieć w nosie i zagrać na nosie używane są do wyrażenia lekceważącej, ignorującej i kpiącej postawy wobec innych, mają bardziej sugestywną wymowę niż syntetyzmy lekceważyć i kpić, pozwalają ukryć informację:

Ale najgorsze jest to, że superprzystojny Jared ma w nosie umizgi Devon i wyraźnie chce umówić się z Lexi... (VG 15/2012, s. 34)

Urugwaj zagrał na nosie między innymi Messiemu i Argentynie, wygrał w pięknym stylu Copa America, ale to na nic. (PN 3/2012, s. 13)

Meksykańska policja twierdzi, że w lutym prawie go złapała, ale to Guzman gra jej na nosie. (P 24/2012, s. 58)

By wyrazić przewagę nad kimś, kto nie chce się podporządkować innym, stosuje się potoczny zwrot utrzeć nosa, który można zastąpić neutralnym czasownikiem poskromić.

Jeśli piłkarze z Dortmundu chcą utrzeć nosa Hoenessowi i pozostałym bogaczom z Monachium, sukces w Lidze Mistrzów jest koniecznością. (PN 17/2012, s. 19) Korci Cię, żeby utrzeć nosa przełożonemu i pokazać mu, jak bardzo nieracjonalne są jego decyzje? (NŻ 13/2012, s. 47)

Nos stał się także podstawą połączenia miewać muchy w nosie używanego na określenie grymaszenia.

Balotelli to napastnik, który miewa muchy w nosie, posadzenie go w takim momencie na ławce rezerwowych spowodowałoby, że zawodnik byłby kompletnie nieprzydatny do końca turnieju. (PN 24/2012, s. 22)

93 H. Kurkowska, S. Skorupka, op. cit., s. 238. 
Związek frazeologiczny pluć sobie w brodę pozwala dobitniej okazać ubolewanie niż syntetyczne żałować.

Llorente zapewne pluje sobie w brodę, że nie zwolnił Pellegrino wcześniej i nie zatrudnił Rafy Beniteza, kiedy ten był jeszcze do wzięcia. (PN 49/2012, s. 34)

Oba połączenia ze składnikiem pies - zejść na psy i wieszać na kimś psy - zostały wykorzystane do wydobycia negatywnych treści, odpowiednio podupaść i obmawiać.

A więc może jednak nie całe dziennikarstwo sportowe zeszło już na psy? (PN $44 / 2012$, s. 10)

Niewiele brakowało, a polskie prawodawstwo mogło zejść na psy. (P 50/2012, s. 98) Jak zwykle przy okazji wielkich piłkarskich turniejów, staram się przyglądać i analizować pracę drużyny, na której najchętniej wiesza się psy. (PN 24/2012, s. 40)

Podkreśla się, że cechą nieoficjalnej odmiany języka jest bogata synonimia. Reguła ta uwidacznia się także we frazeologii, zdarza się bowiem, że w celu określenia jednej czynności funkcjonuje kilka trwałych połączeń wyrazowych, które mogą być używane wymiennie. Oszukać ma aż trzy potoczne ekwiwalenty: wystrychnąć na dudka, nabić w butelkę i robić wodę z mózgu.

Tylko 19 lat i na koncie występy zarówno w Manchesterze United, jak i Juventusie, który podkradł (dla poprawy stosunków stanęło na milionie odstępnego) Anglikom Francuza mniej więcej tak, jak oni wcześniej wystrychnęli na dudka Le Havre. (PN 50/2012, s. 31)

Turysto, nie daj się nabić w butelkę (NŻ 11/2012, s. 31)

Otoczenie konsumenta programami lojalnościowymi, które za pomocą punktów będą robiły wodę z mózgu, nigdy nie nastąpi. (P 24/2012, s. 105)

Podobnie jest w przypadku oczerniać, którego równoważnikami są wieszać psy i zmieszać $z$ błotem. Wymagają one co prawda dopełnienia w innym przypadku, ale ich wartość semantyczna jest zbliżona i w obu wymienionych niżej kontekstach mogłyby pojawić się naprzemiennie.

Zamiast wieszać psy na Kuźniarze, lepiej wziąć przykład z kotów. (NŻ 9/2012, s. 18) 
Bystry pasażer zadzwonił do gazety, która zmieszała z błotem selekcjonera. (PN 41/2012, s. 14)

Wyraźne nacechowanie potoczne mają też związki frazeologiczne mieć pietra, rzucać mięsem i puścić farbę, do zastosowania w komunikacji oficjalnej nadają się wyłącznie ich proste ekwiwalenty: bać się, przeklinać, wygadać się. O tym, że dziennikarz miał poczucie stylistycznej nieodpowiedniości, świadczyć może wzięcie w cudzysłów połączenia rzucić mięsem. W ten sposób zaznaczono, że nie we wszystkich sytuacjach można zastosować ten zwrot.

Myślałem, że nie mam lęku wysokości, jednak pietra trochę miałem. (VG 12/2011, s. 38)

Mówił więcej niż inni, przeklinał na całego, każda okazja była dobra, żeby „rzucić mięsem”. (VG 14/2012, s. 22)

Gdyby sądy miały karać wszystkich za rzucanie mięsem, to po każdej kolejce ligowej mandaty płaciłoby wielu trenerów, a także piłkarzy. (PN 20/2012, s. 45)

Pytany o powody zwłoki, raz puścił farbę. (PN 20/2012, s. 34)

Nie tylko frazeologiczne zastępniki czasowników pojawiają się we współczesnych tekstach. Choć są one grupą dominującą, to odnotowano także potoczne sformułowania funkcjonujące zamiast innych części mowy. Na wyrażeniach przyimkowych opierały się odpowiedniki przysłówków: używane nawet rzadko w codziennych kontaktach do imentu (całkowicie) oraz częściej obserwowane zpocałowaniem ręki.

Obrzydzili mi tego faceta do imentu. (VG 3/2011, s. 12)

Trzy lata później z pocałowaniem w rękę przyjął ofertę Portugalczyków opiewającą na 3,5 miliona. (PN 6/2012, s. 35)

W miejsce pojedynczych rzeczowników pojawiły się natomiast: wyrażające błahość małe piwo, niosące duży ładunek emocjonalny szewska pasja oraz pieszczotliwe cztery kółka. Wyrażenia te odznaczają się większą ekspresją od leksemów drobnostka, samochód i złość, z których zwłaszcza dwa ostatnie cechują się neutralnością.

Tyle że wspomniane spodziewane ruchy transferowe to małe piwo w porównaniu z akcją: zatrzymajmy Milę we Wrocławiu. (PN 49/2012, s. 5-6) 
Mam manię czterech kółek, to chyba kryzys wieku średniego - śmieje się Hugh. (NŻ 9/2012, s. 12)

Tego, który w pojedynkę doprowadzał do szewskiej pasji ośmieszonych i wymanewrowanych rywali. (PN 11/2012, s. 4)

Zaprezentowana analiza pokazuje, że obecność polszczyzny potocznej w analitycznych konstrukcjach i ich syntetycznych odpowiednikach może przejawiać się co najmniej na kilku płaszczyznach - od słowotwórstwa, przez słownictwo, aż po związki frazeologiczne. Czasem przynależność do niższej warstwy językowej jest ledwo dostrzegalna, niektóre sformułowania już na tyle zadomowiły się we współczesnych mediach, że ich obcość stylistyczna może zostać zauważona tylko przez nielicznych purystów. Rzadko bywa, by dziennikarze, mając świadomość, że w ogólnopolskich periodykach nie zawsze przystoi używanie leksyki potocznej, zaznaczali jej odrębność.

Co godne podkreślenia, potoczność ujawnia się nie tylko w wyrazach pospolitych, lecz także w ekwiwalentach nazw własnych. Pomijanie członów w oficjalnych nazwach może być traktowane jako przejaw niedbalstwa czy wręcz lekceważenia tego, o czym się mówi.

Często język kolokwialny lepiej oddaje stany emocjonalne i postawę, pozwala na wyrazistsze przekazanie wartościowania, a dla nazwania jednego fragmentu rzeczywistości używa się kilku synonimów. Związki frazeologiczne pozwalają wyzyskać takie odcienie znaczeniowe, których nie da się wyrazić za pośrednictwem prostych form. Nacechowanie omawianych w tym podrozdziale środków wyrazu potwierdza J. Bartmiński, pisząc: „Odrębność potocznego słownictwa $z$ rejestru emocjonalnego (kolokwialno-emocjonalnego) względem potocznego słownictwa neutralnego polega na znaczniejszym udziale frazeologizmów w pierwszym z nich i związanej z tym większej obrazowości, metaforyczności, a także na ogromnym bogactwie dubletów, tj. równoznacznych wyrażeń służących nie tyle nazwaniu rzeczy, ile ekspresji i zabawie językowej"94.

Trzeba zgodzić się ze stwierdzeniem, że mamy do czynienia z ekspansją potoczności, która zarysowuje się w mediach od początku lat 90. XX w. K. Ożóg, dokonując oceny tego zjawiska, zwraca uwagę na dwa aspekty: jako pozytywne uważa to, że „bardzo dobrze, bo obrazowo, konkretnie emocjonalnie, określa

94 J. Bartmiński, op. cit., s. 121. 
wiele treści, o których publicznie się mówi czy pisze"95. Za negatywne uważa z kolei „nadmierne wykorzystywanie niektórych wyrażeń z polszczyzny potocznej i odmian środowiskowych, co prowadzi do nowego schematyzmu i monotonii" 96. Trudno stwierdzić, czy w omawianych tygodnikach spotykamy się z nadmiarem struktur wywodzących się z mowy dnia codziennego, na pewno jednak jest to proces silnie zaakcentowany w badanej prasie.

\subsubsection{Oficjalność, urzędowość, podniosłość}

Przeciwieństwem potoczności jest posługiwanie się słownictwem należącym do oficjalnej odmiany języka, nierzadko spotykamy się ze sformułowaniami, które nie tyle mają neutralne nacechowanie, ile nadają wypowiedzi charakter podniosły. Zestawienie konstrukcji analitycznych i ich syntetycznych odpowiedników pozwala zauważyć nawiązania do stylu urzędowego, a czasem nawet naukowego, zwłaszcza w strukturach opisowych.

Styl urzędowy zwany jest regulująco-informacyjnym, gdyż teksty takie pełnią zazwyczaj funkcję impresywną i komunikacyjną. Wyodrębnia się powszechnie dwie odmiany stylu urzędowego: styl wypowiedzi kancelaryjnych i styl aktów prawnych ${ }^{97}$. Jako główną cechę wymienia się „dążenie do uzyskania jednoznaczności przekazywanych treści w formie możliwie zwięzłej i ścisłej”98. W tym celu niejednokrotnie używa się połączeń wyrazowych, które mają postać terminów, chętnie wykorzystywane są także kancelaryzmy. „Wymóg precyzji dotyczy w tekstach urzędowych wyboru i doboru uwzględnianej w nich leksyki"99. Z tego względu czasem określone pojęcia są powtarzane, a synonimia jest ograniczona. A. Markowski podkreśla, że aby zachować bezstronność i obiektywizm, nie można posługiwać się formami nacechowanymi indywidualizmem oraz zawierającymi ładunek emocjonalny. Wyrazy oceniające i ekspresywizmy należą do rzadkości. „Odindywidualizowanie tekstów urzędowych, zakładane jako ich cecha gatunkowa, wyraża się przede wszystkim używaniem stałych, gotowych formuł językowych o charakterze schematów składniowych, w znacznym stop-

95 K. Ożóg, op. cit., s. 75.

96 Ibidem.

97 M. Wojtak, Styl urzędowy, [w:] Współczesny język polski, red. J. Bartmiński, Lublin 2001, s. 155.

98 A. Markowski, op. cit., s. 149.

99 M. Wojtak, op. cit., s. 163. 
niu sfrazeologizowanych"100. Dla tekstów urzędowych charakterystyczne są sformułowania o charakterze perswazyjnym i nakazowym, związana z tym dyrektywność, a także posługiwanie się bezosobowymi formami w stronie biernej101. Zwraca się także uwagę na dosłowne traktowanie wypowiedzi: „Teksty urzędowe rzadko odwołują się też do wyobraźni ich odbiorców, stąd nieobecność w nich frazeologizmów i obrazowych metafor opartych na przenośnych znaczeniach wyrazów konkretnych"102.

Oficjalną odmianę polszczyzny reprezentuje też styl naukowy, wyróżnia się jego cztery podstawowe rodzaje: teoretycznonaukowy, dydaktycznonaukowy, popularnonaukowy, praktycznonaukowy ${ }^{103}$. Ma on za zadanie przekazywać sprawdzone informacje o pewnym wycinku rzeczywistości, które zostały uzyskane w wyniku badań naukowych lub oglądu zawodowego ${ }^{104}$. Jego najbardziej charakterystycznym językowym wykładnikiem jest posługiwanie się terminami - „to wyraz albo kilkuwyrazowe połączenie o charakterze nominalnym, mające znaczenie specjalnie definiowane na użytek danej dyscypliny nauki lub techniki i służące do opisywania jej realiów (składników i zachodzących między nimi relacji)”105. Innymi właściwościami tej odmiany języka są: „obiektywizm w przedstawianiu przedmiotu opisu; logiczna spójność wywodu, połączona ze ścisłością i zwięzłością wypowiedzi, przy jednoczesnym wyrażaniu wprost wszelkich treści; abstrakcyjność i bezosobowość, wynikająca w dużym stopniu z intelektualnego charakteru treści oraz brak emocjonalnego zabarwienia wypowiedzi"106. Aby pozostać obiektywnym, stosuje się stronę bierną, formy bezosobowe, czasowniki w stronie zwrotnej, znamienne jest także używanie form liczby mnogiej. W tekstach naukowych nie brakuje wyrażeń modalnych, które mają na celu wyrazić stopień prawdziwości stwierdzeń przytoczonych w tekście. Powszechnie podkreśla się, że wypowiedzi formułowane w tym stylu mogą sprawiać trudności

100 A. Markowski, op. cit., s. 151.

101 Por. A. Markowski, Kultura języka polskiego. Teoria. Zagadnienia leksykalne, Warszawa 2012, s. 113; M. Wojtak, op. cit., s. 157-161.

102 A. Markowski, Polszczyzna końca..., s. 152.

103 S. Gajda, Styl naukowy, [w:] Współczesny język polski, red. J. Bartmiński, Lublin 2001, s. 191.

104 A. Markowski, Polszczyzna końca..., s. 154.

105 A. Markowski, Kultura języka..., s. 112-113.

106 A. Markowski, Polszczyzna końca..., s. 155. 
w odbiorze. Stanisław Grabias uwydatnia: „Współczesnej wiedzy nie da się wyrazić bez uproszczeń językiem ogólnym"107.

Cechą niespotykaną w stylu potocznym jest też podniosłe nacechowanie treści, które niejednokrotnie uwidacznia się w parach składających się z wielowyrazowych określeń i ich nierozbudowanych odpowiedników bliskich znaczeniowo.

Nierzadko zdarza się, że konstrukcje analityczne przyjmują postać definicji, niejako wyjaśniają czy doprecyzowują znaczenie syntetyzmu. Dotyczy to np. wykonawców czynności - dowiadujemy się, że internauta to użytkownik Internetu, narkobaron to narkotykowy baron, sztangista zaś - człowiek sztangi. Widoczne jest tu pokrewieństwo morfologiczne przytoczonych form.

Podnoszono ten problem na wspomnianej wcześniej konferencji Fundacji Legalna Kultura - badania zlecone przez fundację wykazały, że internauci przeważnie nie wiedzą, że korzystając z taniego (lub bezpłatnego) źródła kultury, mogą łamać prawo. (P 50/2012, s. 97)

$\mathrm{Z}$ tego choćby powodu duże znaczenie ma tworzenie przez fundację bazy bezpłatnych i płatnych legalnych źródeł kultury, dzięki którym użytkownicy Internetu mają szansę uniknąć moralnego dyskomfortu czy nawet - jak grożą legislacyjni rygoryści - odpowiedzialności karnej. (P 50/2012, s. 97)

Gdy tylko wybranka osiągnęła pełnoletniość, El Chapo wydał wesele godne najpotężniejszego narkobarona w kraju. (P 24/2012, s. 59)

W światku narkotykowych baronów zasłużył na miano najbardziej pomysłowego: aby wyprowadzić w pole służby graniczne, ukrywał narkotyki nawet w konserwowych papryczkach chilli. (P 24/2012, s. 58-59)

Nie wszyscy takie ciśnienie wytrzymują - uważa psycholog Radosław Tworus, który przez kilka lat współpracował z kadrą sztangistów. (P 51-52/2012, s. 150)

Listopad to nie jest czas bicia rekordów, ludzie sztangi albo są wtedy na wakacjach albo kładą się na stoły operacyjne reperować nadwyrężone zdrowie. (P 51-52/2012, s. 151)

Charakter objaśniający mają także inne określenia odnoszące się do osób. Dziadek definiowany jest jako mąż babci, dyrygent zwany jest kierownikiem orkie-

107 S. Grabias, O ekspresywności języka. Ekspresja a słowotwórstwo, Lublin 1980, s. 190. 
stry lub zastępca dyrektora do spraw artystycznych, pilota mianowano natomiast dowódcą statku powietrznego ${ }^{108}$.

W Polsce dyrygenci tracą na znaczeniu, zwłaszcza że według prawa funkcja dyrektora artystycznego filharmonii nie istnieje. (P 50/2012, s. 93)

Można być tylko zastępcą dyrektora do spraw artystycznych. (P 50/2012, s. 93)

Z drugiej strony, co jest szczególnie ważne w czasach kryzysu, kierownicy orkiestry, czyli mówiąc $\mathrm{z}$ angielska menedżerowie, a z niemiecka intendenci, bardzo zyskali na znaczeniu, bo to oni liczą pieniądze. (P 50/2012, s. 92)

Mężowie babć, czyli dziadkowie, są zmęczeni życiem, nie mają w sobie takich niespożytych sił jak one. (VG 1/2011, s. 27)

Pilot - dowódca statku powietrznego - musi doskonale znać szczegóły budowy samolotu, a także nawigacji - oznacza to, że powinien mieć taką wiedzę jak wszyscy jego podwładni razem wzięci. (VG 1/2011, s. 4)

Wyjaśnienie terminów z zakresu medycyny przynoszą peryfrazy medyczne procedury zapobiegania ciąży na określenie antykoncepcji oraz zdolność do wytwarzania osobników potomnych na określenie rozmnażania.

A najtrudniejszą do pokonania barierą w rozpowszechnianiu antykoncepcji jest nie tyle konserwatywne podłoże kulturowe i religijne, co brak rzetelnej wiedzy o zaletach i skutkach ubocznych medycznych procedur zapobiegania ciąży. (P 24/2012, s. 57)

Rozmnażanie jest jedną z podstawowych cech żywego organizmu. (VG 3/2011, s. 36) Zdolność do wyt warzania osobników potomnych w sposób płciowy lub bezpłciowy zapewnia ciągłość istnienia gatunku. (VG 3/2011, s. 36)

Niemała grupa rzeczownikowych konstrukcji odwołuje się do sformułowań z zakresu sportu, opisowe określenia pomagają niezainteresowanym tą tematyką odbiorcom właściwie odczytać przekaz. Widoczne są peryfrazy odnoszące się do elementów gry: otwierajace podanie to synonim asysty; formacji na boisku: napastnik zasługuje na miano zawodnika z pierwszej linii; poziomów rozgrywkowych: ekstraklasa nazywana jest najwyższa klasa rozgrywkowa, najwyższym

108 Godne podkreślenia jest również użycie w tej peryfrazie nacechowanego podniośle połączenia statek powietrzny zamiast samolot. 
szczeblem czy najwyższą liga - sformułowania te nieznacznie różnią się stopniem oficjalności; wyników: definicja remisu to podział punktów.

Siedem asyst zaliczonych w minionym sezonie winno być decydującym argumentem dla szefów klubów grających w europejskich pucharach. (PN 20/2012, s. 14) Podobnie rzecz miała się z Kupiszem, autorem dziewięciu otwierających podań dla Jagiellonii. (PN 20/2012, s. 14)

Klub z najmłodszym trenerem na ekstraklasowej ławce i jednym z najstarszych napastników w składzie w ostatnich czterech meczach zgromadził aż 10 punktów. (PN 49/2012, s. 38)

I nie chodzi tylko o zawodników z pierwszej linii. (PN 11/2012, s. 14)

Po rundzie jesiennej na miejscach premiowanych awansem są jednak drużyny, które nigdy nie grały w ekstraklasie - Flota Świnoujście i Termalica Bruk-Bet Nieciecza. (PN 49/2012, s. 44)

Polski futbol jest od dawna niedoinwestowany, ale chyba jeszcze nigdy w obecnym stuleciu zespół z najwyższej ligi nie był tak bliski bankructwa. (PN 4/2012, s. 2) Latem odradzałem transfer Damianowi Szczęsnemu, który dostał ofertę z najwyższej klasy rozgrywkowej. (PN 50/2012, s. 44)

Długo nie mógł przebić się do ekstraklasy, a jak już mu się udało, to akurat gnębiły go kontuzje i poważnie na najwyższym szczeblu nie zaistniał. (PN 49/2012, s. 8)

Po zakończeniu rundy jesiennej w rozmowach o drużynie ze Świnoujścia wcale nie dominuje temat, czy zdoła ona awansować do ekstraklasy i gdzie wówczas będzie grać (stadion nie spełnia wymogów licencyjnych najwyższej klasy rozgrywkowej). (PN 49/2012, s. 44)

Trójkolorowi prowadzeni przez Houlliera do awansu potrzebowali tylko remisu. (PN 13/2012, s. 20)

I rzeczony podział punktów (1:1) widniał na tablicy wyników jeszcze kilkadziesiąt minut przed zakończeniem meczu. (PN 13/2012, s. 20)

Urzędowy charakter przejawia się w połączeniach formalne zakończenie makżeństwa, które zastępuje syntetyzm rozwód, instytucja finansowa pojawiającym się zamiast leksemu bank oraz wymiar sprawiedliwości na określenie sądu czy Rada Ministrów jako alternatywnej nazwie rządu. Wymienione analityzmy przynależą do języka prawniczego. 
Jednak mimo rozwodu Małgorzata utrzymuje dobre stosunki z byłym mężem. (NŻ 11/2012, s. 3)

Według naszych informacji, formalne zakończenie małżeństwa państwa Popków nastąpiło pod koniec sierpnia 2012 r. (NŻ 8/2012, s. 2)

Część należności przejęły amerykańskie banki i dlatego spłatę ma gwarantować rząd. (PN 50/2012, s. 33)

Kilka olbrzymich banków poniosło gigantyczne straty z powodu ryzykownych operacji własnych pracowników. (P 50/2012, s. 46)

Szczególne kontrowersje budzą największe instytucje finansowe, zajmujące się równocześnie bankowością tradycyjną i inwestycyjną. (P 50/2012, s. 46)

Część należności przejęły amerykańskie banki i dlatego spłatę ma gwarantować rząd. (PN 50/2012, s. 33)

Za to po kilku miesiącach bojów z ministrem sprawiedliwości Jarosławem Gowinem pod koniec roku rząd podpisał konwencję Rady Europy o zapobieganiu i zwalczaniu przemocy wobec kobiet. (P 51-52/2012, s. 12)

Premier ustala skład rządu i wytycza jego główne cele. (VG 22/2012, s. 41)

Zasiąść w Radzie Ministrów... nie jest tak łatwo:) (VG 22/2012, s. 41)

Argumenty ministra, że konwencja to „dokument niechlujny”, który zniszczy tradycyjny model małżeństwa i „może upowszechniać homoseksualizm”, nie przekonała Rady Ministrów i Polska dołączy do 25 krajów, które będą respektować zapisy konwencji. (P 51-52/2012, s. 12)

Sąd jest zadowolony, bo formalnie wszystko jest w porządku, a czy sprawiedliwie, to pytanie nie mieści się w obowiązkowym słowniku naszego sędziego. (P 50/2012, s. 25)

Sprawa Amber Gold przykuła uwagę opinii publicznej także z racji dwuznacznych zachowań przedstawicieli wymiaru sprawiedliwości. (P 50/2012, s. 24)

Popularnonaukowy wydźwięk mają z kolei obecne na łamach czasopism o zróżnicowanych profilach definicje odnoszące się do różnych dziedzin życia: zdrowia (przyzwyczajenie żywieniowe - dieta), polityki (wielka władza nad krajem - namiestnictwo), historii (wojna polsko-szwedzka - potop), pracy (idea bezinteresownego dobra i pomocy - wolontariat), języka (przysłowie - stara ludowa prawda). Nie tylko informują, jak należy rozumieć użyte w artykule pojęcie, lecz także niektóre z nich są nacechowane aksjologicznie, wchodzące w ich skład przymiotniki nakierunkowują odbiorcę na konkretne aspekty omawianego zjawiska. 
Dużo pewności siebie dodało mi też stosowanie właściwej... diety. (PN 20/2012, s. 22) Po przyjeździe do Niemiec musiałem zupełnie zmienić przyzwyczajenia żywieniowe, ale wyszło mi to wyłącznie na zdrowie. (PN 20/2012, s. 22)

Zaoferował Janowi Zamoyskiemu namiestnictwo, czyli wielką władzę nad krajem. (P 51-52/2012, s. 154)

Podczas potopu, czyli wojny polsko-szwedzkiej, wojska Karola X Gustawa w 1656 r. oblegały Zamość. (P 51-52/2012, s. 154)

Przysłowia, powiadają, są mądrością narodów, dlatego uciekam się do starych ludowych prawd po tym, jak fortuna przydzieliła biało-czerwonym do grupy Grecję, Rosję i Czechy. (PN 49/2011, s. 2)

I dlatego zadania w naszym konkursie będą związane właśnie z wolontariatem ideą bezinteresownego niesienia dobra i pomocy. (VG 4/2011, s. 4)

Formalny charakter przejawia się w dwuwyrazowych konstrukcjach, w których skład wchodzą rzeczowniki odczasownikowe. Warto przytoczyć kilka par: nazwanie i nadanie nazwy, ocenienie i dokonanie oceny, pomaganie i niesienie pomocy, zmienienie i dokonanie zmian, zwyciężenie i odniesienie zwycięstwa. Z jednej strony precyzyjnie i jednoznacznie opisują przywołaną w artykule czynność, ale z drugiej - zwłaszcza gdy dotyczą prozaicznych działań - ich wysoki ton może wzbudzać śmieszność.

Termin, o którym mówimy, oznacza natomiast zebranie wszystkich elementów pod jednym dachem, nadanie temu procesowi nazwy, usystematyzowanie go. (P 24/2012, s. 105) Profesor Jan Chmura, specjalista z zakresu metodologii oraz fizjologii wysiłku fizycznego i teorii sportu, autor ponad 200 prac naukowych i popularnonaukowych w tej dziedzinie, w tym monografii „Szybkość w piłce nożnej”, nie podejmuje się jednak dokonania oceny formy fizycznej naszych piłkarzy. (PN 24/2012, s. 14)

Ale taka jest prawda - jeżeli nie czujesz w sobie chęci niesienia pomocy, to nie myśl o tym zawodzie, bo... nie dasz rady. (VG 14/2012, s. 10)

Jeśli myślisz o dokonaniu radykalnych zmian w swoim życiu zawodowym, to jeszcze nie nadszedł na nie czas. (NŻ 11/2012, s. 47)

Tym razem piłkarze Paris SG nie mieli żadnych kłopotów z odniesieniem zwycięstwa na Parc des Princes. (PN 50/2012, s. 29)

Tendencja do opisowego wyjaśniania widoczna jest także wśród konstrukcji czasownikowych. Nieco oficjalnie brzmią połączenia zregenerować siły, stać się 
największym beneficjentem czy wydać na świat w porównaniu $\mathrm{z}$ ich syntetycznymi ekwiwalentami odpoczać, skorzystać i urodzić. Poprzedzające analityzm stać się największym beneficjentem sformułowanie jak to się ostatnio mówi wyraża ironię wobec orzeczenia peryfrastycznego z komponentem wywodzącym się z łaciny.

Najwięcej odpowiedzialnych za laktację hormonów Twój organizm wytwarza, gdy odpoczywasz. (NŻ 12/2012, s. 32)

O tym, czy zdąży odpocząć przed Euro 2012. (PN 17/2012, s. 3)

Beata Kozidrak (52) była zmęczona, dlatego przed planowaną lada dzień premierą postanowiła zregenerować siły. (NŻ 12/2012, s. 4)

Ale to oni najbardziej na całym zamieszaniu skorzystali; jak to się ostatnio mówi: stali się największymi beneficjentami. (PN 11/2012, s. 18)

Wreszcie urodziła córeczkę! (NŻ 2/20 12, s. 7)

Już od tygodni prasa spekulowała, kiedy Beyoncé (30) wyda na świat swoje pierwsze dziecko. (NŻ 2/2012, s. 7)

Zastępników doczekał się także syntetyzm urodzić się, stosowane wymiennie konstrukcje opuścić łono, przyjść na świat, być na świecie mogą zostać potraktowane w sposób dosłowny, jednocześnie nadają opisywanemu wydarzeniu wzniosłości, podkreślają jego rangę. Specyficzne właściwości ma analityzm opuścićłono, opisuje czynność zachodzącą w trakcie porodu i w związku z tym nie mógłby zostać zastosowany we wszystkich przytoczonych niżej kontekstach.

Jego rodzice także urodzili się w ZSRR, ale ojciec miał niemieckie pochodzenie. (PN 36/2012, s. 26)

Przed wyjazdową batalią ze Swansea City po raz ostatni na koncie Drozdów były cztery z rzędu wygrane, gdy większości graczy nie było jeszcze na świecie, a ich dzisiejszy opiekun zaczynał kopać piłkę w zespole juniorów szkockiego St Mirren. (PN 49/2012, s. 20)

Kiedy Tito przychodził na świat, jego rodzina mieszkała w maleńkim, liczącym poniżej tysiąca mieszkańców miasteczku Bellcaire d'Emporda. (PN 20/2012, s. 34) Dziecko Marianny ma przyjść na świat w kwietniu. (NŻ 4/2012, s. 5)

Tyle gramów będzie miał relikwiarz, projektowany na przyszłościową uroczystość kanonizacji papieża, odwzorowujący wagę Glorii, gdy przyszła na świat. (P 50/2012, s. 27) Tyle tygodni miała, kiedy opuściła łono. (P 50/2012, s. 27) 
Podstawą orzeczeń peryfrastycznych może być też czasownik prowadzić, podkreśla on trwanie jakiejś czynności, a jednocześnie dodaje powagi opisowi. „O ile forma prowadzić obserwacje może być odczytywana neutralnie, o tyle pozorny patos obecny w sformułowaniu prowadzić remont z jednej strony budzi u odbiorcy śmieszność, wywołując skojarzenia z mało zrozumiałym stylem urzędowym, z drugiej jednak użycie takiego połączenia wydaje się uzasadnione - oba wymiennie stosowane orzeczenia pojawiły się w tym samym tekście, nadawcą kierowały zatem prawdopodobnie względy stylistyczne, chciał w ten sposób uniknąć powtórzenia"109. Przeciwne nacechowanie wyłania się z mającego taki sam odpowiednik - remontować - wielowyrazowego zrobić remont, odznacza się ono większą potocznością.

A Czarnogórcy od dawna wnikliwie analizują grę naszej drużyny, selekcjoner Branko Brnović obserwował biało-czerwonych podczas Euro 2012, zaś do Tallina wysłał asystenta Anto Drobnjaka. (PN 36/2012, s. 5)

Nie muszę do nikogo chodzić w tej sprawie, właściciel klubu ma wypracowaną długoletnią strategię budowy zespołu, nieustannie prowadzone są obserwacje kandydatów do gry w Lechu. (PN 50/2012, s. 14)

Remontowaliśmy drogi, odświeżaliśmy centrum miasta - powiedział „Piłce Nożnej” Andrij Sadowy, mer Lwowa, który w trakcie trwania turnieju odgrywa rolę pierwszego gospodarza. (PN 24/2012, s. 27)

- Prowadziliśmy intensywne remonty i renowacje. (PN 24/2012, s. 27)

Rodzice postanowili zrobić remont w mieszkaniu. (VG 9/2011, s. 38)

Podniosłość przekazywanych treści uwidacznia się w analitycznych konstrukcjach czasownikowych z komponentami udzielać (udzielać świadectw, udzielać odpowiedzi), poddać (poddać krytyce, poddać modyfikacji) czy dokonać (dokonać wyboru, dokonać selekcji). Uwydatniają one bardziej niż ich syntetyczne zastępniki (świadczyć110, odpowiadać, krytykować, modyfikować, wybierać, selekcjonować) zarówno wykonawcę czynności, jak i samą czynność.

109 K. Burska, Analityczne konstrukcje czasownikowe..., s. 70.

110 Syntetyzm ten może też przybrać wielowyrazową formę dać świadectwo, która podobnie jak udzielać świadectw - jest nacechowana wzniosłością: Ale też swoją biedą daje świadectwo uczciwości, bo nie kradł i nie oszukiwał, jak ci wszyscy, którzy zawłaszczyli III RP. (P 24/2012, s. 22). 
Gdy rodzice Glorii Wrony udzielają świadectw o jej cudownym uzdrowieniu, publiczność jest proszona o oklaski dla tego dziecka. (P 50/2012, s. 26)

Na część tych pytań dziewczyna nie musi odpowiadać przy mamie, można jeszcze raz porozmawiać z lekarzem po wyjściu mamy z gabinetu na czas badania. (VG 12/2011, s. 57)

Niech każdy sam udzieli sobie odpowiedzi na to pytanie. (PN 44/2012, s. 3)

Co ciekawe, niemieckie media nie poddały zbyt ostrej krytyce drużyny z Leverkusen. (PN 48/2012, s. 34)

Propozycje tematów - wraz z rekomendacjami urzędników poczty - trafiają do ministra administracji i cyfryzacji, który ostatecznie wybiera tematy do druku lub poddaje je modyfikacji. (P 50/2012, s. 101)

55-letni Nawałka jest w tej kwestii specjalistą, za długo siedzi też w futbolu, żeby liczyć na wieczne szczęście, dlatego dokonując selekcji, z natury unika piłkarzy lichej postury, w miarę możliwości pozbywając się z kadry zawodników podatnych na kontuzje. (PN 44/2012, s. 12)

Dziennikarzom nawet się nie śniło, że to na nich spadnie teraz ciężar ochrony najbardziej strzeżonych tajemnic państwowych i że to oni będą musieli dokonywać selekcji, co można ujawnić, a co jednak powinno zostać ukryte. (P 50/2012, s. 10)

Ich drużyna była naprawdę niezła, a on dawał z siebie wszystko, aby udowodnić, że trener dokonał właściwego wyboru, wybierając go do reprezentacji. (VG 1/2011, s. 9)

Podobnie jednoelementowe głosować, poprawić się, przeważać, pytać, radzić i zdecydować nie nadają tak dużej patetyczności jak ich wieloczłonowe zastępniki: oddać głos, ulec poprawie, uzyskać przewagę, zadać pytanie, nieść radę czy podjąć decyzję. Niektóre z wymienionych przynależą do konkretnych odmian, np. w środowisku lekarskim częste będzie posługiwanie się połączeniem ulec poprawie w odniesieniu do staniu zdrowia, z kolei urzędowy ton utrzymany jest $\mathrm{w}$ analityzmach oddać głos i podjać decyzję.

Jestem pewien, że Boniek podoła nowemu, trudnemu zadaniu i spełni oczekiwania nie tylko tych, którzy głosowali na niego, ale również tych, którzy na obecną chwilę nie darzą go sympatią. (PN 44/2012, s. 7)

Każdy, kto odwiedzi stronę konkursu (www.klasazesnow.pl) w dniach 1-28 lutego, będzie mógł oddać swój głos na jedną z nominowanych prac. (VG 4/2011, s. 3)

Nie tylko dlatego, że związkowcy mogliby zostać zepchnięci do podziemia albo w następnych wyborach oddać głos na jakichś ultraradykałów. (P 24/2012, s. 18) 
Syn aktora Maciej Stuhr zapewnił w wywiadzie, że stan zdrowia jego ojca uległ poprawie. (NŻ 13/2012, s. 3)

Z upływem czasu Chorwaci, uzyskując przewagę liczebną, starali się jak najszybciej odbierać podopiecznym Trapa ochotę do gry, pozostawiając z tyłu trzech lub nawet tylko dwóch obrońców. (PN 24/2012, s. 23)

Kiedy ktoś zadaje ci pytanie, czym się interesujesz i w jaki sposób lubisz spędzać wolny czas, w głowie pojawia się myśl: komputer. (VG 23/2012, s. 11)

Prawdą jest, że ostateczne wyjaśnienie zagadki okazało się boleśnie banalne i można zadać pytanie, dlaczego okablowanie eksperymentu nie zostało sprawdzone na samym początku. (P 24/2012, s. 81)

Z czasem mocno umalowane panie w okienkach zaczęły reagować na chcących nieść pomoc i radę rodaków jak na obcych. (PN 24/2012, s. 26)

Wciąż nie mogła się zdecydować. (VG 10/2011, s. 10)

Władze podjęły decyzję o przerwaniu wystawiania spektaklu. (VG 9/2011, s. 63)

Prezydent Miguel Guillen nie potrafi podjąć decyzji o pozbyciu się któregoś z nich, uważa, że stanowią znakomity tandem. (PN 41/2012, s. 8)

Punkt przełomowy to była budowa wieży widokowej Kaszubskie Oko, chociaż kiedy wójt podejmował decyzję, niektórzy też pukali się w głowę. (P 24/2012, s. 117)

Jak pokazuje analiza powyższych przykładów, konstrukcje peryfrastyczne mające jednoelementowe odpowiedniki mogą być ściśle powiązane z oficjalnymi stylami polszczyzny. Zjawisko to przejawia się w używaniu terminów i konstrukcji przybierających formę definicji czy tworzeniu wielowyrazowych struktur w celu precyzyjnego przekazania treści o charakterze urzędowym czy naukowym. Godne podkreślenia jest zróżnicowanie tematyczne form należących do tej grupy, w polskich periodykach znajdujemy nawiązania do sportu, prawa, medycyny, polityki, gospodarki, a także chociażby historii. Nie brakuje też połączeń odwołujących się do życia codziennego, ich peryfrastyczny opis ma służyć lepszemu przyswojeniu zawartości artykułu nawet przez mało obeznanego w danej tematyce czytelnika. Widoczna jest pewna schematyczność w tworzeniu struktur w tej grupie - zwłaszcza orzeczenia peryfrastyczne opierają się na określonych komponentach.

Wydaje się, że swoistą manierą stało się używanie jednostek wyrazowych nacechowanych podniośle. Nie zawsze jest to uzasadnione rzeczywistymi potrzebami, czasem eksponuje się w ten sposób pewne odcienie znaczeniowe, ale częściej taki przesadny patos - zwłaszcza odnoszący się do mało istotnych zagadnień zamiast akcentować treści, wprowadza niezamierzony żartobliwy efekt. 
Analityzmy [...] mające syntetyczne odpowiedniki o znaczeniu synonimicznym

\subsection{Eufemizmy}

Eufemizm definiowany jest jako „każdy środek językowy zastępujący wyraz, wyrażenie lub zwrot, który z jakiegokolwiek powodu nie może być użyty w danym tekście"ll1, to ominięcie, zasłonięcie lub złagodzenie nazwy wprost jakiegoś zjawiska ${ }^{112}$. Określenia zastępcze mogą się pojawiać w miejsce słów nieprzyzwoitych lub drastycznych z przyczyn estetycznych, kultowych lub cenzuralnych ${ }^{113}$, mówi się o ich funkcji polepszającej114, zaznacza się, że środek ten „osłabia silne zabarwienie emocjonalne zastępowanego wyrazu, łagodzi znaczeniową dosadność słowa, a także eliminuje wulgaryzmy oraz wyrazy uznawane za rubaszne lub trywialne"115. Według Anny Dąbrowskiej eufemizmy są neutralne lub nacechowane pozytywnie 116 , Anna Engelking uznaje z kolei neutralność uczuciową określeń eufemistycznych za rzadko występującą, jej zdaniem mogą przejawiać one trojakie nacechowanie: podniosłe i uroczyste, żartobliwe, pogardliwe i lekceważące ${ }^{117}$.

Eufemizm ściśle wiąże się z wartościowaniem, jak zauważa A. Dąbrowska: „już niejako z definicji zawiera element oceny. Posługujemy się eufemizmem dlatego, że nazwę wprost uznajemy za nieodpowiednią (z różnych względów) w danym kontekście czy sytuacji. Mówiący sam ocenia, co w konkretnym akcie mowy musi (lub powinno) być zawoalowane"118. Nie nazywając rzeczy po imieniu, nadawca udowadnia, że zna obowiązujące konwencje społeczne i obyczajowe. W przypadku tekstów dziennikarskich zabieg ten może być użyty także w innych celach - pominięcie nazwy podstawowej i wprowadzanie w jej miejsce sformułowania wartościującego może służyć zyskaniu przychylności adresata, a więc pełnić

111 A. Dąbrowska, Eufemizmy życia codziennego, [w:] Język a kultura, t. 2: Zagadnienia leksykalne i aksjologiczne, red. J. Puzynina, J. Bartmiński, Wrocław 1991, s. 163.

112 Por. definicje przytoczone przez Annę Dąbrowską w monografii Eufemizmy współczesnego języka polskiego, wyd. 2 popr., Łask 2006, s. 38-64.

113 Encyklopedia językoznawstwa..., s. 138.

114 A. Engelking, op. cit., s. 126-127.

115 Słownik terminów literackich, red. J. Sławiński, Wrocław-Warszawa-Kraków 1978, s. 112.

116 A. Dąbrowska, Słownik eufemizmów polskich, czyli w rzeczy mocno, w sposobie łagodnie, wyd. 3, Warszawa 1998, s. 9.

117 A. Engelking, op. cit., s. 127.

118 A. Dąbrowska, Eufemizmy mowy..., s. 120. 
funkcję perswazyjną, a w skrajnych przypadkach nawet manipulować odbiorcami. Podkreśla się również, że eufemizacja może być przyczyną zmian znaczenia lub przesunięć znaczeniowych. Trzeba też dostrzec, iż eufemizmy wykorzystywane są w celach stylistycznych, pozwalają uniknąć powtórzeń i wzbogacić język wypowiedzi, są zatem zabiegiem ornamentacyjnym.

A. Dąbrowska wprowadza rozróżnienie na eufemizmy właściwe (zwane też przez badaczkę eufemizmami langue, językowymi lub ogólnymi), które są zrozumiałe przez ogól, także poza kontekstem, oraz kontekstowe (inaczej eufemizmy parole lub tekstowe), które są określeniami zastępczymi tylko w określonym tekście, a ich właściwe odczytanie i funkcja łagodząca są uwarunkowane kontekstem ${ }^{119}$.

Uczeni zwracają również uwagę na relacje między eufemizmem a synonimem: „stwierdzenie, że eufemizmy są po prostu synonimami, zbytnio upraszczałoby tę bardzo skomplikowaną materię"120. Czasem wyraz podstawowy zanika, wypiera go określenie eufemistyczne, które zajmuje jego miejsce, wówczas nie można mówić już o eufemizmie, bo giną kryteria zastępowania i równoległego funkcjonowania w świadomości użytkowników - cechy niezbędne do uznania jakiegoś sformułowania za językowy środek łagodzący dosadność znaczeniową wypowiedzi. „Wiele określeń zastępczych przechodzi drogę od eufemizmu do synonimu, ponieważ świeżość ich skojarzeń z wyrazem podstawowym stopniowo się zaciera"121.

Pojęcie eufemizmu nieodłącznie związane jest $\mathrm{z}$ tabu. Tabu pierwotne łączone było z religijno-magicznym sposobem myślenia społeczeństw prymitywnych ${ }^{122}$, wiarą w sprawczą moc słowa i utożsamianiem rzeczy z nazwą. Początkowo odnosiło się do wszelkich zjawisk wywołujących lęk, czyli np. śmierci, sił nadprzyrodzonych, dzikich zwierząt ${ }^{123}$. Współcześnie utożsamiane jest z zakazem pewnych zachowań, także zachowań językowych ${ }^{124}$, czyli niemożnością używania danych wyrazów w określonych okolicznościach ${ }^{125}$, związane jest więc ze względami

119 Por. A. Dąbrowska, Eufemizmy życia..., s. 179; eadem, Eufemizmy mowy...

120 A. Dąbrowska, Kilka słów o eufemizmach, [w:] Język a komunikacja 5, t. 1: Aspekty współczesnych dyskursów, red. P. Chruszczewski, Kraków 2004, s. 83.

121 A. Engelking, op. cit., s. 126.

122 S. Widłak, Tabu i eufemizm w językach nowożytnych, „Biuletyn Polskiego Towarzystwa Językoznawczego" 1963, z. 22, s. 90.

123 M. Szwecow-Szewczyk, Tabu i eufemizmy językowe dawniej i dziś, „Poradnik Językowy" 1974, z. 6, s. 286.

124 Z. Leszczyński, Szkice o tabu językowym, Lublin 1988, s. 10.

125 A. Dąbrowska, Kilka słów o..., s. 80-81. 
towarzysko-obyczajowymi i polityczno-propagandowymi ${ }^{126}$. A. Dąbrowska twierdzi: „Nie wypowiadamy jakichś słów czy zwrotów językowych dlatego, że nie chcemy tego robić, nie możemy tego robić, nie powinniśmy tak się zachowywać, czy też nie wolno nam w taki sposób postępować"127. Badaczka przywołuje aktualną definicję: „tabu jest zjawiskiem kulturowym obejmującym wszystko, co jest objęte zakazem społecznym (czasem również prawnym); są to zachowania, których nie należy praktykować, i tematy, jakich nie należy poruszać w danej społeczności (nie wypada o nich mówić), ponieważ są wstydliwe, niebezpieczne, kontrowersyjne, przykre lub niemoralne"128. Stanisław Widłak podzielił przyczyny tabu językowego na cztery grupy ${ }^{129}: 1$ ) wierzenia religijne, magia, strach, zabobon; 2) przyzwoitość, skromność, wstyd; 3) delikatność, uprzejmość, współczucie, litość; 4) roztropność, przezorność, megalomania, spryt i interes osoby mówiącej. Zenon Leszczyński źródeł tabu upatruje w: strachu przed magicznym związkiem między wyrazem (wyrażeniem) a oznaczanym przezeń albo w jakiś sposób związanym z nim zjawiskiem; obawie przed deprecjacją przedmiotu czci; kierowaniu się względami kurtuazyjnymi; ochronie siebie i swoich interesów (dyplomacji); posługiwaniu się zasadami dobrego smaku i dyskrecji ${ }^{130}$. Warto przyjrzeć się kręgom tematycznym, które podlegają procesowi eufemizowania. Najpełniejsze zestawienie przedstawiła A. Dąbrowska w jedynym wydanym w Polsce słowniku poświęconym tej problematyce zatytułowanym Słownik eufemizmów polskich, czyli w rzeczy mocno, w sposobie łagodnie. Wyróżniła ona siedemnaście głównych kategorii, w których mogą pojawiać się środki łagodzące dosadność wypowiedzi: cechy fizyczne człowieka; części ciała; części garderoby; nagość; czynności fizjologiczne; stany fizjologiczne kobiety; życie seksualne; choroby; śmierć i zjawiska z nią związane; odrażający wygląd lub zapach; wady, nałogi i przywary ludzkie; przewinienia, wykroczenia i kary (działania sprzeczne z prawem lub społecznie nieakceptowane); połajanki, przekleństwa, wyzwiska; wierzenia religijne; status finansowy, pieniądze; polityka; określenia zawodów, sklepów i punktów

126 A. Dąbrowska, Eufemizmy życia..., s. 163.

127 Ibidem, s. 81.

128 A. Dąbrowska, Zmiany obszarów podlegających tabu we współczesnej kulturze, [w:] Język a kultura, t. 20: Tom jubileuszowy, red. A. Dąbrowska, A. Nowakowska, Wrocław 2008, s. 175.

129 Podział za: S. Widłak, op. cit., s. 93.

130 Z. Leszczyński, op. cit., s. 14-27. 
usługowych ${ }^{131}$. Po kilkunastu latach badaczka opublikowała artykuł zatytułowany Zmiany obszarów podlegajacych tabu we współczesnej kulturze, w którym zaktualizowała listę tematów tabuizowanych. Na podstawie analizy Korpusu języka polskiego Wydawnictwa Naukowego PWN dostrzegła, że „współcześnie tabu przestaje działać w takich dziedzinach życia społecznego, jak narkotyki, rak i choroby psychiczne, pedofilia, śmierć i cierpienie, operacje plastyczne i-przede wszystkim - seks"132. Lektura czasopism pozwoliła wysnuć wniosek, że wciąż obszarami tabu są: gwałt, śmierć i umieranie, kanibalizm, niektóre części ciała, nagość, pewne choroby, klonowanie, sztuczne zapłodnienie, zagadnienia dotyczące seksu, w tym tematyka seksualna w rozmowach z dziećmi, a także starość czy religia ${ }^{133}$. Dostrzegła więc, że są tematy, które z jednej strony utrzymują tabu, a z drugiej jednocześnie próbują je łamać. Wśród nowych zagadnień, o których niechętnie się mówi, wyróżniła w sferze publicznej politykę oraz podnoszenie prestiżu niektórych zawodów i miejsc, w sferze prywatnej zaś - operacje plastyczne, wysokość zarobków. Funkcjonowaniu tabu pierwotnego i magii językowej w szerszej perspektywie czasowej na przykładzie antroponimii oraz tematyki z obszaru śmierci i umierania przyjrzał się Rafał Zarębski ${ }^{134}$.

Sporo uwagi poświęcono w opracowaniach także językowym sposobom tworzenia eufemizmów. M. Szwecow-Szewczyk za sposoby łagodzenia drastyczności wypowiedzi uznała zmiany fonetyczne i zmiany formy graficznej dokonywane w wyrazach objętych tabu, a także zastępowanie ich synonimami lub konstrukcjami peryfrastycznymi. A. Engelking szczegółowo przyjrzała się dwóm grupom wyodrębnionym na podstawie kryterium semantycznego - mianowicie metafo-

131 W porównaniu z wydaną wcześniej monografią A. Dąbrowskiej poświęconą eufemizmom zabrakło dwóch kategorii: nazw niebezpiecznych zwierząt oraz etykiety językowej, pojawiły się za to określenia zawodów, sklepów i punktów usługowych, a stany fizjologiczne kobiety - wcześniej zaliczane do kategorii nazw czynności fizjologicznych - zostały ujęte w osobnym dziale.

132 Ibidem, s. 178.

133 Ibidem, s. 181-188.

134 R. Zarębski, Przejawy tabu pierwotnego i magii językowej w dawnej $i$ współczesnej polszczyźnie, „Sprawozdania z Czynności i Posiedzeń Naukowych ŁTN” 2013, t. XVII, red. K. Czyżewska, Łódź 2014, s. 241-251. Jak twierdzi: „Obserwacja zjawiska tabu w szerszej perspektywie czasowej dowodzi, że jest to fenomen językowy i kulturowy o wysokim stopniu stałości i niezmienności. Bardzo mocno trzyma się zakotwiczone od wieków w ludzkiej mentalności zwłaszcza tabu pierwotne". Por. ibidem, s. 249. 
rom i metonimiom, ze względu na szczególną formę w kręgu jej rozważań znalazły się też zapożyczenia ${ }^{135}$. S. Widłak podczas rozważań przyczyn eufemizowania wskazuje także na środki językowe, wymienia m.in. przekształcenia fonetyczne i graficzne, określenia przenośne, zdrobnienia, synonimy, omówienia, zapożyczenia. Z. Leszczyński omawia przekształcenia eufemistyczne wyrazów i wyrażeń tabu, elipsy (w tym skracanie wyrazu do pierwszej głoski), synonimy, peryfrazy sfrazeologizowane i doraźne, aluzje, informacje o charakterze metajęzykowym ${ }^{136}$. Najbardziej szczegółowej charakterystyki dokonała A. Dąbrowska, która w monografii poświęconej eufemizmom wyróżniła aż osiem grup. Jej klasyfikacja obejmuje środki fonologiczne, morfologiczne, leksykalne, semantyczne, graficzne, metajęzykowe, suprasegmentalne oraz środki na poziomie wypowiedzenia i tekstu ${ }^{137}$. Szczegółowy podział przedstawia się następująco:

a) środki fonologiczne: ucięcie, metateza, substytucja, aluzja fonetyczna, nazwa pierwszej litery, zmiana dźwięczności głoski, zmiana sposobu wymawiania, b) środki morfologiczne:

- fleksyjne: stopniowanie przymiotników, zamiana liczby pojedynczej na mnogą, zamiana trybu rozkazującego na oznajmujący lub przypuszczający, zmiana rodzaju lub paradygmatu fleksyjnego,

- słowotwórcze: zdrobnienia, zgrubienia, sufiksacja (derywaty tworzone sufiksami o innych funkcjach niż w powyższych grupach), prefiksacja, odrzucenie prefiksu, zmiana jednego członu w złożeniu lub we frazie, skróty i skrótowce, neologizmy,

c) środki leksykalne: synonimy, antonimy, hiperonimy, zapożyczenia z języków obcych, zapożyczenia wewnętrzne,

d) środki semantyczne: metafora, metonimia, peryfraza, antonomazja, litota, ironia, aposjopeza, aluzja, niedomówienie,

e) środki na poziomie wypowiedzi i tekstu: wprowadzanie do wypowiedzi sformułowań typu: ty już wiesz co, wiadomo co, no wiadomo, wiadomo, czym to się skończy, wtrącenia sygnalizujące stosowanie wyrazów lub wyrażeń o charakterze eufemistycznym takie, jak: łagodnie mówiąc, grzecznie mówiąc, jak

135 Jak pisze: „Funkcję eufemistyczną pożyczek wzmacnia ich stosunkowo mały zasięg. Kiedy zapożyczenie staje się powszechnie znane i używane, traci tym samym wyrazistość, utrwala się jako element potocznego języka ogólnego i jego funkcja eufemistyczna słabnie”, A. Engelking, op. cit., s. 126.

136 Z. Leszczyński, op. cit., s. 33-37.

137 A. Dąbrowska, Eufemizmy współczesnego języka polskiego, s. 270-382. 
by to grzecznie powiedzieć, mówić bardziej humanitarnie, zaznaczenie wprost, że używa się eufemizmu, formuły przepraszającej za dosadność czy wulgarność wypowiedzi takie, jak: pani wybaczy, za przeproszeniem, uczciwszy uszy,

f) graficzne środki eufemizowania: wielokropek, cudzysłów, zmiany ortograficzne, inne znaki interpunkcyjne,

g) zabiegi metajęzykowe,

h) środki suprasegmentalne (prozodyczne).

Przedstawione językowe sposoby łagodzenia wypowiedzi dowodzą, że bogactwo środków wykorzystywanych w tym celu jest naprawdę duże i pojawiają się one na wielu płaszczyznach. Co oczywiste, $\mathrm{z}$ racji tego, że w niniejszej pracy analizowane są wyłącznie analityzmy leksykalne i ich jednoelementowe ekwiwalenty, nie wszystkie sposoby zostały odnotowane w czasopismach początku drugiej dekady XXI w. Zebrano jednak różnorodne - zarówno pod względem środków, jak i tematyki - określenia zastępcze.

A. Dąbrowska zaznacza: „W semantyce eufemizm traktowany jest jako jedna z przyczyn zmian znaczenia. Istota tego zjawiska polega na przejściu od znaczenia nie wprost do znaczenia wprost - dany wyraz lub wyrażenie było wykorzystywane do nazywania jakiegoś zjawiska po to, by nie używać verbum proprium, na które nałożone było tabu. Po pewnym czasie nowa nazwa wypiera starą i staje się neutralnym określeniem danego zjawiska"138.

Procesowi eufemizowania może podlegać sam wyraz eufemizm, który w tekście prasowym przyjął postać omówienia słowo z gatunku delikatnych. Peryfraza ta posłużyła także jako zabieg na poziomie wypowiedzi i tekstu sygnalizujący wprowadzenie sformułowań o charakterze łagodnym, za jego pomocą zasygnalizowano bowiem, że analityczne połączenie mało udany zastępuje synonimiczne przymiotniki i imiesłowy nazywające wprost niepomyślny debiut, czyli np. nieudany, słaby czy wręcz beznadziejny:

Po trzecim z rzędu meczu bez zdobyczy bramkowej ciemne chmury zbierają się nad Jose Marią Bakero, prowadzącym ekipę poznańskiego Lecha, a debiut Pavla Hapala na ławce trenerskiej Zagłębia Lubin trzeba uznać za mało udany, używając słów z gatunku delikatnych. (PN 45/2011, s. 47)

138 A. Dąbrowska, Zniekształcenie obrazu rzeczywistości poprzez użycie pewnych środków językowych (eufemizm i kakofemizm), [w:] Językowy obraz świata, red. J. Bartmiński, Lublin 1999, s. 217. 
Dużą grupę stanowią konstrukcje zastępcze odnoszące się do przywar, wad i nałogów ludzkich. Kłamać może być używane wymiennie $\mathrm{z}$ frazeologizmem mijać się z prawdą, a także połączeniami nie mówić prawdy czy mówić niepraw$d e^{139}$. Większym stopniem zasłonięcia niewygodnych treści odznacza się związek frazeologiczny, choć obie przywołane wielowyrazowe struktury mają łagodniejszy wydźwięk niż syntetyzm, który wprost i bez żadnych dwuznaczności nazywa nieuczciwe postępowanie.

Zresztą w meczach reprezentacji nie zawodziłem, to najlepszy dowód, że nie mijam się z prawdą. (PN 6/2012, s. 28)

Ale mężczyźni potrafią mijać się z prawdą też z innych powodów. (NŻ 8/2012, s. 37) Ok, wiedziałam, że nie mówię prawdy, że nie powinnam tego robić, ale Marta jest o wiele bardziej winna. (VG 16/2012, s. 17)

Nawet jeśli ktoś kłamał, to bezpieczniej powiedzieć, że „mija się z prawdą”, „powiedział nieprawdę", niż nazwać go kłamcą, bo to zbyt ogólne. (P 38/2012, s. 97) Precedensem jest przypadek Guardioli, który w 2010 roku za stwierdzenie, iż sędzia Clos Gomez kłamie i wie o tym, został trzy miesiące później ukarany finansowo. (PN 11/2012, s. 2-3)

Czy jest wśród was ktoś, kto nigdy nie skłamał, nigdy nie plotkował, nie oszukiwał? (VG $1 / 2012$, s. 2)

Jestem przekonany, że większość tych respondentów kłamała. (P 50/2012, s. 36)

Często występującym uzależnieniem jest skłonność do nadużywania alkoholu. Określenia osoby pijanej140 też ulegają łagodzeniu, unika się nazywania wprost, a zamiast tego stosuje się analityzmy pod wpływem alkoholu lub - jeszcze bardziej niedookreślone i wieloznaczne - pod wpływem ${ }^{141}$. Być pod wplywem alkoholu ma

139 Według A. Dąbrowskiej litota ta jest mniej eufemizująca niż zawoalowany frazeologizm mijać się z prawdą. Por. A. Dąbrowska, Eufemizmy mowy..., s. 130.

140 Czasem stosuje się syntetyczny eufemizm wstawiony, np. Kiedy wszedł wstawiony na trening, część piłkarzy odmówiła uczestnictwa w zajęciach, donosząc o wszystkim trenerowi. (PN 49/2012, s. 10)

141 Za pomocą tego wyrażenia przyimkowego można też określić kogoś, kto zażywał narkotyki albo inne substancje odurzające, por. Nowe przepisy przewidują też kary dla osób, które wchodzą na stok pod wpływem alkoholu lub narkotyków. (NŻ 3/2012, s. 31) 
też znamiona oficjalności, pojawia się np. w pismach urzędowych czy kronikach policyjnych.

W marcu 2011 r., będąc pod wpływem alkoholu, Antoni wdał się w awanturę z policją. (NŻ 9/2012, s. 7)

W profesjonalnym futbolu nie ma miejsca na pracę pod wpływem, i zostało to Patrikowi przypomniane. (PN 50/2012, s. 4)

Zarządca terenu narciarskiego będzie mógł nie wpuścić pijanego lub odurzonego na trasę, albo nakazać jej opuszczenie (badanie alkomatem wolno będzie przeprowadzić tylko policjantowi). (NŻ 3/2012, s. 31)

Jak ujawniły poniedziałkowe media, piłkarz przyszedł na poniedziałkowy trening pijany. (PN 11/2012, s. 11)

Inną ludzką słabością jest skłonność do kłótni. Peryfrazą, która zastąpiła bezokolicznik kłócić się, jest wchodzić w konflikt. Konflikt definiowany jest przez słowniki jako 'niezgodność, sprzeczność interesów, poglądów'142, kłótnia zaś to 'ostra wymiana zdań, słów między osobami podnieconymi, niezgadzającymi się ze sobą'143, wydaje się zatem, że rozbudowana konstrukcja czasownikowa wywołuje mniej negatywne konotacje.

Nie wchodź teraz w konflikt ze współpracownikami, bo w bezpośrednim starciu możesz tylko stracić. (NŻ 5/2012, s. 47)

Sprzeczkom często towarzyszy posługiwanie się nacechowanym emocjonalnie słownictwem. Wulgaryzmy stanowią więc kolejny licznie reprezentowany krąg tematyczny, a używane zamiast nich eufemizmy są zróżnicowane zarówno pod względem formalnym, jaki semantycznym. Jak pisze A. Dąbrowska: „Przekleństwa są znakami językowymi silnie nacechowanymi ekspresywnie, sygnałem świadczącym o stanie emocjonalnym nadawcy: ich użycie bywa zwykle niekontrolowane. Stosowanie przekleństw jest sprzeczne z dobrym wychowaniem - ktoś mający dobrą kindersztubę nie klnie. Jednak bardzo często są odstępstwa od tej zasady i wówczas stosuje się określenia łagodzące"144. W badanym materiale przeklinać

142 Mały słownik..., s. 347.

143 Ibidem, s. 330.

144 A. Dąbrowska, Eufemizmy mowy..., s. 133. 
bywa zastąpione oficjalnym zwrotem używać wulgarnych stów, potocznym związkiem frazeologicznym rzucać mięsem ${ }^{145}$, doczekało się też dwóch rozbudowanych określeń, które można potraktować jako skumulowane eufemizmy, gdyż nie dość, że same jako całość (rzucać słowami na „k...” i co drugie słowo wrzucać przecinek) osłabiają dosadność słowa, to pojedyncze wyrazy wchodzące w ich skład też są sformułowaniami zastępczymi - zamiast wulgaryzmu kurwa użyto środków graficznych, czyli cudzysłowu i wielokropka, a także wykorzystano metonimię przecinek.

Sam leksem przekleństwo też staje się przedmiotem eufemizowania. By go określić, dziennikarze posługują się konstrukcjami: nieprzyzwoite słowa, soczyste słowa, soczyste słownictwo czy nieparlamentarne słówka - wszystkie wymienione za pomocą przymiotników delikatnie podkreślają niestosowność ich powszechnego używania. Przeciwne funkcje może pełnić połączenie śmieciarska gadanina, którego pejoratywne nacechowanie podkreślają zarówno derywaty od ujemnie wartościujących słów śmieciarz i gadać, jak i formant rzeczownikowy -ina wskazujący na przynależność do augmentatywów i ekspresywizmów. Jak widać, w polskich periodykach eufemistycznych określeń doczekały się nie tyle wulgaryzmy, ile ogólne określenia dotyczące posługiwania się brzydkimi wyrazami ${ }^{146}$.

Nie używaj wulgaryzmów, wyrazów z języka potocznego i takich, które nie pasują do tematu i formy wypracowania egzaminacyjnego. (VG 7/2011, s. 28)

Jak tam sobie chłopaki między sobą słowami na „k...” rzucają, to ich sprawa. (VG 7/2011, s. 17)

Chłopaka, który co drugie słowo wrzuca przecinek - żenada. (VG 3/2011, s. 22)

- Magda przeklina, by przypodobać się Edwardowi Miszczakowi, bo szef stacji lubi soczyste słowa - zdradza nam znajomy słynnej kucharki. (NŻ 1/2012, s. 11)

Wówczas była już pewna, że soczyste słownictwo popłaca, więc dlatego tak szaleje. (NŻ 1/2012, s. 11)

Dziennikarz Marcin Meller (43) jest znany ze swej słabości do nieparlamentarnych słówek. (NŻ 1/2012, s. 11)

145 Szczegółowa analiza tego frazeologizmu została przedstawiona w podrozdziale poświęconym potoczności. Por. s. 204.

146 Może to wynikać z faktu, że zgodnie z rozdz. 2, art. 12. Ustawy z dnia 26 stycznia 1984 r. Prawo prasowe dziennikarz zobowiązany jest do unikania używania wulgaryzmów. 
Nie będziecie przez to lepsi, a jeśli śmieciarska gadanina was dowartościowuje, to tylko pogratulować. (VG 3/2011, s. 22)

Gdyby sądy miały karać wszystkich za rzucanie mięsem, to po każdej kolejce ligowej mandaty płaciłoby wielu trenerów, a także piłkarzy. (PN 20/2012, s. 45)

Mówił więcej niż inni, przeklinał na całego, każda okazja była dobra, żeby „rzucić mięsem”. (VG 14/2012, s. 22)

Ale zamiast mówić mu, że przeklina równie brzydko jak jego koledzy, lepiej powiedzieć: „Nie lubię, gdy przeklinasz”. (NŻ 13/2012, s. 36)

Oni pewnie też uważają, że jesteśmy wulgarne, bo faktycznie sporo dziewczyn przeklina. (VG 7/2011, s. 17)

Z wyroku sądu, który uniewinnił pana za używanie nieprzyzwoitych słów w miejscu publicznym, chyba jest pan zadowolony? (PN 20/2012, s. 45)

Zmęczeni jej przeklinaniem, do jej nazwiska dodają w żartach przekleństwo, którego używa najczęściej. (NŻ 1/2012, s. 11)

Nierzadko ocenie społecznej podlegają cechy fizyczne innych osób, zwłaszcza wiek i waga. Przedmiotem procesu eufemizowania mogą być zarówno określenia odnoszące się do osoby zbyt grubej, jak i zbyt szczupłej. By nie urazić otyłych, pisze się o nich, że mają puszyste kształty lub są słusznej budowy - oba te połączenia mają pozytywny wydźwięk. Nie mówimy, że ktoś przytył, ale posługujemy się peryfrazami przybrał na wadze, przybyło tłuszczu, przybyło nieco ciała czy było kogoś za dużo. Tycie określane jest książkowo przyrostem masy ciała. Dzięki określeniom zastępczym niekorzystna zmiana wyglądu zewnętrznego jest łatwiejsza do zaakceptowania.

W zimę mniej się ruszam, więc jakoś tak na brzuchu i udach tłuszczu przybywa. (VG 9/2011, s. 27)

Działo się tak, bo było jej... zwyczajnie za dużo. (NŻ 13/2012, s. 5)

Jeśli nie chcesz, by synek nadmiernie przybrał na wadze, wyeliminuj napoje gazowane zawierające mnóstwo cukru. (NŻ 4/2012, s. 32)

Jeśli przybyło Ci nieco ciała, to zadbaj już teraz o swoją sylwetkę, by zdążyć przed latem. (NŻ 9/2012, s. 47)

Ale jej mama też do szczupłych nie należała, starsza siostra również była słusznej budowy. (VG 8/2011, s. 10)

Tymczasem odczuwają one głód, często potworny, ale w obawie przed przyrostem masy ciała odmawiają przyjmowania jedzenia. (VG 21/2012, s. 16) 
Jeśli czuje się kochana i akceptowana, nie walczy z puszystymi kształtami. (NŻ 12/2012, s. 10)

Na przeciwnym biegunie znajdują się połączenia odnoszące się do osób chudych. A. Dąbrowska pisze: „Przypuszczalnie negatywne nastawienie do tej cechy wiąże się z zakorzenionym przekonaniem, że tylko ludzie dobrze wyglądający są zdrowi i dobrze im się powodzi"147. W polskich czasopismach mała waga traktowana jest jako pożądana, co jednak nie oznacza, że brakuje rozbudowanych ekwiwalentów czasownika chudnąć. Wielowyrazowe połączenia informują nas o skutkach diety - tracimy zatem kilogramy, ważymy kilka kilogramów mniej, zrzucamy kilka kilo/sporo kilogramów, a obwód naszego pasa maleje.

Przestań myśleć, że wszystkie twoje kłopoty znikną i życie stanie się idealne, tylko dlatego, że będziesz ważyć kilka kilogramów mniej. (VG 17/2012, s. 36)

Choć stracili niewiele kilogramów, to uczestnikom badań obniżyło się ciśnienie krwi i spowolnił rytm pracy serca, wzrosła wydolność, poprawił nastrój, a obwód pasa zmalał. (P 51-52/2012, s. 113)

Traci kilogramy (NŻ 10/2012, s. 4)

A jeśli już zrzucisz kilka kilo, dbaj o utrzymanie jędrnej skóry w tym miejscu. (NŻ 13/2012, s. 23)

Sporo kilogramów zrzucił ponownie Aleksander Kwaśniewski. (P 24/2012, S. 122)

Nawet jeżeli już jest wystarczająco mała, to i tak postanawiają schudnąć. (VG 9/2011, s. 27)

Większość ludzi zaczyna ćwiczyć, by schudnąć. (P 51-52/2012, s. 113)

Skalpel chirurga pomaga schudnąć. (NŻ 4/2012, s. 35)

Kult młodości powoduje, że zamiast przymiotnika najstarszy w tekstach prasowych pojawia się peryfraza najbardziej zaawansowany wiekiem. Co ciekawe, w przytoczonym kontekście odnosi się ona do mniej więcej 30-letnich zawodników, ludzie w takim wieku przez wielu zostaliby uznani za młodych.

Z kolei najbardziej zaawansowani wiekiem piłkarze znaleźli się w drużynie Irlandii. (PN 24/2012, s. 33)

147 A. Dąbrowska, Eufemizmy mowy..., s. 128. 
Niemiły zapach określić można imiesłowem przymiotnikowym śmierdzący, a także rozbudowaną formą dziwnie pachnący. Ujęcie jej w cudzysłów podpowiada odbiorcy, że połączenie to ma zabarwienie ironiczne.

O wiele sympatyczniej pakować się po feriach do czystego niż „dziwnie pachnącego” plecaka. (VG 3/2011, s. 7)

Łagodzone jest także słownictwo związane ze stanami fizjologicznymi kobiety. „Tabu nałożone na fizjologię organizmu kobiecego (menstruacja, ciąża, poród) ma prastare podłoże, wiąże się bowiem z pierwotnym tabu magicznym. [...] Mechanizmy tych zmian fizjologicznych nie były dobrze znane, stąd też lęk przed nimi. Dzisiaj podłoże tabu trochę się zmieniło, nie można jednak uznać, że tabu pierwotne (lęk i szacunek dla Nieznanego i Niezrozumiałego) całkowicie zanikło"148. Omija się zwłaszcza słowo menstruacja, a w zamian używa połączeń ogólnych i mało precyzyjnych, które właściwie da się odczytać tylko w kontekście, np. kobiece sprawy czy bardziej pojemne semantycznie pewne powody. Znamienne jest to, że wszystkie eufemistyczne określenia menstruacji pochodzą z czasopisma dla młodzieży, co sygnalizuje, że właśnie dla dojrzewających dziewcząt jest to temat wstydliwy, o którym nie mówi się głośno.

Blanka napisała, że mogą się spotkać, ale raczej nie na basenie, bo z pewnych powodów nie może tam iść. (VG 17/2012, s. 25)

Ania zrozumiała, że „pewne powody” to kobiece sprawy, na które rady nie ma, basen musi poczekać. (VG 17/2012, s. 25)

Przecież nawet w czasie miesiączki można robić praktycznie wszystko (może poza pływaniem w basenie przez pierwsze dwa dni okresu). (VG 15/2012, s. 16)

Żartobliwe zabarwienie uwidacznia się w połączeniu wizyta bociana na określenie ciąży. Dwuwyrazowy analityzm odwołuje do wierzeń ludowych i przekazywanych najmłodszym historyjek, zgodnie z którymi to bocian przynosi na wiosnę nowo narodzone dzieci.

Ale sądząc po jej rozanielonej minie na imprezie TVP, nie miałaby pewnie nic przeciwko rychłej wizycie bociana... (NŻ 9/2012, s. 5)

148 Ibidem, s. 140-141. 
Ulubienica wywiadów przyznała, że czuje się gotowa na kolejną ciążę. (NŻ 13/2012, s. 4)

W celach terapeutycznych, a także by wykazać współczucie i zrozumienie wobec kobiety, która poroniła, dziennikarze posługują się nie tylko syntetycznym czasownikiem, ale wykorzystują też wielowyrazowe nie donosić ciąży. Modulant nie pozwala delikatniej przekazać bolesną informację.

Luiza nie donosiła ciąży, z której tak bardzo się cieszyła. (NŻ 7/2012, s. 2)

Potem okazało się, że w trakcie zdjęć poroniła. (NŻ 7/2012, s. 42)

Środkiem wyrazu użytym w celach eufemistycznych - o czym już wspominano - może być też zapożyczenie. Posłużenie się medycznym terminem mastektomia dla określenia amputacji piersi, mimo iż zastosowanym w znaczeniu dosłownym, pozwala na uniknięcie dosadności. Słownictwo specjalistyczne nie jest mocno zakorzenione w polszczyźnie ogólnej, dlatego może służyć przekazywaniu informacji w sposób zawoalowany. Tym, co sprawia, że wyrazy obce wykorzystywane są jako środki łagodzące, może być także ich niecodzienność brzmieniowa. Z czasem, gdy zaczynają wnikać do odmiany ogólnej i dostają się do powszechnego obiegu, ich funkcja łagodząca maleje, aż w końcu zanika i zastępują je nowo zapożyczane wyrazy ${ }^{149}$.

Wbrew początkowym objawom, że po mastektomii będzie musiała zrezygnować z seksu, nic takiego się nie stało. (P 5/2011, s. 56)

Miała już też za sobą amputację piersi - nie jednej, obu! (P 5/2011, s. 56)

149 Wydaje się, że z takim zjawiskiem mamy do czynienia w przypadku słowa antykoncepcja - kiedyś to zapożyczenie brzmiało tajemniczo, mogło więc być używane jako eufemizm, z czasem spowszedniało, por. A najtrudniejszą do pokonania barierą w rozpowszechnianiu antykoncepcji jest nie tyle konserwatywne podłoże kulturowe i religijne, co brak rzetelnej wiedzy o zaletach i skutkach ubocznych medycznych procedur zapobiegania ciąży. (P 24/2012, s. 57). Być może podobny mechanizm obowiązywał w parze peruka i sztuczne włosy: Francuski król Ludwik XIV, panujący na przełomie XVII i XVIII w., wylansował bujne peruki, które nosiły także dobrze urodzone kobiety. (P 51-52/2012, s. 147). Szał na sztuczne włosy osiągnął szczyt - także dosłownie - pół wieku później, w czasach Marii Antoniny, której nadworna stylistka Rosa Bertin, przez złośliwych nazywana ministrem urody, oraz fryzjer królowej Leonard tworzyli skomplikowane konstrukcje, wysokie na kilkadziesiąt centymetrów. (P 51-52/2012, s. 147) 
Tabu obyczajowemu podlega leksyka związana z życiem seksualnym człowieka. Na niemówienie bezpośrednio o przeżyciach i doznaniach erotycznych wpływa głównie ich intymność. W zgromadzonym materiale tabuizacji podlegają nazwy stosunku płciowego oraz określenia zdrady małżeńskiej, rozstania czy homoseksualizmu. Współżyć jest stosowane wymiennie z konstrukcją robić to składającą się z mało precyzyjnego czasownika oraz zaimka wskazującego, a także połączeniem o szerokim zakresie znaczeniowym spać z kimś. Słownik eufemizmów polskich, czyli w rzeczy mocno, w sposobie łagodnie jako określenie łagodzące podaje też uprawiać seks (analogicznie mogłoby się tam znaleźć też mieć seks), choć wydaje się, że konstrukcje te jednoznacznie nazywają odbycie stosunku płciowego i ich nadrzędnym celem nie jest eufemizowanie.

Marysia powiedziała jej więc, że bardzo się spieszy, i że termin jest na sierpień - dziewięć miesięcy po tym listopadzie, gdy po raz pierwszy spała z Tomkiem. (P 24/2012, s. 38)

On ciągle nalega, żeby to zrobić. (VG 23/2012, s. 12)

I dorosły, który uprawia seks z małoletnią, będzie karany. (VG 3/2011, s. 11)

W ubiegłym roku sternik FIFA na wieść, iż rzeczony już Terry uprawiał seks z byłą partnerką kolegi klubowego Wayne’a Bridge’a oświadczył: - W krajach o kulturze łacińskiej takiego typu zachowania nie tylko nie potępia się, ale wręcz pochwala. (PN 47/2011, s. 27)

W listopadzie mieli pierwszy seks, zaraz potem Marysi jakby urósł brzuch. (P 24/2012, s. 37)

Co natomiast z osobami, które ukończyły 15. rok życia (ale są niepełnoletnie) i współżyją? (VG 3/2011, s. 11)

Obiektem męskiego pożądania są często kobiece piersi. W artykule prasowym zostały one określone metaforą poduszki rozkoszy, która - choć tajemnicza i niejednoznaczna - uwypukla ich rolę podczas aktu seksualnego.

Młode, bez kompleksów, bezczelnie świadome swych poduszek rozkoszy, pokazują ich na stronach internetowych dziesiątkami - małe, duże, średnie. (P 7/2011, s. 87)

Kobiece piersi to od zawsze fascynujący obiekt erotyczny. (P 7/2011, s. 85) 
Zamiast jednoznacznie wskazującego na niewłaściwe zachowanie wobec partnera czasownika $z d r a d z i c ́$ autorzy tekstów posługują się kolokacją być niewiernym, która ma zdecydowanie łagodniejszy wydźwięk.

Piotr twierdzi, że to Magda była niewierna. (NŻ 3/2012, s. 43)

W serialu „Klan” gra kobietę, która tuż przed ślubem zdradza swojego męża i zachodzi w ciążę z kochankiem. (NŻ 6/2012, s. 6)

Bolesnym momentem w związku jest nie tylko zdrada, lecz także rozstanie. Aby wykazać się taktem, nie pisze się wprost, że ktoś się rozstał, ale używa się opisowych konstrukcji nie byćjuż parą i złożyć miłosną broń. Szczególnie interesujące jest to drugie połączenie, składa się bowiem ze związku frazeologicznego $z \nmid o z \dot{y c ́}$ broń ('zrezygnować z ubiegania się o coś' WSF, s. 25) poszerzonego o przymiotnik miłosny. Prawidłowe rozszyfrowanie tej innowacji wymaga niemałych kompetencji odbiorczych, kluczowe okazuje się zapoznanie z kontekstem.

Wprawdzie 6 grudnia przyjechała do Olafa Lubaszenki jego ukochana Hanna Wawrowska, ale tylko po to, by mu oznajmić, że odtąd nie będą już parą. (NŻ 2/2012, s. 9)

Po 3 latach gorącego romansu i jeszcze bardziej ognistych kłótniach, para złożyła miłosną broń... (NŻ 3/2012, s. 17)

A co najważniejsze, u boku aktorki zabrakło jej partnera, biznesmena Kuby Sićko (35), z którym rozstała się w listopadzie. (NŻ 2/2012, s. 44)

Mimo rosnącej tolerancji dla mniejszości seksualnych w XXI w. dla licznych wciąż jest to temat niewygodny, o którym najlepiej nie mówić wcale, a jeśli trzeba - to tylko w sposób zakamuflowany. Homoseksualiści są więc omownie zwani parami tej samej płci.

Oświadczenie prezydenta Obamy w wywiadzie dla telewizji ABC, że pary tej samej płci powinny móc się pobrać, przyjęły z radością. (P 20/2012, s. 52)

Nie zmienia tego także sama deklaracja prezydenta - bo musi tu wkroczyć Kongres albo Sąd Najwyższy - ale wzmocniła nadzieje amerykańskich homoseksualistów, że to już tylko kwestia czasu. (P 20/2012, s. 52) 
Oparcie się na skojarzeniach biblijnych posłużyło do eufemizacji kolejnej dziedziny objętej tabu - mianowicie nagości. W miejsce jednoznacznego nago pojawiło się żartobliwe połączenie $w$ stroju Adama, które odwołuje czytelnika do starotestamentowej Księgi Rodzaju. Znajomość frazeologii wymagana jest z kolei przy odczytaniu mającej taki sam syntetyczny odpowiednik peryfrazy $w$ całej krasie.

Zapytany, czy przedstawia go w stroju Adama, Rafał Maserak odparł tajemniczo: No cóż, na obrazie jest cała moja sylwetka... (NŻ 7/2012, s. 9)

Tancerz pokazał się w całej krasie na zdjęciu w kalendarzu „Gentleman” za imponujące honorarium w wysokości 15 tys. zł! (NŻ 9/2012, s. 2)

Wystąpił nago! (NŻ 9/2012, s. 2)

A. Dąbrowska wspomina o silnym zakorzenieniu tabu śmierci w naszej kulturze: „Poczucie strachu związane z nieuchronnością jej nadejścia, a także niewiadoma losu po śmierci powoduje, że mówimy o niej z lękiem"150. O towarzyszącej ludziom grozie związanej z kresem egzystencji wspomina też Igor Borkowski: „Śmierć budzi u współczesnego człowieka nieprzeparty lęk. Przeczy wierze w niespożyte możliwości opanowania natury ludzkiej przez gatunek ludzki. Koniec życia budzi lęk, gdyż w zlaicyzowanym społeczeństwie nie jest już progiem, po którego przekroczeniu przechodzi się do krainy życia wiecznego, ale stanowi niewyjaśnialną zagadkę"151. Dlatego za pomocą tworzywa językowego trzeba śmierć oswoić, sprawić, by to, co przerażające i bolesne, nabrało nowego sensu. Eufemizmy odgrywają więc w tym kręgu tematycznym nadrzędną rolę ${ }^{152}$. Nie mówi się wprost umrzeć czy zginąć, ale używa się mocno osadzonych w kontekście orzeczeń peryfrastycznych być daleko stąd i nie wrócić do domu, które ze względu na swoją wieloznaczność łagodnie przekazują informację o śmierci.

150 A. Dąbrowska, Eufemizmy mowy..., s. 125.

151 I. Borkowski, Śmierci tajemnicze wrota. Językowy świat inskrypcji nagrobnych, [w:] Język a kultura, t. 13: Językowy obraz świata i kultura, red. A. Dąbrowska, J. Anusiewicz, Wrocław 2000, s. 343.

152 Oczywiście nie wszystkie zastępcze określenia śmierci mają charakter eufemizmów, wiele z nich ma nacechowanie oficjalne, podkreśla podniosłość tego momentu. Przekształcenia semantyczne słownictwa z pola wyrazowego związanego $\mathrm{z}$ umieraniem zostały omówione w poprzednim podrozdziale. Por. s. 162-163. 
Kamera zaglądała w oczy roztańczonej Szaflarskiej, zatrzymywała się na Witoldzie Grucy, niegdyś wielkim tancerzu, na Irenie Kwiatkowskiej, która kilka miesięcy później będzie już daleko stąd, ale póki co głośno dowodzi, że diabła granego przez Nowickiego „wcale się nie przelękła, tylko strach zagrała”, na Stefanie Burczyku, który podpisze pakt z diabłem, byle ostatni raz zagrać przed widzami. (P 51-52/2012, s. 129)

Do domu nie wróciło 96 kibiców, w tym wiele dzieci. (PN 6/2012, s. 6)

Z kolei sformułowania nie ma kogoś wśród żywych i dokonać żywota co prawda z jednej strony jasno przekazują komunikat, ale z drugiej nie nazywają dosłownie, są więc łatwiejsze do zaakceptowania niż syntetyczne umrzeć. Przyczyną użycia drugiego z wymienionych połączeń może być też to, że odwoływało do zwierząt, posługiwanie się analityzmem mogłoby być uznane za nadmierną, nieprzystającą do tematyki personifikację.

Nie ma już wśród żywych wojownika, sportowca o nieposkromionych ambicjach, Czarodzieja z narożnika, jak pisała o Nim prasa zagraniczna. (PN 11/2012, s. 4)

Z wyliczeń wynika, że gdyby rzeczywiście nie było różnic między dużymi, długo żyjącymi gatunkami i małymi, żyjącymi krótko, to każdy wieloryb lub słoń powinien dokonać żywota z powodu nowotworu, zanim osiągnąłby wiek reprodukcyjny. (P 50/2012, s. 81)

Metaforyczny charakter widoczny jest w zestawieniu czarować w innym, lepszym ze świató $w^{153}$ - określenie takie wzbudza w odbiorcach poczucie, że śmierć nie jest kresem, ale początkiem czegoś lepszego, pozwala więc ze spokojem przyjąć wiadomość o odejściu. Potwierdza to tezę A. Engelking, że „duża grupa metaforycznych określeń śmierci opiera się na pojmowaniu jej jako zasadniczej przemiany życia, jako przejścia do rzeczywistości o innej jakości niż ta, którą postrzegamy zmysłowo"154.

153 Konstrukcja ta ma także swoje uzasadnienie w treści artykułu. Tekst dotyczy nagłej śmierci Włodzimierza Smolarka, zwanego Czarodziejem z narożnika, autor posłużył się więc także grą językową polegającą na wykorzystaniu wyrazów czarować i czarodziej opartych na takich samych morfemach.

154 A. Engelking, op. cit., s. 119. 
Teraz Czarodziej z narożnika będzie czarował już w innym, lepszym ze światów... (PN 11/2012, s. 5)

Nie brakuje metafor gaśnięcia, opartych na porównaniach człowieka z płonącą świecą ${ }^{155}$. Ważnym elementem połączenia zgasnąć przedwcześnie jest przysłówek podkreślający, że nigdy nie ma odpowiedniego momentu na śmierć, zawsze nadejdzie ona zbyt szybko.

Dzieci megagwiazd, które zgasły przedwcześnie, nie chcą żyć w cieniu sławnych rodziców. (NŻ 8/2012, s. 17)

Do metafor przejścia zaliczymy natomiast opisową strukturę odejść z tego świata, która może sugerować, że istnieje jeszcze jakaś inna rzeczywistość, a tym samym pozwala zmniejszyć obawy.

Trzy tygodnie później jej ukochany tata odszedł z tego świata. (NŻ 11/2012, s. 8)

Metonimiczny charakter ma peryfraza zamilknąć na zawsze, która budzi skojarzenia z jedną z faz procesu umierania, jaką jest ustanie oddechu, powodującą, że człowiek nie może już wydobyć z siebie więcej słów.

Anioł z New Jersey zamilkł na zawsze. (NŻ 7/2012, s. 42)

Dużą obrazowością wykazał się autor opartej na zamienni konstrukcji wielowyrazowej dosięgnie go śmiercionośna kula. Dzięki temu sformułowaniu w jednym zdaniu udało mu się plastycznie przedstawić i przyczynę, i skutek.

Za chwilę dosięgnie go śmiercionośna kula. (VG 10/2011, s. 57)

Wśród sformułowań odnoszących się do umierania pojawiają się takie, które mogą być interpretowane wieloznacznie, bo w ich skład wchodzą bardzo pojemne semantycznie elementy, jak np. zaimek określony to. Dopiero wczytanie się w tekst pozwala na odkrycie zamaskowanej w ten sposób zawartości treściowej.

155 Ibidem, s. 123. 
Kiedy w końcu nadeszło to nieuniknione, to ona zamknęła mu powieki. (NŻ 7/2012, s. 14)

Przyczyną śmierci może być zabijanie, które w tekście prasowym przybrało patetyczną formę odbieranie życia, sprawiającą, że drastyczność czynności ulega pomniejszeniu.

Widać przez niego szaleńca, który po objęciu władzy ogłosił się Bogiem i dał sobie prawo do odbierania życia. (PN 6/2012, s. 11)

Ocaleć przyjęło także obrazową postać uniknąć spotkania z gilotyną, która wskazuje odbiorcom, w jaki sposób pozbawiano życia w dawnych czasach.

Moda na skomplikowane i ciężkie jak królewska władza peruki skończyła się razem z wybuchem rewolucji francuskiej, a możni, którzy uniknęli spotkania z gilotyną, nosili przez kolejne dziesięciolecia naturalne fryzury. (P 51-52/2012, s. 147)

Małgorzata Hodalska, omawiając peryfrazy eufemizacyjne w prasie po śmierci Jana Pawła II, podkreślała, że ich stosowanie to wyraz szacunku dla czytelnika, a także środek umożliwiający wytworzenie wrażenia współodczuwania i bliskości autorów tekstów i ich odbiorców ${ }^{156}$. Podobne funkcje uwidaczniają się w przedstawionych zastępczych określeniach śmierci.

Łagodzone bywają także sytuacje, które w złym świetle ukazywałyby wykonawcę jakiejś czynności lub osobę będącą obiektem tychże działań. Mówiący dba o własny interes, dlatego przedstawia siebie jak najkorzystniej157. Przyczyną nie jest już raczej tabu, lecz szeroko pojęta dyplomacja, zasady dobrego wychowania, niekiedy też strach, np. przed zemstą.

Decyzję szkoleniowca o chwilowej nieprzydatności zawodnika i zdjęciu go z boiska zamiast wyrazić wprost bezokolicznikiem zejść, opisuje się peryfrastycznie opuścić plac gry, a nawet za pomocą budzącego skojarzenia z pozasportowymi dziedzinami życia powędrować do zajezdni.

156 M. Hodalska, Mocarz Ducha zamieszkał w niebie. Peryfrazy ornamentacyjne i eufemizacyjne w prasie, „Język Polski” 2010, z. 4-5, s. 309.

157 A. Dąbrowska, Kilka słów o..., s. 82. 
I po chwili Iniesta spudłował minimalnie, a po minucie Balotelli najpierw zabrał piłkę ostrzyżonemu specjalnie na turniej na krótko Sergio Ramosowi, a potem dał mu się ośmieszyć i powędrował do zajezdni decyzją trenera. (PN 24/2012, s. 31) Sytuacja zmieniła się, gdy plac gry opuścił z powodu kontuzji Tomasz Bandrowski. (PN 41/2012, s. 22)

By osłabić dosadność piłkarskiego znaczenia słowa nieskuteczność, wykorzystano eufemistyczne połączenia niemoc strzelecka, strzelecka abstynencja czy indolencja strzelecka. Ze względu na swoje obce pochodzenie rzeczowniki abstynencja i indolencja mogą wprowadzać element enigmatyczności, nie dla wszystkich będą zrozumiałe - bo zazwyczaj występują w innym otoczeniu leksykalnym - co sprawia, że idealnie nadają się do ukrycia nieprzyjemnych treści.

Kibice za nim przepadają, w przeszłości wybaczali mu długie miesiące strzeleckiej abstynencji. (PN 11/2012, s. 33)

Ale indolencja strzelecka wcale nie była znakiem firmowym wyłącznie Holendra. (PN 20/2012, s. 19)

24-latek sprawdził się w europejskich pucharach, dziwić może jednak strzelecka niemoc $w$ reprezentacji Łotwy. (PN 33/2012, s. 31)

Potem odezwał się grzech Barcy z meczu z Chelsea, czyli nieskuteczność. (PN 17/2012, s. 33)

Analityczne konstrukcje pokazać komuś drzwi i podziękować komuś za prace - mimo iż ich zadaniem jest przekazanie negatywnych informacji - mają łagodniejszą wymowę niż ich syntetyczny ekwiwalent wyrzucić.

Kiedy przestał strzelać gole, pozycja Beniteza zaczęła się chwiać, aż w końcu też pokazano mu drzwi na Anfield. (PN 48/2012, s. 23)

Po czterech miesiącach i trzech punktach podziękowano mu za pracę. (PN 20/2012, s. 16)

Propagowanie dążeń pacyfistycznych stoi u podstaw eufemizowania leksemu wojna. Czyny zbrojne, militarne wyczyny czy działania wojenne koncentrują uwagę odbiorcy na tym, że jest to jedynie czynność (czyny, działania), a nawet jakieś osiągnięcie (wyczyn), sprawiając, że towarzyszące rzeczownikom przydaw- 
ki (zbrojny, militarny, wojenny) nie budzą tak dużej grozy jak w przypadku, gdy posługujemy się wyłącznie krótką formą wojna.

Dramatyczne losy Mazurów po zakończeniu działań wojennych. (P 51-52/2012, s. 114) Trudności pojawiają się dopiero wówczas, kiedy chodzi o przeszłe czyny zbrojne służące zdobyczom terytorialnym, podbijaniu czy kolonizowaniu innych ludów. (P 24/2012, s. 21)

Współczesna wrażliwość etyczna, i rodząca się (w bólach co prawda) europejska wspólnotowość skłaniają do niepodkreślania samych militarnych wyczynów, niestawiania na piedestale podbojów, nieczynienia z nich głównych elementów narodowej dumy. (P 24/2012, s. 21)

Wojna pokazana tak jak nigdy dotychczas w polskim filmie. (P 51-52/2012, s. 114)

Działania niezgodne z prawem to procedery karalne, dlatego też niechętnie się o nich wspomina. „Pieniądze to temat, o którym nie zawsze wypada czy też można mówić. W wielu wypadkach - głównie gdy okoliczności ich zarobkowania lub przekazywania nie są bez zarzutu - nie tylko nie wypada, ale wprost nie należy o nich mówić bez ogródek. Do takich sytuacji bez wątpienia należy dawanie łapówek"158. I właśnie dlatego w prasie obok słów łapówka i korupcja znajdziemy urzędowe odpowiedniki analityczne korzyść majątkowa i czerpanie korzyści majątkowych.

Drugim podejrzanym o czerpanie korzyści majątkowych z racji zajmowanego stanowiska jest były zięć Havelange’a, prezydent konfederacji futbolu Brazylii Ricardo Teixeira. (PN 48/2011, s. 29)

Włodzimierz B. usłyszał zarzut przyjęcia łapówki w kwocie 2 tysięcy złotych, natomiast Mariusz T. usłyszał dwa zarzuty przyjęcia korzyści majątkowych na łączną kwotę 5 tysięcy złotych. (PN 43/2011, s. 11)

Korupcja pełniła w ówczesnej Polsce rolę, którą dziś pełni tragedia smoleńska i którą przed Smoleńskiem pełniła lustracja. (P 51-52/2012, s. 31)

Wszelkie określenia synonimiczne czasownika przegrać o zróżnicowanych odcieniach semantycznych zostały omówione wcześniej ${ }^{159}$, warto jednak przy-

158 A. Dąbrowska, Eufemizmy życia..., s. 172.

159 Por. s. 170-172 niniejszej pracy. 
pomnieć, że wśród nich znalazły się też eufemizmy gubić punkty, tracić oczka, nie sprostać, dostać od rywali lekcję futbolu, wrócić do domu bez punktów, które mają na celu pomniejszenie porażki.

Analiza powyższych przykładów dowodzi, że osłabianie semantycznej wartości słów w zbiorze analityzmów i syntetyzmów nie jest zjawiskiem jednostkowym, ale występuje powszechnie i dotyczy różnych kręgów tematycznych. Aby złagodzić dosadność znaczeniową, dziennikarze posługują się zróżnicowanymi środkami leksykalnymi i semantycznymi: metaforami, metonimiami, peryfrazami, zapożyczeniami, synonimami, związkami frazeologicznymi (także poddanymi przekształceniom). Niezbyt często do oznaczenia eufemizmów wykorzystywane są zabiegi graficzne, choć spotkać można wielokropki i cudzysłowy. Odnotowano też nieliczne przykłady środków na poziomie wypowiedzi i tekstu. Dominacja płaszczyzny leksykalno-semantycznej jako sposobu łagodzenia nie dziwi, ma bowiem uzasadnienie w tym, że niniejsza praca opiera się na badaniu połączeń wyrazowych i ich jednoelementowych ekwiwalentów.

Eufemizmy pozwalają skoncentrować uwagę odbiorcy na danym elemencie opisywanego zjawiska, narzucając tym samym określony sposób percepcji rzeczywistości. Zwykle przedmiot, sytuacja czy czynność nie są postrzegane całościowo, ale wydobywa się tylko fragment i na tym opiera budowanie znaczenia przenośnego. Może to prowadzić do zniekształcenia obrazu otaczającego nas świata. A. Dąbrowska wspomina tu o funkcji maskującej, twierdząc, że niektóre zastępcze połączenia wyrazowe „przedstawiają jakieś zjawisko w taki sposób, że uwaga odbiorcy skierowana jest na te opinie i fragmenty wypowiedzi, na które życzy sobie nadawca”160, Mariola Szymczak-Rozlach dodaje: „Często eufemizacja jako proces w wypadku maskowania rzeczywistości jest bliska zjawisku manipulacji"161. To, co niewygodne, jest więc kamuflowane. O zniekształceniu postrzegania rzeczywistości trzeba mówić głównie w odniesieniu do rodzaju wypowiedzi dziennikarskiej: w tekstach informacyjnych możemy mieć do czynienia z rzeczywistym działaniem manipulacyjnym, inaczej postrzegamy je w publicystyce: jest to zabieg przypisany na stałe do tego gatunku, mający przede wszystkich charakter wartościujący.

160 A. Dąbrowska, Zniekształcanie obrazu rzeczywistości..., s. 223.

161 M. Szymczak-Rozlach, Leksyka eufemizujaca (na materiale słowackim i polskim), [w:] Obraz človeka v jazyku, red. J. Vaňko, Nitra 2014, s. 169. 
Nie wszystkie eufemistyczne określenia są łatwe do interpretacji, zdarza się, że zrozumienie sformułowań metaforycznych wymaga od czytelnika zaangażowania intelektualnego. Dominują eufemizmy kontekstowe, tworzone ze słów pojemnych semantycznie i mało precyzyjnych, do ich deszyfracji oczekuje się od czytelnika zagłębienia w lekturę.

Istotnym elementem określeń zastępczych - co już zasugerowano - jest wartościowanie. Najczęściej wydobywa się pozytywne aspekty przedstawianego zjawiska, choć nie brakuje połączeń ironicznych. Czasem widoczne jest przejście od określenia wywołującego negatywne konotacje do neutralizowania tych skojarzeń.

\subsection{Metafora i metonimia jako główne sposoby tworzenia odpowiedników nazw własnych}

Dużą grupę zgromadzonych na potrzeby niniejszej pracy peryfraz stanowią opisowe określenia nazw własnych. Stefan Kałuski i Tomasz Komornicki niewystępujące $\mathrm{w}$ atlasach i encyklopediach, a jednocześnie funkcjonujące w języku potocznym, literaturze lub gwarach specjalistycznych nazwy geograficzne nazywają niekonwencjonalnymi nazwami geograficznymi lub geograficznymi przydomkami162. Aby deskrypcje określone ${ }^{163}$ mogły zostać użyte zamiast imion własnych, muszą pełnić funkcję referencyjną, wówczas można je stosować do wyznaczania tych samych przedmiotów, do których odnoszą się nomina propria164. Jak czytamy w Encyklopedii językoznawstwa ogólnego: „Różnica między imieniem własnym a deskrypcją określoną użytą w funkcji referencyjnej polega jedynie na sposobie wyznaczania: deskrypcja określona odsyła do przedmiotu poprzez jego

162 S. Kałuski, T. Komornicki, Słownik niekonwencjonalnych nazw geograficznych, Warszawa 1996, s. 5.

163 „Deskrypcje określone to opisowe wyrażenia identyfikujące, czyli wyrażenia, które mają zdolność wskazywania, wyznaczania obiektów indywidualnych, dla odróżnienia ich od innych, poprzez przypisanie im pewnych właściwości. [...] Mają one jednego, niepowtarzalnego referenta w danej, określonej wspólnocie komunikacyjnej”. Zbudowane są z wyrazów pospolitych oraz nazw własnych. Deskrypcja określona może być zastąpiona przez nazwę własną i odwrotnie. Por. Z. Kaleta, Teoria nazw własnych, [w:] Polskie nazwy własne. Encyklopedia, red. E. Rzetelska-Feleszko, Warszawa-Kraków 1998, s. 33.

164 Por. hasła: deskrypcja określona, deskrypcja nieokreślona, transpozycja, funkcja referencyjna, [w:] Encyklopedia językoznawstwa... 
jednoznaczny opis, czyli poprzez wymienienie właściwości przysługujących tylko danemu przedmiotowi i żadnemu innemu"165.

Szczególna rola, którą nomina propria odgrywają w procesie komunikacji, „polega na wyróżnieniu konkretnej osoby lub obiektu spośród wszystkich takich samych lub podobnych obiektów danej klasy"166. Była już o tym mowa, że zdaniem wielu badaczy nazwy własne przede wszystkim nazywają, a nie znaczą ${ }^{167}$. Tezę tę przywołuje także Mirosław Bańko podczas analizowania peryfrastycznych odpowiedników imion własnych: „przyjmuje się, że nazwy własne, w przeciwieństwie do nazw pospolitych, mają odniesienie (referencję), lecz nie mają konotacji (treści, sensu) i w rezultacie nie mają też denotacji (zakresu). Można powiedzieć, na co dana nazwa wskazuje, lecz nie można powiedzieć, co znaczy"168. Mariusz Rutkowski podkreśla, iż wtórne użycie nazw własnych odsuwa na dalszy plan funkcję referencyjną i sprawia, że „zaczynają w nazwach ujawniać się nowe funkcje, aktualizują się rozmaite konotacje, zmieniona jest też referencja - nazwa nie oznacza już swego prymarnego denotatu (obiektu), lecz jest «przeniesiona» na inny obiekt"169.

M. Bańko, omawiając stosunki między peryfrazą a jej ekwiwalentem w postaci nazwy właściwej, poruszył także istotne zagadnienie synonimii. Według niego nie można tu mówić o synonimiczności: „Przyjmowana ogólnie definicja synonimii zakłada, że relacja ta łączy wyrazy lub wyrażenia o tej samej treści (intencji, konotacji), a nie tym samym zakresie (ekstensji, denotacji). Z tożsamości treści dwóch nazw wynika, że pokrywają się ich zakresy, ale odwrotna zależność nie zachodzi"170. Jako przykład przywołuje tu peryfrazy ojczyzna futbolu i ojczyzna Szekspira, które choć nie mają tego samego znaczenia, to oznaczają ten sam kraj. Jako drugi argument podaje: „O synonimiczności (czyli pokrywaniu się treści) nazwy peryfrastycznej i nazwy właściwej trudno mówić też z tego powodu, że

165 Encyklopedia językoznawstwa..., s. 106.

166 E. Rzetelska-Feleszko, Nazwy własne, [w:] Encyklopedia kultury polskiej XX wieku, t. 2: Współczesny język polski, red. J. Bartmiński, Wrocław 1993, s. 397.

167 E. Rzetelska-Feleszko twierdzi, że całkowite odbieranie nazwom własnym znaczenia jest „zbytnim uproszczeniem, a zwolennicy tej tezy pojmują termin «znaczenie nazwy» zbyt wąsko i jednostronnie”. Zob. ibidem.

168 M. Bańko, Peryfrazy w naszym życiu, „Poradnik Językowy” 2002, z. 9, s. 20.

169 M. Rutkowski, Metafory motywowane metonimicznie (metaftonimie) na przykładzie nazw własnych, „Białostockie Archiwum Językowe” 2008, nr 8, s. 95.

170 M. Bańko, Peryfrazy w naszym życiu, s. 6. 
wiele peryfraz zastępuje nazwę własną, a nazwom własnym tradycyjny pogląd odmawia w ogóle treści"171. Wskazuje, że zgodnie z tym założeniem przywołane wcześniej peryfrazy coś znaczą, ale Anglia - ich oficjalny odpowiednik - pozbawiony jest znaczenia. Badacz dochodzi ostatecznie do wniosku, że „ekwiwalencję peryfrazy i nazwy właściwej można określić jedynie jako współzakresowość"172. Oznacza to zatem, iż mają one takie samo odniesienie w tekście oraz mogą być wzajemnie zastępowane.

M. Bańko zwraca także uwagę, że odpowiedniość wyrażeń omownych i nazw właściwych nie jest wzajemnie jednoznaczna, to znaczy jedna peryfraza może odnosić się do kilku różnych desygnatów i przeciwnie - ta sama nazwa właściwa może być określana za pomocą kilku różnych konstrukcji opisowych. Obie tendencje znajdują potwierdzenie w materiale wyekscerpowanym $\mathrm{z}$ polskich periodyków z początku drugiej dekady XXI w.

Zastępcze określenia antroponimów czy toponimów są często metaforami. Istotą tego zjawiska jest „odniesienie jakiejś nazwy do obiektu, do którego uprzednio jej nie odnoszono"173, z przeniesieniem tym związane jest przypisanie nowego znaczenia. Badająca przenośnie w tekście użytkowym Katarzyna Mosiołek-Kłosińska przywołuje też definicję tego pojęcia, odwołując się do lingwistyki kulturowej. Stwierdza: „Metafora nie jest zestawieniem dwu słów, lecz «zderzeniem» dwu pojęć, dwu myśli o przedmiotach. Sens metaforyczny rodzi się nie w wyniku zastąpienia jednego wyrazu innym, ale dzięki przywołaniu przez mówiących ciągu skojarzeń związanych z porównywanymi przedmiotami. Wypowiedź metaforyczna składa się nie z dwóch wyrazów lub znaczeń, lecz z dwóch zespołów pojęciowych. Metafora jest zatem nie tyle sposobem mówienia o zjawiskach, ile sposobem ich rozumienia, myślenia o nich"174. Badaczka podkreśla zatem nie tylko semantyczny, ale i kulturowy wymiar metafory 175 .

171 Ibidem.

172 Ibidem.

173 K. Mosiołek-Kłosińska, Metafora w tekście użytkowym - charakterystyka, próba oceny normatywnej, „Poradnik Językowy” 1997, z. 10, s. 9.

174 Ibidem, s. 2.

175 Jak pisze: „Przeniesienie cechy może odbywać się nie tylko na płaszczyźnie semantycznej, lecz także kulturowej - nazwa obiektu, do którego odnosi się temat główny, zostaje odniesiona do przedmiotu nazywanego przez temat pomocniczy nie dzięki aktualizacji cech semantycznych, lecz dzięki wyłonieniu w świadomości 
Czesław Kosyl zauważa, że „nazwa własna użyta jest metaforycznie, jeśli naruszony zostaje jej, utrwalony w świadomości społecznej, związek denotacyjny"176. Związek denotacyjny określa on jako „związek nazwy z denotatem, tj. z przedmiotowym korelatem tej nazwy w rzeczywistości pozajęzykowej albo, w wypadku onomastyki literackiej, z pomyślanym korelatem tej nazwy w rzeczywistości kreowanej przez autora"177.

Zofia Kaleta wspomina o znaczeniu pragmatycznym nazw własnych, definiując je jako „znaczenie nazwy własnej zrozumiałe jedynie w ramach określonego kontekstu społeczno-kulturowego i określonego systemu wartości"178. Zaliczyć tu trzeba nomina propria powstałe w wyniku metafory i metonimii - ich znaczenie ,jest zrozumiałe jedynie w określonym środowisku, gdzie znane są motywacje przezwisk funkcjonujących w obrębie określonych norm obyczajowych i norm ocen"179.

Można wyróżnić kilka charakterystycznych schematów, według których budowane są metaforyczne konstrukcje opisowe pojawiające się w miejsce oficjalnych nazw miast, krajów czy kontynentów. W przypadku aglomeracji miejskich chętnie wykorzystywaną podstawą jest leksem stolica, który nie ma jednak w takich przypadkach znaczenia 'główne miasto państwa, w którym znajduje się siedziba centralnych urzędów'180, lecz podkreśla ważność opisywanego ośrodka na jakimś obszarze. Tworzone w ten sposób omówienia są zazwyczaj jednoznaczne, choć nieraz do właściwego odczytania wymagają od odbiorcy niemałej wiedzy z zakresu geografii. Jako przykłady niech posłużą pary: stolica Podlasia i Białystok, stolica Bawarii i Monachium, stolica Małopolski i Kraków, stolica Dolnego Ślaska i Wrocław, stolica Górnego Śląska i Katowice, stolica Siedmiogrodu i Kluż-Napoka.

Następny przystanek na naszej trasie to Białystok. (VG 20/2012, s. 61)

użytkowników języka obrazu kojarzonego ze zjawiskiem, do którego odnosi się temat główny". Zob. ibidem, s. 20-21.

176 Cz. Kosyl, Metaforyczne użycie nazw własnych, [w:] Z zagadnień słownictwa współczesnego języka polskiego, red. M. Szymczak, Wrocław-Warszawa-KrakówGdańsk 1978, s. 134.

177 Ibidem.

178 Z. Kaleta, Teoria nazw własnych, s. 26.

179 Ibidem.

180 Mały słownik..., s. 960. 
Błędy proceduralne i częste zmiany wykonawców skutkują tym, że w Białymstoku nadal nie ma obiektu piłkarskiego z prawdziwego zdarzenia. (PN 49/2012, s. 14) Przecież jeszcze niedawno Tomasz Hajto czuł oddech Michała Probierza i Dariusza Wdowczyka na plecach, głośno mówiło się, że zmiana szkoleniowca w stolicy Podlasia jest tylko kwestią czasu. (PN 48/2012, s. 2)

Od trzech lat tereny nieczynnej Kopalni Węgla Kamiennego Katowice położone w samym centrum Katowic, stolicy Górnego Śląska, są prawdziwą Mekką dla wszystkich miłośników nowych brzmień elektronicznych. (VG 16/2012, s. 4)

W poprzedni weekend, kiedy w Kluż-Napoka odbyły się derby, piłkarze Universitatei po raz pierwszy od czterech miesięcy zobaczyli pieniądze. (PN 49/2012, s. 11)

Jeśli chodzi o stolicę Siedmiogrodu, znacznie lepiej wiedzie się szczególnie w XXI wieku zespołowi CFR. (PN 49/2012, s. 11)

Właściciele drogich sklepów w Krakowie powinni zaopatrzyć się w najlepsze i najbardziej wytworne towary rodem z Paryża i Mediolanu. (PN 46/2011, s. 38)

Teraz Ala debatuje z mamą czy wracać za ocean, czy jednak zostać w Krakowie i urządzić prawdziwie rodzinne święta wielkanocne. (NŻ 13/2012, s. 5)

Bo nie dość, że włoski szkoleniowiec, który uchodzi za konesera dzieł sztuki, zdecydował się na stolicę Małopolski, to jeszcze spodobał mu się hotel położony o rzut kamieniem od Rynku Głównego. (PN 46/2011, s. 38)

Już w sobotnie przedpołudnie całe Monachium żyło spotkaniem Bayernu z Borussią. (PN 49/2012, s. 2)

Gdyby jednak wsłuchać się tylko w głosy przechodniów, wyszłoby, że znajdujemy się w Dortmundzie, a nie w stolicy Bawarii. (PN 49/2012, s. 2)

I bardzo dobrze, bo Wrocław ma - jak na polskie standardy - okazałe zbiory. (P 50/2012, s. 83)

Trudno w to uwierzyć, ale w największym muzeum stolicy Dolnego Śląska nie można było obejrzeć europejskiej sztuki od ponad 20 lat. (P 50/2012, s. 83)

Podobny mechanizm budowania omówienia ujawnia się w peryfrazie imprezowa stolica słowackich Tatr odnoszącej się do Łomnic, tym razem jednak posłużono się odwołaniem nie do regionu, lecz masywu górskiego. Istotną wartość do tego określenia wnosi przydawka imprezowa, która pozwala odróżnić oparty na tej samej podstawie opisowej ekwiwalent Popradu - czyli stolica słowackich Tatr - od Łomnic.

Łomnice - imprezowa stolica słowackich Tatr - nocą rozbrzmiewa klubowymi rytmami. (NŻ 2/2012, s. 24) 
Konstrukcje analityczne z komponentem stolica mogą służyć także nie tyle podkreśleniu faktu, że z jakichś przyczyn dane miejsce jest najważniejsze w regionie, ile informować o ich szczególnej roli ze względu na nadzwyczajne właściwości czy niespotykaną gdzie indziej działalność. Wyobrażanie sobie Paryża jako miasta, które wyznacza obowiązujące na całej kuli ziemskiej trendy odzieżowe oraz kosmetyczne, znalazło odzwierciedlenie w rozbudowanym sformułowaniu stolica mody i perfum. „Poprzedzenie omówienia stolica walca przymiotnikiem światowa uwypukla, że postrzeganie Wiednia jako miasta, w którym narodził się walc, ma charakter globalny"181.

\section{Czemu zatem nie byłaś jeszcze w Wiedniu? (VG 15/2012, s. 27)}

W sobotę już z samego rana ruszył autem w kierunku Wiednia. (PN 50/2012, s. 4) Chciał pooddychać alpejskim powietrzem, poczuć atmosferę światowej stolicy walca, a przy okazji rzucić pańskim okiem na nieruchomość, którą ma w Austrii od czasu występów w tamtejszej Bundeslidze. (PN 50/2012, s. 4)

Resztę życia spędził na emigracji w Paryżu. (VG 3/2011, s. 40)

Jak udało się nam dowiedzieć, zabrał więc mamę do Paryża, gdzie mieszka jego nowa dziewczyna Katarzyna Gwizdała (31), robiąca tam karierę pod pseudonimem Kate Rozz. (NŻ 1/2012, s. 3)

Poza tym z terminalu St Pancras Station w Londynie do znajdującej się w centrum Paryża Gare du Nord można się przemieścić pociągiem pod kanałem La Manche w czasie nieprzekraczającym dwóch godzin. (PN 45/2011, s. 29)

David B., jako jeden z ekspertów od wody kolońskiej po goleniu, czułby się jak ryba w wodzie w stolicy mody i perfum. (PN 45/2011, s. 29)

Innym sposobem określania metropolii jest posługiwanie się leksemem miasto, do którego dołączane są precyzujące przydawki. Nazwanie Liverpoolu miastem Beatlesów wywołuje konotacje z pochodzącym z tej części Anglii zespołem muzycznym, zastępowanie nazwy Gdańsk dwuwyrazowym określeniem miasto Neptuna budzi skojarzenia z zabytkową fontanną z postacią boga mórz z mitologii rzymskiej, położoną w reprezentatywnej części miasta, z kolei odwołujące się do czasów antycznych określenie Rzymu jako Wiecznego Miasta ma akcentować jego potęgę i niezniszczalność.

181 K. Burska, Peryfraza a jej jednowyrazowy..., s. 238-239. 
Liverpool, czyli miasto Beatlesów, jest położony na zachodnim wybrzeżu północnej Anglii, około $340 \mathrm{~km}$ od Londynu, na północnym brzegu estuarium rzeki Mersey. (PN 15/2012, s. 37)

Rzym kryje w sobie także... inne państwo. (VG 6/2011, s. 14)

Włochy - rodzina, pizza i Wieczne Miasto (VG 6/2011, s. 2)

Gracze z Wiecznego Miasta wygrali czwarte kolejne spotkanie w Serie A. (PN 50/2012, s. 32)

Gdańsk witał wjeżdżających do miasta kibiców latarniami umajonymi flagami wszystkich uczestników Euro. (PN 24/2012, s. 31)

Kiedy kilkudziesięciotysięczny tłum przewali się ze stadionu do centrum Gdańska, Poznania, Wrocławia, Warszawy, służby miejskie będą musiały zbierać śmieci ciężarówkami, naprawiać uszkodzone wiaty, znaki i kosze. (P 24/2012, s. 16)

Wszystkim zaparło dech, gdy dziewczęta w bursztynowych kostiumach efektowną choreografią otworzyły finały ME w mieście Neptuna. (PN 24/2012, s. 31)

Miano miasta włókniarzy przylgnęło do dwóch różnych nazw właściwych, w tekstach prasowych określa się tak zarówno Manchester, jak i Łódź. Peryfraza ta przypomina odbiorcom o tradycjach włókienniczych i odzieżowych rozwijanych na tych obszarach. Nie dziwi, że oba miasta mają taki sam odpowiednik opisowy, wszak Łódź - właśnie ze względu na rozwój tej samej gałęzi przemysłu co w angielskiej aglomeracji - bywa nazywana też polskim Manchesterem ${ }^{182}$. Ewa Straś uważa, że peryfrazy wykorzystujące odwołanie do innego miasta „stanowią swoistą hiperbolę, akt nobilitacji dla mniej znanych denotatów, a niezupełna ich identyczność sygnalizowana jest przez określniki wskazujące na kontynent, kraj czy część świata"183. Cz. Kosyl wskazuje na jednokierunkowość takiej metaforyzacji: „nazwa denotatu o wyższej randze służy jako określenie metaforyczne dla nazwy denotatu o niższej randze”184. M. Rutkowski dodaje: „zazwyczaj wzorcowe obiekty są wartościowane pozytywnie, zaś ich lokalne odpowiedniki są

182 Por. M. Bańko, Słownik peryfraz, czyli wyrażeń omownych, wyd. 2, Warszawa 2009, s. 175; S. Kałuski, T. Komornicki, Słownik niekonwencjonalnych..., s. 127.

183 E. Straś, Peryfrazy w środkach masowego przekazu (na materiale prasy polskiej i rosyjskiej), [w:] Konfrontacje języków słowiańskich na poziomie leksyki, słowotwórstwa i składni, red. P. Czerwiński przy współpr. M. Borek, Katowice 2001, s. 104 .

184 Cz. Kosyl, Metaforyczne użycie nazw..., s. 138. 
traktowane jako gorsze wersje, aspirujące dopiero do rangi reprezentowanej przez «oryginały»"185.

O problemach piłkarzy z alei Unii kibice słyszą nieprzerwanie od kilku, jeśli nie kilkunastu, sezonów i prawdę mówiąc, przyzwyczaili się już, że w Łodzi albo zapowiadają strajk, albo już są w jego trakcie. (PN 5/2012, s. 47)

Wychowankowie - Michał Łabędzki, Marek Saganowski, Rafał Kujawa czy Artur Gieraga - mogą chodzić po mieście włókniarzy z podniesionymi głowami. (PN 20/2012, s. 18)

Społeczeństwo zawsze mieliśmy ofiarne, ale łódzkie szwaczki nie należą do bogatej kasty, co prężniejsze zakłady pracy w polskim Manchesterze też już dawno odwróciły się plecami do piłkarzy. (PN 5/2012, s. 47)

W tym samym czasie drugi zespół w tabeli, też z miasta włókniarzy, United wygrywał 1:0 z Sunderlandem. (PN 20/2012, s. 37)

Nieoczekiwanych porażek doznały dwie drużyny z Manchesteru, uznawane przez wielu fachowców za głównych kandydatów do udziału w tegorocznym wielkim finale LE. (PN 11/2012, s. 31)

Były zawodnik Manchesteru City powiedział młodszemu rodakowi, iż w Mieście Włókniarzy życie jest bardzo nudne. (PN 33/2012, s. 41)

Wykorzystywanym w wyrażeniach omownych synonimem słowa miasto jest gród, leksem ten odznacza się podniosłym nacechowaniem, wskazuje na bogatą historię opisywanego za jego pośrednictwem miejsca. M. Bańko podkreśla, że jest to „składnik peryfraz określających jakieś stare, zabytkowe miasto ze względu na charakterystyczną dla niego cechę"186. Odwołanie do legendy o smoku wawelskim i królu Kraku widoczne jest w analityzmach gród Kraka i miasto Kraka, które zastępują syntetyczną nazwę Kraków.

Właściciele drogich sklepów w Krakowie powinni zaopatrzyć się w najlepsze i najbardziej wytworne towary rodem z Paryża i Mediolanu. (PN 46/2011, s. 38) Przecież w mieście Kraka są dwa nowoczesne obiekty Wisły i Cracovii, gdzie warunki do prowadzenia treningów są o niebo lepsze niż na Suchych Stawach. (PN 46/2011, s. 38)

185 M. Rutkowski, Nazwy własne w strukturze metafory i metonimii, Olsztyn 2007, s. 220. 186 M. Bańko, Słownik peryfraz..., s. 61. 
WAGs, jak zwie się te panie, zapewne są już po wstępnych rozmowach z jakąś agencją turystyczną, która zorganizuje im przyjemny pobyt w grodzie Kraka. (PN 46/2011, s. 38)

Umieszczane w podstawach konstrukcji opisowych leksemy mekka i centrum przekazują, że desygnat, do którego się odnoszą, jest miejscem, w którym koncentruje się jakaś działalność lub rozwijane są jakieś zainteresowania, a w związku z tym chętnie przybywają do niego ludzie. M. Rutkowski wiąże z mekką następującą wartość konotacyjną: „najważniejsze, centralne miejsce dla jakiejś grupy ludzi; cel pielgrzymek, miejsce święte"187. Ewa Straś zauważa, że tylko w niektórych takich połączeniach związek z miastem zostaje zachowany, często wskazują one na „rozszerzenie znaczenia denotacyjnego nazwy użytej metaforycznie”188, ze zjawiskiem takim mamy do czynienia np. w peryfrazie mekka improwizacji zastępującej nazwę Chicago.

Teraz, w prezencie na szóste urodziny (obchodzą 16 czerwca), podarowali sobie wyjazd do mekki improwizacji - Chicago. (P 24/2012, s. 98)

Tradycja tych przedziwnych pielgrzymek ma swoje początki w XVI stuleciu, gdy miasteczko Zefat przekształciło się w światowe centrum żydowskiego mistycyzmu, czyli Kabały, a mędrcy owego okresu znajdowali wieczny odpoczynek w galilejskiej ziemi, w pobliżu ich uczonych w Piśmie Świętym poprzedników. (P 24/2012, s. 100)

Nierzadko wykorzystuje się nazwę innego miasta. Podobieństwo do powszechnie znanego, słynącego z jakichś walorów miejsca można zaakcentować poprzez użycie przydawki mały. Sugeruje ona, że oba miasta łączą jakieś wspólne właściwości, lecz ten gród, do którego przyrównywany jest inny, ma większą renomę. Co prawda Bukareszt i Częstochowa dzięki peryfrazom odpowiednio mały Paryż i mały Rzym zostają w jakiś sposób wywyższone, bo w ten sposób podkreśla się zbliżoną architekturę lub podobną lokalizację do pierwowzorów, ale jednak wskazuje się, że odpowiedniki nigdy nie przewyższą pod tym względem Paryża czy Rzymu.

Bukareszt to pechowe miasto. (VG 8/2011, s. 23)

Kiedyś był piękny, określany nawet mianem „małego Paryża”. (VG 8/2011, s. 23)

187 M. Rutkowski, Słownik metafor i konotacji nazw własnych, Olsztyn 2012, s. 83.

188 E. Straś, Peryfrazy w środkach..., s. 105. 
Tutaj jednak nie możemy się dziwić, bowiem Daniel pochodzi spod Częstochowy, zagłębia polskiego czarnego sportu. (VG 12/2011, s. 59)

Miasto polskie położone na siedmiu wzgórzach, zwane czasem „małym Rzymem”. (VG 12/2011, s. 63)

Ciekawie prezentuje się inne alternatywne określenie Częstochowy - zagłębie polskiego czarnego sportu. Ta analityczna konstrukcja zawiera w sobie inną peryfrazę - żuzel zwany jest tu czarnym sportem - dopiero jej odszyfrowanie pozwala na wydobycie znaczenia całości.

Tutaj jednak nie możemy się dziwić, bowiem Daniel pochodzi spod Częstochowy, zagłębia polskiego czarnego sportu. (VG 12/2011, s. 59)

Właściwości wartościujące ma posługiwanie się komponentem perła, wyraz ten jest „jednym z bardziej rozpowszechnionych na oznaczenie miejsca z różnych względów cennego, niepospolitego"189. Dzięki nazwaniu Dubrownika perła Adriatyku ${ }^{190}$ wyzyskuje się jego malownicze położenie, bogactwo zabytków i popularność wśród turystów.

W Dubrowniku życie tętni 24 godziny na dobę (VG 12/2011, s. 21)

Dubrownik - perła Adriatyku (VG 12/2011, s. 20)

Hollywood, dzielnica amerykańskiego Los Angeles, która słynie jako jeden z najważniejszych ośrodków kinematografii na świecie, zyskało miano Fabryki Snów. Połączenie to sugeruje, że angaż w tej wytwórni filmowej jest dla wielu spełnieniem marzeń.

Najmłodsza panna Gummer, 20-letnia Louisa dopiero stawia pierwsze kroki w Hollywood. (NŻ 9/2012, s. 14)

Jeszcze do niedawna na tle upstrzonymi znakami firmowymi sponsorów imprezy fotografowano się głównie w Hollywood. (P 24/2012, s. 108)

189 Ibidem, s. 106.

190 M. Bańko zauważa, że peryfraza ta może odnosić się także do Wenecji. Por. M. Bańko, Słownik peryfraz..., s. 161. 
W Fabryce Snów po raz 84. wręczono najbardziej pożądane złote statuetki na świecie. (NŻ 9/2012, s. 7)

Peryfrastyczne zastępniki nazw własnych mają na celu ukazanie nie tylko pozytywnych skojarzeń, metaforyczne określenia mogą mieć ironiczny wydźwięk, tak można odczytać połączenie sypialnia stolicy na określenie Żyrardowa. „Z jednej strony dziennikarz podkreśla w ten sposób, że ceny mieszkań są tam o wiele niższe niż w Warszawie, co niewątpliwie przynosi korzyści, z drugiej jednak dobitnie pokazuje, że jest to miejsce drugiej kategorii - ludzie przybywają do podwarszawskiej miejscowości jedynie na spoczynek, a ich codzienne życie koncentruje się w stolicy"191.

Jest ich coraz więcej, bo mieszkania w Skierniewicach są tańsze niż w Żyrardowie, nazywanym już od dawna sypialnią stolicy. (P 13/2012, s. 102)

Przenośne nazwy krajów także budowane bywają według ustalonego wzorca kompozycyjnego. Na plan pierwszy jako element peryfraz wysuwa się leksem kraj, dołączane są do niego różnorakie określenia, które pozwalają zwrócić uwagę na elementy w jakiś sposób związane z danym regionem świata. Kraj Kawy czy Kraj Tulipanów koncentrują się na warunkach przyrodniczych jednoznacznie kojarzonych z Brazylią i Holandią, pozwalają wyeksponować walory środowiska naturalnego.

Nowy przekaz: Brazylia jest wielka i różnorodna; jest krajem równych, o których władza dba w równym stopniu. (P 50/2012, s. 106)

Spotykamy się w Polsce, w Brazylii albo w połowie drogi. (NŻ 2/2012, s. 19)

Natomiast FIFA ma problem, gdyż prace w Brazylii, która za dwa lata organizuje mundial, postępują nad wyraz opieszale. (PN 11/2012, s. 10)

Jak widać, w klubie ze Stamford Bridge jeszcze mocniej będzie się stawiać na zawodników z Kraju Kawy. (PN 50/2012, s. 35)

Do Holandii jechał pan, mając gwarancję, że będzie pierwszym bramkarzem Rody? (PN 44/2012, s. 22)

- Skład reprezentacji Holandii przez prawie dwa lata, czyli od czasu mistrzostw świata, prawie się nie zmienia - mówi Janusz Kowalik, były reprezentant Polski mieszkający w Kraju Tulipanów. (PN 11/2012, s. 24)

191 K. Burska, Peryfraza a jej jednowyrazowy..., s. 239. 
Charakterystyczne ukształtowanie terenu stało się przyczynkiem do posługiwania się analityzmem Kraj Tysiąca Jezior na określenie Finlandii. Liczebnik tysiąc nie może zostać tutaj potraktowany dosłownie, gdyż według szacunkowych danych na obszarze tym znajduje się kilkadziesiąt tysięcy naturalnych zbiorników wodnych, ma on uosabiać po prostu wielość.

Choć był to dosyć śmiały krok ówczesnego prezesa federacji Sauli Niinistoe, na pewno nie miał przełożenia na to, iż rok później został wybrany prezydentem Finlandii. (PN 33/2012, s. 30)

Ale w stolicy Kraju Tysiąca Jezior, prawie nikt nie robił z tego narodowej tragedii. (PN 33/2012, s. 30)

Dwóch odmiennych - ale opartych na tej samej podstawie - peryfraz doczekała się Japonia. Omówienie Kraj Kwitnącej Wiśni wykorzystuje skojarzenie z kwitnącym na wiosnę drzewem, które dla wielu stanowi symbol tego azjatyckiego kraju, ,jego stylizowany wizerunek często występuje w emblematyce, wzornictwie i reklamie"192. Druga alternatywna nazwa - Kraj Wschodzacego Słońcakoncentruje się wokół położenia geograficznego tego państwa. To wielowyrazowe określenie znajduje potwierdzenie na japońskiej fladze, na której wizerunek wschodzącego słońca przybrał postać czerwonego koła na białym tle ${ }^{193}$.

W Japonii na przykład wybiera się kolejką linową do buddyjskiej świątyni Engyoi na górze Shosha. (P 51-52/2012, s. 94)

Turniej odbywający się w Japonii przejdzie do historii futbolu, bo testowana jest technologia goal-line, która ma pomagać sędziom piłkarskim w upewnieniu się, czy piłka przekroczyła linię bramkową. (PN 50/2012, s. 37)

Anna Kieda odsłania uroki (ale i mankamenty) życia w Kraju Kwitnącej Wiśni. (VG 17/2012, s. 35)

Meksykański Monterrey miał więcej czasu od Chelsea na aklimatyzację w Kraju Wschodzącego Słońca, bo już w ostatnią niedzielę w meczu ćwierćfinałowym najlepszy zespół klubowy strefy CONCACAF spotkał się z południowokoreańskim Ulsan Hyundai i wygrał 3:1. (PN 50/2012, s. 37)

192 M. Bańko, Słownik peryfraz..., s. 79. Por. też S. Kałuski, T. Komornicki, Słownik niekonwencjonalnych..., s. 63.

193 Por. M. Bańko, Słownik peryfraz..., s. 83. 
Czasem do stworzenia omówienia wykorzystuje się inną nazwę własną. Z takim zabiegiem spotykamy się w przypadku kraju Azteków - to alternatywne określenie Meksyku ma proweniencje historyczne i związane jest z ludnością indiańską, która w średniowieczu zamieszkiwała te tereny.

Reprezentacja Meksyku po raz pierwszy grała w finale turnieju olimpijskiego. (PN 33/2012, s. 38)

Wydawało się, że mecz zakończy się wynikiem 2:0 dla piłkarzy z kraju Azteków, ale w czasie doliczonym przez sędziego honorowego gola dla Brazylii strzelił Hulk. (PN 33/2012, s. 38)

Wydaje się, że o ile wymienione peryfrazy już na stałe zakorzeniły się w świadomości odbiorców, o tyle niektóre z elementem kraj mają raczej charakter doraźny i ich obecność w środkach masowego przekazu odnotowano jednostkowo. W tej grupie umieścić można choćby wielowyrazowe konstrukcje kraj autostrad i porządku, kraj odkrywców, kibiców i fado czy kraj, który ma ostry smak papryki - połączenia te bazują na skojarzeniach ze specyficznymi rodzajami infrastruktury, typowymi sposobami zachowania, historycznymi dokonaniami, nieodłącznymi elementami kultury czy kuchni, są zatem zbudowane według takich samych mechanizmów co funkcjonujące od lat analityzmy zastępujące inne oficjalne nazwy geograficzne.

Niemcy - kraj autostrad i porządku... (VG 7/2011, s. 14)

Portugalia - kraj odkrywców, kibiców i fado (VG 1/2011, s. 16)

Węgry - kraj, który ma ostry smak papryki... (VG 2/2011, s. 2)

Bazami zastępczych nazw krajów są też wyrazy państwo czy wyspa. Opisowa konstrukcja Państwo Środka przedstawia mniemania Chińczyków o potędze i wielkości obszaru, który zamieszkują. M. Bańko pisze: „Nazwa ta pochodzi z czasów, gdy kraj ten był samowystarczalnym imperium, a jego mieszkańcy mieli skłonność do postrzegania go jako centrum świata"194.

Na tym, że powstała polska fabryka w Chinach, polski region sporo zyskuje. (P 5152/2012, s. 58)

194 Ibidem, s. 158. 
Ale zarobi, gdy projekty (żeby jeszcze nie mówić o know-how), okucia i coś tam jeszcze do chińskiej fabryki pojedzie, a resztę dokupi się na miejscu i okna powstaną w Państwie Środka. (P 51-52/2012, s. 58)

Nauka mandaryńskiego (to język urzędowy Chin, w całym Państwie Środka jest ponad 50 różnych jego odmian) to nie tylko alfabet i artykulacja. (VG 2/2011, s. 7) Jednak to nie koniec informacji z Państwa Środka. (PN 51-52/2011, s. 89)

Mitologiczne konotacje wywołuje posługiwanie się połączeniem Wyspa Afrodyty zamiast urzędowej nazwy Cypr, przypomina ono, że według mitu grecka bogini miłości miała wyłonić się z piany właśnie na cypryjskim wybrzeżu.

W czasie II wojny światowej przebywał na Cyprze, a później w Tel Awiwie. (VG 9/2011, s. 48)

Po identyczną pomoc dla banków zgłosi się wkrótce Cypr - pieniędzy potrzebuje niewiele, ale wstydu naje się co niemiara, bo za dwa tygodnie obejmuje prezydencję Unii Europejskiej. (P 24/2012, s. 10)

Mistrz Polski poleci na tylko jedno zagraniczne zgrupowanie, na Cypr, a gros treningów odbędzie we Wrocławiu. (PN 49/2012, s. 6)

Kiedy kilka lat temu opowiadałem w Polsce, że kluby z Wyspy Afrodyty grają coraz lepiej i wkrótce mogą sporo zamieszać w europejskich pucharach, moich słów nie traktowano zbyt poważnie. (PN 11/2012, s. 35)

Połączenie zielona wyspa z celtycką tradycja jest rozszerzoną wersją odnoszącej się do Irlandii peryfrazy zielona wyspa, przypisanie tego koloru wiąże się ze sprzyjającymi do rozwoju roślinności warunkami środowiska naturalnego. Dopowiedzenie wskazuje, że kultura Celtów jest mocno związana z tą częścią Wielkiej Brytanii.

Irlandia - zielona wyspa z celtycką tradycją (VG 10/2011, s. 18)

Religijne nawiązania uwidaczniają się w posługiwaniu się nazwą Ziemia Święta. Palestyna zyskała takie określenie ,jako miejsce narodzin, życia i śmierci Chrystusa oraz cel krucjat i pielgrzymek chrześcijańskich"195.

195 Ibidem, s. 246. 
Pobyt w Jerozolimie i w Betlejem w Palestynie dla Moniki, jako osoby wierzącej, okazał się wyjątkowym duchowym przeżyciem. (NŻ 13/2012, s. 4)

Oczekiwania rychłego upadku starego porządku były w żydowskiej Palestynie za czasów Jezusa dość powszechne. (P 51-52/2012, s. 21)

Aktorka (38) zabrała narzeczonego Roberta w podróż przedślubną do Ziemi Świętej. (NŻ 13/2012, s. 4)

Mało komu trzeba opisywać urodę tych okolic Ziemi Świętej, do której dziś masowo pielgrzymują i Polacy. (P 51-52/2012, s. 20)

Wplatanie do konstrukcji opisowych leksemu ojczyzna ma służyć podkreśleniu, że z tego właśnie kraju ktoś lub coś się wywodzi. Skojarzenia z rezydującym w rumuńskiej Transylwanii wampirycznym arystokratą Drakulą budzi peryfraza ojczyzna wampira i niedźwiedzi, swobodę obyczajową panującą we Francji wyraża połączenie ojczyzna wolności seksualnej, przywoływanie w rozbudowanej formie analitycznej ojczyzna Wajdy, Kantora, potem Wałęsy i Solidarności postaci ze świata kultury i polityki oraz nazwy związku zawodowego odgrywającego ważną rolę w wydarzeniach historycznych czasu przełomu podkreśla, jaki wpływ miały te osoby i wydarzenia na budowę wolnej Polski.

A poza tak mocnymi alkoholami Rumunia wytwarza wspaniałe wina - mocne, aromatyczne. (VG 8/2011, s. 23)

Rumunia - ojczyzna wampira i niedźwiedzi... (VG 8/2011, s. 22)

Wszystko wskazuje na to, że Francja stanie się dwunastym krajem na świecie, który zalegalizuje małżeństwa homoseksualne. (P 51-52/2012, s. 67)

Ale Francuzi są podzieleni - w ojczyźnie wolności seksualnej rośnie front obrony tradycyjnej rodziny. (P 51-52/2012, s. 67)

Polska zza żelaznej kurtyny, ojczyzna Wajdy, Kantora, potem Wałęsy i Solidarności - to był temat. (P 51-52/2012, s. 159)

Polska w zjednoczonej Europie stała się Holandią, Słowacją czy inną Austrią, i dzięki Bogu. (P 51-52/2012, s. 159)

Znaczenie metaforyczne wydobywa także posługiwanie się członem kolebka, wskazuje on na miejsce, w którym coś miało swój początek. O tym, że piłka nożna narodziła się w Anglii, mówi peryfraza kolebka futbolu, duży wpływ starożytnych Greków na rozwój kultury w Europie wyraża zaś omówienie kolebka naszej europejskiej cywilizacji. 
A mimo to na Anglię, kolebkę futbolu, zagłosowało 2 z 22 członków komitetu wykonawczego FIFA (powinno głosować 24 członków, ale dwóch wykluczono ze względu na ciążące na nich zarzuty korupcyjne). (P 13/2012, s. 15)

Ostatnio sporo mówi się o Grecji, bo jest w nie najlepszej sytuacji ekonomicznej. (VG 9/2011, s. 24)

To w ogóle dziwny kraj - niby kolebka naszej europejskiej cywilizacji, a gdyby nie ogrom ruin, które spotyka się tu co krok - nikt by się tego nie domyślił. (VG 9/2011, s. 24)

Trzy odmienne połączenia odnoszące się do Jamajki są oparte na zróżnicowanych asocjacjach i w związku z tym pozwalają zwrócić uwagę na inne znaczenia. Nieprzeciętne umiejętności lekkoatletów pochodzących z wyspy znalazły odzwierciedlenie w metaforze światowa fabryka sprinterów, komponent fabryka może budzić jednak negatywne konotacje, ponieważ kojarzy się z produkowaniem czegoś na masową skalę, nierzadko z pominięciem zasad humanitarnych. Subiektywne spostrzeżenia obrazuje analityzm najpiękniejsza wyspa Karaibów, peryfraza kraj Bonda, Marleya i Bolta poprzez wskazanie, że pobyt tutaj przyczynił się do stworzenia przez Iana Fleminga serii powieści z Jamesem Bondem, oraz przywołanie nazwisk znanych jamajskich obywateli: piosenkarza i biegacza pozwala zniwelować pejoratywny wizerunek tego kraju.

Ian Fleming, twórca Bonda, był w Jamajce zakochany; tu w zaprojektowanym przez niego bungalowie Goldeneye (nazwa wzięta od kryptonimu operacji niemieckiej, potem był to tytuł kolejnej książki i filmu) narodziły się prawie wszystkie przygody agenta 007. (P 51-52/2012, s. 73)

Sprinterzy byli w kraju witani morzem zielono-żółto-czarnych flag, a Jamajkę - nie pierwszy raz - nazywano światową fabryką sprinterów. (P 51-52/2012, s. 75)

Jeszcze Kolumb twierdził, że to najpiękniejsza wyspa Karaibów. (P 51-52/2012, s. 75)

Kraj Bonda, Marleya i Bolta (P 51-52/2012, s. 73)

Nieoficjalne odpowiedniki nazw kontynentów odwołują do koloru skóry mieszkańców ${ }^{196}$ - Afryka bowiem to Czarny Ląd lub Czarny Kontynent - albo

196 Jak zauważa M. Bańko, skojarzenia takie są wtórne, nazwy te bowiem „w rzeczywistości jednak pochodzą od tytułu książki angielskiego podróżnika Henry’ego Mortona Stanleya Through the Dark Kontinent". Zob. ibidem, s. 40. 
zaznaczają, że niektóre obszary (Europa) były znane przed epoką wielkich odkryć geograficznych - Stary Kontynent.

Fortuny plantokracji, budującej olśniewające pałace w Anglii, powstały z pracy czarnych niewolników z Afryki, którzy często marli. (P 51-52/2012, s. 73)

Ale Nigeryjczykowi nie udało się w sobotę pokonać bramkarza Wolverhampton, więc Drogba jako pierwszy przedstawiciel Afryki zamknął pierwszą setkę goli w Premier League. (PN 11/2012, s. 29)

Rozgrywany w cyklu dwuletnim turniej ma status mistrzostwa Czarnego Kontynentu. (PN 46/2011, s. 33)

Debiutująca w Pucharze Narodów Afryki Gwinea Równikowa dotarła do najlepszej ósemki, a Gabon dopiero drugi raz w historii tak daleko zaszedł w mistrzostwach Czarnego Lądu. (PN 6/2012, s. 5)

To kolejny dowód, że oferta z Grecji nie pojawiła się przypadkiem, a biorąc pod uwagę, że jeszcze do niedawna podobny kierunek obierali trenerzy cieszący się znacznie większym uznaniem w Europie, Probierz ma prawo czuć się wreszcie szkoleniowcem dowartościowanym. (PN 45/2011, s. 47)

Niemniej Polska zajmuje obecnie szóste miejsce w Europie pod względem liczby firm. (P 50/2012, s. 51)

Nobel, kasa, bezrobocie: za zasługi w jednoczeniu Starego Kontynentu uhonorowano Unię Pokojową Nagrodą Nobla. (P 51-52/2012, s. 17)

W gazetach można było przeczytać, że Euro 2012 dla nowej generacji to ostatnia lekcja futbolu od zawodników, którzy w minionej dekadzie rozsławili ukraiński futbol na Starym Kontynencie. (PN 24/2012, s. 24)

UEFA zgodziła się także zwiększyć kwotę wypłacaną za udział ich graczy w mistrzostwach Starego Kontynentu. (PN 11/2012, s. 10)

Peryfrazy zawierające odwołania do kolorów pojawiają się także w zastępnikach oficjalnych nazw ciał niebieskich. Wyobrażenia o barwie Księżyca znalazły swoje odbicie w połączeniu Srebrny Glob, M. Bańko doszukuje się genezy tej nazwy w tytule powieści Jerzego Żuławskiego Na srebrnym globie ${ }^{197}$. Widoczne na niebie rdzawe zabarwienie Marsa przyczyniło się z kolei do posługiwania się wyrażeniem omownym Czerwona Planeta.

197 Por. ibidem, s. 202. 
A gdzieś po 2025 r. taikonauci postawią stopę na Księżycu i niewiele później na Marsie. (P 51-52/2012, s. 63)

Także w 2014 r. na Księżycu ma się stawić indyjsko-rosyjski lądownik bezzałogowy, poprzednio indyjska sonda była na Srebrnym Globie w 2008 r. i jako pierwsza w historii odnalazła tam ślady wody. (P 51-52/2012, s. 63-64)

Samodzielnie buduje ona rakiety, lata z satelitami i zapowiada, że około 2025 r. będzie mogła, przy użyciu swojego sprzętu, zabrać człowieka na Marsa. (P 51-52/2012, s. 64)

Start ich sondy zaplanowano na listopad 2013 r., więc w okolice Czerwonej Planety powinna dotrzeć w połowie 2014 r. (P 51-52/2012, s. 63)

Niektóre alternatywne określenia toponimów oparte są na metonimii, ich podstawą jest przyległość jakichś zjawisk, a nie - jak w przypadku metafory - ich podobieństwo. Figura ta sprawia, że „wyrażenie oznacza przedmiot będący referentem innego wyrażenia, które jest w styczności z jego właściwym referentem. Metonimia nie powoduje zatem zmiany czy przesunięcia znaczenia wyrażeń, lecz modyfikuje ich referencję"198. M. Bańko zalicza tu wyrażenia lokatywne, adlatywne i ablatywne. Badacz postuluje, że można je włączać do wyrażeń omownych, gdyż „podobnie jak peryfrazy nazywają one nie wprost. Poza tym, podobnie tym razem jak metafory, charakteryzują się one niepełną odpowiedniością formy i treści"199.

Częstym przypadkiem jest używanie do określenia jakiegoś obszaru nazwy rzeki, która przepływa przez opisywany kraj lub miasto. Zamiast do Niemiec pisze się za Nysę i Odrę, Stambuł zyskuje miano metropolii nad Bosforem, Francja - kraju nad Sekwana, Polska zaś definiowana jest z wykorzystaniem nazw trzech różnych rzek: to kraj nad Wisła - czasem poprzedzony wartościującą pozytywnie przydawką piękny - a także obszar między Bugiem a Odrą. Pierwsze określenie opiera się na nazwie najdłuższej rzeki w naszej ojczyźnie, której znaczenie akcentuje użyta w innym tekście peryfraza królowa polskich rzek, drugie natomiast, odwołując się do wód okalających nasze terytorium od zachodu i wschodu, podkreśla rozciągłość obszaru, na którym znajduje się Rzeczpospolita.

Wszystko wskazuje na to, że Francja stanie się dwunastym krajem na świecie, który zalegalizuje małżeństwa homoseksualne. (P 51-52/2012, s. 67)

198 Encyklopedia językoznawstwa..., s. 330.

199 M. Bańko, Peryfrazy w naszym..., s. 8. 
Jeden z nich dotyczy piłkarzy i trenera w kraju nad Sekwaną. (PN 13/2012, s. 20) Kiedy znudziło mu się życie w metropolii nad Bosforem, wrócił do Premier League, by bronić najpierw barw Boltonu, a ostatnio Chelsea. (PN 51-52/2011, s. 89) Po raz pierwszy Diego pojawił się w Niemczech w 2006 roku. (PN 49/2012, s. 23) Jeśli zresztą tego nie zrobi, Franciszek Smuda będzie musiał zrobić użytek ze swego niemieckiego paszportu i ewakuować się za Nysę i Odrę, gdyż nad Wisłą nie będzie miał czego szukać. (PN 49/2011, s. 2)

Przyjeżdża do Polski tylko na Boże Narodzenie i Wielkanoc. (VG 4/2011, s. 12)

O to samo chciałbym zapytać odpowiedzialnych za arbitrów i asystentów w pięknym kraju nad Wisłą. (PN 49/2011, s. 33)

Po tym jak w polskiej grupie znalazły się reprezentacje Grecji, Rosji i Czech, między Bugiem a Odrą zapanowała wielka euforia. (PN 49/2011, s. 47)

Jeśli Jürgen Klopp nam pokazał, co może osiągnąć z polskimi piłkarzami utalentowany trener z kraju o wyżej rozwiniętej kulturze futbolowej, to Franz Smuda dowiódł, jak można błyskawicznie zwinąć im skrzydła i sformatować na jedenastkę po polsku rozmemłaną, co to wciela w życie najsłynniejsze bon moty legendarnych trenerów z kraju nad Wisłą (w tym przypadku sławetne „Wygraliśmy jedną połowę” Wojciecha Łazarka). (P 24/2012, s. 14)

Wkrótce Puchar Henri Delaunaya trafi do innych miast nad Wisłą, a potem zostanie przeniesiony do kraju współorganizatora Euro 2012. (PN 17/2012, s. 21)

Kto wie, może osiemdziesiąt lat po tak zwanym Cudzie nad Wisłą, ponownie na obiekcie położonym nad królową polskich rzek zdarzy się cud - piłkarski. (PN 24/2012, s. 47)

Urzędową nazwę państwa może także zastąpić odwołanie do półwyspu, na którym jest on położony. Taki schemat budowania alternatywnych określeń zaproponowano w analitycznej konstrukcji na Półwysep Apeniński, która występuje zamiennie z oficjalnym syntetyzmem Włochy.

Aż 27 milionów euro wyłożył na niego Juventus, ale we Włoszech całkowicie zawiódł. (PN 49/2012, s. 23)

Kiedy latem włoską krainę, już nie mlekiem i miodem płynącą, opuszczał następny zastęp gwiazd (Zlatan Ibrahimović, Thiago Silva, Ezequiel Lavezzi) i właściwie nikogo godnego uwagi nie udało się sprowadzić na Półwysep Apeniński, wydawało się, że tamtejsze kluby pogrążą się w przeciętności. (PN 50/2012, s. 30) 
Innym sposobem zwrócenia uwagi na jakieś miejsce jest nazywanie go z wykorzystaniem charakterystycznego obiektu - dwukrotnie Wawel urósł do rangi zabytku, który najlepiej opisze Kraków. Jak zauważa M. Hodalska, takie wyrażenie lokalizujące „oparte jest na metonimii, która pełni funkcje wartościujące, przypominając o królewskiej historii naszego kraju"200. Konstrukcje miasto pod Wawelem i u stóp Wawelu podkreślają także, że położony na wzgórzu zamek góruje nad byłą stolicą Polski.

Gdyby ułożyć tabelę, okazałoby się, że przewodzi w niej Korona Kielce, która w dodatku jako jedyny zespół w tym czasie odniosła komplet zwycięstw, za rywala mając między innymi Wisłę w Krakowie. (PN 11/2012, s. 6)

Ponieważ miasto pod Wawelem nie jest areną Euro 2012, liczba fanów, którym zechce się zboczyć $\mathrm{z}$ trasy, aby zobaczyć być może reprezentantów robiących zakupy w Galerii Krakowskiej albo pijących kawę na przykład w Sukiennicach, będzie więcej niż skromna. (PN 46/2011, s. 38)

U stóp Wawelu narodziło się plemię wojowniczych partyzantów miejskich, rodzaj krakowskich guerillas. (P 5/2011, s. 96)

Wydaje się, że mechanizm synekdochy - traktowanej przeważnie jako odmiana metonimii - stał u podstaw analitycznej konstrukcji przy Piotrkowskiej i wokót, posłużenie się nazwą najbardziej reprezentacyjnej ulicy w Łodzi na określenie całego miasta może być zabiegiem określanym jako pars pro toto. Słynna część Łodzi ma odwoływać czytelnika do całej aglomeracji położonej w centralnej Polsce.

Czerwona lampka powinna zapalić się obu fachowcom już po drugim meczu rundy rewanżowej, gdy w Łodzi nastąpił podział punktów w starciu z Lechią. (PN 20/2012, s. 18)

Jeśli potwierdzi się podpisanie kontraktu przez byłego już ełkaesiaka Marcina Kaczmarka z Widzewem, to przez chwilę przy Piotrkowskiej i wokół zrobi się o tym głośno. (PN 3/2012, s. 13)

Trudno doszukać się przenośni w opisowych formach kraj współorganizatora Euro 2012 czy największy kraj muzułmański, wydaje się, że dominuje

200 M. Hodalska, op. cit., s. 305-306. 
w nich charakter informacyjny. O ile nawiązanie do Ukrainy jako gospodarza mistrzostw Europy w piłce nożnej w 2012 r. będzie zawsze aktualne, o tyle trzeba mieć świadomość, że zasięg oddziaływania religii muzułmańskiej może się zmieniać $\mathrm{z}$ biegiem lat i za jakiś czas nazywanie w ten sposób Indonezji może się zdezaktualizować201.

Według zgodnych opinii fachowców przeciwnik z Ukrainy był do przejścia, ale w drugiej odsłonie meczu wybrańcy Saschy Lewandowskiego dwukrotnie dali się zapędzić w kozi róg i... przegrali. (PN 48/2012, s. 34)

Wkrótce Puchar Henri Delaunaya trafi do innych miast nad Wisłą, a potem zostanie przeniesiony do kraju współorganizatora Euro 2012. (PN 17/2012, s. 21)

Obecnie Konspol buduje ogromną wytwórnię wędlin w Indonezji, największym kraju muzułmańskim. (P 51-52/2012, s. 60)

Dosłownie trzeba potraktować również struktury analityczne nasz zachodni sąsiad i za naszą zachodnią granica - odwołują się one do elementarnej wiedzy z zakresu geografii, wskazując położenie Niemiec względem Polski.

Pamiętajmy, że tacy piłkarze jak Stephen Schroeck, który reprezentuje Filipiny, czy Daniel Williams i Fabian Johnson, którzy grają dla Stanów Zjednoczonych, dorastali w Niemczech. (PN 36/2012, s. 26)

A wam z czym kojarzy się nasz zachodni sąsiad? (VG 7/2011, s. 14)

Jeszcze kilkadziesiąt godzin przed pierwszym meczem reprezentacji Niemiec na Euro za naszą zachodnią granicą panował spory niepokój. (PN 24/2012, s. 29)

Niezwykle ciekawa motywacja ujawnia się podczas próby analizy przydomków funkcjonujących w przestrzeni sportowej202. Liczba zebranych przykładów dowodzi, że zjawisko zastępowania oficjalnych nazw kadr narodowych i drużyn

$201 \mathrm{~W}$ analizowanym przykładzie peryfraza ma postać dopowiedzenia, więc nie sprawia problemów interpretacyjnych.

202 Przedstawione tu rozważania dotyczące motywacji przydomków sportowych zostały opublikowane w artykule K. Burska, Motywacja semantyczna alternatywnych nazw drużyn piłkarskich, [w:] Bogactwo językowe i kulturowe Europy w oczach Polaków i cudzoziemców 3, red. M. Gaze, P. Góralczyk-Mowczan, Łódź 2015, s. 158-169. 
klubowych jest bardzo rozpowszechnione 203 . Z przeniesieniem nazwy herbu na całe państwo mamy do czynienia w przypadku połączenia Trzy Korony na określenie Szwecji. Nazywający reprezentantów tego skandynawskiego państwa przydomek odwołuje do herbu mniejszego przedstawiającego wspomniane symbole władzy królewskiej na niebieskim tle. Symbol ten wywodzi się z czasów średniowiecza i jest jednym z najstarszych w Europie 204 .

W trakcie kwalifikacji Euro 2012 bronił barw Rosenborga Trondheim, od stycznia natomiast gra dla Celticu Glasgow, który nie musiał zapłacić za reprezentanta Szwecji nawet funta. (PN 6/2012, s. 24)

Nie znamy wyniku pierwszego meczu Ukraińców na Euro 2012 (w poniedziałek współgospodarze zagrali na Stadionie Olimpijskim w Kijowie ze Szwecją), ale jeśli Błochinowi udało się ograć zespół Trzech Koron, dobitnie potwierdził wszystkie przedturniejowe zapowiedzi. (PN 24/2012, s. 24)

Nawiązanie do angielskiego godła - trzech drapieżnych zwierząt na czerwonym tle - uwidacznia się w wyrażeniu omownym drużyna narodowa spod znaku trzech lwów. Orzeł - jako symbol siły - widnieje w herbie Nigerii, nie dziwi więc fakt, że reprezentantów tego kraju nazywa się Super Orłami.

Trudno sobie wyobrazić ekipę Anglii podczas Euro 2012 bez tego duetu urodzonego w aglomeracji Liverpoolu. (PN 15/2012, s. 37)

Polak potrafi, a rywal również przeżywa ostatnio spore problemy, bo prezentująca najwyższy poziom i jakże lukratywna Premiership nie przekłada się na sukcesy drużyny narodowej spod znaku trzech lwów. (PN 41/2012, s. 47)

203 Wiele wpisów internetowych poświęconych jest genezie i funkcjonowaniu zastępczych nazw reprezentacji i klubów, na uwagę zasługują chociażby następujące artykuły: K. Wirkowska, Przydomki drużyn piłkarskich, http://redlog. pl/2008/03/12/przydomki-druzyn-pilkarskich/; P. Kasprzyk, Jakie historie kryja przydomki uczestników mundialu, http://historia-news.pl/ciekawostki/82-jakie-historie-kryj-przydomki-uczestnikow-mundialu.html; T. Jaszczuk, Młot na Kanarki, czyli o przydomkach, http://krotkapilka.pl/artykul,mlot_na_kanarki_ czyli_o_przydomkach,1541

204 Por. K. J. Guzek, >Tre Kronor< herb mniejszy Królestwa Szwecji. Geneza - wzór funkcja, Zduny 2011, http://www.lowicz.eu/docs/tre_kronor_4.pdf 
Nigeria przegrała rywalizację na ostatniej prostej na swoim terenie w stolicy Abudży z niezbyt przecież wysoko notowaną Gwineą. (PN 46/2011, s. 33)

Fankluby reprezentacji Super Orłów rozsiane są w wielu krajach. (PN 46/2011, s. 33)

Do flagi narodowej Ghany nawiązuje przydomek Czarne Gwiazdy, składa się ona bowiem z poziomych pasów w trzech kolorach: czerwonym, żółtym i zielonym, na środkowym umieszczona jest właśnie czarna gwiazda. Jak pisze analizujący pochodzenie alternatywnych określeń nazw reprezentacji narodowych biorących udział w mistrzostwach świata w Republice Południowej Afryki Piotr Kasprzyk, czarna gwiazda „oznacza [...] rdzenną ludność, a także ideały walki z kolonializmem, patriotyzm i wspólną pracę. Sformułowania [tego - przyp. KB] często używał Kwame Nkrumah - pierwszy prezydent Ghany, a zarazem człowiek, który wywalczył niepodległość dla tego państwa. Chciał on, by futbol odgrywał dużą rolę w krzewieniu ducha oporu, poczucia indywidualizmu i tożsamości narodowej, a przede wszystkim godności. Dlatego też swego rodzaju patronatem objął drużynę narodową"205. Określenie to ma zatem także przypominać o szczególnym znaczeniu piłkarskiej reprezentacji w budowaniu wielkości tego afrykańskiego kraju.

W półfinale Zambia spotka się z reprezentacją Ghany, która czterokrotnie wygrywała Puchar Narodów Afryki, ale po raz ostatni było to 30 lat temu. (PN 6/2012, s. 6) W zespole Czarnych Gwiazd grał wtedy Abedi Ayew Pele, a na PNA 2012 rodzinne tradycje kontynuują jego synowie: Jordan Ayew i Andre Ayew, który wykorzystał koszmarny błąd tunezyjskiego bramkarza i strzelił gola dającego Ghanie zwycięstwo 2:1. (PN 6/2012, s. 6)

Nieoficjalne nazwy klubów mogą też odwoływać do symboli znajdujących się w klubowych herbach. Tak jest na przykład z przydomkiem Southampton FC Święci - nawiązuje on do aureoli umieszczonej nad piłką w emblemacie tego zespołu. Ten świetlisty krąg z kolei wiąże się z tym, że klub „powstał [...] przy kościele Świętej Marii jako drużyna kościelna"206. Armata obecna w herbie innego

205 http://historia-news.pl/ciekawostki/82-jakie-historie-kryj-przydomki-uczestnikow-mundialu.html [dostęp: 05.05.2014].

206 http://krotkapilka.pl/artykul,mlot_na_kanarki_czyli_o_przydomkach,1541 [dostęp: 05.05.2014]. 
klubu z Wysp Brytyjskich - Arsenalu Londyn - przyczyniła się do upowszechnienia syntetyzmu Kanonierzy. Ma to uwarunkowania historyczne, pierwsi piłkarze tego klubu pracowali bowiem w fabryce broni ${ }^{207}$. Gracze Realu Madryt często występują w mediach jako Królewscy - korona pojawiła się w emblemacie tego zespołu po tym, jak „29 czerwca 1920 klub otrzymuje z rąk króla Alfonso XIII tytuł królewski, który pozwala na umieszczenie w swojej dotychczasowej nazwie członu Real"208. Umiejscowiona w logo Panathinaikosu Ateny roślina sprawia, że zawodników z tego greckiego klubu nazywa się Koniczynkami, obecny w górnej części herbu FC Porto fikcyjny stwór przyczynił się zaś do rozpowszechnienia przydomka Smoki.

W sobotę były bramkarz reprezentacji Polski podpisał kontrakt $\mathrm{z}$ beniaminkiem Premier League Southampton FC. (PN 39/2012, s. 25)

Jego szybkość i ciągłe nękanie bocznych obrońców na tyle spodobały się ówczesnemu menedżerowi Southampton Alanowi Pardewowi, że wziął juniora do kadry pierwszego zespołu Świętych. (PN 6/2012, s. 33)

Irlandczyk trenował w akademii Arsenalu Londyn, ale jego kariera w barwach Kanonierów skończyła się na jednym występie w zespole seniorów. (PN 6/2012, s. 41) W ostatnich trzech meczach w Premier League Kanonierzy zdobyli jedynie dwa punkty - po remisach z Aston Villą Birminhgam i Evertonem Liverpool. (PN 49/2012, s. 36)

Największe kawałki telewizyjnego tortu, warte po 150 milionów euro, trafiają do Barcelony i Realu Madryt, gdy pozostała osiemnastka musi między siebie rozdzielić podobną kwotę. (PN 50/2012, s. 25)

Dla Królewskich sobotni mecz był z kategorii być albo nie być, bo kolejne powiększenie straty nie tylko do Atletico, ale przede wszystkim do Barcelony, w zasadzie eliminowało ich z wyścigu o mistrzostwo Hiszpanii. (PN 49/2012, s. 34)

Wszystko przez Józefa Wandzika, którego dublerem był długo w Panathinaikosie Ateny i dlatego od 1990 do 1997 roku rozegrał zaledwie 15 meczów w greckiej ekstraklasie. (PN 11/2012, s. 27)

207 Więcej o historii herbu Arsenalu Londyn można przeczytać w serwisie internetowym kibiców tego zespołu: http://www.kanonierzy.com/section_id-18_historia_herbu.shtml [dostęp: 05.05.2014].

208 http://www.realmadrid.pl/index.php?co=symbole\&dzial=herb [dostęp: 05.05.2014]. O ewolucji herbu Realu Madryt patrz też: http://www.realmadryt.net. pl/herb_klubu.php [dostęp: 05.05.2014]. 
Kibice Koniczynek nazywali go zdrajcą i życzyli jak najgorzej, gdy spotkali go na ulicach Aten. (PN 11/2012, s. 27)

Porażka pod koniec stycznia 1:3 z Gil Vicente zakończyła serię spotkań bez porażki FC Porto. (PN 6/2012, s. 39)

Zwycięstwo nad Smokami poprawiło nieco nastroje na Parc des Princes, bo nawet prezes pochwalił zespół, a zadowolony był nie tylko z wyniku, ale i ze stylu gry. (PN 50/2012, s. 34)

Funkcjonujące w środowisku sportowym nazwy zwierząt przeniesione na kluby piłkarskie również mają swoje odzwierciedlenie w herbach: Valencia CF to Nietoperze, Tottenham Hotspur - Koguty, Wolverhampton Wanderers F.C. Wilki, Benfica Lizbona - Orty, Sporting Lizbona - Lwy, West Bromwich Albion - Drozdy, Unia Tarnów - Jaskółki, FC Koeln - Kozły. Podtrzymywaniu nieoficjalnych nazw służą różnorodne zabiegi, które mają spopularyzować przydomki. Katarzyna Wirkowska wyjaśnia: „Tradycją na Estadio da Luz [stadion Benfiki - przyp. KB] od lat pozostaje, że przed każdym meczem wypuszczany przez włodarzy orzeł zatacza krąg nad boiskiem, po czym na nie zlatuje”209.

Po czterech wygranych z rzędu ekipa West Bromwich Albion dostała zadyszki. (PN 49/2012, s. 33)

Przed wyjazdową batalią ze Swansea City po raz ostatni na koncie Drozdów były cztery z rzędu wygrane, gdy większości graczy nie było jeszcze na świecie, a ich dzisiejszy opiekun zaczynał kopać piłkę w zespole juniorów szkockiego St Mirren. (PN 49/2012, s. 20)

Jednak w obfitującym w emocje spotkaniu rozgrywanym w 30 stopniowym upale piłkarze Juana Martineza pokazali się z najlepszej strony wyłączając z gry najlepszych zawodników Nietoperzy z Roberto Soldado na czele. (PN 41/2012, s. 27)

El Comendante, jak nazywają 31-letniego Argentyńczyka koledzy, spróbuje teraz pomóc FC Porto odzyskać stracony dystans punktowy do lidera ekstraklasy Benfiki Lizbona. (PN 6/2012, s. 31)

Obie mają po siedem punktów, ale bilans ich bezpośrednich meczów jest korzystny dla lizbońskich Orłów, które 5 grudnia na Camp Nou zagrają z Barcą. (PN 49/2012, s. 2) W Tottenhamie Hotspur numer ten przynależny jest Garethowi Bale'owi, jednemu z najbardziej ofensywnie ustawionych graczy Kogutów. (PN 6/2012, s. 36)

209 http://redlog.pl/2008/03/12/przydomki-druzyn-pilkarskich/ [dostęp: 05.05.2014]. 
Nawet gdy mąż odszedł do Realu Madryt, a później Tottenhamu Londyn, nadal cieszyła się za naszą zachodnią granicą statusem celebrytki. (PN 41/2012, s. 35)

W zespole Kogutów broni bowiem wiekowy Amerykanin Brad Friedel, a sir Alex Ferguson nie jest zadowolony ani z postawy Davida de Gei, ani Andersa Lindegaarda. (PN 6/2012, s. 29)

Dodatkowo Wilki po spadku do Championship przez cztery lata będą miały wypłacane pieniądze rekompensujące straty finansowe spowodowane degradacją. (PN 50/2012, s. 25)

Bo Benfica, która w Lidze Mistrzów zmierzy się z Zenitem Sankt Petersburg, podpisała umowę z byłym graczem Sportingu Lizbona Yannickiem Djalo. (PN 6/2012, s. 31)

Jednak w sierpniu ubiegłego roku nie przedłużył umowy z Lwami z Lizbony. (PN 6/2012, s. 31)

Poza tym, największą bolączką krezusów jest gra obronna, a mówiąc precyzyjniej - bezradność w powstrzymywaniu szybkich ataków, z których akurat słyną Morszczuki. (PN 33/2012, s. 42)

Czwartą Resovię dzieli jedynie pięć punktów od trzynastej Unii Tarnów. (PN 44/2012, s. 45)

Jaskółkom pozostały mgliste wspomnienia po znakomitym początku sezonu. (PN 44/2012, s. 45)

Informacja podana przez dziennik „Bild” o przejściu Lukasa Podolskiego do Arsenalu Londyn zelektryzowała niemieckich kibiców, a już w szczególności fanów FC Koeln. (PN 11/2012, s. 28)

Mimo to Kozły ciągle zajmują miejsce 16 i już powoli muszą się szykować na baraż z trzecią drużyną 2. Bundesligi. (PN 17/2012, s. 19)

Równie chętnie wykorzystywanym sposobem tworzenia przydomków jest odwoływanie się do koloru lub kroju strojów, w których występują zawodnicy ${ }^{210}$. Pionowe paski materiału (odpowiednio biało-czerwone i biało-czarne) na koszulkach piłkarzy przyczyniły się do powstania przydomków Pasy na określenie Cracovii Kraków i Zebry/Zeberki na określenie Udinese Calcio. W tym drugim przypadku skojarzenie ze zwierzętami opiera się na wykorzystaniu na trykotach sportowców tych samych barw, które są charakterystyczne dla przywołanych ssaków.

210 Zaznaczyć trzeba, że często kolory strojów powiązane są z barwami występującymi w herbie. 
W środę kibice Cracovii oczekiwać będą na wielki cud, jakim niewątpliwie będzie ewentualna wygrana Pasów nad Podbeskidziem Bielsko-Biała. (PN 14/2012, s. 47)

W listopadzie i grudniu na meczach z udziałem Pawłowskiego pojawiali się skauci m.in. Udinese Calcio, którzy wcześniej z Młodej Ekstraklasy Zagłębia Lubin wyłowili także Piotra Zielińskiego. (PN 6/2012, s. 16)

Kluby dość szybko doszły do porozumienia, z tym że Zeberki chciały Polaka ściągnąć natychmiast. (PN 6/2012, s. 16)

Juve A.D.2012 odstaje poziomem i pięknem gry jeszcze także od tego, gdy na krajowych i europejskich boiskach w ekipie Zebr występowali Michel Platini, Zinedine Zidane, Zbigniew Boniek czy Roberto Baggio. (PN 20/2012, s. 35)

Przeniesienie nazwy koloru koszulek na zawodników klubu dokonuje się w przypadku Niebieskich (Ruch Chorzów) czy zielonych ${ }^{211}$ (tym mianem określane są dwie drużyny: polska Radomiak Radom i francuska AS Saint-Etienne). Fioletowe barwy Anderlechtu Bruksela sprawiły, że zespół ten nazywa się Fiołkami. W polskiej prasie zakorzeniły się też obcojęzyczne określenia kolorów, odnoszą się one przede wszystkich do klubów włoskich: Viola to ACF Fiorentina (wł. viola - fioletowy), rossoneri to AC Milan (wł. rosso - czerwony, nero - czarny), inny klub z Mediolanu - Inter - to nerazzuri (wł. nero - czarny, azurro - niebieski).

Ruch Chorzów grał do tego stopnia źle, że trudno kogokolwiek dodatkowo dołować. (PN 50/2012, s. 9)

Gdyby tak jeszcze Niebiescy grali na nowym stadionie, zamiast pełnego dobrych wspomnień, ale przestarzałego obiektu przy Cichej, mielibyśmy idealną i darmową reklamę polskiej ekstraklasy w postaci gola z rzutu wolnego Marka Z. (PN 9/2012, s. 11)

Najlepszy wynik spośród beniaminków osiągnął Radomiak Radom. (PN 48/2012, s. 45)

Zieloni przez kilka kolejek nawet liderowali rozgrywkom, ale nie byli w stanie usadowić się w ścisłej czołówce z powodu fatalnej postawy w spotkaniach wyjazdowych. (PN 48/2012, s. 45)

211 Zachowano pisownię zgodną z tekstem źródłowym, choć zgodnie z zasadami ortograficznymi przydomki powinny być pisane dużą literą. 
Za tydzień w każdym razie cała Francja patrzeć będzie na Saint-Etienne, gdzie zajmujący trzecie miejsce $\mathrm{w}$ tabeli zieloni podejmować będą w derbach regionu lidera z Lyonu. (PN 49/2012, s. 31)

Natomiast Marcin Wasilewski, który z Anderlechtem Bruksela awansował do Champions League na drodze eliminacji, będzie musiał się zmierzyć ze zdecydowanym faworytem grupy C Milanem oraz z Zenitem Sankt Petersburg i Malagą, z którymi Fiołki nie będą wcale stały na straconej pozycji. (PN 36/2012, s. 19)

W spotkaniu z Fiołkami padł remis i były to pierwsze punkty stracone u siebie przez Malagę w LM. (PN 50/2012, s. 34)

Napastnik, który w przeszłości strzelił dla Violi 49 goli w 71 występach, po prawdzie był alternatywą awaryjną, bo w klubie już witali się z Dimitarem Berbatowem. (PN 36/2012, s. 28)

Tuż po niej słuszną czerwoną kartkę obejrzał Barrientos, nieco później z metrowego spalonego wyrównał El Shaarawy i rossoneri swoją przewagę udokumentowali jeszcze dwoma - zresztą pięknymi - golami. (PN 49/2012, s. 29)

Jako boss nerazzurich Mancini nie zwojował wiele na arenie międzynarodowej. (PN 50/2012, s. 11)

Zdarza się, że kilka przydomków funkcjonuje równolegle. Niektóre mają silne właściwości wartościujące, połączenia Duma Katalonii czy Duma Wielkopolski nie tylko podkreślają rangę klubów, ale także - poprzez użycie toponimu - silnie identyfikują go $\mathrm{z}$ regionem.

FC Barcelona to nie tylko Duma Katalonii, to duma sportowego świata. (PN 7/2012, s. 13)

Na szczęście, w odróżnieniu od na przykład Realu Madryt lat 50., za dwie dekady będzie można swobodnie włączyć zapis jednego z wielu doskonałych meczów Barcy i napawać się grą FCB. (PN 7/2012, s. 13)

Ale mając wielkie pieniądze, nie można kupić tego, czym obecnie dysponuje Duma Katalonii. (PN 11/2012, s. 34)

Aż do poniedziałkowego meczu Legii, którego wyniku - zamykając gazetę - nie znaliśmy, na czele tabeli usadowił się Lech Poznań. (PN 43/2012, s. 38)

Zaś miejsce na podium mógłby uratować tylko cud, który jednak przy kiepskim przygotowaniu Dumy Wielkopolski do rozgrywek nie ma prawa się zdarzyć. (PN 9/2012, s. 2) 
Kiedy przejmował Kolejorza, wielu twierdziło, że to rozwiązanie tymczasowe, bo wkrótce Lecha poprowadzi ktoś z tak zwanym nazwiskiem. (PN 50/2012, s. 12)

Bardzo zróżnicowane są odpowiedniki Łódzkiego Klubu Sportowego, który nazywany jest ekonomicznie ełksą/Ełksą - syntetyzm ten nawiązuje do skrótowca ŁKS. Przydomkiem mającym ciekawą motywację są Rycerze Wiosny, to autorskie połączenie zostało użyte po raz pierwszy w prasie pod koniec lat 50. ubiegłego wieku dla podkreślenia zwycięstwa drużyny z Łodzi mimo niesprzyjających okoliczności. Jego pochodzenie tłumaczy się następująco: „Wszystko to za sprawą wspaniałego meczu piłkarzy ŁKS z 7 kwietnia 1957 r., gdy grając przez większość meczu w dziesiątkę, piłkarze ŁKS pokonali Górnika Zabrze 5:1. Po tym meczu dziennikarz «Przeglądu Sportowego» red. Jerzy Zmarzlik nadał drużynie ŁKS przydomek Rycerze Wiosny”212. Opatrzył on swój artykuł tytułem: „Panowie, kapelusze z głów! Tak grają Rycerze Wiosny”213. Określenie to na stałe przylgnęło do tego zespołu i mimo upływu lat jest wciąż często spotykane w tekstach prasowych. Inne opisowe sformułowania odwołują do lokalizacji siedziby tego klubu (zespół z alei Unii, sportowa spółka z alei Unii, klub z alei Unii) lub jego położenia na terytorium naszego kraju (ekstraklasowy klub ziedziba w centralnej części Polski). Ostatnie wymienione sformułowanie jest mało precyzyjne i mogłoby się też odnosić do kilku innych drużyn.

Wiem, co piszę, bo tak się składa, że dane mi było poznać środowisko ełksy, z którego wywodziło się kilku moich zaufanych przyjaciół. (PN 4/2012, s. 2)

W beznadziejnej sytuacji rękę do Ełksy wyciągnął biznesmen Andrzej Voigt, namówiony przez Mirosława Bulzackiego, jedną z największych legend klubu. (PN 7/2012, s. 2)

Doskonale wiem, że profesjonalny futbol nie jest zabawą dla harcerzy, a tym bardziej dla ubogich, ale tak zwyczajnie po ludzku - szkoda mi Łódzkiego Klubu Sportowego. (PN 7/2012, s. 2)

O tym, że $\mathbf{K S}$ nie będzie miał środków na dokończenie sezonu, osoby zarządzające klubem wiedziały jeszcze przed jego startem, kiedy nie udało się pozyskać strategicznego inwestora. (PN 7/2012, s. 2)

212 Program Orange Ekstraklasy „Ełkaesiak”, 07.04.2007 r., s. 5.

213 Por. informacje zawarte na oficjalnej stronie ŁKS Łódź, http://www.lkslodz.pl/ pilka,fan-zone,lks-maskotka [dostęp: 05.05.2014]. 
Nie ma obaw, że ktoś wspomni Rycerzy Wiosny. (PN 3/2012, s. 13)

Tragiczna sytuacja w zespole ŁKS spowodowała, że od kilku dni jesteśmy świadkami ogólnospołecznej zrzutki pieniężnej na rzecz wsparcia ekstraklasowego klubu z siedzibą w centralnej części Polski. (PN 5/2012, s. 47)

Przecież już w listopadzie minionego roku jeden z potencjalnych, ale niedoszłych, inwestorów alarmował, że w sportowej spółce $z$ alei Unii brakuje co najmniej czterech milionów złotych na dokończenie rozgrywek, a po zaległe należności zgłaszają się wierzyciele. (PN 4/2012, s. 2)

Skoro Wieszczycki i Kłos, a więc ludzie, w których żyłach płynie ełkaesiacka krew, powiedzieli: pas, w trakcie rundy, na dodatek przed meczem z Bełchatowem, który może zadecydować o pozostaniu w ekstraklasie lub degradacji, to oznacza, że finanse i wydolność organizacyjna klubu z alei Unii są w dramatycznym stanie. (PN 47/2011, s. 2)

Dwa lata zajęło sportowe przywrócenie miejsca, które administracyjnie zespołowi z alei Unii zabrano. (PN 45/2011, s. 9)

W alternatywnych nazwach drużyn sportowych znajdziemy odniesienia nie tylko do symboli klubowych - logo czy barw. Chętnie eksponuje się również walory obszaru, z którym związany jest zespół, mogą to być warunki środowiska naturalnego, położenie, nawiązanie do historii czy odwołanie do tradycyjnych gałęzi przemysłu.

Lokalizacja na terenach górzystych, zarówno w Polsce, jak i Szkocji, spowodowała, że zespoły Podbeskidzia Bielsko-Biała i Invernes CT zyskały miano Górali. Położenie Świnoujścia jako jedynego miasta w Polsce na wyspach sprawia, że drużyna z tego miasta - Flota - chętnie posługuje się przydomkiem Wyspiarze. Inne miasto z województwa zachodniopomorskiego - Szczecin - jest ośrodkiem portowym, w związku z tym piłkarze mającej tam siedzibę Pogoni są nazywani Portowcami.

W środę kibice Cracovii oczekiwać będą na wielki cud, jakim niewątpliwie będzie ewentualna wygrana Pasów nad Podbeskidziem Bielsko-Biała. (PN 14/2012, s. 47) Pietrasiak zatem jest czysty, ale wyniku meczu z Lechem nikt Góralom niestety nie anuluje. (PN 49/2012, s. 10)

Legia, grając słabo, zrewanżowała się Góralom za jesienną porażkę. (PN 11/2012, s. 38) 
Aktualny lider Scottish Premier League Celtic Glasgow pokonał na trudnym terenie Inverness CT 2:0. (PN 6/2012, s. 42)

Łukasz Załuska spędził cały mecz z Góralami na ławce, zaś Paweł Brożek nie znalazł się w kadrze meczowej. (PN 6/2012, s. 42)

Po rundzie jesiennej na miejscach premiowanych awansem są jednak drużyny, które nigdy nie grały w ekstraklasie - Flota Świnoujście i Termalica Bruk-Bet Nieciecza. (PN 49/2012, s. 44)

To jasno wskazuje, że mimo dobrych wyników większość ekspertów Wyspiarzy nadal nie traktuje poważnie i nie widzi ich w gronie kandydatów do awansu. (PN 49/2012, s. 44)

Liderująca Pogoń Szczecin podejmie u siebie Piasta Gliwice. (PN 11/2012, s. 40) Ten mecz powinien pokazać, czy zima nie wybiła z rytmu Portowców. (PN 11/2012, s. 40)

Rozwój przemysłu węglowego na obszarze Doniecka znalazł swoje odzwierciedlenie w nieoficjalnej nazwie Szachtara - Górnicy. Tradycje farmaceutyczne w Leverkusen sprawiły, że tamtejszy klub - Bayer - chętnie nazywa się Aptekarza$m i$. Także w polskich nazwach odnajdujemy podobne konotacje - znajdująca się w Płocku rafineria ropy naftowej wpłynęła na nadanie Wiśle przydomka Nafciarze, z kolei przemysł wydobywczy i przetwórczy rud miedzi w Lubinie oddziałał na powstanie nazwy miedziowi na określenie graczy Zagłębia.

Na nic zdały się tłumaczenia, że chodzi o stadion na Konwiktorskiej, mecz piłkarski i kilka tysięcy zmarzniętych ludzi, w tym kilkunastu skautów, między innymi z Borussii Dortmund, Bayernu Monachium, Bayeru Leverkusen, Anderlechtu Bruksela, Lille, Olympique Marsylii, podobno też z Manchesteru United i Interu Mediolan. (PN 47/2012, s. 41)

Jeśli Aptekarze unikną niespodziewanych wahań formy, z tym, co reprezentują dzisiaj, mogą myśleć o miejscu w przyszłorocznej Lidze Mistrzów. (PN 50/2012, s. 26)

Dobrze idzie Szachtarowi Donieck, który ma już cztery punkty, a w ostatniej serii uzyskał prestiżowy remis w Turynie z Juventusem. (PN 41/2012, s. 34)

Podobno właściciele Szachtara Rinat Achmetow i Chelsea Roman Abramowicz dobrze się znają, więc Górnicy z Doniecka na pewno postawią twarde warunki mistrzowi Włoch. (PN 48/2012, s. 32) 
Coraz lepiej zespół Skorży radzi sobie również w rozgrywkach ekstraklasy, gdyby nie zaległy mecz z Zagłębiem Lubin, prawdopodobnie byłby dziś liderem ligowych zmagań. (PN 44/2011, s. 47)

- Nie porównywałbym jednak ligowej rywalizacji z pucharem, tym bardziej, że zespół miedziowych budowany jest już od trzech sezonów - podkreśla Stoki. (PN 41/2012, s. 22)

Wisła Płock po raz kolejny wygrała mecz różnicą jednej bramki. (PN 41/2012, s. 45) Nafciarze grali perfekcyjnie w defensywie i do bólu skutecznie w ofensywie (dziewięć minimalnych zwycięstw). (PN 48/2012, s. 45)

Odwołanie do historycznej nazwy Lecha Poznań - Klub Sportowy Kolejowego Przysposobienia Wojskowego Poznań Dworzec, a później Kolejowy Klub Sportowy ${ }^{214}$ - znajdujemy w przydomku Kolejorz oraz jego sporadycznie notowanej wersji w liczbie mnogiej. Uwypukleniu związku wielkopolskiego klubu z regionem służy utworzenie nazwy zgodnie z cechami dialektalnymi.

7 - Tyle meczów na osiem rozegranych na wyjeździe wygrał w tym sezonie Lech Poznań. (PN 50/2012, s. 8)

Natomiast z Michniewiczem do niedzieli także (jeszcze?) nikt z Poznania się nie kontaktował, choć podobno Rutkowski pozbył się uprzedzeń z przeszłości do szkoleniowca, który był przed siedmiu laty największym ulubieńcem fanów Kolejorza. (PN 9/2012, s. 2)

Wrzucili Kolejorzom trójkę, a przecież mogli jeszcze dobić gospodarzy. (PN 49/2012, s. 2)

Warto przyjrzeć się jeszcze innym nazwom własnym i ich zastępczym określeniom. Wśród peryfraz pojawiających się w miejsce antroponimów popularne jest posługiwanie się komponentem królowa lub król, który ma podkreślać wyjątkowość kobiety lub mężczyzny w jakiejś dziedzinie, ich nieprzeciętne zdolności czy sposób zachowania. Nadzwyczajne dokonanie muzyczne Madonny obrazuje wyrażenie omowne królowa popu, analityzm Król Futbolu podkreśla, że Pele posiadał wybitne umiejętności piłkarskie, które pozwalają uważać go za najlepszego sportowca w tej dyscyplinie na świecie.

214 Por. historia klubu na oficjalnej stronie internetowej: http://www.lechpoznan.pl/ od,1922,roku,do,dzis [dostęp: 06.05.2014]. 
- Chciałam jej podziękować, bo dała mi życie - powiedziała wzruszona Madonna (53). (NŻ 5/2012, s. 12)

Łzy królowej popu (NŻ 5/2012, s. 12)

Taką koszulkę przygotował sobie Król Futbolu, Pele, na mecz, w którym zdobył pamiętną, tysięczną, bramkę w karierze. (PN 6/2012, s. 37)

Inny słynny piłkarz - Eusebio - nazywany jest Czarną Perłą z Mozambiku. To metaforyczne określenie nie tylko akcentuje pochodzenie zawodnika, ale przede wszystkim wskazuje, że jest kimś niepospolitym, wyróżnia się jakimiś nadzwyczajnymi właściwościami.

Na zaproszenie UEFA do Lwowa przyleciał legendarny Eusebio, ale z nietęgą miną przyglądał się poczynaniom swoich następców. (PN 24/2012, s. 10)

Częściej od Czarnej Perły z Mozambiku na telebimach pojawiał się inny Portugalczyk, trener Realu Madryt Jose Mourinho, który oglądał mecz w towarzystwie synka. (PN 24/2012, s. 10)

Znane z hucznie świętowanego karnawału brazylijskie Rio de Janeiro posłużyło do stworzenia peryfrazy balangowicz $z$ Rio. Jest ona mocno osadzona w kontekście i mogłaby się odwoływać do wielu różnych osób. Tekst podpowiada, że tym razem tak nazwano piłkarza Adriano.

Nikt nie zawraca sobie nim głowy, mimo że Inter bije rywala aż 4:0 po bramce Figo i aż trzech Adriano. Balangowicza z Rio. (PN 48/2012, s. 12)

Bazująca na chętnie wykorzystywanym w sporcie słownictwie wojskowym 215 analityczna struktura brazylijski marszałek wojska przypisuje Diego najwyższy stopień wojskowy, a drużynę mianuje siłą zbrojną, która ma odpierać ataki wroga.

Po raz pierwszy Diego pojawił się w Niemczech w 2006 roku. (PN 49/2012, s. 23)

215 Szczegółowo o militaryzmach w języku piłki nożnej pisał Wojciech Pelczar w artykule Zmilitaryzowany futbol. O wojskowym aspekcie języka piłkarskich sprawozdań prasowych, [w:] Język - teoria - dydaktyka: Materiały 21. konferencji językoznawczej zorganizowanej w Trzcinicy $k$. Jasła $w$ dniach 27-29 maja 1998 roku, red. B. Greszczuk, Rzeszów 1999, s. 303-309. 
Brazylijski marszałek jego [trenera Lorenza-Guenthera Koestnera - przyp. KB] wojska nadal grałbardzo dobrze. (PN 49/2012, s. 23)

Analityczna konstrukcja nacja słynąca z biznesowej żyłki odwołuje się do stereotypu narodowościowego - zwraca uwagę na cechę, która powszechnie kojarzy się z nacją żydowską, czyli umiejętność prowadzenia interesów.

A skoro tak uważa Grant, czyli Żyd, a więc człowiek nacji słynącej z biznesowej żyłki, to musi być w tym duża porcja prawdy. (PN 51-52/2011, s. 89)

Nawiązania do starożytności wyłaniają się z połączenia przybysz z Hellady, uwypuklają, że naród grecki ma wielowiekową tradycję.

Natomiast od ćwierćfinału już nikt go nie pokonał, a Grecy wygrywali kolejno po 1:0 z Francją w 1/4 finału, z Czechami w półfinale, i wreszcie w finale z Portugalią. (PN 11/2012, s. 27)

Obrona przybyszów z Hellady ze wspaniałym Traianosem Dellasem oraz bezbłędnym bramkarzem Antoniosem Nikopolidisem na czele grała doskonale. (PN 11/2012, s. 27)

Również w sferze religijnej nie brakuje wielowyrazowych zastępników nazw własnych, tendencja taka widoczna jest w obu największych wyznaniach monoteistycznych. „Święta księga islamu nie ma - w przeciwieństwie do odpowiadającego jej syntetyzmu - neutralnego wydźwięku, ale podkreśla ważność Koranu dla muzułmanów. Podobne relacje zachodzą między Biblią a Pismem Świętym"216. Umieszczenie w obu peryfrazach przydawki święty sugeruje, że księgi te są przedmiotem kultu.

Wszystko, co Ratzinger pisze o Jezusie, wynika z wiary, że Biblia mówi prawdę, w całości i w szczegółach. (P 51-52/2012, s. 19)

Młody Jezus rozmawiał z rabinami, znawcami Pisma Świętego. (P 51-52/2012, s. 21) Tylko naukowa krytyka Koranu może go wyrwać z rąk fundamentalistów. (P 51$52 / 2012$, s. 70)

216 K. Burska, Peryfraza a jej jednowyrazowy..., s. 244. 
Wspólnie doszli do wniosku, że choć ten odnaleziony Koran zgadza się w większości z obecnie używaną wersją świętej księgi islamu, są w nim całe fragmenty dotychczas nieznane, a jak twierdzi Puin, manuskrypty noszą również ślady poprawek. (P 51-52/2012, s. 70)

Odwołanie do sfery sacrum znajdziemy też w wyrażeniu omownym świątynia futbolu - tak nazwany został angielski stadion piłkarski Wembley. Zastosowanie komponentu świątynia sprawia, że obiekt, na którym rozgrywane są mecze, zostaje wyniesiony do rangi miejsca wyjątkowego, otoczonego czcią. Posługiwanie się wyrazami z kręgu religijnego to charakterystyczna cecha języka sportowego, Mariusz Koper zauważa: „Słownictwo genetycznie religijne, które funkcjonuje w leksyce wspólnoodmianowej, w piłce nożnej jest jeszcze dodatkowo motywowane kultem samej dyscypliny. Dla Brazylijczyków futbol stawiany jest czasami na równi z religią. [...] Sakralizacja piłki nożnej i deifikacja piłkarzy widoczna jest także u kibiców"217.

W ostatnią niedzielę w świątyni futbolu, za jaką uchodzi Wembley, królowała meksykańska fala. (PN 33/2012, s. 38)

Inne chrematonimy też podlegają peryfrastycznemu objaśnianiu. Interesująco wyglądają zastępcze określenia popularnych marek samochodów. Częstym składnikiem takich analityzmów są wyrazy wskazujące na lokalizację koncernu (odwołanie do kontynentu: amerykański gigant samochodowy, kraju: ikona brytyjskiej motoryzacji czy miejscowości: firma z Maranello). Odnoszące się do samochodów Rolls-Royce połączenie ikona brytyjskiej motoryzacji podkreśla ich wielką wartość, z kolei nazwanie ich autami z „silver lady” na masce wykorzystuje symbol nieodłącznie kojarzony z tą marką. Znacznie mniejszą precyzją odznacza się odwołująca się do Ferrari analityczna konstrukcja 1,2 mln zł na kołach, ponieważ może ona wskazywać na kilka różnych desygnatów.

217 M. Koper, „Poezja futbolu”. Kilka uwag o języku sprawozdawców sportowych, [w:] Język polski. Współczesność. Historia, red. W. Książek-Bryłowa, H. Duda, Lublin 2003, s. 57. Por. M. Koper, „Turku, kończ ten mecz!” O mówionej odmianie języka dziennikarzy sportowych raz jeszcze, [w:] Sport w mediach, red. M. Jarosz, P. Drzewiecki, P. Płatek, Warszawa 2013, s. 294-296. 
Chlubiąc się setkami milionów zadeklarowanych kibiców na świecie, MU podpisał kontrakt sponsorski z firmą Chevrolet, który opiewa na 559 milionów dolarów. (PN 33/2012, s. 17)

Z początkiem sezonu 2014-15 na koszulkach zawodników najpopularniejszego klubu piłkarskiego na świecie pojawi się logo amerykańskiego giganta samochodowego. (PN 33/2012, s. 17)

Dowcip ten nabiera nowego sensu, gdy ogląda się najnowsze modele Ferrari za szybą w budynku, gdzie najgodniejsi przedstawiciele klasy robotniczej pili kiedyś koniak, czyli w dawnej siedzibie KC PZPR. (P 51-52/2012, s. 54)

Obsługa ocenia, czy to potencjalny klient, czy może zwykły miłośnik motoryzacji, który chce tylko z bliska zobaczyć, jak wygląda 1,2 mln zł na kołach. (P 51-52/2012, s. 54)

Auta sprzedają się jak świeże bułeczki, tegoroczna pula została wyczerpana już w lutym, a polski dealer firmy z Maranello dostał z centrali nagrodę za sprzedaż samochodów z najbogatszym wyposażeniem. (P 51-52/2012, s. 54)

Firma Rolls-Royce nie podaje nawet, ile samochodów sprzedała w poszczególnych krajach. (P 51-52/2012, s. 54)

Autami z silver lady na masce cieszy się już kilkudziesięciu Polaków. (P 51-52/2012, s. 55)

Słynna ikona brytyjskiej motoryzacji - Rolls-Royce - została uratowana przed bankructwem przez koncern BMW, a Bentleya ocalił Volkswagen. (P 51-52/2012, s. 56)

Stany emocjonalne towarzyszące aktorom, reżyserom, scenarzystom i innym ludziom z branży filmowej podczas rozdawania nagród przez Amerykańską Akademię Sztuki i Wiedzy Filmowej wyraża peryfraza najbardziej pożądane złote statuetki na świecie, która podkreśla wartość Oskarów.

Tornatore jest przecież zdobywcą Oskara za film „Cinema Paradiso”. (NŻ 12/2012, s. 44)

W Fabryce Snów po raz 84. wręczono najbardziej pożądane złote statuetki na świecie. (NZ̈ 9/2012, s. 7)

Licznie reprezentowane są alternatywne określenia antroponimów. Jak zaznacza A. Cieślikowa: „Semantyka przezwisk, ich stale odnawiany repertuar zależy od zwyczajów w grupie, ale przede wszystkim od stosunku uczuciowego mię- 
dzy nazywanym a nazywającym"218. Duża grupa przezwisk odwołuje do cech fizycznych. Wydaje się, że podstawą do utworzenia pseudonimu Grubcio stała się postura bramkarza Rafała Misztala. Charakterystyczna fizjonomia sprawia, że Rafa Benitez zwany jest Księgowym, potwierdzenie pochodzenia tego syntetyzmu znajdujemy w tekście prasowym. Sędziwy wiek trenera Oresta Lenczyka znajduje odzwierciedlenie w nadanym mu przydomku Nestor ${ }^{219}$. Oprócz tego, że był on wówczas najstarszym szkoleniowcem pracującym w ekstraklasie, nazwa ta sugeruje, iż z powodu zasług cieszy się powszechnym szacunkiem. Takie konotacje przypisuje Nestorowi także M. Rutkowski: „osoba najstarsza w jakimś gronie, często: obdarzona autorytetem"220.

Chojniczanka była dużo skuteczniejsza i... miała w swoich szeregach Rafała Misztala. (PN 44/2012, s. 44)

Czapki z głów przed Grubciem! (PN 44/2012, s. 44)

Jeszcze większe powody do rozmyślań ma nowy opiekun Chelsea Rafa Benitez. (PN 48/2012, s. 23)

Zwany z racji wyglądu Księgowym nie będzie miał łatwego życia na Stamford Bridge. (PN 48/2012, s. 23)

Orest Lenczyk - po blamażu Śląska Wrocław najpierw w kwalifikacjach Ligi Mistrzów, a następnie Ligi Europy - nie jest już trenerem mistrza Polski. (PN 36/2012, s. 2)

No, chyba że Nestor wcześniej znajdzie pracę. (PN 36/2012, s. 3)

Chwilowa niedyspozycja i związany z nią niekorzystny wygląd spowodował, że do Piotra Włodarczyka przylgnęło określenie Nędza. Sam zawodnik tłumaczy swój pseudonim tak: „Wymyślił go trener Lenczyk, gdy grałem w Ruchu. Pewnego dnia stawiłem się na zbiórce z ponad 40 -stopniową temperaturą. Akurat wyjeżdżaliśmy na mecz do Łodzi. Gdy mnie trener zobaczył, to powiedział, że wyglądam jak nędza. I tak już się przyjęło"221.

218 A. Cieślikowa, Przezwiska, [w:] Polskie nazwy własne. Encyklopedia, red. E. Rzetelska-Feleszko, Warszawa-Kraków 1998, s. 130.

219 Wpływ na powstanie tego przydomka mógł mieć też fakt, że ojciec Oresta Lenczyka ma na imię Nestor.

220 M. Rutkowski, Słownik metafor..., s. 89.

221 http://www.sportowefakty.pl/pilka-nozna/259185/piotr-wlodarczyk-o-nedzy-i-grze-w-baltyku [dostęp: 07.05.2014]. 
Djibril Cisse kiedyś rywalizował o miejsce w wyjściowym składzie Auxerre z naszym Piotrem Włodarczykiem. (PN 6/2012, s. 30)

O Nędzy słuch właściwie zaginął, tymczasem Francuz nadal jest bohaterem głośnych transferów. (PN 6/2012, s. 30)

Mina twarzy powszechnie kojarzona z hiszpańskim trenerem Vicente del Bosque pozwala go nazywać Sfinks, przenośnie bowiem definiuje się go następująco: 'zagadkowa istota, zagadkowy nieprzenikniony człowiek, symbol tajemniczości'222.

Vicente del Bosque 27 maja ogłosi skład kadry i trudno sobie wyobrazić, by włączył do niej swego podstawowego środkowego obrońcę. (PN 20/2012, s. 27)

Równie niskie jest prawdopodobieństwo, że Sfinks do defensywy cofnie Sergio Busquetsa. (PN 20/2012, s. 27)

Przywoływane już kilkukrotnie w niniejszej pracy słownictwo z zakresu wojskowości stosowane w terminologii sportowej miało wpływ na nazwanie Rinusa Michelsa Generałem. Wytłumaczenie znajdujemy w artykule:

Dla niego każdy mecz był jak wojna i dlatego otrzymał przydomek Generał, zresztą był zwolennikiem niemal wojskowej dyscypliny. (PN 17/2012, s. 27)

Rinus Michels doprowadził Ajax Amsterdam do pierwszego triumfu w Pucharze Mistrzów, a reprezentację Holandii do pierwszego wicemistrzostwa świata i tytułu mistrza Europy. (PN 17/2012, s. 27)

Dla 64-letniego Generała tak się zakończyła kariera trenerska. (PN 17/2012, s. 27)

Posługiwanie się syntetyzmem Faraon ujawnia egipskie pochodzenie Stephana El Shaarawy'ego, Egipt bowiem nazywany jest krajem faraonów od nazwy starożytnych władców ${ }^{223}$.

Stephan El Shaarawy po 11 kolejkach przewodzi klasyfikacji strzelców. (PN 45/2012, s. 28)

222 Mały słownik..., s. 909.

223 Por. M. Bańko, Słownik peryfraz..., s. 78. 
Pierwsi byli Mario Balotelli i Davide Santon jeszcze z czasów gry w Interze, w tym sezonie wystrzelił Marco Veratti z Paris SG, nieco uśpiony czeka na eksplozję Mattia Destro z Romy, ale obecnie najwyżej stoją akcje Faraona. (PN 45/2012, s. 29)

Popularne wśród kibiców rymowane powiedzenie Franek łowca bramek obrazujące niespotykaną umiejętność zdobywania goli przez Tomasza Frankowskiego funkcjonuje w skróconej wersji jako przydomek Łowca.

Podobnego zdania jest Tomasz Frankowski, ikona zespołu znad Białej Rzeki. (PN 49/2012, s. 14)

A przynajmniej nie było do soboty, kiedy Łowca $z$ dwoma trafieniami odprawił Górnika Zabrze. (PN 17/2012, s. 39)

Katarzyna Dawidowicz, analizując zastępniki imion i nazwisk sportowców, zwraca uwagę na jeszcze inną motywację: „Za szczególnie interesujące należy uznać przezwisko nadane nieco przewrotnie Wtorek piłkarzowi o nazwisku Niedzielan”224. Sam zawodnik w wypowiedzi dla „Gazety Krakowskiej” wyjaśniał następująco: „Byłem w Zagłębiu Lubin i wołali na mnie Sobota. Przechodząc do Górnika Zabrze Michał Probierz powiedział - teraz będziesz Wtorek i to się przyjęło"225.

Na pierwszym zgrupowaniu w Kamieniu koło Rybnika Andrzeja Niedzielana jeszcze nie było. (PN 6/2012, s. 18)

Pytanie tylko, czy Fornalikowi po raz drugi uda się odbudować Wtorka. (PN 6/2012, s. 18)

Fotograf natury Dariusz Karp, który mieszka w lesie w drewnianej chacie w stylu trapersko-indiańskim, ma przydomek Wódz-prawdopodobnie dlatego, że wygląda i ubiera się jak Indianin, a przecież wódz to osoba wysoko postawiona w hierarchii plemion indiańskich.

224 K. Dawidowicz, „Biba”, „Lijek”, „Wtorek”, „Grucha”, czyli o przezwiskach polskich sportowców, [w:] Język w komunikacji, t. 1, red. G. Majkowski, Częstochowa 2011, s. 100 .

225 http://www.gazetakrakowska.pl/artykul/429923,jak-to-andrzej-niedzielan-przez-blonia-przeskoczyl,id,t.html?cookie=1 [dostęp: 05.05.2014]. 
W pobliskim przysiółku Tajenko ludzie mówią o Darku Karpie niewiele. (P 5152/2012, s. 164)

Anna Gniedziejko, u której Wódz kupuje czasem jajka, wspomina, że dał jej w prezencie kalendarz ze zdjęciami zwierząt. (P 51-52/2012, s. 164)

Motywacje większości zastępników oficjalnych antroponimów opierają się na skojarzeniach z imionami lub nazwiskami. Wiele z nich przybiera postać wyrazów pospolitych, ale przyczyną ich powstania było formalne podobieństwo $z$ apelatywem, a nie rzeczywiste odniesienie do cech fizycznych (Bobo, Mały) i psychicznych (Świr), sprawowanych funkcji (Dziekan, Prezes), pochodzenia (Jankes), postaci z filmów (Janosik, Reksio), zwierząt (Jelonek, Niedźwiedź, Ryba), roślin (Jodła, Listek), owoców (Mandaryna), przedmiotów (Kosa, Młynek, Sagan), elementów otaczającego świata (Kałuża, Stoki), wykonywanych zawodów (Ślusarz) czy stron $($ Lewy).

Dopiero kiedy wróciło stare, to znaczy po 20 latach przerwy skończyła się odyseja - jak sam barwnie mówi - trenera Bogusława Kaczmarka po kraju, zespół z Wybrzeża zaczął grać efektownie, a przy tym skutecznie. (PN 48/2012, s. 18)

W dodatku działacze nie chcą tworzyć w drużynie kominów płacowych, ale akurat w tym przypadku nawet sam Bobo lobbował u właściciela klubu Andrzeja Kuchara, aby może jednak odejść od tej reguły. (PN 48/2012, s. 19)

Mecz obserwował uważnie Dariusz Dziekanowski. (PN 33/2012, s. 2)

- Trochę dziwnie się czuję - powiedział zasmucony Dziekan. (PN 33/2012, s. 3)

Cieszyć musi przede wszystkim fakt, że do siatki trafiają napastnicy - trzy gole strzelił Arkadiusz Piech, po dwa Maciej Jankowski i Paweł Abbott. (PN 6/2012, s. 18)

Ale do jakiego zagranicznego klubu trafi Jankes, przekonamy się zapewne dopiero w letnim oknie transferowym. (PN 6/2012, s. 19)

Za stołem pojawia się główny bohater dnia, selekcjoner biało-czerwonych, Pawel Janas. (PN 20/2012, s. 47)

Dziennikarze i zaproszeni goście nie wykluczali małych niespodzianek, wszakże Janosik już wcześniej zapowiedział, że za zasługi nikt na mundial nie pojedzie. (PN 20/2012, s. 47)

Arbitra meczu w Bielsku-Białej krytyce poddał Ireneusz Jeleń. (PN 49/2012, s. 10)

Czy właśnie dlatego Jelonek postanowił nie wykorzystać prezentu i spudłował z 11 metrów? (PN 49/2012, s. 10) 
Niewątpliwie Tomaszowi Jodłowcowi bardzo pomógł fakt, że wraz z nim na środku obrony Stanisław Lewy zaczął ustawiać Marcina Kowalczyka. (PN 50/2012, s. 41) Jodła ratownik (PN 50/2012, s. 41)

Kiedy w październiku 2004 roku Paweł Janas ogłasza kadrę na eliminacyjne mecze z Austrią i Walią, zapada konsternacja. Radosław Kałużny? (PN 41/2012, s. 14) Wytyka im, że wcześniej skreślili Kałużę, który w takiej formie jak w Wiedniu, wciąż jest reprezentacji potrzebny. (PN 41/2012, s. 14)

Bohaterem meczu natomiast został Jakub Kosecki - zdobywca dwóch bramek i autor asysty przy trafieniu Danijela Ljuboi. (PN 49/2012, s. 39)

W piątek Kuba Kosecki przypomniał wszystkim w Polsce, że piłka nożna jest tak popularnym sportem, bo dobrze grać może w nią każdy. (PN 48/2012, s. 47)

Tym bardziej jest to możliwe, że młody Kosa ma także znakomitą technikę strzału (szkoda, że tylko jedną nogą) i łatwość dochodzenia do sytuacji bramkowych. (PN 48/2012, s. 4)

Temat transferu Roberta Lewandowskiego zaistniał w czerwcu i teraz pojawił się znów, a my spróbujemy oddzielić prawdę od fałszu, prawdopodobne od nieprawdopodobnego. (PN 49/2012, s. 28)

Co prawda w minionej kolejce Lewy zszedł z boiska bez trafienia, a jego zmiennik - Lucas Barrios - zdobył gola, ale to nie powinno mieć żadnego wpływu na kształt rankingu napastników Juergena Kloppa. (PN 6/2012, s. 13)

W tym tygodniu ma zostać utworzony w PZPN departament zagraniczny, na którego czele ma stanąć Michał Listkiewicz. (PN 49/2012, s. 13)

To jednak Zbyszek Boniek będzie decydował o jej tematyce i zakresie obowiązków, jakie mi ewentualnie powierzy - powiedział „PN” Listek. (PN 49/2012, s. 13)

W klubowej kadrze jest jeszcze Patryk Małecki. (PN 11/2012, s. 23)

Zwłaszcza upadek tego pierwszego jest poruszający, biorąc pod uwagę, że za poprzedni sezon Małego sklasyfikowaliśmy na pierwszym miejscu. (PN 20/2012, s. 14) Zbigniew Małkowski, bramkarz Korony Kielce, wziął udział w treningu piłkarzy ręcznych Vive Targi Kielce. (PN 44/2012, s. 10)

Mały daje radę! (PN 44/2012, s. 10)

- Ja miałam implanty tak dawno, że już nawet o nich zapomniałam - powiedziała nam Marta Wiśniewska, czyli Mandaryna (33). (NŻ 1/2012, s. 13)

Dla Młynka to nie pierwszyzna. (PN 50/2012, s. 10)

Teraz podejrzewam, że to samotność wybrała mnie, a ja z czasem ją polubiłem - wyznaje Marek Niedźwiedzki (57) w autobiografii „Nie wierzę w życie pozaradiowe”. (NŻ 7/2012, s. 44) 
Nieśmiały „Niedźwiedź” nie był zdobywcą - to jego kolega Karol został mężem Aliny. (NŻ 7/2012, s. 44)

Po centrze Magiery piłkę do bramki skierował głową Prejuce Nakoulma. (PN 11/2012, s. 37)

Na szczęście mają ciemnoskórego Prezesa, który staje się kolekcjonerem drobiu. (PN 11/2012, s. 37)

W Poznaniu nie ukrywano, że usilnie szukają środkowego napastnika, ale angaż 40-letniego Piotra Reissa, z którym rozstano się przed trzema laty, jest trudny do wytłumaczenia. (PN 36/2012, s. 10-11)

Reksio będzie straszył. (PN 36/2012, s. 10-11)

- Jakoś mi się specjalnie nie podobała - mówił Andrzej Rybiński (62). (NŻ 12/2012, s. 46)

- Ryba, fajny utworek - mówili. (NŻ 12/2012, s. 46)

Ani z klubu, ani do klubu, jeśli oczywiście do zdrowia wróci Marek Saganowski. (PN 48/2012, s. 7)

Mogę potwierdzić, że odstępstwa od normy w pracy Marka serca były już, gdy Sagan występował jeszcze w Southampton. (PN 48/2012, s. 7)

Trenerzy stawiają na młodziė̇ w różnych konfiguracjach, ale na pewno nie można teraz upraszczać, mówiąc, że Piotrek Stokowiec, nie mając wyboru, postawił na młodych. (PN 48/2012, s. 15)

Owszem, Stoki, stawia na młodych, ale już doświadczonych, będących od dawna w grupie i w szatni pierwszego zespołu. (PN 48/2012, s. 15)

Po porażce Lecha z Legią najmocniej oberwało się Bartoszowi Ślusarskiemu. (PN 48/2012, s. 12)

W Hamburgu chłop sobie jeszcze postrzela, a w Poznaniu Ślusarz już siedem zapakował i idzie na życiówkę. (PN 50/2012, s. 11)

Niestety, tylko do momentu, gdy ogłoszono, że trenerem menedżerem został Piotr Świerczewski. (PN 7/2012, s. 2)

A nawet jeśli Świr okaże się utalentowanym kandydatem na trenera i/lub menedżera, najpierw tych profesji będzie się musiał nauczyć, na co potrzeba czasu. (PN 7/2012, s. 2)

Ciekawe rozwiązanie można zaobserwować w przydomku Ajwen - jest to fonetyczny zapis nazwiska Iwan zgodny z regułami wymowy obowiązującymi w języku angielskim. 
Analityzmy [...] mające syntetyczne odpowiedniki o znaczeniu synonimicznym

Przypomina mi Ajwena (Andrzeja Iwana - przyp. red.), gdy zaczynał grać w piłkę. (PN 48/2012, s. 19)

Część przezwisk przybiera formę imion odwołujących się swoją strukturą do nagłosu nazwiska osoby, do której nawiązują. Zwykle reprezentują one deminutiva: Boguś to Rafał Boguski, Franek - Tomasz Frankowski, Tomek - Jan Tomaszewski.

Pierwsze wyjazdowe zwycięstwo w tym sezonie Wisła Kraków zawdzięcza Rafałowi Boguskiemu. (PN 44/2012, s. 39)

Boguś trafił do siatki dwa razy w bliźniaczych sytuacjach. (PN 44/2012, s. 39)

Najpierw Dawid Plizga do Tomasza Frankowskiego, a ten do Euzebiusza Smolarka, który wykorzystał sam na sam z Michalem Peskoviciem. (PN 50/2012, s. 40) Tymczasem w klubie nie ma ponoć zgodności co do tego, czy warto z Frankiem przedłużyć wygasającą w czerwcu umowę. (PN 17/2012, s. 39)

Jan Tomaszewski, człowiek, który w 1973 roku zatrzymał na Wembley Anglię, tak wspomina Smolarka. (PN 11/2012, s. 5)

Ale tak jak i Tomek, on również raz skapituluje; po rzucie wolnym Djorkaeffa na trzy minuty przed końcem meczu. (PN 33/2012, s. 47)

Nawiązanie do imion w formie nieoficjalnej widoczne jest także w alternatywnych nazwach Poldi (kojarzącej się z Leopoldem) na określenie Lukasa Podolskiego, Rado (kojarzącej się z Radosławem) na określenie Miroslava Radovicia i Ludo na określenie Ludovica Obraniaka.

W tym miejscu możemy się pokusić o spekulacje, jak może sobie poradzić w Arsenalu Lukas Podolski. (PN 17/2012, s. 28)

Najczarniejszy scenariusz zakłada więc stratę Poldiego i minimalny zysk, który nie pozwoli nawet w części wypełnić powstałej luki. (PN 11/2012, s. 28)

Jedyna konkretna oferta napłynęła latem dla Miro Radovicia. (PN 48/2012, s. 7) Chcieli Rado za 600 tysięcy (PN 48/2012, s. 7)

Ale to właśnie on był zwolennikiem wydania miliona euro na Ludovica Obraniaka i trzeba przyznać, że była to jedna z najlepszych personalnych decyzji Bordeaux w ostatnim czasie. (PN 48/2012, s. 35) 
I okazało się, że Ludo mocno przyczynił się do zwycięstwa w derbach Garonny, choć sam nawet nie wiedział, że rywalizacja z Tuluzą ma takie znaczenie dla fanów GB. (PN 6/2012, s. 3)

Jako przydomki nazywające mężczyzn mogą być też wykorzystane żeńskie imiona w urzędowej postaci, np. Kazimiera i Liza odnoszą się odpowiednio do Jacka Kazimierskiego i Bixente Lizarazu, podstawą do ich utworzenia było podobieństwo formalne $\mathrm{z}$ nazwiskami.

Piechniczek ma pretensje do bramkarza Jacka Kazimierskiego. (PN 6/2012, s. 47) A dla Kazimiery to w ogóle nie był dobry czas. (PN 6/2012, s. 47)

Ulubiony numer Bixente Lizarazu. (PN 6/2012, s. 37)

Wszystko się zgadzało, ale numer taki przyjął Liza w Bawarii podczas swego drugiego tam pobytu w latach 2005-06. (PN 6/2012, s. 37)

Włoskie imię Gianni stało się ksywką Tomasza Hajty nie bez powodu - nawiązuje ona bowiem do znanego włoskiego projektanta Gianniego Versace, ponoć ulubionej marki odzieżowej byłego piłkarza. W tygodniku „Wprost” znajdujemy takie wyjaśnienie: „Tomasz Hajto - zgodnie mówią wszyscy - zawsze lubił się wyróżniać. Starannie ułożoną fryzurą, lecz przede wszystkim strojem. Nawet zwykły podkoszulek musiał mieć odpowiednią metkę. Stąd ksywa Gianni - w jego szafie podobno większość garniturów to kolekcja Gianniego Versace"226.

Tomasz Hajto w Jagiellonii? (PN 3/2012, s. 13)

Sporo dostaje się od szkoleniowca zwłaszcza asystentom liniowym, ale zapytany przez nas po wygranym meczu z Legią o formę psychiczną Gianni odpowiedział z uśmiechem: - Uważam, że zawsze byłem i nadal jestem normalny. (PN 49/2012, s. 16)

Tożsamy z imieniem obcego pochodzenia jest przydomek trenera Franciszka Smudy Franz. Wydaje się, że wpływ na powstanie tego alternatywnego określe-

226 http://www.wprost.pl/ar/286960/Gianni/?pg=1 [dostęp: 08.05.2014], por. wywiad z Tomaszem Hajtą na portalu Menstream: http://menstream.pl/wiadomosci-reportaze-i-wywiady/tomasz-hajto-o-szansach-polakow-na-euro-i-pijanstwie-w-sporcie,1,1097511.html [dostęp: 08.05.2014]. 
nia miało nie tylko podobieństwo brzmieniowe, ale także fakt, iż szkoleniowiec posiada oprócz polskiego również niemieckie obywatelstwo, a w dokumentach naszych zachodnich sąsiadów widnieje właśnie jako Franz 227.

Po remisie na inaugurację Euro 2012, który trudno nazwać zwycięskim, podopieczni Franciszka Smudy zachowali szanse na wyjście z grupy. (PN 24/2012, s. 4) Przecież od 30 lat czekamy, żeby Polacy zagrali jak nie-Polacy, dopiero trzeba było Franza, żeby niczym Kolumb postawił jajo w pionie. (P 24/2012, s. 13)

Nowy szef związku wcale jednak nie musi skończyć tak jak Franz, czyli odejść w niesławie. (PN 44/2012, s. 2)

Cz. Kosyl podkreśla: „W użyciu metaforycznym nazwa własna uzyskuje nową, sekundarną wartość językową. Wartość ta staje się w obrębie tekstu jej wartością podstawową. Nie oznacza to jednak, że prymarna wartość nazwy własnej-metafory ginie całkowicie. Z punktu widzenia tekstu staje się ona jej wartością drugorzędną i funkcjonuje w świadomości użytkowników języka jako wartość utajona. [...] Metafora istnieje dopóty, dopóki wartość utajona (prymarna) nazwy nakłada się na jej wartość tekstową (sekundarną)”228.

Metafora i metonimia są ważnymi figurami wykorzystywanymi do budowania odpowiedników nazw własnych. Nie wszystkie zastępniki antroponimów, toponimów i chrematonimów wykorzystują mechanizm podobieństwa lub przyległości cech, czasem opisowe określenia mają przede wszystkim charakter informacyjny. Interesująco przedstawia się motywacja przezwisk. Wśród nominacji bezpośredniej dominują takie, które opierają się na charakterystyce zewnętrznej osoby nazywanej. Przejawami nominacji pośredniej są podobieństwa pod względem charakteru, zachowania czy wykonywanej czynności ${ }^{229}$. Wiele syntetyzmów zastępujących imiona i nazwiska zbudowanych jest na formalnym podobieństwie z oficjalną nazwą, powstały twór odwołuje się do apelatywów lub innych onimów, mamy więc do czynienia z motywacją strukturalną.

227 http://www.express.de/fussball/franciszek-smuda--poldi-ist-botschafter-des-neuen-europa-,3186,14695380.html [dostęp: 08.05.2014].

228 Cz. Kosyl, Metaforyczne użycie nazw..., s. 142.

229 Por. Cz. Kosyl, Nazwy osobowe, [w:] Encyklopedia kultury polskiej XX wieku, t. 2: Współczesny język polski, red. J. Bartmiński, Wrocław 1993, s. 435-436. 
W analizowanej grupie szczególnym bogactwem wyróżniają się alternatywne określenia toponimów, a także wszelkich nazw związanych ze sportem - reprezentacji narodowych, klubów piłkarskich, imion i nazwisk trenerów i piłkarzy. M. Koper uważa, że pronominacja jest osobliwością onomastyki sportowej i manierą sprawozdawczą, wprowadzanie określeń charakteryzujących często służy hiperbolizacji wypowiedzi 230 .

Głównym zadaniem odpowiedników nazw właściwych jest nie nazywanie, lecz akcentowanie pewnych zjawisk, np. słabych lub mocnych stron, eksponowanie najważniejszych właściwości, koncentrowanie się na jednym, wybranym elemencie jakiejś całości. Bardzo często są one nacechowane aksjologicznie, „narzucają pewną wizję przedmiotu przez jednostronnie wartościującą charakterystykę"231. M. Bańko dostrzega, że peryfrastyczne połączenia „przenikają nasz język i służą tworzeniu lub modelowaniu pojęć, a więc do pewnego stopnia ukierunkowują naszą percepcję rzeczywistości"232. Istnienie kilku analityzmów odwołujących do tego samego syntetyzmu pozwala wyeksponować te cechy, na które dziennikarz chciał zwrócić szczególną uwagę. Nierzadko peryfrazy budowane są z wykorzystaniem stereotypów, odzwierciedlają one „uproszczony sposób widzenia świata przez użytkowników danego języka"233. Jak twierdzi E. Straś, połączenia takie „interpretując otaczającą rzeczywistość, potęgują wyrazistość przekazu i jego oddziaływanie na adresata, jak również urozmaicają tekst i nadają mu specyficzny koloryt"234.

\section{Podsumowanie}

W części tej zaprezentowano semantyczne zróżnicowanie analityzmów leksykalnych mających jednoelementowe odpowiedniki. Najrzadziej zaobserwowana została relacja równoznaczności. Dowodzi to słuszności przywoływanego w opracowaniach twierdzenia, że trudno jest za pomocą dwóch różnych jednostek leksykalnych wyrazić identyczne treści. Wydaje się, że rzeczywiste ekwiwalenty naj-

230 Por. M. Koper, „Poezja futbolu”..., s. 59; idem, Emocje w języku sprawozdawców sportowych, [w:] Rejestr emocjonalny języka, red. K. Wojtczuk, V. Machnicka, Siedlce 2009, s. 72.

231 E. Straś, Peryfrazy w środkach..., s. 103.

232 M. Bańko, Peryfrazy w naszym..., s. 3.

233 Ibidem, s. 21.

234 E. Straś, Peryfrazy w środkach..., s. 109. 
częściej obecne są w grupie przymiotników i przysłówków, kilka egzemplifikacji odnotowano wśród rzeczowników i czasowników. Charakterystyczną podstawą kolokacji werbo-nominalnych tożsamych semantycznie z syntetyzmami jest mieć. Zdecydowanie nie da się odnaleźć zgodności znaczeniowej w klasie nomina propria, gdyż każde zmiany w obrębie nazw własnych niosą ze sobą jakąś nadwyżkę semantyczną, przeważnie o charakterze ekspresywnym.

Analityzm i syntetyzm mogą wyzyskiwać inne odcienie znaczeniowe, wchodzące w skład struktur złożonych wyrazy pozwalają zwrócić uwagę odbiorcy na dodatkowy składnik semantyczny, np. konkretny aspekt opisywanej czynności, podkreślają ważność pewnych elementów opisu przy jednoczesnym pomijaniu innych - prawdopodobnie w opinii piszącego mniej ważnych - jej przejawów. Wyeksponowany może zostać wykonawca czynności albo podjęte przez niego działania. W triadach synonimicznych składających się z syntetycznych czasowników, kolokacji werbo-nominalnych i związków frazeologicznych lub dwóch różnych określeń analitycznych i uniwerbizmu widoczne jest zróżnicowane natężenie precyzyjności opisu, poszczególne ekwiwalenty różnią się wartościowaniem, ekspresywnością, stopniem oficjalności czy zabarwieniem stylistycznym. Zwykle to forma prosta jest bardziej pojemna semantycznie, a wielowyrazowa konstrukcja pomaga dopowiedzieć, które znaczenie nierozbudowanej formy chciał wydobyć autor. Czasem dochodzi nawet do takiej sytuacji, że różne konstrukcje mające taki sam ekwiwalent mogą przekazywać przeciwstawne treści (np. umrzeć to zarówno tracić życie, być daleko stąd, jak i czarować w innym lepszym ze światów). Bywa również tak, że różnice semantyczne między konstrukcjami peryfrastycznymi a odpowiadającymi im syntetyzmami są niemałe (np. zapomnieć i wyrzucić z pamięci, skrzywdzić i zrobić krzywdę), choć przeważnie określa się je mianem subtelnych.

Odmiennie mogą przedstawiać się także związki frazeologiczne, które da się sprowadzić do takiego samego prostego odpowiednika. Nawet gdy istnieje kilka trwałych połączeń wyrazowych na określenie jednego stanu czy zjawiska, to każde $z$ nich pozwala na spojrzenie $z$ innej perspektywy i zaakcentowanie innego sposobu ujęcia, zamienniki mogą uwypuklać opisywany stan czy cechę, informować o natężeniu i intensywności lub różnicować pod względem wyrazistości, obrazowości i dokładności. Co wielokrotnie zaznaczano, nigdy pojedynczy wyraz nie będzie w stanie wyrazić dokładnie tego samego co frazeologizm, ten drugi zawsze będzie miał nadbudowę w postaci stylistycznego nacechowania.

Nie tylko związki frazeologiczne i ich syntetyczne odpowiedniki różnią się zabarwieniem stylistycznym, prawidłowość ta uwidacznia się we wszystkich parach 
składających się z formy prostej i złożonej. Na plan pierwszy zdecydowanie wysuwa się opozycja potoczność - oficjalność. Wśród omawianych konstrukcji wiele jest uniwerbizmów (derywaty z sufiksami -(ów)ka, -ak, -ina, elipsy subsantywizujące i deadiektywizujące), ich przynależność do nieoficjalnej odmiany języka jest powszechnie podkreślana, choć należy nadmienić, że niektóre formy zuniwerbizowane są od dawna powszechnie używane i ich potoczność jest niemal niezauważalna. Krótkie formy mogą być neosemantyzmami, zdarza się też, że jeden uniwerbizm ma kilka ekwiwalentów wieloelementowych. Sporą frekwencję form eliptycznych, derywatów paradygmatycznych i dezintegralnych odnotowano w klasie nomina propria. Język dnia powszedniego przejawia się nie tylko w zakresie słowotwórstwa, ale przede wszystkim poprzez dobór leksyki. W dubletach znaczeniowych pojawia się sporo sformułowań, przy których widnieje w słownikach kwalifikator 'potoczny' - i dotyczy to zarówno pojedynczych leksemów ( fiskus, zawodówka, samobój), jak i form złożonych (strzelić focha, pstrykać fotki, szef rządu). Szczegółowo zanalizowany został także semantyczny wymiar potocznej frazeologii. I tu również można wydzielić dwie grupy - związek frazeologiczny należy do nieoficjalnej odmiany polszczyzny, a jego ekwiwalent ma charakter neutralny bądź podniosły (mieć muchy w nosie i grymasić, nabić w butelkę i oszukać, rzucać mięsem i przeklinać) albo - przeciwnie - stałe połączenie wyrazowe nadaje się do użycia w komunikacji oficjalnej, ma nacechowanie podniosłe, a syntetyzm należy do języka codziennego (wyciagnąć pomocna dłoń i pomóc, zabrać głos i przemówić, wieść prym i przodować).

Zróżnicowanie semantyczne pokazują także konstrukcje charakteryzujące się przynależnością do stylu urzędowego i naukowego. Nie brakuje wieloelementowych połączeń, które przybierają postać definicji będącej de facto wyjaśnieniem syntetyzmu. Alternatywne określenia mogą wprowadzać wysoki ton i dodawać wypowiedzi wzniosłości.

Bardzo duża grupa zgromadzonych przykładów została przypisana do kategorii eufemizmów, zazwyczaj to rozbudowana konstrukcja ma charakter łagodzący, choć zdarza się, że funkcję tę pełni syntetyzm. Eufemizacji podlegają zróżnicowane tematycznie obszary, m.in. wady i nałogi ludzkie, wulgaryzmy, cechy fizyczne, stany fizjologiczne kobiety, życie seksualne, nagość, śmierć, działania stawiające ich wykonawcę w złym świetle, działania niezgodne z prawem - zakres tematyczny w dużej mierze pokrywa się więc z ustaleniami A. Dąbrowskiej, został jednak trochę poszerzony. Bogaty jest repertuar środków formalnych służących łagodzeniu dosadności wypowiedzi. 
Ciekawie prezentują się sposoby służące tworzeniu odpowiedników nazw własnych, określenia zastępcze są zazwyczaj metaforami lub metonimiami. Konstrukcje opisowe bazują na podstawach, które wydobywają aspekty znaczeniowe, np. stolica, miasto, gród, mekka, centrum, perła, kraj, wyspa, ojczyzna, kolebka każda z nich niesie konkretną wartość, która w połączeniu z toponimem pozwala w oryginalny sposób scharakteryzować opisywane miejsce.

Odwoływanie do innych denotatów odbywa się poprzez zestawianie polskich i obcych nazw geograficznych (np. polski Manchester, mały Paryż). Do opisu miejsc używane są także nazwy innych związanych w jakiejś mierze obszarów lub obiektów (metropolia nad Bosforem, u stóp Wawelu). Novum jest tworzenie rozbudowanych peryfraz, które przybierają postać zdania.

Licznie reprezentowane są przydomki klubów sportowych i drużyn narodowych funkcjonujące równolegle z oficjalnymi nazwami. Mechanizm ich powstawania sprowadza się do wykorzystywania w peryfrazach odwołań do herbów, elementów umieszczonych w godłach, barw klubowych czy narodowych, kroju i koloru koszulek, w których występują zawodnicy, specyficznych cech geograficznych regionu, w którym siedzibę ma klub.

Wyrażenia omowne pojawiają się też w miejsce antroponimów i chrematonimów, nie są obojętne stylistycznie, niosą ze sobą pewien ładunek ekspresywny. Podobnie jest w przypadku przezwisk, które zastępują imiona i nazwiska.

Posługiwanie się strukturami funkcjonującymi w polszczyźnie oficjalnej pozwala zachować dystans między nadawcą a odbiorcą, wprowadzanie form socjolektalnych czy - zwykle nacechowanych - odpowiedników nazw własnych zrozumiałych tylko w określonym środowisku sprzyja pogłębianiu familiarnych relacji.

Godny uwypuklenia jest fakt, że analizowane struktury nierzadko mogą należeć do kilku opisywanych w niniejszej rozprawie kategorii, zastosowana klasyfikacja jest tylko jedną z możliwych i nie wyklucza innych rozstrzygnięć.

Nie wszystkie zaprezentowane pary synonimiczne są łatwe w deszyfracji, zdarza się, że zrozumienie rozbudowanej konstrukcji wymaga od czytelnika niemałego trudu interpretacyjnego. Informacja bywa z różnych przyczyn zakamuflowana i to odbiorca - wykorzystując często wiedzę pozajęzykową - musi dotrzeć do sensu, który autor w jakiś sposób przed nim ukrył. 



\section{Pragmatyka}

Pragmatyka bywa definiowana rozmaicie. Jak zauważa Katarzyna Jaszczołt: „W sensie najbardziej ogólnym, jest to nauka o «praktycznym» znaczeniu wypowiedzi, tzn. o ich znaczeniu w kontekście dyskursu"1. Przeglądu stanowisk różnych uczonych na temat pragmatyki dokonał Janusz Anusiewicz w pracy Wprowadzenie w problematykę pragmatyki lingwistycznej2. Analizował on też pierwotne znaczenie tego pojęcia oraz jego występowanie w słownikach języka polskiego. W tradycyjnym ujęciu Charlesa Morrisa pragmatyka pojmowana jest jako dział semiotyki badający relacje między znakami a ich użytkownikami. „W szerokim znaczeniu obejmuje takie aspekty użycia języka, jak komunikowanie, rozumienie, wyrażanie, motywacje psychologiczne mówiących, uwarunkowania społeczne komunikacji językowej”3. J. Anusiewicz podkreśla, że w tym rozumieniu „głównym celem pragmatyki jest dostarczenie użytkownikom języka praktycznej wiedzy o wartości środków językowych z uwagi na optymalną realizację zamiaru komunikatywnego nadawcy, czyli celu wypowiedzi, i w konsekwencji - efektywnego oddziałania na zachowanie się odbiorcy"4. Wśród kategorii pojęciowych istotnych w tym modelu wymienia się: nadawcę, odbiorcę,

1 K. Jaszczołt, Pomiędzy semantyką a pragmatyka, [w:] Metodologie językoznawstwa. Podstawy teoretyczne, red. P. Stalmaszczyk, Łódź 2006, s. 131.

2 J. Anusiewicz, Wprowadzenie w problematykę pragmatyki lingwistycznej, „Acta Universitatis Wratislaviensis. Studia Linguistica XII” 1988, s. 1-29.

3 Encyklopedia językoznawstwa ogólnego, red. K. Polański, Wrocław-WarszawaKraków 1993, s. 415.

4 J. Anusiewicz, op. cit., s. 8. 
tekst, społeczną i fizyczną sytuację aktu komunikacyjnego, odniesienie znaku językowego do obiektywnej, pozajęzykowej rzeczywistości, modalny, emocjonalny i intelektualny stosunek nadawcy i odbiorcy do tekstu będącego realizacją określonego systemu językowego, problem rozumienia i odbioru tekstu warunkowany czynnikami pozajęzykowymi - historycznymi, socjologicznymi, kulturowymi i stylistycznymi, ważnymi do odbioru tekstu, a zatem odbioru zamiaru nadawcy i realizacji celu, który nadawca przez odpowiednio optymalne skonstruowanie tekstu chce osiągnąć 5 .

Pragmatyka w ujęciu Georga Klausa ma za zadanie „badanie języka jako narzędzia i środka przekazu wszelkich informacji oraz ich wpływu na zachowanie odbiorców, na ich przekonania, postawy oraz poglądy, na uznany przez nich system wartości, na uczucia i emocje"6, koncentruje się na funkcjach: kumulatywnej, perswazyjnej, performatywnej i ekspresywnej.

Według Roberta Stalnakera przedmiotem badań pragmatyki są akty mowy oraz warunki, w których one się spełniają: „Stalnaker zadaniem pragmatyki czyni ustalenie i zdefiniowanie typów aktów mowy i produktów mowy oraz podanie tych wyróżników kontekstów sytuacyjnych, które określają bliżej zamiar nadawcy danego tekstu i pomagają go rozpoznać, jak też stwarzają warunki do spełnienia się aktów mowy"7.

Przywołując różne koncepcje, J. Anusiewicz dochodzi do wniosku, że można by oddzielić pragmatykę teoretyczną od empirycznej, pierwsza zajmowałaby się systemem językowym, druga zaś jednostkowymi aktami komunikacji językowej - konkretnymi użyciami języka, w relacjach do użytkowników języka, z uwzględnieniem kontekstu i konsytuacji ${ }^{8}$.

W centrum rozważań Dietera Wunderlicha znalazły się związki środków językowych z procesem komunikacji oraz „badanie tego, jaki wpływ ma użycie określonych środków językowych na reakcje, zachowanie i postępowanie odbiorców"9.

J. Anusiewicz zwraca także uwagę na kulturowy wymiar pragmatyki lingwistycznej - człowiek, nabywając umiejętność posługiwania się językiem,

\footnotetext{
5 Ibidem, s. 9.

6 Ibidem, s. 10.

7 Ibidem, s. 12-13.

8 Ibidem, s. 17.

9 Ibidem.
} 
przejmuje także wartościowanie rzeczywistości utrwalone w tym języku. Jak twierdzi, „istnieją w języku zobiektywizowane elementy systemu wartościowania (nie tylko emocjonalnego, ale i intelektualnego) rzeczy i zjawisk, właściwe i charakterystyczne dla określonych narodów, grup społecznych - społeczności językowych"10. Postuluje zatem utworzenie kulturowo-lingwistycznej koncepcji pragmatyki, w której będzie ona pojmowana jako „dyscyplina badająca zespół ocen, wartościowań, przekonań, poglądów oraz doświadczeń danej społeczności językowej, związanych z uogólnioną praktyką społeczną człowieka, a niesionych przez system języka, przekazywanych przyszłym pokoleniom oraz wpływających na ludzkie przekonania, systemy wartości i - co za tym idzie - postawy, działania, a więc na określoną ideologię"ll.

Krystyna Pisarkowa podkreśla, że fundamentalnym pojęciem pragmatyki językoznawczej jest powodzenie aktu komunikacji12. Wyróżnia cztery rodzaje funkcji pragmatycznej tekstu mówionego: ekspresywną - poszukiwanie kontaktu, perswazyjną - poszukiwanie sprzymierzeńca, deskryptywną - chęć poinformowania, metatekstową - motyw konstruktywny.

Stephen C. Levinson jest autorem książki ${ }^{13}$, która prezentuje angloamerykańskie postrzeganie pragmatyki, wywodzące się w dużej mierze z filozoficznych badań nad językiem. Przedstawia liczne definicje omawianego zjawiska, próbując ustosunkować się do każdej z nich i znaleźć słabe i mocne strony. Warto przywołać chociaż kilka. Badacz za niedoskonałe uznaje określenie: „pragmatyka zajmuje się badaniem zasad, które wyjaśnią, dlaczego pewne zdania mają charakter anomalny i nie mogą być poprawnie wygłoszone"14, przy czym jako wyjaśnianie anomalii rozumie „wskazanie, że nie istnieją zwyczajne konteksty, w których można ich [zdań - przyp. KB] poprawnie użyć"15. Mało precyzyjna - mająca bowiem wiele wspólnego z psycholingwistyką i socjolingwistyką - jest zdaniem S. Levinsona definicja mówiąca, że „pragmatyka obejmuje badania nad językiem prowadzone z perspektywy funkcjonalnej, to znaczy - próbuje objaśniać aspekty struktury językowej przez odniesienie do pozajęzykowych przyczyn

\footnotetext{
10 Ibidem, s. 21.

11 Ibidem, s. 21-22.

12 K. Pisarkowa, Pragmatyczna motywacja hipotaksy, [w:] Semantyka tekstu i jezyka, red. M. R. Mayenowa, Wrocław 1976, s. 203.

13 S. C. Levinson, Pragmatyka, przekł. T. Ciecierski, K. Stachowicz, Warszawa 2010.

14 Ibidem, s. 7.

15 Ibidem.
} 
i uwarunkowań"16. Wspomina, że w opinii niektórych uczonych przedmiotem badań są wyłącznie zasady rządzące użyciem języka z pominięciem opisu jego struktury. Zgodnie z tymi założeniami teoria pragmatyczna „w istotny sposób jest związana z ujednoznacznianiem zdań przez kontekst, w którym zdania te są wypowiadane"17, jednak autor opracowania zauważa, że konteksty w rzeczywistości pełnią bardziej rozbudowane funkcje, pozwalają tworzyć nowe interpretacje np. poprzez użycie ironii czy aluzji.

S. Levinson postuluje, żeby przy definiowaniu pragmatyki uwzględnić dwa zagadnienia: zależne od kontekstu aspekty struktury językowej oraz zasady rządzące użyciem wyrażeń mające niewiele wspólnego ze strukturą językową. Definicja informująca o włączeniu w zakres pragmatyki pewnych elementów znaczeniowych mogłaby - według amerykańskiego badacza - przedstawiać się następująco: „Pragmatyka obejmuje badanie tych aspektów znaczenia, które nie są opisywane przez teorię semantyczną"18. Wspomina się również, że dla pragmatyki ważne jest znaczenie w kontekście, podczas gdy semantyka zajmuje się znaczeniem poza kontekstem lub niezależnym od kontekstu. Dużą popularnością cieszy się definicja, u której podstaw leży zagadnienie stosowności lub fortunności. Głosi ona, że „pragmatyka obejmuje badania zdolności użytkowników języka do łączenia zdań z kontekstami, w których zdania te byłyby stosowne"19. Takie ujęcie ma swoich zwolenników zarówno wśród językoznawców, jak i filozofów, choć S. Levinson uważa je za zbyt ograniczające, ponieważ w zakres pragmatyki powinny być włączone mechanizmy, które pozwalają nadawcy zakomunikować więcej od tego, co rzeczywiście powiedział.

Piotr Stalmaszczyk dokonał zestawienia różnych definicji semantyki formalnej i pragmatyki, wskazał pięć typów ${ }^{20}$. Semiotyczną teorię pragmatyki reprezentuje przywoływany już w niniejszej pracy Ch. Morris. Koncepcję Richarda Montague i Roberta Stalnakera, którzy włączyli do badań kontekst użycia wyrażeń językowych, P. Stalmaszczyk nazywa kumulacyjną teorią pragmatyki, gdyż „dotyczy ona kumulowania poszczególnych relacji: w obrębie relacji pragmatycz-

\footnotetext{
16 Ibidem, s. 8.

17 Ibidem.

18 Ibidem, s. 13.

19 Ibidem, s. 27.

20 P. Stalmaszczyk, Semantyka formalna i pragmatyka: przegląd wybranych definicji, „Biuletyn Polskiego Towarzystwa Językoznawczego” 2008, z. LXIV, s. 9-24.
} 
nych zawarte są relacje semantyczne i składniowe, a w relacjach semantycznych zawarte są relacje składniowe"21. Elementami systemu pragmatyki formalnej w ujęciu R. Montague są zatem: wyrażenia językowe, desygnaty wyrażeń językowych, użytkownicy języka, kontekst użycia, relacje pomiędzy tymi elementami ${ }^{22}$. Delimitacyjna teoria pragmatyki, sformułowana przez Geralda Gazdara, głosi, że „pragmatyka zajmuje się tymi aspektami znaczenia wypowiedzi, których nie można jednoznacznie ustalić przez odwołanie się do warunków prawdziwości"23. Ujęcie Romana Kalisza zakładające, że pragmatyka to dziedzina językoznawstwa „zajmująca się skutecznym działaniem człowieka poprzez użycie środków językowych" 24 , zostało nazwane przez autora opracowania prakseologiczną teorią pragmatyki. Ostatni wyróżniony typ to pragmatyka mentalna, jej reprezentantami są Robyn Cartson (określająca pragmatykę jako zdolność umysłu do interpretowania ludzkiego zachowania komunikacyjnego) i Kent Bach (twierdzący, że pragmatyka „wnosi wkład nie w to, co zostało powiedziane, ale tylko w decyzję mówiącego na temat tego, co mówca ma na myśli, przy założeniu, że powiedział to, co powiedział"25). Jej prekursorem jest polski logik Kazimierz Ajdukiewicz.

Na temat różnych koncepcji pragmatyki wypowiedziała się także Renata Grzegorczykowa podczas wystąpienia zatytułowanego O różnych rozumieniach pragmatyki w językoznawstwie w ramach konwersatorium Kierunki współczesnej semantyki prowadzonego na Uniwersytecie Warszawskim ${ }^{26}$. Podkreśliła trudności w definiowaniu tego pojęcia, wskazując, że niejednokrotnie jest ono rozmyte i niejednoznaczne. Badaczka omawia trzy główne możliwości rozumienia tego zagadnienia, każda z nich jest swoistą adaptacją myśli Ch. Morrisa. Po pierwsze, pragmatyka może być pojmowana jako informacje charakteryzujące uczestników komunikacji, czyli nadawcę i odbiorcę; zalicza się tutaj elementy ekspresywne,

21 Ibidem, s. 14.

22 Ibidem, s. 15.

23 Ibidem.

24 R. Kalisz, Pragmatyka językowa, Gdańsk 1993, s. 9, cyt za: P. Stalmaszczyk, op. cit., s. 17.

25 K. Bach, Context ex Machina, [w:] Semantics versus Pragmatics, red. Z. G. Szabó, Oxford 2005, s. 42, cyt. za: P. Stalmaszczyk, op. cit., s. 17.

26 R. Grzegorczykowa, O różnych rozumieniach pragmatyki w językoznawstwie, wykład wygłoszony 02.10.2013, http://www2.polon.uw.edu.pl/ZBG/ [dostęp: 27.05.2014]. 
postawy modalne, asocjacje semantyczne ${ }^{27}$. Po drugie, pragmatyka to reguły użycia wyrażeń zależne od sytuacji komunikacyjnej (tzw. kompetencja pragmatyczna rozmówców). R. Grzegorczykowa podkreśla, że „w tym ujęciu reguły pragmatyczne decydują o przystosowaniu się zachowania językowego do sytuacji komunikacyjnej, określają wybór odpowiedniego środka językowego spośród zagadnień synonimicznych"28. W szerszej perspektywie pragmatykę można rozumieć jako wszelkie reguły określające zachowanie językowe człowieka. Trzecie ujęcie postuluje pojmowanie pragmatyki jako studium działania językowego. Uczona zalicza tu - zgodnie z założeniami teoretyków nurtu generatywnego - zasady używania języka, „wszystko, co w interpretacji wypowiedzi zależy od kontekstu, sytuacji komunikacyjnej, wiedzy i intencji mówiących"29. Nowe rozumienie - zdaniem R. Grzegorczykowej - najlepiej oddają słowa: „wszystko, co nie zostało powiedziane za pomocą użytego kodu językowego, uznaje się za informację należącą do pragmatyki"30. Zaklasyfikowała tutaj następujące obszary ${ }^{31}$ : odczytanie okazjonalizmów dotyczących referencji użytych grup nominalnych (w tym przede wszystkim nazw własnych), określeń czasu i miejsca; odczytanie aktualnej intencji wypowiedzi (siły alokucyjnej); odczytanie implikatur, a więc tego, co nadawca chce przekazać poza znaczeniem dosłownym, poprzez złamanie tzw. zasad konwersacji; interpretacja wypowiedzi zależna od wiedzy kulturowej, encyklopedycznej i faktograficznej odbiorcy; indywidualne przeżycia odbiorcy wywołane usłyszeniem wypowiedzi.

Badaczka zwraca także uwagę na obszary pograniczne między pragmatyką a semantyką. Włączyć tu można „odczytania znaczeń niedosłownych, wypracowanych przez odbiorcę na podstawie kodu, wiedzy o świecie i wiedzy o sytuacji komunikacyjnej"32, problem interpretacji frazeologizmów, odczytywanie wieloznaczności opartej na metonimii i metaforze, niedosłowność związaną z zagadnieniem metonimii, rozumienie wypowiedzi uzależnione od indywidualnej wiedzy i przekonań rozmówców czy interpretację znaczeń konotacyjnych.

\footnotetext{
27 Ibidem, s. 3.

28 Ibidem, s. 4.

29 Ibidem, s. 5.

30 Ibidem.

31 Ibidem, s. 5-6.

32 Ibidem, s. 9.
} 
R. Grzegorczykowa proponuje ostatecznie, by termin pragmatyka odnosił się do dwóch zjawisk: 1) „To wszystko, co w akcie komunikacji językowej warunkowane jest sytuacją mówienia i indywidualną wiedzą rozmówców”33, 2) „Reguły zachowań językowych (kompetencja pragmatyczna mówiących) określające językowy sposób współżycia społecznego (językowego «bycia wśród ludzi»), a więc wybór odpowiednich słów, wyrażeń językowych "pasujących» do sytuacji, w tym przede wszystkim formuł grzecznościowych" 34 .

W innym artykule badaczka ta odniosła się do różnic między semantyką a pragmatyką: „Oddzielenie tego, co powiedziane, od tego, co wnioskowane, stanowi podstawę oddzielenia semantyki (informacji przekazywanej przez kod) od pragmatyki (informacji wynikającej z użycia kodu)"35. Ważną kategorią pragmatyczną, która występuje w większości wymienionych ujęć, jest kontekst.

\section{Kontekst}

Do zgodnego z intencją nadawcy odczytania - o czym już wspominano w niniejszej rozprawie - często niezbędny jest kontekst. Encyklopedia językoznawstwa ogólnego przytacza następującą jego definicję: „Element lub zespół elementów występujących w tekście bezpośrednio przed daną jednostką (fonemem, morfemem, wyrazem, składnikiem, zdaniem) i bezpośrednio po niej. Pod wpływem kontekstu jednostka może ulegać różnym modyfikacjom, i to na wszystkich płaszczyznach języka”36. W Encyklopedii języka polskiego czytamy z kolei: „Chodzi o otoczenie językowe lub sytuacyjne. W tym drugim znaczeniu używa się też terminu konsytuacja”37. Przez pojęcie konsytuacji rozumie się „warunki, w których odbywa się dany akt mówienia"38, zalicza się do nich: miejsce i czas aktu mówienia, przynależność społeczną mówiącego i słuchającego, rodzaj kontaktu między uczestnikami. Autorzy przytaczają też definicję kontekstu (sytuacji) aktu

33 Ibidem, s. 12.

34 Ibidem.

35 R. Grzegorczykowa, Problem funkcji języka i tekstu w świetle teorii aktów mowy, [w:] Język a kultura, t. 4: Funkcje języka i wypowiedzi, red. J. Bartmiński, R. Grzegorczykowa, Wrocław 1991, s. 12.

36 Encyklopedia językoznawstwa..., s. 185.

37 Encyklopedia jezyka polskiego, red. S. Urbańczyk, Wrocław-Warszawa-Kraków 1994, s. 168.

38 Ibidem. 
mowy: „rozumiany jako suma okoliczności towarzyszących wypowiedzi, czyli jej tło pozajęzykowe, odgrywa ważną rolę, bo współdecyduje o skutkach tej wypowiedzi, a jeśli jest to wypowiedź wykonawcza, o udatności, czyli powodzeniu całego aktu mowy"39. W jego skład wchodzą czynniki fizyczne, społeczne i merytoryczne. Wyjaśnienie to zbliżone jest zatem do hasła znajdującego się przy konsytuacji. Jadwiga Puzynina, analizując czynniki wpływające na rozumienie tekstu literackiego, przywołuje rodzaje kontekstów pomocnych w tym procesie: językowe (składniowe, leksykalne i frazeologiczne), parajęzykowe (interpunkcyjne), treściowe (w tym dotyczące świata przedstawionego), strukturalne (odnoszące się do struktury formalno-treściowej danego tekstu, m.in. związane z gatunkiem i stylem tekstu), intertekstowe, społeczno-kulturowe (w tym dotyczące świata przedstawionego) i dotyczące osoby autora (psychologiczne, światopoglądowe, biograficzne ${ }^{40}$. Konteksty językowe, parajęzykowe, treściowe i strukturalne mogą być rozpatrywane jako bliskie - tj. w obrębie danego tekstu, autorskie - tj. charakterystyczne dla danego autora i ogólne - tj. charakterystyczne dla współczesnych autorowi tekstów, inaczej mówiąc dla normy językowej danej epoki ${ }^{41}$.

Sebastian Przybyszewski przywołuje stanowiska badaczy na temat wpływu kontekstu na znaczenie. Wskazuje, że Jerrold Katz i Jerry Fodor, „nie negując ważności czynników kontekstowych dla interpretacji rzeczywistych wypowiedzi - twierdzą, że semantyka interesuje znaczenie niezależnie od kontekstu"42. Przeciwnego zdania jest John Firth, „dla którego nie istnieje semantyka nieuwzględniająca kontekstu"43.

Niektórzy postulują istnienie kontekstu zerowego, zwanego inaczej neutralnym, który „nie jest konieczny, by zrozumieć znaczenie jednostki lub określić jej kształt formalny"44, definiuje się go jako „znaczenie badanej jednostki przypisywane jej przez rodzimego użytkownika języka w sytuacji, gdy nie dysponuje on

39 Ibidem, s. 169.

40 J. Puzynina, Kontekst a rozumienie tekstu, [w:] Polska genologia lingwistyczna, red.

D. Ostaszewska, R. Cudak, Warszawa 2008, s. 258-259.

41 Ibidem.

42 S. Przybyszewski, Kontekst w badaniach nad językiem, „Media. Kultura. Komunikacja Społeczna” 2009, nr 5, s. 80.

43 Ibidem.

44 B. Hałas, A. Wojciechowska, Kontekst a innowacje leksykalne w prasie, „Poradnik Językowy" 1999, z. 8-9, s. 65. 
żadnymi informacjami dotyczącymi kontekstu, w jakim dana jednostka została użyta"45.

Zbigniew Nęcki i Aleksy Awdiejew wyróżnili cztery typy kontekstów46: semantyczny (językowy) - obejmujący wszystkie wypowiedzi poprzedzające akt komunikacji oraz wypowiedzi późniejsze wpływające na jego interpretację, a także zachowania niewerbalne towarzyszące aktowi komunikacji; interpersonalny - uwzględniający pozycję nadawcy i odbiorcy, odwołujący się do interakcji społecznych; zadaniowy (instrumentalny) - odwołujący się do działalności pozajęzykowej; kulturowy - odnoszący się do wspólnoty doświadczeń pozajęzykowych. S. Przybyszewski proponuje rozpatrywanie kontekstu na trzech płaszczyznach: poziomie samego tekstu, poziomie interakcji między wypowiedzią a najbliższym otoczeniem oraz z uwzględnieniem ponadsytuacyjnych i ponadjednostkowych warunków wpływających na znaczenie wypowiedzi ${ }^{47}$.

Przeglądu różnych stanowisk w zakresie rozumienia kontekstu dokonały też Bożena Hałas i Anna Wojciechowska, które badając innowacje leksykalne w prasie, posługują się tym pojęciem „w odniesieniu do okoliczności towarzyszących wypowiedzi, czyli jej tła pozajęzykowego, pozajęzykowych uwarunkowań znaczenia tekstu" 48 .

Inne rozumienie terminu kontekst obecne jest w kognitywizmie. Jak pisze P. Stalmaszczyk: „W teorii relewancji kontekst określa się raczej jako zbiór przesłanek używanych przy interpretacji wypowiedzi, czyli konstrukt psychologiczny, oraz jako podzbiór założeń na temat świata"49. S. Przybyszewski podkreśla, że "problem kontekstu sprowadzony jest do kognitywnych procesów dokonujących się w umysłach rozmówców. Z punktu widzenia wspomnianej teorii nadawca, tworząc wypowiedź, zakłada, że odbiorca dysponuje informacjami kontekstualnymi niezbędnymi do interpretacji wypowiedzi. Natomiast założenie, że odbiorca dysponuje wspomnianymi informacjami jest konsekwencją założenia, że taka wiedza jest w danym momencie dostępna"50.

45 S. Przybyszewski, op. cit., s. 80.

46 Z. Nęcki, Komunikacja międzyludzka, Kraków 2001, s. 92-97.

47 S. Przybyszewski, op. cit., s. 82. Odwołuje się tutaj do rozróżnienia na kotekst, konsytuację i kontekst kulturowy, które zaproponowała B. Boniecka w artykule Tekst w kontekście, „Polonica” 1994, s. 43-67.

48 B. Hałas, A. Wojciechowska, op. cit., s. 66.

49 P. Stalmaszczyk, op. cit., s. 18.

50 S. Przybyszewski, op. cit., s. 86. 
W wypowiedziach pisanych trudniej jest badać właściwości pragmatyczne niż w żywej mowie, nie da się rzecz jasna uwzględnić wszystkich wymienionych wyżej czynników kontekstowych. Co oczywiste, odbiorca nie ma możliwości dopytania nadawcy, musi bazować tylko na tym, co uda mu się wydobyć z tekstu. $\mathrm{Na}$ takich założeniach będzie się opierała analityczna część rozdziału poświęconego pragmatyce.

Otoczenie leksykalne jest niezwykle istotne zwłaszcza wtedy, gdy jedna konstrukcja syntetyczna może mieć kilka wielowyrazowych odpowiedników. Wówczas sąsiedztwo innych wyrazów naprowadza odbiorcę na właściwy tok interpretacji. Na przykład w tekstach prasowych wykorzystywane są dwa należące do terminologii sportowej znaczenia czasownika strzelić - odwołujące do oddać strzał i strzelić bramkę, dwa odpowiedniki ma także ławka - ławka rezerwowych i ławka trenerska.

Już w siódmej minucie po faulu Matysika Boy strzela z wolnego w okno. (PN 6/2012, s. 47)

Cesc strzelił dwa gole i zakończył w ten sposób ośmiomiesięczną passę bez zdobyczy bramkowej - poprzednio strzelił 8 lutego w pucharowym meczu z Valencią. (PN 50/2012, s. 21)

Przez następne 38 lat nie zdarzyło się, aby na ławkach klubów ekstraklasy zasiadało trzech menedżerów, którzy mają przynajmniej dziesięcioletni staż. (PN 12/2012, s. 19) Houlier ze swej strony trochę spuścił z tonu, twierdząc, że to on wprowadził Ginolę z lawki. (PN 13/2012, s. 20)

Po 4165 dniach przerwy na ławce w meczu Bundesligi zasiadł Otto Rehhagel. (PN 10/2012, s. 39)

Po pierwszej części sezonu Lennon po prostu nie ma zbyt wielu argumentów, by któregoś z nich posadzić na lawce. (PN 6/2012, s. 41)

Podczas World Cup w RPA wszedł raz z lawki w meczu z Chile. (PN 36/2012, s. 31) Rezerwowi czekają na ławce. (VG 3/2011, s. 18)

Ważność kontekstu ujawnia się też w przypadku, gdy syntetyzm jest tożsamy z istniejącym już w języku wyrazem, a więc wówczas, gdy mamy do czynienia $\mathrm{z}$ polisemią ${ }^{51}$. Elementy pojawiające się $\mathrm{w}$ wypowiedzi obok takiego leksemu po-

$51 \mathrm{O}$ wieloznaczności konstrukcji syntetycznych pisali szczegółowo w cytowanych kilkakrotnie w tej pracy monografiach J. Miodek i E. Szczepańska. 
zwalają naprowadzić na jedno z kilku użyć lub wydobyć jego nowe - nierzadko metaforyczne lub metonimiczne - znaczenie. Jako przykłady mogą posłużyć: czerwień - kolor i czerwona kartka; doping - zagrzewanie do walki i środki dopingujące; energetyk - osoba pracująca w zakładzie energetycznym i napój energetyczny; główka - zdrobnienie od wyrazu głowa i strzał głową; komórka - podstawowy element budowy organizmów roślinnych lub zwierzęcych, niewielkie pomieszczenie służące jako spiżarnia, skład opału itp., mały, ciemny pokoik, najmniejsza jednostka organizacyjna w przedsiębiorstwie lub organizacji społecznej albo politycznej, przegroda $\mathrm{z}$ wosku o sześciokątnym przekroju, będąca zasadniczą częścią plastra pszczelego, część jakiegoś urządzenia stanowiąca najmniejszy, czasem podstawowy jego element i telefon komórkowy ${ }^{52}$; kryminat - więzienie i powieść kryminalna; młodzieżowiec - aktywny członek organizacji młodzieżowej, starszy mężczyzna ubierający się młodzieżowo i zawodnik w wieku od 21 do 23 lat ${ }^{53}$; młodzieżówka - frakcja młodych w jakiejś organizacji, starsza kobieta ubierająca się młodzieżowo i kadra sportowa skupiająca zawodników w wieku od 21 do 23 lat ${ }^{54}$; róg - część ciała u zwierząt, instrument muzyczny, ostry koniec czegoś, kant, zbieg dwóch ulic i rzut rożny; strona - prawy albo lewy bok czegoś, płaszczyzna kartki w książce, zeszycie itp., aspekt czegoś, kierunek, określone terytorium, uczestnik sporu, procesu, zatargu, forma czasownika wyrażająca stosunek podmiotu do orzeczenia i strona internetowa (informacje umieszczone w Internecie pod jakimś adresem) ${ }^{55}$; źóltko - środek jaja ptasiego otoczony białkiem i żółta kartka. Zobrazujmy to konkretnymi użyciami w tekście:

Co prawda w drugim meczu fazy grupowej już nie zdołał powtórzyć strzeleckiego wyczynu i na placu gry przebywał do 76 minuty, jednak w tym czasie mocno się musiał nabiegać, bo od 9 minuty rywale grali z przewagą zawodnika (czerwień ujrzał Tunezyjczyk Karim Haggui). (PN 41/2012, s. 32)

Za kierownicą na dopingu. (NŻ 9/2012, s. 31)

Golkiper Bogdanki Sergiusz Prusak odbił główkę Szymona Kaźmierowskiego, ale przy dobitce Michała Świderskiego był bezradny. (PN 36/2012, s. 41)

52 Definicje komórki za: Mały słownik języka polskiego, red. E. Sobol, Warszawa 2000, s. 343.

53 Definicje młodzieżowca za: http://sjp.pwn.pl/szukaj/m\%C5\%82odzie\%C5\%BCowiec [dostęp: 14.06.2014].

54 Definicje młodziė̇ówki za: http://sjp.pwn.pl/szukaj/m\%C5\%82odzie\%C5\%BC\%C3\% B3wka [dostęp: 14.06.2014].

55 Definicje strony za: Mały słownik..., s. 965-966. 
Dla mnie najgorszą rzeczą jest brak komórki. (PN 33/2012, s. 31)

Na przerwach gadał przez komórkę albo o czymś intensywnie myślał. (VG 6/2011, s. 8)

Paweł przez ten czas z komórką przy uchu nastawia ekspres, a potem pije kawę. (P 13/2012, s. 103)

Czasy, kiedy kryminały uważano za „literaturę wagonową”, niezbyt wyrafinowaną rozrywkę czytelniczą, którą nie należy się zbytnio przed nikim chwalić, na szczęście odeszły już w niepamięć. (P 24/2012, s. 95)

Zamiast utrzymać ją w tej okolicy, czyli osłaniać lub ewentualnie spróbować wywalczyć róg lub aut, wstrzelił futbolówkę w pole karne. (PN 13/2012, s. 20)

Mamy róg. (PN 24/2012, s. 7)

Gdynianie wygrali 2:0, kontrowersje wywołał jednak przepis o młodzieżowcu i rzekomym niedopilnowaniu przez gospodarzy, by przez pełne dziewięćdziesiąt minut przebywał zawodnik spełniający odpowiednie kryteria. (PN 33/2012, s. 16-17)

Występował w naszej drużynie U-16, ale potem wybrał niemiecką młodzieżówkę. (PN 49/2012, s. 33)

Gra przecież w mistrzowskim zespole jednej z najsilniejszych lig świata, a całkiem niedawno zakończył dopiero wiek młodzieżowca - ocenia trener naszej młodzieżówki i ekspert w dziedzinie Bundesligi, Stefan Majewski. (PN 6/2012, s. 13)

Dzięki przenośnym komputerom osobistym czy odtwarzaczom multimedialnym możesz czytać e-booki, słuchać audiobooków czy przeglądać strony w wybranym języku w autobusie, w poczekalni u dentysty czy gdziekolwiek zechcesz. (VG 21/2012, s. 15)

Kilkanaście sekund później Joel Zuniga uderzył w brzuch Sebastiana Giovinco i obejrzał drugie żółtko. (PN 33/2012, s. 27)

Wypadł ze składu Vrdoljak, kontuzjowany jest Michał Żewłakow, a Artur Jędrzejczyk ma na koncie dwa żółtka. (PN 33/2012, s. 36)

Część wyrazów wieloznacznych odwołuje się do różnych znaczeń wydobywających skojarzenia z cyframi - i tutaj też kontekst decyduje o właściwej deszyfracji, np. jedenastka - liczba 11, coś oznaczonego numerem 11, drużyna składająca się z jedenastu graczy, rzut karny w piłce nożnej56; setka - liczba sto, coś złożonego ze stu jednostek, coś oznaczonego numerem 100 oraz wiele znaczeń potocznych:

56 W tym przypadku sformułowanie jedenastka odnosi się do 11 metrów - odległości, z jakiej zawodnik wykonuje rzut karny. 
banknot stuzłotowy, tkanina zawierająca 100\% wełny, dziesiąta część litra wódki, mapa sporządzona w skali 1:100, bieg na 100 metrów czy stuprocentowa sytuacja; szesnastka - liczba 16, coś oznaczonego numerem 16, wartość rytmiczna dźwięku równa połowie wartości ósemki, pole karne w piłce nożnej.

Jedenastkę pewnie wykorzystał Diego. (PN 50/2012, s. 27)

Sędzia Robert Małek nie ustrzegł się rażących pomyłek, na pewno mniejszym błędem byłoby podyktowanie jedenastki dla zespołu Tomasza Kafarskiego (za faul Rafała Gikiewicza na Piotrze Wiśniewskim) niż niedostrzeżenie, iż po rzucie rożnym Marek Wasiluk niedopuszczalnie staranował bramkarza przyjezdnych, młodziutkiego Wojciecha Pawłowskiego. (PN 44/2011, s. 2)

A wcześniej setkę, w której wielu powinien uderzać lewą, a nie prawą nogą. (PN 41/2012, s. 7)

Kaczmarek oddał mu futbolówkę, a Stępiński ośmieszył w szesnastce Piotra Malarczyka i pewnym uderzeniem zdobył bramkę. (PN 49/2012, s. 40)

Znajomość większego fragmentu tekstu przydaje się także wówczas, gdy krótkie formy mają postać neologizmów. Bez zapoznania się z tematyką artykułu oraz występującymi w nim analitycznymi konstrukcjami inteligencja etosowa, egzamin humanistyczny czy burżuazja kredy towa trudno byłoby przeciętnemu czytelnikowi odgadnąć znaczenie syntetyzmów etosowiec, human i kredytowiec. Dziennikarz, używając najpierw rozbudowanych odpowiedników, daje jasną podpowiedź, która pomaga odbiorcy właściwie zinterpretować nienotowaną wcześniej formę.

Biznesokraci, etosowcy i kredytowcy. (P 51-52/2012, s. 55)

Jak to było na humanie... (VG 10/2011, s. 40)

Również formy wielowyrazowe mogą zyskać nowe znaczenie dzięki umieszczeniu ich w konkretnym otoczeniu leksykalnym. Tak jest w przykładzie na świeżym powietrzu, który dopiero w kontekście może zostać - zgodnie z zamierzeniem dziennikarza - odczytany jako na wolności.

Obaj pozowali na nieprzejednanych szeryfów i zbawicieli, tymczasem L. został skazany prawomocnym wyrokiem za korupcję, zaś T. musiał w minionym tygodniu wpłacić gigantyczną kaucję, żeby nadal przebywać na świeżym powietrzu. (PN 48/2011, s. 2) 
Zapoznanie się z tekstem niezbędne jest do rozszyfrowania eufemistycznych struktur analitycznych nie wrócić do domu i czarować w innym, lepszym ze światów. Ich dosłowne potraktowanie, czyli odczytanie w izolacji, bez przyjrzenia się poprzedzającym te zdania fragmentom wypowiedzi, prowadziłoby do nieścisłości, a wręcz - dezinformacji.

Do domu nie wróciło 96 kibiców, w tym wiele dzieci. (PN 6/2012, s. 6) Teraz Czarodziej z narożnika będzie czarował już w innym, lepszym ze światów... (PN 11/2012, s. 5)

Jednoznaczna interpretacja jest utrudniona w przypadku połączeń, które mimo iż składają się z kilku komponentów, są mało precyzyjne, ponieważ poszczególne elementy mają tak szeroki zakres, że mogą wskazywać na różne desygnaty. Jednocześnie w takich sytuacjach podważeniu ulega teza o większej precyzji konstrukcji złożonych od ich jednoelementowych odpowiedników. Zaliczyć tu można chociażby takie struktury, jak: 1,2 mln zł na kołach, ekstraklasowy klub z siedzibą w centralnej części Polski, nasz reprezentacyjny obiekt.

Obsługa ocenia, czy to potencjalny klient, czy może zwykły miłośnik motoryzacji, który chce tylko z bliska zobaczyć, jak wygląda $\mathbf{1 , 2}$ mln zł na kołach. (P 51-52/2012, s. 54) Tragiczna sytuacja w zespole ŁKS spowodowała, że od kilku dni jesteśmy świadkami ogólnospołecznej zrzutki pieniężnej na rzecz wsparcia ekstraklasowego klubu z siedzibą w centralnej części Polski. (PN 5/2012, s. 47)

Nigdy nie przepadałem za cyrkowymi występami, ale sytuacja z naszym reprezentacyjnym obiektem, czyli Stadionem Narodowym, przypomina kiepski spektakl pod namiotem albo rozsuwanym dachem, jak kto woli. (PN 7/2012, s. 47)

Kontekst odgrywa znaczącą rolę także w alternatywnych nazwach własnych. Bywa, że taka sama konstrukcja opisowa odnosi się do kilku obiektów, czytający musi zatem uważnie śledzić tekst, by nie pomylić opisywanych miejsc. Tak jest np. z Łodzią i Manchesterem, które są nazywane miastem włókniarzy, peryfraza mały Paryż może mieć aż trzy odpowiedniki: rumuński Bukareszt, polski Mikstat oraz szwajcarską Genewę 57 .

57 Por. S. Kałuski, T. Komornicki, Słownik niekonwencjonalnych nazw geograficznych, Warszawa 1996, s. 76. 
Wychowankowie - Michał Łabędzki, Marek Saganowski, Rafał Kujawa czy Artur Gieraga - mogą chodzić po mieście włókniarzy z podniesionymi głowami. (PN 20/2012, s. 18)

Drugi potentat z miasta włókniarzy - United - też nie zaszalał na rynku transferowym. (PN 6/2012, s. 30)

Kiedyś był piękny, określany nawet mianem „małego Paryża”. (VG 8/2011, s. 23)

Uważne wczytanie się w treść artykułu ułatwia także interpretację przydomka Górale, który może nazywać graczy zarówno z klubu mającego swoją siedzibę w Polsce, jak i na Wyspach Brytyjskich. Podobnie jest $\mathrm{z}$ formą zuniwerbizowaną Narodowy, która ma dwa analityczne odpowiedniki: Stadion Narodowy i Teatr Narodowy.

Legia, grając słabo, zrewanżowała się Góralom za jesienną porażkę. (PN 11/2012, s. 38)

Łukasz Załuska spędził cały mecz z Góralami na ławce, zaś Paweł Brożek nie znalazł się w kadrze meczowej. (PN 6/2012, s. 42)

Czy ten karny na Narodowym to najważniejszy moment w życiu Przemysława Tytonia? (PN 24/2012, s. 13)

W ciasnym foyer Narodowego zasiadali Zbigniew Zapasiewicz i Ignacy Gogolewski, świece donosiła Danuta Szaflarska. (P 51-52/2012, s. 129)

Syntetyczne nazwy własne osobowe bywają tożsame z wyrazami pospolitymi, dopiero umiejscowienie ich w konkretnym otoczeniu leksykalnym sprawia, że odbiorca utożsamia je z osobami. Naprowadzić może także na pewno grafia - zapis wielką literą.

- Trochę dziwnie się czuję - powiedział zasmucony Dziekan. (PN 33/2012, s. 3)

Czy właśnie dlatego Jelonek postanowił nie wykorzystać prezentu i spudłował z 11 metrów? (PN 49/2012, s. 10)

Jodła ratownik (PN 50/2012, s. 41)

Wytyka im, że wcześniej skreślili Kałużę, który w takiej formie jak w Wiedniu, wciąż jest reprezentacji potrzebny. (PN 41/2012, s. 14)

Turcy i Hiszpanie chcą Kosę! (PN 48/2012, s. 8)

To jednak Zbyszek Boniek będzie decydował o jej tematyce i zakresie obowiązków, jakie mi ewentualnie powierzy - powiedział „PN” Listek. (PN 49/2012, s. 13) 
Mały daje radę! (PN 44/2012, s. 10)

Dla Młynka to nie pierwszyzna. (PN 50/2012, s. 10)

Nieśmiały „Niedźwiedź” nie był zdobywcą - to jego kolega Karol został mężem Aliny. (NŻ 7/2012, s. 44)

- Ryba, fajny utworek - mówili. (NŻ 12/2012, s. 46)

Jeśli nie, to w miejsce Sagana trzeba będzie sprowadzić napastnika. (PN 48/2012, s. 7)

Lżony z trybun Ślusarz zaproponował kibicowi, by ten zszedł do niego na murawę. (PN 48/2012, s. 12)

Mam oczywiście swoje powody, żeby Świra nie lubić, ale tym razem nie zamierzam urządzać osobistych wycieczek. (PN 7/2012, s. 2)

Na szczęście mają ciemnoskórego Prezesa, który staje się kolekcjonerem drobiu. (PN 11/2012, s. 37)

Przyczyn wzrostu notowań Polaków na międzynarodowym rynku pracy Doktor upatruje w znacznej poprawie szkolenia w polskich klubach. (PN 6/2012, s. 13)

Dla 64-letniego Generała tak się zakończyła kariera trenerska. (PN 17/2012, s. 27)

Pierwsi byli Mario Balotelli i Davide Santon jeszcze z czasów gry w Interze, w tym sezonie wystrzelił Marco Veratti z Paris SG, nieco uśpiony czeka na eksplozję Mattia Destro z Romy, ale obecnie najwyżej stoją akcje Faraona. (PN 45/2012, s. 29)

Zwany z racji wyglądu Księgowym nie będzie miał łatwego życia na Stamford Bridge. (PN 48/2012, s. 23)

No, chyba że Nestor wcześniej znajdzie pracę. (PN 36/2012, s. 3)

Równie niskie jest prawdopodobieństwo, że Sfinks do defensywy cofnie Sergio Busquetsa. (PN 20/2012, s. 27)

Tato strzela pierwszego gola już w 10 minucie, potem rządzi w środku boiska, przestawia rywali. (PN 41/2012, s. 14)

Anna Gniedziejko, u której Wódz kupuje czasem jajka, wspomina, że dał jej w prezencie kalendarz ze zdjęciami zwierząt. (P 51-52/2012, s. 164)

Niektóre przezwiska mają taką samą formę jak inne nazwy własne. Również i w tym przypadku niezbędny jest kontekst, a często także kompetencje wykraczające poza sam język - obeznanie w otaczającej rzeczywistości, a w szczególności w problematyce, którą podejmuje artykuł.

Ale do jakiego zagranicznego klubu trafi Jankes, przekonamy się zapewne dopiero w letnim oknie transferowym. (PN 6/2012, s. 19) 
Minął jednak rok i Janosik przypomniał sobie o defensywnym pomocniku. (PN 41/2012, s. 14)

A dla Kazimiery to w ogóle nie był dobry czas. (PN 6/2012, s. 47)

Reksio będzie straszył (PN 36/2012, s. 10-11)

Ale tak jak i Tomek, on również raz skapituluje; po rzucie wolnym Djorkaeffa na trzy minuty przed końcem meczu. (PN 33/2012, s. 47)

Warto zasygnalizować też prawdopodobieństwo szybkiej dezaktualizacji niektórych wymienionych w pracy jednostek leksykalnych. Struktury wielowyrazowe największy portal społecznościowy, najbardziej pożadane złote statuetki na świecie, największy kraj muzułmański, najdroższy obiekt piłkarski w Polsce są trafnie odczytywane tu i teraz, z biegiem lat mogą jednak odnosić się do innych desygnatów, gdyż wchodzące w ich skład przymiotniki w stopniu najwyższym nie są na stałe przypisane odpowiednio do Facebooka, Oskarów, Indonezji, Stadionu Narodowego w Warszawie, mogą za jakiś czas wskazywać na zupełnie inne obiekty i miejsca. Zapoznanie się z otoczeniem leksykalnym odgrywa tu zatem niezwykle ważną rolę.

Aby właściwie zinterpretować przekaz medialny, czytelnik nierzadko musi wykazać się wiedzą pozajęzykową. R. Grzegorczykowa pisze: „Zauważmy, że współczesne teksty publicystyczne pełne są tego typu aluzji, często odwołujące się do faktów efemerycznych, które jednak warunkują rozumienie wypowiedzi, sprawiając, że osoby «niewtajemniczone» w kod kulturowy, nie mające wiedzy o tych faktach, zostają wyłączone z komunikacji" ${ }^{58}$. Wydaje się, że dotyczy to nie tylko publicystyki, ale też innych gatunków obecnych w polskich czasopismach.

Niemałe kompetencje wymagane są od odbiorcy, który natrafia na artykuł wypełniony peryfrazami odwołującymi się do nazw własnych. I choć zwykle ornamentacyjne wyrażenia omowne stosowane są w konkretnym tekście wymiennie ze słownikowymi odpowiednikami, to jednak nie zawsze odgadnięcie, na jaki desygnat powołuje się autor, jest proste. Znajomość geografii, nierzadko dość szczegółowa, przydaje się podczas deszyfracji wielowyrazowych połączeń z komponentami stolica, kraj, perła, metropolia, do których dołączane są toponimy, np.:

58 R. Grzegorczykowa, op. cit., s. 6. 
W stolicy Podlasia dobiegł końca konflikt ultrasów z organizatorami masowych imprez sportowych, za jakie zgodnie z ustawą uznawane są mecze piłkarskiej ekstraklasy. (PN 49/2012, s. 14)

Jeden z nich dotyczy piłkarzy i trenera w kraju nad Sekwaną. (PN 13/2012, s. 20)

Dubrownik - perła Adriatyku. (VG 12/2011, s. 20)

Od trzech lat tereny nieczynnej Kopalni Węgla Kamiennego Katowice położone w samym centrum Katowic, stolicy Górnego Śląska, są prawdziwą Mekką dla wszystkich miłośników nowych brzmień elektronicznych. (VG 16/2012, s. 4)

Jeśli chodzi o stolicę Siedmiogrodu, znacznie lepiej wiedzie się szczególnie w XXI wieku zespołowi CFR. (PN 49/2012, s. 11)

Bo nie dość, że włoski szkoleniowiec, który uchodzi za konesera dzieł sztuki, zdecydował się na stolicę Małopolski, to jeszcze spodobał mu się hotel położony o rzut kamieniem od Rynku Głównego. (PN 46/2011, s. 38)

Jednak przeważającym czynnikiem była chyba trudna adaptacja w specyficznym otoczeniu klubu ze stolicy Bawarii. (PN 17/2012, s. 28)

O to samo chciałbym zapytać odpowiedzialnych za arbitrów i asystentów w pięknym kraju nad Wisłą. (PN 49/2011, s. 33)

Jeśli Jürgen Klopp nam pokazał, co może osiągnąć z polskimi piłkarzami utalentowany trener z kraju o wyżej rozwiniętej kulturze futbolowej, to Franz Smuda dowiódł, jak można błyskawicznie zwinąć im skrzydła i sformatować na jedenastkę po polsku rozmemłaną, co to wciela w życie najsłynniejsze bon moty legendarnych trenerów z kraju nad Wisłą (w tym przypadku sławetne „Wygraliśmy jedną połowę” Wojciecha Łazarka). (P 24/2012, s. 14)

Kiedy znudziło mu się życie w metropolii nad Bosforem, wrócił do Premier League, by bronić najpierw barw Boltonu, a ostatnio Chelsea. (PN 51-52/2011, s. 89)

Trudno w to uwierzyć, ale w największym muzeum stolicy Dolnego Śląska nie można było obejrzeć europejskiej sztuki od ponad 20 lat. (P 50/2012, s. 83)

Łomnice - imprezowa stolica słowackich Tatr - nocą rozbrzmiewa klubowymi rytmami. (NŻ 2/2012, s. 24)

Meksykański Monterrey miał więcej czasu od Chelsea na aklimatyzację w Kraju Wschodzącego Słońca, bo już w ostatnią niedzielę w meczu ćwierćfinałowym najlepszy zespół klubowy strefy CONCACAF spotkał się z południowokoreańskim Ulsan Hyundai i wygrał 3:1. (PN 50/2012, s. 37)

Orientowanie się w położeniu geograficznym niezbędne jest także w styczności z następującymi peryfrazami: 
A wam z czym kojarzy się nasz zachodni sąsiad? (VG 7/2011, s. 14)

Jeśli zresztą tego nie zrobi, Franciszek Smuda będzie musiał zrobić użytek ze swego niemieckiego paszportu i ewakuować się za Nysę i Odrę, gdyż nad Wisłą nie będzie miał czego szukać. (PN 49/2011, s. 2)

Jeszcze kilkadziesiąt godzin przed pierwszym meczem reprezentacji Niemiec na Euro za naszą zachodnią granicą pa nował spory niepokój. (PN 24/2012, s. 29)

$\mathrm{Ba}$, że w ogóle ktoś między Bugiem i Odrą wykaże się tak szaloną inicjatywą. (PN 51-52/2011, s. 2)

Oprócz położenia warto znać także charakterystyczne cechy klimatyczne, warunki środowiska przyrodniczego, obiekty architektoniczne, bo często te informacje wykorzystywane są w wyrażeniach omownych.

Drużyny z Kraju Kawy zwyciężały także w dwóch pierwszych edycjach po reaktywacji klubowego mundialu w 2005 i 2006 roku. (PN 49/2012, s. 22)

Ale w stolicy Kraju Tysiąca Jezior, prawie nikt nie robił z tego narodowej tragedii. (PN 33/2012, s. 30)

Wszystkim zaparło dech, gdy dziewczęta w bursztynowych kostiumach efektowną choreografią otworzyły finały ME w mieście Neptuna. (PN 24/2012, s. 31)

- Skład reprezentacji Holandii przez prawie dwa lata, czyli od czasu mistrzostw świata, prawie się nie zmienia - mówi Janusz Kowalik, były reprezentant Polski mieszkający w Kraju Tulipanów. (PN 11/2012, s. 24)

Ponieważ miasto pod Wawelem nie jest areną Euro 2012, liczba fanów, którym zechce się zboczyć z trasy, aby zobaczyć być może reprezentantów robiących zakupy w Galerii Krakowskiej albo pijących kawę na przykład w Sukiennicach, będzie więcej niż skromna. (PN 46/2011, s. 38)

U stóp Wawelu narodziło się plemię wojowniczych partyzantów miejskich, rodzaj krakowskich guerillas. (P 5/2011, s. 96)

Anna Kieda odsłania uroki (ale i mankamenty) życia w Kraju Kwitnącej Wiśni. (VG 17/2012, s. 35)

Jeśli potwierdzi się podpisanie kontraktu przez byłego już ełkaesiaka Marcina Kaczmarka z Widzewem, to przez chwilę przy Piotrkowskiej i wokół zrobi się o tym głośno. (PN 3/2012, s. 13)

Węgry - kraj, który ma ostry smak papryki... (VG 2/2011, s. 2) 
Pomocne w odczytywaniu niekonwencjonalnych nazw własnych bywa także ogólne zainteresowanie otaczającą nas rzeczywistością, przydatna okazuje się znajomość współczesnych realiów. Poza wiedzą z zakresu historii, gospodarki czy polityki czytelnik powinien interesować się szeroko rozumianą kulturą: znać mitologię, legendy, obyczaje, religię, być obeznanym w świecie muzyki, teatru, filmu i sportu, kojarzyć wybitne postaci z jakiegoś regionu i bohaterów narodowych. Operowanie w czasopismach takimi nazwami potwierdza przynależność nadawcy i odbiorcy do tego samego kręgu kulturowego.

Teraz, w prezencie na szóste urodziny (obchodzą 16 czerwca), podarowali sobie wyjazd do mekki improwizacji - Chicago. (P 24/2012, s. 98)

Nic dziwnego, że na ulicach Nikozji przez całą noc panowało szaleństwo, tymczasem w Lyonie szok i niedowierzanie, że ich Olympique mógł zostać wyeliminowany przez rywala z Wyspy Afrodyty. (PN 11/2012, s. 34)

Gracze z Wiecznego Miasta wygrali czwarte kolejne spotkanie w Serie A. (PN 50/2012, s. 32)

Obrona przybyszów z Hellady ze wspaniałym Traianosem Dellasem oraz bezbłędnym bramkarzem Antoniosem Nikopolidisem na czele grała doskonale. (PN 11/2012, s. 27) Po remisie Manchesteru United u siebie z Evertonem i wygranej Manchesteru City z Wolverhampton hitowo zapowiada się konfrontacja zespołów z miasta włókniarzy w poniedziałek 30 kwietnia. (PN 17/2012, s. 34)

Tutaj jednak nie możemy się dziwić, bowiem Daniel pochodzi spod Częstochowy, zagłębia polskiego czarnego sportu. (VG 12/2011, s. 59)

Ale Francuzi są podzieleni - w ojczyźnie wolności seksualnej rośnie front obrony tradycyjnej rodziny. (P 51-52/2012, s. 67)

To w ogóle dziwny kraj - niby kolebka naszej europejskiej cywilizacji, a gdyby nie ogrom ruin, które spotyka się co krok - nikt by się tego nie domyślił. (VG 9/2011, s. 24)

A mimo to na Anglię, kolebkę futbolu, zagłosowało 2 z 22 członków komitetu wykonawczego FIFA (powinno głosować 24 członków, ale dwóch wykluczono ze względu na ciążące na nich zarzuty korupcyjne). (P 13/2012, s. 15)

Przecież w mieście Kraka są dwa nowoczesne obiekty Wisły i Cracovii, gdzie warunki do prowadzenia treningów są o niebo lepsze niż na Suchych Stawach. (PN 46/2011, s. 38)

WAGs, jak zwie się te panie, zapewne są już po wstępnych rozmowach z jakąś agencją turystyczną, która zorganizuje im przyjemny pobyt w grodzie Kraka. (PN 46/2011, s. 38) 
Liverpool, czyli miasto Beatlesów, jest położony na zachodnim wybrzeżu północnej Anglii, około $340 \mathrm{~km}$ od Londynu, na północnym brzegu estuarium rzeki Mersey. (PN 15/2012, s. 37)

Irlandia - zielona wyspa z celtycką tradycją (VG 10/2011, s. 18)

Obecnie Konspol buduje ogromną wytwórnię wędlin w Indonezji, największym kraju muzułmańskim. (P 51-52/2012, s. 60)

Kraj Bonda, Marleya i Bolta (P 51-52/2012, s. 73)

Sprinterzy byli w kraju witani morzem zielono-żółto-czarnych flag, a Jamajkę - nie pierwszy raz - nazywano światową fabryką sprinterów. (P 51-52/2012, s. 75)

Tradycja tych przedziwnych pielgrzymek ma swoje początki w XVI stuleciu, gdy miasteczko Zefat przekształciło się w światowe centrum żydowskiego mistycyzmu, czyli Kabały, a mędrcy owego okresu znajdowali wieczny odpoczynek w galilejskiej ziemi, w pobliżu ich uczonych w Piśmie Świętym poprzedników. (P 24/2012, s. 100)

Wydawało się, że mecz zakończy się wynikiem 2:0 dla piłkarzy z kraju Azteków, ale w czasie doliczonym przez sędziego honorowego gola dla Brazylii strzelił Hulk. (PN 33/2012, s. 38)

Polska zza żelaznej kurtyny, ojczyzna Wajdy, Kantora, potem Wałęsy i Solidarności - to był temat. (P 51-52/2012, s. 159)

Wkrótce Puchar Henri Delaunaya trafi do innych miast nad Wisłą, a potem zostanie przeniesiony do kraju współorganizatora Euro 2012. (PN 17/2012, s. 21)

W Fabryce Snów po raz 84. wręczono najbardziej pożądane złote statuetki na świecie. (NŻ 9/2012, s. 7)

Decyzje dotyczące sprzedaży praw do transmisji zawodów, wyboru sponsorów międzynarodowych i narodowych, a także licencjobiorców chcących wykorzystywać prawa do symboliki mistrzostw zapadają w Nyon, małej szwajcarskiej miejscowości nieopodal Genewy, gdzie centralę ma UEFA. (P 13/2012, s. 13)

David B., jako jeden z ekspertów od wody kolońskiej po goleniu, czułby się jak ryba w wodzie w stolicy mody i perfum. (PN 45/2011, s. 29)

Portugalia - kraj odkrywców, kibiców i fado (VG 1/2011, s. 16)

Chciał pooddychać alpejskim powietrzem, poczuć atmosferę światowej stolicy walca, a przy okazji rzucić pańskim okiem na nieruchomość, którą ma w Austrii od czasu występów w tamtejszej Bundeslidze. (PN 50/2012, s. 4)

Na początku ubiegłego tygodnia do położonej nad Jeziorem Genewskim w Nyonie siedziby władz europejskiego futbolu zaproszono przedstawicieli mediów, którym przedstawiono między innymi dość znamienne dane. (PN 5/2012, s. 33) 
Ze światowej federacji wyszedł do AFA faks przypominający, że statut FIFA zabrania mieszania sportu i polityki. (PN 8/2012, s. 39)

Z najnowszego audytu obejmującego rok finansowy 2009-10 wynika, iż 665 klubów, w których sprawozdania księgowe ma wgląd centrala futbolu, dorobiło się strat sięgających 1,6 miliarda euro. (PN 5/2012, s. 33)

Częściej od Czarnej Perły z Mozambiku na telebimach pojawiał się inny Portugalczyk, trener Realu Madryt Jose Mourinho, który oglądał mecz w towarzystwie synka. (PN 24/2012, s. 10)

Start ich sondy zaplanowano na listopad 2013 r., więc w okolice Czerwonej Planety powinna dotrzeć w połowie 2014 r. (P 51-52/2012, s. 63)

W historii tej ciężarnej dziewicy, która stanęła samotnie naprzeciw świata, w czasach, gdy kamienowano za przedmałżeński seks? (P 51-52/2012, s. 24)

Wiedza taka przydaje się nie tylko przy rozszyfrowywaniu odpowiedników nomina propria, również w peryfrazach zastępujących wyrazy pospolite znajdziemy takie odniesienia.

Przez lata karp był żelaznym punktem wigilijnej wieczerzy. (P 50/2012, s. 30)

Karp jest ostatnim towarem w całej Unii, który trafia do klienta w formie żywej. (P 50/2012, s. 32)

Oprócz takich gadżetów, mających coś wspólnego z dyscypliną legendarnego Michaela Jordana, w jego zbiorach odnaleźć można także bilety, programy i autografy żużlowe. (VG 12/2011, s. 59)

Cała rodzina podśmiewała się z siedemnastoletniej Patrycji, która pierwszy raz w życiu została tak na poważnie „trafiona strzałą Amora”. (VG 16/2012, s. 24)

Zdarza się, że u podstaw nazwy znajdują się skojarzenia intertekstualne, choć współczesny odbiorca rzadko musi sięgać tak daleko, by ją trafnie rozszyfrować. Niektóre peryfrastyczne określenia używane są tak powszechnie, że nie trzeba znać ich genezy, żeby wiedzieć, do czego się odnoszą.

W przeddzień 34 urodzin Didier Drogba przeszedł do historii Premier League jako pierwszy piłkarz z Czarnego Lądu, któremu udało się strzelić sto goli. (PN 11/2012, s. 29)

Rozgrywany w cyklu dwuletnim turniej ma status mistrzostwa Czarnego Kontynentu. (PN 46/2011, s. 33) 
Komitet Wykonawczy UEFA podjął decyzję o przeprowadzeniu Euro 2020 w kilku krajach Starego Kontynentu. (PN 50/2012, s. 11)

Także w 2014 r. na Księżycu ma się stawić indyjsko-rosyjski lądownik bezzałogowy, poprzednio indyjska sonda była na Srebrnym Globie w 2008 r. i jako pierwsza w historii odnalazła tam ślady wody. (P 51-52/2012, s. 63-64)

Wydaje się, że kontekst kulturowy ujawnia się w przykładach, w których zestawiane są ze sobą dwie zbieżne pod jakimś względem nazwy własne. Adresat musi bowiem porównać dwa - zdawałoby się - niemające wspólnych cech miejsca, wykazać się wszechstronną wiedzą, która pozwoli znaleźć punkty styczne i rozwikłać zaproponowaną przez dziennikarza zagadkę językową.

Kiedyś był piękny, określany nawet mianem „małego Paryża”. (VG 8/2011, s. 23) Miasto polskie położone na siedmiu wzgórzach, zwane czasem „małym Rzymem”. (VG 12/2011, s. 63)

Społeczeństwo zawsze mieliśmy ofiarne, ale łódzkie szwaczki nie należą do bogatej kasty, co prężniejsze zakłady pracy w polskim Manchesterze też już dawno odwróciły się plecami do piłkarzy. (PN 5/2012, s. 47)

Nieraz alternatywne określenia tworzone są na zasadzie konwencji, przytaczania subiektywnych opinii czy nawet wykorzystywania stereotypów, dlatego przydaje się duży zasób wiadomości, który pomaga poszerzać horyzonty.

Jeszcze Kolumb twierdził, że to najpiękniejsza wyspa Karaibów. (P 51-52/2012, s. 75)

Niemcy - kraj autostrad i porządku... (VG 7/2011, s. 14)

Rumunia - ojczyzna wampira i niedźwiedzi... (VG 8/2011, s. 22)

Jest ich coraz więcej, bo mieszkania w Skierniewicach są tańsze niż w Żyrardowie, nazywanym już od dawna sypialnią stolicy. (P 13/2012, s. 102)

A skoro tak uważa Grant, czyli Żyd, a więc człowiek nacji słynącej z biznesowej żyłki, to musi być w tym duża porcja prawdy. (PN 51-52/2011, s. 89)

Kto wie, może osiemdziesiąt lat po tak zwanym Cudzie nad Wisłą, ponownie na obiekcie położonym nad królową polskich rzek zdarzy się cud - piłkarski. (PN 24/2012, s. 47)

Taką koszulkę przygotował sobie Król Futbolu, Pele, na mecz, w którym zdobył pamiętną, tysięczną, bramkę w karierze. (PN 6/2012, s. 37) 
Łzy królowej popu (NŻ 5/2012, s. 12)

Już piąty rok z rzędu młodzi fani, w swych krótkich filmach video, pokażą, jaki potencjał drzemie w królowej nauk. (VG 17/2012, s. 5)

W ostatnią niedzielę w świątyni futbolu, za jaką uchodzi Wembley, królowała meksykańska fala. (PN 33/2012, s. 38)

Medycyna braci mniejszych (P 51-52/2012, s. 108)

Wśród kibiców piłkarskich popularne jest budowanie zastępczych określeń drużyn z wykorzystaniem nawiązań do godła państwowego, flagi narodowej, herbów i barw klubowych, kroju strojów. Takie działania mają na celu wytworzenie wspólnoty między dziennikarzami a fanami. Nie każdy jest bowiem w stanie trafnie odgadnąć symbole, które posłużyły do stworzenia przydomka.

Swoją drogą Pasy przyzwyczaiły już swoich kibiców, że ci do ostatniej chwili muszą drżeć o ekstraklasowy byt zespołu. (PN 8/2012, s. 47)

Zatem po 32 latach obecnemu pokoleniu Drozdów udało się nawiązać do wyczynu Robsona i spółki, a więc wygrać w ekstraklasie cztery mecze z rzędu. (PN 49/2012, s. 20)

Fiołkom nieco gorzej wiedzie się jednak w Lidze Mistrzów. (PN 48/2012, s. 36)

Jaskółkom pozostały mgliste wspomnienia po znakomitym początku sezonu. (PN 44/2012, s. 45)

Irlandczyk trenował w akademii Arsenalu Londyn, ale jego kariera w barwach Kanonierów skończyła się na jednym występie w zespole seniorów. (PN 6/2012, s. 41)

A Koguty zaoferowały za Capela tamtego lata 15 milionów euro. (PN 6/2012, s. 35) Nawet sobie żartowano, że stało się to przez długie oczekiwanie na szansę gry w zespole Koniczynek. (PN 11/2012, s. 27)

Kibiców Kozłów powinny niestety niepokoić najnowsze doniesienia dziennika „Bild”. (PN 11/2012, s. 28)

Dlaczego dwaj Argentyńczycy musieli odejść i czy rzeczywiście dojdzie do rozwodu Portugalczyka z Królewskimi? (PN 50/2012, s. 22)

Dla obrońców Niebieskich Kosa był jednak zbyt trudnym przeciwnikiem. (PN 49/2012, s. 39)

Nietoperze odpowiedziały dwoma trafieniami, w rewanżu zapowiada się walka na śmierć i życie. (PN 17/2012, s. 16) 
Podopiecznych trenera Vitora Pereiry czeka jednak trudne zadanie, aby prześcignąć Orły z Lizbony, a także nie dać plamy w Lidze Europy z Manchesterem City. (PN 6/2012, s. 31)

10000 - tylu kibiców Trzech Koron spodziewanych jest na Ukrainie. (PN 6/2012, s. 25)

Do Tokio ekipa Smoków udała się 20-godzinnym lotem niemal tydzień przed starciem z Penarolem. (PN 50/2012, s. 10)

Kiedy Holendrowi pokazano drzwi, w jednym meczu Clarke’owi dane było samodzielnie prowadzić Sroki. (PN 49/2012, s. 20)

Jego szybkość i ciągłe nękanie bocznych obrońców na tyle spodobały się ówczesnemu menedżerowi Southampton Alanowi Pardewowi, że wziął juniora do kadry pierwszego zespołu Świętych. (PN 6/2012, s. 33)

$\mathrm{Na}$ jego szczęście Wilki przegrały z Freiburgiem 0:2 (czwarta z rzędu porażka do zera!) i w końcu Magatha zwolniono. (PN 49/2012, s. 23)

Kluby dość szybko doszły do porozumienia, z tym że Zeberki chciały Polaka ściągnąć natychmiast. (PN 6/2012, s. 16)

Juve A.D.2012 odstaje poziomem i pięknem gry jeszcze także od tego, gdy na krajowych i europejskich boiskach w ekipie Zebr występowali Michel Platini, Zinedine Zidane, Zbigniew Boniek czy Roberto Baggio. (PN 20/2012, s. 35)

Niektóre zastępcze nazwy drużyn tworzone są w odwołaniu do ich lokalizacji, niezbędne bywa zatem identyfikowanie klubów z określonym regionem i jego cechami charakterystycznymi.

Legia, grając słabo, zrewanżowała się Góralom za jesienną porażkę. (PN 11/2012, s. 38)

Łukasz Załuska spędził cały mecz z Góralami na ławce, zaś Paweł Brożek nie znalazł się w kadrze meczowej. (PN 6/2012, s. 42)

Podobno właściciele Szachtara Rinat Achmetow i Chelsea Roman Abramowicz dobrze się znają, więc Górnicy z Doniecka na pewno postawią twarde warunki mistrzowi Włoch. (PN 48/2012, s. 32)

Nafciarze grali perfekcyjnie w defensywie i do bólu skutecznie w ofensywie (dziewięć minimalnych zwycięstw). (PN 48/2012, s. 45)

Ten mecz powinien pokazać, czy zima nie wybiła z rytmu Portowców. (PN 11/2012, s. 40) 
To jasno wskazuje, że mimo dobrych wyników większość ekspertów Wyspiarzy nadal nie traktuje poważnie i nie widzi ich w gronie kandydatów do awansu. (PN 49/2012, s. 44)

Zdarza się, że jeden obiekt zyskuje kilkanaście zamienników, a każdy z nich wysuwa na plan pierwszy jego inne cechy konstytutywne. Jako egzemplifikacja niech posłużą alternatywne określenia stadionu wybudowanego w Warszawie z okazji Euro 2012 - Narodowego. Niektóre są mocno osadzone w kontekście językowym, odczytywane w izolacji mogłyby odnosić się do zupełnie innych desygnatów, inne z kolei wymagają od odbiorców znajomości realiów pozajęzykowych, opierają się bowiem na odwołaniach do ekonomii, gospodarki, geografii czy architektury.

Nowy wspaniały obiekt piłkarski jednocześnie podniósłby rangę wyjątkowo mało prestiżowego i traktowanego w Polsce po macoszemu turnieju tysiąca drużyn. (PN 13/2012, s. 47)

Dziś już wiemy, że nie tylko Superpuchar, ale również Puchar Polski otrzymał zakaz wstępu na imponujący i monumentalny obiekt usytuowany po drugiej stronie Wisły, ale jednak na wprost Pałacu Kultury i Nauki. (PN 13/2012, s. 47)

Kiedy bowiem - jeśli nie podczas meczu podwyższonego ryzyka - najlepiej jest sprawdzić wszystkie procedury, zabezpieczenia i ogólne funkcjonowanie najdroższego - a zatem pewnie (choć wcale nie na pewno) także najnowocześniejszego i najbardziej funkcjonalnego - obiektu piłkarskiego w Polsce? (PN 6/2012, s. 2) Ktoś powie: pomieszanie z poplątaniem, i zapewne będzie miał rację, bo w kwestii reprezentacyjnego obiektu wybudowanego w stolicy nie wiadomo, czy lepiej się śmiać, czy raczej płakać. (PN 6/2012, s. 47)

Cóż, jeśli wszystko nadal wokół Narodowego będzie się tak ślimaczyć jak dotychczas, to na pełne i bezwarunkowe oddanie do użytku sztandarowego stadionu w kraju poczekamy do mistrzostw Europy. (PN 6/2012, s. 2)

Nigdy nie przepadałem za cyrkowymi występami, ale sytuacja z naszym reprezentacyjnym obiektem, czyli Stadionem Narodowym, przypomina kiepski spektakl pod namiotem albo rozsuwanym dachem, jak kto woli. (PN 7/2012, s. 47)

Główna polska arena finałów Euro 2012 została oddana do użytku. (PN 5/2012, s. 2) Chciał wynająć nasz reprezentacyjny stadion na kilka godzin, dla potrzeb kilkudziesięciu osób. (PN 12/2012, s. 11) 
Zdążyliśmy, choć organizowanie uroczystości oddania do użytku Stadionu Narodowego było zabawne - o samym fakcie poinformowano ledwie dzień wcześniej, a na naszym sztandarowym obiekcie nie ma jeszcze... boiska. (PN 51-52/2011, s. 9)

Czasami wymagana jest znajomość specjalistycznych zagadnień. Reguły obowiązujące w piłce nożnej stały się podstawą rozbudowanych konstrukcji z komponentem punkt pozwalających określić wynik meczu. Aby poznać rezultat spotkania, odbiorca musi zatem wiedzieć, jaka zdobycz punktowa przyznawana jest za zwycięstwo, a o ile wzrasta dorobek drużyny w przypadku remisu. Nie wystarczy ogólna orientacja w realiach sportowych, ponieważ każda dyscyplina ma odrębne zasady.

Grający w dziewięciu gospodarze zdołali jednak utrzymać skromne prowadzenie i sięgnęli po ważne trzy punkty. (PN 11/2012, s. 28)

Możemy zgarnąć trzy punkty. (PN 33/2012, s. 15)

Ktoś powie: z wielkiej chmury mały deszcz, bo ani Jaga specjalnie nie wzbogaciła się we Wrocławiu, ani tym bardziej Śląsk nie stracił szansy na mistrzostwo, gubiąc dwa punkty. (PN 48/2012, s. 2)

Mateusz Miłoszewski zastąpił Tomasza Reginisa i zdobył oczko w Łowiczu. (PN 36/2012, s. 43)

Tylko Motor zainkasował punkt, który pozwolił opuścić ostatnią lokatę w tabeli. (PN 41/2012, s. 45)

Do wąskiego grona kierowane są także peryfrazy, w których odwoływano się do znajomości branży motoryzacyjnej59, gdyż nie każdy ma kompetencje pozwalające na bezbłędne dopasowanie nazw producentów samochodów do takich wielowyrazowych połączeń.

Z początkiem sezonu 2014-15 na koszulkach zawodników najpopularniejszego klubu piłkarskiego na świecie pojawi się logo amerykańskiego giganta samochodowego. (PN 33/2012, s. 17)

Auta sprzedają się jak świeże bułeczki, tegoroczna pula została wyczerpana już w lutym, a polski dealer firmy $\mathbf{z}$ Maranello dostał z centrali nagrodę za sprzedaż samochodów z najbogatszym wyposażeniem. (P 51-52/2012, s. 54)

59 O tym, do jakich desygnatów odwołują przywołane peryfrazy, była mowa w rozdziale poświęconym semantyce. Por. s. 273-274. 
Autami z silver lady na masce cieszy się już kilkudziesięciu Polaków. (P 51-52/2012, s. 55)

Słynna ikona brytyjskiej motoryzacji - Rolls-Royce - została uratowana przed bankructwem przez koncern BMW, a Bentleya ocalił Volkswagen. (P 51-52/2012, s. 56)

Trzeba też wspomnieć o związkach frazeologicznych. Ich właściwa interpretacja w dużej mierze zależy od kompetencji odbiorcy. O ile utrwalone w powszechnej świadomości połączenia wyrazowe nie powinny sprawiać czytelnikowi większych problemów, o tyle posługiwanie się zestawieniami, które używane są w codziennej komunikacji sporadycznie, wymaga od adresata posiadania niemałego zasobu wiedzy.

Choć jest to oczywiste, to jednak istotne wydaje się zaznaczenie, że nie tylko odbiorca musi wykazać się erudycją. Duże kompetencje musi mieć dziennikarz tworzący artykuł (a także redaktorzy i korektorzy decydujący o ostatecznym kształcie publikacji i korygujący pojawiające się pomyłki), wszak to on decyduje się na ubarwienie swojego tekstu konstrukcjami analitycznymi i ich syntetycznymi odpowiednikami, a żeby to uczynić, powinien zgłębić tematykę, którą się zajmuje. To autor wyszukuje informacje i podsuwa swoje propozycje czytelnikowi, a ten otrzymuje gotowe rozwiązania, które musi zdeszyfrować. Z pozoru wydaje się, że łatwiej mają publikujący w czasopismach specjalizujących się w wybranej tematyce, ponieważ muszą orientować się jedynie w określonej dziedzinie, podczas gdy piszący w tygodnikach przeznaczonych dla ogółu odbiorców muszą być wszechstronni, jednak de facto czytelnik łatwiej wybacza ewentualne błędy tym drugim. Periodyki specjalistyczne mają stałe grono odbiorców mocno zaznajomionych z daną branżą, którzy tego samego wymagają od autorów.

\section{Wkaźniki metatekstowe}

Zdarza się, że na poziomie wypowiedzenia pojawiają się elementy, które niemalże wprost sugerują czytelnikowi, jak ma interpretować pojawiające się w tekście połączenia. Omawiając leksykalne wykładniki ekwiwalencji, Adam Bednarek pisze: „Obiekty ekwiwalentne to obiekty pod pewnym względem takie same. Nadawca tekstu, wypowiadając wyrażenia stojące po obu stronach inaczej mówiąc, innymi słowy, krótko mówiąc, mówiąc prościej, reasumuję, mianowicie, następujące, na przykład, tzn., tj., czyli mówi (chce powiedzieć), pod pewnymi względami, to 
samo"60. W zgromadzonym materiale często pojawiającym się wyrażeniem metajęzykowym jest czyli, które Anna Wierzbicka - podobnie jak tzn. i tj. - proponuje interpretować: „powiem to samo inaczej”61. Badaczka traktuje je jako operatory metatekstowe, które w sposób jawny ustalają ekwiwalencję lub quasi-ekwiwalencję wewnątrz tekstu ${ }^{62}$. K. Pisarkowa zauważa, że posługiwanie się strukturą parataktyczną, włączną (mianowicie, czyli) jest uwarunkowane pragmatycznie "dążeniem do powodzenia rozumianego jako akceptacja"63. Nadawca chce zostać właściwie zrozumiany, dlatego - nie będąc pewnym, czy odbiorca prawidłowo odczyta jego intencje, lub pragnąc podkreślić jakieś sformułowanie - używa wskaźników, co pozwala skoncentrować uwagę czytelnika na zaznaczonych w ten sposób równoważnych elementach wypowiedzi i jednocześnie zapobiega ewentualnym nieporozumieniom.

Mężowie babć, czyli dziadkowie, są zmęczeni życiem, nie mają w sobie takich niespożytych sił jak one. (VG 1/2011, s. 27)

Bywała nim Fortuna, czyli boski kaprys. (P 51-52/2012, s. 26)

Są kibice i... są kibole, czyli rozrabiaki, przez których nawet kluby piłkarskie mają kłopoty i których nikt nie chce widzieć na trybunach. (VG 1/2011, s. 18)

Zaoferował Janowi Zamoyskiemu namiestnictwo, czyli wielką władzę nad krajem. (P 51-52/2012, s. 154)

Bywała nim Opatrzność, czyli boża troska. (P 51-52/2012, s. 26)

Podczas potopu, czyli wojny polsko-szwedzkiej, wojska Karola X Gustawa w 1656 r. oblegały Zamość. (P 51-52/2012, s. 154)

Na takie okazje wymyślono tartinki, czyli małe, acz bardzo wymyślne i smakowite kanapeczki. (P 51-52/2012, s. 154)

- Ja miałam implanty tak dawno, że już nawet o nich zapomniałam - powiedziała nam Marta Wiśniewska, czyli Mandaryna (33). (NŻ 1/2012, s. 13)

Liverpool, czyli miasto Beatlesów, jest położony na zachodnim wybrzeżu północnej Anglii, około $340 \mathrm{~km}$ od Londynu, na północnym brzegu estuarium rzeki Mersey. (PN 15/2012, s. 37)

60 A. Bednarek, Wykładniki leksykalne ekwiwalencji. Analiza semantyczna wyrażeń typu czyli, Toruń 1989, s. 4.

61 A. Wierzbicka, Metatekst w tekście, [w:] Polska genologia lingwistyczna, red.

D. Ostaszewska, R. Cudak, Warszawa 2008, s. 293.

62 Ibidem.

63 K. Pisarkowa, op. cit., s. 207. 
Taką samą rolę odgrywa w poniższym wypowiedzeniu zestawienie spójników awięc.

A skoro tak uważa Grant, czyli Żyd, a więc człowiek nacji słynącej z biznesowej żyłki, to musi być w tym duża porcja prawdy. (PN 51-52/2011, s. 89)

Podobnym celom służą także znaki interpunkcyjne, są one często dużą podpowiedzią dla odbiorcy. Funkcję taką pełni myślnik, wśród wielu jego zastosowań autorzy Nowego słownika ortograficznego wymieniają też unikanie dwuznaczności64. Wydaje się, że ma on zbliżoną wartość do omówionego wyżej wyrażenia metajęzykowego czyli - znajdujące się po obu jego stronach pojedyncze wyrazy i konstrukcje złożone należy bowiem traktować jako równoważne. Przejście od analityzmu do syntetyzmu doprecyzowuje, pozwala rozwiać ewentualne wątpliwości czytelnika, kierunek odwrotny zaś służy podkreśleniu, wyjaśnieniu i uwypukleniu cech charakterystycznych opisywanych osób, miejsc, przedmiotów, czynności czy pojęć. Jako przykłady niech posłużą:

Pilot - dowódca statku powietrznego - musi doskonale znać szczegóły budowy samolotu, a także nawigacji - oznacza to, że powinien mieć taką wiedzę jak wszyscy jego podwładni razem wzięci. (VG 1/2011, s. 4)

Oprócz karpia ma jeszcze szczupaka, amura, okonia, karasia i króla ryb słodkowodnych - sandacza. (P 50/2012, s. 31)

I dlatego zadania w naszym konkursie będą związane właśnie z wolontariatem ideą bezinteresownego niesienia dobra i pomocy. (VG 4/2011, s. 4)

Teraz, w prezencie na szóste urodziny (obchodzą 16 czerwca), podarowali sobie wyjazd do mekki improwizacji - Chicago. (P 24/2012, s. 98)

Słynna ikona brytyjskiej motoryzacji - Rolls-Royce - została uratowana przed bankructwem przez koncern BMW, a Bentleya ocalił Volkswagen. (P 51-52/2012, s. 56)

Niemcy - kraj autostrad i porządku... (VG 7/2011, s. 14)

Rumunia - ojczyzna wampira i niedźwiedzi... (VG 8/2011, s. 22)

64 Nowy słownik ortograficzny PWN z zasadami pisowni i interpunkcji, red. E. Polański, Warszawa 2002, s. CXVI. 
Dopowiedzenie może być też wydzielone przecinkami.

Od trzech lat tereny nieczynnej Kopalni Węgla Kamiennego Katowice położone w samym centrum Katowic, stolicy Górnego Śląska, są prawdziwą Mekką dla wszystkich miłośników nowych brzmień elektronicznych. (VG 16/2012, s. 4) Obecnie Konspol buduje ogromną wytwórnię wędlin w Indonezji, największym kraju muzułmańskim. (P 51-52/2012, s. 60)

A mimo to na Anglię, kolebkę futbolu, zagłosowało 2 z 22 członków komitetu wykonawczego FIFA (powinno głosować 24 członków, ale dwóch wykluczono ze względu na ciążące na nich zarzuty korupcyjne). (P 13/2012, s. 15)

Charakter naprowadzający mają również dopowiedzenia w postaci struktur wielowyrazowych. Znajdujące się po kropce rozwinięcie formy syntetycznej jest swoistym komentarzem do myśli kończącej poprzednie wypowiedzenie, a jednocześnie sugestią dla czytelnika, jak należy interpretować nierozbudowane sformułowanie.

W roli reżyserów wydarzeń obsadziliśmy więc polityków. Ludzi, w których ręce została złożona największa władza. (P 51-52/2012, s. 27)

Kim jest polski premier? Jest szefem państwowego aparatu. Jest szefem największej firmy w kraju. (P 51-52/2012, s. 29)

Nikt nie zawraca sobie nim głowy, mimo że Inter bije rywala aż 4:0 po bramce Figo i aż trzech Adriano. Balangowicza z Rio. (PN 48/2012, s. 12)

Nierzadko nadawca wprost wprowadza ekwiwalentną formę za pomocą struktur składających się z czasowników (są, za jakq uchodzi), imiesłowów (nazywany, zwany) czy wyrażenia porównawczego ( jako). Taki przekaz jest jednoznaczny i nie wymaga od odbiorcy głębokiej analizy, by poznać tok rozumowania dziennikarza.

W końcu lew to król zwierząt, a to do czegoś zobowiązuje (VG 13/2011, s. 46) Ryby jako symbol chrześcijaństwa i produkt przyklasztorny wyłączone były z wszelkich ograniczeń. (P 50/2012, s. 32)

Coraz wyraźniej - także w kontekście sprawy aresztowanej niedawno za długi matki dwójki dzieci - pojawia się dylemat, czy sędziowie są tylko bezrefleksyjnymi wykonawcami sztywnej litery prawa, czy prawdziwymi szafarzami sprawiedliwości? (P 50/2012, s. 24) 
Jest ich coraz więcej, bo mieszkania w Skierniewicach są tańsze niż w Żyrardowie, nazywanym już od dawna sypialnią stolicy. (P 13/2012, s. 102)

W ostatnią niedzielę w świątyni futbolu, za jaką uchodzi Wembley, królowała meksykańska fala. (PN 33/2012, s. 38)

Bywa nazywany Nestorem, nie tylko z racji drugiego imienia, a także Oro Profesoro. (PN 44/2011, s. 2)

Zwany z racji wyglądu Księgowym nie będzie miał łatwego życia na Stamford Bridge. (PN 48/2012, s. 23)

Zdarza się, że piszący posługuje się rozbudowaną formą wprowadzającą, konstrukcja jak to się ostatnio mówi oprócz funkcji naprowadzającej jest w poniższym przykładzie także wyrazem dezaprobaty autora wobec modnego w ostatnich czasach posługiwania się wyrazami obcego pochodzenia.

Ale to oni najbardziej na całym zamieszaniu skorzystali; jak to się ostatnio mówi: stali się największymi beneficjentami. (PN 11/2012, s. 18)

O odwołaniu się do powszechności sądów świadczy poprzedzanie struktur wieloczłonowych zwrotem $t z w$., który sugeruje, że nadawca przywołuje cudzą opinię, podkreśla w ten sposób swój dystans do użytego w artykule sformułowania. A. Dąbrowska zwraca uwagę na jeszcze jedną rolę dodatkowego elementu w postaci tak zwany, jej zdaniem „może być zabiegiem językowym celowo obniżającym wartość nazywanego zjawiska"65, jego siła pejoratywna objawia się w podważaniu wiarygodności następującej po nim jednostki leksykalnej.

Kolor elegancki, szykowny, tzw. nowa czerń. (NŻ 4/2012, s. 20)

Odautorskie wskaźniki dla czytelnika mogą pojawić się też w nawiasie. Tak jest w przypadku przezwisk, których wyjaśnienia dziennikarz - prawdopodobnie świadom małej popularności alternatywnych określeń wśród potencjalnych odbiorców - wprowadził za pomocą sformułowania przyp. red.

65 A. Dąbrowska, Zniekształcanie obrazu rzeczywistości poprzez użycie pewnych środków językowych (eufemizm i kakofemizm), [w:] Językowy obraz świata, red. J. Bartmiński, Lublin 1999, s. 226. 
Uważni obserwatorzy poczynań Gianniego (boiskowy pseudonim szkoleniowca przyp. red.) twierdzą jednak, że o stylu gry zespołu w głównej mierze decyduje dyspozycja Tomasza Bandrowskiego. (PN 49/2012, s. 15)

Przypomina mi Ajwena (Andrzeja Iwana - przyp. red.), gdy zaczynał grać w piłkę. (PN 48/2012, s. 19)

W nawiasie umieszczono też raz podpowiedź, jak odczytać syntetyzm pochodzący od skrótowca.

Z lotniska nowiutką eskaemką (Stołeczna Kolej Miejska) Kowalski w 25 min przyjechał do stacji Śródmieście - parę kroków od strefy kibica. (P 24/2012, s. 15)

\section{Funkcje konstrukcji analitycznych}

Zanim przyjrzymy się celom, jakim może być podporządkowane użycie analityzmów leksykalnych w tekstach prasowych, warto przedstawić ogólne rozważania na temat funkcji językowych ${ }^{66}$. Karl Bühler wyróżniał w akcie komunikacji nadawcę, odbiorcę, znak i rzeczywistość, relacje między nimi można opisać następująco: „Znak pełni wobec nadawcy funkcję symptomu (wyrażając jego stan psychiczny i fizyczny), wobec odbiorcy funkcję sygnału (apelu), a wobec rzeczywistości funkcję symbolu (przedstawienia)"67. Zgodnie z tym wyróżniano zatem funkcję przedstawieniową (zwaną potem kognitywną, symboliczną, denotatywną, referencjalną i reprezentatywną) „polegającą na odsyłaniu świadomości użytkowników języka do określonych przedmiotów i zjawisk świata pozajęzykowego przez przyporządkowanie takim przedmiotom i zjawiskom określonych wyrażeń językowych"68, ekspresywną (zwaną też emotywną) służącą wyrażaniu pewnych cech nadawcy oraz impresywną (zwaną apelującą, imperatywną, konatywną), która „polega na oddziaływaniu na zachowanie odbiorcy za pomocą wyrażeń językowych, np. kiedy nadawca każe odbiorcy coś zrobić”69. Sześć elementów wymieniał

66 Problemowi temu został poświęcony cały tom z serii Język a kultura, t. 4: Funkcje języka i wypowiedzi, red. J. Bartmiński, R. Grzegorczykowa, Wrocław 1991.

67 R. Grzegorczykowa, Problem funkcji..., s. 12.

68 Encyklopedia jezykoznawstwa..., s. 168.

69 Ibidem. 
Roman Jakobson: nadawcę, odbiorcę, kontekst, komunikat, kod, przypisywał im następujące funkcje: emotywną, impresywną (konatywną), poznawczą, poetycką, fatyczną, metajęzykową (metalingwistyczną). Funkcja fatyczna służy nawiązaniu i podtrzymaniu kontaktu między nadawcą a odbiorcą, „funkcja metalingwistyczna polega na skoncentrowaniu się na problemie języka jako systemu (kodu)"70. Jak pisze Grażyna Habrajska: „Natomiast raczej metafunkcja niż funkcja poetycka (estetyczna), skierowana na sposób organizacji komunikatu, realizować może każdą z wcześniej wymienionych funkcji, zwracając uwagę na formę przekazu"71. Na uwagę zasługuje stanowisko polskiej badaczki Haliny Kurkowskiej, która poszerzyła teorię Leona Zawadowskiego. Twierdzi ona, że „system językowy pełni jedną jedynie funkcję generatywną, która polega na zdolności tworzenia tekstów (a ściślej na byciu podstawą tworzenia tekstów), teksty zaś przekazują informację o rzeczywistości"72. Przekazywanie na mocy kodu wiąże się z dwiema funkcjami: komunikatywną i prezentatywną (socjolingwistyczną), z kolei informowanie nie na mocy kodu łączy się z funkcją ekspresywną lub impresywną. Antoni Furdal za nadrzędną uznaje funkcję komunikatywną, podporządkowane są jej emocjonalna, symboliczna i impresywna, w układzie komunikatywnym bez odbiorcy można też wyróżnić funkcje ekspresywną i poznawczą ${ }^{73}$.

R. Grzegorczykowa buduje swoją kilkukrotnie modyfikowaną klasyfikację funkcji w oparciu o teorię aktów mowy. Podkreśla, że „konkretne wypowiedzi łączą w sobie najczęściej wiele funkcji"74. Do funkcji systemu zalicza generatywną i poznawczą (symboliczną, reprezentatywną), zamierzone wypowiedzi pełnią funkcje: informacyjną, sprawczą (polegającą na stwarzaniu na mocy wiary - zalicza się tu magię ludową i akty sakralne - lub stwarzanie stanów społecznych na mocy pewnych konwencji ${ }^{75}$ ), nakłaniającą (impresywną), ekspresywną i kreatywną (dotyczy wypowiedzi poetyckich), niezamierzone zaś - charakteryzującą (zdradzanie cech nadawcy, wpływanie na odbiorcę $\left.{ }^{76}\right)$. Do ogółu działań językowych przypisane są z kolei funkcje socjalizująca, mająca za zadanie jednoczyć

70 Ibidem.

71 G. Habrajska, Nakłanianie, perswazja, manipulacja językowa, „Acta Universitatis

Lodziensis. Folia Litteraria Polonica” 2005, nr 7, t. 2, s. 92.

72 R. Grzegorczykowa, Problem funkcji..., s. 15.

73 Por. ibidem, s. 16.

74 Ibidem, s. 21.

75 Ibidem, s. 24.

76 Ibidem. 
członków danej społeczności, i kulturotwórcza, zwana też kumulatywną, polegająca na ,gromadzeniu i przechowywaniu wiedzy, doświadczeń pokoleń, świata wartości, przechowywaniu w postaci tekstów utrwalonych lub zachowanych w pamięci mówiących"77.

Jakim funkcjom podporządkowane jest użycie konstrukcji analitycznych? J. Anusiewicz, badający występowanie wielowyrazowych połączeń w różnych odmianach stylistycznych, twierdził, że ich ekspansja powodowana jest przez cztery czynniki: „konieczność i potrzebę uniknięcia nieporozumień między nadawcą a odbiorcą"78, czyli ułatwienie komunikacji poprzez usunięcie wieloznaczności, którą niosą syntetyzmy; dążenie do precyzji i wyrazistości semantycznej, które przejawia się „w dążności do wyrażania osobnymi elementami kategorialnych i indywidualno-leksykalnych cech semantycznych, które w sposób skumulowany sygnalizuje prosta forma wyrazu"79; przyczyny pozajęzykowe - „konieczność wyrażania istotnych elementów kultury i cywilizacji, potrzebę precyzyjnego, ścisłego i dokładnego sygnalizowania wzajemnej zależności, skomplikowania i złożoności procesów myślowych"80; chęć stylistycznego zróżnicowania tekstu - „Przydatne są one [analityzmy - przyp. KB] przede wszystkim do budowania wypowiedzi o charakterze uroczystym, poważnym, oficjalnym, podniosłym, a nawet ostrożnym i wyważonym, stając się czynnikami konstytutywnymi dla specjalizujących się odmian języka (stylów)"81, służą urozmaiceniu tekstu.

Rozważania nad zadaniami konstrukcji analitycznych prowadził też W. Cockiewicz, porównywał wyniki badań nad językiem Telewizji Polskiej z lat 70. ubiegłego stulecia z wnioskami wynikającymi z monografii J. Anusiewicza oraz zebranym przez niego materiałem telewizyjnym z końca XX w. Do wymienionych przez poprzednika kryteriów posługiwania się połączeniami wielowyrazowymi dołożył dwa czynniki: funkcję retardacyjną, która spowalnia tempo wypowiedzi i ma dać nadawcy czas do namysłu: „Ma ona zastosowanie w wypowiedzi mówionej, ale nie wygłaszanej z pamięci, najczęściej publicznej, kiedy

77 Ibidem, s. 25.

78 J. Anusiewicz, Konstrukcje analityczne we współczesnym języku polskim, Wrocław 1978, s. 172.

79 Ibidem.

80 Ibidem, s. 173.

81 Ibidem. 
mówcy bardziej niż zwykle zależy na starannej, eleganckiej formie"82, takim rozwiązaniem posługują się często osoby mało kompetentne językowo lub niemające doświadczenia w przemawianiu; czynnik naśladowczy - o posługiwaniu się tego typu konstrukcjami decyduje moda językowa: „Kiedy mówiącemu w sytuacji publicznej zaczyna brakować wyrażeń w jego przekonaniu dostatecznie «eleganckich», nadających się do takiej oficjalnej wypowiedzi, ucieka się do gotowych schematów, zapamiętanych z praktyki językowej osób, które uważa w tej mierze za autorytet" 83 . Badacz zaznacza, że w materiale telewizyjnym zgromadzonym w książce Właściwości składniowo-stylistyczne języka Telewizji Polskiej dominują peryfrazy o właściwościach retardacyjnych. Postuluje, by traktować je jako środek retoryczny: „wyrażenie takie ułatwia także słuchaczowi zrozumienie wypowiedzi i podkreśla jej ważność poprzez zwrócenie specjalnej uwagi na wyróżniony w ten sposób fragment"84. Porównując te wyniki z wnioskami wynikającymi z analizy materiału zgromadzonego 20 lat później, dostrzega sporadyczne występowanie konstrukcji opisowych w wypowiedziach dziennikarzy, częściej - ale i tak stosunkowo rzadko - pojawiają się one w ustach osób zawodowo niezwiązanych z telewizją. Nagromadzenie analityzmów dostrzegalne jest za to w transmisji obrad Sejmu RP. Analizując pełnione tam funkcje, stwierdza: „Odnosi się wrażenie, że w tych wypowiedziach konstrukcje analityczne nie służą ani precyzji, ani obiektywności wypowiedzi, ani żadnemu podobnemu celowi, lecz są raczej [...] środkiem ekstensywnej gospodarki słowem" 85 .

Odwołania do badań Z. Kurzowej i W. Cockiewicza odnajdujemy u I. Loewe, autorka kontynuuje analizę wielowyrazowych konstrukcji w polskiej telewizji, koncentrując się na przykładach wyekscerpowanych z programów emitowanych pod koniec pierwszej dekady XXI w . Badaczka dostrzega nowe, nienotowane do tej pory funkcje: demonstratywną, która ma na celu wyeksponowanie nadawcy, promocję jego wizerunku, podkreślenie kontrastu między prowadzącym program a osobami, które tylko w nim uczestniczą, jak twierdzi I. Loewe,

82 W. Cockiewicz, Konstrukcje analityczne $w$ języku polskiej telewizji $w$ latach siedemdziesiątych i dziś, [w:] Język w mediach masowych, red. J. Bralczyk, K. Mosiołek-Kłosińska, Warszawa 2000, s. 146.

83 Ibidem.

84 Ibidem, s. 148.

85 Ibidem, s. 152. 
w tym przypadku „zabiegi na języku są z gruntu kreacją, zabawą słowem”" metajęzykową, służącą wytworzeniu dystansu zarówno między rozmówcami, jak i nadawcą a przekazywaną przez niego treścią; stylizacyjną; eufemizacyjną - obniżającą moc sądu. Potwierdza używanie peryfraz w celach retardacyjnych i naśladowczych.

Do funkcji analityzmów w poezji młodopolskiej I. Loewe zaliczyła natomiast: uwyraźnianie przekazu, kształtowanie fazowości, dynamiki lub spowalnianie stanów i procesów, zmienność ról semantycznych widocznych w planie wyrażania. W swojej monografii podkreślała poetycką funkcję kolokacji, którą określała jako „zdolność kreowania poetyckich światów przez profilowanie nowych treści w porównaniu z bazowymi (utrwalonymi w słowniku i we frazeologii) zwrotami werbo-nominalnymi" 87.

Badająca konstrukcje analityczne w stylu liturgicznym A. Sieradzka-Mruk zauważyła, że stosuje się je w celu podkreślenia, wzmocnienia jakiegoś elementu wypowiedzi 88 , są środkami etykiety językowej - mają charakter form grzecznościowych, używane są także w funkcjach stylistycznych - pomagają podczas tłumaczenia oddaćłacińską stronę bierną, uniknąć nietypowej dla polszczyzny tautologii czy zapobiec dwuznaczności ${ }^{89}$. Badaczka zwróciła również uwagę na inny aspekt: „Użycie takich form ma zalety: podkreśla w pewien sposób rzeczownikowe nazwy ważnych pojęć, takich jak zbawienie, łaska, wolność, co może mieć znaczenie dydaktyczne - może uczyć abstrakcyjnego myślenia o sprawach wiary (np. myślenia o tym, czym jest łaska Boża, zbawienie itp.), ułatwiać zbudowanie systemu wartości (zbawienie, wolność jako wartości, do których dąży wierzący) [...]"90.

I. Loewe przytacza powszechnie obowiązujące sądy: „ekonomizujące wypowiedź typowe dla potoczności są uniwerbizmy, zaś predykacja peryfrastyczna dystansuje nadawcę wobec treści i jest wyrazem wyrazistości i precyzji w języku"91. Z badań w niniejszej pracy wynika, że bez wątpienia nacechowanie potoczne uwidacznia się w formach zuniwerbizowanych, choć - jak wykazano w rozdziale

86 I. Loewe, Konstrukcje analityczne w polskiej telewizji na progu drugiej dekady XXI wieku, „Stylistyka” 2010, XIX, s. 183.

87 I. Loewe, Konstrukcje analityczne w poezji Młodej Polski, Katowice 2000, s. 123.

88 A. Sieradzka-Mruk, Konstrukcje analityczne we współczesnym polskim stylu liturgicznym, „Język Polski” 2012, z. 3, s. 196.

89 Ibidem, s. 197-198.

90 Ibidem, s. 200.

91 I. Loewe, Konstrukcje analityczne w polskiej..., s. 184. 
poświęconym semantyce - niektóre sposoby tworzenia syntetyzmów stały się tak powszechne, że ich przynależność do nieoficjalnej odmiany języka nie zawsze jest dostrzegana. Co więcej, w badanym materiale odnotowano takie przykłady, w których - wręcz przeciwnie - to rozbudowana struktura ma znamiona potoczności, a jej jednoelementowy ekwiwalent jest częściej używany w oficjalnych wypowiedziach. Przy toczmy tu chociażby pary: pstrykać fotki i fotografować, zaliczyć asystę i asystować, dać sygnał i zasygnalizować, zaliczyć debiut i zadebiutować czy dać radę i poradzić. Również w analityzmach zastępujących pojedyncze rzeczowniki można znaleźć przykłady obrazujące łamanie powszechnie obowiązującej tendencji, np. szef rządu i premier, szef kadry i selekcjoner, strzelanie focha i obra$\dot{z} a n i e$. Wiele jest także frazeologizmów, które składają się z elementów kolokwialnych, podczas gdy to ich ekwiwalent odznacza się stylem wysokim (np. pluć sobie w brodę i żałować, utrzeć komuś nosa i poskromić, wystrychnać na dudka i oszukać, małe piwo i drobnostka).

Trudno nie zgodzić się z twierdzeniem licznych badaczy, że to konstrukcje wielowyrazowe są bardziej precyzyjne od swoich syntetycznych odpowiedników, służą więc celom komunikacyjnym. Nierzadko formy proste są wieloznaczne (jako przykład niech posłużą przywoływane w poprzednim podrozdziale uniwerbizmy), ich właściwe odczytanie uzależnione jest od zapoznania się z kontekstem, struktury złożone z kolei są prostsze i bardziej jednoznaczne w odbiorze, nazwanie w ten sposób pewnych faktów, czynności, obiektów i zjawisk ułatwia czytelnikowi interpretację. Z jednej strony konstrukcje analityczne są więc wyrazistsze i pozwalają uwydatnić więcej, z drugiej jednak zdarza się, że rozbudowane połączenia mają charakter eufemizmów, a wówczas czytelnik nie dowiaduje się wprost, co dziennikarz chciał przekazać. Autor posługuje się zawoalowanymi sformułowaniami z różnych względów: obyczajowych, społecznych, cenzuralnych czy prawnych. Element niedopowiedzenia zawierają na przykład takie łagodzące dosadność wypowiedzi struktury, jak: pewne powody, być pod wplywem czy zrobić to.

Z eufemizowaniem często wiąże się także wartościowanie, trzeba zatem wymienić i tę właściwość analityzmów. Publikujący, zastępując pojedynczy wyraz formą omowną, może użyć pozytywnie bądź negatywnie nacechowanych komponentów, które wpływają na wydźwięk całej konstrukcji. Posługiwanie się wyrazami nieobojętnymi aksjologicznie wpływa także na postrzeganie całego połączenia przez odbiorców (por. budzące negatywne skojarzenia sformułowania śmieciarska gadanina, mijać się z prawdą, być niewiernym). Nacechowanie 
aksjologiczne uwidacznia się nie tylko w eufemizmach, lecz także w wyrażeniach omownych, których głównym celem nie jest omijanie niewygodnych tematów. Część peryfraz zawiera wyrazy prymarnie wartościujące, inne dopiero w kontekście nabierają określonego wydźwięku. Zastępcze określenia wyzyskujące dodatnie wartości mogą pełnić funkcję perswazyjną - dziennikarz, wywołując pozytywne skojarzenia, łatwiej zyskuje aprobatę czytelnika. Właściwości takie ma chociażby zagadkowy tytuł Kraj Bonda, Marleya i Bolta, który nie informując wprost, wzmaga ciekawość odbiorcy poprzez przy toczenie nazwisk znanych osób, pozornie ze sobą niezwiązanych. Posługiwanie się rozbudowanymi środkami łagodzącymi wypowiedź pozwala nadawcy ukryć niewygodne treści, czasem jednak może wprowadzać czytelnika w błąd, bo nie wszystkie eufemizmy są łatwe do rozszyfrowania. Wykorzystywanie analityzmów o funkcji eufemistycznej może być wygodnym rozwiązaniem dla autora, który nie zawsze może - albo chce - ujawnić bezpośrednio swoje myśli. Wydaje się, że osłabieniu znaczenia syntetyzmu może towarzyszyć też funkcja manipulacyjna, jak chociażby w peryfrastycznych odpowiednikach wojny - zastępowanie tego wyrazu połączeniami czyny zbrojne, działania wojenne i militarne wyczyny wydobywa - dzięki zastosowaniu budzących pozytywne konotacje rzeczowników - dodatnie aspekty, tym samym zasłaniając negatywne konotacje.

Przeciwieństwem eufemizowania będzie wyrażanie wprost swoich myśli. I tutaj też z pomocą przychodzą dziennikarzowi konstrukcje analityczne, które pełnią niejednokrotnie funkcję ekspresywną, pozwalają dobitnie wyrazić swoje zdanie. Wyrazem ironii są choćby konstrukcje biegacze z gwizdkami na określenie sędziów, sypialnia stolicy jako alternatywna nazwa Żyrardowa czy dziwnie pachnacy pojawiające się zamiast bezpośredniego sformułowania śmierdzący. Sugestywne są bez wątpienia związki frazeologiczne, zwłaszcza występujące na gruncie polszczyzny potocznej (ale nie tylko), gdyż pozwalają obrazowo i nierzadko dosadnie wyrazić odczucia nadawcy czy opisać otaczającą rzeczywistość. Przywołajmy kilka przykładów: nie mieć co do garnka włożyć, nabrać wody w usta, sięgnać do portfela, wziąć coś pod lupę, strzelić buraka.

Ważnym czynnikiem powodującym wzmożone pojawianie się struktur złożonych są względy stylistyczne. Wymienne stosowanie krótkich i długich form pozwala urozmaicić tekst, wyeliminować powtórzenia, to także dobra okazja dla autora do zaprezentowania swojego kunsztu językowego, wykazania się kreatywnością - ujawnia się więc wymieniana w opracowaniach poświęconych temu zagadnieniu funkcja demonstratywna. Wielowyrazowym połączeniom 
stawia się także zadania ornamentacyjne ${ }^{92}$. W celach zdobniczych wprowadza się nie tylko eufemizmy, funkcja estetyczna uwidacznia się zwłaszcza w zastępnikach nazw własnych: niekonwencjonalnych nazwach geograficznych czy przydomkach klubów piłkarskich. Jak argumentuje M. Koper: „Ciekawą osobliwością z zakresu onomastyki sportowej jest częste zastępowanie przez sprawozdawców nazwy państwa, imienia i nazwiska piłkarza określeniem charakteryzującym. Zjawisko pronominacji to jedna z manier sprawozdawczych, mająca za zadania urozmaicić i uatrakcyjnić przekaz telewizyjny. [...] Peryfrastyczność określeń opartych na metaforze i metonimii spełnia w tym wypadku funkcję ornamentacyjno-estetyczną"93. Interesująco przedstawiają się szczególnie te peryfrazy, które do tej pory występowały sporadycznie lub wcale nie były notowane, np. poduszki rozkoszy, mistrz kielni, strażnik pamięci, mekka improwizacji, światowa fabryka sprinterów, kraj, który ma ostry smak papryki. Potwierdzają one nie tylko twórcze zdolności autorów, lecz także są wyrazem możliwości kreacyjnych tkwiących w języku. Peryfrastyczne przydomki wykorzystywane w słownictwie sportowym często służą hiperbolizacji wypowiedzi. Połączenia o zabarwieniu emocjonalnym pozwalają wyrazić stanowisko dziennikarza wobec zaistniałych wydarzeń. Uwypuklenie informacji odbywa się także za pomocą nacechowanych form, np. dostać baty, roznieść w pył czy ponieść klęske pojawiających się zamiast przegrać.

Analityzmy leksykalne i ich syntetyczne odpowiedniki mogą także być wykładnikiem wysokiego stylu, nadawać wypowiedzi podniosłe nacechowanie i wprowadzać patetyczny ton. Często traktuje się je jako elementy nierozerwalnie związane ze stylem urzędowym. Właściwość ta ujawnia się w następujących połączeniach wielowyrazowych: formalne zakończenie matżeństwa, wymiar sprawiedliwości, idea bezinteresownego niesienia dobra i pomocy, stać się największym beneficjentem, prowadzić obserwacje.

Czasem osobami posługującymi się analityzmami i ich syntetycznymi odpowiednikami kierują względy normatywne. Nie wszystkie wielowyrazowe połączenia są aprobowane przez wydawnictwa poprawnościowe, piszący próbują zatem dostosować swoją wypowiedź do reguł obowiązujących w polszczyźnie.

92 O tej cesze peryfraz pisał w swoich publikacjach M. Bańko.

93 M. Koper, „Poezja futbolu”. Kilka uwag o języku sprawozdawców sportowych, [w:] Język polski. Współczesność. Historia, red. W. Książek-Bryłowa, H. Duda, Lublin 2003, s. 59. 
Jako przykład niech posłuży połączenie mieć miejsce, które według słowników jest nadużywane w stylu publicystycznym i powinno być zastępowane przez odbyć się lub zdarzyć się.

Wspomnieć trzeba też o funkcji ludycznej. Aby zyskać sympatię odbiorcy, wplata się do tekstu połączenia humorystyczne, które pozwalają zmniejszyć dystans między autorem a czytelnikiem, co sprzyja nakłanianiu adresata do podjęcia określonych działań, zmiany jego zachowania, postawy lub przekonań, do głosu dochodzi zatem czasem funkcja impresywna. Żartobliwe zabarwienie uwidacznia się choćby w sformułowaniu wizyta bociana na określenie ciąży czy związku frazeologicznym $w$ stroju Adama, którego jednoelementowy odpowiednik to nago. Umacnianiu familiarnych stosunków służy też posługiwanie się przezwiskami.

Określenia peryfrastyczne bywają wprowadzane w celach stylizacyjnych, archaizacji może służyć wykorzystanie kolokacji wznosić modły zamiast syntetycznego czasownika modlić się. Obecne w ukazujących się na łamach „Victora Gimnazjalisty" artykułach zwroty charakterystyczne dla języka młodzieżowego, np. strzelić focha, pstrykać fotki, human, polak, komóra, ogólniak, budowlanka, mają na celu upodobnienie tekstów do socjolektu uczniowskiego.

Nie brakuje połączeń, które budzą skojarzenia z twórczością pisarską, a przez to mają zbliżyć artykuł do tekstu prozatorskiego czy wiersza. Wzorowane na języku poetyckim są na przykład połączenia z oczu pociekły mu łzy, łzy popłynęły komuś po policzkach, metaforyczny charakter mają zaś analityczne konstrukcje powędrować do zajezdni, spuścić zasłonę miłosierdzia, złożyć miłosną broń, zostać trafionym strzała Amora.

Istotna jest także funkcja identyfikacyjna, która uwidacznia się w posługiwaniu alternatywnymi nazwami w odniesieniu do osób czy drużyn piłkarskich. Za pomocą nieformalnych sformułowań uwypukla się tożsamość grupy społecznej - wszak nie dla wszystkich zrozumiałe będą przezwiska czy przydomki klubowe, a dopiero ten, kto będzie je umiał właściwie deszyfrować, może być traktowany jak swój. Taki zabieg służy więc podkreślaniu opozycji my - oni. Zjawisko takie uwidacznia się nie tylko w prasie sportowej, lecz także - o czym wyżej wspomniano - młodzieżowej - teksty tam drukowane pisane są językiem, który ma dotrzeć do określonej grupy docelowej. Pojawiają się zatem wielowyrazowe i syntetyczne połączenia, którymi chętnie na co dzień posługują się uczniowie. Wydaje się, że o funkcji identyfikacyjnej mówić można także w przypadku połączeń zrozumiałych dla określonego kręgu kulturowego, bazowanie chociażby na skojarzeniach 
religijnych trafnie odczytywanych jedynie w danym gronie może zacieśniać więzy między autorem tekstu a czytelnikiem.

Czasem różnica między opisywanymi formami sprowadza się do wyeksponowania podmiotu bądź - przeciwnie - obiektu. Konstrukcje analityczne mogą przenosić punkt ciężkości z przedmiotu na wykonawcę albo odwrotnie. Pisała o tym I. Loewe: „kolokacje odpowiadają na potrzebę wyrazistości w języku, rozkładają treść na dwa segmenty, oddalają w owej strukturze agensa na rzecz eksponowania obiektu będącego przedmiotem wyrażenia, stanu, uczucia, zjawiska przyrodniczego" 94 . Zabieg taki widoczny jest chociażby w omawianych szczegółowo w niniejszej pracy wielowyrazowych ekwiwalentach czasowników strzelićltrafić.

Wykorzystywanie synonimicznych form o zróżnicowanej liczbie słów spowodowane może być względami praktycznymi. „Publikujący wiedzą, że wprowadzenie konkretnych konstrukcji jest modne i pozwoli im zyskać przychylność czytelników"95. Nadmierne używanie cieszących się popularnością zwrotów może jednak sprawić, że teksty upodobniają się do siebie i zanika ich indywidualizm.

\section{Analityzmy leksykalne a profil pisma i gatunek wypowiedzi}

W niniejszej pracy analizie poddano cztery czasopisma o zróżnicowanych profilach: społeczno-politycznym, sportowym, edukacyjnym i poradnikowo-rozrywkowym. Przykłady pochodziły ze wszystkich obecnych na łamach tych periodyków gatunków: artykułów publicystycznych, wywiadów, recenzji, notatek prasowych, relacji czy opowiadań. Przekrój pojawiających się form wypowiedzi, jak i podejmowanej tematyki był więc zróżnicowany. Zamierzeniem nie było sporządzenie danych statystycznych, które pokazywałyby dokładne rozmieszczenie poszczególnych jednostek leksykalnych w badanych tygodnikach i występujących w nich gatunkach, lecz zaprezentowanie ogólnych tendencji. W. Cockiewicz wśród dziedzin, w których najczęściej obserwowane były analityzmy czasowniko-

94 I. Loewe, Konstrukcje analityczne w polskiej telewizji..., s. 177-178.

95 K. Burska, Analityczne konstrukcje czasownikowe w polskich tygodnikach, [w:] Słowo we współczesnych dyskursach, red. B. Kudra, K. Jachimowska, E. Szkudlarek-Śmiechowicz, Łódź 2014, s. 83. 
we w wypowiedziach telewizyjnych lat 70., wymienił: życie społeczne i gospodarcze, politykę, kształtowanie opinii publicznej, technikę, zarządzanie, planowanie. Wydaje się, że zestaw ten można by rozszerzyć obecnie zwłaszcza o problematykę sportową, wysoko plasuje się opisywanie spraw życia codziennego. Rzadko pojawiają się też konstrukcje, które da się zakwalifikować do trzech ostatnich grup wymienionych przez badacza, wpływ na to może mieć profil analizowanych periodyków. Uczeni wskazywali, że kategoriami najczęściej opisywanymi z wykorzystaniem struktur złożonych w poezji są uczucia, doznania i stany. W tekstach publicystycznych z kolei w ten sposób tworzy się opisy czynności, procesów i operacji. Przeprowadzone badania pozwalają na stwierdzenie, że konstrukcje analityczne posiadające syntetyczne ekwiwalenty wykorzystywane są do nazwania postaw, odczuć, sposobów działania, a także wielu elementów otaczającego świata - regionów geograficznych, miejsc, obiektów, osób, organizacji.

J. Anusiewicz sceptycznie podchodził do posługiwania się analityzmami leksykalnymi w publicystyce: „Ich stosowanie należałoby więc ograniczyć do tekstów pełniących przede wszystkim funkcję komunikatywną. Stąd też pojawiają się one najczęściej w sprawozdaniach, komunikatach PAP-u, Interpressu, artykułach politycznych, notatkach agencyjnych, popularnych artykułach informacyjnych, komentarzach prasowych, radiowych i telewizyjnych, tekstach dziennika radiowego i telewizyjnego, a także ogłoszeniach i reklamach. Przeprowadzone badania wykazały, że sporadycznie występują one w felietonach, reportażach, esejach, artykułach publicystycznych, gdzie realizowana jest w dużym stopniu funkcja ekspresywna języka, pełniona między innymi przez takie elementy, jak konstrukcje syntetyczne"96. Opisując analityzmy rzeczownikowe, dodawał także: „Teksty doniesień agencyjnych, artykułów informacyjnych, reklam, ogłoszeń pełnią przede wszystkim funkcję komunikatywną. Dlatego tam głównie powinny się pojawiać realizujące tę funkcję konstrukcje analityczne. Nie możemy ich stosowania zalecać w publicystyce - reportażach, felietonach, esejach - gdzie nie chodzi wyłącznie o czysto komunikatywną funkcję języka, ponieważ taka wypowiedź raziłaby bezosobowością, suchością, beznamiętnością relacji. Struktury opisowe powinny się tu pojawiać sporadycznie, w miarę potrzeby" 97 . Wydaje się, że jego postulaty nie zostały zaakceptowane. We współczesnych artykułach publicystycznych nie brakuje złożonych konstrukcji, a ich obecność nie wpływa

96 J. Anusiewicz, Konstrukcje analityczne we współczesnym..., s. 177-178.

97 Ibidem, s. 63. 
na odbiór tekstu, wręcz przeciwnie - często urozmaica przekaz. W niniejszym opracowaniu przyjęto jednak szerszą definicję konstrukcji analitycznych, warunkiem nie było bowiem występowanie wspólnych morfemów, stąd mogą wynikać rozbieżności w porównaniu z wynikami J. Anusiewicza. Można nawet zaryzykować stwierdzenie, że wywiady, felietony i eseje to typy tekstów, w których konstrukcje złożone odznaczają się najwyższą częstością występowania. Publikujący ma bowiem - w przeciwieństwie do gatunków informacyjnych - o wiele większą swobodę wypowiedzi, stąd może pozwolić sobie na posługiwanie się wymyślnymi formami. Uwarunkowane jest to także długością wypowiedzi - zwykle teksty publicystyczne mają większą objętość niż te o funkcji powiadamiającej, stwarzają więc możliwości operowania jednostkami peryfrastycznymi. W publicystyce dostrzegalne jest także chętne sięganie po związki frazeologiczne mające syntetyczne odpowiedniki.

Warto przyjrzeć się także, w których fragmentach tekstu umieszczane są analityzmy i syntetyzmy. Co oczywiste, najwięcej egzemplifikacji - i to zarówno wielowyrazowych, jak i składających się z jednego elementu - odnotowano w zasadniczej części artykułu. Omawiane konstrukcje pojawiały się także w mniejszym natężeniu w lidach, tytułach i podpisach pod zdjęciami. Ciekawe wydaje się prześledzenie ich obecności w nagłówkach, gdyż powszechnie sądzi się, że to ten właśnie element jako pierwszy zwraca uwagę czytelnika i decyduje o tym, czy zapozna on się z treścią całej wypowiedzi prasowej98. Zazwyczaj tytuły odznaczają się ekonomią środków językowych, dlatego nie dziwi fakt, że pojawiają się w nich syntetyzmy w postaci opartych na dezintegracji przezwisk (Lewy na pasach, Samotność Niedźwiedzia, Jodła ratownik, Turcy i Hiszpanie chca Kosę!, Zieniu, czyli przekleństwo Pasów), uniwerbizmów (Pięćlat na kontrolę skarbówki, Za kierownica na dopingu), złożeń (Piosenkarka wzorem dla ekomatek!), nie brakuje też prostych odpowiedników frazeologizmów (Wystąił nago!), orzeczeń peryfrastycznych (Dlaczego oni zdradzaja?, Wreszcie urodziła córeczkę!) i analitycznych konstrukcji rzeczownikowych (Rządy granatu, Goracy orange). Okazuje się, że w celach perswazyjnych wprowadzane są także konstrukcje analityczne: ekspresywne związki frazeologiczne (Uwa-

98 Por. chociażby W. Pisarek, Nowa retoryka dziennikarska, Kraków 2002; U. Żydek-Bednarczuk, Wprowadzenie do lingwistycznej analizy tekstu, Kraków 2005; E. Pałuszyńska, Nagłówki w „Gazecie Wyborczej” (ekspresywna leksyka, frazematyka, metaforyka), Łódź 2006; M. Ślawska, Tytut - najmniejszy tekst prasowy, „Rocznik Prasoznawczy” 2008, R. II, s. 117-126; J. Dobosiewicz, Magia tytułu prasowego, [w:] Język nowych mediów, red. K. Michalewski, Łódź 2012, s. 139-147. 
ga na biała śmierć!, Kelner stracił dla niej głowę!, Turysto, nie daj się nabić w butelkę, Łapie oddech w Hiszpanii), nacechowane aksjologicznie wyrażenia omowne (Łzy królowej popu, Anioł z New Jersey zamilkł na zawsze), enigmatyczne odpowiedniki nazw własnych (Kraj Bonda, Marleya i Bolta), kolokacje werbo-nominalne (Traci kilogramy). Ciekawym zabiegiem jest łączenie w tytułach syntetyzmu i odpowiadającej mu formy wieloelementowej, taki sposób nazywania tekstów, w których przedstawiane są warte zobaczenia kraje, wypracowali redaktorzy dwutygodnika dla młodzieży, np. Portugalia - kraj odkrywców, kibiców i fado, Niemcy - kraj autostrad i porzadku..., Rumunia - ojczyzna wampira i niedźwiedzi..., Wegry-kraj, który ma ostry smak papryki, Irlandia - zielona wyspa z celtycka tradycją.

Trudno określić jednoznacznie, w którym z omawianych tygodników jest największa frekwencja analityzmów mających syntetyczne odpowiedniki. Pod względem zróżnicowania na plan pierwszy wysuwa się „Piłka Nożna” - to właśnie w tym periodyku odnotowano najbardziej różnorodne połączenia, co jednak nie oznacza, że liczba obecnych na jego łamach konstrukcji analitycznych musi być największa. Czasopismo to odznacza się bogatymi ekwiwalentami oficjalnych nazw własnych - zarówno osobowych, jak i miejscowych. Alternatywne nomina propria są zresztą chętnie wykorzystywane we wszystkich trzech pozostałych periodykach, powszechnie korzysta się z przezwisk oraz ozdobnych odpowiedników nazw geograficznych. Na łamach wszystkich czasopism pojawia się także słownictwo z zakresu życia codziennego.

Warte podkreślenia jest to, że można wydzielić takie konstrukcje, które były obecne we wszystkich omawianych czasopismach. W tej grupie znalazłyby się wielowyrazowe sformułowania i ich syntetyczne odpowiedniki powstałe na drodze uniwerbizacji, a także związki frazeologiczne, które da się sprowadzić do ekwiwalentu jednoelementowego.

\section{Podsumowanie}

Zaprezentowane rozważania pragmatyczne skoncentrowane są wokół kompetencji nadawczo-odbiorczych użytkowników języka polskiego. Ponieważ badania dotyczyły tekstów pisanych, nie wszystkie czynniki pragmatyczne mogły zostać uwzględnione, wiele z nich jest bowiem dostrzegalnych w komunikacji mówionej. Skupiono się na tym, co we właściwym odbiorze znajdujących się w artykułach jednostek leksykalnych jest zależne od kontekstu, wskaźników odautorskich i wiedzy czytelnika. 
Otoczenie leksykalne odgrywa znaczącą rolę wówczas, gdy mamy do czynienia z wyrazami polisemicznymi, a więc gdy jednemu syntetyzmowi odpowiada kilka konstrukcji analitycznych. Zapoznanie się z informacjami zamieszczonymi w bezpośrednim sąsiedztwie pozwala odbiorcy wybrać najodpowiedniejsze z kilku możliwych znaczeń, zapobiega nieporozumieniom przy interpretacji materiału. Kontekst jest ważny dla czytelnika, gdy styka się z neologizmami - wartość semantyczna nienotowanych wcześniej wyrazów jest łatwiejsza do rozszyfrowania. Nierzadko autor naprowadza adresata na właściwy trop, umieszczając w tym samym tekście wieloelementowe odpowiedniki. Spora grupa zanalizowanych eufemizmów ma także charakter kontekstowy, odczytane w izolacji nie spełniałyby funkcji łagodzenia dosadności wypowiedzi. Kompetencje językowe sprawdza też umieszczanie w tekstach związków frazeologicznych, czytelnik musi bowiem wiedzieć, że nie należy dosłownie odczytywać trwałych połączeń wyrazowych.

Odbiorca tekstów medialnych musi być obeznany w otaczającej go rzeczywistości - nie wystarczy, że jest tylko obserwatorem, powinien także wykazać się wiedzą pozajęzykową. Odczytanie niektórych analityzmów wymaga rozległych zainteresowań, przydają się wiadomości z zakresu historii, biologii, architektury, gospodarki, polityki, sportu, kultury, ekonomii. Zwłaszcza przy analizie periodyków kierowanych do wąskiej grupy docelowej niezbędna okazuje się znajomość specjalistycznych zagadnień. Do rozwikłania pojawiających się czasem nawiązań intertekstualnych potrzebna jest znajomość literatury, filmu i muzyki.

Zdarza się, że zaobserwowane połączenia bazują na odwołaniach do kontekstu kulturowego, konieczne jest zatem poruszanie się po tej samej płaszczyźnie doświadczeń pozajęzykowych. Operowanie wspólnymi odwołaniami kulturowymi sprzyja pogłębianiu więzi między nadawcą a odbiorcą.

Oczekiwaną przez dziennikarza interpretację wspomaga umieszczanie wskaźników metatekstowych, które sugerują, żeby znajdujące się po obu ich stronach elementy wypowiedzi traktować jako równoważne. W tej roli dobrze spisują się nie tylko operatory metatekstowe, lecz także znaki interpunkcyjne: myślniki i przecinki. Dopowiedzenia wieloskładnikowe (czasem nawet w postaci zdania) bywają wprowadzane po kropce jako rozwinięcie myśli. Zdarza się, że nadawca sam podpowiada, np. umieszczając swoje sugestie w nawiasie, by mieć pewność, że rzadko stosowane w prasie jednostki będą właściwie odczytane. Tym samym zwraca uwagę odbiorcy na zaznaczony w ten sposób fragment. 
Funkcjonalne zróżnicowanie konstrukcji analitycznych mających syntetyczne odpowiedniki jest bardzo bogate. Obserwuje się nie tylko wymieniane w dotychczasowych opracowaniach funkcje, pojawiają się także nowe. Zdarza się, że jedno połączenie realizuje w wypowiedzi prasowej kilka zadań.

Określenia peryfrastyczne mogą być wyznacznikiem potoczności, ale też mieć charakter oficjalny i wprowadzać podniosłe albo urzędowe nacechowanie. Wiele pełni funkcję eufemizacyjną. Analityzmy leksykalne są źródłem ekspresji, umożliwiają nadawcy precyzyjnie opisać postawy, odczucia i stany, bywają nośnikiem hiperbolizacji. Nierzadko zawierają w sobie element wartościujący, co sprawia, że mają działanie perswazyjne, a czasem nawet manipulacyjne. Na pierwszy plan może wysuwać się funkcja demonstratywna, która pozwala zaprezentować kreatywność słowną autora. Wyszukane, oryginalne połączenia są wprowadzane w celach ornamentacyjnych, wzbogacają tekst i zapobiegają monotonii. Dzięki długim formom możliwe jest wyeksponowanie podmiotu bądź przedmiotu opisu. Posługiwanie się złożonymi jednostkami wyrazowymi zapewnia stylistyczne zróżnicowanie wypowiedzi. Piszącymi kierują czasem względy normatywne albo chęć podporządkowania się modzie językowej. Ważnym aspektem używania konstrukcji analitycznych jest stylizacja. Niektóre połączenia mogą mieć zabarwienie ironiczne albo żartobliwe, w przypadku tych drugich można mówić o funkcji ludycznej. Umieszczanie konstrukcji zrozumiałych tylko dla określonej grupy docelowej sprzyja większej identyfikacji sympatyków drużyn sportowych, wyznawców tej samej religii czy poglądów, zwolenników jakiejś idei.

Podkreśla się, że struktury złożone są precyzyjniejsze i dokładniejsze od swoich jednoelementowych odpowiedników. W zdecydowanej większości analiza zgromadzonego materiału pozwala na potwierdzenie tej tezy, choć trzeba podkreślić - co zostało omówione w pracy na konkretnych przykładach - że odnotowano przypadki, kiedy to rozbudowane formy składały się z wyrazów o tak ogólnym znaczeniu, że nie odsyłały jednoznacznie do określonego desygnatu.

Zwrócono także uwagę, jaki wpływ na występowanie konstrukcji analitycznych mających nierozbudowane ekwiwalenty mają profil pisma i gatunki się w nim ukazujące. Poddane obserwacji jednostki leksykalne nie są dominantą określonych form wypowiedzi, pojawiają się w artykułach zróżnicowanych genologicznie i tematycznie. Ich obecność została potwierdzona zarówno w tekstach zasadniczych, jak i nagłówkach, lidach czy podpisach pod zdjęciami. 



\section{Zakończenie}

Tworząc artykuł prasowy, dziennikarz decyduje, za pomocą jakich środków językowych opisze przedstawioną w nim rzeczywistość. Wybór formy długiej lub krótkiej niesie z sobą określone konsekwencje, jak podkreśla A. Dąbrowska: „Naświetlenie jakiegoś zjawiska zależy od nadawcy: czy nazwie on rzecz po imieniu, używając nazwy wprost, czy też użyje określenia dowartościującego bądź deprecjonującego wartość tego zjawiska"l. Sięgającym po konstrukcje analityczne mogą przyświecać różnorakie cele. O tym, że jest to zabieg chętnie wykorzystywany w prasie na początku drugiego dziesięciolecia XXI w., świadczyć może liczba zgromadzonych na potrzeby niniejszej rozprawy przykładów, a także ich bogactwo tematyczne, strukturalne i funkcjonalne.

Warto przypomnieć, że jako cel postawiono sobie przyjrzenie się, z jakich komponentów zbudowane są analityzmy leksykalne mające syntetyczne odpowiedniki, jakie relacje znaczeniowe zachodzą między omawianymi jednostkami, jakie kompetencje nadawczo-odbiorcze są wymagane do właściwego odczytywania peryfraz i ich odpowiedników oraz jakie role przypisywane są konstrukcjom analitycznym i ich ekwiwalentom we współczesnych periodykach. Zamierzeniem było skonfrontowanie wyników badań z wnioskami wypływającymi z dotychczas wydanych opracowań poświęconych tytułowemu zagadnieniu. Przyjęto szeroką definicję konstrukcji analitycznych, jako analityzm leksykalny uznano

1 A. Dąbrowska, Zniekształcanie obrazu rzeczywistości poprzez użycie pewnych środków językowych (eufemizm i kakofemizm), [w:] Językowy obraz świata, red. J. Bartmiński, Lublin 1999, s. 215. 
bowiem co najmniej dwuwyrazowe określenie, które posiada jednowyrazowy odpowiednik tożsamy lub bliski znaczeniowo.

Podział struktur złożonych pod względem przynależności ich jednoelementowych ekwiwalentów do części mowy wykazał, że najwięcej jest konstrukcji czasownikowych i rzeczownikowych, a także odpowiedników nazw własnych. Potwierdziły się tym samym obserwacje badaczy, gdyż najwięcej opracowań dotyczy właśnie orzeczeń peryfrastycznych, choć Violetta Machnicka - która analizowała peryfrazy rozumiane jako tropy, odrzucała zatem te, które nie pełnią funkcji estetycznej - doszła do innego wniosku: „W środkach masowej komunikacji zdecydowanie dominują peryfrazy proste (dwuskładnikowe) rzeczownikowe, czyli zastępujące rzeczowniki, choć zdarzają się peryfrazy czasownikowe i przysłówkowe"2 . Ponadto zgromadzono analityzmy przymiotnikowe, przysłówkowe, zaimkowe, liczebnikowe i modulantowe, wymienione w trzech ostatnich grupach nie były do tej pory przedmiotem opisu językoznawców, w badanym materiale odnotowano je jednak sporadycznie i miały równoważniki tylko w postaci związków frazeologicznych. W pozostałych przypadkach oprócz frazeologizmów wyróżniono konstrukcje mające wspólne morfemy z syntetyzmami oraz niewykazujące morfologicznego pokrewieństwa.

W grupie czasownikowej do najchętniej używanych podstaw zalicza się dać, dokonać, mieć, prowadzić, udzielać - co pokrywa się z badaniami J. Anusiewicza, A. Bogusławskiego i W. Cockiewicza - a także doznać, nieść, odnotować, poddać i zaliczyć. Zdecydowanie na pierwszym miejscu plasuje się mieć, do którego dołączane są rzeczowniki i wyrażenia przyimkowe, np. mieć złudzenia, mieć pod kontrola, mieć wplyw.

Zaznacza się tendencja do tworzenia analityzmów z wykorzystaniem alternatywnych podstaw czasownikowych, co jednak nie wpływa na zmianę formy krótkiej, np. fotografować to robić fotki i ustrzelić fotkę, remontować to prowadzić remont i robić remont, świadczyć to dać świadectwo i udzielić świadectwa.Zdarza się też sytuacja odwrotna - ten sam rzeczownik bywa dołączany do kilku czasowników, a formy syntetyczne są wówczas zróżnicowane, np. odpowiednikami mieć w pamięci i wyrzucić z pamięci są kolejno pamiętać i zapomnieć. Łączliwość wyrazów jest więc wykorzystywana na rozmaite sposoby.

2 V. Machnicka, Peryfrazy wokół nas, czyli o konstrukcjach omownych używanych we wspótczesnych środkach masowego przekazu (na tle rozważań teoretycznych), [w:] Język nowych mediów, red. K. Michalewski, Łódź 2012, s. 329. 
J. Anusiewicz twierdził: „Wyraz podrzędny informuje o znaczeniu całej konstrukcji, stanowiąc semantyczne jądro całego zwrotu”. W zdecydowanej większości zebranych egzemplifikacji to właśnie rzeczownik wpływa na znaczenie orzeczenia peryfrastycznego, trzeba jednak podkreślić, że odnotowano jednostkowe przykłady odbiegające od tego założenia: w złożonych konstrukcjach odwołujących się do trafić i strzelić to czasownik odgrywa decydującą rolę (strzelić gola, trafić do siatki, trafić do siatki rywala, trafić do bramki), a raz nawet przydawka rzeczownikowa (wpisać się na listę strzelców), a w przypadku pary trenowaći prowadzić z ławki trenerskiej - przydawka przymiotnikowa. Podział formalny jest w zasadzie zbieżny z dotychczasowymi ustaleniami - czasowniki łączą się z rzeczownikami w przypadkach zależnych (pod względem częstości występowania są to: biernik, dopełniacz, celownik, narzędnik) bądź wyrażeniami przyimkowymi. Nie zebrano przykładów będących połączeniem czasowników z bezokolicznikami, ale za to pojawiło się zestawienie z przysłówkiem (wyjść zwycięsko), a także wymienione wyżej dwie egzemplifikacje, w których pokrewieństwo morfologiczne ujawniało się w przydawkach.

Dla orzeczeń peryfrastycznych niemających wspólnych morfemów z syntetyzmem charakterystyczne jest występowanie wielu synonimów. Najbardziej produktywnym czasownikom odpowiada nawet kilkanaście struktur złożonych o zróżnicowanej strukturze i zazwyczaj każda wydobywa inne aspekty semantyczne czy stylistyczne. Przytoczmy chociażby ekwiwalenty przegrać (gubić punkty, tracić oczka, dostać baty, ponieść porażkę, wrócić bez punktów, doznać porażki, oddać punkty, otrzymać od rywali lekcje futbolu, poznać smak porażki, zaznać goryczy porażki, zaznać porażki, stracić punkty, ponieść klęskę) czy umrzećlzginąć (stracić życie, oddać życie, ponieść śmierć, nie wrócić do domu, kogoś nie ma już wśród żywych, czarowaćw innym, lepszym ze światów, kogośdosięła śmiercionośna kula, zamilknać na zawsze, nadeszło to nieuniknione, zgasnąć przedwcześnie, być daleko stąd, dokonać żywota, odejść z tego świata). To tutaj najlepiej uwidacznia się inwencja twórcza dziennikarzy, wybrane formy mają charakter jednostkowy, choć w niektórych kręgach tematycznych widoczna jest powtarzalność. Pod względem budowy prezentują większą wariantywność niż podgrupa czasowników ze wspólnymi morfemami, składają się bowiem z połączeń czasowników z rzeczownikami w różnych przypadkach, wyrażeniami przyimkowymi lub przymiotnikami. Nie brakuje modulantów, zaimków, przysłówków i imiesłowów. Nierzadko rzeczowniki rozbudowane są o przydawki wyrażane rzeczownikami, przymiotnikami, liczebnikami. 
Czasowniki mogą mieć także po kilka ekwiwalentów frazeologicznych, nie zawsze jednak możliwe jest ich wymienne użycie, np. dominować to grać pierwsze skrzypce, nadawać ton, cośbierze nad kimś, nad czymś górę, oszukać z kolei to wystrychnać na dudka, nabić w butelkę, robić wodę z mózgu, wyprowadzić w pole. Czasem na jednej podstawie rzeczownikowej budowane są różne stałe połączenia wyrazowe. Pod względem budowy wszystkie frazeologizmy z tej grupy zaliczane są do zwrotów.

W grupie konstrukcji rzeczownikowych mających wspólne morfemy z niezłożonymi odpowiednikami trudno jest mówić o charakterystycznych podstawach. J. Anusiewicz, M. Honowska i W. Cockiewicz wymieniali chociażby takie, jak: fakt, problem, sprawa, zagadnienie, w badanych czasopismach występowały one jednak sporadycznie. Być może rozbieżności wynikają z innej podstawy materiałowej (wspomniani badacze analizowali też język mówiony), a może współcześni dziennikarze świadomie rezygnują z posługiwania się niewiele wnoszącymi do wypowiedzi rzeczownikami. Analiza formalna dowodzi, że najchętniej stosuje się połączenia rzeczowników z przymiotnikiem oraz rzeczownikiem w dopełniaczu, co jest zgodne $\mathrm{z}$ mechanizmami zaobserwowanymi przez J. Miodka w latach 70. $\mathrm{XX}$ w. Ponadto obecne są sformułowania składające się z rzeczowników i wyrażeń przyimkowych. Wśród syntetyzmów rzeczownikowych dominują uniwerbizmy powstałe w wyniku elipsy substantywizującej (liniowy, nocny, schabowy) lub deadiektywizującej (igrzyska, rzecznik, strona), dezintegracji (doping, energetyk, human) lub derywacji sufiksalnej (budowlanka, skarbówka, spożywczak), sporadycznie notowane są złożenia (narkobaron, ekomatka). Wiele znajdujących się $\mathrm{w}$ tej grupie rzeczowników było pierwotnie przymiotnikami, uległy więc procesowi substantywizacji.

Rzeczowniki złożone nieposiadające substancjalnej tożsamości ze swoimi prostymi ekwiwalentami zbudowane są zwykle z połączeń rzeczowników z rzeczownikami w dopełniaczu, przymiotnikami, imiesłowami, liczebnikami i wyrażeniami przyimkowymi. Chętnie sięga się po rzeczowniki odczasownikowe. Pojawia się sporo konstrukcji składających się z więcej niż dwóch elementów. Podobnie jak i w grupie czasowników również tutaj zaznacza się bogata synonimia - jednemu leksemowi często odpowiada kilka ekwiwalentów o zbliżonej wartości semantycznej, ale odmiennej budowie, np. wulgaryzm to nieprzyzwoite słowa, soczyste słowa, soczyste słownictwo, nieparlamentarne słówka, śmieciarska gadanina; odpowiednikami bramkarza są: pozycja między słupkami, specjalista od łapania piłki, specjalista od stania między słupkami; chudnięcie definiowane 
jest jako pozbycie się nadwagi, doprowadzenie wagi do normy i utrata nadwagi. Związki frazeologiczne, które odpowiadają pojedynczym rzeczownikom, są wyrażeniami, czasem pierwotnie należały do kategorii zwrotów, lecz poddane zostały nominalizacji.

Wśród mechanizmów tworzenia analityzmów przymiotnikowych największą częstotliwością odznacza się schemat wyrażenie przyimkowe + przymiotnik (o charakterze socjologicznym, $w$ formie żywej, w kolorach żólto-niebieskich), sporadycznie występują połączenia wyrażenia przyimkowego z rzeczownikiem $\mathrm{w}$ dopełniaczu ( $w$ kolorze pomarańczy) oraz przysłówka z przymiotnikiem (czysto marketingowy). Nie odnaleziono pozostałych dwóch sposobów generowania jednostek przymiotnikowych uwzględnionych przez J. Anusiewicza, a mianowicie rzeczownik + przymiotnik oraz wyrażenie przyimkowe zastępujące przymiotnik. Z kolei nieliczne analityzmy przysłówkowe mające wspólne morfemy z syntetyzmem oparte były na modelu wyrażenie przyimkowe + przymiotnik ( $w$ sposób naturalny, w sposób płciowy). Większe bogactwo w tej grupie wykazały frazeologizmy - pod względem struktury zaliczane do wyrażeń lub zredukowanych o czasownik zwrotów - nieraz jeden przysłówek miał kilka ekwiwalentów frazeologicznych, np. całkowicie to do imentu i do szpiku kości, natychmiast to z miejsca i na zawołanie, spokojnie to bez szemrania i zzimna krwia.

Szerokie rozumienie analityzmu pozwoliło na zbadanie także ekwiwalentów nazw własnych. Tutaj również dało się dostrzec - bądź nie - pokrewieństwo morfologiczne. Opisano dwa zjawiska: nazwie własnej odpowiada inna nazwa własna lub nazwie własnej odpowiada połączenie zbudowane z wyrazów pospolitych. Równoważnikami imienia i nazwiska mogą być: przezwiska pochodzące od nazwiska (Błaszczu - Jakub Błaszczykowski, Ibra - Zlatan Ibrahimowić, Ślusarz Bartosz Ślusarski), przezwiska pochodzące od imienia (Ebi - Euzebiusz Smolarek, Ludo - Ludovic Obraniak, Prezes - Prejuce Nakoulma) lub przezwiska pochodzące od imienia i nazwiska (najrzadziej spotykana możliwość, np. Zibi - Zbigniew Boniek, Zizou - Zinedine Zidane), a także przezwiska niemające wspólnych morfemów z imieniem i nazwiskiem. Zabieg formalny służący do tworzenia alternatywnych nazw osobowych to przeważnie ucięcie, często połączone ze zmianą paradygmatu fleksyjnego, dodaniem sufiksów lub alternacjami w podstawie słowotwórczej. Wiele alternatywnych nazw osobowych jest zbieżnych formalnie z wyrazami pospolitymi (np. Doktor, Księgowy, Wódz). Przydomki klubowe też mogą nawiązywać do nazwy klubu (Barca - FC Barcelona, Juve - Juventus Turyn, Piastunki - Piast Gliwice) lub się do niej nie odwoływać - więcej przynależy do 
drugiej grupy, np. Drozdy - West Bromwich Albion, Koniczynki - Panathinaikos Ateny, Smoki - FC Porto. Ekwiwalentem tej samej nazwy drużyny może być zarówno przydomek syntetyczny, jak i rozbudowana peryfraza (np. Kolejorz i Duma Wielkopolski to określenia Lecha Poznań). Często pojawiającym się mechanizmem tworzenia syntetyzmów od zróżnicowanych klas nomina propria jest uniwerbizacja (Bałtyk, Popielec, Stany). Równolegle z uniwerbizmami występują nierzadko rozbudowane formy opisowe. Zdecydowanie najczęściej jednoczłonowa nazwa własna ma wielowyrazowe odpowiedniki, prym wiodą tutaj nazwy geograficzne (miasta, kraje, kontynenty, planety) - a ich podstawami są przeważnie leksemy stolica, miasto, ojczyzna, kraj i kolebka - choć pojawiają się też antroponimy czy chrematonimy. Zdarza się, że jednej nazwie przysługuje kilka wyrażeń omownych, jako przykład niech posłuży Kraków i jego peryfrastyczne odpowiedniki: miasto pod Wawelem, u stóp Wawelu, stolica Małopolski, miasto Kraka, gród Kraka. Wielowyrazowe połączenia odnoszące się do nazw własnych to różne kombinacje rzeczowników z przymiotnikami, przysłówkami, rzeczownikami, imiesłowami i wyrażeniami przyimkowymi.

Liczba komponentów wchodzących w skład wszystkich zanalizowanych połączeń wielowyrazowych waha się od dwóch do nawet kilkunastu, przy czym najczęściej we wszystkich grupach występowały połączenia dwu, trzy- i - trochę rzadziej - czteroelementowe. Pewnym novum, dotychczas niepoddawanym szczegółowemu oglądowi, jest obecność w tekstach dziennikarskich konstrukcji kilkunastoskładnikowych, które mieszczą się w obrębie kształtu definicji, np. istota, która nie wie, czy nici jej istnienia nagle nie przetnie sarkoma płuc; rozrabiaki, przez których nawet kluby piłkarskie mają kłopoty i których nikt nie chce widzieć na trybunach; imponujacy i monumentalny obiekt usytuowany po drugiej stronie Wisly, ale jednak na wprost Pałacu Kultury i Nauki; ciężarna dziewica, która stanęła samotnie naprzeciw świata, w czasach, gdy kamienowano za przedmatżeński seks. Z jednej strony formy takie mogą budzić zaciekawienie ze względu na oryginalne ujęcie tematu, $\mathrm{z}$ drugiej zaś ich rozbudowana struktura sprawia, że trudno je zapamiętać, ich rozpowszechnianie jest mało prawdopodobne. Można je zatem uznać za okazjonalizmy tekstowe - pojawiły się tylko raz w określonym otoczeniu leksykalnym, zostały wykorzystane na potrzeby konkretnego artykułu i nie będą już więcej używane.

Ciekawe spostrzeżenia przynosi analiza semantyczna zgromadzonych jednostek. Pełna synonimia jest - co zresztą podkreślają współcześni lingwiści - rzadkością, najczęściej spotykamy się z synonimią częściową. Jako równoznaczne 
uznane zostały takie pary, które mogą być używane wymiennie we wszystkich kontekstach, nie są nacechowane ekspresywnie ani stylistycznie, a ich nadrzędnym celem jest informacyjność. Rzeczywiste ekwiwalenty tworzą zatem konstrukcje przymiotnikowe i przysłówkowe oraz ich proste odpowiedniki ([stroje] $w$ kolorze pomarańczy i pomarańczowe, [karp] w formie żywej i żywy, [kojarzyć się] w sposób naturalny i naturalnie), a także rzeczowniki, których forma opisowa ma postać prostej definicji (mistrzostwa świata i mundial, dwanaście miesięcy i rok, polska waluta i złoty), oraz wybrane orzeczenia peryfrastyczne z podstawą mieć i odpowiadające im syntetyzmy, np. mieć zamiar i zamierzać, mieć watpliwości i wątpić, mieć oddziaływanie i oddziaływać.

Częściej jednak dublety służyć mają wydobyciu odcieni znaczeniowych, profilowaniu pojęć. Określenia peryfrastyczne mogą akcentować różne aspekty opisywanych czynności, stanów, działań, pozwalają wyzyskać te składniki semantyczne, których nie da się wyrazić za pomocą formy prostej. Zwykle różnice między syntetyzmem a analityzmem są nieznaczne, choć od notowano przypadki, kiedy rozbieżności semantyczne były dość duże. Zauważalne jest funkcjonowanie w grupie czasowników triad: analityzm - frazeologizm - konstrukcja opisowa (pomóc - przyjść w sukurs, podać pomocna dłoń, wyciagnąć rękę - nieść pomoc). Jeśli pojawiają się w jednej publikacji, to służą ukazaniu pełnego i dokładnego opisu, niejako wzajemnie się uzupełniają, pomagając czytelnikowi stworzyć całkowity obraz zdarzeń. Bywa, że jedna forma prosta (np. wygrać, umrzeć czy strzelić) ma kilkanaście zastępników, wówczas trudno mówić o konstrukcjach równoważnych, zazwyczaj każdej z nich przypisana jest subtelnie zróżnicowana wartość znaczeniowa. Czasem w takich szeregach synonimicznych spotyka się połączenia wyrażające treści przeciwstawne.

Specjalizacji znaczenia służą też frazeologizmy. Mimo iż funkcjonujące synonimicznie połączenia da się sprowadzić do takiego samego syntetyzmu, to nie zawsze związki te można stosować wymiennie. Zwracała na to uwagę B. Rejakowa: „W języku funkcjonują pary synonimicznych jednostek - frazeologizm - leksem (jednostki te mogą mieć taką samą wartość semantyczną, przy jednoczesnym zróżnicowaniu nacechowania stylistycznego)"3. Różnią się nie tylko wartością stylistyczną, ale często nacechowaniem emocjonalnym, zabarwieniem aksjologicznym czy poziomem ekspresji.

3 B. Rejakowa, Pojedynczy wyraz jako forma przekładu zwiazku frazeologicznego (wartości referencyjne i stylistyczne), „Annales UMCS. Sectio F” 1988, s. 345. 
Największą częstotliwość występowania odnotowały konstrukcje różniące się walorami stylistycznymi, wyraźnie zarysowało się przeciwstawienie kategorii potoczności i oficjalności. Przyjęło się twierdzić, że to formy krótkie częściej spotykane są w nieoficjalnej odmianie polszczyzny, ale jak pokazał zgromadzony materiał, w rozbudowanych konstrukcjach również dostrzega się elementy języka dnia powszedniego. Mechanizmem powstawania wyrazów przypisywanym do stylu potocznego jest uniwerbizacja, różne jej warianty dostrzega się podczas tworzenia skondensowanych form będących zarówno wyrazami pospolitymi, jak i nazwami własnymi - zwłaszcza elipsa któregoś członu onimu świadczy o przynależności powstałego w ten sposób leksemu do niższego rejestru.

Tworzone są zestawy trzech określeń na określenie jednego desygnatu, różnią się one stopniem nacechowania stylistycznego, np. język polski-polski-polak, telefon komórkowy - komórka - komóra. Opozycja neutralność - potoczność uwidacznia się także w parach składających się z frazeologizmu i syntetyzmu. Frazeologia potoczna jest bardzo rozbudowana, co jednak nie oznacza, że nie da się dostrzec zestawów, w których to trwałe połączenie wyrazowe jest obojętne stylistycznie, a jego odpowiednik ma cechy kolokwialne.

Nowe aspekty znaczeniowo-stylistyczne pozwala wydobyć też wprowadzenie nacechowania urzędowego. Naukowy charakter ujawnia się w peryfrazach budowanych na kształt definicji, są one wyjaśnieniem i doprecyzowaniem tego, co nie zostało ujawnione za pomocą formy niezłożonej. Zabieg taki wykorzystywany jest zwłaszcza wówczas, gdy mamy do czynienia z terminologią specjalistyczną, omówienie pozwala na przybliżenie niezrozumiałych dla części odbiorców treści (np. antykoncepcja i medyczne procedury zapobiegania ciąży, napastnik i zawodnik z pierwszej linii, rozwód i formalne zakończenie małżeństwa). Peryfrastyka taka dodaje opisowi podniosłości, wydaje się, że czasem jest to przesadny, niczym nieuzasadniony patos, a wówczas zamiast uwypuklać opisywane zjawisko, może śmieszyć.

Szeroko omówioną kategorią, w której ujawniają się nowe znaczenia, jest eufemizowanie. Już sama decyzja o niemówieniu wprost o jakimś zjawisku sprawia, że pewne jego odcienie znaczeniowe zostają zatajone, a inne wysunięte na pierwszy plan. Określenia zastępcze są wykładnikami wartościowania. Zwykle to multiwerbizm opisuje tematy objęte tabu, odnotowano też rzadkie przypadki, gdy eufemizmem jest jednoelementowa forma. Bogactwo podejmowanych kręgów tematycznych zazębia się z tymi wydzielonymi przez A. Dąbrowską, do eufemizowania wykorzystywane są rozmaite środki formalne. 
Metafora i metonimia to z kolei główne sposoby służące tworzeniu odpowiedników nazw własnych. Widoczna jest schematyczność w budowaniu nieoficjalnych nazw geograficznych, chętnie korzysta się z podstaw rzeczownikowych, które uwypuklają jakieś cechy opisywanego miejsca - jego ważność, szczególną rolę, rangę historyczną, położenie, walory środowiska przyrodniczego itp. Wykorzystywana jest także relacja podobieństwa do obszarów zlokalizowanych w innych częściach świata, co ma na celu wywyższenie tych mniej znanych. V. Machnicka dostrzega, że omówienia takie są często definicyjnymi odpowiednikami nazw własnych: „Definicje peryfrastyczne różnią się od typowych definicji słownikowych tym, że nie tyle służą one celom nominatywnym, co raczej kreatywnym, oceniającym, nie przekazują najważniejszych informacji o przedmiocie, lecz za pomocą nowatorskiej, indywidualnej prezentacji tegoż przedmiotu eksponują w jego opisie cechy drugorzędne, często wybierane przypadkowo, okazjonalnie (stąd peryfrazy okazjonalne), nie zaś te utrwalone w powszechnym odbiorze jako pierwszoplanowe"4. Szczegółowo opisana została również motywacja przydomków klubów sportowych i reprezentacji narodowych. Najczęściej dochodzi do przeniesienia nazwy herbu, elementu widniejącego na godle, fladze narodowej lub strojach na nazwę całej drużyny. Inny mechanizm polega na wykorzystaniu lokalizacji lub charakterystycznych cech regionu (np. gałęzi przemysłu, historii). Antroponimy opisowe - podobnie jak toponimy - opierają się na charakterystycznych podstawach, które ułatwiają waloryzowanie, np. król, królowa, perła. Syntetyczne przezwiska zaś odwołują do cech fizycznych, pochodzenia, pełnionych funkcji, skojarzeń z imionami lub nazwiskami.

J. Anusiewicz pisał w swojej monografii: „Stosowanie konstrukcji analitycznych wyklucza możliwość rozmaitych interpretacji, eliminuje emocjonalne zabarwienie stylistyczne, czyniąc styl neutralnym znaczeniowo”. O ile z pierwszą częścią tej wypowiedzi trzeba się zgodzić, o tyle analiza przykładów dowiodła, że formy złożone nierzadko są nacechowane stylistycznie czy emocjonalnie, natomiast syntetyzmowi można przypisać neutralność.

Skłonność do wieloznaczności konstrukcji syntetycznych - tak akcentowana m.in. przez J. Miodka i E. Szczepańską - widoczna jest przede wszystkim w zestawie analityzmów czasownikowych i rzeczownikowych. Taki sam strukturalnie syntetyzm odwołuje wtedy do kilku zróżnicowanych konstrukcji wieloelementowych, np. strzelić to strzelić gola, ale i oddać strzał, ławka to zarówno ławka

4 V. Machnicka, op. cit., s. 328. 
trenerska, jak i ławka rezerwowych. Charakterystyczne jest, iż właściwość ta ujawnia się często w klasie nazw własnych, przykładami mogą być Mały na określenie zarówno Patryka Małeckiego, jak i Zbigniewa Małkowskiego oraz Narodowy, który odnosi się do Stadionu Narodowego i Teatru Narodowego. Większość form zuniwerbizowanych jest także tożsama $\mathrm{z}$ istniejącymi już wyrazami, jak pokazano w rozdziale poświęconym pragmatyce, jeden leksem może odnosić się nawet do kilkunastu elementów rzeczywistości pozajęzykowej.

Zaznaczyć trzeba, że nierzadko analityzmy leksykalne mają inne wymogi składniowe niż ich syntetyczne odpowiedniki, stąd nawet jeśli obie formy przekazują zbliżone treści, to można zaobserwować różnice syntaktyczne, np. mieć pod opieką i opiekować się, prowadzić remont i remontować, współczuć i odczuwać współczucie.

Posługiwanie się wyrażeniami omownymi i ich ekwiwalentami wymaga sporych kompetencji zarówno od odbiorcy, jak i nadawcy. Wskaźnikiem, który naprowadza na właściwe odczytanie wieloelementowych połączeń, jest kontekst - nie tylko językowy, rozumiany jako sąsiedztwo leksykalne, ale także kulturowy, odwołujący do wspólnoty doświadczeń pozajęzykowych. Otoczenie leksykalne niezbędne jest do odszyfrowania konkretnego znaczenia wyrazów polisemicznych, neologizmów, eufemizmów czy związków frazeologicznych. B. Rejakowa zauważyła, że „te same wartości mogą być przekazywane różnymi środkami i na odwrót, takie same strukturalnie środki mogą być eksponentami różnych wartości"5. Adresat musi zatem umieć poruszać się w gąszczu oferowanych mu propozycji słownych. Ważna jest nie tylko wiedza o języku, kompetentny czytelnik to taki, który odznacza się wszechstronnym obeznaniem w świecie. Mnogość obecnej na łamach periodyków tematyki sprawia, że przydają się rozległe zainteresowania, wiadomości nawet $\mathrm{z}$ bardzo wąskich dziedzin. Nie ma chyba zagadnień, które nie mogłyby zostać przedstawione z wykorzystaniem analityzmów mających syntetyczne odpowiedniki. Mniej obeznanemu w rzeczywistości czytelnikowi nadawca podsuwa gotowe rozwiązania w postaci wskaźników metatekstowych, które mają naprowadzić na pożądany przez dziennikarza sposób interpretacji.

Wielość funkcji pełnionych przez konstrukcje analityczne powoduje, że tak chętnie wykorzystywane są w czasopismach o różnych profilach. Jako że mogą pełnić funkcję wartościującą, eufemistyczną, perswazyjną, manipulacyjną, eks-

5 B. Rejakowa, op. cit., s. 344. 
presywną, demonstratywną, estetyczną, ornamentacyjną, hiperbolizującą, ludyczną, impresywną, stylizacyjną, identyfikacyjną, ułatwiają precyzyjne formułowanie myśli i sprzyjają pozyskiwaniu czytelnika. Odnotowano wcale nierzadkie przypadki, gdy jednej formie przypisanych było kilka różnych ról, np. jednocześnie funkcje eufemistyczną i manipulacyjną pełnią odpowiedniki wojny: czyny zbrojne, działania wojenne i militarne wyczyny; eufemistyczną i ludyczną - żartobliwe nazwanie ciąży wizytą bociana; wyrazem ekspresji i wyznacznikiem potoczności są choćby frazeologizmy: zejść na psy, robić wodę z mózgu, puścićfarbę; alternatywne określenia drużyn piłkarskich i zawodników są używane zarówno w celach ornamentacyjnych, jak i identyfikacyjnych (Duma Katalonii, Rycerze Wiosny, Król Futbolu); stylizacja i identyfikacja ujawniają się w posługiwaniu się jednostkami należącymi do socjolektu młodzieżowego (strzelanie focha, polak, human); połączenie czarować w innym lepszym ze światów ma nie tylko łagodzić przekaz, lecz także zdobić wypowiedź.

Analiza czterech periodyków dowiodła, że multiwerbizmy używane są niezależnie od tematyki pisma i grupy docelowej. Nadają się one do opisywania realiów sportowych, politycznych, ekonomicznych, historycznych, gospodarczych, prawniczych, kulturalnych, młodzieżowych, a także przestrzeni edukacyjnej czy świata show-biznesu. Obserwuje się przenikanie specjalistycznych połączeń - kiedyś obecnych tylko na łamach sprofilowanych czasopism - z prasy hobbystycznej do periodyków o charakterze ogólnym, np. takie same słownictwo dotyczące futbolu obecne jest zarówno w „Piłce Nożnej”, „Polityce”, jak i „Victorze Gimnazjaliście”.

Wielowyrazowe połączenia mające proste odpowiedniki są chętnie używane w zróżnicowanych genologicznie tekstach - zarówno informacyjnych, jak i publicystycznych. Co zrozumiałe, większe możliwości mają autorzy felietonów i komentarzy, gdyż gatunki te sprzyjają wprowadzaniu do tekstów dłuższych, niekonwencjonalnych połączeń, które są efektem zindywidualizowanego postrzegania rzeczywistości. Można użyć form jednoznacznych, które sprawią, że już po pobieżnym zapoznaniu się z artykułem odbiorca odczyta przekaz, można też bawić się z czytelnikiem i ukryć pewne sensy, powodując, że przerwie monotonną lekturę i odda się refleksjom. W opracowaniach podkreśla się, że stosowanie wyrażeń omownych stało się modne we współczesnej publicystyce: „Peryfraza należy do konstrukcji często spotykanych zarówno w odmianie mówionej, jak i pisanej języka. Jako trop pozwalający w niebanalny sposób wyrazić różnorodne treści, nadać wypowiedzi odpowiedni odcień stylistyczno-semantyczny, szczególną 
popularnością cieszy się obecnie zwłaszcza w tekstach publicystycznych"6. Multiwerbizmy i ich ekwiwalenty pojawiają się w różnych częściach artykułów: od nagłówków, przez lidy, korpus główny, aż po podpisy pod zdjęciami.

Istnienie analityzmów leksykalnych mających syntetyczne odpowiedniki nie jest zjawiskiem charakterystycznym tylko dla tekstów prasowych. Nawet pobieżna obserwacja innych współczesnych przekazów medialnych pozwala stwierdzić, że opisywane w niniejszej pracy tendencje nie są specyfiką jedynie prasy, konstrukcje takie dostrzega się na stronach internetowych (co nie dziwi - wszak ci sami dziennikarze często publikują zarówno w czasopismach, jak i na portalach), a także słyszy się w radiu i telewizji.

Skłonność do peryfrastyki i dążenie do ekonomicznego wyrażania myśli współwystępują w tekstach czasopism, żadna z przedstawionych form opisu nie dominuje, można nawet zaobserwować, że wzajemnie się uzupełniają. Dla tych, którzy twierdzą, że nadmiar jednostek leksykalnych utrudnia komunikację, warto przytoczyć słowa A. Dąbrowskiej: ,język jest rozrzutny, skoro daje do dyspozycji tyle nazw jednego zjawiska lub kilku bardzo podobnych zjawisk. Wiadomo jednak, że system językowy jest ekonomiczny i funkcjonalny i służy potrzebom użytkowników. Skoro więc istnieje tak wiele określeń, są one potrzebne"7. Trzeba zatem doceniać bogactwo synonimicznych struktur, gdyż pozwalają odkrywać nowe znaczenia, wydobywają nacechowanie stylistyczne, są wykładnikami wartościowania, nośnikami ekspresji i wreszcie urozmaicają tekst, a być może tym samym w dobie kultury audiowizualnej zachęcają przynajmniej część odbiorców do regularnego sięgania po tytuły prasowe.

6 V. Machnicka, Peryfrazy Bolesława Prusa, Siedlce 2011, s. 48.

7 A. Dąbrowska, Kilka słów o eufemizmach, [w:] Język a komunikacja 5, t. 1: Aspekty wspótczesnych dyskursów, red. P. Chruszczewski, Kraków 2004, s. 83. 


\section{Bibliografia}

Anusiewicz J., Konstrukcje analityczne we współczesnym języku polskim, Wrocław 1978.

Anusiewicz J., Konstrukcje analityczne w języku mówionym, [w:] Miejska polszczyzna mówiona. Metodologia badań, red. W. Lubaś, Katowice 1976, s. 85-102.

Anusiewicz J., Konstrukcje analityczne w języku prasy, „Wrocławski Rocznik Prasoznawczy" 1974, s. 61-86.

Anusiewicz J., Wprowadzenie w problematykę pragmatyki lingwistycznej, „Acta Universitatis Wratislaviensis" 1988, Studia Linguistica XII, s. 1-29.

Bach K., Context ex Machina, [w:] Semantics versus Pragmatics, red. Z. G. Szabó, Oxford 2005.

Bańko M., Peryfrazy w naszym życiu, „Poradnik Językowy” 2002, z. 9, s. 3-23.

Bańko M., Słownik peryfraz, czyli wyrażeń omownych, wyd. 2, Warszawa 2009.

Bartmiński J., Styl potoczny, [w:] Encyklopedia kultury polskiej XX wieku, t. 2: Współczesny język polski, red. J. Bartmiński, Wrocław 1993, s. 115-134.

Bartmiński J., Niebrzegowska S., Profile a podmiotowa interpretacja świata, [w:] Profilowanie w języku i w tekście, red. J. Bartmiński, R. Tokarski, Lublin 1998, s. 211-224.

Bąba S., Frazeologia polska. Studia i szkice, Poznań 2009.

Bednarek A., Wykładniki leksykalne ekwiwalencji. Analiza semantyczna wyrażeń typu czyli, Toruń 1989.

Bogusławski A., Jednostki języka a produkty językowe. Problem tzw. orzeczeń peryfrastycznych, [w:] Z zagadnień słownictwa współczesnego języka polskiego, Wrocław 1978, s. 17-30. 
Boniecka B., Tekstw kontekście, „Polonica” 1994, s. 43-67.

Borkowski I., Śmierci tajemnicze wrota. Językowy świat inskrypcji nagrobnych, [w:] Język a kultura, t. 13: Językowy obraz świata i kultura, red. A. Dąbrowska, J. Anusiewicz, Wrocław 2000, s. 343-354.

Bralewski D., Od przekładu do słownika. Korpus równoległy w redakcji słowników tlumaczeniowych, Łask 2012.

Burska K., Analityczne konstrukcje czasownikowe w polskich tygodnikach, [w:] Słowo we współczesnych dyskursach, red. B. Kudra, K. Jachimowska, E. Szkudlarek-Śmiechowicz, Łódź 2014, s. 67-84.

Burska K., Motywacja semantyczna alternatywnych nazw drużyn piłkarskich, [w:] Bogactwo językowe i kulturowe Europy w oczach Polaków i cudzoziemców 3, red. M. Gaze, P. Góralczyk-Mowczan, Łódź 2015, s. 158-169.

Burska K., Peryfraza a jej jednowyrazowy odpowiednik (na materiale polskich tygodników), [w:] Idee, wartości, stowa w życiu publicznym, red. L. Kuras, G. Majkowski, J. Makowska, Łódź 2014, s. 237-248.

Burska K., Właściwości strukturalne i semantyczne antroponimów i ich odpowiedników w prasie sportowej, „ęzyk. Komunikacja. Informacja” 2016, t. 11, red. A. Godzich, M. Lewandowski, I. Koutny, P. Nowak, J. Taborek.

Burska-Ratajczyk B., Wartościowanie komunikacji językowej (na materiale frazeologii gwar mazowieckich), [w:] Język, społeczeństwo, wartości, red. E. Laskowska, I. Benenowska, M. Jaracz, Bydgoszcz 2008, s. 71-84.

Buttler D., Innowacje składniowe powojennego trzydziestopięciolecia, [w:] Współczesna polszczyzna. Wybór zagadnień, red. H. Kurkowska, Warszawa 1986, s. 111-129.

Buttler D., Innowacje składniowe współczesnej polszczyzny (Walencja wyrazów), Warszawa 1976.

Buttler D., Leksykalne czasowniki positkowe w konstrukcjach peryfrastycznych typu „wywrzeć wplyw” na przełomie XIX i XX wieku, [w:] Z problemów frazeologii polskiej i słowiańskiej, t. 4, red. M. Basaj, D. Rytel, Wrocław 1988, s. 71-82.

Buttler D., Niektóre problemy opisu zjawiska uniwerbizacji, „Slavistična revija” 1997, Lublana, s. 435-447.

Buttler D., Połączenia typu ulec zniszczeniu w języku polskim, „Poradnik Językowy" 1968 , z. 7, s. 349-359.

Buttler D., Procesy multiwerbizacji we współczesnej polszczyźnie, „Poradnik Językowy" 1978, s. 54-62.

Buttler D., Semantyka a składnia w związkach wyrazowych. V. Ekspansja konstrukcji analitycznych, „Poradnik Językowy” 1967, z. 1, s. 6-18. 
Buttler D., Tendencje rozwojowe współczesnej polszczyzny, [w:] Współczesna polszczyzna. Wybór zagadnień, praca zbiorowa pod red. H. Kurkowskiej, Warszawa 1986, s. 187-219.

Buttler D., Wszędobylska -ówka, „Poradnik Językowy” 1988, z. 8.

Buttler D., Kurkowska H., Satkiewicz H., Kultura języka polskiego. Zagadnienia poprawności gramatycznej, Warszawa 1971.

Chlebda W., Cheops prozy, Pcim i balceroid... Derywaty nazw własnych a leksykografia, „Poradnik Językowy” 1995, z. 2, s. 11-21.

Chlebda W., Elementy frazematyki. Wprowadzenie do frazeologii nadawcy, Opole 1991.

Chlebda W., Frazematyka, [w:] Współczesny język polski, red. J. Bartmiński, Lublin 2001, s. 327-334.

Chlebda W., W stronę frazeologii pragmatycznej, „Poradnik Językowy” 1997, z. 2, s. $1-10$.

Cieślikowa A., Przezwiska, [w:] Polskie nazwy własne. Encyklopedia, red. E. Rzetelska-Feleszko, Warszawa-Kraków 1998.

Cieślikowa A., Przezwiska zbiorowe i przydomki, [w:] Polskie nazwy własne. Encyklopedia, red. E. Rzetelska-Feleszko, Warszawa-Kraków 1998.

Cieślikowa A., Pseudonimy, [w:] Polskie nazwy własne. Encyklopedia, red. E. Rzetelska-Feleszko, Warszawa-Kraków 1998.

Cockiewicz W., Konstrukcje analityczne w języku polskiej telewizji w latach siedemdziesiątych i dziś, [w:] Język w mediach masowych, red. J. Bralczyk, K. Mosiołek-Kłosińska, Warszawa 2000, s. 143-153.

Czeszewski M., Słownik polszczyzny potocznej, Warszawa 2008.

Daszczyńska I., O internacjonalizacji wyrażeń peryfrastycznych, [w:] Współczesne tendencje rozwoju języków słowiańskich, t. 1, red. M. Blicharski, H. Fontański, Katowice 1994, s. 35-42.

Dawidowicz K., „Biba”, „Lijek”, „Wtorek”, „Grucha”, czyli o przezwiskach polskich sportowców, [w:] Język w komunikacji, t. 1, red. G. Majkowski, Częstochowa 2011, s. 95-102.

Dąbrowska A., Eufemizmy mowy potocznej, [w:] Język a kultura, t. 5: Potoczność w języku i kulturze, red. J. Anusiewicz, S. Nieckula, Wrocław 1992, s. 119-178.

Dąbrowska A., Eufemizmy współczesnego języka polskiego, wyd. 2 popr., Łask 2006.

Dąbrowska A., Eufemizmy życia codziennego, [w:] Język a kultura, t. 2: Zagadnienia leksykalne i aksjologiczne, red. J. Puzynina, J. Bartmiński, Wrocław 1991, s. $163-180$. 
Dąbrowska A., Kilka słów o eufemizmach, [w:] Język a komunikacja 5, t. 1: Aspekty współczesnych dyskursów, red. P. Chruszczewski, Kraków 2004, s. 79-84.

Dąbrowska A., Słownik eufemizmów polskich, czyli w rzeczy mocno, w sposobie łagodnie, wyd. 3, Warszawa 1998.

Dąbrowska A., Zmiany obszarów podlegających tabu we współczesnej kulturze, [w:] Język a kultura, t. 20: Tom jubileuszowy, red. A. Dąbrowska, A. Nowakowska, Wrocław 2008, s. 173-196.

Dąbrowska A., Zniekształcenie obrazu rzeczywistości poprzez użycie pewnych środków językowych (eufemizm i kakofemizm), [w:] Językowy obrazświata, red. J. Bartmiński, Lublin 1999, s. 215-227.

Dobosiewicz J., Magia tytułu prasowego, [w:] Jezyk nowych mediów, red. K. Michalewski, Łódź 2012, s. 139-147.

Dobrzyńska T., Metafora, Wrocław 1984.

Dubisz S., Językoznawstwo polonistyczne w minionym dwudziestoleciu (19902009) - próba opisu i wniosków, „Przegląd Humanistyczny” 2010, z. 5-6, s. 93-110.

Encyklopedia języka polskiego, red. S. Urbańczyk, Wrocław-Warszawa-Kraków 1994.

Encyklopedia językoznawstwa ogólnego, red. K. Polański, Wrocław-WarszawaKraków 1993.

Encyklopedia kultury polskiej XX wieku, t. 2: Współczesny język polski, red. J. Bartmiński, Wrocław 1993.

Engelking A., Istota i ewolucja eufemizmów (na przykładzie zastępczych określeń śmierci), „Przegląd Humanistyczny” 1984, nr 4, s. 115-129.

Fajfer E., Uwagi o roli czasownikowych konstrukcji analitycznych w przekazach telewizyjnych, [w:] Badania nad językiem Telewizji Polskiej, red. Z. Kurzowa, Warszawa 1985, s. 155-162.

Gajda S., Styl naukowy, [w:] Współczesny język polski, red. J. Bartmiński, Lublin 2001, s. 183-199.

Głowińska K., Popularny słownik frazeologiczny, Warszawa 2000.

Głowiński M., Peryfrazy współczesne, „Teksty I” 1972, nr 3, s. 48-58.

Grabias S., O ekspresywności języka. Ekspresja a słowotwórstwo, Lublin 1980.

Grzegorczykowa R., O konstrukcjach z bezokolicznikiem przyczasownikowym w języku polskim, „Biuletyn Polskiego Towarzystwa Językoznawczego” 1967, t. XXV, s. 121-126. 
Grzegorczykowa R., Profilowanie a inne pojęcia opisujące hierarchiczna strukturę znaczenia, [w:] Profilowanie w języku i w tekście, red. J. Bartmiński, R. Tokarski, Lublin 1998, s. 9-17.

Grzegorczykowa R., Problem funkcji języka i tekstu w świetle teorii aktów mowy, [w:] Język a kultura, t. 4: Funkcje języka i wypowiedzi, red. J. Bartmiński, R. Grzegorczykowa, Wrocław 1991, s. 11-28.

Habrajska G., Nakłanianie, perswazja, manipulacja językowa, „Acta Universitatis Lodziensis. Folia Litteraria Polonica" 2005, nr 7, t. 2, s. 91-125.

Hałas B., Wojciechowska A., Kontekst a innowacje leksykalne w prasie, „Poradnik Językowy" 1999, z. 8-9, s. 64-72.

Hartenstein K., Konstrukcje z czasownikiem funkcyjnym (opisowe) we współczesnym jezzyku rosyjskim - rozważania na temat definicji, [w:] Wspótczesna polszczyzna mówiona w odmianie opracowanej (oficjalnej), red. Z. Kurzowa, W. Śliwiński, Kraków 1994, s. 45-63.

Hodalska M., Mocarz Ducha zamieszkał w niebie. Peryfrazy ornamentacyjne i eufemizacyjne w prasie, „Język Polski” 2010, z. 4-5, s. 302-309.

Honowska M., Język prasy osobliwy twór socjalny, „Biuletyn Polskiego Towarzystwa Językoznawczego" 1972, z. XXX, s. 61-66.

Jabłońska M., Nowe przyimkowe konstrukcje analityczne w języku polskim, [w:] Ruch w języku - język w ruchu, red. K. Liszczyk-Kubina, M. Maciołek, Katowice 2012, s. 49-59.

Jadacka H., Wpływ mediów na złagodzenie kryteriów poprawności słowotwórczej, [w:] Polszczyzna w komunikowaniu publicznym. Prace poświęcone Prof. Halinie Satkiewicz z okazji jubileuszu Jej i Jej Zakładu, red. W. Gruszczyński, J. Bralczyk, G. Majkowska, Warszawa 1999, s. 27-36.

Jaszczołt K., Pomiędzy semantyka a pragmatyka, [w:] Metodologie językoznawstwa. Podstawy teoretyczne, red. P. Stalmaszczyk, Łódź 2006, s. 131-154.

Jędrzejko E., Konstrukcje analityczne w historii polszczyzny - zarys problematyki, [w:] Stowo i czas, red. S. Gajda, A. Pietryga, Opole 1998, s. 37-47.

Jędrzejko E., Problemy predykacji peryfrastycznej. Konstrukcje - Znaki - Pojęcia, Katowice 2002.

Jędrzejko E., Słownictwo tzw. analityczne w opisie leksykalnym (propozycja opisu i klasyfikacji), [w:] Opisać słowa, red. A. Markowski, Warszawa 1992, s. 50-61. Jędrzejko E., „Stary” problem - nowe (?) możliwości. Uwagi o analityczności w słowniku i wariancji mechanizmów znakotwórczych, [w:] Nowe czasy, nowe języki, nowe (i stare) problemy, red. E. Jędrzejko, Katowice 1998, s. 146-161. 
Jędrzejko E., Z problemów opisu analityzmów werbo-nominalnych, [w:] Słownik polskich zwrotów werbo-nominalnych, red. E. Jędrzejko, Warszawa 1998, s. 3-71.

Język a komunikacja 5, t. 1: Aspekty wspótczesnych dyskursów, red. P. Chruszczewski, Kraków 2004.

Język a kultura, t. 2: Zagadnienia leksykalne i aksjologiczne, red. J. Puzynina, J. Bartmiński, Wrocław 1991.

Język a kultura, t. 4: Funkcje języka i wypowiedzi, red. J. Bartmiński, R. Grzegorczykowa, Wrocław 1991.

Język a kultura, t. 5: Potoczność w języku i kulturze, red. J. Anusiewicz, S. Nieckula, Wrocław 1992.

Język a kultura, t. 13: Językowy obraz świata i kultura, red. A. Dąbrowska, J. Anusiewicz, Wrocław 2000.

Język a kultura, t. 20: Tom jubileuszowy, red. A. Dąbrowska, A. Nowakowska, Wrocław 2008.

Język nowych mediów, red. K. Michalewski, Łódź 2012.

Język - teoria - dydaktyka: Materiały 21. konferencji językoznawczej zorganizowanej w Trzcinicy k. Jasła w dniach 27-29 maja 1998 roku, red. B. Greszczuk, Rzeszów 1999.

Język w mediach masowych, red. J. Bralczyk, K. Mosiołek-Kłosińska, Warszawa 2000.

Jodłowski S., Substantywizacja przymiotników w języku polskim, Wrocław-Warszawa-Kraków 1964.

Kaleta Z., Teoria nazw własnych, [w:] Polskie nazwy własne. Encyklopedia, red. E. Rzetelska-Feleszko, Warszawa-Kraków 1998.

Kalisz R., Pragmatyka językowa, Gdańsk 1993.

Kałuski S., Komornicki T., Słownik niekonwencjonalnych nazw geograficznych, Warszawa 1996.

Kania S., Tokarski J., Zarys leksykologii i leksykografii polskiej, Warszawa 1984. Karaś A., Językowa konceptualizacja uczuć z grupy strachu na podstawie konstrukcji werbo-nominalnych, „Poradnik Językowy” 2003, z. 4, s. 27-35.

Karaś A., NowakE., Znaczenie predykatu a wybór werbalizatora w konstrukcjach analitycznych (na przykładzie konstrukcji z predykatami chęć, ochota, pragnienie, żądza), „Poradnik Językowy” 1999, z. 1, s. 11-20.

Karaś M., Nazwy własne i ich klasyfikacje (nazwy osobowe), „Biuletyn Polskiego Towarzystwa Językoznawczego" 1972, s. 103-150. 
Kita M., Ekspansja potoczności, „Prace Językoznawcze”, t. 19: Studia polonistyczne, red. A. Kowalska, A. Wilkoń, Katowice 1991, s. 83-90.

Kniagininowa M., Struktury opisowe - znamienna cecha stylu dziennikarskiego, „Język Polski" 1963, z. 2, s. 148-157.

Koper M., Emocje w języku sprawozdawców sportowych, [w:] Rejestr emocjonalny języka, red. K. Wojtczuk, V. Machnicka, Siedlce 2009, s. 67-76.

Koper M., „Poezja futbolu”. Kilka uwag o języku sprawozdawców sportowych, [w:] Język polski. Współczesność. Historia, red. W. Książek-Bryłowa, H. Duda, Lublin 2003, s. 51-62.

Koper M., „Turku, kończ ten mecz!” O mówionej odmianie języka dziennikarzy sportowych raz jeszcze, [w:] Sport w mediach, red. M. Jarosz, P. Drzewiecki, P. Płatek, Warszawa 2013, s. 284-298.

Kosyl Cz., Metaforyczne użycie nazw własnych, [w:] Z zagadnień słownictwa wspótczesnego języka polskiego, red. M. Szymczak, Wrocław-Warszawa-Kraków-Gdańsk 1978, s. 133-143.

Kosyl Cz., Nazwy osobowe, [w:] Encyklopedia kultury polskiej XX wieku, t. 2: Współczesny język polski, red. J. Bartmiński, Wrocław 1993, s. 423-437.

Kudra B., Kreatywność leksykalna w dyskursie polskiej prasy lat osiemdziesiątych i dziewięćdziesiątych, Łódź 2001.

Kurkowska H., Skorupka S., Stylistyka polska. Zarys, Warszawa 1966.

Lachur Cz., Zarys językoznawstwa ogólnego, Opole 2004.

Lakoff G., Johnson M., Metafory w naszym życiu, przekł. T. Krzeszowski, Warszawa 1988.

Leszczyński Z., Szkice o tabu językowym, Lublin 1988.

Lesz-Duk M., Przejście konstrukcji syntetycznych w analityczne, „Język Polski” 1985, z. 3, s. 157-171.

Levinson S. C., Pragmatyka, przekł. T. Ciecierski, K. Stachowicz, Warszawa 2010.

Lewicki A. M., O możliwości zastosowania pojęcia formantu we frazeologii, [w:] idem, Studia z teorii frazeologii, Łask 2003, s. 245-250.

Lewicki A. M., Zwroty frazeologiczne, czyli predykaty w formie składników nieciagtych, „Studia Gramatyczne I” 1977, s. 135-143.

Lewicki A. M., Pajdzińska A., Frazeologia, [w:] Współczesny język polski, red. J. Bartmiński, Lublin 2001, s. 315-333.

Linde-Usiekniewicz J., Jak zmieniało się językoznawstwo w Polsce w minionym dwudziestoleciu?, „Przegląd Humanistyczny” 2010, z. 5-6, s. 111-119. 
Loewe I., Analityzmy werbo-nominalne a młodopolski dekadentyzm (na przykładzie pola stanów mentalnych), [w:] W kręgu języka polskiego. Śląsko-poznańskie kolokwia lingwistyczne, red. E. Jędrzejko, Katowice 2001, s. 131-150.

Loewe I., Konstrukcje analityczne w poezji Młodej Polski, Katowice 2000.

Loewe I., Konstrukcje analityczne w polskiej telewizji na progu drugiej dekady XXI wieku, „Stylistyka” 2010, XIX, s. 177-188.

Loewe I., Konstrukcje analityczne wśród metafor. Struktura, semantyka i funkcja analityzmów w poezji K. Przerwy-Tetmajera, „Poradnik Językowy” 1997, z. 7, s. $42-52$.

Machnicka V., Istota oraz typologia peryfraz wywodzacych się z Pisma Świętego lub nawiązujących do wydarzeń, postaci i przedmiotów biblijnych (na materiale wybranym ze „Słownika peryfraz, czyli wyrażeń omownych” Mirosława Bańki), „Acta Universitatis Lodziensis. Folia Linguistica Rossica 2”: Język - struktura - styl. Współczesne kierunki badań lingwistycznych, red. J. Wierzbiński, A. Ginter, Łódź 2006, s. 83-103.

Machnicka V., Konstrukcje peryfrastyczne związane ze śmiercią na tle innych określeń omownych w „Faraonie” Bolesława Prusa, „Styl”, Rocznik Międzynarodowy, nr 4, red. M. Ž. Čarkić, Belgrad 2005, s. 343-355.

Machnicka V., Peryfrazy śmierci w tekstach Bolesława Prusa, „Conversatoria Linguistica”, Międzynarodowy Rocznik Naukowy. Rok II: 2008, red. K. Wojtczuk, Siedlce 2009, s. 63-76.

Machnicka V., Peryfrazy Bolesława Prusa, Siedlce 2011.

Machnicka V., Peryfrazy wokół nas, czyli o konstrukcjach omownych używanych we współczesnych środkach masowego przekazu (na tle rozważań teoretycznych), [w:] Język nowych mediów, red. K. Michalewski, Łódź 2012, s. 322-332.

Mały słownik języka polskiego, red. E. Sobol, Warszawa 2000.

Markowski A., Kultura języka polskiego. Teoria. Zagadnienia leksykalne, Warszawa 2012.

Markowski A., Polszczyzna końca XX wieku, Warszawa 1992.

Metodologie językoznawstwa. Podstawy teoretyczne, red. P. Stalmaszczyk, Łódź 2006.

Michalewski K., Kreowanie wartości wyrazów, [w:] Współczesna leksyka, red. K. Michalewski, cz. 2, Łódź 1998, s. 3-8.

Mieczkowska H., Analityzmy leksykalne w ujęciu słowacko-polskim, „Studia z Filologii Polskiej i Słowiańskiej” 2006, t. 41, Warszawa, s. 177-190. 
Mietła J., Multiwerbizacja w języku polskim i czeskim, Toruń 1998.

Miodek J., Syntetyczne konstrukcje leksykalne w języku polskim, Wrocław 1976.

Miodek J., Syntetyczne konstrukcje leksykalne w języku prasy, „Wrocławski Rocznik Prasoznawczy" 1972, s. 107-156.

Mindak J., Peryfrastyczne konstrukcje predykatywne z parafraza przymiotnikowa (na materiale polskim, serbsko-chorwackim i macedońskim), Wrocław-Warszawa-Kraków-Gdańsk-Łódź 1985.

Mosiołek-Kłosińska K., Metafora w tekście użytkowym - charakterystyka, próba oceny normatywnej, „Poradnik Językowy” 1997, z. 10, s. 1-23.

Nęcki Z., Komunikacja międzyludzka, Kraków 2001.

Nowak E. A., Opis semantyczny analitycznych konstrukcji werbo-nominalnych (na przykładzie AWN oznaczających wybrane uczucia pozytywne), „Polonica” 2000, t. XXI, Kraków, s. 25-49.

Nowakowska B., Nowe połaczenia wyrazowe we współczesnej polszczyźnie, Kraków 2005.

Nowe czasy, nowe języki, nowe (i stare) problemy, red. E. Jędrzejko, Katowice 1998.

Nowe słownictwo polskie. Materiały z prasy z lat 1972-1981, cz. 1-2, red. D. Tekiel, Wrocław 1988-1989.

Nowe słownictwo polskie. Materiały zprasy z lat 1981-2000, cz. 1-4, red. T. Smółkowa, Wrocław 2004-2006.

Nowy słownik ortograficzny PWN z zasadami pisowni i interpunkcji, red. E. Polański, Warszawa 2002.

Nowy słownik poprawnej polszczyzny, red. A. Markowski, Warszawa 2002.

Nykiel-Herbert B., Jeszcze raz o uniwerbizacji, „Polonica” 1989, s. 193-201.

Obraz človeka v jazyku, red. J. Vaněk, Nitra 2014.

Ochmann D., Nowe wyrazy złożone o podstawie zdezintegrowanej w języku polskim, Kraków 2004.

Orłoś T., Nowsze uniwerbizmy w czeskim języku potocznym, [w:] W kręgu języka. Materiały konferencji „Słowotwórstwo - słownictwo - polszczyzna kresowa” poświęconej pamięci Profesor Zofii Kurzowej Kraków 16-17 maja 2008, red. M. Skarżyński, M. Szpiczakowska, Kraków 2009, s. 301-307.

Ożdżyński J., Polskie współczesne słownictwo sportowe, Wrocław-WarszawaKraków 1970.

Ożóg K., Polszczyzna przełomu XX i XXI wieku. Wybrane zagadnienia, wyd. 3, Rzeszów 2007. 
Pałuszyńska E., Nagłówki w „Gazecie Wyborczej” (ekspresywna leksyka, frazematyka, metaforyka), Łódź 2006.

Pelczar W., Zmilitaryzowany futbol. O wojskowym aspekcie języka piłkarskich sprawozdań prasowych, [w:] Język - teoria - dydaktyka: Materiały 21. konferencji językoznawczej zorganizowanej w Trzcinicyk. Jasła w dniach 27-29 maja 1998 roku, red. B. Greszczuk, Rzeszów 1999, s. 303-309.

Pisarek W., Nowa retoryka dziennikarska, Kraków 2002.

Pisarkowa K., Pragmatyczna motywacja hipotaksy, [w:] Semantyka tekstu i języka, red. M. R. Mayenowa, Wrocław 1976, s. 203-212.

Pisarska A., Tomaszkiewicz T., Współczesne tendencje przekładoznawcze. Podręcznik dla studentów neofilologii, Poznań 1998.

Pokorska-Szczodruch E., Przymiotnikowe i przysłówkowe konstrukcje analityczne w tekstach prasowych: opis stylistyczny i semantyczny, „Poradnik Językowy” 2006, z. 10, s. 103-110.

Polska genologia lingwistyczna, red. D. Ostaszewska, R. Cudak, Warszawa 2008.

Polszczyzna w komunikowaniu publicznym. Prace poświęcone Prof. Halinie Satkiewicz z okazji jubileuszu Jej i Jej Zakładu, red. W. Gruszczyński, J. Bralczyk, G. Majkowska, Warszawa 1999.

Polskie nazwy własne. Encyklopedia, red. E. Rzetelska-Feleszko, Warszawa-Kraków 1998.

Problemy frazeologii europejskiej I, red. A. M. Lewicki, Warszawa 1996.

Profilowanie w języku i w tekście, red. J. Bartmiński, R. Tokarski, Lublin 1998.

Przybyszewski S., Kilka uwag o roli kontekstu w komunikacji, „Prace Językoznawcze” XI, Olsztyn 2009, s. 179-189.

Przybyszewski S., Kontekst w badaniach nad językiem, „Media. Kultura. Komunikacja Społeczna” 2009, nr 5, s. 79-86.

Puzynina J., Język wartości, Warszawa 1992.

Puzynina J., Kontekst a rozumienie tekstu, [w:] Polska genologia lingwistyczna, red. D. Ostaszewska, R. Cudak, Warszawa 2008, s. 246-262.

Rejakowa B., Pojedynczy wyraz jako forma przekładu zwiazku frazeologicznego (wartości referencyjne i stylistyczne), „Annales UMCS. Sectio F” 1988, s. 341-352.

Rejter A., Uniwerbizacja jako proces historycznojęzykowy, [w:] Żywe problemy historii języka, red. M. Kuźnicki, M. Osiewicz, Poznań 2010, s. 75-85.

Rejter A., Uniwerbizmy w języku prasy drugiej połowy XX wieku. Próba analizy diachronicznej, [w:] Wokół słów i znaczeń, t. 4: Słowotwórstwo a media, red. I. Badyda, J. Maćkiewicz, E. Rogowska-Cybulska, Gdańsk 2011, s. 307-317. 
Ruch wjęzyku-językwruchu, red. K. Liszczyk-Kubina, M. Maciołek, Katowice 2012. Rutkowski M., Metafory motywowane metonimicznie (metaftonimie) na przykładzie nazw własnych, „Białostockie Archiwum Językowe” 2008, nr 8, s. 95-104. Rutkowski M., Nazwy własne w strukturze metafory i metonimii. Proces deonimizacji, Olsztyn 2007.

Rutkowski M., Słownik metafor i konotacji nazw własnych, Olsztyn 2012.

Rzetelska-Feleszko E., Nazwy własne, [w:] Encyklopedia kultury polskiej XX wieku, t. 2: Współczesny język polski, red. J. Bartmiński, Wrocław 1993, s. 397-402. Rzetelska-Feleszko E., W świecie nazw własnych, Warszawa-Kraków 2006.

Satkiewicz H., Budżetówka, Krajówka, zbrojeniówka, „Poradnik Językowy” 1993, z. 6, s. 371-374.

Satkiewicz H., Innowacje słowotwórcze w powojennym trzydziestoleciu, [w:] Współczesna polszczyzna, Warszawa 1981, s. 130-155.

Sawicka G., Struktura współczesnych skrótowców, „Acta Universitatis Lodziensis. Folia Linguistica" 1998, z. 37, s. 153-165.

Siatkowska E., Syntaktyczne i analityczne nazwy w języku czeskim i polskim, „Prace Filologiczne” 1964, t. 18, cz. 2, s. 219-237.

Sieradzka-Mruk A., Konstrukcje analityczne we współczesnym polskim stylu liturgicznym, „Język Polski” 2012, z. 3, s. 194-203.

Skorupka S., Z zagadnień leksykografii. Synonimika, „Poradnik Językowy” 1953, z. 4, s. 21-25.

Słowiańska onomastyka. Encyklopedia, t. 1, red. E. Rzetelska-Feleszko, A. Cieślikowa, przy współudziale J. Dumy, Warszawa-Kraków 2002.

Słownik polskich zwrotów werbo-nominalnych. Zeszyt próbny, red. E. Jędrzejko, Warszawa 1998.

Słownik synonimów, red. A. Dąbrówka, E. Geller, R. Turczyn, Warszawa 1995.

Słownik terminologii medialnej, red. W. Pisarek, Kraków 2006.

Słownik terminów literackich, red. M. Głowiński, T. Kostkiewiczowa, A. Okopień-Sławińska, J. Sławiński, wyd. 3, popr. i rozsz., Wrocław 2000.

Słownik terminów literackich, red. J. Sławiński, Wrocław-Warszawa-Kraków 1978. Słownik wyrazów bliskoznacznych, red. D. Ludwiczak, A. Piskadłowa, E. Tarki-Huczek, Warszawa 1998.

Słowo i czas, red. S. Gajda, A. Pietryga, Opole 1998.

Sojda S., Kategoria rodzaju wobec procesów uniwerbizacyjnych (na materiale polskim i słowackim), [w:] Kategorie w języku. Język w kategoriach, red. M. Cichońska, Katowice 2009, s. 163-171. 
Sport w mediach, red. M. Jarosz, P. Drzewiecki, P. Płatek, Warszawa 2013.

Stalmaszczyk P., Semantyka formalna i pragmatyka: przeglad wybranych definicji, „Biuletyn Polskiego Towarzystwa Językoznawczego” 2008, z. LXIV, s. 9-24.

Straś E., Peryfrazy w środkach masowego przekazu (na materiale prasy polskiej i rosyjskiej), [w:] Konfrontacje języków słowiańskich na poziomie leksyki, słowotwórstwa i składni, red. P. Czerwiński przy współpr. M. Borek, Katowice 2001, s. 102-110.

Szczepańska E., Derywacja a uniwerbizacja (na przykładzie sufiksu-ka w języku polskim i czeskim), „Rocznik Slawistyczny” 1992, 48, cz. 1, s. 51-56.

Szczepańska E., O dezintegracji w procesie tworzenia uniwerbizmów (na przykładzie języka polskiego i czeskiego), „Poradnik Językowy” 1992, z. 2, s. 129-133.

Szczepańska E., Uniwerbizacja w języku czeskim i polskim, Kraków 1994.

Szkudlarek E., Kontekstowa elipsa akomodowanych jednostronnie uzupetnień predykatu, „Acta Universitatis Lodziensis. Folia Linguistica” 1999, 38, s. 89-96.

Szober S., Człowiek współczesny w zwierciadle języka, [w:] idem, Wybór pism, Warszawa 1959, s. 345-353.

Szober S., Na straży języka. Szkice z zakresu poprawności i kultury języka, Warszawa 1937.

Szwecow-Szewczyk M., Tabu i eufemizmy językowe dawniej i dziś, „Poradnik Językowy" 1974, z. 6, s. 285-293.

Szymczak-Rozlach M., Leksyka eufemizująca (na materiale słowackim i polskim), [w:] Obraz človeka v jazyku, red. J. Vaněk, Nitra 2014, s. 165-181.

Ślawska M., Tytuł - najmniejszy tekst prasowy, „Rocznik Prasoznawczy” 2008, R. II, s. 117-126.

Tokarski R., Słownictwo jako interpretacja świata, [w:] Encyklopedia kultury polskiej XX wieku, t. 2: Współczesny język polski, red. J. Bartmiński, Wrocław 1993, s. 335-362.

Ulitzka E., Polskie werbo-nominalne konstrukcje analityczne oznaczajace pozytywne stany emocjonalne (z rzeczownikami radość, wesołość, uciecha, euforia, zadowolenie, szczęście), „Roczniki Humanistyczne” 2004, z. 6, t. 52, s. 113-148.

Vetulani G., Kolokacje werbo-nominalne jako odrębne jednostki języka i ich zastosowanie, [w:] W kręgu języka polskiego. Śląsko-poznańskie kolokwia lingwistyczne, red. E. Jędrzejko, Katowice 2001, s. 58-75.

Vetulani G., Rzeczowniki predykatywne języka polskiego, „Studia Romanica Posnaniensia" 1995, t. 20, Poznań, s. 177-197. 
Vetulani G., Rzeczowniki predykatywne języka polskiego. W kierunku syntaktycznego słownika rzeczowników predykatywnych, Poznań 2000.

Warchala J., Dialog potoczny a tekst, Katowice 1991.

Warchala J., Kategoria potoczności w języku, Katowice 2003.

Waszakowa K., Słowotwórstwo współczesnego języka polskiego. Rzeczownikizformantami paradygmatycznymi, wyd. 2 popr., Warszawa 1996.

Widłak S., Tabu i eufemizm w językach nowożytnych, „Biuletyn Polskiego Towarzystwa Językoznawczego" 1963, z. 22, s. 89-102.

Wielki słownik frazeologiczny PWN z przysłowiami, oprac. A. Kłosińska, E. Sobol, A. Stankiewicz, Warszawa 2009.

Wierzbicka A., Hipotaksa i konstrukcje nominalne w rozwoju polszczyzny, „Pamiętnik Literacki" 1962, s. 195-216.

Wierzbicka A., Metatekst w tekście, [w:] Polska genologia lingwistyczna, red. D. Ostaszewska, R. Cudak, Warszawa 2008, s. 281-296.

W kręgu języka. Materiały konferencji „Słowotwórstwo - słownictwo - polszczyzna kresowa" poświęconej pamięci Profesor Zofii Kurzowej Kraków 16-17 maja 2008, red. M. Skarżyński, M. Szpiczakowska, Kraków 2009.

W kręgu języka polskiego. Śląsko-poznańskie kolokwia lingwistyczne, red. E. Jędrzejko, Katowice 2001.

Wojtak M., Styl urzędowy, [w:] Współczesny język polski, red. J. Bartmiński, Lublin 2001, s. 155-171.

Współczesne tendencje rozwoju języków słowiańskich, t. 1, red. M. Blicharski, H. Fontański, Katowice 1994.

Zaręba A., Osobowe nazwy własne i ich miejsce w systemie językowym, „Poradnik Językowy" 1979, z. 1, s. 1-12.

Zarębski R., Przejawy tabu pierwotnego i magii językowej w dawnej i wspótczesnej polszczyźnie, „Sprawozdania z Czynności i Posiedzeń Naukowych ŁTN” 2013, t. XVII, red. K. Czyżewska, Łódź 2014, s. 241-251.

Zwiegincew W., Semazjologia, Warszawa 1962.

Z problemów frazeologii polskiej i słowiańskiej, t. 1-4, red. M. Basaj, D. Rytel, Wrocław 1982-1988.

Z zagadnień słownictwa współczesnego języka polskiego, red. M. Szymczak, Wrocław-Warszawa-Kraków-Gdańsk 1978.

Żmigrodzki P., Oddziaływanie analitycznych konstrukcji werbo-nominalnych na inne składniki zdania, „Poradnik Językowy” 1998, z. 7, s. 1-16. 
Bibliografia

Żmigrodzki P., Strukturyzacja analityzmów werbo-nominalnych w modelu gramatyki generatywnej, „Polonica” 1998, t. XIX, Kraków, s. 49-66.

Żmigrodzki P., Właściwości składniowe analitycznych konstrukcji werbo-nominalnych, Katowice 2000.

Żydek-Bednarczuk U., Wprowadzenie do lingwistycznejanalizy tekstu, Kraków 2005.

\section{Netografia}

Grzegorczykowa R., O różnych rozumieniach pragmatyki w językoznawstwie, http://www2.polon.uw.edu.pl/ZBG/

Guzek K. J., >Tre Kronor< herb mniejszy Królestwa Szwecji. Geneza - wzór funkcja, Zduny 2011, http://www.lowicz.eu/docs/tre_kronor_4.pdf

Jaszczuk T., Młot na Kanarki, czyli o przydomkach, http://krotkapilka.pl/ artykul,mlot_na_kanarki_czyli_o_przydomkach,1541

Kasprzyk P., Jakie historie kryją przydomki uczestników mundialu, http://historia-news.pl/ciekawostki/82-jakie-historie-kryj-przydomki-uczestnikow-mundialu.html

Wirkowska K., Przydomki drużyn piłkarskich, http://redlog.pl/2008/03/12/przydomki-druzyn-pilkarskich/

Miejski słownik slangu i mowy potocznej, http://www.miejski.pl/

Słownik jezzkka polskiego, http://sjp.pwn.pl/

http://historia-news.pl/ciekawostki/82-jakie-historie-kryj-przydomki-uczestnikow-mundialu.html [dostęp: 05.05.2014].

http://krotkapilka.pl/artykul,mlot_na_kanarki_czyli_o_przydomkach,1541 [dostęp: 05.05.2014].

http://menstream.pl/wiadomosci-reportaze-i-wywiady/tomasz-hajto-o-szansach-polakow-na-euro-i-pijanstwie-w-sporcie,1,1097511.html [dostęp: 08.05.2014].

http://redlog.pl/2008/03/12/przydomki-druzyn-pilkarskich/ [dostęp: 05.05.2014].

http://www.express.de/fussball/franciszek-smuda--poldi-ist-botschafter-des-neuen-europa-,3186,14695380.html [dostęp: 08.05.2014].

http://www.gazetakrakowska.pl/artykul/429923,jak-to-andrzej-niedzielan-przez-blonia-przeskoczyl,id,t.html?cookie=1 [dostęp: 05.05.2014].

http://www.gazetawroclawska.pl/artykul/704127,jan-miodek-strzelac-focha,id,t. html?cookie=1 [ dostęp: 12.04.2014]. 
http://www.kanonierzy.com/section_id-18_historia_herbu.shtml [dostęp: 05.05.2014].

http://www.lechpoznan.pl/od,1922,roku,do,dzis [dostęp: 06.05.2014]. http://www.lkslodz.pl/pilka,fan-zone,lks-maskotka [dostęp: 05.05.2014].

http://www.realmadrid.pl/index.php?co=symbole\&dzial=herb [dostęp: 05.05.2014].

http://www.realmadryt.net.pl/herb_klubu.php [dostęp: 05.05.2014].

http://www.sportowefakty.pl/pilka-nozna/259185/piotr-wlodarczyk-o-nedzy-i-grze-w-baltyku [dostęp: 07.05.2014].

http://www.wprost.pl/ar/286960/Gianni/?pg=1 [dostęp: 08.05.2014]. 



\section{Analytical lexical constructions and their synthetic equivalents in the press}

\section{Summary}

In the dissertation the issue of analytical lexical constructions which have synthetic (one-word) equivalents is taken into consideration. The dissertation undertakes an analysis of material from 2011 until 2012. The research material consists of approximately three thousands lexical constructions coming from four polish weekly magazines (sports, political, entertainment and educational) which are designated for diversified recipients.

The aim of the work is to answer the questions of what components analitisms are built, what semantic relation can we notice between analytical lexical constructions and their equivalents, what functions do they perform and what do recipient and sender need to decipher periphrases.

There is a noticeable duality in the thesis structure - it is divided into a theoretical and an analytical part. The theoretical part focuses on the definitions and theses referring to the following issues: verbo-nominal collocations, synthetic constructions, periphrases, multiverbization, phraseologisms, univerbation.

In the dissertation a new definition of the term analytical lexical construction was created. As analitisms are treated at least two-words structures which have one-word equivalents with identical or similar meaning.

In the analytical part of the dissertation the descriptive and synthetic lexical constructions were examined with regard to the structural, semantic and pragmatic aspects. 
